Faculdade de Arquitetura e Urbanismo

Universidade de São Paulo

Francine Gramacho Sakata

\title{
PARQUES URBANOS NO BRASIL 2000 a 2017
}

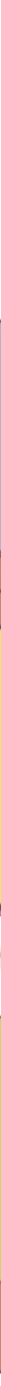

São Paulo 2018 


\section{PARQUES URBANOS NO BRASIL 2000 a 2017}




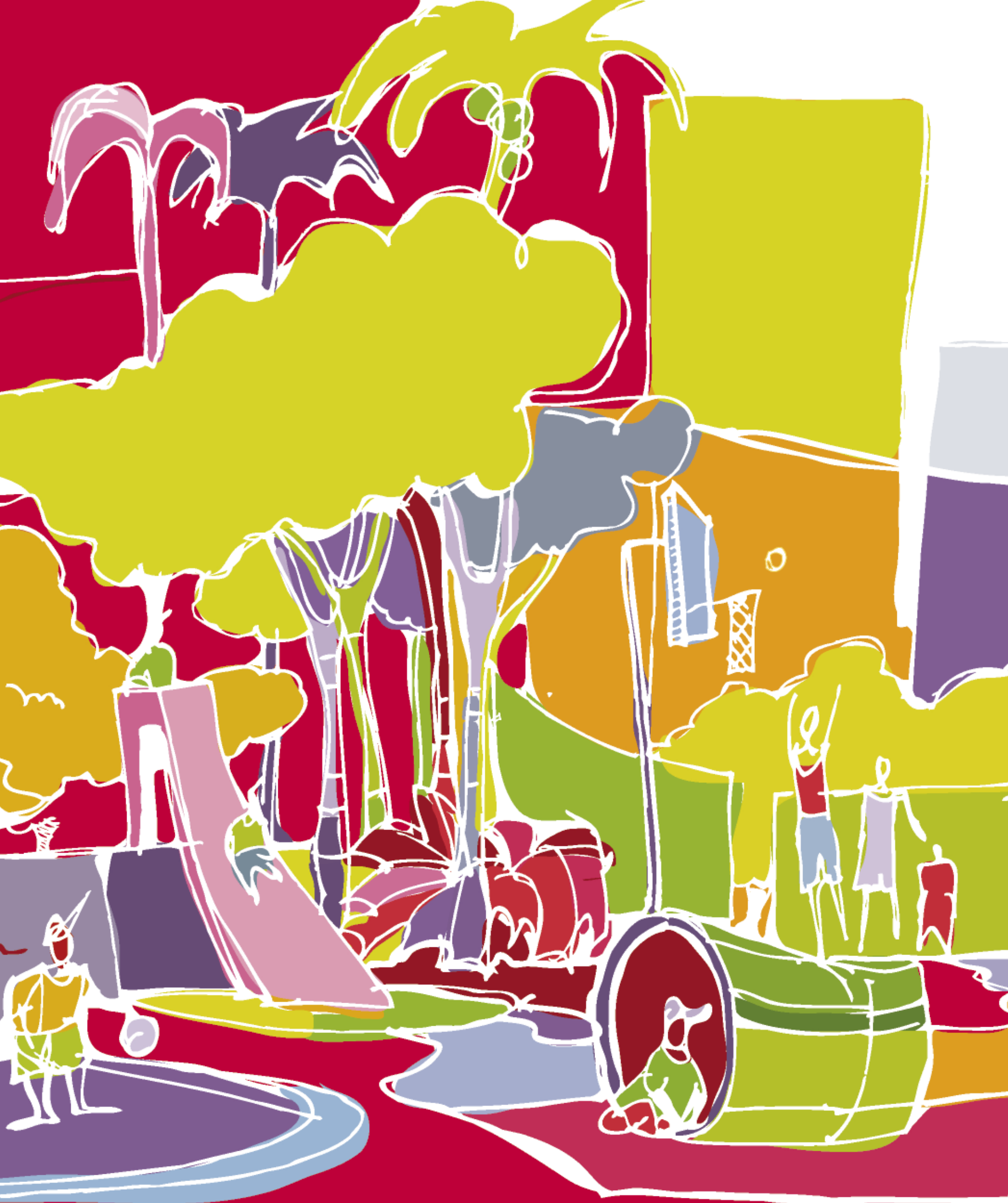




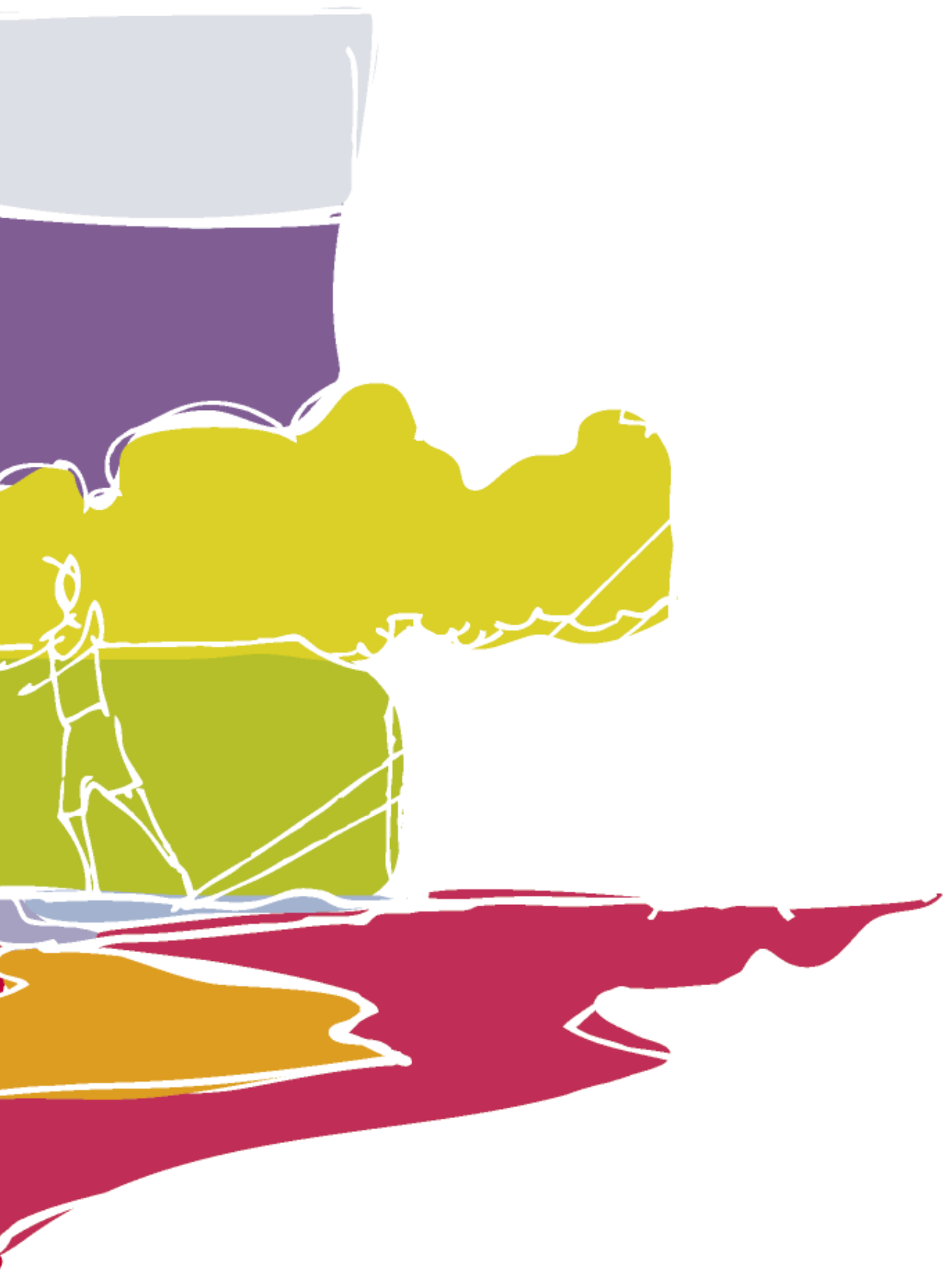


Autorizo a reprodução e divulgação total ou parcial deste trabalho, por qualquer meio convencional ou eletrônico, para fins de estudo e pesquisa, desde que citada a fonte.

Catalogação na publicação

Serviço de Biblioteca e Documentação

Faculdade de Arquitetura e Urbanismo da Universidade de São Paulo

Ilustrações: Silvio Soares Macedo

Sakata, Francine Gramacho

Parques Urbanos no Brasil - 2000 a 2017 / Francine Gramacho

Sakata. -- São Paulo, 2018.

348 p. : il

Orientador: Fábio Mariz Gonçalves.

Coorientador: Silvio Soares Macedo.

Tese (Doutorado - Arquitetura e Urbanismo) -- Universidade de São Paulo, Faculdade de Arquitetura e Urbanismo, 2018.

1. Parques urbanos. 2. Parques públicos. 3. Espaços livres.

I. GONÇALVES, FÁBIO MARIZ. II. MACEDO, SILVIO SOARES. III. TÍTULO. 


\section{Francine Gramacho Sakata}

\section{PARQUES URBANOS NO BRASIL 2000 a 2017}

Tese apresentada à Faculdade de Arquitetura e Urbanismo da Universidade de São Paulo, para obtenção do título de Doutor em Arquitetura e Urbanismo.

Versão corrigida. 0 original encontra-se no Programa de PósGraduação da FAUUSP.

Área de Concentração: Paisagem e Ambiente

Linha de Pesquisa: Espaços livres

Orientador: Prof. Dr. Fábio Mariz Gonçalves

Co-orientador: Prof. titular Silvio Soares Macedo

São Paulo

2018 



\section{AGRADECIMENTOS}

A Silvio Soares Macedo, meu grande mestre, e Fábio Mariz Gonçalves, que aceitou continuar a orientação deste trabalho. Muitas das reflexões aqui colocadas foram generosamente compartilhadas por eles. A Josefina Capitani, por todo apoio; Caroline Ribeiro de Souza, pela coleta de dados e produção de mapas; Felipe Neres, Pedro Fernandes e Tiago Regueira, pelo apoio técnico; Ana Cecília de Arruda Campos e Catharina Lima, pela banca de qualificação; Valéria Diniz e Maria Etelvina Sakata, pela revisão de texto. A equipe do Quapá, em especial, Helena Degreas, Eugenio Queiroga, João Meyer, Fany Galender, Vanderli Custódio, Mayumi Hyrie, Isabela Sollero, Leonardo Loyolla, Mateus Oliveira, Rafael Pegoraro, Victória Ribeiro e lsabela Billi. Aos amigos Ana Lucia de Faria Burjato, Paulo Gonçalves, Miriam Salles, Paulo Oliveira, Eduardo Barra, Yara Hasegawa, Michel e Ciça Gorski. Aos pesquisadores que estudam parques pelas cidades brasileiras e aos colegas da arquitetura paisagística.
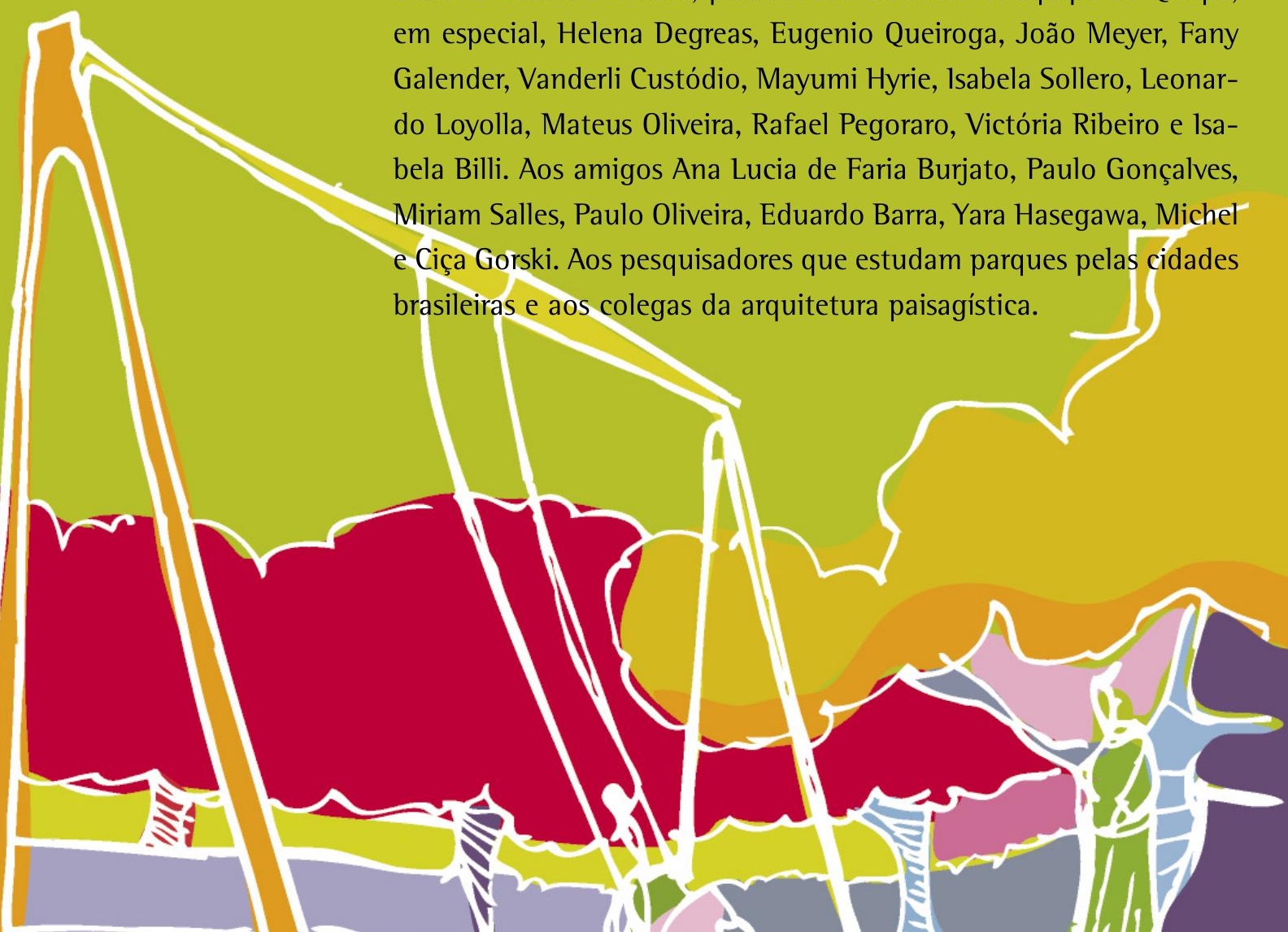
Este trabalho é dedicado a meus pais - Katsumi e Etelvina. 
SAKATA, F. G. Parques Urbanos no Brasil - 2000 a 2017. 2018. 348 p. Tese (Doutorado - Arquitetura e Urbanismo) - Faculdade de Arquitetura e Urbanismo, Universidade de São Paulo, São Paulo, 2018.

\section{RESUMO}

Nesta tese o parque urbano brasileiro dos primeiros anos do século $X X 1$ é apresentado como uma figura diferente dos parques dos séculos XIX e XX. As diferenças dizem respeito, principalmente, aos programas de uso e à distribuição pelo espaço urbano. Jardins urbanos que se destinavam à fruição das elites no século XIX e das massas no século XX apresentam-se, entre 2000 e 2015, como figura híbrida, relacionada à preservação ambiental e ao lazer mas não necessariamente a ambos. Surgem novos tipos de parque, como os lineares, que tanto se apresentam em forma de conjuntos de pequenos espaços livres articulados por curso d'água, como de projetos de grande envergadura que articulam uma sequência de parques no território urbano. Em algumas capitais brasileiras, como São Paulo, Belo Horizonte, Goiânia, Brasília, Campo Grande, Vitória, Recife e Manaus, o número de parques públicos se multiplicou no período. 0 mesmo processo não foi observado em capitais litorâneas como Rio de Janeiro e Fortaleza, onde a orla segue como um grande parque linear. Todo o conjunto de parques vistos demonstra que houve mudança na percepção do valor do parque urbano pela sociedade brasileira, fato capitalizado pelo poder público e pela iniciativa privada. As novas características e as localizações dos parques em bairros periféricos onde a renda dos moradores é baixa impõem novos desafios para o projeto e a gestão.

Palavras-chave: Parques urbanos. Parques públicos. Espaços livres. 
SAKATA, F. G. Parques Urbanos no Brasil - 2000 a 2017. 2018. 348 p.

Tese (Doutorado - Arquitetura e Urbanismo) - Faculdade de Arquitetura e

Urbanismo, Universidade de São Paulo, São Paulo, 2018.

\section{ABSTRACT}

In this thesis the Brazilian urban park of the first years of the $21^{\text {st }}$ century is presented as a different figure from the parks of the $19^{\text {th }}$ and $20^{\text {th }}$ centuries. The differences mainly concern uses and distribution in the urban space. Urban gardens for the enjoyment of elites in the nineteenth century and the masses in the twentieth century are, between 2000 and 2015, as a hybrid figure, related to environmental preservation and leisure, but not necessarily to both. At that time new types of parks appeared, such as linear ones, which are in the form of sets of small free spaces articulated by watercourse, as well as large-scale projects that articulate a sequence of parks in the urban territory. In some Brazilian capitals, such as Sao Paulo, Belo Horizonte, Goiania, Brasilia, Campo Grande, Vitoria, Recife and Manaus, the number of public parks has multiplied in this period. The same process was not observed in coastal capitals like Rio de Janeiro and Fortaleza, where the border follows as a large linear park. The whole set of parks seen shows that there was a change in the perception of the value of the urban park by Brazilian society, a fact capitalized by the public power and private initiative. The new features and locations of parks - in neighborhoods where residents' incomes are low - create new challenges for design and management.

Keywords: Urban parks. Public parks. Open spaces. 


\section{APRESENTAÇÃO}

Em 2002 foi publicado pela Editora da Universidade de São Paulo (Edusp) o livro Parques urbanos no Brasil, de Silvio Soares Macedo e Francine Sakata. Parques, praças e calçadões de 25 cidades brasileiras vinham sendo visitados para levantamentos de campo desde 1994 pelo grupo de pesquisadores do Projeto de pesquisa Quadro do Paisagismo no Brasil (Quapá), sediado na FAUUSP. Nele os autores tratam da evolução do parque brasileiro nos séculos XIX e XX e apresentam um panorama dos principais parques e calçadões de 17 capitais brasileiras.

Debrucei-me novamente sobre esse material para o desenvolvimento da dissertação de mestrado apresentada em 2005, cujo foco é a produção, em larga escala, de praças ou parques entre 1980 e 2000 nas cidades de São Paulo (SP), Rio de Janeiro (RJ), Curitiba (PR), São Luiz (MA) e Salvador (BA). Conjuntos de projetos paisagísticos de grande visibilidade pública foram criados por programas governamentais. As motivações e arranjos que os conduziram às obras eram muito ligados a interesses políticos. Foram aprofundadas questões de projeto e gestão e realizadas conclusões sobre a durabilidade e validade das obras. A dissertação originou o livro Paisagismo urbano - requalificação ou criação de imagens, publicado pela Edusp em 2011.

Entre 2005 e 2016, desenvolvi projetos para parques através da empresa NKEF Arquitetos Associados, seguindo diretrizes do Departamento de Parques e Áreas Verdes (Depave) da Secretaria Municipal 
do Verde e do Meio Ambiente da Prefeitura de São Paulo (SVMA). Participei dos projetos dos parques Cohab Raposo Tavares, Horto do Ipê, Linear Cabuçu de Cima, Paraisópolis, Linear Córrego da Água Podre e Leopoldina Orlando Villas-Bôas. Lecionei no curso de graduação em Arquitetura e Paisagismo do Centro Universitário FIAM-FAAM e, desde 2006, tenho participado da gestão da Associação Brasileira de Arquitetos Paisagistas (ABAP). Sou frequentadora assídua de parques, que, com outros espaços do cotidiano, acolhem a diversidade social. Posso afirmar que passei meus melhores finais de semana em parques públicos.

Em 2014 regressei à FAUUSP e ao grupo de pesquisa Quapá-SEL (Sistema de Espaços livres), fonte de renovado material de trabalho, arcabouço teórico e contato permanente com grupo de pesquisadores, que hoje constitui o maior grupo de pesquisa em Arquitetura e Urbanismo do país. 0 Quapá-SEL tem promovido oficinas em universidades por todo o país, nas quais se reúnem pesquisadores de São Paulo e pesquisadores locais para diagnosticar as cidades a partir de quatro questões: (1) morfologia urbana; (2) sistemas de espaços livres; (3) agentes construtores da forma urbana; (4) legislação urbanística. Pude participar das oficinas em Fortaleza, Goiânia, São José dos Campos (SP), Curitiba, São Paulo e Porto Alegre entre outras viagens e eventos. Silvio Soares Macedo, criador do Quapá, explica que muitos estudos urbanísticos traduzem teorias estrangeiras para a realidade brasileira sem dar conta das nossas cidades, que buscam explicá-las a partir dos processos econômicos/sociais. E que é preciso, primeiro, enxergar as cidades reais, suas transformações e a multiplicidade de agentes que operam no território para, depois, explicar os processos que operaram as transformações. Quando reconhecemos a complexidade das transformações e as especificidades de cada cidade, incrementamos nossa capacidade, como arquitetos e urbanistas, de intervir de modo efetivo nesses processos.

Por meio da rede de pesquisa Quapá-SEL e da revista Paisagem e Ambiente, editada pelo professor Silvio Soares Macedo, tenho tido contato com novos conhecimentos sobre o assunto. Outra fonte de material de trabalho tem sido o Google Acadêmico, ferramenta de 
1 DELABIO, José Cristiano; SOBAGE, Milton Norio. 0 ozônio troposférico e os parques arborizados. Revista Acadêmica Oswaldo Cruz. ano 4, n.13 janeiro-março 2017.

2 SANTANA, Jaqueline de Oliveira et al. Parques Públicos de Ouro Preto: Um Importante Recurso de Promoção da Saúde. LICERE - Revista do Programa de Pós-graduação Interdisciplinar em Estudos do Lazer. v. 19, n. 3 (2016) pesquisa que permite acessar trabalhos, artigos e jornais acadêmicos. Todos os artigos que citam o livro Parques urbanos no Brasil é encaminhado para meu e-mail, como "0 ozônio troposférico e os parques arborizados"1 e "Parques públicos de Ouro Preto: recurso de promoção da saúde" 2 . Tais artigos revelam que o tema em questão extrapola a área da arquitetura e urbanismo: interessa, também, às áreas da saúde, história, turismo, economia e ecologia.

Esse conjunto de experiências - práticas e acadêmicas - me motivaram a estudar o parque urbano brasileiro no período entre 2000 e 2017 , focando especialmente a forma como os parques servem à sociedade brasileira. Uma pesquisa com frequentadores de parques paulistanos (citada no capítulo 5 desta tese) revelou que a maioria sabia que existiam outros parques na cidade, mas não era capaz de dizer o nome de algum sem ser o de onde estavam. Tal fato aconteceu especialmente com frequentadores de baixa renda e revelou que há muitas pessoas para as quais o parque é a única opção de lazer cultural e esportivo. Criados para "escapar do urbano", os parques são, paradoxalmente, espaços para usufruir da vida urbana e da diversidade que ela oferece.

Para o desenvolvimento deste trabalho, optei junto com meu orientador por apresentar os parques brasileiros a partir das premissas do Projeto Quapá-SEL, que compreende os espaços livres de forma sistêmica, como uma infraestrutura que se relaciona com as demais - e que é, também, uma construção sociocultural. Buscamos avaliar os parques nas cidades amplamente, com algumas generalizações, sem a pretensão de oferecer respostas definitivas para um assunto impossivel de ser esgotado. Graças ao trabalho em rede e sua metodologia, o Quapá-SEL tem dado conta de explorar cidades variadas. Em relação aos parques, colhemos e construímos informações nas oficinas, nos grupos de trabalho sobre Sistemas de Espaços livres, mas o material sistematizado não é completo nem homogêneo entre as diferentes cidades. Mesmo com lacunas, foi possível traçar um quadro sobre a produção geral dos parques e sua distribuição nas cidades. Em relação à apropriação e manutenção, apontamos questões que pudemos desenvolver a partir desta pesquisa. Os dados, especialmente sobre os custos, são escassos e difíceis de serem 
obtidos. 0 entendimento da manutenção de espaços públicos como processo passivel de sistematização e atividade-fim do poder público - e não como um fardo - precisa amadurecer na sociedade brasileira.

0 conjunto de grandes e médias cidades aqui apresentado como estudo de caso também é objeto de estudo do projeto Quapá-SEL. Era visivel para nós que estavam feitos investimentos e sendo reservadas terras para parques e que havia esforços político-administrativos repercutindo no cotidiano das cidades. A fim de investigar se o investimento feito em parques está sendo válido, esta tese trata do que é o parque urbano para a sociedade brasileira no início do século XX1, como foram feitos, onde se localizam e quais são as decorrências destas ações. 


\section{SUMÁRIO}

\section{INTRODUÇÃO}

1 O PARQUE URBANO BRASILEIRO CONTEMPORÂNEO 29

1.1 O parque urbano dos séculos XIX e XX 32

1.2 Conceito de parque para o século XX 38

1.3 Categorias de parques 46

1.40 parque contemporâneo $\quad 51$

1.5 Novas categorias de parques pelo mundo 54

1.6 Novas categorias de parques no Brasil 62

1.7 Novo conceito para o parque urbano brasileiro contemporâneo 82

2

GESTÃO DE OPORTUNIDADES

91

2.1 Agentes

91

2.2 Arranjos

98

2.3 Motivações

102

3 DISTRIBUIÇÃO PELO ESPAÇO URBANO

3.1 Quadro Geral

3.2 São Paulo

3.3 Belo Horizonte

134

154

3.4 Goiânia

163

3.5 Distrito Federal 174

3.6 Curitiba 184

3.7 Campo Grande 194

3.8 Manaus 201

3.9 Vitória 207

3.10 Recife $\quad 214$

3.11 Rio de Janeiro $\quad 220$

3.12 Salvador 227

3.13 Fortaleza $\quad 235$

3.14 Belém 241

$\begin{array}{ll}3.15 \text { Porto Alegre } & 247\end{array}$

DESENHOS 255

4.1 Parque Ecológico Brasileiro 258

4.2 Arquitetos paisagistas e processos de trabalho 271

4.3 Projetos selecionados 275

5 DESAFIOS PARA GESTÃO E MANUTENÇÃO 309

CONSIDERAÇÕES FINAIS

REFERÊNCIAS BIBLIOGRÁFICAS 


\section{INTRODUÇÃO}

Entre 2000 e 2015, os parques urbanos se multiplicaram pelas cidades brasileiras. Em Goiânia, por exemplo, havia três parques implantados até 1996. Em 2016, são 39 parques e bosques equipados que podem ser utilizados pela população, de um total de190 áreas reservadas para essa finalidade que ainda não foram convertidas em parques públicos. Somando-se todas as 16 capitais brasileiras apresentadas neste trabalho, há 234 parques abertos, que prestam serviços ambientais e estão disponiveis para a fruição.

Este processo não foi significativo em algumas grandes cidades litorâneas - como Rio de Janeiro, Maceió, Santos, Fortaleza e Florianópolis -, nas quais a orla da praia ainda é o grande parque urbano, pela diversidade de usos sociais que acolhe, seja na areia ou no calçadão. Vitória e Recife são exceções. Nas capitais e grandes cidades do interior - como São Paulo, Belo Horizonte, Brasília, Campo Grande, Curitiba, Sorocaba, São José dos Campos e Rio Branco -, o fenômeno é evidente.

No grupo de pesquisa Quapá-SEL, parte-se da premissa de que os sistemas de espaços livres das cidades corresponde à infraestrutura urbana, da mesma forma que a distribuição de energia, drenagem de águas pluviais, moradia social, transporte e escolas. As vias ruas e avenidas - são os principais espaços livres urbanos, suportes das redes de energia, drenagem, transporte etc. Como áreas de lazer, recreação, esporte e descanso, os parques são parte desse sistema, 
cumprindo as seguintes funções ambientais: conservar a vegetação; contribuir na retenção e infiltração das águas das chuvas; regular o microclima. Mas, ao estudar a produção de parques no Brasil entre 2000 e 2015 , observa-se que tanto pode ser fator de valorização imobiliária e melhoria da qualidade de vida nos bairros como problema de gestão, manutenção e segurança para o poder público.

\section{As cidades não são as mesmas}

Neste início de século XXl, grandes mudanças aconteceram no país. 0 Brasil passou por períodos de prosperidade e mudanças econômicas que impactaram toda a população por meio da geração de empregos e mudanças na distribuição da renda, beneficiando especialmente as classes de rendas média e média-baixa; programas federais de estímulo à construção; retorno do financiamento habitacional; abertura de capital das incorporadoras; obras de infraestrutura; avanços na legislação ambiental; novas tecnologias e popularização da aquisição de automóveis.

0 Produto Interno Bruto (PIB) brasileiro entre 2000 e 2015 cresceu 51,34\%. Segundo o Banco Mundial, entre 2004 e 2014 o Brasil retirou da pobreza mais de 28,6 milhões de pessoas', sem, contudo, mudar a grande concentração de renda no topo, que se manteve estável².

A população passou de 174,3 milhões, em 2000, para 190,7 milhões em 2010. E foi estimada em 207,6 milhões em $2017^{3}$. Mas seu crescimento está desacelerando de forma consistente: basta saber que a taxa de crescimento médio entre 2000 e 2010 foi de 1,17\% ao ano; 0,80\% entre 2015 e 2016; 0,77\% entre 2016 e 2017.

De 2000 a 2010, a frota de veículos automotores passou de 29,5 milhões de unidades para 64,8 milhões, um aumento de 119\%. Em 2010 o país tinha a média de um veículo para cada 2,94 habitantes ${ }^{4}$, ocupando garagens e ruas, transportando, comumente, um passageiro. As ruas e avenidas, principais espaços livres urbanos, não
1 BANCO MUNDIAL. 2017. Salvaguardas Contra a Reversão dos Ganhos Sociais Durante a Crise Econômica no Brasil. Disponivel em: http://documents.worldbank. org/curated/pt/469091487328690676/ Safeguarding-against-a-reversal-in-social-gains-during-the-economic-crisis-in-Brazil

2 SOUZA, Pedro H. A desigualdade vista do topo: a concentração de renda entre os ricos no Brasil, 1926-2013. Universidade de Brasilia, Instituto de Ciências Sociais. Brasilia, 2016.

3 https://cidades.ibge.gov.br/brasil/panorama

4 Dados do Departamento Nacional de Trânsito (Denatran). http://www.progresso. com.br/caderno-a/veiculos/frota-de-veiculos-cresce-119-em-dez-anos-no-brasil-aponta-denatran 
5 De 2000 a 2010, os domicilios passaram de 3.284.446 para 3.944.171 e a população de 10.925.422 para 11.903.349 (um incremento de 659.725 domicilios). Dados coletados por João Meyer para a Oficina Quapá-SEL II do Rio de Janeiro. RELATÓRIO OFICINA OUAPÁ-SEL II RIO DE JANEIRO-RJ 05 e 06 de dezembro de 2016 - Org. Vanderli Custódio

6 PEGORARO, Rafael Lopez. Transformação Urbana no Brasil: estudo de cinco centros urbanos. Relatório Científico Final. São Paulo: FAPESP, 2017. Processo FAPESP: 2015/04226-9.

7 GOVERNO DO BRASIL. Infográfico Minha Casa Minha Vida - Balanço 30.03. 30/03/2016

Disponivel em: http://www.brasil.gov. br/infraestrutura/2016/03/minha-casa-minha-vida-realiza-sonho-da-moradia-propria-para-10-milhoes-de-brasileiros/ infogrfico29.03MCMVBalano.png/view aumentaram tanto. Novas vias foram abertas por todo o país nas bordas e áreas de expansão, mas a estrutura viária estava dada e as alterações foram pontuais nos centros.

As médias e grandes cidades brasileiras ficaram mais construídas; o número de domicílios cresceu mais que a população. Na Região Metropolitana do Rio de Janeiro, por exemplo, o crescimento do número de domicílios entre 2000 e 2010 foi de 20,1\%; o da população, 9\%. 0 aumento do número de domicílios se deve à nova composição das famílias, que é menor, e ao fato de muitas pessoas passarem a morar sozinhas. Mas isto significa um quinto das casas ou apartamentos acrescidos na cidade. Para uma década, é um crescimento expressivo ${ }^{5}$.

A pesquisa Quapá-SEL investigou as transformações nas cidades brasileiras no início do século XXI, diferenciando três processos: (1) transformação por adição, quando áreas não urbanas são incorporadas à mancha urbana; (2) transformação por consolidação, quando áreas vazias são construídas dentro dos tecidos urbanos; (3) transformação por substituição, quando a volumetria construída é alterada: ampliada, trocada por outra ou demolida ${ }^{6}$.

Por meio dos estudos que compõem a pesquisa, nota-se que as transformações por adição são comuns nas bordas das manchas urbanas; nas regiões metropolitanas, ultrapassam os limites dos municípios-sede, estendendo-se a territórios de municípios vizinhos. 0 fato de maior destaque nas periferias foi a extensa construção de conjuntos habitacionais de baixa renda associada ao Programa Minha Casa Minha Vida (MCMV), que buscou equacionar o déficit habitacional reprimido. Em que pesem as críticas aos modelos urbanísticos, os números impressionam e permitem ter ideia da abrangência e escala do programa, que contratou mais de quatro milhões de unidades, das quais entregou 2,6 milhões em 5.330 municípios diferentes ${ }^{7}$, marcando de forma permanente várias das paisagens urbanas brasileiras.

ldentificam-se, também, áreas expressivas nas regiões metropolitanas ocupadas por loteamentos fechados - no padrão Alphaville -, com casas amplas e piscinas, que surgem próximos das rodovias. 
São grandes glebas muradas que geram descontinuidades no tecido urbano, isto é, não é possível cruzá-las, e caminhar no entorno dos muros é desagradável. Tais loteamentos são figuras frequentes não apenas nas metrópoles, mas também nas médias e pequenas cidades.

As ocupações irregulares, caracterizadas pela precariedade construtiva e ausência de infraestrutura básica, continuaram presentes, porém com menor ocorrência. Muitas ocupações ilegais passaram a ser planejadas, atendendo a parâmetros urbanísticos, visando à possível regularização futura. Nas bordas urbanas de Belo Horizonte, vimos ocupações com arruamento e lotes nas dimensões da lei. Ficou mais difícil distinguir, apenas pela observação, as ocupações regulares das irregulares, e não faz mais sentido falar em cidade legal e ilegal, como ocorria na década de 1990. Há, inclusive, muitas ocupações irregulares de camadas de rendas médias e altas em Brasília, por exemplo.

Nas bordas das cidades, no contexto dessa expansão fragmentada, entre tecidos urbanos de conjuntos habitacionais, loteamentos fechados e invasões, houve também a criação de alguns parques, especialmente como reservas ambientais - uma forma de tentar resguardar porções ambientalmente mais valiosas das paisagens, agora urbanas. Mas os usos sociais destes parques ainda estão, em geral, por ser definidos. Todos os espaços livres que estas expansões urbanas geraram ainda demandam qualificações. Em contextos onde os muros dos loteamentos são onipresentes, não fica claro se os espaços públicos terão boas condições para apropriações sociais.

As transformações por consolidação são comumente verificadas dispersas pela mancha urbana, tendendo a se concentrar entre os $\operatorname{arcos}$ da adição e o centro da substituição. A consolidação foi o fenômeno mais observado e caracterizou-se, principalmente, pela construção de edificações de pequeno porte e edifícios em lotes vazios, adensando bairros preexistentes ${ }^{8}$.

Se este adensamento ocorre em bairros onde há infraestrutura, pode significar que esta foi otimizada, mas se o adensamento ocorre em áreas sem infraestrutura, a precariedade se perpetua, podendo agra-
8 Quatro dos mapas produzidos por Pegoraro e Ribeiro serão apresentados, com os parques, no capítulo 3.

RIBEIRO, Victória Mendes. Uso e ocupação recente de áreas pouco adensadas e suas áreas livres no espaço urbano brasileiro - o caso das cidades de Anápolis, Uberlândia, Palmas, Brasília, Cuiabá e Goiânia. Relatório científico final - FAPESP 2016/21205-8. São Paulo: FAUUSP, 2018. 
var-se. Muitas famílias de baixa renda puderam revestir, pintar e equipar suas casas, e algumas favelas perderam o ar de improviso que as caracterizava, porém persistem as desigualdades sociais, os problemas de transporte público e o esgotamento sanitário, a falta de estabilidade geotécnica e a insegurança. Faltam calçadas adequadas e espaços livres tratados para o lazer.

A ocupação dos lotes no território das cidades também significa a supressão de áreas verdes que contribuíam para drenagem, regulação da temperatura, insolação e ventilação das edificações existentes. 0 adensamento construtivo, em muitos lugares, significou abrupta perda da qualidade ambiental oriunda dos vazios remanescentes. Às vezes, o "lote desocupado" guardava recursos significativos, como nascentes d'água, árvores, mirantes para a paisagem. Houve, assim, a criação de parques em tecidos urbanos que estão sendo adensados (transformações por consolidação). Mais uma vez, não é um fato generalizado, mas pontual, ao sabor de uma conjunção de programas políticos e oportunidades que viabilizem a reserva da terra em bairros em processo de adensamento.

Por último, as transformações por substituições são características dos centros expandidos e áreas consolidadas. Pelos levantamentos do Quapá-SEL, ocorrem em menor quantidade, se comparadas às outras, geralmente dentro do intervalo de 5\% a 15\% do total transformado. Há a tendência de as construções horizontais serem substituídas por prédios, mas a substituição pode ser por outra tipologia, não necessariamente pela verticalização. ${ }^{9}$

A construção de torres de apartamentos para o mercado imobiliário pode se dar em lotes vazios (transformação por consolidação), em lotes antes ocupados por residências em bairros já valorizados ou em terrenos de instalações industriais que se tornaram obsoletas, em bairros em processo de valorização (transformação por substituição). Em todas estas situações, como os investimentos envolvidos são altos, a construção de edifícios de apartamentos precisa se associar à oferta de infraestrutura (transporte, comércio, serviços, saúde e ensino), à ideia de "qualidade de vida" e de valorização futura dos bairros em que se instala. Por isso, a verticalização costuma 
ser impulsionada por transformações nos bairros. Ela, por sua vez, contribuirá para impulsionar ainda mais esse tipo de construção

0 adensamento populacional e construtivo também significou mais impermeabilização do solo. Shoppings, edifícios comerciais e residenciais têm subsolos de garagem e mantêm, por imposição da legislação edilícia de muitas grandes cidades, faixas permeáveis obrigatórias, não muito significativas. Os bairros com predominância de casas são ainda mais impermeáveis: as casas foram ampliadas e os recuos frontais, laterais e de fundo foram cobertos. Em cidades como São Paulo, Rio de Janeiro e Campo Grande, as respostas do poder público às enchentes têm sido a construção de piscinões de concreto nos fundos de vale - medida cara, de manutenção difícil e geradora de muitos inconvenientes. Portanto, os piscinões não são a melhor resposta para o problema.

Nas áreas em que as transformações se dão por substituição, a terra é menos disponível e mais cara. Se não há reservas públicas desocupadas para a criação de parques, é difícil viabilizá-los. As manifestações populares que clamaram pela criação do parque Augusta, em São Paulo, esbarraram no alto preço do terreno. Em Fortaleza existe o desejo, expresso por decreto, de converter muitas das lagoas da cidade em parques. Mas as lagoas foram loteadas, inclusive as áreas cobertas pela água, e o poder público precisa contornar a situação fundiária para mudar a relação das lagoas com a cidade.

Por outro lado, por serem áreas tradicionais de moradia, existe a pressão vinda dos cidadãos e o interesse do mercado imobiliário na qualificação dos bairros e na melhoria da imagem de porções específicas da cidade.

\section{A legislação ambiental}

As intervenções públicas sistemáticas pela conservação ambiental no Brasil ganharam corpo a partir dos anos 1980, com as primeiras disposições ambientais nacionais. Ao longo do tempo, os consensos 
10 Hotspots de biodiversidade são área de relevância ecológica por abrigar espécies endémicas. A Conservation International identificou 34 áreas no mundo que são alvo de suas atividades de conservação.

http://www.mma.gov.br/biomas/cerrado e http://www.bbc.com/portuguese/brasil-39358966

11 COELHO, Leonardo Loyolla. Compensação ambiental: uma alternativa para viabilização de espaços livres públicos para lazer e convívio na cidade de São Paulo. Dissertação (Mestrado). São Paulo: FAUUSP, 2008. sobre quais recursos devem ser preservados e de que forma isto pode ser feito se ampliaram. A princípio, para o senso comum, apenas ecossistemas como a Amazônia e o Pantanal eram dignos de preservação, e não o Cerrado ou a Caatinga. Nas cidades os charcos e restingas não possuíam o mesmo status dos bosques. Com a compreensão da interdependência das partes, os campos, mangues e dunas ganharam relevância. Em 2017 foi a vez do Cerrado soar o alerta. Já com 75\% de sua área tomada pela expansões agrícola e pecuária, e muitas espécies consideradas condenadas à extinção, passa a ser tratado como um dos principais hotspots mundiais de biodiversidade ${ }^{10}$.

Conforme progrediam os entendimentos dos técnicos e se aparelhavam as administrações estaduais e municipais com secretarias e colegiados de meio ambiente, o estabelecimento de leis para amparar a preservação evoluiu. A Lei Federal 6.938/81 (BRASIL, 1981) apontou, pela primeira vez, a figura do Licenciamento Ambiental e trouxe o conceito de responsabilidade objetiva: o poluidor é obrigado a indenizar ou reparar os danos ao meio ambiente e a terceiros causados por sua atividade. Em 1986 foi a vez do Conselho Nacional do Meio Ambiente (Conama) consolidar o uso do Estudo de Impacto Ambiental (EIA) como principal ferramenta dos processos de licenciamento. Em 1998 a Lei de Crimes Ambientais, Lei Federal 9.605 (BRASIL, 1998), potencializou a aplicação de compensações ambientais e, em 2000, a Lei Federal 9.985 implantou o Sistema Nacional de Unidades de Conservação (SNUC) e consolidou as resoluções do Conama (BRASIL, 2000). Em 2004 o Instituto Brasileiro do Meio Ambiente e dos Recursos Naturais Renováveis (lbama) instituiu a Câmara Federal de Compensação Ambiental (CFCA), representando um precedente para a abertura de câmaras de compensação nas esferas estadual e municipal ${ }^{11}$.

0 estabelecimento de instrumentos que permitissem a transferência de recursos de licenciamentos ambientais para os órgãos de meio ambiente seguiu a evolução jurídica, que não é a mesma em todos os estados. Os recursos de Termos de Compensação Ambiental (TCAs) ou de Ajustamento de Conduta (TACs) foram importantes, a partir dos anos 1990, para a criação e o aparelhamento de parques 
tanto em periferias como em bairros de alto padrão (em algumas cidades mais que em outras).

Foi preciso estabelecer o conceito de dano ambiental, e os técnicos do poder público precisaram arbitrar as métricas que regulamentariam as trocas, estabelecendo qual o valor de uma árvore perdida e outros recursos ainda mais difíceis de mensurar, de definir quem seria responsável, quanto e como deveria pagar - e quem deveria receber. Na prática o valor do dano ambiental é proporcional aos custos gerais do empreendimento e deve ser uma porcentagem do valor da obra, preferencialmente sem inviabilizá-la.

\section{Os novos parques}

Os parques se proliferaram neste contexto de transformações urbanas e nova legislação ambiental. Muitas vezes como meio de preservação de recursos naturais existentes, outras vezes para cumprir, simultaneamente, os papéis de conservação de recursos e provisão de espaços de lazer e esporte, valorizando os bairros que recebem novos empreendimentos imobiliários.

No período de 2000-2017, observou-se que ao mesmo tempo em que se construíam cidades fragmentadas - com loteamentos fechados para camadas de alta, média e baixa renda (caso de muitos conjuntos do Programa MCMV) - e condomínios de torres de apartamentos com térreos "completos" (termo utilizado na propaganda de imóveis para o conjunto piscina, playground, quadra, salas de ginástica e de festa), os espaços públicos passaram a ser demandados ainda mais, tanto para usos tradicionais como para novos usos - de carnavais de rua a rondas noturnas de grupos de ciclistas. Corridas de rua ganharam adeptos; o número de animais domésticos, especialmente cães, aumentou; a população exige passeios, parques, calçadões e ciclovias: os espaços livres nunca estiveram tão cheios.

Em pesquisa do Datafolha ${ }^{12}$, o Parque Ibirapuera, em São Paulo (SP), foi escolhido como o símbolo da capital paulista pelos mo-
12 FOLHA DE SÃO PAULO. Morador elege Ibirapuera símbolo da cidade. São Paulo. 25/01/2004.

Disponivel em: http://www1.folha.uol. com.br/folha/cotidiano/ult95u89111.shtml 
radores em 2004, desbancando nesse ano a avenida Paulista. $\mathrm{Na}$ década de 1940, época da construção do lbirapuera, as áreas verdes não foram mencionadas nos jornais: divulgavam-se o obelisco, a marquise e os edifícios. Com o tempo o parque perdeu áreas para a construção de novos edifícios, até que a população se opôs à passagem de uma pista pelo meio do parque nos anos 1990. A via, atual túnel Ayrton Senna, foi então construída sob o lago do parque $^{13}$. 0 lbirapuera e seus espaços livres ganharam importância e o reconhecimento da população. Em 2018 o parque chega a receber cerca de 100 mil pessoas nos domingos ensolarados.

Grandes parques foram construídos entre 2000 e 2017 no país, como o da Juventude (2007) e o do Povo (2008) em São Paulo; o Mangal das Garças (2005) em Belém; o Madureira (2012/2015) no Rio de Janeiro. Também foram feitos muitos parques com projetos mais simples, que aproveitam ao máximo o relevo e as estruturas existentes. Nestes a facilidade de execução e o baixo custo são privilegiados como critérios de projeto. Muitos se articulam por caminhos que envolvem os bosques já formados, com bancos, brinquedos e os onipresentes "aparelhos de ginástica para a terceira idade”. Nesses casos, quando realizados os projetos de plantio, são discretos, pontuais e complementares.

Estes parques mais simples e em áreas periféricas fazem parte da história dos parques, do Paisagismo e do Urbanismo brasileiro, mas são fenômenos recentes, de grande escala e relevância para muitas cidades brasileiras. Por um lado, são espaços de uso efetivo ou com potencial de virem a ser usados mas, por outro, espelham o relativo despreparo dos quadros funcionais das prefeituras para implantá-los e geri-los. É possivel que sua existência contribua positivamente para a mudança desse quadro.

Os parques implantados confirmam que a cultura de uso e manutenção dos parques urbanos possui, no Brasil, uma raiz elitista. Portanto, o novo conjunto é um passo importante para que se tornem mais democráticos e inclusivos. Pode-se esperar que as gerações que

13 MIGLIONICO, Rosa Itálica. Parque do lbirapuera - um ícone da paisagem paulistana. Doutorado, FAUUSP, 2007. crescerem utilizando os parques se comprometam com sua defesa e a manutenção. Se muitos destes parques não forem mais do que estratégias de proteção efetiva de várzeas e encostas, para impedir 
ocupações inadequadas e ilegais, é possível que sejam reservados, qualificados e abertos à efetiva utilização da população no futuro.

Ter esse expressivo conjunto de parques significa o passo possível, oportuno e importante no sentido de aprimorar o sistema de espaços livres urbanos destas cidades. Tal passo só foi possível pelo entendimento do papel dos parques implantados nas décadas anteriores. A intensa utilização destes - cotidiana ou esporádica - na segunda metade do século XX mostrou à população, aos políticos e agentes imobiliários seus múltiplos potenciais.

Além dos papéis ambiental, social e urbanístico, ressalta-se a carência histórica de espaços urbanos públicos qualificados e democráticos em todas as cidades brasileiras - tão injustas e desiguais quanto a sociedade que as constrói. É fundamental assumir o desafio de gerir os espaços públicos para o uso amplo da população.

0 arquiteto Ginés Garrido, responsável pelo projeto do parque Madrid Río, um dos parques implantados em Madrid ao longo da primeira década do século XXI - portanto no mesmo período dos parques aqui analisados - afirmou que os espaços públicos são os lugares onde as democracias se medem: "[...] um pais é tanto mais democrático na medida em que os seus espaços públicos são aproveitados e usados por uma maior diversidade de pessoas. São os lugares onde todas as pessoas são um pouco iguais. Os extremos são difíceis - os mais pobres raramente desfrutam dos espaços públicos e os mais ricos também - mas, conforme os países se fazem mais democráticos, também as classes médias crescem e, portanto, há uma razão social em dar importância aos parques." ${ }^{14}$

Espera-se, por meio desta tese, contribuir com a avaliação do significado presente e potencial do conjunto de parques públicos que será apresentado para as cidades brasileiras.

\section{As hipóteses}

14 ORESTEN, José; IANOLI, Rafael. Como revitalizar as margens de um rio mudou a capital da Espanha. Nexo Jornal. De: 24/09/2017.

Disponivel em: https://www.nexojornal. com.br/entrevista/2017/09/24/Como-revitalizar-as-margens-de-um-rio-mudou-a- capital-da-Espanha 
No período entre 2000 e 2015, houve mudanças na percepção do valor do parque urbano pela sociedade brasileira, o que levou à criação sistemática de novos parques. 0 poder público e o mercado imobiliário compreenderam e capitalizaram o fato.

Nos anos 2000, o poder público, devido à impossibilidade de agir conforme a real necessidade e demanda da população e à necessidade de capturar recursos de fontes variadas, não age pautado pelo planejamento urbano, mas pelo aproveitamento das oportunidades. 0 fortalecimento do discurso ambiental - até por conta do aproveitamento de verbas provenientes de compensações ambientais - levou a função de recreação para segundo plano nos parques urbanos.

Aqui coloca-se a hipótese de que estes novos parques são diferentes dos parques do século XX e parte deles está em lugares das cidades que nunca os tiveram, servindo a pessoas que nunca usufruíram de parques, impondo novas necessidades para o projeto, gestão e manutenção.

\section{Estrutura do trabalho}

Cada capítulo foi estruturado em torno de pontos fundamentais e de outros que se desdobram a partir deles.

0 capítulo 1 buscou responder o que é o parque urbano brasileiro no início do século XXI e quais as diferenças em relação aos anteriores. Também apresentamos os tipos de parques que existiam e os que surgiram recentemente, inclusive o "Parque Ecológico" - que é mais o estabelecimento de postura geral em relação à natureza do que uma nova categoria de parque. Observamos que a nomenclatura parque foi estendida a outras categorias de espaços livres.

O capítulo 2 trata dos arranjos para a criação de parques, que ora se dão a partir de planos urbanísticos, ora são feitos através da gestão das oportunidades que surgem. As verbas oriundas de Compensa- 
ção Ambiental foram em parte responsáveis pelo boom de parques. Neste capítulo novamente tipificamos os parques, desta vez pela motivação de sua criação.

0 capítulo 3 apresenta a espacialização dos parques pelo território de algumas cidades e é traçado um breve panorama de cada uma, relacionando vetores de crescimento, renda e políticas públicas ao conjunto de parques.

0 capítulo 4 é sobre o desenho ou o projeto paisagístico dos parques do início do século XXl. Foram escolhidos casos mais emblemáticos - tanto de parques que são casos raros e únicos como daqueles cujo modelo também foi utilizado em um grande número de outros projetos. Nossas questões giram em torno do que tem sido encomendado aos projetistas e como o desenho dos parques favorece a apropriação.

No capitulo 5 são levantadas questões sobre gestão e manutenção. Buscou-se elencar problemas que o poder público enfrenta para manutenção de espaços livres públicos em diferentes partes das cidades e fazer considerações sobre o que tem sido feito.

Nas considerações finais retomamos as colocações feitas ao longo do texto tendo como questão de fundo os desafios para a gestão. 


\section{O PARQUE URBANO BRASILEIRO CONTEMPORÂNEO}

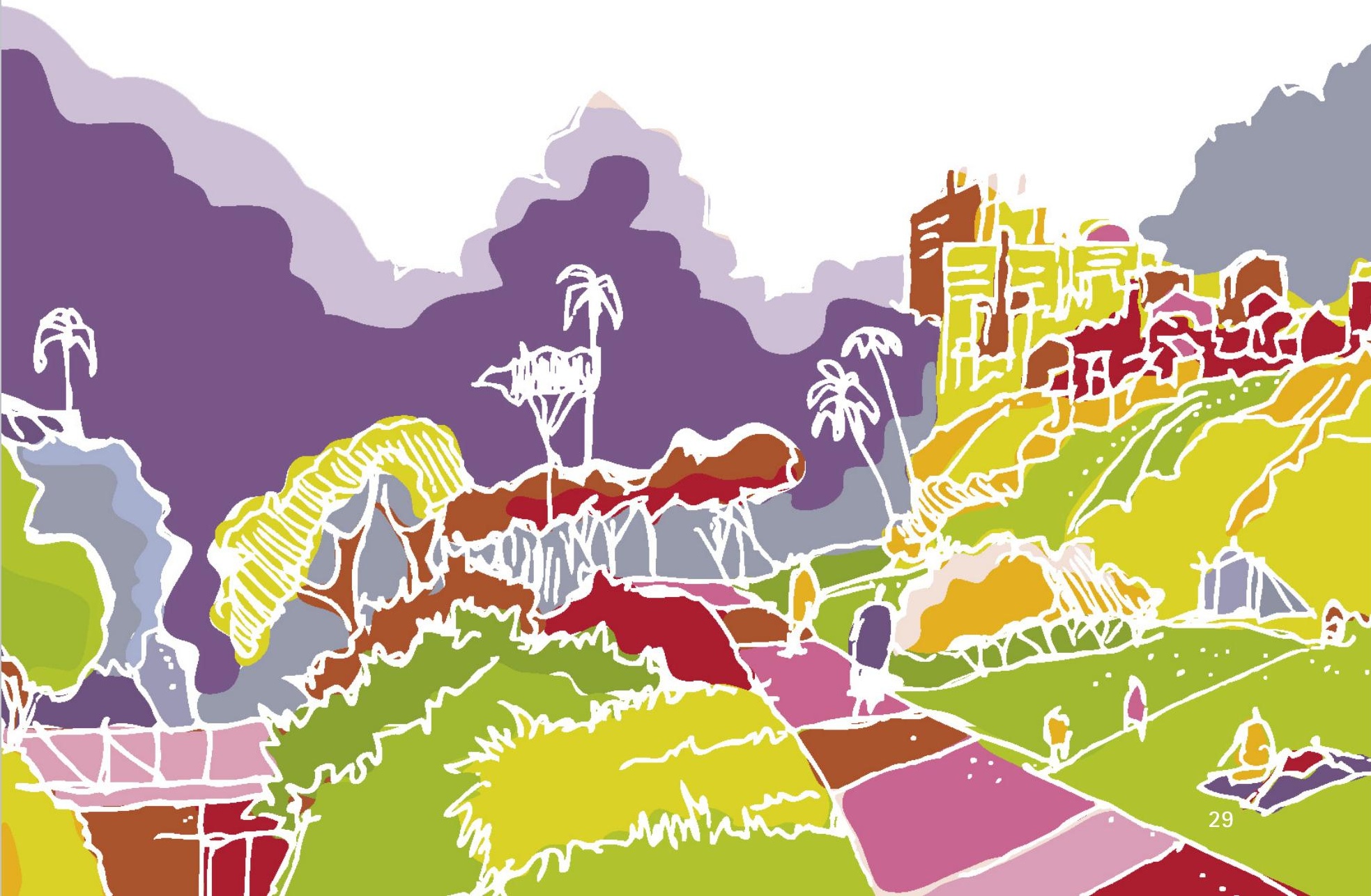


1 De autoria de Silvio Soares Macedo e Francine Sakata, conta a história dos parques no Brasil e apresenta seus principais exemplares, distribuidos por 17 cidades brasileiras. Resultou de uma pesquisa sobre parques e praças, feita por órgãos públicos, que começava com a cata dos projetos e seguia com levantamentos fotográficos, desenhos de campo para ajuste dos caminhos e marcação das massas de vegetação, processamento gráfico em novos desenhos e, por fim, análise das obras.

MACEDO, Silvio S.; SAKATA, Francine. Parques Urbanos no Brasil. São Paulo: Edusp, 2001.
Em um trecho do livro Parques urbanos no Brasil ${ }^{1}$, escrito ainda no século XX, Macedo e Sakata (2001, P. 14 e 15) disseram: o “[...] parque urbano é todo espaço de uso público destinado à recreação de massa, qualquer que seja o seu tipo, capaz de incorporar intenções de conservação e cuja estrutura morfológica é autossuficiente, isto é, não é diretamente influenciada em sua configuração por nenhuma estrutura construída em seu entorno”. Nessa época considerou-se que para um parque ser definido como tal era preciso haver: apropriação social; usos múltiplos de lazer; algum grau de isolamento da cidade para usufruto dos frequentadores; relativa independência do parque em relação ao entorno. Tais caraterísticas distinguiam os conceitos de parque e praça.

Entre 2000 e 2017, surgiram muitos parques que não se enquadravam neste conceito. Alguns eram espaços com nomes de parque, mas não proporcionavam os usos recreativos característicos destes. Áreas que a legislação ambiental quis proteger - que podem ter potencial para se tornarem espaços de visitação e lazer - foram decretadas parques. Existiam, também, casos opostos: espaços com o uso característico, ocupados pela população nos finais de semana, mas sem a denominação "parque”. Categorias variadas de espaços livres, como praças, também passaram a ser chamadas parques. Tais fatos dificultavam a tarefa de classificação - e ainda mais a gestão.

0 nome "parque" foi adotado para caracterizar logradouros como espaços públicos de proteção ambiental ou de lazer, mas não necessariamente com ambas características. Em São Paulo (SP) a adoção da categoria parque ocorreu para mudar a gestão do espaço, que passa a ser de responsabilidade da SVMA, que possui quadros funcionais e recursos específicos. Por esse motivo - relativo à gestão - e, também, para inflar o número de parques criados em determi- 
nada gestão administrativa, algumas praças foram assumidas pela SVMA e denominadas parques. Eram cercadas quando conveniente e fechadas à noite.

Estamos interessados nesta tese tanto nos espaços com características tradicionais de parque quanto naqueles que foram denominados desta forma. Alguns casos deixam claro que não se tratam de parques mas outros apontam a necessidade de rever o conceito de parque para que seja possivel inclui-los nesta categoria.

\subsection{0 parque urbano nos séculos $X I X$ e $X X$}

0 parque urbano do imaginário coletivo - com bosques, gramados, caminhos e equipamentos para jogos e brincadeiras - é um tipo de espaço urbano que surgiu na Europa como consequência da Revolução Industrial, da necessidade de prover as cidades com espaços para recreação das massas que se urbanizaram, habitando grandes cidades industriais congestionadas e poluídas. Mas a imagem romântica e idealizada do parque antecede o século XIX: é a composição de campos gramados, bosques e lagos acomodados sobre o terreno suavemente modelado, que havia sido aplicada na reconfiguração das propriedades rurais inglesas.

A ideia do parque como lugar de trocas sociais surgiu ainda antes, entre os aristocratas dos séculos XVl e XVll, sem comportar o povo, muito menos esportes. 0 hábito de passear por jardins aristocráticos e avenidas arborizadas (ou boulevards) é relatado a partir do final do século XVl em algumas cidades europeias, desenvolvendo-se na Espanha, Itália e França, nas cidades da América espanhola e no Brasil. 0 passeio público do Rio de Janeiro (1783), encomendado a Mestre Valentim pelo vice-rei do Estado do Brasil, prestava-se a embelezar a cidade nos moldes europeus e servir de passeio para a elite local, que trajava vestidos e casacas pesadas sob o sol dos trópicos enquanto contemplava o mar. FIGURAS (1.01) (1.02) 
Vaux-le-Vicomte (1653), França. Os jardins projetados por André Le Nôtre eram lugar de afirmação de status e de festas cenarizadas. Em 1661, Luís XIV confiscou o palácio e tomou-o para si.
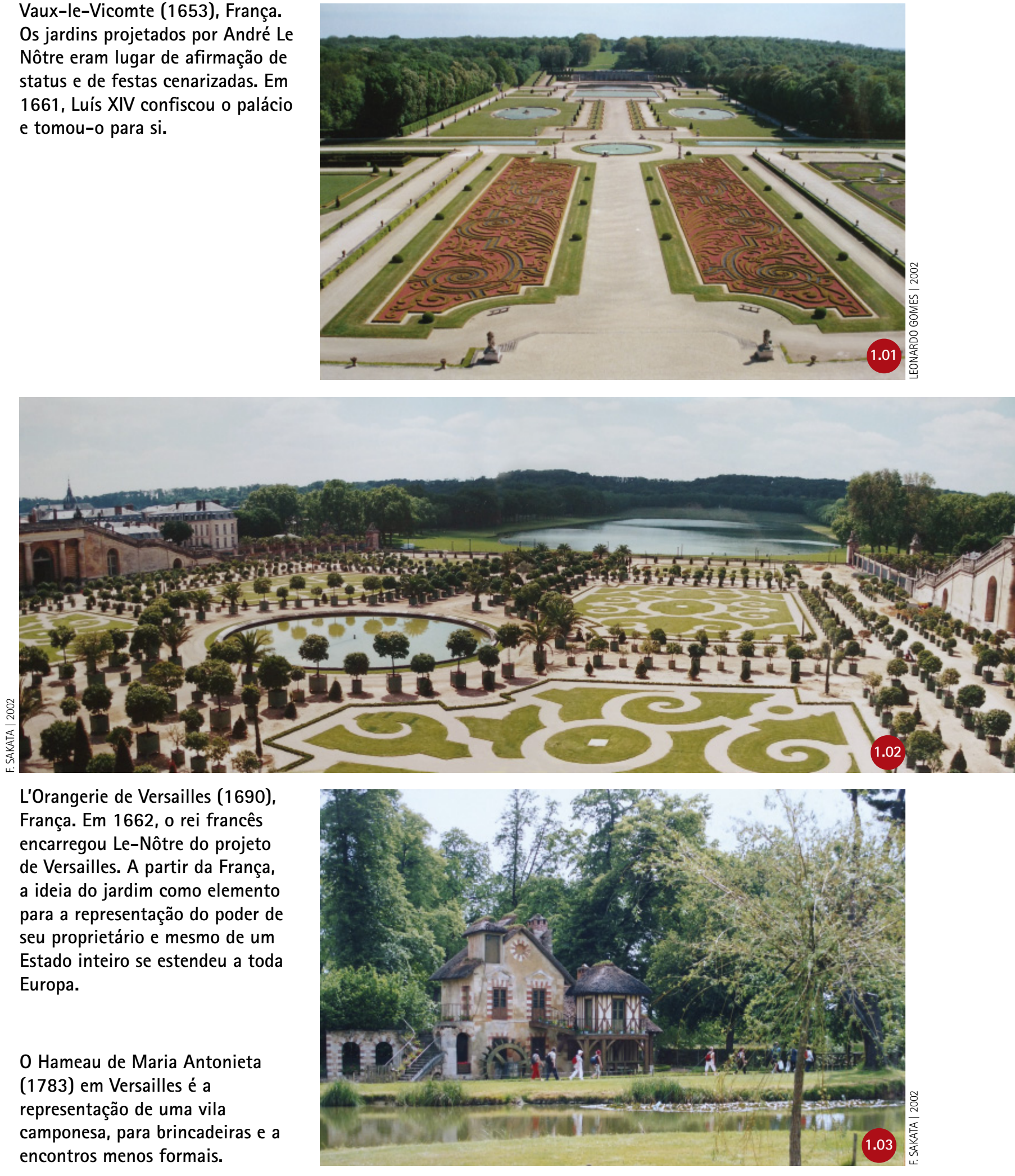
A Inglaterra, no cenário dos latifúndios, não adotou o estilo geométrico dos jardins italianos e franceses e forjou um novo estilo paisagístico. No século XVIIl, intensificou-se a privatização das terras públicas, os commons, e muitos camponeses foram obrigados mudar para as cidades, havendo muitas propriedades a serem modeladas e fortunas disponiveis para isso. Uma residência de campo em Chiswick, construída em 1725 nos arredores de Londres, construída junto do grande jardim pitoresco ao redor da mansão clássica, com caminhos serpenteantes, bosques de aspecto natural, tanques, obeliscos e pequenos templos. 0 jardim era montado com etapas de visitação repletas de citações poéticas e históricas: um templo grego aqui, um pagode chinês mais à frente. ${ }^{2}$

Segundo Panzini, para os proprietários rurais das classes elevadas, as paisagens campestres se tornaram recursos cênicos nos quais a nação era apresentada como a nova Roma republicana, a caminho da grandeza imperial. Assim, os fragmentos das épocas antigas presentes nos parques não se referiam ao passado, mas ao futuro da lnglaterra, numa espécie de inversão histórica.

Lancelot Brown (1715-1783) desenhou mais de 170 parques com uma técnica que consistia em valorizar o que estava presente, remodelando o terreno com sequências de concavidades e convexidades, com matas serpenteantes, laguinhos acomodados em suaves depressões. William Chambers acrescentou ainda mais efeitos ou surpresas visuais que Lancelot Brown, a fim de suscitar sensações nos visitantes. 1.04

A visão de parque que temos no início do século XXI e os princípios de projeto da paisagem devem muito à escola inglesa. 0 parque do lbirapuera (1940) foi modelado e plantado nesses termos e segue como referência no século XXI. Muitos dos parques executados no país nos anos 2000 são simplificações deste ideal.

No século XVIII, ao lado do nascimento do jardim à inglesa, nasceu também uma nova categoria de espaço livre: o jardim público. De início eram particulares, abertos ao uso coletivo pelas classes urbanas emergentes que ansiavam reproduzir modos sociais da elite. 0 estilo paisagístico romântico e naturalista das propriedades rurais foi transposto para as cidades em residências, praças e parques. 0
2 Franco Panzini escreve a história da arquitetura da paisagem, incluindo a história dos jardins e parques públicos de forma detalhada, cronológica e clara. Os parques públicos são apresentados como construções coletivas: o autor soma acontecimentos na França, na Inglaterra, no Oriente, na Alemanha, nos Estados Unidos e no Brasil, que contribuíram para a construção dos parques como conhecidos hoje.

PANZINI, Franco. Projetar a natureza: arquitetura da paisagem e dos jardins desde as origens até a época contemporânea. São Paulo: Senac São Paulo, 2013. 
Kew Gardens (1761), Londres. William Chambers inspirou-se nos jardins orientais que, segundo ele, suscitavam sensações nos visitantes, e criou sequências de vistas que fossem "sedutoras", "tenebrosas" ou "agradáveis". A criação de sequências de vistas que surpreendam o visitante é ainda hoje objetivo de muitos trabalhos de arquitetura paisagística.
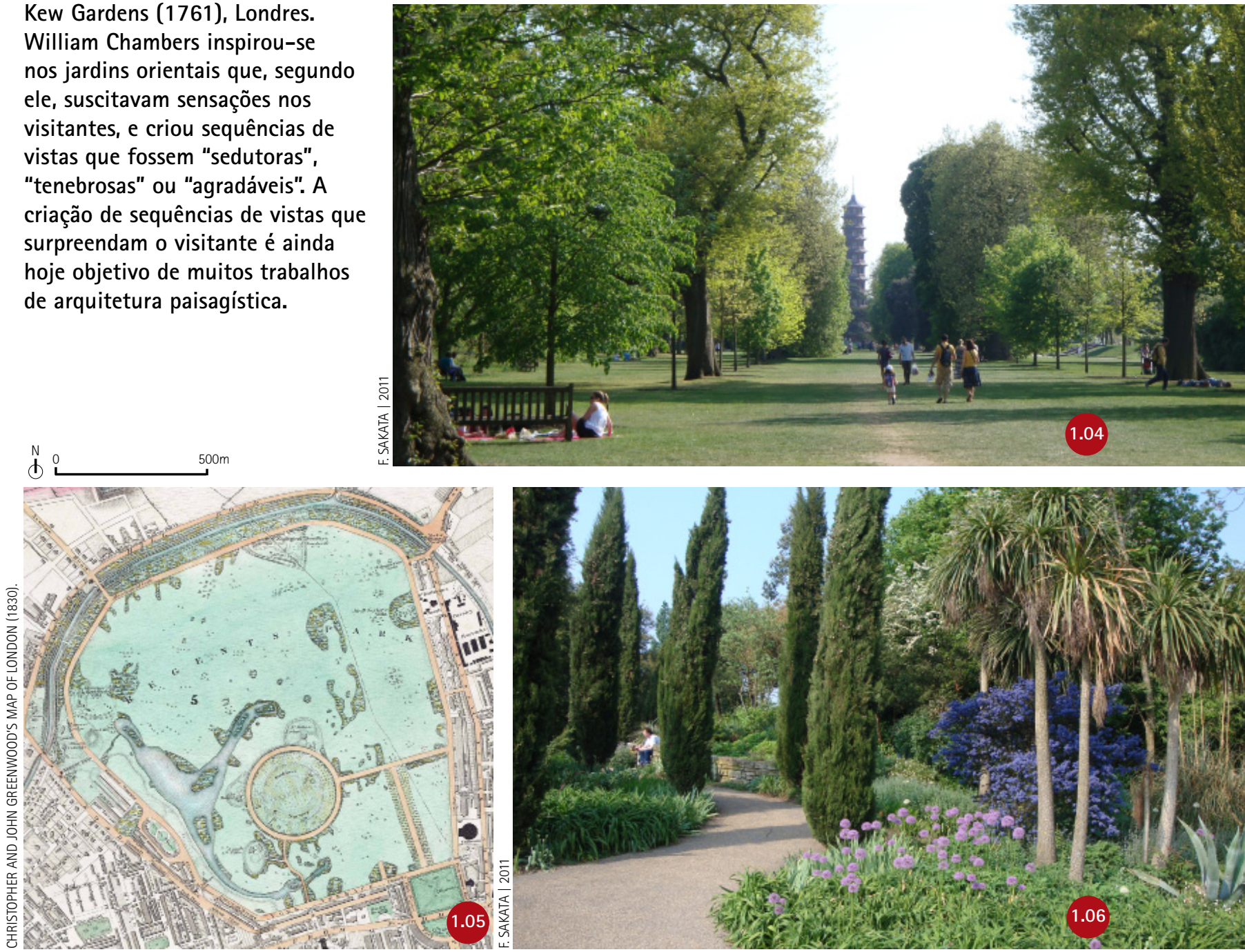

The Regent's Park (1810), projetado por John Nash. Inicialmente era aberto duas vezes por semana, mas se podia caminhar diariamente nas calçadas em sua volta.

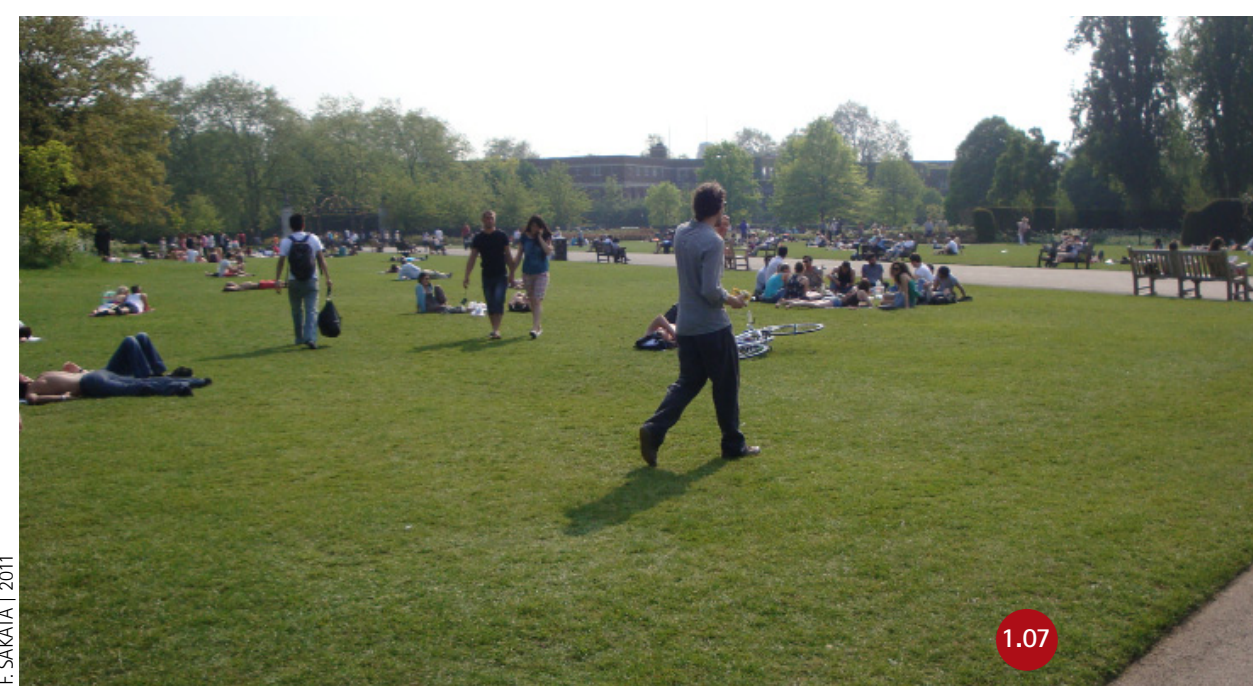


Regents Park (1810) foi o primeiro parque de grandes dimensões a unir o estilo inglês com o uso de parque urbano e a comercialização das ricas habitações dispostas no entorno da área verde. ${ }^{3} 0$ conceito de parque público urbano foi consolidado no Birkenhead Park (1843), próximo de Londres. Concebido por Joseph Paxton, foi o primeiro parque criado a partir de fundos públicos para o uso do próprio público. $^{4}$ 1.05 1.06

A cidade de Paris foi redesenhada a partir de seu sistema de espaços livres. Entre 1853 e 1870, o Barão de Haussmann dirigiu um plano colossal de renovação urbana cuja marca foi a criação de uma rede hierarquizada de espaços verdes, definidos pelas dimensões
Parc Monceau (reformado em 1861), em Paris, tem uma colunata imitando uma ruína em meio ao espelho d'água e a gramados suavemente modelados. A burguesia da época construiu palácios em torno do parque.
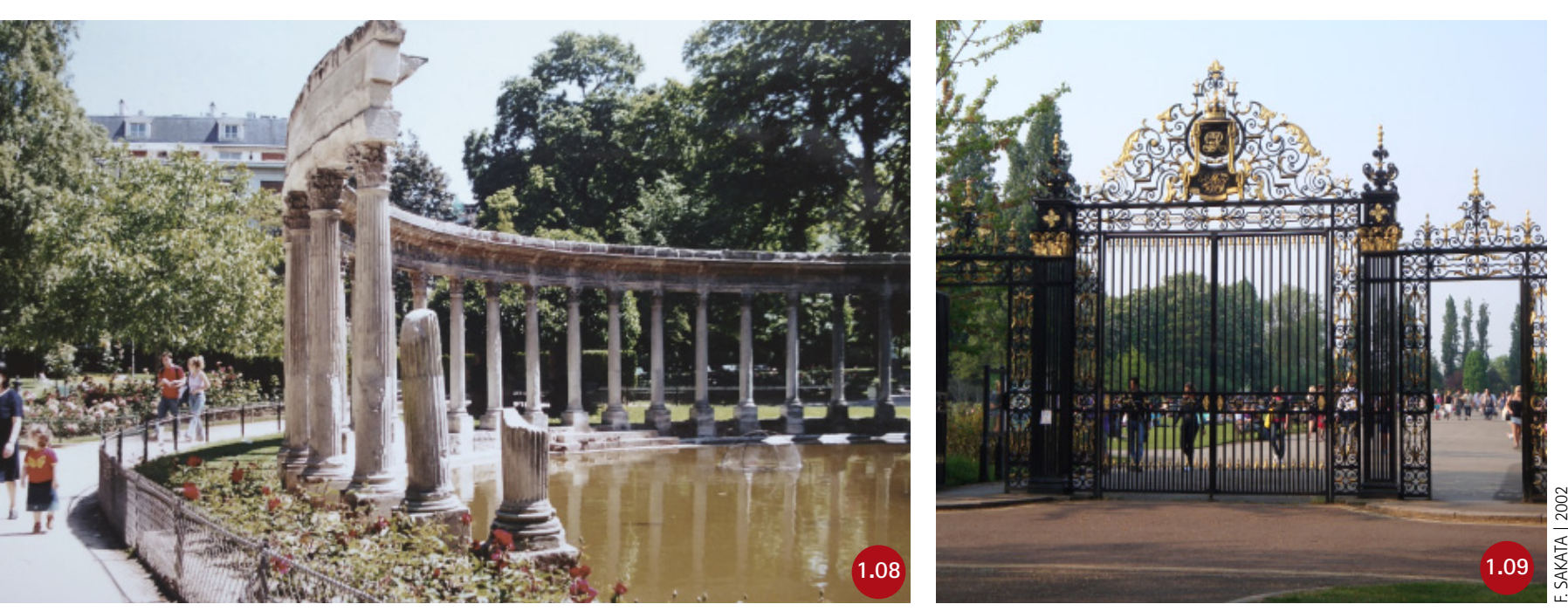

e funcionalidades em relação ao raio de influência: dois grandes parques, destinados a toda a metrópole, situados em quadrantes opostos; parques menores nos bairros em formação; pequenos espaços verdes no centro histórico; ruas arborizadas. Adolphe Alphand foi o paisagista encarregado de produzir parques ricamente ornamentados por riachinhos, pedras e grutas moldadas em concreto, pontes de concreto imitando troncos de madeira, quiosques e suportes para cartazes em ferro fundido. Esta natureza idealizada foi construída com o que havia de mais sofisticado na indústria. ${ }^{5}$

No século XIX, nos Estados Unidos, foram estruturados importantes parques em grandes extensões de terra no entorno das cidades, 36
30 texto de Jellicoe, publicado em 1975 , é referência sobre a história do paisagismo.

JELLICOE, Geoffrey e Susan. El paisaje del hombre. Barcelona: Gustavo Gili, 1995. p. 268

4 LIMA, Catharina P. C. dos Santos. Natureza e Cultura: o conflito de Gilgamesh. Paisagem e Ambiente: Ensaios, São Paulo, n. 18, 2004, p. 7-57.

5 PANZINI, Franco. Projetar a natureza: arquitetura da paisagem e dos jardins desde as origens até a época contemporânea. São Paulo: Senac, 2013. 
Central Park (1857), Nova York, foi categorizado como parque regional, porque exige maior grau de gestão em relação aos parques locais menores. compradas pelos governos para se configurarem como áreas de lazer. 1.101.11

Para Catharina Lima, os parques, jardins urbanos e cidades-jardins representam as formas que o século XIX encontrou para reconciliar a ação humana com os processos naturais. Essa busca é recorrente na história da civilização, e, em cada periodo histórico, assume configurações diferentes ${ }^{6}$. Na Europa, após a Revolução Industrial, a natureza precisou ser cenograficamente inserida no ambiente urbano como forma de compensar a domesticação humana na vida moderna.
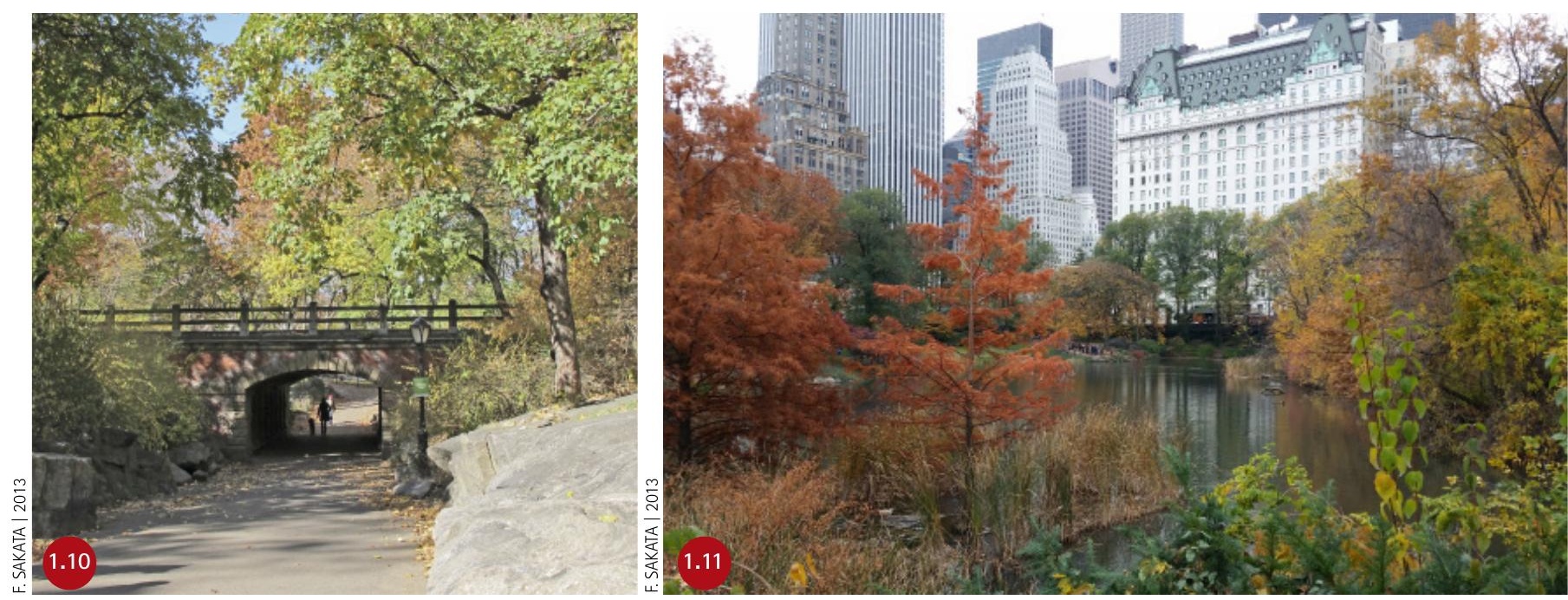

\section{Os primeiros parques no Brasil}

6 LIMA, Catharina P. C. dos Santos. Natureza e Cultura: o conflito de Gilgamesh. Paisagem e Ambiente: Ensaios, São Paulo, n. 18,2004 , p. 7-57.
0 Passeio Público do Rio de Janeiro, criado em 1783, com desenho geométrico de Mestre Valentim, foi totalmente reformulado em 1862 por Auguste Glaziou, a pedido do Imperador Pedro 11, apresentando desenho romântico, curvas sinuosas e lago - como estava sendo feito em Paris, segundo o estilo inglês.

0 Brasil se modernizava, o Rio de Janeiro foi remodelado, e nos principais centros do país sente-se o efeito dessa modernização. Porém, no Brasil do século XIX e na primeira metade do século XX, 
o parque é parte do cenário, um elemento importado, totalmente alheio às necessidades sociais da massa urbana da época, que usufruía de terreiros e várzeas para passeios, banhos, jogos e piqueniques. As cidades cresceram de modo descontínuo e contavam com enormes vazios urbanos, geralmente várzeas de rios, apropriados pela população mais pobre tanto para a moradia quanto para 0 lazer. Apenas a partir da segunda metade do século XX, devido à escassez de áreas para lazer, os equipamentos urbanos de lazer se tornaram uma necessidade social. ${ }^{7}$ (1.12)
Jardim da Luz (1835), São Paulo. 0 Jardim Botânico de São Paulo transforma-se em parque e se torna ponto de encontro dos barões do café e suas famílias. A localização era privilegiada e o parque foi uma das peças na construção da imagem do bairro dos Campos Elíseos.

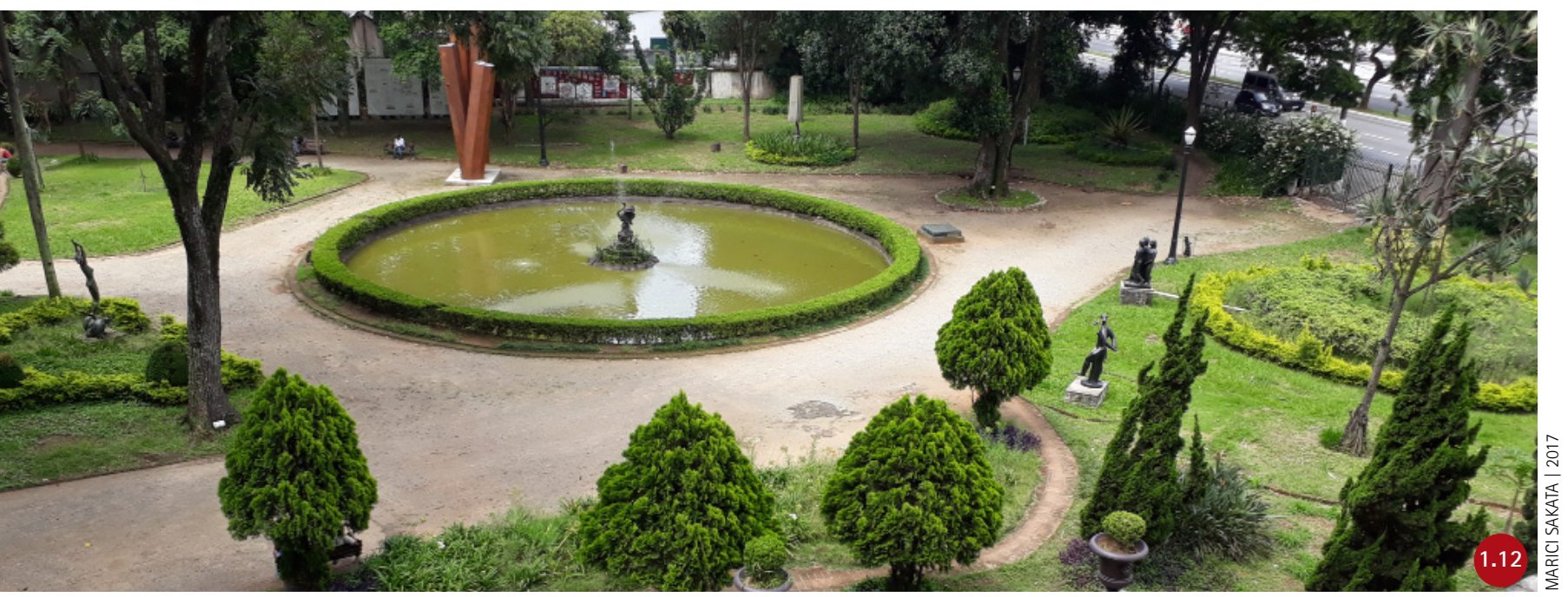

\subsection{Século XX: eclético e moderno}

Em termos de composição paisagística, houve uma fase de mistura estilística entre o final do século XIX e o início do XX, chamada de ecletismo. Entre a tradição do XIX e o experimentalismo do XX, surgiu uma onda revivalista e nacionalista que se traduziu na sobreposição de tendências diversas, na colagem de jardins à italiana, à francesa ou à inglesa.

A arte e a arquitetura moderna se opuseram aos valores do ecletismo. $\mathrm{Na}$ Europa um marco da busca de transpor os princípios modernos
7 MACEDO, Silvio e SAKATA, Francine. Parques Urbanos no Brasil. São Paulo: EDUSP, 2001. 
No filme Mon Oncle (1958), de Jacques Tati, a família burguesa recorre a casa e jardim modernos como símbolo de status. 0 jardim como uma obra de arte geométrica é ridicularizado. A maquete (foto à direita) foi apresentada na Bienal de Veneza de 2014. para a composição dos jardins é a grande Exposition Internationale des Arts Décoratifs et Industriels Modernes (1925) em Paris. Houve estímulo para que os jardins assumissem identidade compatível com a nova arquitetura. Mas, na Europa, os pequenos jardins de formas geométricas e coloridas não deixaram grande legado. 1.13

Nos Estados Unidos, no Japão e no Brasil, a arquitetura paisagística moderna se desenvolve com excelência durante o século XX. No Japão os estilos históricos dos tradicionais jardins japoneses são reelaborados e reinterpretados poeticamente pelos novos autores, sem perder o formalismo e a mística que lhes eram características. Nos Estados Unidos, Thomas Church, Lawrence Halprin, Garrett Eckbo e
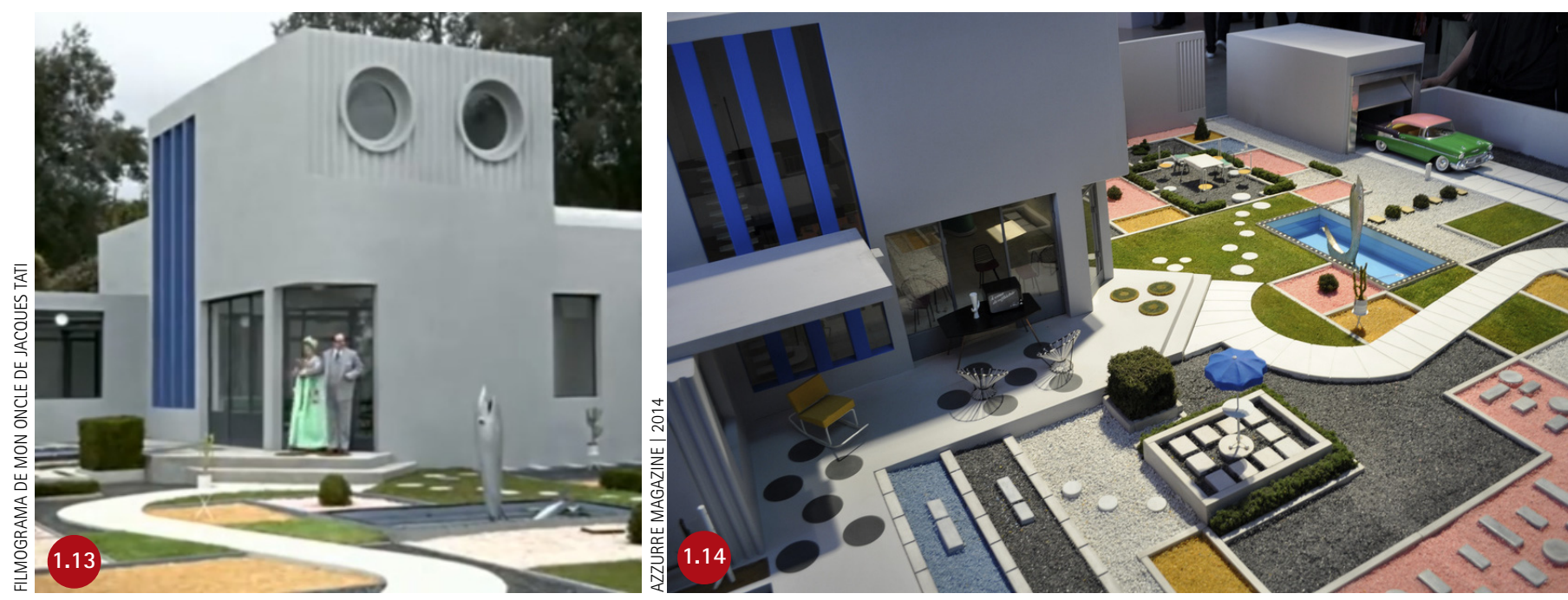

8 PANZINI, Franco. Projetar a natureza: arquitetura da paisagem e dos jardins desde as origens até a época contemporânea.. São Paulo: Senac, 2013. outros arquitetos paisagistas, trabalhando na costa oeste, definem a nova linguagem para o desenho dos jardins - vinculada à arquitetura moderna, com linhas sinuosas ou geométricas mais soltas e amplas, que se encaixam nas paisagens também amplas do país.

No século XX, novas funções e modos de apropriação foram introduzidos nos parques públicos. A recreação infantil exigiu playgrounds e tanques de areia, e a atividade esportiva trouxe para os parques pistas de corridas e de bicicletas, através de alongamento, quadras e campos. Conforme Panzini, o parque moderno, com infraestrutura para a prática esportiva e recreativa ao ar livre, como expressão do lazer das massas, e não da beleza das cidades, surgiu 
na Alemanha. No início do século XX, especialmente após a Primeira Guerra Mundial, foi feito um grande número de espaços verdes para socialização em contato com a natureza - agora vista como imprescindivel fonte de vitalidade. Os Volkspark eram campos circundados por maciços de árvores de espécies europeias, sem concessões ao exotismo, abrigando grande variedade de instalações: campos de atletismo, quadras de tênis, tanques de areia, pista de patinação, piscina infantil e hortas. Também a função de conservação de recursos naturais, até então não comum, foi acrescentada. ${ }^{9}$

Nos Estados Unidos, no início do século XX, o poder público enfatizou a criação de parques de bairro, com piscinas, playgrounds e edifícios cívicos, que serviam também para integrar os imigrantes. Após a Segunda Guerra Mundial, surgiram recursos para a abertura de novos parques, que continuaram focando atividades recreativas e esportivas. 0 espaço verde nos parques urbanos possuía importância secundária. A vegetação era privilégio dos parques naturais, destinados à preservação dos habitat naturais, com incentivo à recreação de baixa intensidade em trechos restritos a áreas de piquenique e trilhas. ${ }^{10}$

No Brasil, a partir das décadas de 1940 e 1950, com a intensa urbanização, os novos hábitos culturais e a diminuição dos espaços livres que podiam ser usados para o lazer, a figura do parque público multifuncional ganhou importância. Alguns jardins botânicos, parques de palácios e terrenos em torno de sedes de fazenda foram convertidos no século XX em parques públicos, que aproveitam a qualidade de seus espaços, originalmente tratados para a elite, para o usufruto da população.

Grandes parques modernos foram construídos a partir dos anos $1940^{11}$. São parques para recreação, concebidos com quadras esportivas, playgrounds e pisos amplos. Mas os caminhos para o passeio apresentam-se sinuosos, à inglesa, entre gramados, bosques e lagos. Há trilhas e pontes, como nos parques do passado, apenas sendo eliminadas estátuas, grutas e recantos. ${ }^{12}$ 1.15 1.10 (1.18)

Nos anos 1960 e 1970, os parques públicos foram feitos com base no naturalismo, também presente nas propostas de novos bairros e cidades dos arquitetos do movimento moderno. Na composição dos espaços livres e da vegetação, prevalecia uma espécie de romantismo. ${ }^{13}$
9 PANZINI, Franco. Projetar a natureza: arquitetura da paisagem e dos jardins desde as origens até a época contemporânea. . São Paulo: Senac, 2013

10 CRANZ, Galen e BOLAND, Michael. Defining the Sustainable Park: A Fifth Model for Urban Parks. Landscape Journal, 23, 2004, p. 2-4.

11 Uma discussão aprofundada sobre os parques públicos e a história dos parques de São Paulo pode ser lida em: BARTALINI Vladimir. Parques públicos municipais de São Paulo: a ação da municipalidade no provimento de áreas verdes de recreação. 1999. 354 f. Tese (Doutorado em Arquitetura e Urbanismo) - Faculdade de Arquitetura e Urbanismo, Universidade de São Paulo, São Paulo, 1999.

12 MACEDO, Silvio e SAKATA, Francine. Parques Urbanos no Brasil. São Paulo: EDUSP, 2001.

13 PANZINI, Franco. Projetar a natureza: arquitetura da paisagem e dos jardins desde as origens até a época contemporânea. São Paulo: Senac, 2013. 

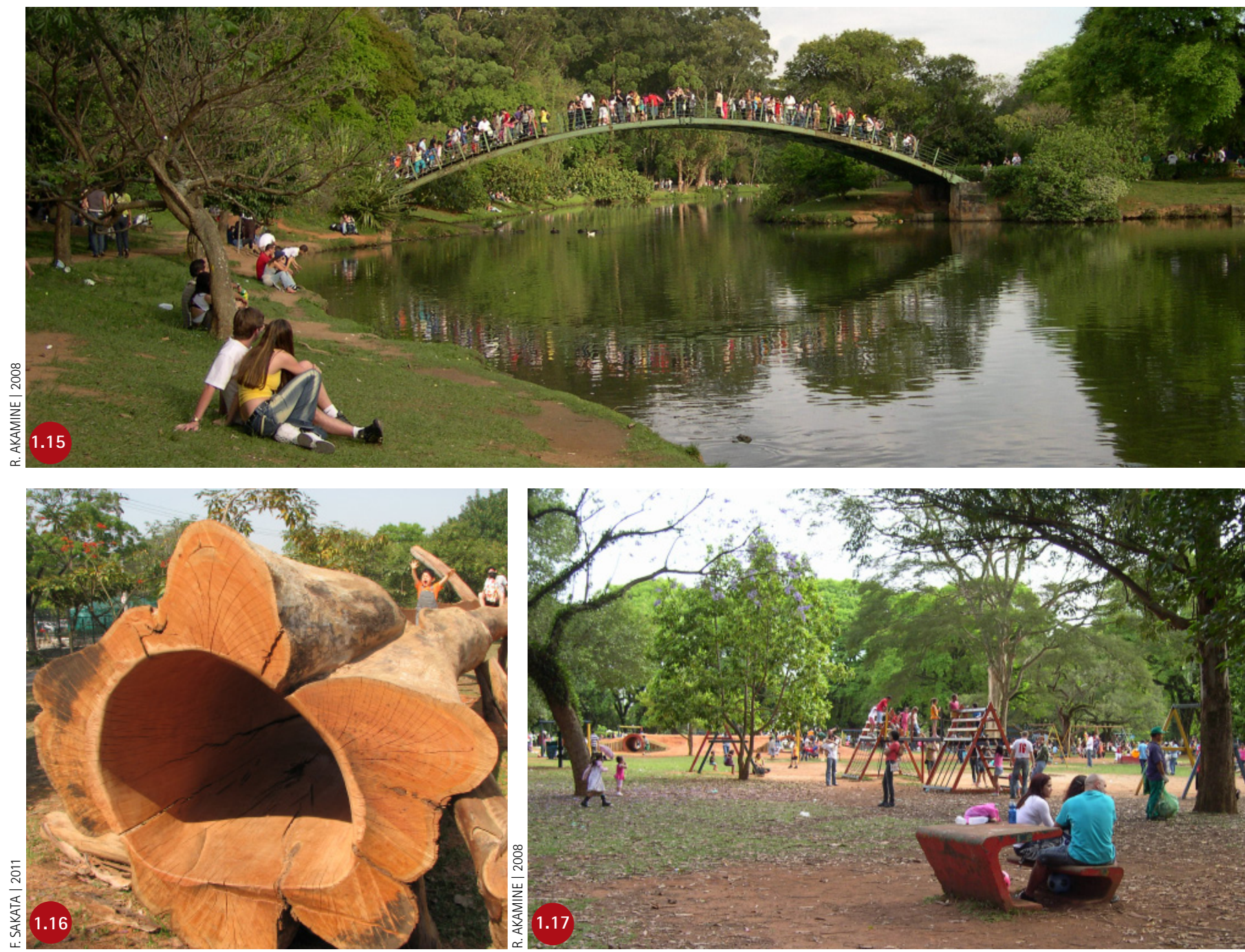

O Parque do Ibirapuera (1954), emSão Paulo, é exemplo de grande parque moderno. Destinase a valorizar a cidade e ao uso recreativo das massas urbanas.

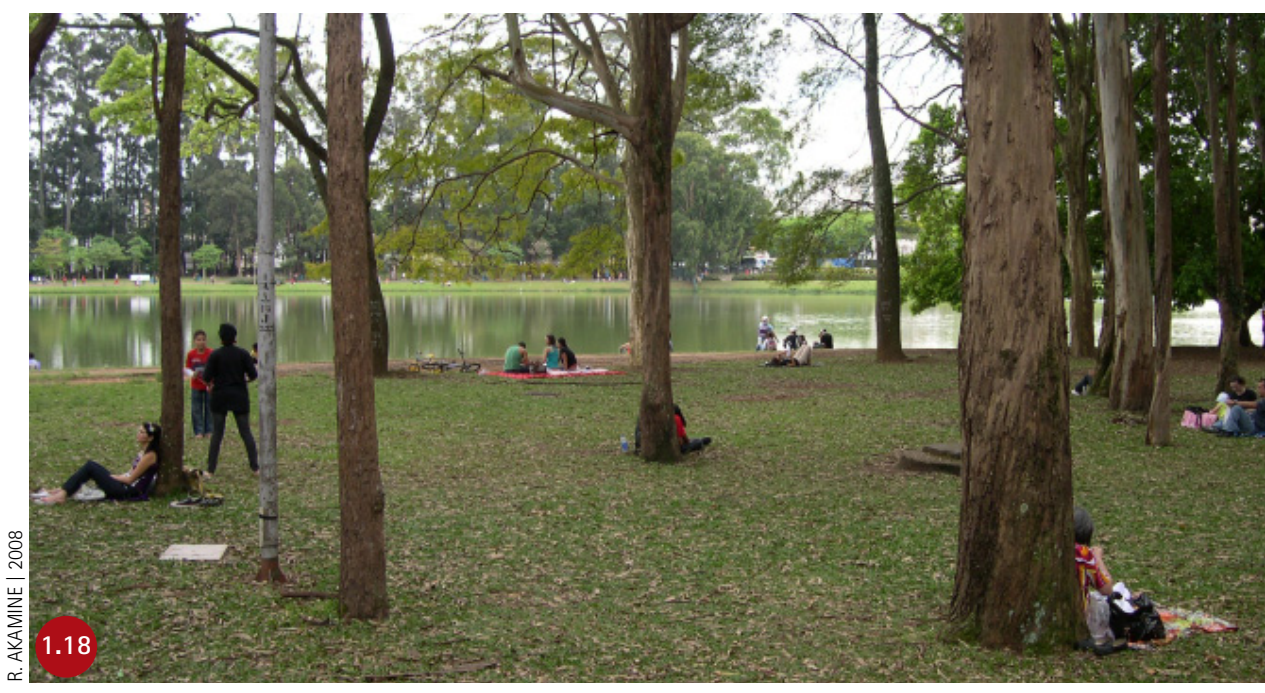




\section{A popularização do parque moderno no Brasil}

Nas décadas de 1970 e 1980, a criação de parques nas grandes cidades brasileiras tornou-se um dos objetivos do poder público, incluído nos programas de governo e na rotina da máquina administrativa. Grande número dos parques das cidades de São Paulo, Rio de Janeiro e Curitiba é deste período, da primeira geração de parques modernos, que possui a característica de serem parques de vizinhança, mais simples que os grandes parques tradicionais. (1.19)

Em Curitiba muitos parques desta década têm estrutura linear, pois acompanham o curso d'água e aproveitam os lagos formados pelos rios, além de bosques já existentes. Estes primeiros parques receberam intervenções discretas. Seus projetos paisagísticos buscavam valorizar os recursos existentes. Vias foram construídas para o acesso aos parques, delimitando-os, e para fiscalização.

A segunda geração de parques em Curitiba (1990 a 2000) teve projetos mais rebuscados, com ornamentos de acordo com temas como a colonização italiana, alemã ou portuguesa. Seguiram a linha inaugurada pelo Parque João Paulo 11 ou Bosque Polonês (1980) e incorporaram a função de símbolo da cidade e de pontos turísticos. Em geral a estrutura destes mais novos parques apresenta núcleo bastante processado, com construções vistosas, e todo o seu entorno possui ambientes naturais preservados ou com poucas intervenções. ${ }^{14}$

Muitos dos parques nos bairros da parte norte da capital paranaense foram criados como forma de prevenir a invasão das áreas por favelas. Inicialmente, o relevo mais acidentado apresentava maior dificuldade para a ocupação e, para prevenir a invasão das faixas de drenagem e os fundos de vale por moradias precárias, uma das ações preventivas foi a criação do sistema de parques. 0 Departamento de Parques e Praças foi estruturado, ficando encarregado também da fiscalização da ocupação. 0 parque urbano, além do lazer, da preservação ambiental e da valorização imobiliária, transformavase, em Curitiba, peça de propaganda da cidade. (1.20) 1.21
14 SAKATA, Francine. Paisagismo Urbano: Requalificação e criação de imagens. São Paulo, EDUSP, 2011. 
Parque Severo Gomes (1989), em São Paulo. Muitos dos parques feitos na cidade a partir de 1970 foram localizados ao redor do centro expandido, em áreas previstas pelos loteamentos ou em antigas chácaras. Foram feitos pelo recém-criado Departamento de Parques e Jardins, desenhados com caminhos, espaços de estar e equipamentos de lazer.

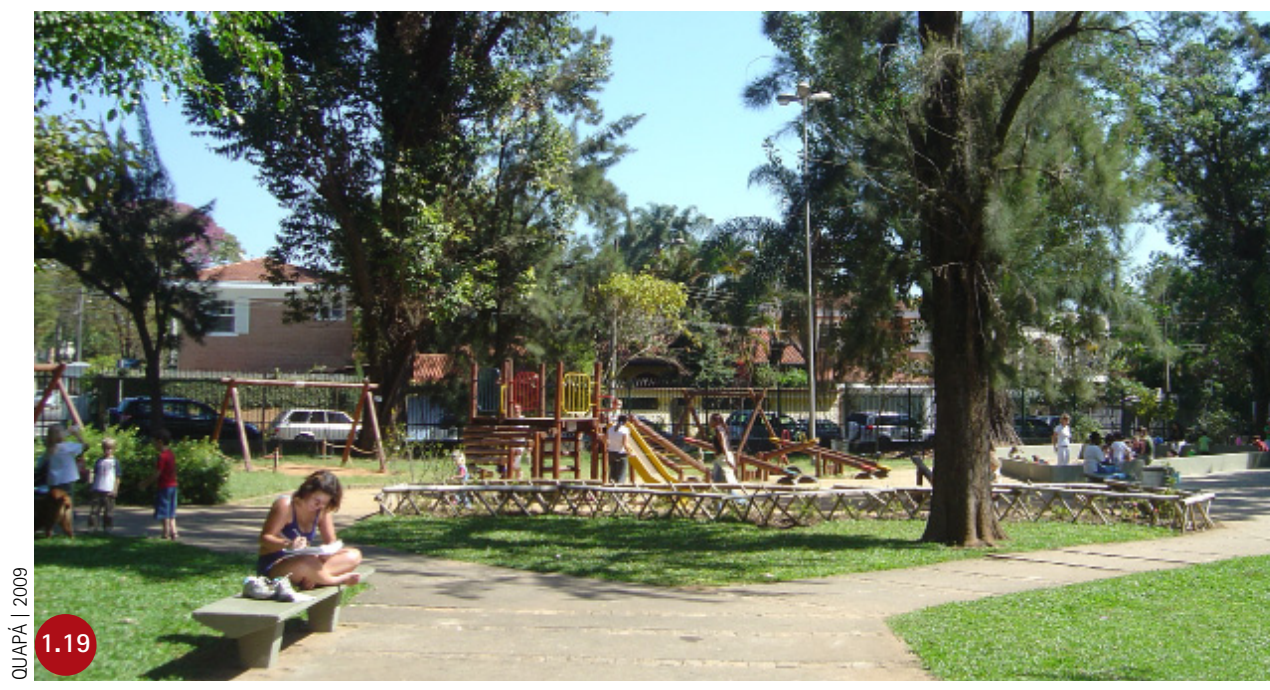

Parque Tingui (1994), em Curitiba, tem uma edificação típica ucraniana como ponto focal. 0 restante do parque recebeu trilhas, gramados e bancos. A via que cruza o parque pode ser percorrida de carro e foi mais tarde aproveitada no percurso do ônibus turístico.

Abaixo, o Parque Tanguá (1996), em Curitiba, feito junto a duas pedreiras interligadas por um túnel com trecho de rio navegável. $A$ transformação de áreas degradadas, como pedreiras, em espaços de uso agrada a população.
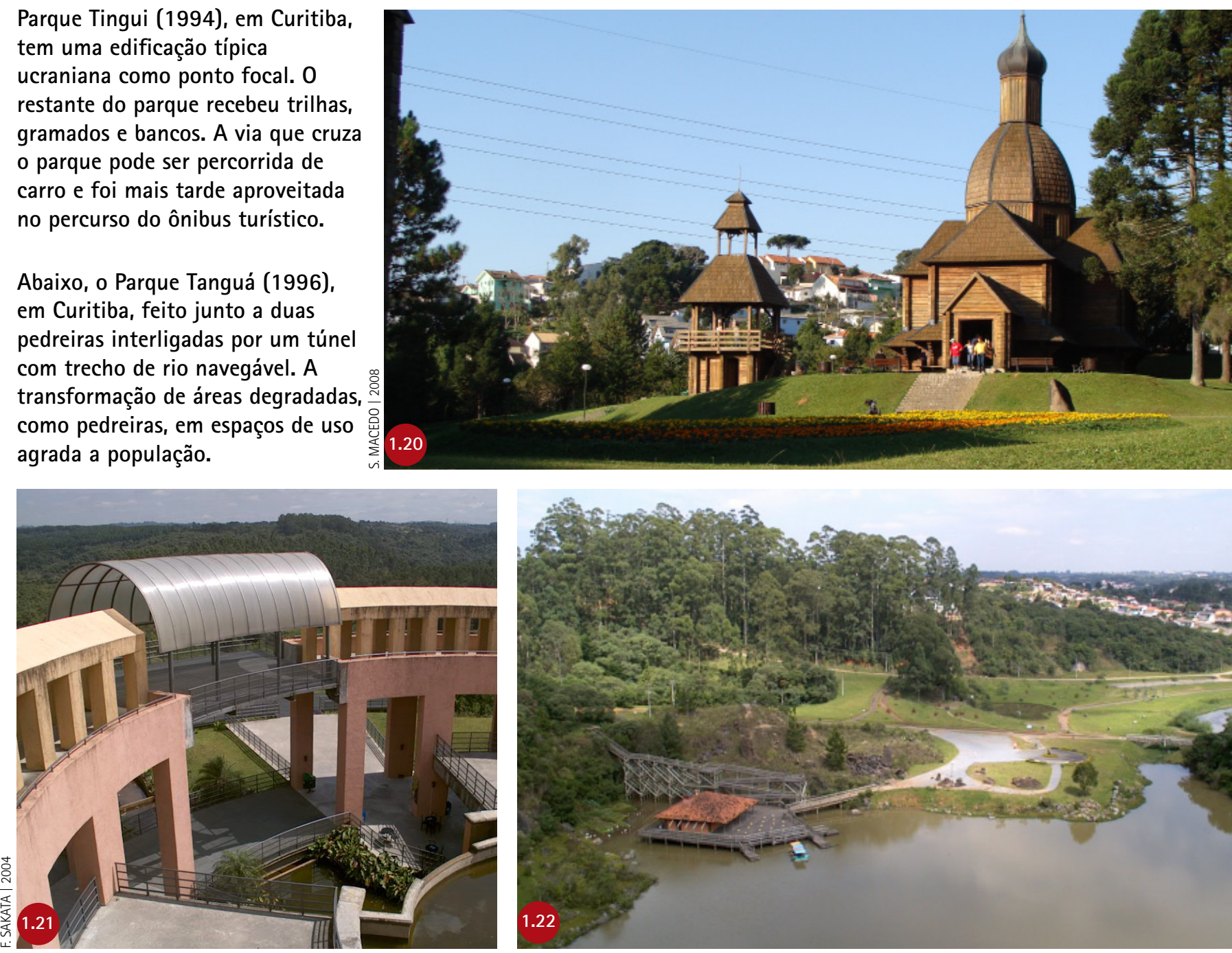


\section{0 conceito de parque no século $X X$}

0 parque tradicional surgiu como peça-chave do urbanismo dos séculos XIX e XX. A ideia do parque urbano traz em si a contradição de fugir do urbano. Foi concebido como um espaço público urbano que pressupõe oposição ao que a cidade representa. A ideia fundadora é a da fuga para um cenário campestre, associado à valorização urbana, à valorização dos loteamentos da classe alta e também da média, que almejava o estilo de vida daquela. Assim o parque tradicional se difundiu no mundo e no Brasil.

Quadro: Oposições associadas a espaços urbanos e a parques

\begin{tabular}{l|l}
\hline $\begin{array}{l}\text { Características associadas aos } \\
\text { espaços urbanos }\end{array}$ & $\begin{array}{l}\text { Características associadas aos } \\
\text { espaços dos parques }\end{array}$ \\
\hline construído & livre \\
\hline coberto & aberto \\
\hline apertado & amplo \\
\hline árido & vegetado \\
\hline sensação de ar poluído & sensação de ar mais limpo \\
\hline preferencialmente seco & com lago \\
\hline pessoas com pressa & pessoas passando o tempo \\
\hline pessoas tensas & pessoas relaxadas \\
\hline com carros & sem carros \\
\hline crianças contidas & crianças ativas \\
\hline $\begin{array}{l}\text { alerta permanente para a } \\
\text { segurança - abordagens, roubos, } \\
\text { sequestro (Brasil) }\end{array}$ & $\begin{array}{l}\text { expectativa de se sentir } \\
\text { relativamente mais seguro }\end{array}$ \\
\hline
\end{tabular}

Imaginariamente, parques são lugares para perceber o espaço aberto, o céu, o sol e a sombra, o calor e o frio, o vento e a chuva. Neles os pedestres não precisam disputar trajetos com carros e outros veículos (disputa desigual). Opõem-se a abrigos e vias e trazem diversidade à rotina. Além disso, não são lugar de trabalho, mas de "tempo livre", que imaginamos empregar, em situações de bonança, em revigorar mente e corpo. 
15 ECKBO, Garret. Urban landscape design. Boston: McGraw-Hill Book Co, 1964 In: CASIMIRO, Matheus de Vasconcelos. 2017. A invenção e reinvenção do parque público paulistano: um olhar sobre a produção municipal. Dissertação (Mestrado em Arquitetura e Urbanismo - Faculdade de Arquitetura e Urbanismo da Universidade Presbiteriana Mackenzie, São Paulo, 2017. P. 87.

16 Idem.

17 BARTALINI, Vladimir. Parques públicos municipais de São Paulo:a ação da municipalidade no provimento de áreas verdes de recreação. 1999. 354 f. Tese (Doutorado em Arquitetura e Urbanismo) - Faculdade de Arquitetura e Urbanismo, Universidade de São Paulo, São Paulo, 1999.

KLIASS, Rosa Grena. Parques urbanos de São Paulo. São Paulo: Pini, 1993.
Este ideal pressupõe o parque com algum grau de isolamento em relação ao entorno urbano. A praça é a categoria de espaço livre onde não se perde a percepção das ruas e construções. 0 parque é o espaço que possui certa independência formal em relação ao entorno - do qual o visitante consegue perceber determinado grau de isolamento.

De acordo com Eckbo (1964), a finalidade do parque público consiste em propiciar interação entre o homem e a natureza:

Parques são espaços com usos limitados e formas flexíveis, desenvolvidos com o mínimo de construção e o máximo de elementos naturais e matérias virgens, destinados para recreação genérica, contemplação, meditação, para dormir ou sonhar, namorar, socialização e para divertimentos informais. São espaços de intensidade limitada sem uso predeterminado. Os espaços do parque são desenvolvidos para criar uma integração intensa entre o homem e a natureza, havendo ajustes para a coexistência de cada um. ${ }^{15}$

0 parque também deve oferecer equipamentos de lazer para recreação coletiva tanto em quantidade como em variedade. Inúmeros autores compartilham da visão de que o parque público urbano é a delimitação de um trecho de sítio dentro da cidade, com predominância de recursos naturais e destinado à apropriação de lazer pela população. Magnoli (2006) atribui a característica da dimensão aos parques públicos. Seriam os elementos integrantes ao Sistema de Espaços livres responsáveis por promover o reencontro do homem com a natureza. Os parques públicos seriam protagonistas dentro deste sistema de espaços da cidade, podendo haver variações quanto à sua dimensão: "escalas, abrangências e ritmos". ${ }^{16}$

Kliass e Bartalini reforçam a função de lazer dos parques urbanos como resposta à intensificação da expansão urbana e ao novo ritmo introduzido pelo tempo artificial da cidade industrial. Os parques se apresentam, ao mesmo tempo, como espaços amenizadores das estruturas urbanas e compensadores das massas edificadas. Ao traçar a evolução dos parques em São Paulo, os autores citados os relacionam com a cidade em que se quer viver e os modelos internacionais transpostos para a realidade paulistana. ${ }^{17}$ 
A partir destas referências, e com base no conjunto de parques brasileiros observados por nós pelo país, definiu-se em 2001 a ideia que esta tese propõe rever: parque urbano é todo espaço de uso público destinado à recreação de massa, qualquer que seja o seu tipo de atividade recreativa, capaz de incorporar intenções de conservação, e cuja estrutura morfológica é relativamente autossuficiente. ${ }^{18} 0$ uso para recreação e lazer das massas urbanas se configurava como peça-chave na definição do parque do século XX e o distinguia dos parques anteriores, reservados a aristocratas e às classes altas.

\subsection{Categorias de espaços livres urbanos e de parques}

A partir da remodelação de Paris, Jean-Claude Forestier lançou em 1906 Grandes villes et systèmes de parcs, fixando uma proposta completa para um sistema de áreas verdes integrado e ampliado para o espaço metropolitano. Estas ideias estiveram presentes como pano de fundo da proposta urbanística de Joseph-Antoine Bouvard para São Paulo. ${ }^{19}$

0 sistema seria composto de:

- grandes reservas e paisagens, deixadas em estado natural em lugares quase sempre distantes;

- parques suburbanos, distribuídos regularmente, segundo a necessidade das cidades, com árvores e gramados e o menos possível de ruas, construções e ornamentos inúteis;

- grandes parques urbanos, lugares de passeios e jogos, para o embelezamento das cidades;

- pequenos parques (jardins de bairro), ou puramente ornamentais, ou áreas para jogos e exercícios, distribuídos amplamente e ao alcance de todos, a não mais de $2 \mathrm{~km}$ de distância das famílias;

- áreas de recreação, pequenos terrenos com 2.000 a 3.000 m², numerosamente distribuidos, especialmente em bairros onde crianças não têm onde brincar;

- hortas-educadoras, para cidades menores, para que as crianças aprendam sobre horticultura e agricultura;
18 MACEDO, Silvio e SAKATA, Francine. Parques Urbanos no Brasil. São Paulo: EDUSP, 2001.

19 BARTALINI, Vladimir. Parques públicos municipais de São Paulo: a ação da municipalidade no provimento de áreas verdes de recreação. 1999. 354 f. Tese (Doutorado em Arquitetura e Urbanismo) - Faculdade de Arquitetura e Urbanismo, Universidade de São Paulo, São Paulo, 1999, p. 86-87.

Utiliza-se aqui o termo hortas-educadoras em substituição à Jardins d'Enfants (traduzido por Bartalini como "Jardins de infância"). Jardim da infância remete à ideia de creche. As hortas-educadoras ressurgem contemporaneamente, para lazer, sociabilização e alimentação. 
20 Sobre os objetivos de Olmsted para fundir paisagem e infraestrutura recomenda-se:

BONZI, Ramón Stock. Emerald Necklace - Infraestrutura urbana projetada como paisagem. $L A B V E R D E n^{\circ} 9$, dez. 2014. Disponivel em: http://www.revistas.usp.br/ revistalabverde/article/view/84547

21 KLIASS, Rosa Grena; MAGNOLI, Miranda Martinelli. Áreas verdes de recreação. Paisagem e Ambiente. São Paulo, FAU/USP, n. 21, 2006, p. 245-256.

22 CRANZ, Galen e BOLAND, Michael. Defining the Sustainable Park: A Fifth Model for Urban Parks. Landscape Journal, 23, 2004, p. 2-4.
- avenidas-promenade, vias de comunicação da cidade, que ligam os parques e todo o conjunto para que o passeio nunca seja interrompido; podem contribuir na valorização das visuais, beiras de rio e paisagens interessantes.

Em Boston, entre 1878 e 1895, Frederick Law Olmstead propôs um cinturão de parques de diferentes dimensões interligados por ruas em meio à vegetação. No Emerald Necklace (Colar de Esmeraldas), de Olmsted, os parques são as joias e resolvem, simultaneamente, a provisão de áreas de lazer e as questões de drenagem pluvial. Esta é mais uma categoria de espaços livres: o cinturão de parques, a articulação de uma sequência de parques que, com esta junção, acaba criando a figura de um parque que é a soma das partes. ${ }^{20}$

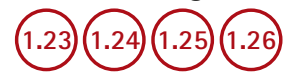

Na década de 1960, em São Paulo, Rosa Kliass e Miranda Magnoli conceberam um sistema integrado de parques para a cidade, o Plano de "Áreas Verdes de Recreação" 21, composto por 29 parques setoriais distribuídos pela malha urbana. As ideias dos sistemas e dos parques lineares de Olmsted foram trazidas pelas arquitetas para São Paulo. Este plano não foi executado e o sistema de áreas verdes foi reduzido violentamente nos anos seguintes. Mas, no campo teórico, foi grande a repercussão e as ideias ali contidas viraram consenso entre acadêmicos e técnicos ao longo dos anos. $\mathrm{Na}$ década de 2000, a criação de parques lineares relacionada a cursos d'água é tributária do plano de Kliass e Magnoli.

Galen Cranz ${ }^{22}$, autora que estuda os parques norte-americanos, identificou quatro tipos de parques urbanos ao longo de quatro gerações. A autora explica que foi como se a cada 30 ou 50 anos cada geração tivesse ideias diferentes sobre como os parques podem contribuir com as cidades. São eles:

- Espaço de lazer (Pleasure Ground), de 1850-1900;

- Parque cultural e esportivo (Reform Park), de 1900-1930;

- Equipamento de recreação (Recreation Facility), de 1930-1965;

- Sistemas de espaços livres (Open Space System), de 1965 em diante.

Durante as duas primeiras eras (Pleasure Ground e Reform Park), os encarregados pelos parques justificavam sua criação enumerando objetivos sociais: reduzir conflitos de classe, reforçar a unidade da 
Paley Park (1967), em Nova York, projeto de Robert Zion. Com $390 \mathrm{~m}^{2}$, é o mais famoso pocket park e permanece hoje exatamente como em 1967, quando foi aberto. Tem uso público e propriedade e gestão da Fundação William Paley. Ao fundo, há uma cascata que transforma o espaço, pela visão, pela umidade e pelo som. A cascata, certamente, inspirou Peter Walker no projeto de 2011 para o Memorial 11 de setembro. família, socializar imigrantes, conter doenças e educar cidadãos. A terceira era - "Equipamentos de Recreação" - começou com Robert Moses, em 1930, no New York City’s Park Department. Para Moses, os parques são serviços públicos tão essenciais, que sequer requerem justificativas. Ele estendeu o serviço para os subúrbios e áreas urbanas que ainda não os possuíam. Foram acrescentados ginásios, quadras de asfalto, estacionamentos, sendo a vegetação secundária nestes espaços. Para o contato com a vegetação, os norte-americanos contavam com os parques naturais - distantes dos centros urbanos, com núcleos de visitação, espaços para piquenique e trilhas rústicas.
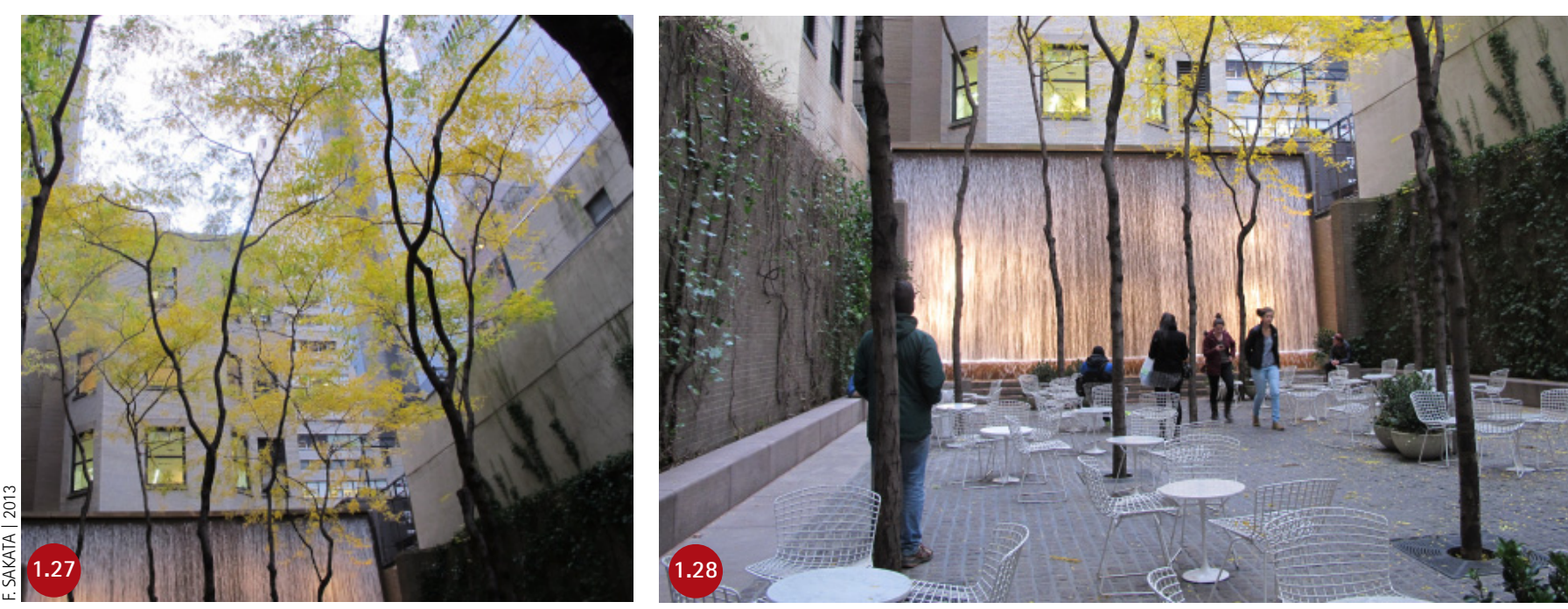

A geração seguinte questionou a padronização e a "esterilidade" das Recreation Facilities. John Lindsey, então candidato a prefeito de Nova York, publicou um artigo e recrutava os arquitetos paisagistas a desenvolverem projetos específicos para cada sítio. Aflorava uma visão mais artística e sensível à cultura popular. Nesta época passou também a vigorar a ideia de que a recreação pode acontecer em qualquer lugar: nas ruas, telhados, waterfronts, trilhos abandonados e até em parques e praças. Cada parque passou a ser entendido como parte de uma rede de espaços conectados. Os parques construídos com a ideologia do Open Space System buscam se integrar aos espaços livres da cidade. (1.27) 
Surgiu na década de 1960 nos Estados Unidos, idealizada por Robert Zion, uma nova categoria de espaço público, os parques de bolso (Pocket Parks), que aproveitavam pequenos lotes, criando áreas de estar e isolamento nas áreas mais movimentadas e valorizadas da cidade. São miniparques em lotes entre os edifícios, com lugar para sentar ao ar livre, para almoçar e, eventualmente, com parque infantil. ${ }^{23}$ No Brasil, alguns foram feitos pontualmente, por comerciantes e eles não figuram nas políticas públicas.

Os calçadões das orlas também são uma categoria de espaços livres tradicional no Brasil, considerada como parque no livro Parques urbanos no Brasil. Calçadões de praia ou de rio, quando estruturados para uso da população, são parques urbanos lineares, nos quais a vegetação cede lugar, como protagonista, à água e à areia. Oferecem usos múltiplos e invariavelmente têm grande visibilidade. Ainda que não sejam isolados fisicamente em relação ao conjunto urbano, os calçadões em geral propõem o isolamento da cidade: olhe para o mar, escute as ondas, dispa-se um pouco. 1.29

No século XXI, no boom de parques sobre o qual aqui se discorre, as capitais litorâneas não tiveram aumento expressivo, como ocorreu nas capitais do interior, com exceção de Vitória. Para atender a interesses políticos e imobiliários e à demanda da população por áreas de lazer e esporte, as cidades litorâneas, no mesmo período, investiram na requalificação de calçadões e orlas.
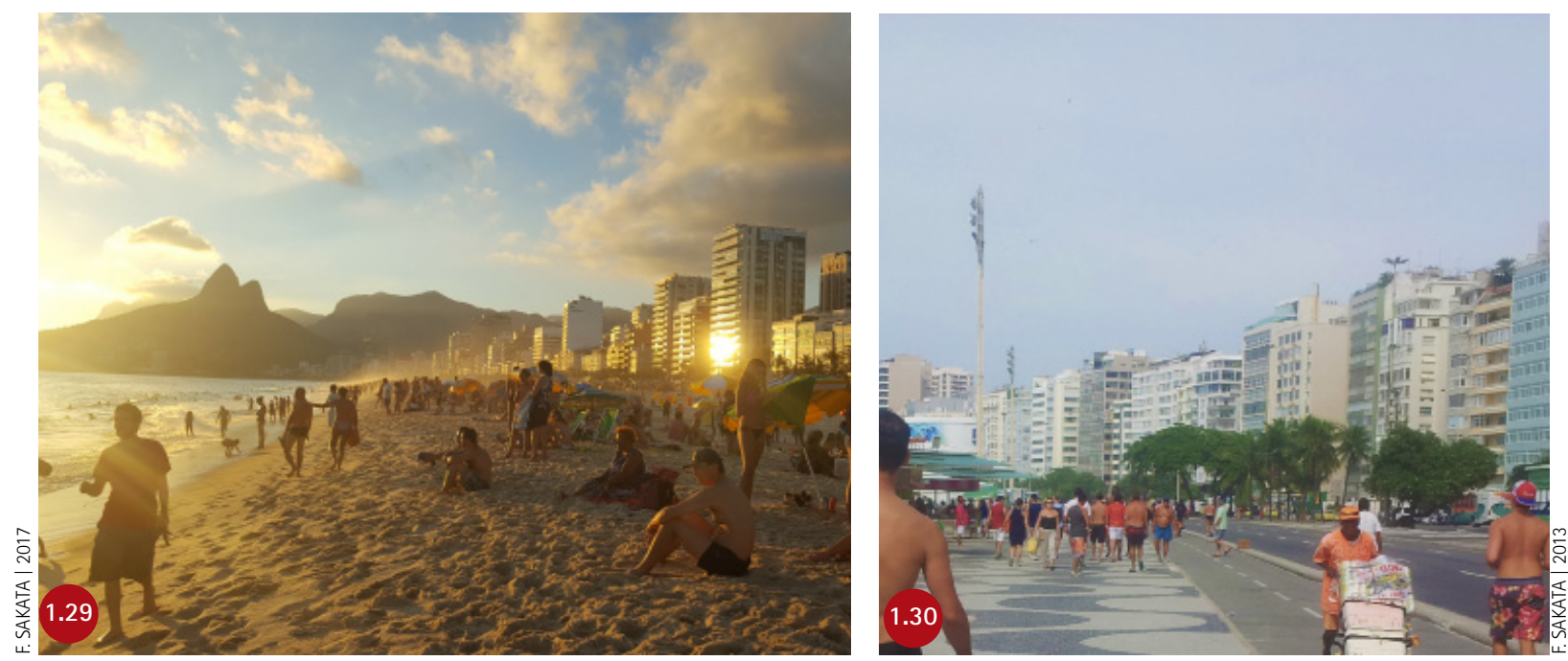

23 Sobre Robert Zion, recomenda-se a leitura de:

BARRA, Eduardo. Paisagens Úteis: Escritos Sobre Paisagismo. Rio de Janeiro: Mandarim, 2006.

Praia de Ipanema, Rio de Janeiro. Nas cidades litorâneas, a orla com seus calçadões e praias é o grande parque linear. 


\subsection{0 parque contemporâneo}

Na Europa, nas últimas décadas do século XX, os parques voltam a ganhar destaque, com a renovação do repertório formal, a incorporação de novos elementos arquitetônicos e a redescoberta do papel de qualificação cultural que poderiam desempenhar. Nos novos parques de Barcelona - Parc de la Creueta del Coll (1987) e Parc Diagonal Mar (2001), e de Paris - Promenade Plantée (1993), Parc de la Villette (1997), Parc de Bercy (1997) e Parc André Citröen (2001) -, são experimentadas novas linguagens: geométricas, amplas e favoráveis à apropriação por grande número de pessoas simultaneamente. Estes parques estão associados, ao mesmo tempo, a interesses imobiliários e políticos de requalificação de áreas em transformação. 1.311.32

No Brasil algumas transformações na forma de conceber o espaço urbano começaram a ficar claras a partir dos anos 1980. Os princípios rígidos modernos estavam sendo contestados e o espaço livre começou a ser projetado com mais liberdade, novas formas, concessões ao consumo, aos revivalismos e à fantasia. 0 livro Parques urbanos no Brasil nomeia esta linha projetual de contemporânea. ${ }^{24}$ (1.34) 1.35

0 conservacionismo, que surgiu como preocupação depois da Primeira Guerra Mundial, foi ampliado no final do século XX. Em 1921, nos Estados Unidos, surgiu a ideia de uma trilha de 3 mil quilômetros na Costa Leste, a trilha Apalache, para que as pessoas conhecessem e contribuíssem com a preservação das paisagens. Nos 100 anos seguintes, novas trilhas foram construídas, conectando parques naturais. Em 2017, o sistema de trilhas possuía 80 mil quilômetros. É um exemplo da dimensão que a ideia de conservação adquiriu mundialmente - até porque, ao mesmo tempo, avançavam com muito mais força a devastação e a poluição em todos os ecossistemas. 1.36 

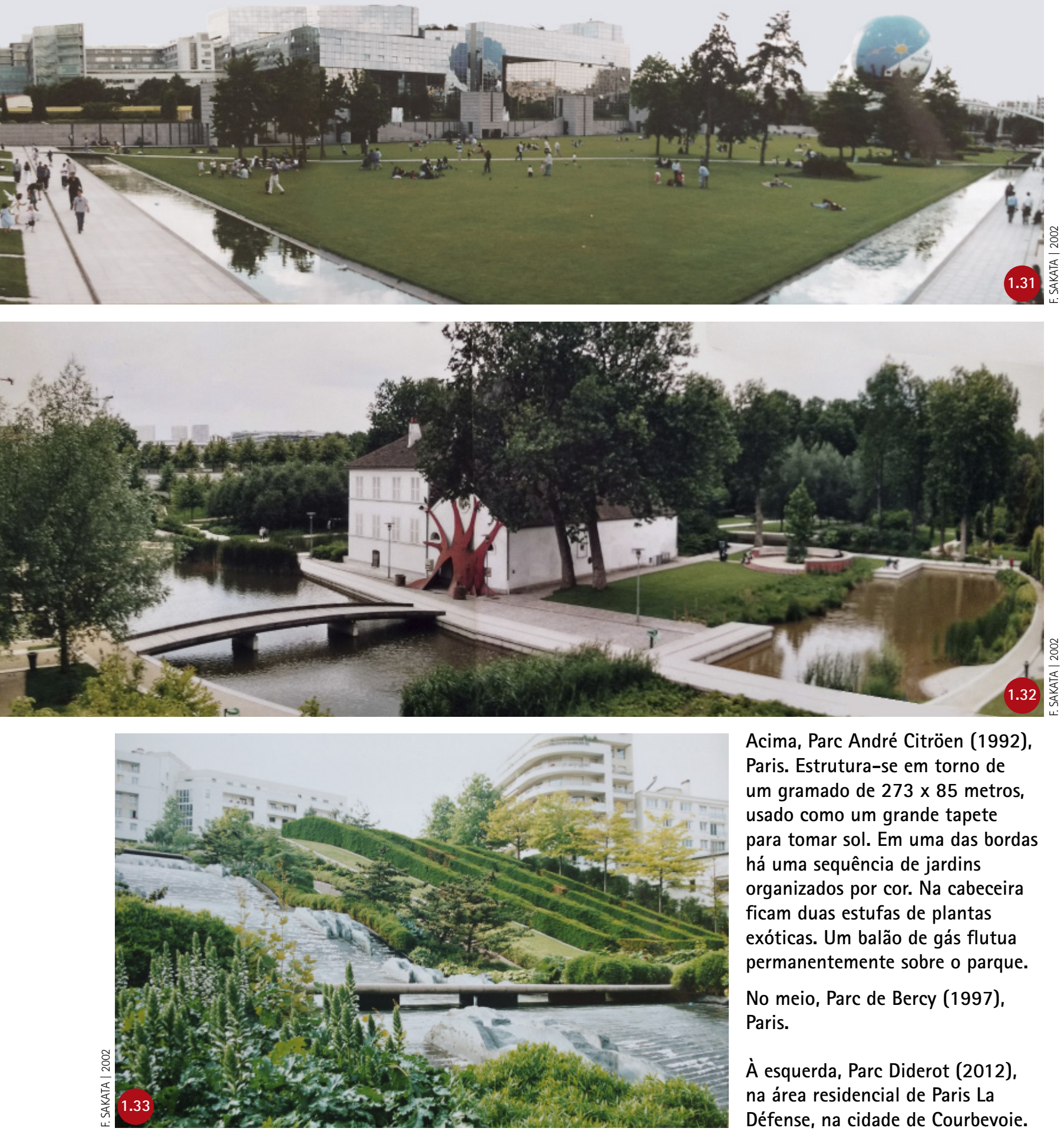

Acima, Parc André Citröen (1992), Paris. Estrutura-se em torno de um gramado de $273 \times 85$ metros, usado como um grande tapete para tomar sol. Em uma das bordas há uma sequência de jardins organizados por cor. Na cabeceira ficam duas estufas de plantas exóticas. Um balão de gás flutua permanentemente sobre o parque.

No meio, Parc de Bercy (1997), Paris.

À esquerda, Parc Diderot (2012), na área residencial de Paris La Défense, na cidade de Courbevoie. 
Um conjunto de espaços públicos de Salvador, criado para valorizar a orla e o turismo, surge ao longo da orla marítima, como os parques Costa Azul (1996) e Jardim dos Namorados (1999), e a praça Nossa Senhora da Luz (2000). Deste período apenas o Dique do Tororó (1998) e o parque das Esculturas (1998) não se voltam para o Atlântico.

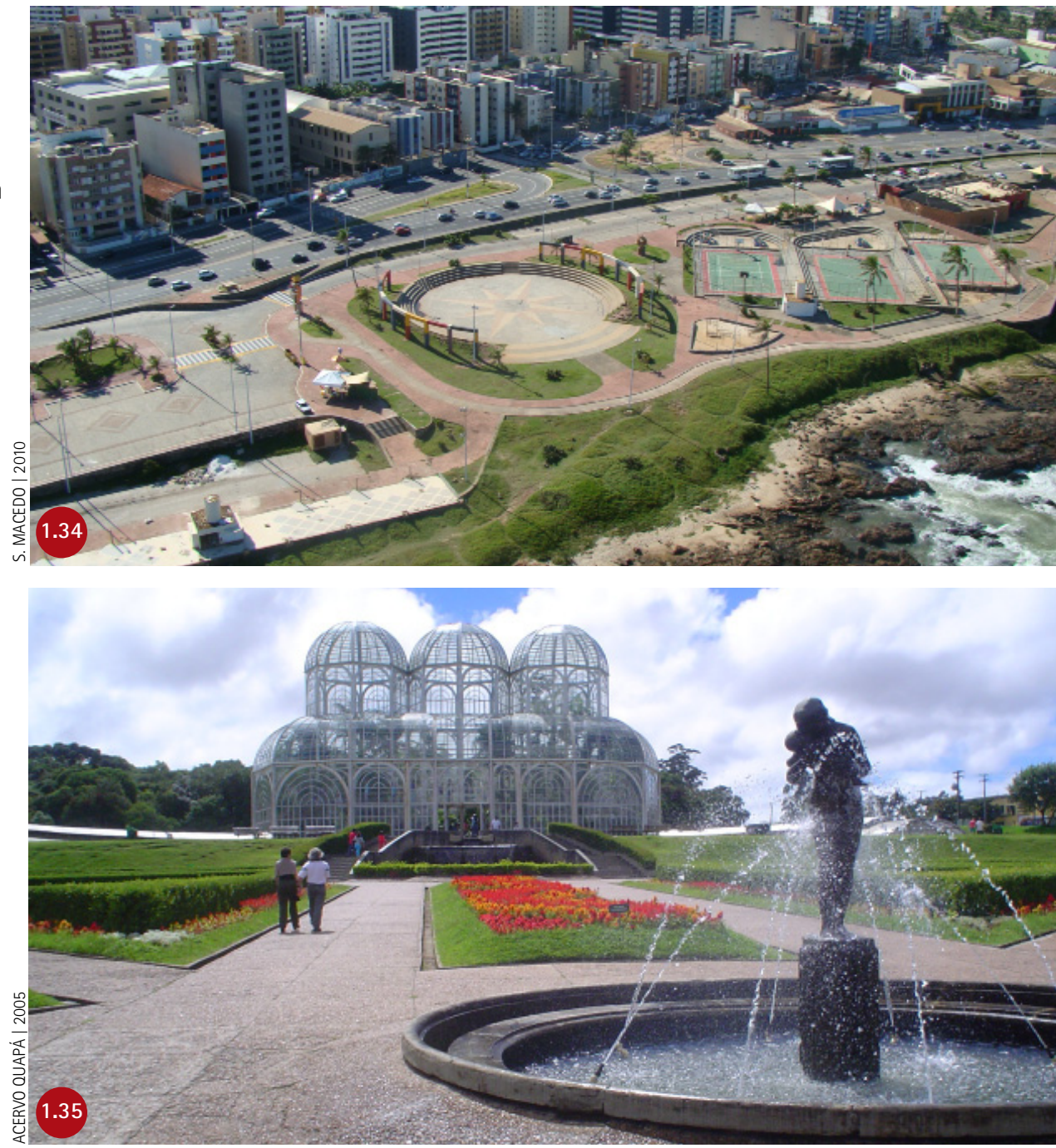

Parque Mello Barreto (1994), Rio de Janeiro. Os parques de Fernando Chacel e Sidney Linhares na Barra da Tijuca combinam manguezal, dunas e a mata atlântica em jardins esteticamente ordenados. Estes parques foram feitos por uma grande construtora que, depois de tratar esta orla, loteou a gleba com apartamentos de luxo - o condomínio Península. A valorização do mangue e da lagoa ajudou a equiparar o preço dos apartamentos com aqueles voltados para a beira-mar.

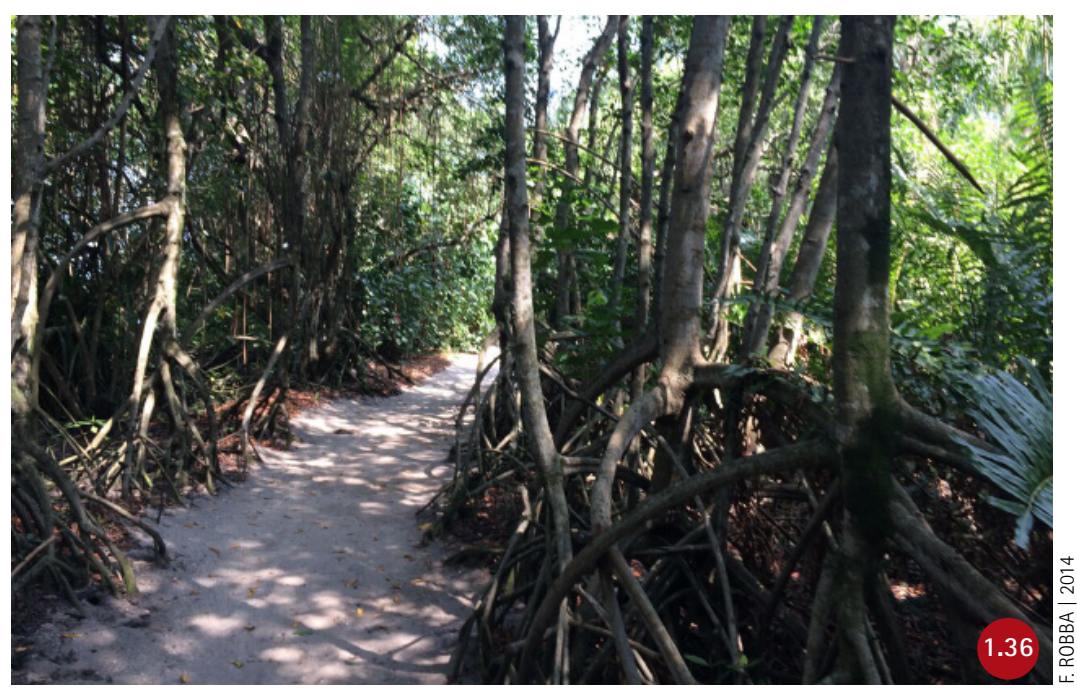




\subsection{Novas categorias de parques pelo mundo}

Nas cidades ricas, muitos projetos de espaços livres impressionantes foram feitos nos anos 2000, na linha dos primeiros parques contemporâneos de Barcelona e Paris. Ainda que seja muito comentado o caso do High Line Park de Nova York, construído com a participação popular sobre uma linha férrea elevada e desativada, as obras de paisagismo mais vistosas dos anos 2000 são, sem dúvida, os waterfronts. Segue uma lista das novas categorias de extensos espaços urbanos para lazer de massa que podem, por isto, ser considerados parques:

- parques lineares inseridos na malha urbana: com comprimento muito maior do que a largura, tornaram-se figuras urbanísticas comuns mundialmente, pois nas malhas urbanas mais densas, muitos espaços livres que poderiam ser convertidos em parques tinham formato linear - os terrenos de antigas ferrovias ou viadutos demolidos; 1.37 (1.38) 1.39

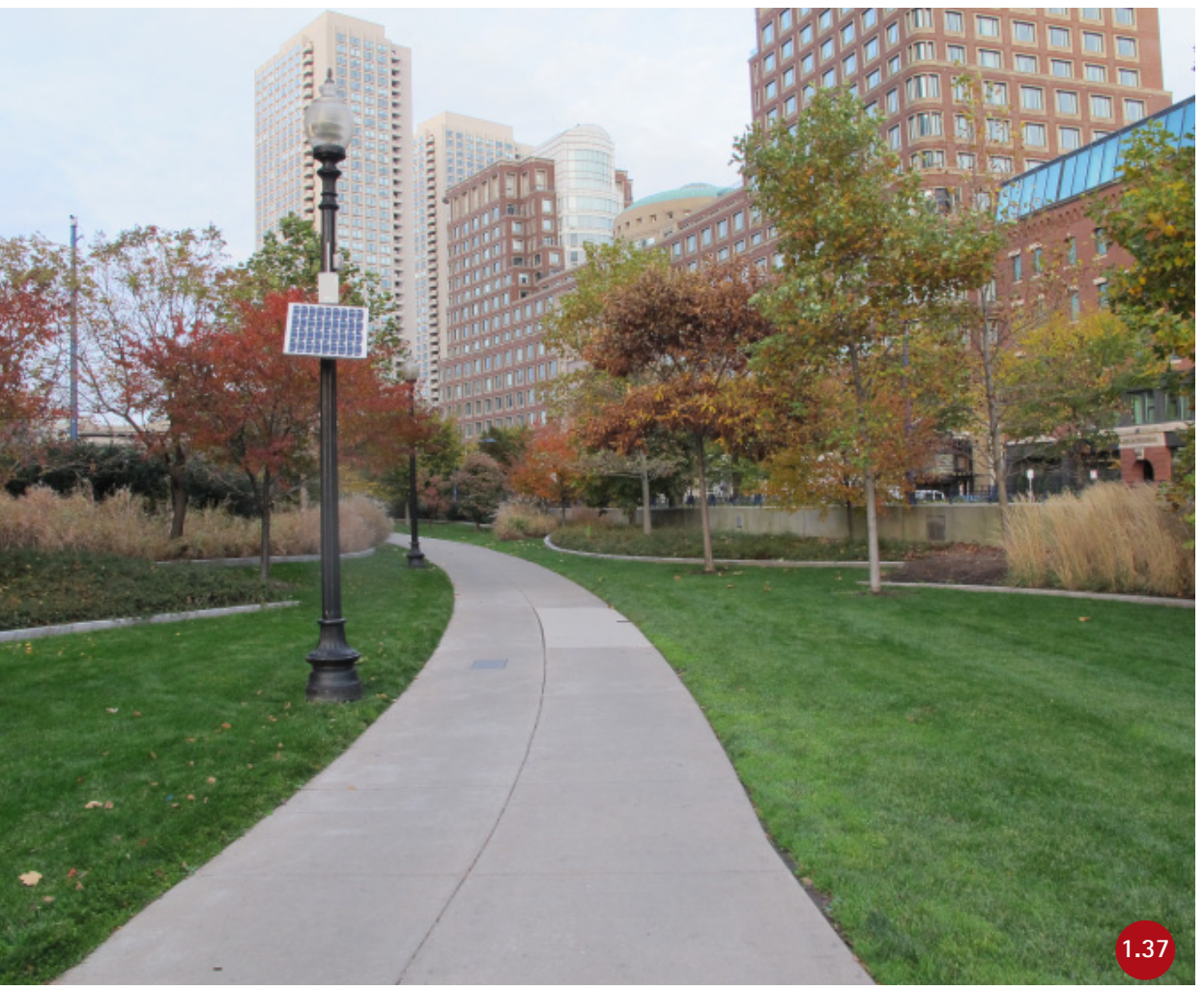

Rose Kennedy Greenway (2008), Boston. Um viaduto elevado foi demolido depois de muitos anos de discussões e abriu uma faixa de terra ao longo de bairros antigos, diversificados e valiosos, que foi aproveitada como parque.

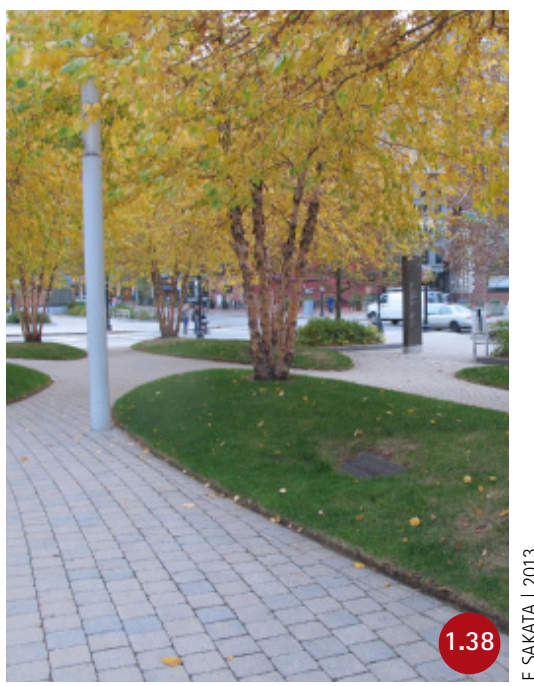




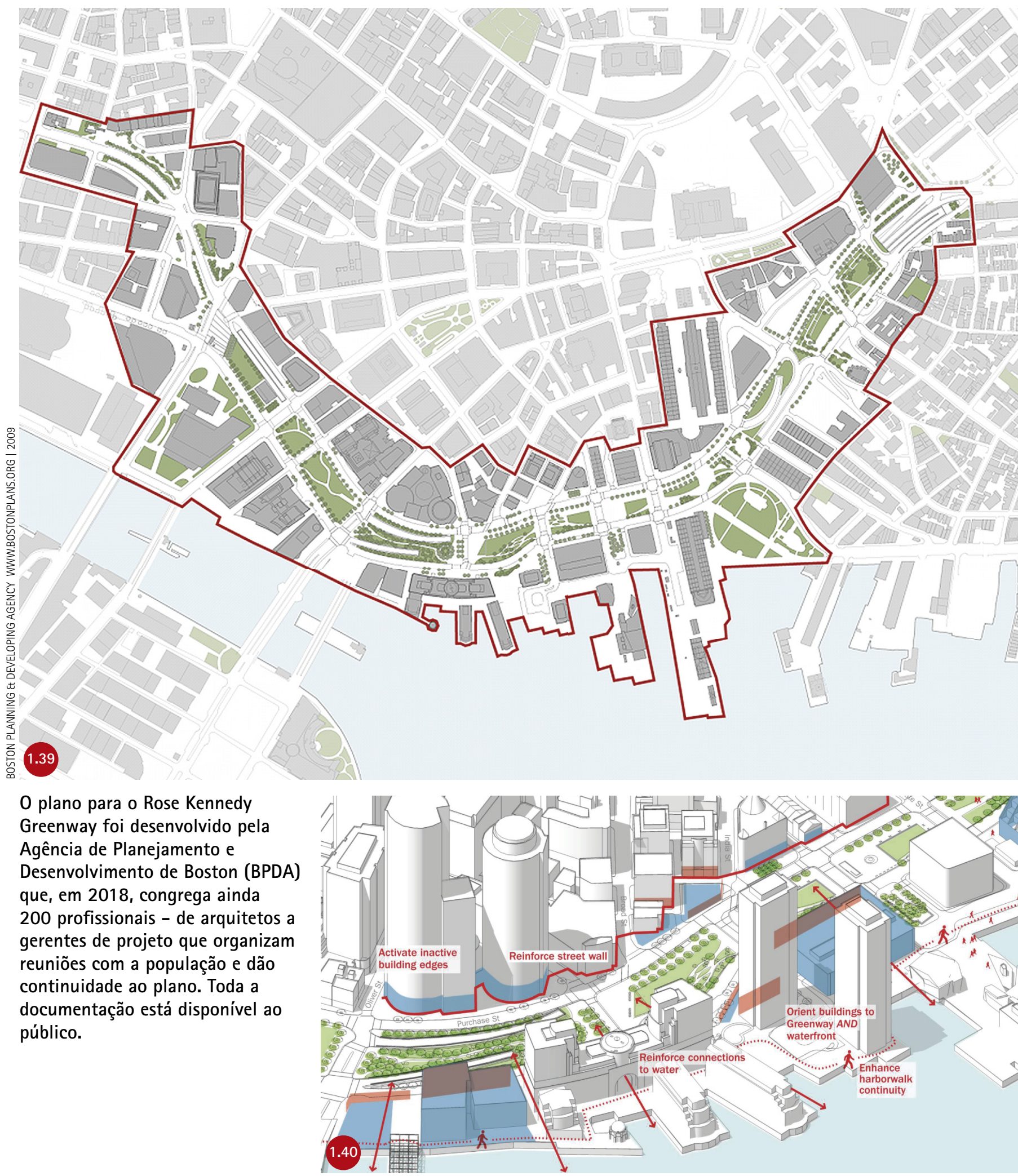


- parques lineares ao longo de rios: feitos na orla do rio, espaço de muita visibilidade. Em Madrid a prefeitura decidiu soterrar em túneis os 6 quilômetros da rodovia M-30, trecho em que se encontrava com o rio Manzanares, e fazer um parque que criasse conexões urbanas, inclusive das paisagens naturais presentes ao sul e ao norte da cidade ${ }^{25}$; 1.4.
25 SIQUEIRA, Mariana. Vias marginais de rio Manzanares são enterradas para criação de parque linear em Madri, Espanha. Revista AU, Edição 212, Novembro/2011.

Disponivel em: <http://au17.pini.com.br/ arquitetura-urbanismo/212/vias-marginais-de-rio-manzanares-sao-enterradas-para-criacao-de-240789-1.aspx>.
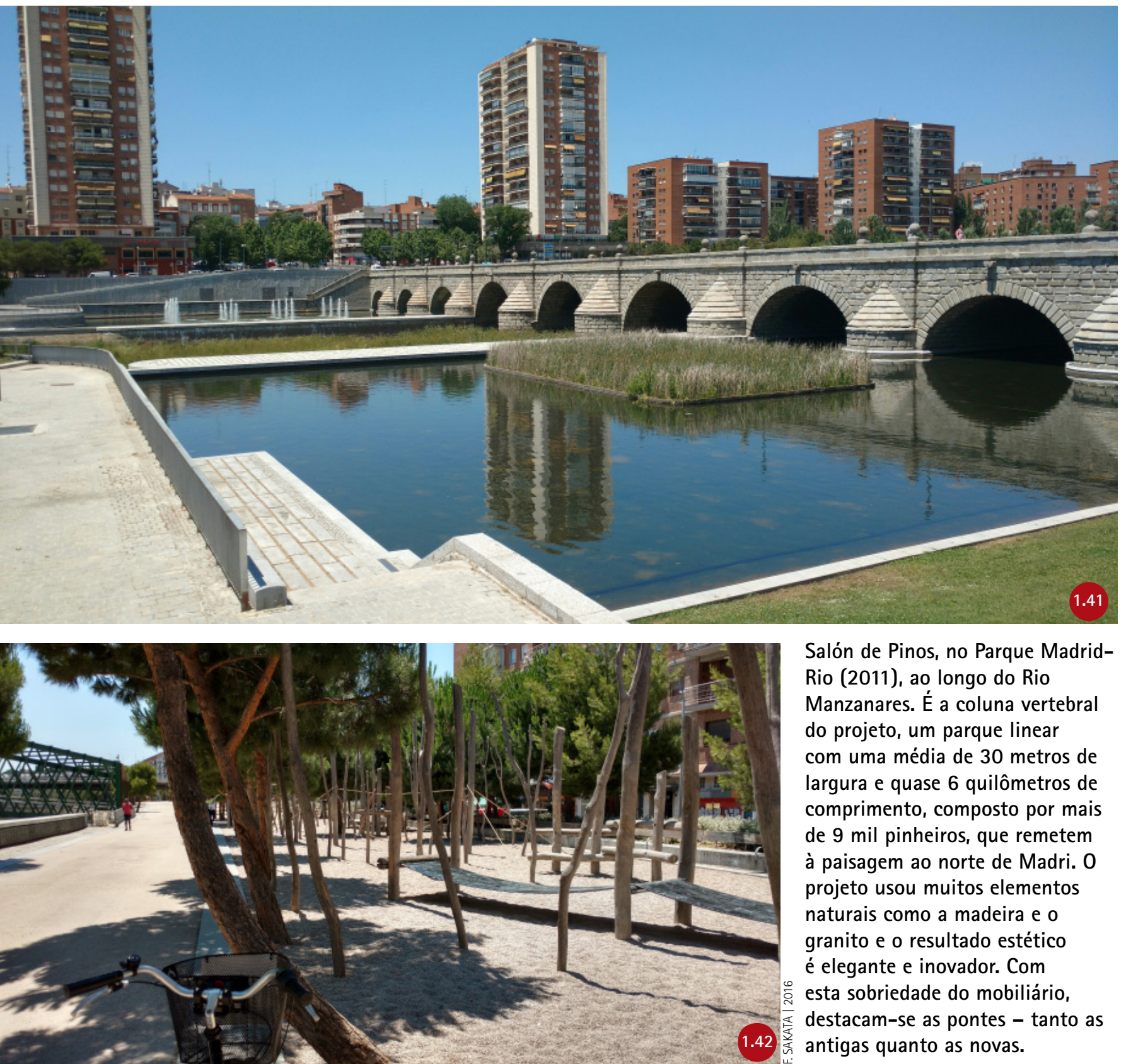

Salón de Pinos, no Parque MadridRio (2011), ao longo do Rio Manzanares. É a coluna vertebral do projeto, um parque linear com uma média de 30 metros de largura e quase 6 quilômetros de comprimento, composto por mais de 9 mil pinheiros, que remetem à paisagem ao norte de Madri. 0 projeto usou muitos elementos naturais como a madeira e o granito e o resultado estético é elegante e inovador. Com esta sobriedade do mobiliário, destacam-se as pontes - tanto as antigas quanto as novas. 
High Line Park (2009), em Nova York. Em 2016, chegou a 2.400 metros. Na maior parte de seu comprimento a largura é de cerca de 9 metros.

Abaixo, no trecho aberto em 2014, o playground do High Line que simula as vigas metálicas que estruturam o viaduto. A brincadeira é se esgueirar por elas.

- parques lineares "aéreos": feitos sobre viadutos de antigas linhas de trem, como a Promenade Plantée (1993) em Paris e o High Line Park (2009) em Nova York. A comunidade, no caso do High Line, fez uma campanha contra a demolição do viaduto e a favor de sua transformação. 0 High Line hoje é tomado como um caso grave de gentrificação. A valorização do entorno foi tão intensa que não há ferramentas para prover habitação a preços acessiveis na região; (1.43) 1.44
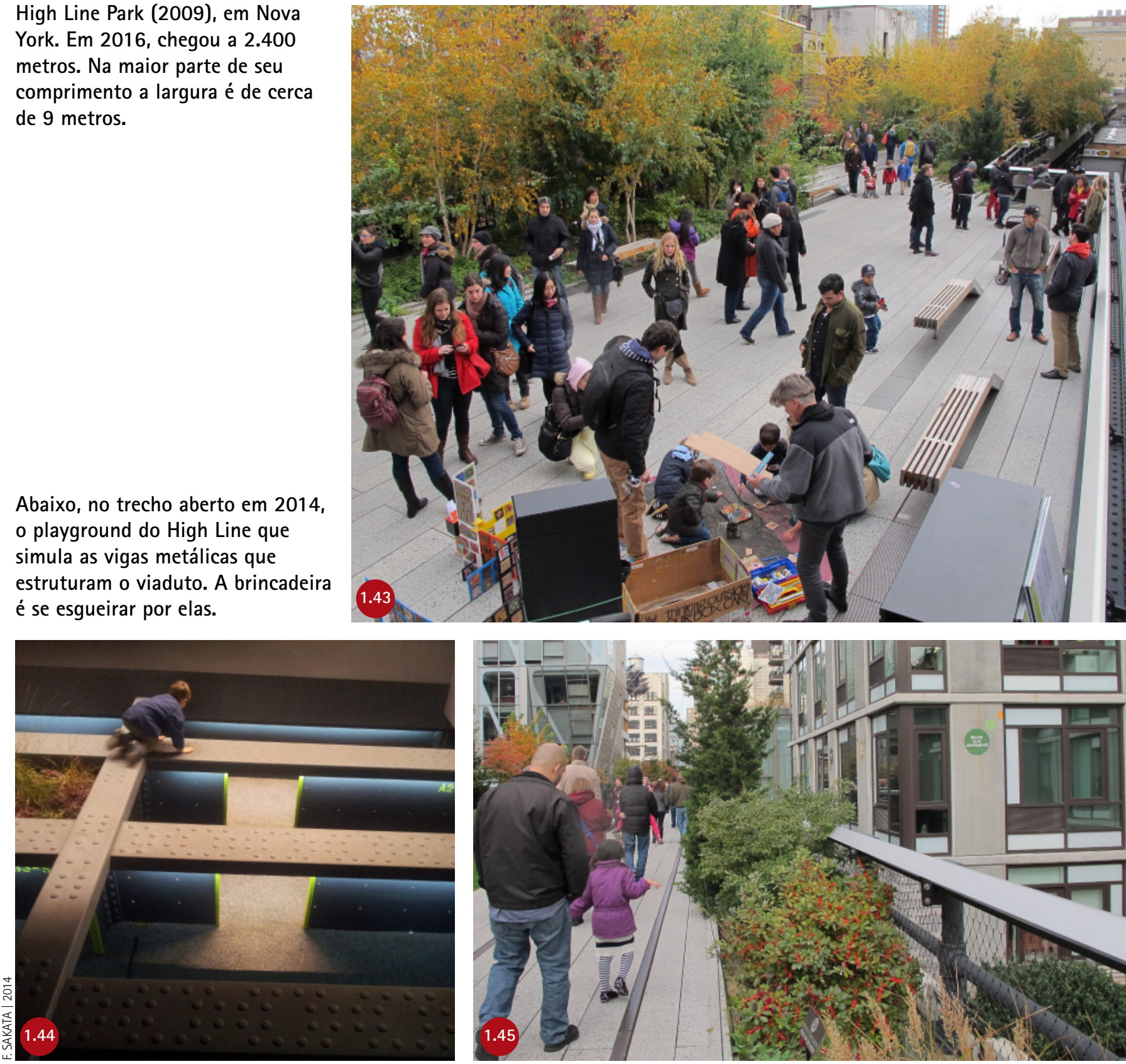
- waterfronts (calçadões) com vista para mar, baía ou rio: em muitas grandes cidades, as estruturas portuárias ficaram obsoletas e estão sendo requalificadas para uso urbano. Em Nova York, toda a orla do rio Hudson, que nunca foi muito apropriada pela população, vai se transformando em uma sequência de espaços de lazer e de quadras valorizadas para o mercado imobiliário. Há extensas obras tanto no lado de Manhattan, quanto no Brooklyn; 1.46 1.47
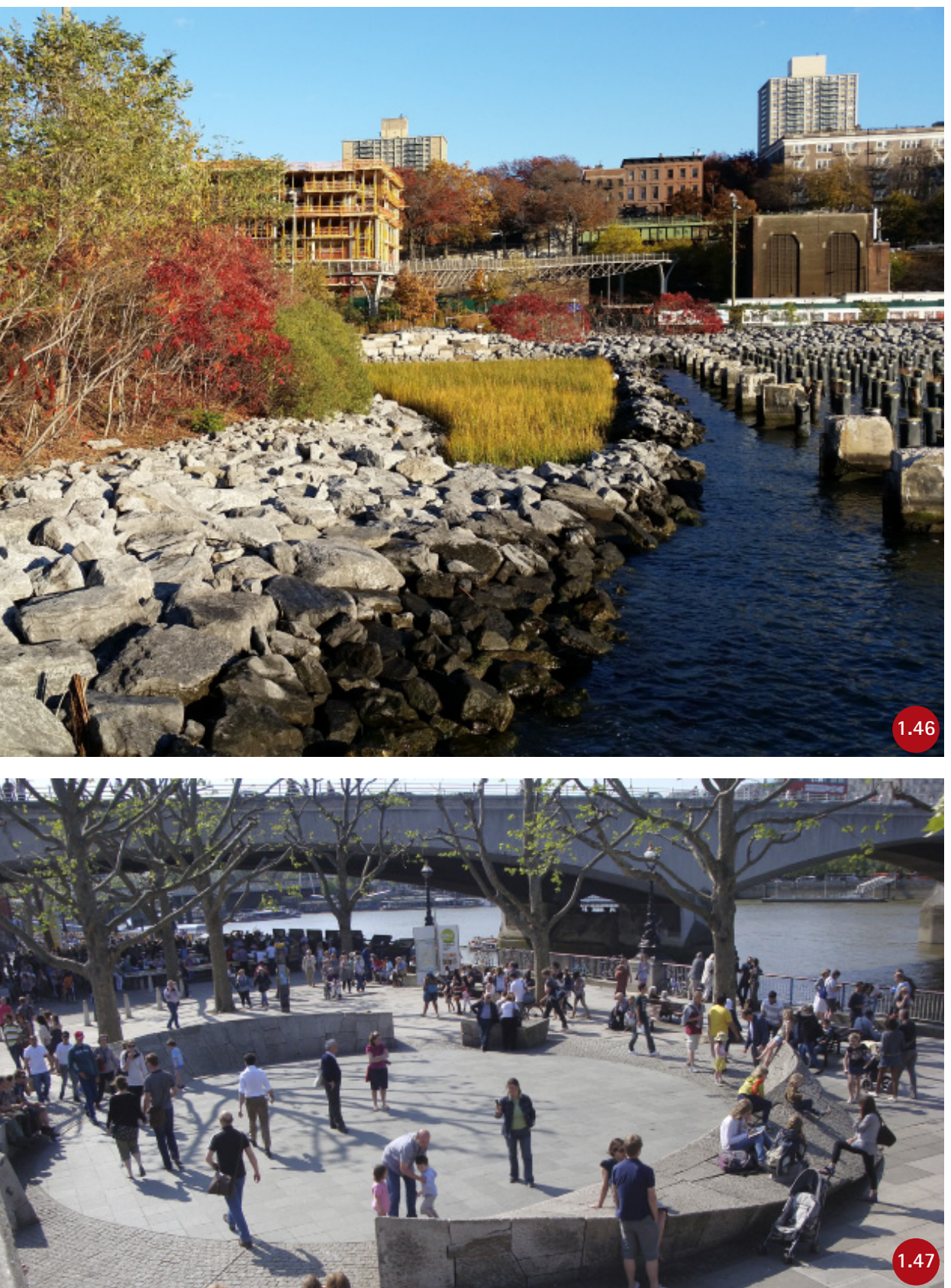

The Brooklyn Bridge Park (20032018). Com pouco mais de 2 quilômetros, substituiu as obsoletas instalações portuárias por um espaço com grande variedade de atividades, inclusive campos de futebol em um deck sobre o rio Hudson, sempre com vista para Manhattan.

Abaixo, margens do Tâmisa, no Distrito Southbanks, em Londres. Em 2000 foi desenvolvido um masterplan para a área que incluía três espaços públicos: praça central, Festival Riverside e Festival Terrace.

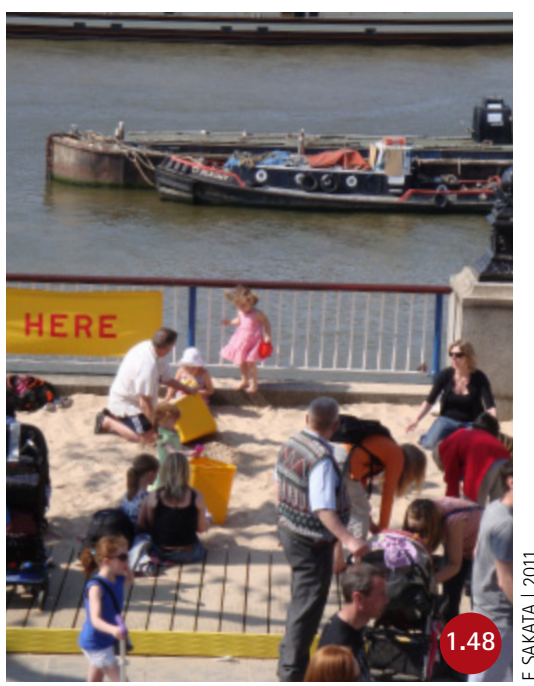


Pier C Park (2010), Hoboken.

Projetado por Michael Van

Valkenburgh Associates Inc., no memorial do projeto, consta que a vegetação foi especificada com plantas que pudessem abrigar ninhos de aves.
- parque flutuante: com vista para Manhattan, do outro lado do rio Hudson, criou-se uma ilha flutuante que oferece espaço recreativo sobre a água e valoriza a cidade de Hoboken, a poucos minutos de Nova York, como uma alternativa de moradia; 1.49
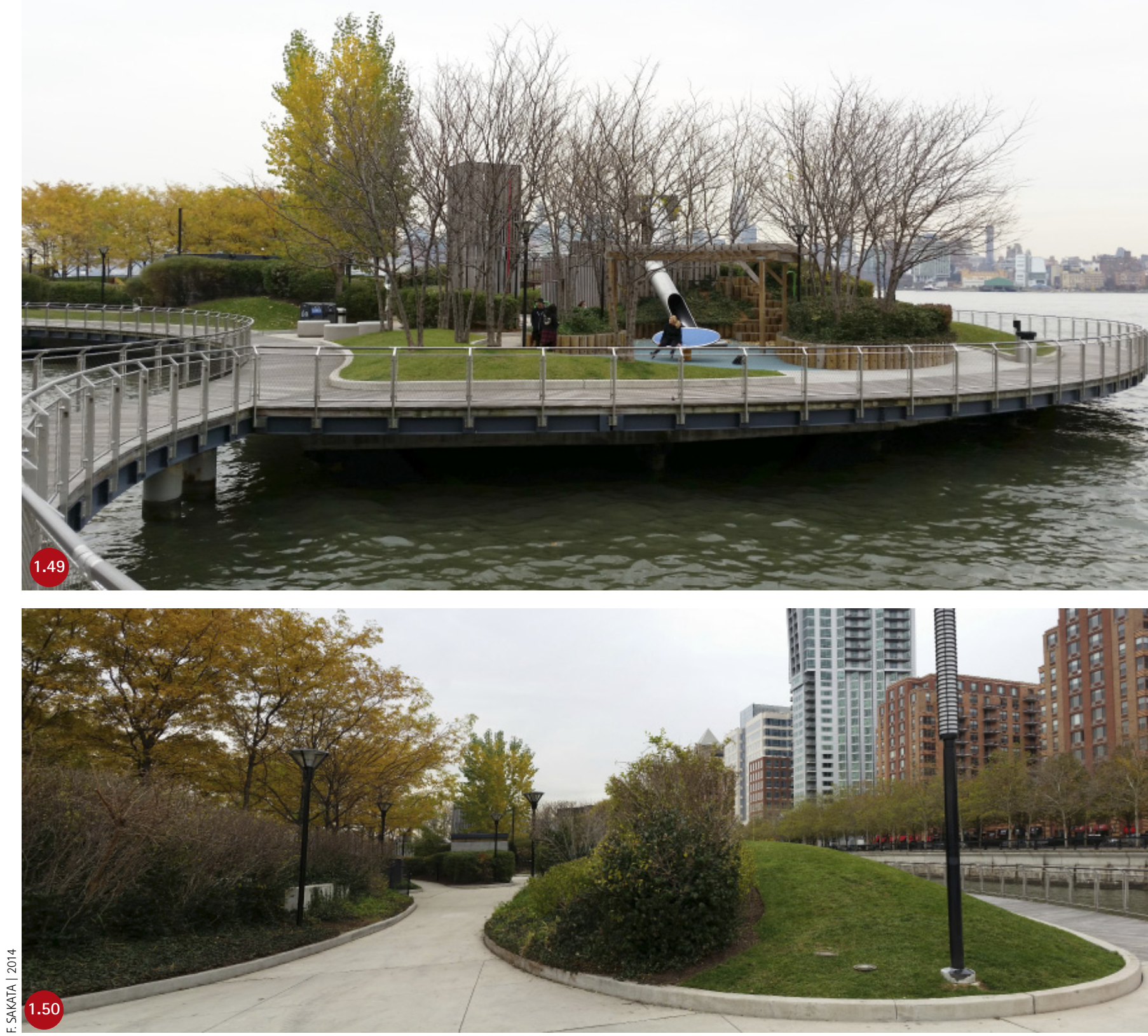
- parque-aeroporto: Tempelhofer, um aeroporto desativado, em Berlim, foi aberto provisoriamente em 2010, após pressão popular, para ser usado como parque, com mínima intervenção. A área de quase $4.000 .000 \mathrm{~m}^{2}$ era composta principalmente pela pista, os gramados do aeroporto e o antigo terminal. Em 2013 a prefeitura apresentou a proposta de um plano urbanístico para o desenvolvimento imobiliário na área, com torres residenciais, tanto para o mercado regular como para a habitação social, torres comerciais, indústrias, quadras esportivas e biblioteca. As construções ocupariam 25\% da área, e o restante continuaria como parque. A população fez campanha contra o projeto, em favor da preservação da totalidade da área como parque público. 0 referendo popular foi realizado em 2014, e a proposta de preservação venceu com 64\% dos votos ${ }^{26} ;$ 1.51 1.52
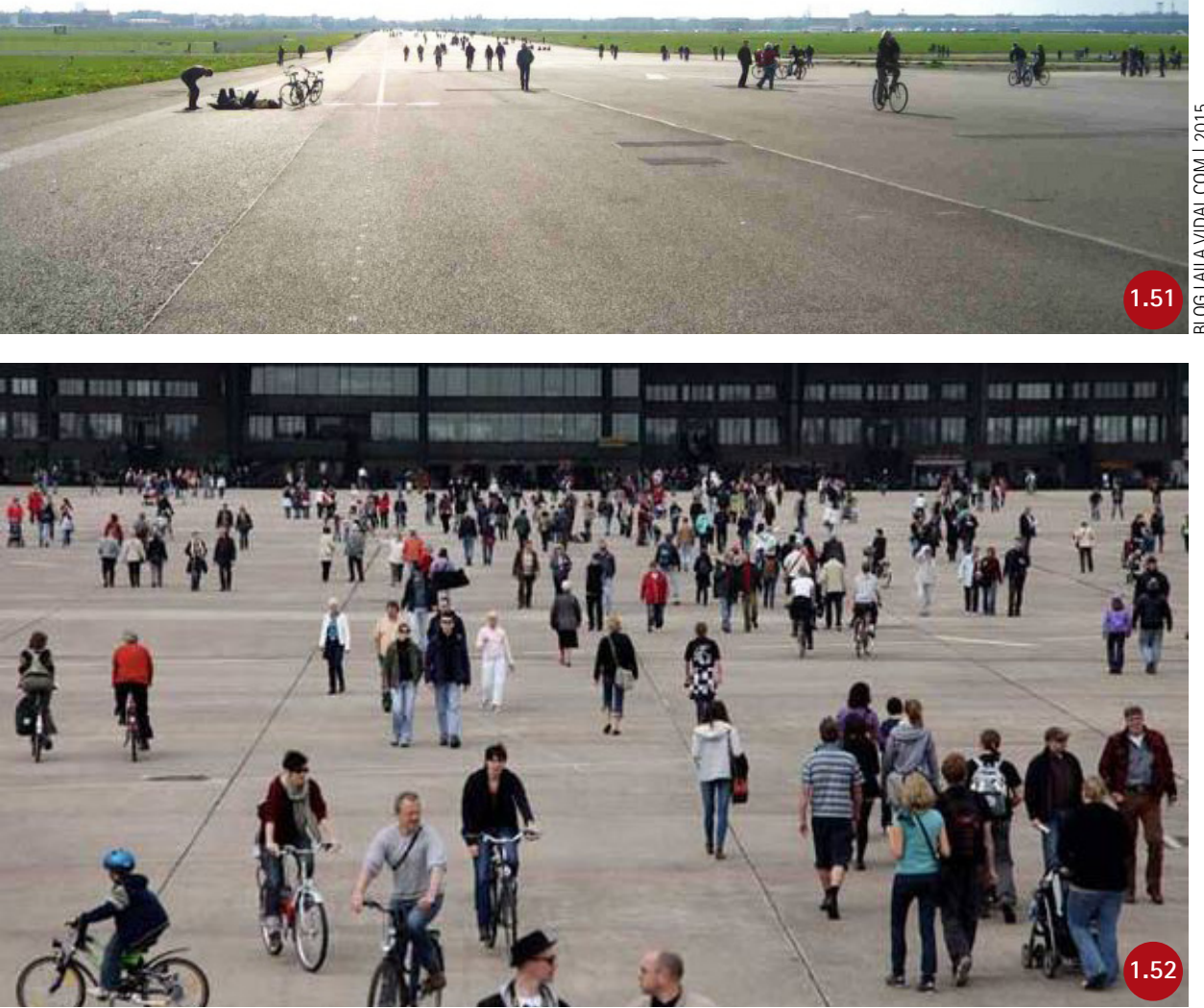

60
260 caso do Tempelhof é um exemplo do potencial de mobilização popular para apropriar o que é público. A história é contada e discutida em:

ROLNIK, Raquel. Participação cidadã e futuro das cidades. Blog da Raquel Rolnik. 25/05/2016.

Disponivel em: <https://raquelrolnik. wordpress.com/2016/05/25/participacao-cidada-e-futuro-das-cidades/>.

VANNUCHI, Luanda; SCHILLER, Mariana.

As lutas por espaços públicos em São

Paulo e o caso Tempelhof. ObservaSP, 29/03/2017.

Disponivel em: <https://observasp. wordpress.com/2017/03/29/as-lutas-por-espacos-publicos-em-sao-paulo-e-o-caso-do-tempelhof/>.

Parque do Aeroporto Templehof (2010), em Berlim. Assim que foi aberto, o espaço se transformou em um dos parques mais frequentados da cidade, preferido por skatistas, ciclistas e adeptos do kiteboard. Os gramados foram usados para piqueniques e jogos de bola e grupos de moradores começaram a implantar jardins e hortas comunitárias e promover eventos de música, teatro e dança. 
- parques ecológicos (Sustainable Park): são aqueles com novos propósitos filosóficos de sustentabilidade e ecologia. Tanto podem evocar meramente o simbolismo ecológico como restaurar de fato sistemas ecológicos funcionais.

Para reconhecer esta categoria, a quinta geração de parques americanos, Galen $\mathrm{Cranz}^{27}$ analisou, entre 1982 e 2002, 125 parques em revistas de Arquitetura Paisagística, levando em conta: forma física, programa de atividades, agentes promotores, intenções e beneficiários atuais e a reação do público (conforme as revistas). Foram encontrados parques de todos os tipos, mas predominavam os Sistemas de Espaços Livres (46\%) e, em segundo lugar, os Parques Sustentáveis (23\%). Os novos parques apresentam nova estética (ver Capítulo 4), mas, em princípios gerais, Cranz identifica duas características novas:

I. os projetos buscam a autossuficiência de recursos materiais: as estruturas construídas são posicionadas no terreno e desenhadas de forma a minimizar o impacto ambiental. Valorizou-se o uso de plantas mais adaptadas à umidade de cada lugar. No Central Park, um bosque antigo foi lentamente convertido em bosque nativo, que se autorregenerou. Para reduzir a manutenção, muitos administradores adotaram a postura de "deixar a natureza fazer o máximo de trabalho possivel". A sustentabilidade também diz respeito à viabilidade social e cultural, sendo criadas organizações para levantar fundos e parcerias público-privadas;

II. quando integrados ao tecido urbano, os parques podem ter 0 papel de resolver problemas urbanos para além de suas divisas, como questões de infraestrutura, contaminação do solo, saúde e bem-estar. A ideia de integrar corpos d'água, vias e parques não é nova, mas em Boston, o Emerald Necklace, de Olmstead, foi mais exceção do que regra. As cidades também têm muitas áreas de aterros, indústrias desativadas e outras instalações obsoletas em terrenos que ficaram contaminados e impróprios para a construção. Mesmo assim, são uma excelente oportunidade para parques, já

27 CRANZ, Galen e BOLAND, Michael. Defining the Sustainable Park: A Fifth Model for Urban Parks. Landscape Journal 23:2-04. 2004. que as plantas recuperam o solo. Os parques podem contribuir para melhorar a saúde das pessoas e conectá-las umas com as outras e com o meio ambiente. 


\subsection{Novas categorias de parques no Brasil}

A preocupação com a conservação ambiental sempre se mostrou bastante direcionada a árvores e florestas, mas na década de 1980 houve uma inflexão nas posturas e ampliou-se o entendimento das relações ecológicas. Campos de cerrados, dunas, manguezais, charcos e as águas em geral foram envolvidos nas preocupações. Os parques passaram a ser criados também para atender necessidades ambientais $^{28}$. Neles também passaram a existir atividades ligadas à educação ambiental, o que se tornou mais intenso nos anos 1990. A legislação ambiental brasileira evoluiu, tornou-se avançada nos anos 2000. Rigorosa, dava instrumentos ao poder público para aprovar ou não obras de médio e grande porte, para aplicar sanções e capturar recursos por meio de multas e compensações ambientais.

Praticamente todos os novos parques produzidos a partir de 2000 foram descritos como parques sustentáveis, ainda que a sustentabilidade fosse apenas parte do discurso que justifica sua criação. De fato, como espaços parcialmente permeáveis e arborizados, os parques cumprem funções ecológicas, contribuem para a drenagem urbana, manutenção do microclima e diminuição das ilhas de calor. ${ }^{29}$ Mesmo aqueles criados para a provisão de lazer em áreas carentes são apresentados como ações de cunho ambiental. Como Galen Cranz, podemos considerar que todos os parques contemporâneos brasileiros são "parques ecológicos”, pois, ao menos filosoficamente, foram ligados a esta questão.

As novas categorias de parques que encontramos no Brasil:

- Parques de conservação e bosques dentro da malha urbana e sem apropriação de lazer: no meio urbano, vários parques passaram a ser concebidos como Unidades de Conservação (UCs). São parques que não possuem as funções de lazer e recreação como prioridade. Há casos em que o acesso do público é vetado e outros nos quais o lazer, quando introduzido, se restringe a trilhas, algumas vezes apenas nos limites externos.
28 Vários parques estaduais na cidade de São Paulo foram criados com função primordial de proteção aos mananciais ou de remanescentes de vegetação, caso dos parques estaduais da Cantareira, Capivari-Monos, Fontes do Ipiranga, Serra do Mar. 0 parque Anhanguera, municipal, foi criado a partir de grandes áreas preservadas.

BARTALINI, Vladimir. Parques públicos municipais de São Paulo. A ação da municipalidade no provimento de áreas verdes de recreação. 1999. 354f. Tese (Doutorado em Arquitetura e Urbanismo) - Faculdade de Arquitetura e Urbanismo, Universidade de São Paulo, São Paulo, 1999.

29 Para Matheus Casimiro, pesquisador que participou do processo de criação de parques em São Paulo, na contemporaneidade os parques tendem a ser criados a partir de suas funções ecológicas, tornando-se prioritária a contribuição na drenagem urbana, preservação da rede hidrica, manutenção do microclima e diminuição das ilhas de calor.

CASIMIRO, Matheus. Vira praça, vira parque. Blogdapaisagem. 11/03/2016. Disponivel em: <https://blogdapaisagem. wordpress.com/2016/03/11/vira-praca-vira-parque/>. 
30 A Portaria do Ministério do Meio Ambiente $n^{\circ} 245$ de 11 de julho de 2011 reconheceu o Mosaico Carioca, composto por 2 UCs federais, 4 UCs estaduais e 17 UCs municipais.

RIO DE JANEIRO, Prefeitura. Secretaria Municipal de Meio Ambiente - SMAC: Áreas Protegidas. 26/01/2010.

Disponivel em: http://alvaraja.rio.rj.gov.br/ web/smac/exibeconteudo?id=2812667

31 Projeto "Pesquisa e análise de aplicação de instrumentos em planejamento urbano ambiental no município de São Paulo". Produto 3. Relatório - Instrumentos de Planejamento Urbano-Ambiental do Sistema Municipal de Planejamento. São Paulo: LabHab/FAUUSP, SVMA, junho de 2006. Mimeo. p.25-28. In: WHATELY, Marussia; SANTORO, Paula Freire; GONÇALVES, Bárbara Carvalho; GONZATTO, Ana Maria. Parques urbanos municipais de São Paulo:subsídios para a gestão. São Paulo, Instituto Socioambiental, 2008.

32 Agência de Notícias da Prefeitura de Curitiba. Mais sete áreas do Município serão transformadas em bosques de conservação. De: 01/10/2014.

Disponivel em: http://www.curitiba.pr.gov. $\mathrm{br} /$ noticias/mais-sete-areas-do-municipio-serao-transformadas-em-bosques-de-conservacao/34296
Em 2000, o Sistema Nacional de Unidades de Conservação (SNUC) estabeleceu 12 categorias de Unidades de Conservação que se diferenciam quanto à forma de proteção e usos permitidos. A lei partiu de figuras jurídicas já existentes, como Floresta Nacional, Parque Nacional, Estação Ecológica e Área de Proteção Ambiental (APA), e unificou a nomenclatura para todo o país. Há variações estaduais e municipais em função de categorização anterior. A Secretaria Municipal de Meio Ambiente (SMAC) da Prefeitura do Rio de Janeiro tem no cadastro de Áreas Protegidas ${ }^{30}$ : Área de Proteção Ambiental (APA), Área de Proteção Ambiental e Recuperação Urbana (APARU), Área de Relevante Interesse Ecológico (ARIE), Reserva Biológica, Parque e Bem Natural Tombado. Nesta categorização de áreas protegidas, o parque é uma área protegida de posse e domínio públicos, destinado à visitação e ao lazer, e, quando criado pelo município, é denominado Parque Natural Municipal. Este parque natural se aproxima do parque urbano.

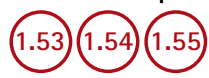

O Plano Diretor de 2002 do município de São Paulo criou novas figuras no Sistema de Áreas Verdes, além dos tradicionais parques urbanos e praças públicas, como: áreas verdes públicas de Proteção Integral (parques e reservas); áreas verdes públicas ou privadas de Uso Sustentável. Os parques foram hierarquizados em relação à sua função de barreira ao crescimento urbano e divididos em: urbanos; de beira de represa; de amortecimento (funcionando como tampão de proteção entre uma UC e o tecido urbano); de contenção de ocupação (para amortecimento de áreas com forte pressão por ocupação). ${ }^{31}$

No setor sul da cidade de Curitiba, a partir de 2010 alguns bosques em terrenos públicos, em bairros mais pobres, foram cercados e tiveram o uso público vetado em vez de serem convertidos em parques. Como o poder público em Curitiba é mais rigoroso com a categorização, estes espaços não foram considerados parques, mas Bosques de Conservação da Biodiversidade Urbana (BCBUs). A municipalidade implanta calçadas em torno da área, do lado de fora da cerca, para que as pessoas possam apreciar o bosque durante a caminhada. Esta nova categoria, que "[...] tem como objetivo a preservação de bancos genéticos [...]"32, contorna as dificuldades imediatas de gestão destes espaços. (1.58) 
Parque Ecológico e Cultural Vitória (data de criação desconhecida), no Bairro Vitória, em Belo Horizonte. É considerado um parque, com legislação específica, não implantado.
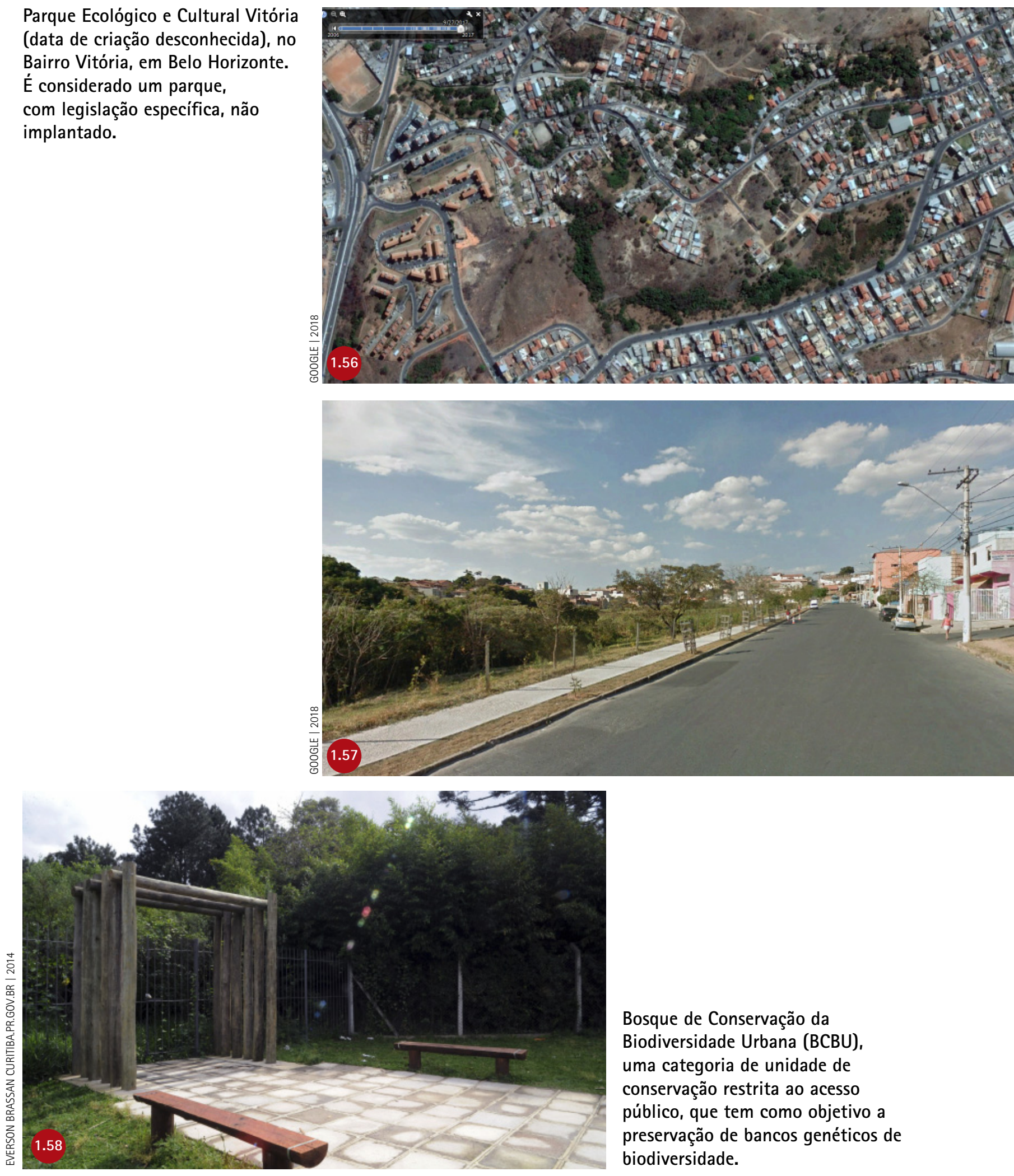

Bosque de Conservação da Biodiversidade Urbana (BCBU), uma categoria de unidade de conservação restrita ao acesso público, que tem como objetivo a preservação de bancos genéticos de biodiversidade. 
Em Sorocaba, no interior paulista, o poder público investiu na criação de um sistema de parques ao longo dos rios, que se deu a partir da construção do Parque do Campolim, em um bairro nobre da cidade. A cidade conta, em 2017, com 23 parques municipais.

Nas fotos, o Parque das Águas Maria Barbosa Silva (2008). Tratase de uma bacia de contenção de chuvas e um grande equipamento de lazer, com eventos artísticos e alta visitação. Possui anfiteatro, praça de eventos, pista de caminhada, ciclovias, pistas de skate, playground, aparelhos para ginástica e quadra de areia.
- Parques lineares de rios ou represas: possuem como característica intrínseca grande extensão e pouca largura. Há casos em que são tão estreitos e diminutos, que formam no máximo uma rede de pracinhas articuladas por um canal e vias - que não constituiriam um parque; em outros, os trechos são largos, permitindo que o usuário deixe de perceber a malha urbana lindeira e usufrua da experiência convencional de parque. 1.62 1.63

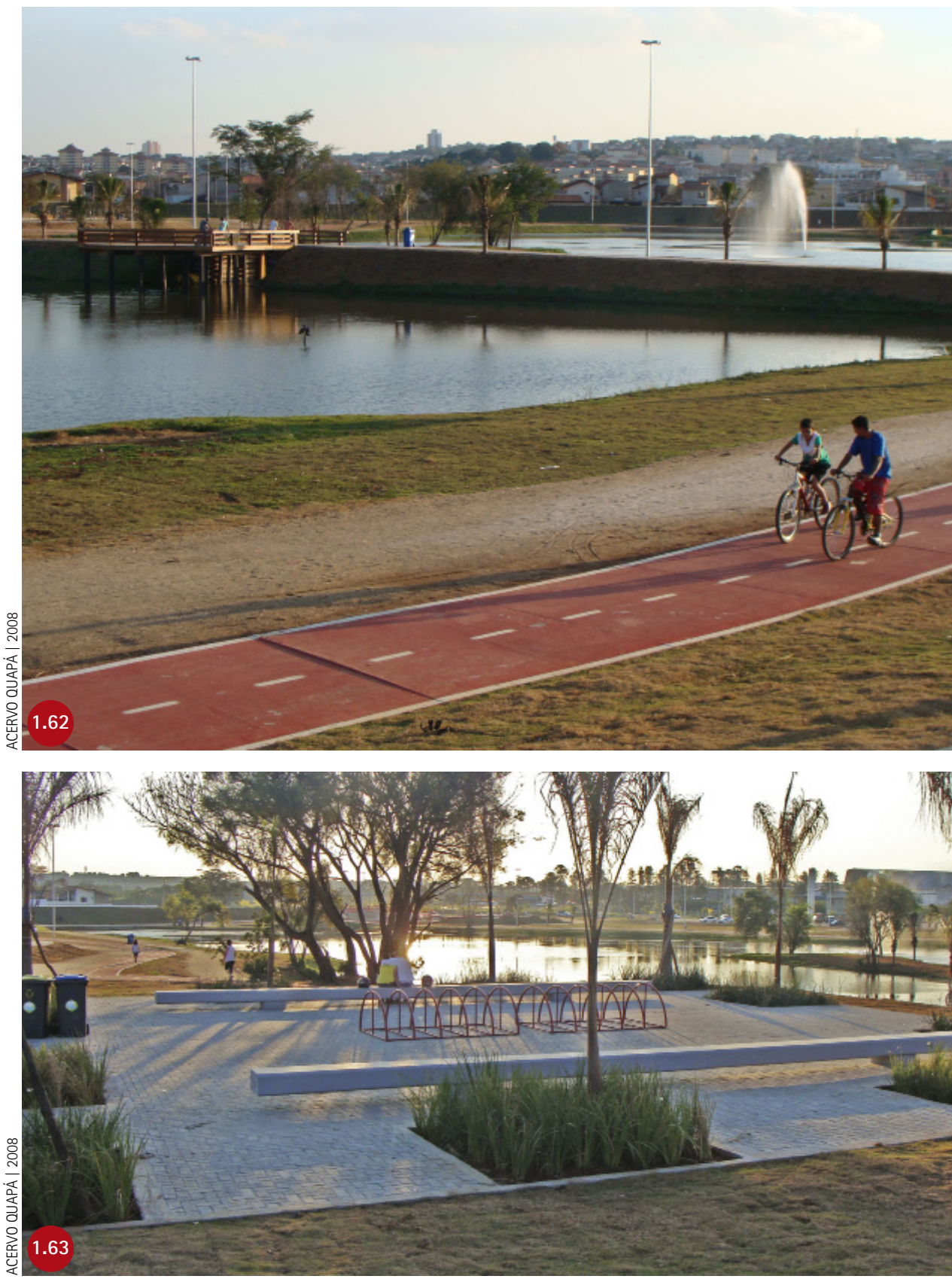




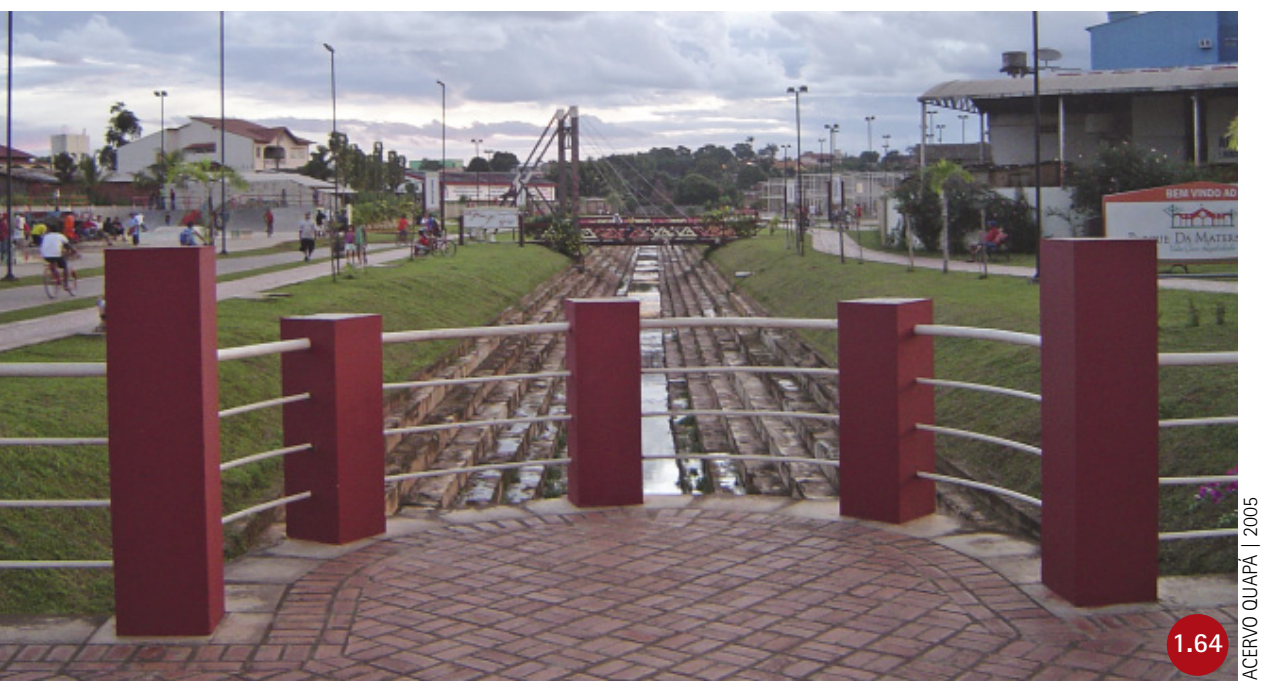

Parque da Maternidade (2002), em Rio Branco. 0 parque tem $6 \mathrm{~km}$ de extensão e foi feito com a remoção de moradias que existiam junto ao Igarapé da Maternidade. Apontamse melhorias na drenagem pluvial, na conectividade dos bairros e oferta de espaços de lazer e encontros.

0 parque linear, em São Paulo, subverteu o critério para definição de parque também pela impossibilidade de ser cercado. A Prefeitura de São Paulo distingue os parques das praças pela presença de cercamentos que permitem fechar a área à noite. Mas isto só é conveniente para os parques nucleares. No caso dos parques lineares, que surgem a partir de 2002, a relação com vias e habitações é mais próxima e precisam ser atravessados no maior número de pontos possíveis, de forma que o gradeamento é indesejável.

O Programa de Recuperação Ambiental de Cursos d’Água e Fundos de Vale do município definiu parques lineares como "[...] intervenções urbanísticas que visam recuperar para os cidadãos a consciência do sítio natural em que vivem, ampliando progressivamente as áreas verdes." ${ }^{34} \mathrm{~A}$ definição, vaga e aberta, faz menção à educação ambiental e à redescoberta do terreno ocupado.

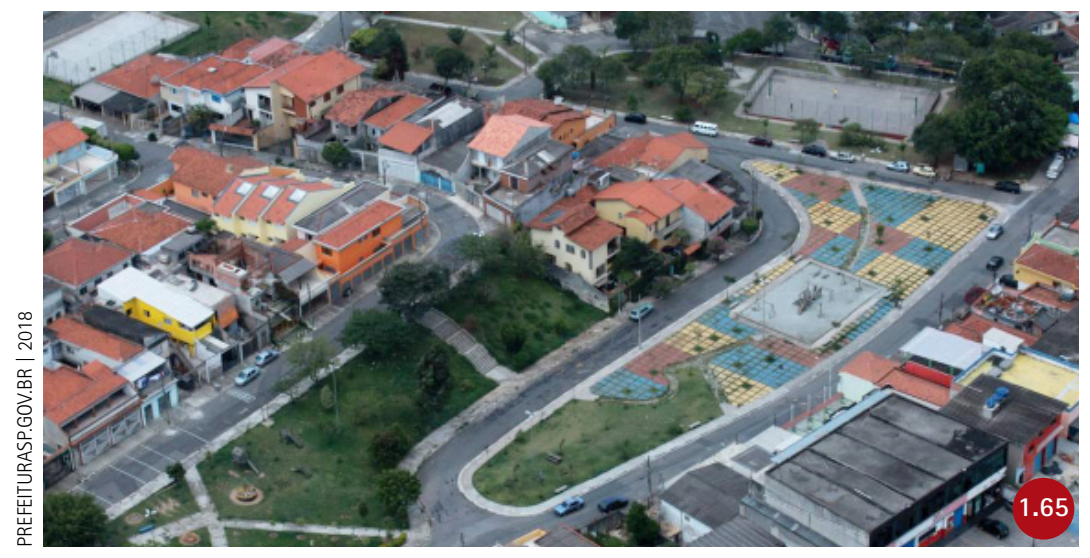

Parque Linear Ipiranguinha (2007), São Paulo. 0 parque, neste caso, é a soma de espaços livres urbanos que seriam melhor categorizados como praças. Sua gestão é mais similar a destes espaços. 
35 GALENDER, Fany e CAMPOS, Ana Cecília M. de Arruda. Ações públicas em São Paulo voltadas para recuperação dos corpos d'água: percepção e apropriação. Texto apresentado no III Seminário APPs Urbana Belém, 2014.

Parque do Sapé (2014), São Paulo. 0 parque aqui é a soma de espaços livres urbanos de naturezas e tamanhos diversos são articulados pelo rio. A busca para que o rio deixe de ser percebido como um canal de esgoto é a ação de caráter ambiental. Feito para estratos de renda mais baixa, é intensamente utilizado - um modelo e um desafio para as administrações públicas.
No período analisado, foram implantados pelo poder público parques lineares nos bairros e também junto de conjuntos habitacionais, com a remoção parcial ou integral de favelas. É possível considerar este parque linear como um parque de fato quando, além dos trechos mais estreitos, há trechos com larguras generosas, equipados para o lazer e com a presença de recursos naturais. 1.65 1.66

A Secretaria de Habitação paulistana projetou e implantou muitos espaços livres próximos de conjuntos de moradia popular. A denominação parque era dada quando a gestão era transferida, administrativamente, para a SVMA. ${ }^{35}$ Estes parques não podem ser cercados, porque os espaços têm relação muito próxima com vias e habitações, e a população precisa cruzá-los intermitentemente. Isso subverteu o conceito de parque da Prefeitura de São Paulo, que os definia como áreas verdes cercadas, com regras e horários de funcionamento.

Para que estas obras fossem concretizadas, foram necessárias articulações intersecretariais e com as concessionárias estaduais - que

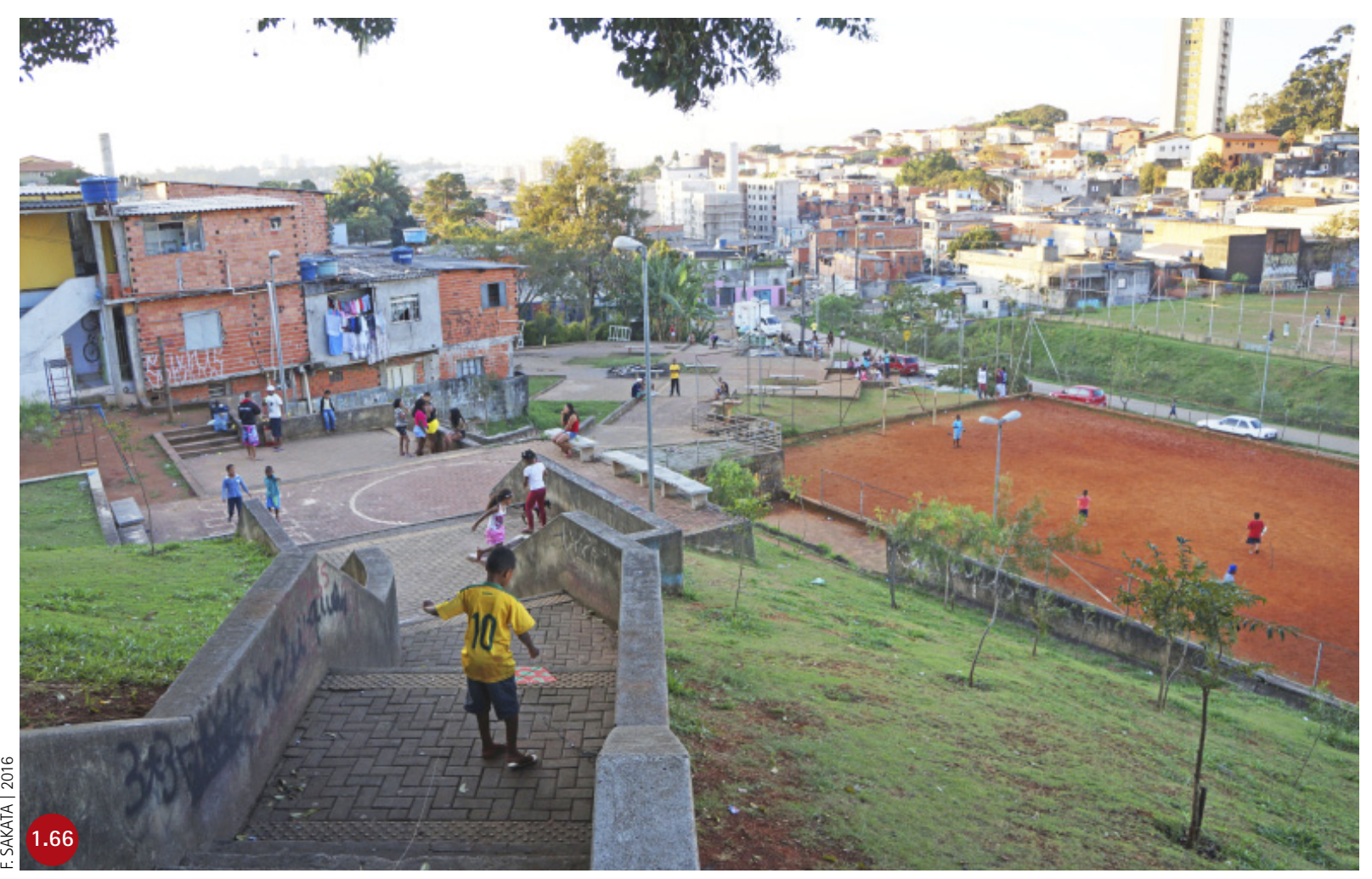


foram facilitadas pela existência de um programa político. A criação da figura dos parques lineares pela SVMA foi crucial para que estes espaços pudessem ser gerados. Entretanto, nem todos são parques.

A qualificação de áreas livres em conjuntos habitacionais em vizinhanças de renda baixa é uma novidade no Brasil deste período e, apesar dos esforços, ainda é pontual. Em geral erguiam-se conjuntos habitacionais em bairros distantes, sobre extensas áreas livres não qualificadas, com o tempo ocupadas por estacionamentos ou varais ou cercadas e privatizadas.

Em favelas de bairros mais centrais e densos, quando se faz uma remoção, seja para a construção de um conjunto habitacional ou para abrir o curso do rio, a implantação de áreas de lazer qualificadas é um modo de tentar garantir que o espaço não volte a ser ocupado por moradias.

Os problemas de manutenção nestas áreas são visíveis. É comum haver pisos e mobiliários quebrados, pontes inacabadas, lixo e água acumulada. Ao mesmo tempo, o uso é intenso, as crianças têm onde brincar. A gestão destes espaços é um grande desafio para os próximos anos. É preciso reconhecer que não são apenas espaços de um bairro pobre, mas espaços da cidade, tão importantes quanto os demais.

- Rua-parque: no âmbito do Programa 100 parques, a prefeitura chegou a apresentar à população, em 2013, o projeto de conversão de um conjunto de ruas residenciais e praças em um novo tipo de parque, em uma área lindeira a um córrego retificado. 0 parque linear do Córrego do Cabuçu não foi implantado. A área consistia em um conjunto de praças e áreas livres desconectado e sem equipamentos, ruas asfaltadas convencionais com poucos trechos arborizados e raríssimas áreas permeáveis. Por tratar-se de uma Área de Preservação Permanente (APP), as ruas vizinhas ao córrego foram reprojetadas com estratégias de traffic calming, para conciliar a circulação de veículos dos moradores, compartilhadas com pedestres e ciclistas. As praças foram englobadas pelo "parque", com pisos para usos de lazer, playground e equipamento para ginástica. 0 resultado seria um conjunto de calçadas-ruas e pequenas pracinhas interligadas, identificadas como parque linear. 1.67) 1.68 


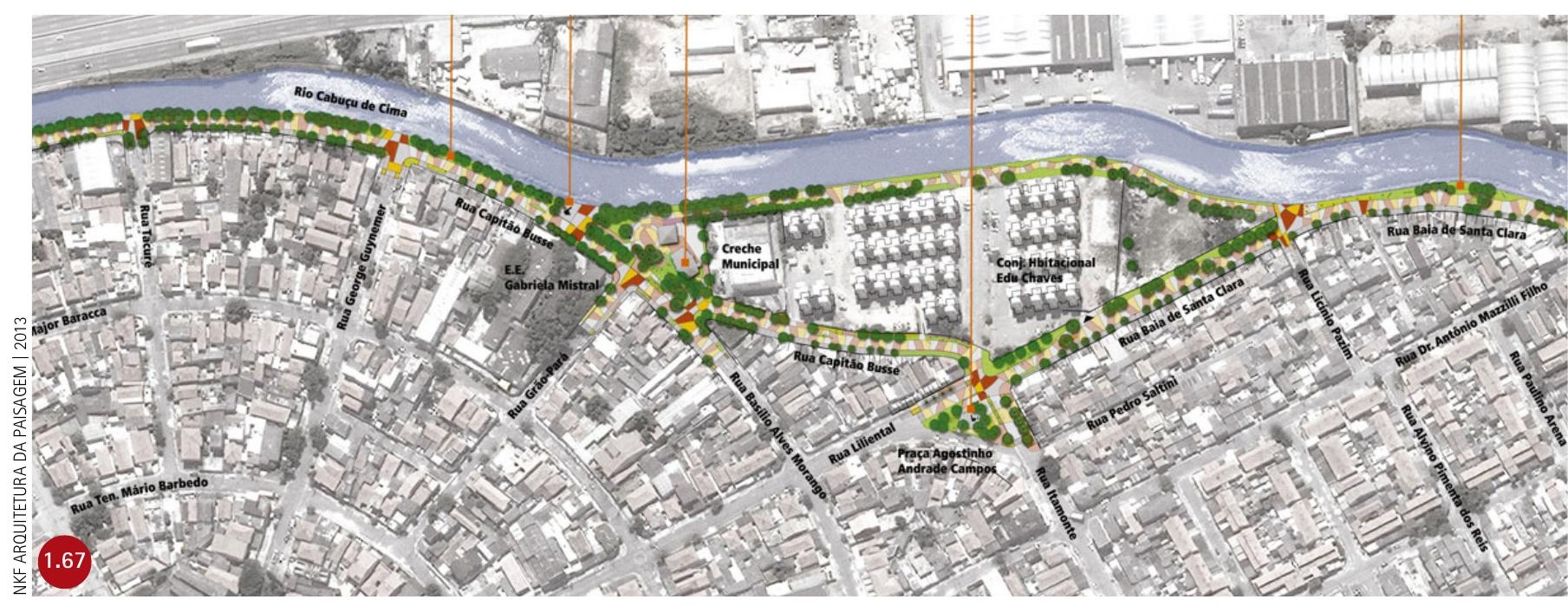

No projeto do Parque Linear Cabuçu de Cima, concebido pela Prefeitura de São Paulo e com projeto básico desenvolvido pela NKEF Arquitetura da Paisagem em 2013, as vias são caminhos compartilhados por pedestres, ciclistas e pelos automóveis que acessam as casas. 0 projeto não foi executado mas a lei do município chegou a ser alterada para incluir a via de traffic-calming (trânsito calmo) como uma via regular.
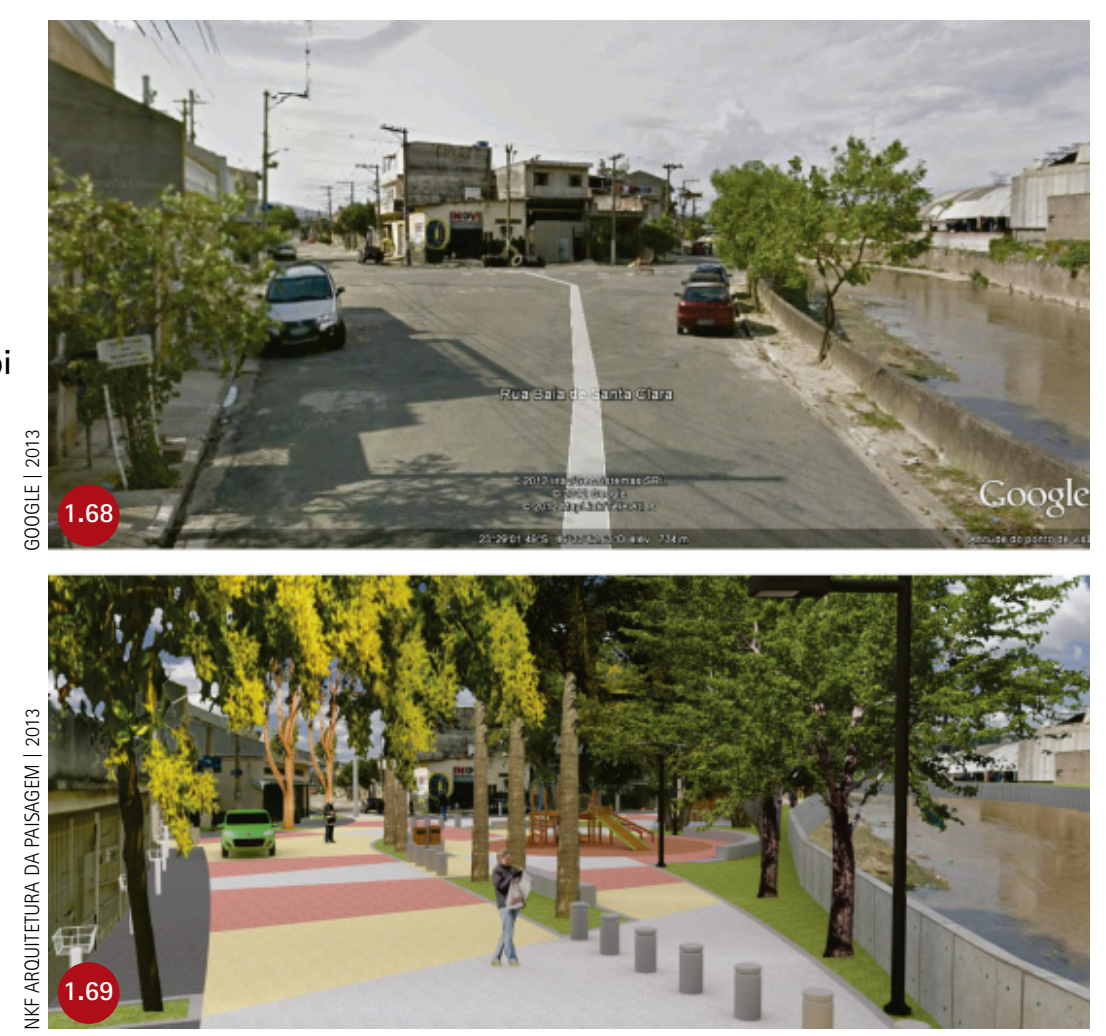

- Praças que viram parques: talvez por conta da sobrevalorização das questões ambientais, houve o entendimento equivocado de que os parques seriam superiores às praças, como se sempre tivessem relação com a preservação ambiental, e as praças, não. Como se estas não recebessem cuidados como ocorre com os parques. 

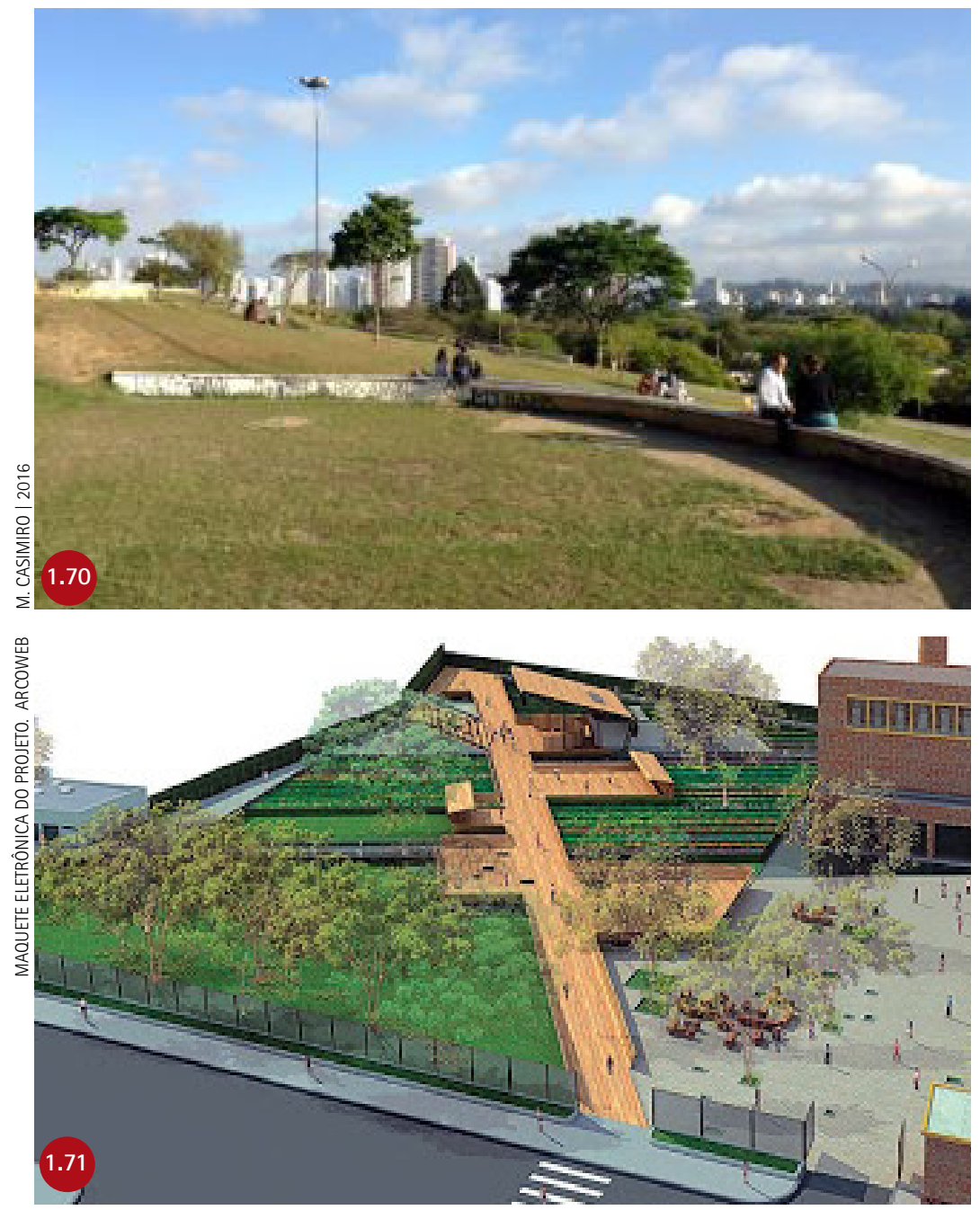

Em São Paulo, entre 2013 e 2015, houve um aumento de solicitações de entidades civis para o enquadramento de praças como parques. Casos como as praças da Sé e Roosevelt não foram adiante, mas alguns pedidos foram atendidos, como o novo Parque Tatuapé (praça do antigo Lions Clube Penha, com $19.128 \mathrm{~m}^{2}$ ) e a Praça Pôr do Sol (com 28. $358 \mathrm{~m}^{2}$ ). São áreas sem a presença de elementos naturais de relevância e com uso público estabelecido. A gestão dos parques municipais é responsabilidade da Secretaria Municial do Verde e do Meio Ambiente (SVMA) e a das praças, das subprefeituras. Os parques são cercados, possuem horários para fechamento e contratos para segurança. A população e o poder público acreditaram que, como parques, estas áreas seriam mais bem geridas, o que aponta a necessidade de rever a gestão das praças. ${ }^{36}$ (1.71) 72
Praça Por-do-Sol, em São Paulo, convertida em parque. Os solicitantes dessa alteração entenderem que, como parques, estas áreas estariam em melhores condições de gestão.

\section{A Praça Victor Civita (2008)} foi contada pelo Programa 100 Parques como parque. Em 2016 a editora Abril, que havia construído o espaço e o administrava promovendo atividades esportivas e culturais, entregou-o à prefeitura e os programas foram interrompidos. É um projeto sofisticado, que requer sofisticada manutenção - 0 que a prefeitura tem dificuldade de fazer. Além disso, poucas pessoas passam por lá. Sem os programas de animação, a praça não possui demanda de uso.

36 CASIMIRO, Mateus. Vira praça, vira parque. Blogdapaisagem, 11/03/2016. Disponivel em: <https://blogdapaisagem. wordpress.com/2016/03/11/vira-praca-vira-parque/>. 
37 Decreto № 13.286, de 14 de Janeiro de 2014. "Art. 10 Fica estabelecida a criação dos Parques Urbanos das Lagoas do Município de Fortaleza, área verde urbana pertencente ao Sistema Municipal de Áreas Verdes: I - Lagoa da Parangaba. II - Lagoa do Porangabussu. III - Lagoa da Messejana. IV - Lagoa Maria Vieira. V - Lagoa da Itaperaoba. VI - Lagoa do Mondubim. VII - Lagoa do Opaia. VIII - Lago Jacarey. IX - Lagoa do Catão. X - Lagoa da Maraponga. XI - Lagoa do Papicu. [ ... ] Art. $3^{\circ}$ As demais lagoas do Município de Fortaleza terão seus limites definidos posteriormente para efeito de criação de parques urbanos ou de parques lineares, se em conjunto com outros recursos hídricos, em consonância com a legislação ambiental e municipal vigente.
- Lagoas urbanas: Em Fortaleza, depois de obras como um estádio, um aquário, e de reformas de necessidade questionável no calçadão da praia de Iracema, as atenções se voltaram para a criação do parque do Cocó, situado no novo vetor da expansão imobiliária das camadas de renda alta. Outras tentativas para a criação de parques surgem, como uma lei que converte mais de uma dezena de lagoas em parques públicos ${ }^{37}$. Algumas acolhem feiras no entorno e são conhecidas; outras apenas são visiveis pelas fotos aéreas, e não são percebidas pela população. As lagoas são oportunidades para parques e a qualificação dos bairros à sua volta. Entretanto, não se trata de áreas públicas. 0 loteamento original da cidade dividiu todo o território em vias e lotes, inclusive o entorno das lagoas e 0 espelho d'água. É preciso grande esforço político, administrativo e jurídico para convertê-las em parques públicos de fato. Para a Lagoa da Sapiranga foi instituida uma Operação Urbana Consorciada que busca redefinir a ocupação no entorno e viabilizar a instituição deste parque municipal.
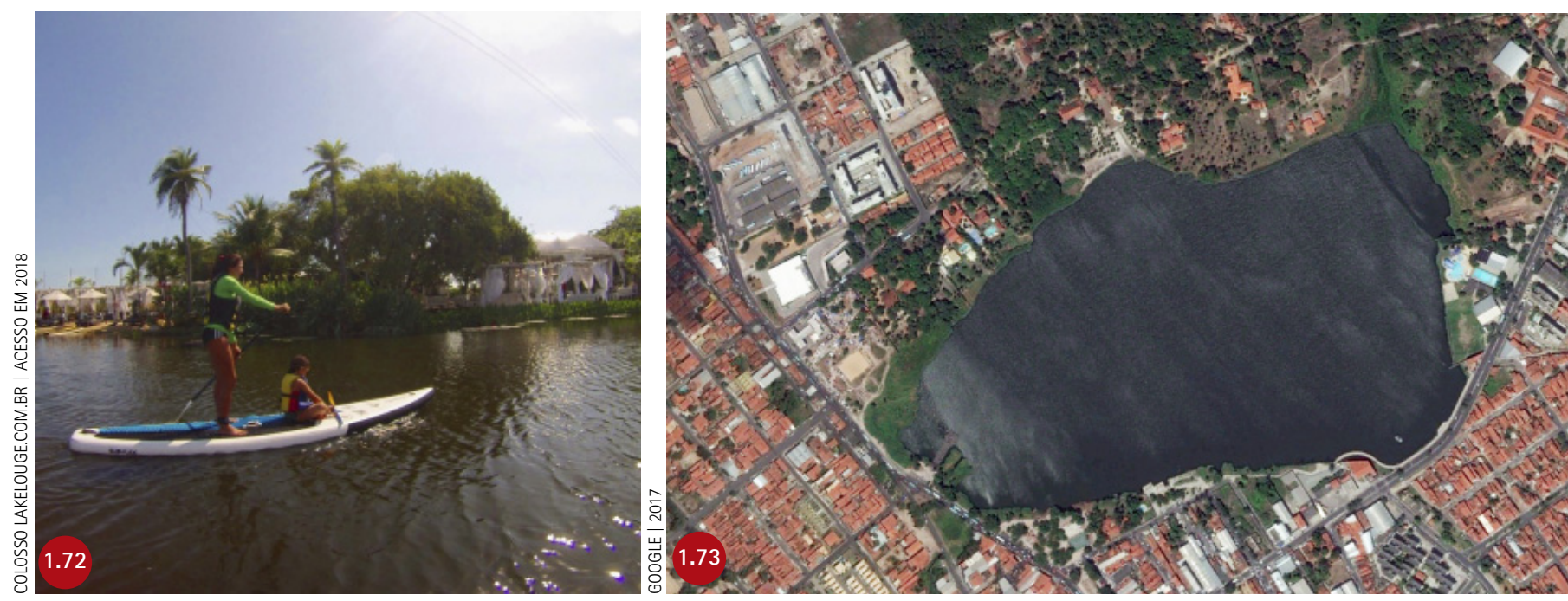

Lagoa do Colosso, em Fortaleza, a única lagoa urbana que tem tido apropriações esportivas. 0 acesso ao espelho d'água se dá por uma área privada, o restaurante Colosso Lake Lounge.

À direita, Lagoa da Messejana, em bairro popular.
Os parques se tornaram a solução genérica para todos os elementos urbanos protegidos por leis que não têm como serem incorporados ao tecido urbano regular - rios, lagoas e orlas, bens tombados ou bosques protegidos. Assim, acabam sendo definidos em locais que muitas vezes não apresentam condições adequadas de uso ou gestão. Entretanto, no caso de Fortaleza, as lagoas tendem a se tornar excelentes parques, em especial as que já possuem passeios e feiras ao redor. 
- Parques-quintais: em São Paulo a Casa Modernista (1928), projeto do arquiteto Gregori Warchavchik com jardins de Mina Klabin, foi assumida pela prefeitura e convertida em parque público em 2008 pelo Programa 100 parques. Contido em um lote urbano, este caso não poderia ser considerado um parque, mas uma outra categoria de espaços livres: jardim público ou jardim do Museu. Muitos jardins de palacetes foram convertidos em áreas públicas, e muitos museus brasileiros têm áreas livres com apropriações de passeio e recreação, mas sem serem considerados parques. 1.74 1.75

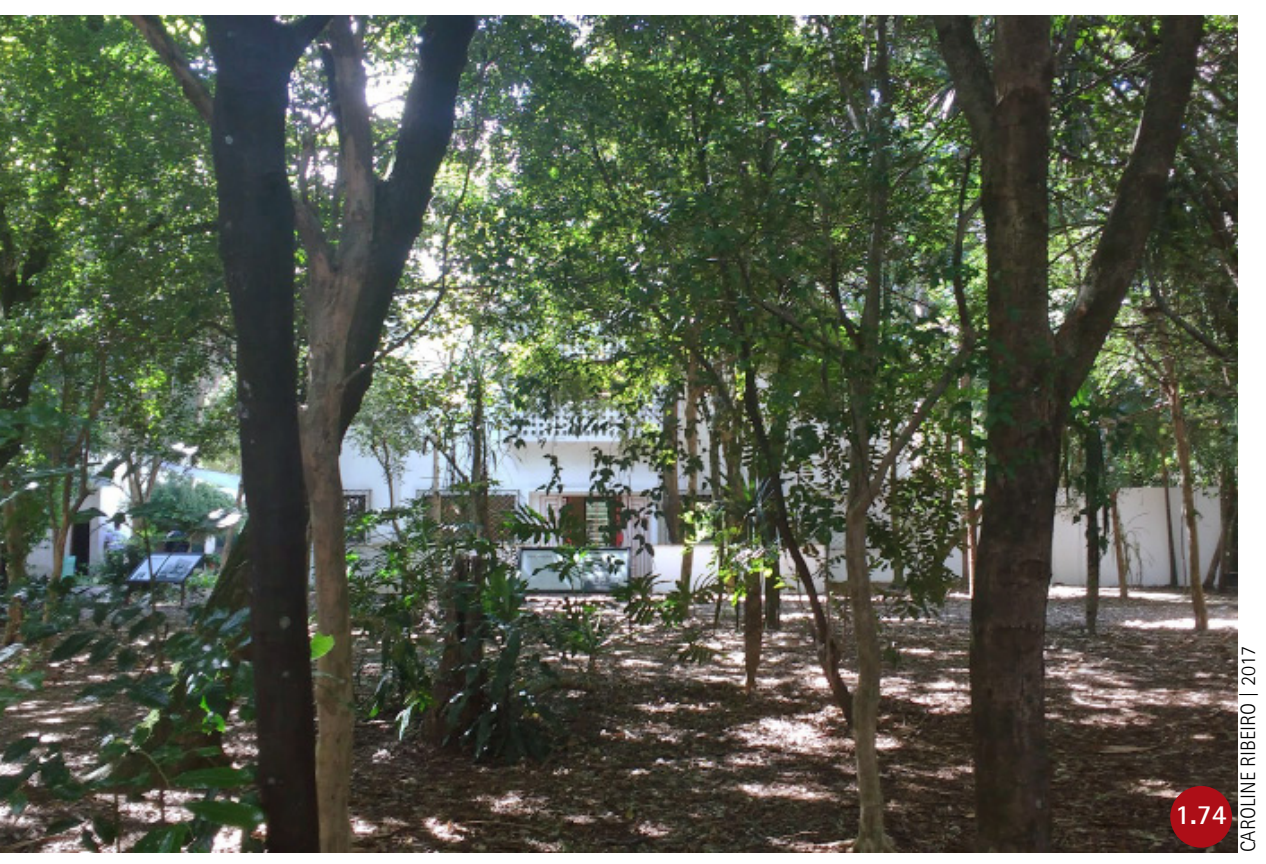

Parque Casa Modernista (2008), São Paulo. Trata-se, de fato, de um grande quintal, que agora é público. Em 2017, com poucos eventos, a visitação foi esparsa.
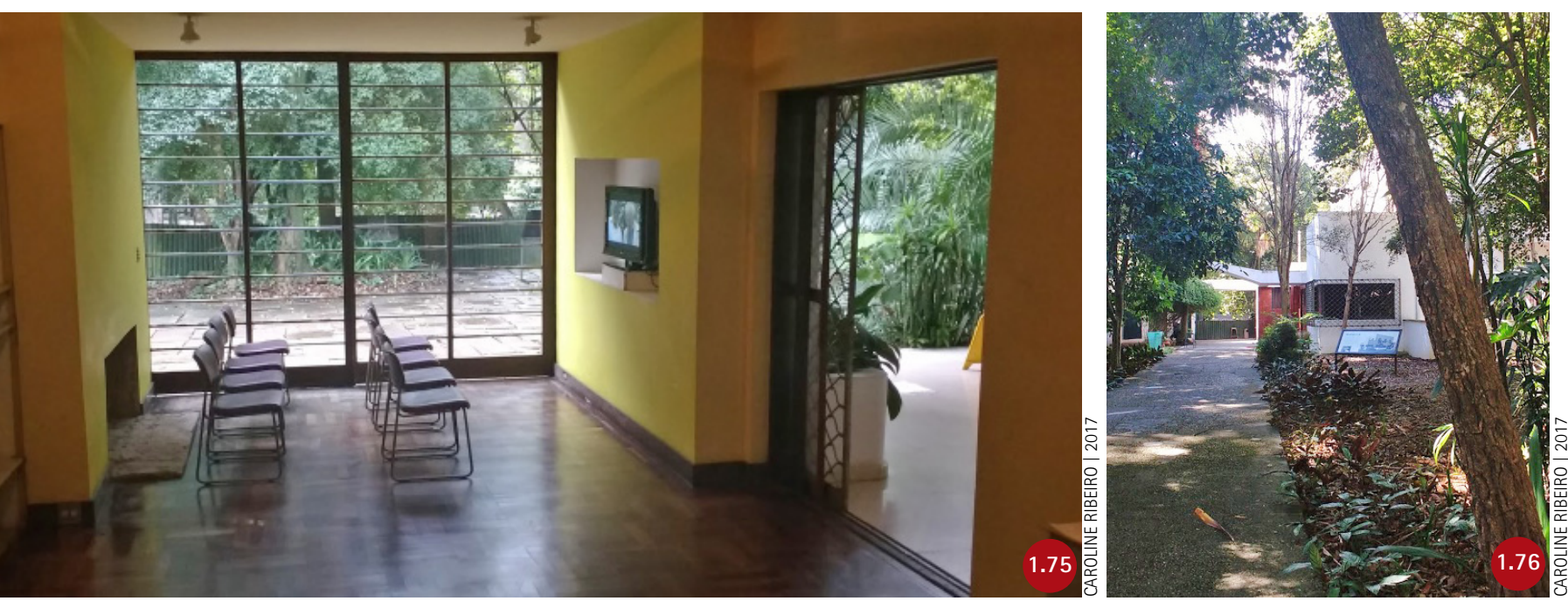
- Parques de esportes radicais: o Centro de Esportes Radicais (2016), em São Paulo, tem características e uso de parque, mas não recebeu oficialmente tal denominação. Construído junto da Marginal Tietê, possui $38.000 \mathrm{~m}^{2}$, circuitos e pistas para skate, Bike BMX, patins inline, patinete, parkour, ciclovias, pista de caminhada, área para shows e playground. Como no Parque Madureira, no Rio de Janeiro, há percursos para praticantes experientes e iniciantes. 0 equipamento paulistano não foi chamado de parque para que não ficasse sob a gestão da SVMA, mas da Secretaria de Esportes e Lazer. Isto demonstra que o nome "parque" acaba sendo conferido por razões administrativas, e não urbanísticas. Urbanisticamente, trata-se de um parque público de fato, cercado e com múltiplas atividades para o lazer de massa.
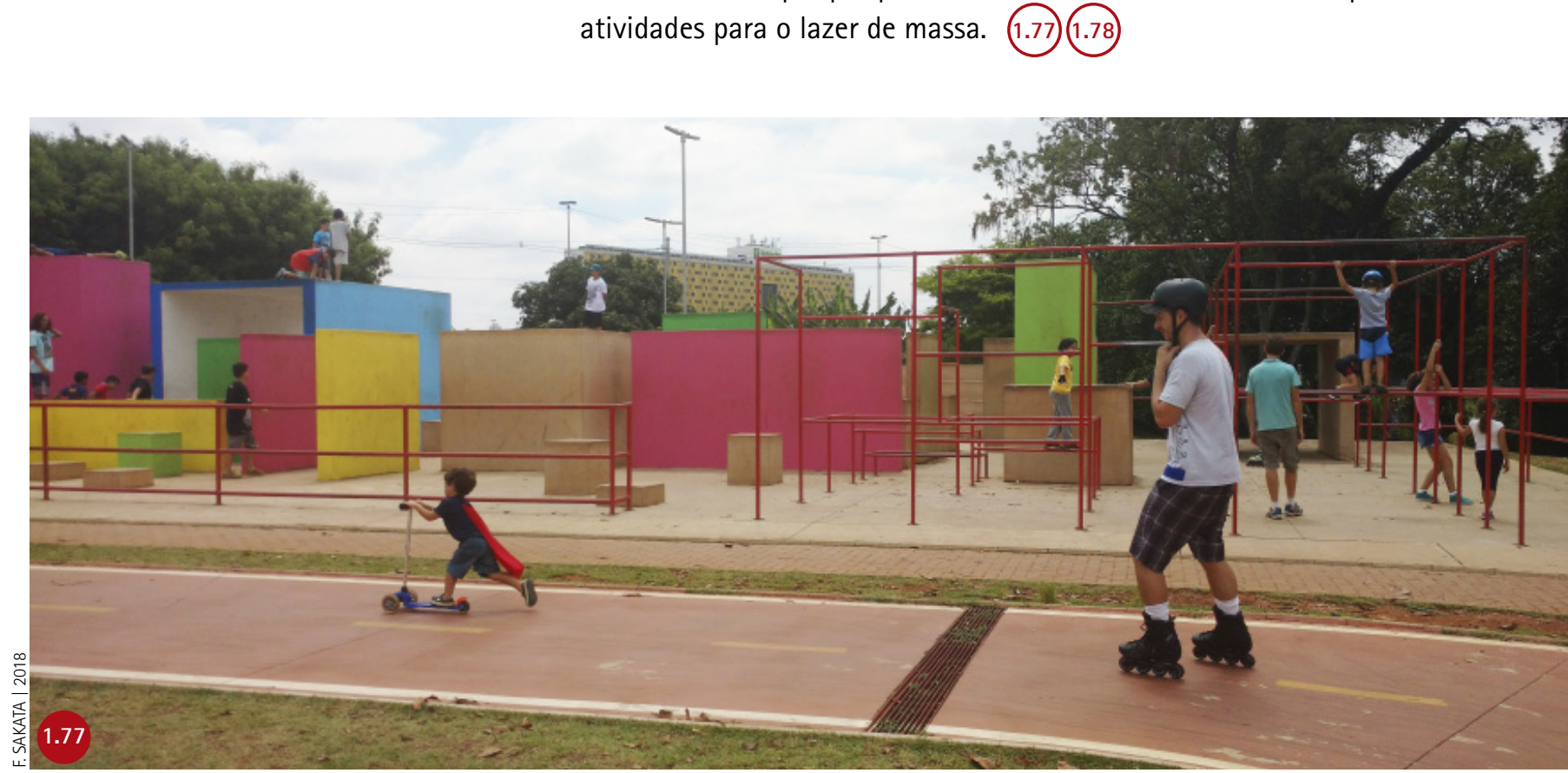

Centro de Esportes Radicais (2016), São Paulo. Tem usos de lazer típicos de parque mas a vegetação ficou em segundo plano. Isso demonstra que, popularmente, o termo parque tem uma relação mais forte com o jardim do que com os usos de lazer.

Orla Morena (2010), em Campo Grande, no canteiro que divide as duas pistas da Avenida Noroeste. Contava com 2,3 km de extensão e pista de skate.

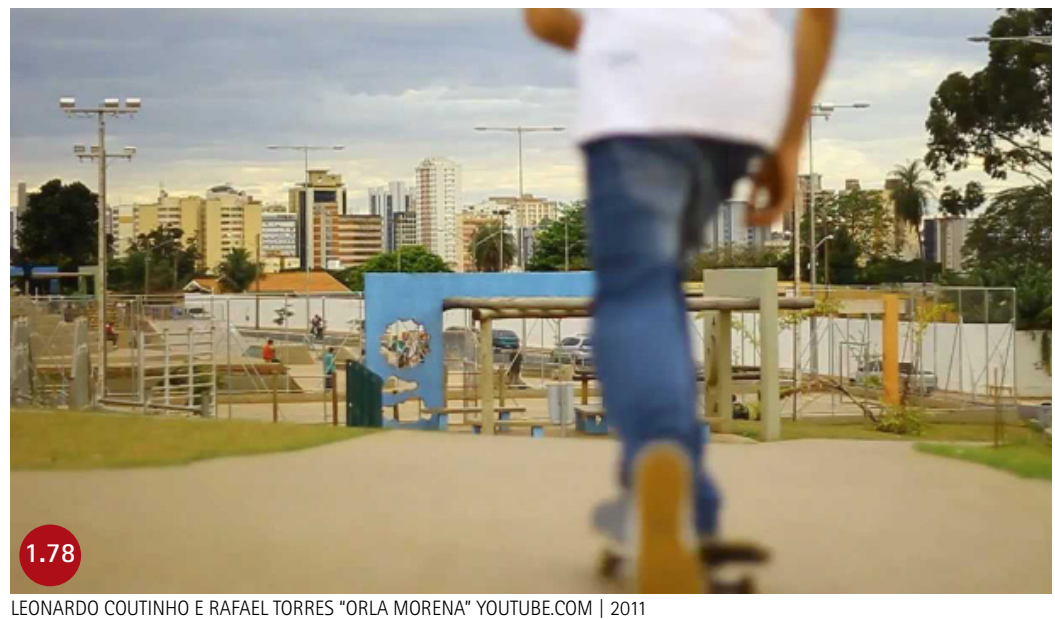


Em Manaus foram criados dois "parques da juventude”, com ênfase no programa esportivo, e outros estão sendo idealizados. No Rio de Janeiro há ainda o Parque Radical de Deodoro (2017), com piscinas e circuito de canoagem slalom. (1.79)
Parque Radical de Deodoro (aberto em 2015, fechado em 2016 e reaberto em 2017), Rio de Janeiro. Construído para as Olimpíadas, é um legado para a população.
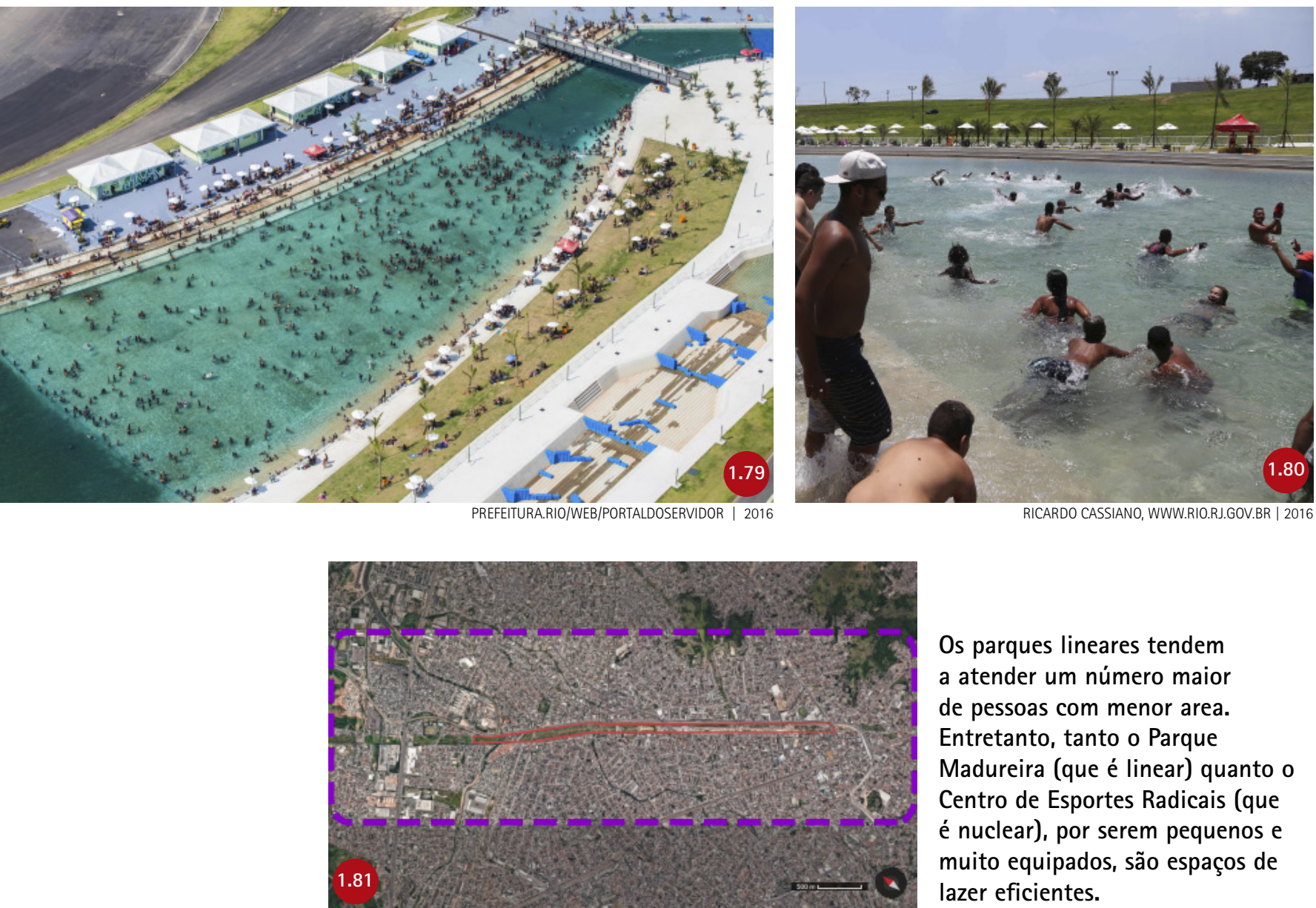

Os parques lineares tendem a atender um número maior de pessoas com menor area. Entretanto, tanto o Parque Madureira (que é linear) quanto o Centro de Esportes Radicais (que é nuclear), por serem pequenos e muito equipados, são espaços de lazer eficientes.

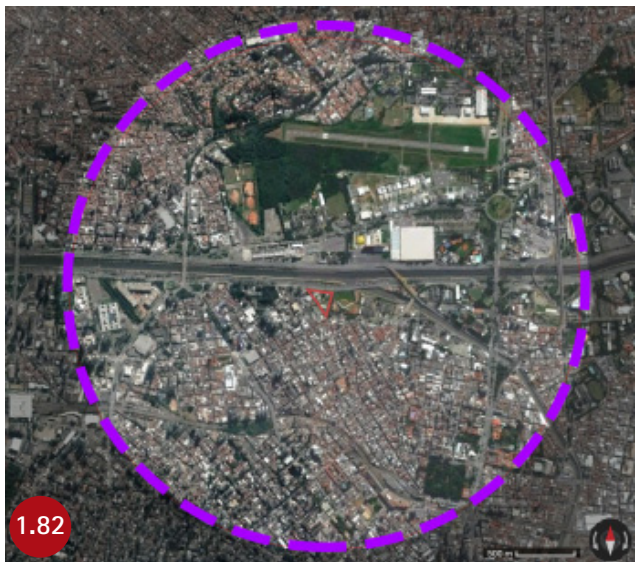

Se for considerado como raio de atendimento de 2 quilômetros de distância e densidade de 150 hab/ ha, o Parque Madureira, com seus 3,6 quilômetros de extensão e 255 mil m², atende 404 mil pessoas.

Com mesmo raio de atendimento, de 2 quilômetros, o Centro de Esportes Radicais, em São Paulo, com $38,5 \mathrm{mil} \mathrm{m}^{2}$, atende 6,2 milhões de $\mathrm{m}^{2}$, ou 93 mil pessoas. Sendo um parque pequeno, cada $\mathrm{m}^{2}$ atende 2,4 pessoas no entorno. 
- Avenidas de lazer e o parque Minhocão: avenidas que são fechadas para os veículos aos domingos não se tornam parques, mas assumem usos típicos de parque. A cidade de Bogotá, na Colômbia, foi pioneira em abrir a via que cruza a cidade exclusivamente para pedestres e ciclistas. No Brasil, nos anos 2010, houve aumento do número de avenidas exclusivas para pedestres aos domingos. As pessoas caminham, correm, brincam, marcam encontros, descansam à sombra, como nos melhores parques. ${ }^{38} 1.83$ (1.84

Avenida em Bogotá, Colômbia. Aos domingos, 121 quilômetros de ruas são bloqueadas aos carros.

Avenida Paulista. Aberta para pedestres aos domingos a partir de 2015. A Federação Paulista de Ciclismo estima que, durante os dias de bloqueio, circulem na avenida até 40 mil ciclistas.

Em Brasília, o Eixão, em 2017, com múltiplos usos esportivos e contemplativos, inclusive aluguel de carrinhos, infláveis e trampolins.
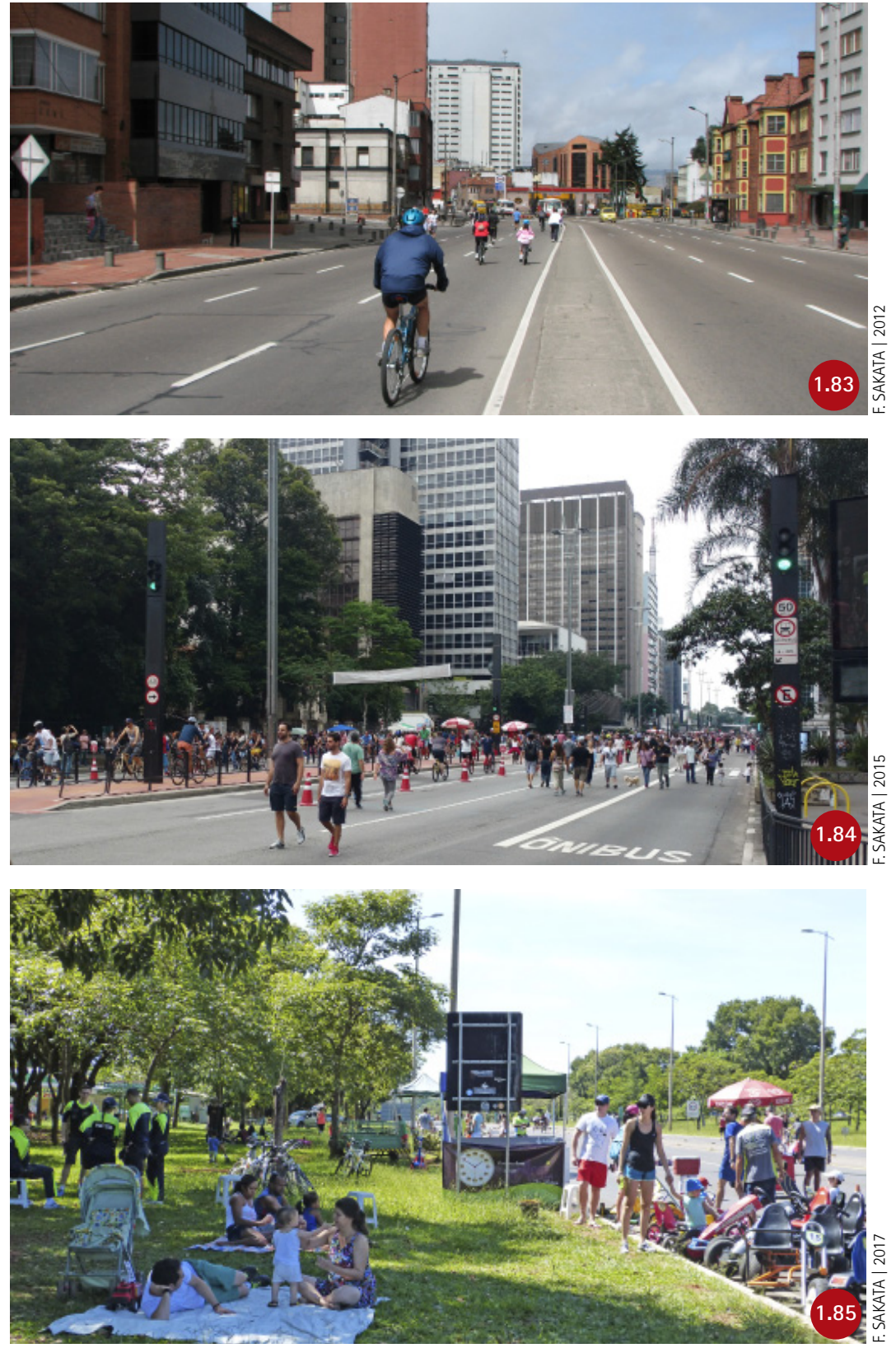
No Rio de Janeiro, a avenida Atlântica se torna uma extensão do calçadão da praia, abrigando corredores, patinadores e ciclistas que não teriam vez na pista, que é insuficiente no dia de folga da população. Em Brasília o Eixão possui usos de parque aos domingos. No Rio de Janeiro, a avenida à beira-mar é incorporada ao grande parque, a orla, ampliando-o. Em Goiânia, tem-se a Avenida Goiás. Ainda que apresentem usos de parque, avenidas não são parques, mas alternativas inteligentes para ampliar as opções de lazer em locais que já existem e que, aos domingos, podem ser dispensados do tráfego de veículos. 0 custo para a municipalidade é baixo, havendo grande impacto social.
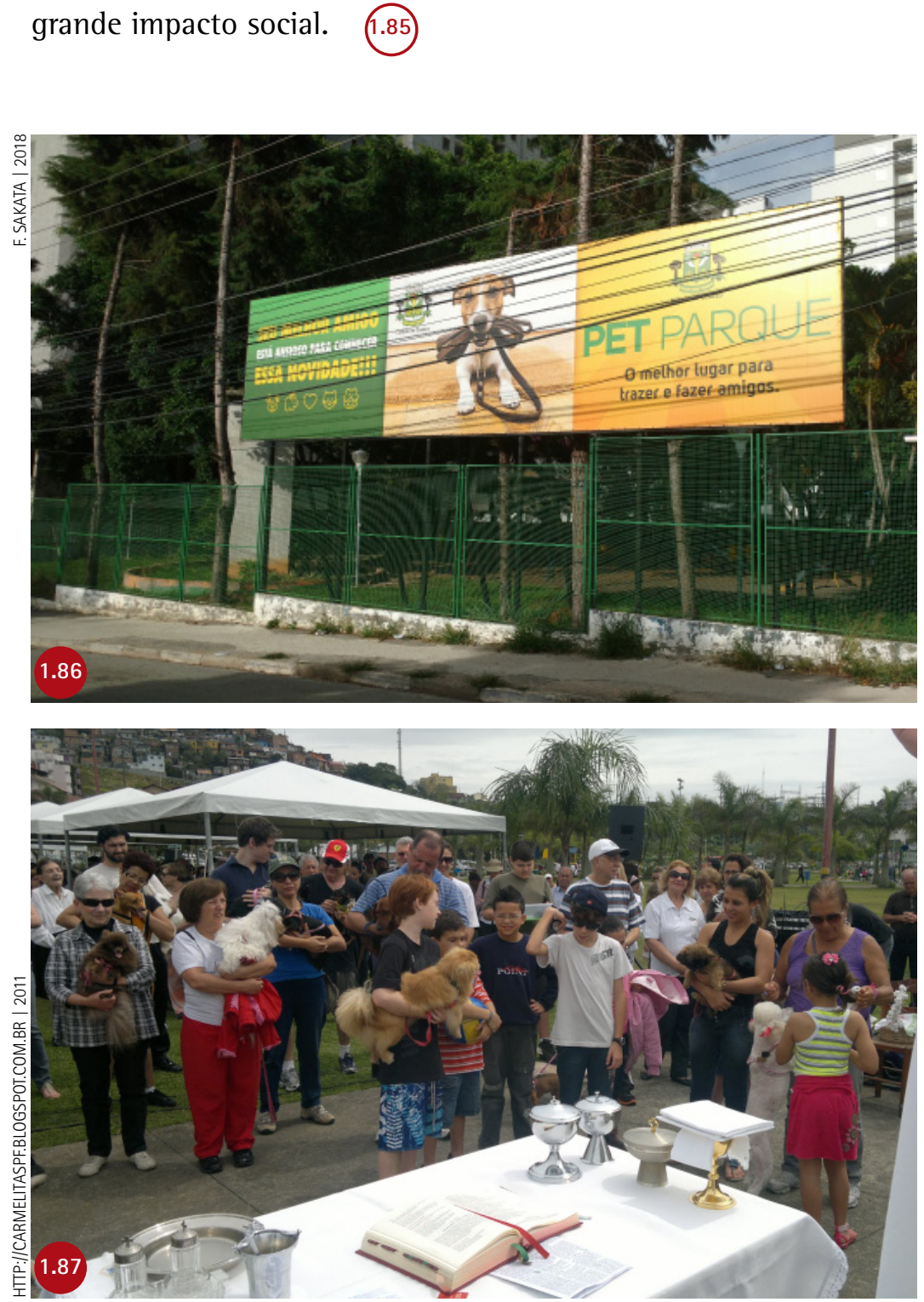

Petpark (2017), em Osasco/SP, um pequeno parque para cães, contido em um lote urbano. Cresceu no país a população que tem cães e novas demandas estão relacionadas a este fato. Uma delas é a criação de áreas cercadas em praças e parques para que animais possam brincar sem coleira, os "cachorródromos".

Missa campal com benção de animais no Parque de Coqueiros (1999), em Florianópolis. 
39 Eugenio Queiroga introduz o conceito de pracialidade: às vezes, um espaço não considerado praça permite usos citadinos que the conferem uma qualidade de praça, ou pracialidade. De forma análoga, o autor fala em parquealidade: espaços onde as pessoas têm a sensação de estarem em um parque demonstram sua parquealidade, mas não se tornam parques por isso.

QUEIROGA, Eugenio. Dimensões públicas do espaço contemporâneo: resistências e transformações de territórios, paisagens e lugares urbanos brasileiros. 2012. $284 \mathrm{f}$. Tese (Livre-docência) - Faculdade de Arquitetura e Urbanismo, Universidade de São Paulo, São Paulo, 2012.
Festas populares, eventos esportivos de rua, feiras, viradas culturais, a parada gay, os encontros pet e manifestações em geral subvertem a lógica de apropriação dos espaços de circulação. As corridas de rua, provas que têm se popularizado por todo país e reunido milhares de pessoas. Em São Paulo, segundo dados da Federação Paulista de Atletismo, foram realizadas 361 corridas de rua com alvará e 237 sem alvará. Há, inclusive, o "Circuito Rios e Ruas” com as rotas propostas por bacias hidrográficas. 0 espaço público tem sido utilizado de muitas novas formas, o que não acontecia há anos. Além dos significados culturais, os eventos também movimentam a economia e atraem turistas. 1.86 (1.87)

0 "Parque Minhocão" surgiu em São Paulo a partir das manifestações pelo fechamento do elevado Costa e Silva para os veículos, com o objetivo de ser usado exclusivamente como área de recreação. 0 viaduto elevado, conhecido como Minhocão, foi construído em 1971 e tirou a qualidade dos espaços livres e das moradias do entorno de duas maneiras: através da sua estrutura, que rouba o céu e a luz, e do fluxo de veículos em alta velocidade, que provoca ruído e poluição. Em 1989, atendendo reivindicações dos moradores para reduzir a poluição sonora e do ar, a prefeitura estabeleceu o horário de silêncio à noite, das $21 \mathrm{~h} 30 \mathrm{~m}$ às $6 \mathrm{~h} 30 \mathrm{~m}$, vigente até hoje, já com intenção do fechamento aos finais de semana. Em 1990 foram instaladas telas de proteção nas laterais do elevado e o tráfego foi interditado aos domingos para que o espaço pudesse ser apropriado como área de lazer. ${ }^{39}$

Em 2013 foi montada a Associação Parque Minhocão e outras surgiram, como o Movimento Desmonte do Minhocão (MDM), intensificando as discussões sobre os destinos do Minhocão, existentes desde sua construção. A Associação Parque Minhocão se posiciona a favor dos usos recreativos; o MDM é a favor da demolição do viaduto, porque o uso recreativo e os eventos culturais também geram incômodos para os moradores. Em 2015, por conta da mobilização do MDM, a prefeitura estabeleceu o fechamento do Minhocão aos sábados, a partir das $15 \mathrm{~h}$ e, em 2016, o prefeito sancionou uma lei que criou o Parque Minhocão. Esta não implicou em nenhuma alteração física do espaço, nem alterou o horário de abertura, mas 

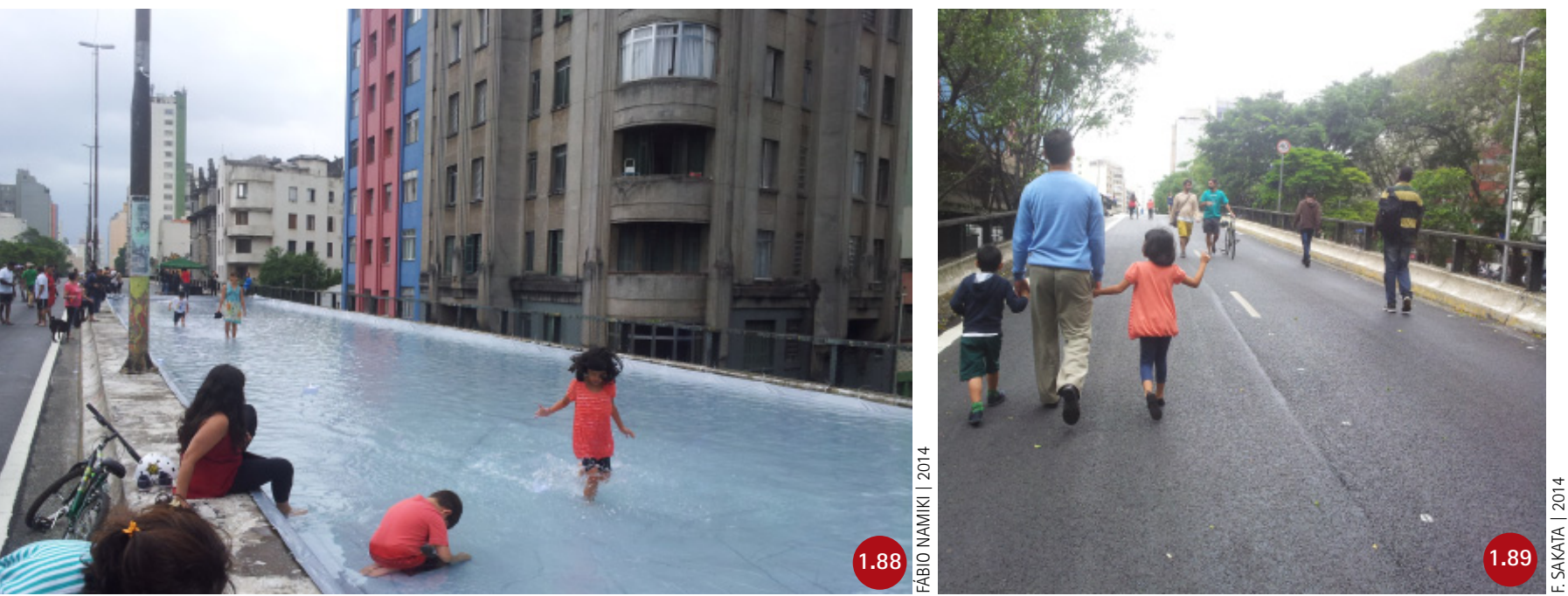

foi a sinalização da vontade do poder público de eventualmente efetivar o parque, o que permitiria a criação de um conselho gestor para discutir melhorias, alterações no funcionamento da via e até mesmo uma possível demolição. ${ }^{40}$

0 High Line Park de Nova York é tomado como referência para estes movimentos, mas há muitas diferenças de escala, inserção urbana e governança, e ainda não há consenso a respeito. 0 que têm em comum é o fato de serem viadutos, e esta condição faz com que o frequentador tenha algum grau de isolamento da cidade - mais físico que visual - nos momentos de lazer. A cidade, percebida com distanciamento, aproxima esta categoria da categoria dos parques urbanos. 0 Parque Minhocão é, em 2017, um parque em vias de se realizar, com ausência de recursos naturais, mas pleno de apropriações de lazer. 1.80

A piscina no Minhocão foi uma instalação artística da arquiteta Luana Geiger em 2014. 0 "Parque Minhocão" tornou-se, em 2017, ainda uma ideia de parque. Aos finais de semana veta-se o tráfego e o pavimento é utilizado para caminhar, pedalar, brincar com as crianças. A via se torna um parque esporádico, com gestão própria de área de lazer. Os usos públicos são transformadores.
40 RODRIGUES, Felipe S. S. Razões do Parque Minhocão. Vitruvius Arquitextos 209.05 urbanismo ano 18, out. 2017.

Disponivel em http://www.vitruvius.com. br/revistas/read/arquitextos/18.209/6751

41 SCHILLER, Mariana; CALDEIRA, Daniel Ávila. Cercar o Minhocão é a solução? Blog Observa SP, 06/09/2017.

Disponivel em: $<$ https://observasp. wordpress.com/2017/09/06/cercar-o-minhocao-e-a-solucao/s. 


\section{Quadro síntese dos tipos de parques}

Compondo as categorias de Espaços Livres listadas pelo Quapá-SEL, montou-se o seguinte quadro de espaços livres com nomes e/ou usos relacionados a parques:

\section{PARQUES TRADICIONAIS}

\begin{tabular}{|c|c|}
\hline TIPO & SUBTIPO \\
\hline \multirow{3}{*}{$\begin{array}{l}\text { Grandes parques de preservação urbanos (com grandes áreas) nas bordas } \\
\text { da cidade }\end{array}$} & Com uso metropolitano \\
\hline & Com núcleo para uso da vizinhança \\
\hline & Fechado ou com visitação restrita \\
\hline \multirow{4}{*}{$\begin{array}{l}\text { Parques tradicionais, com formato nuclear (ou compacto) } \\
\text { - podem ser associados a rios ou represas }\end{array}$} & Regional ou metropolitano \\
\hline & Da cidade \\
\hline & De bairro \\
\hline & De vizinhança \\
\hline \multicolumn{2}{|l|}{$\begin{array}{l}\text { Bosques com trilhas, estares, playground e outros equipamentos de lazer } \\
\text { em bairros tradicionais }\end{array}$} \\
\hline \multicolumn{2}{|l|}{ Calçadões e praias de mar e rio } \\
\hline $\begin{array}{l}\text { Centros comunitários e centros esportivos públicos com área livre } \\
\text { generosa }\end{array}$ & \\
\hline
\end{tabular}

\section{NOVAS CATEGORIAS DE ESPAÇOS LIVRES}

\begin{tabular}{|c|c|}
\hline \multirow{5}{*}{$\begin{array}{l}\text { Parques lineares } \\
\text { - associados a linhas férreas, viadutos, rios ou represas }\end{array}$} & Longos \\
\hline & Curtos \\
\hline & Aéreos (High Line, Minhocão) \\
\hline & $\begin{array}{l}\text { Muito estreito, a soma de pequenos } \\
\text { espaços de recreação de conjunto } \\
\text { habitacional }\end{array}$ \\
\hline & Rua-parque ou via-parque \\
\hline \multicolumn{2}{|c|}{$\begin{array}{l}\text { Parques de preservação urbanos de vários portes contidos na malha } \\
\text { urbana, sem usos públicos ou com uso muito restrito }\end{array}$} \\
\hline \multicolumn{2}{|l|}{ Bosques com trilhas em bairros periféricos } \\
\hline \multicolumn{2}{|l|}{ Bosques inacessiveis, normalmente em bairros periféricos } \\
\hline \multicolumn{2}{|l|}{ Área decretada como parque, mas sem intervenção ou uso } \\
\hline \multicolumn{2}{|l|}{ Parque desativado } \\
\hline \multicolumn{2}{|l|}{ Lagoas no meio da malha urbana com passeio e feiras em volta } \\
\hline \multicolumn{2}{|l|}{ Praça de grandes dimensões, convertida em parque } \\
\hline \multicolumn{2}{|l|}{ Parques de esportes radicais } \\
\hline \multicolumn{2}{|l|}{ Quintais de casarões e museus que se tornam áreas públicas } \\
\hline Avenidas de final de semana & \\
\hline
\end{tabular}




\subsection{Novo conceito para o parque urbano brasileiro}

Até 2000 consideramos em nossas pesquisas parques urbanos como espaços livres nas cidades, com dimensões generosas, destinados para a fruição social - passeio, contemplação, convivência, recreação infantil e esporte. Estruturados pela vegetação, pela água, pelo relevo ou por todos estes elementos combinados, foram considerados parques por seu papel de lazer e práticas sociais. Nas últimas duas décadas, porém, a denominação "parque" foi usada para novas ou antigas categorias, que não eram consideradas parques.

A ideia de parque é muito difundida e positiva. No imaginário, é sempre idílico: a natureza recriada dentro da cidade. Sempre associados ao embelezamento, aos bairros das classes altas e à vida urbana da mais alta qualidade, os parques passaram também a ser sinônimos de conservação ambiental e limites à ocupação urbana.

A associação do parque às qualidades urbana e ambiental foi o ponto mais importante para a difusão da nomenclatura "parque" a categorias diversas de espaços livres, mas faltaram vocábulos para nomeá-las adequadamente. A denominação "parque" se generalizou por conveniência e falta de alternativas semânticas. Foram adotados: parque linear, parque ecológico, zooparque etc.

Em São Paulo, para atingir a meta numérica de criar cem parques em uma gestão, o Programa 100 parques criou muitos deles, como há muitos anos não se fazia. Mas o programa também nomeou como "parques" espaços que não foram abertos à visitação pública, bosques muito pequenos e sem atrativos para recreação e espaços que eram denominados praças. Espaços de usos menos variados ou sem usos foram alçados à categoria de parque para contarem com verbas capturadas por termos de compensação ambiental e para constarem como feitos políticos.

Se mantida a premissa de que o parque urbano deve ter o lazer urbano como seu principal papel, que precisa ter grandes dimensões e ser estruturado por vegetação, água ou relevo, deve-se desclassificar parte destes novos parques e assumir que foram assim denominados equivocadamente. Entretanto, para avançar o debate, seria 
mais interessante estabelecer um novo conceito, que, na medida do possivel, acolhesse estes parques "errados". As motivações que geraram estas figuras no Brasil são apresentadas no Capítulo 2, mas pode-se dizer que foram os novos hábitos urbanos e as mudanças de postura em relação à conservação ambiental que colocaram espaços livres distintos sob a mesma nomenclatura, fato potencializado pela necessidade da propaganda, que buscou associar qualquer intervenção à preservação de elementos naturais.

0 principal processo de descaracterização do conceito tradicional de parque urbano foi sua aproximação com os parques naturais ou com as UCs. Parques naturais são figuras distintas dos parques urbanos. Distantes das cidades, podem ou não estarem abertos à fruição humana. Contemporaneamente, criou-se o entendimento de que para atrair recursos viabilizadores da atividade-fım - a preservação - é importante que os parques naturais atraiam pessoas e sejam conhecidos. 0 sucesso da preservação depende de haver pessoas que defendam as áreas. 0 Parque Nacional da Floresta da Tijuca, na cidade do Rio de Janeiro, por ser o mais conhecido dos parques nacionais, é também o mais vigiado, o que conta com mais funcionários e o que recebe mais recursos. Parques urbanos e parques nacionais são categorias muito diferentes mas os parques naturais municipais se aproximaram dos parques urbanos.

Em 2012, o Código Florestal (Lei Federal n 12.651/2012) criou as Áreas de Proteção Permanente (APPs) urbanas e foi fruto da crescente preocupação da sociedade com os recursos hídricos e remanescentes vegetais. Trata-se de uma lei genérica, que não considera a história da cidade, os processos urbanos já em curso, que não responde às demandas sociais. As áreas decretadas como protegidas podem ser públicas ou particulares. Mesmo sendo pública, sua conversão em parque pode não ser viável em curto prazo: depende de recursos financeiros e humanos e de existir real demanda para usos de lazer no local. Ainda que os parques em APPs não possam ser imediatamente criados, estão reservados por lei, constituindo estoque de áreas para futuros parques.

Em Vitória, o poder público mostrou-se pioneiro em relação à criação de órgãos públicos relacionados ao meio ambiente. A Secretaria 
Municipal de Meio Ambiente (Semmam) do município foi criada em 1986, antes da Constituição de 1988, que conferiu aos municípios responsabilidades sobre o patrimônio ambiental. Uma das ações privilegiadas pela Semmam desde a sua implantação está relacionada à criação de UCs e áreas verdes públicas. Inicialmente, não havia diferenciação entre as UCs e áreas verdes públicas, como os parques urbanos. Com o passar do tempo, o termo "parque urbano" passou a ser associado aos parques desprovidos de atributos ambientais, que não se enquadravam na legislação do SNUC. ${ }^{41}$ Assim, o parque urbano foi definido em Vitória não pelos usos de lazer, mas pela ausência de fragmentos naturais a proteger.

Em Fortaleza, o Decreto 13.286, de 14/01/2014, define que entre as áreas verdes no município de Fortaleza:

[...] os Parques Urbanos conformam uma categoria, cujo objetivo principal é a preservação e, em casos justificados, a conservação da cobertura vegetal da faixa de preservação permanente dos recursos hídricos e do seu entorno, compatibilizando-as com a oferta de equipamentos e espaços de lazer urbano.

No Distrito Federal, a criação de parques foi intensamente direcionada pela conservação; na delimitação das áreas, não se distinguiram as urbanas das não urbanizadas e o território foi lido do ponto de vista dos recursos a conservar. Os parques urbanos foram classificados como parques ecológicos, que são uma categoria das UCs. A instância governamental dividiu-as nos seguintes tipos: matas nativas, parques ecológicos, estações ecológicas, resbio (reserva da biosfera do (errado), reserva particular do patrimônio natural, reserva biológica, Floresta Nacional de Brasília (Flona) e monumento natural. Este trabalho não conseguiu contar com precisão os parques urbanos do Distrito Federal, porque as malhas urbanas ora contornavam parques, ora não contornavam, e muitos não foram ainda qualificados para apropriações sociais. ${ }^{42}$

Nas franjas das zonas norte e sul de São Paulo, foram também criados parques que são UCs. Nestas regiões existem bairros populosos entremeados por encostas da serra (ao norte) e braços das represas (ao sul), em urbanização fragmentada, com vias de acesso tortuosas e mal servidas por transporte e outras redes de infraestrutura.
41 A primeira Área de Proteção criada pelo município de Vitória foi a Estação Ecológica llha do Lameirão, em 1986, dando destaque à preservação do ecossistema do manguezal (ressaltando novamente a preocupação Secretaria com esse ecossistema). Posteriormente, foi criado o Parque Municipal Gruta da Onça, em 1988, preservando o ecossistema da mata atlântica. 0 municipio também se beneficiou com a criação do Parque Natural da Fonte Grande. Tal ação partiu da Assembleia Legislativa do Estado do Espírito Santo e apenas a partir da implantação do parque a transferência da responsabilidade passou para a Secretaria Municipal.

TRIGUEIRO, Aline; LEONARDO, Flavia Amboss Merçon. A gestão política do meio ambiente na cidade de Vitória-ES: reflexões sobre a criação de parques naturais e áreas verdes. Anais do Seminário Nacional de Pós-Graduação em Ciências Sociais da UFES v. 1, n. 1 (2011)

42 São exemplos de parques ecológicos o parque Olhos d' Água e o parque das Águas Claras; de estações ecológicas: UnB, Jardim Botânico, Águas emendadas; resbio: Parque Nacional de Brasilia. 
A relação da população com a natureza é contraditória: ao mesmo tempo, a proximidade é motivo de orgulho e grande incômodo, pois faltam serviços urbanos. Neste contexto, os parques não são simulacros da natureza no ambiente citadino, são a própria natureza, a ausência do urbano, no que ela tem de majestoso e de incômodo. Não está claro ainda como estes parques serão geridos.

Assim, o que se vê é a fusão do parque natural - a UC por excelência, com uso público controlado - com o parque urbano, espaço livre para o lazer de massa, estruturado por vegetação, água ou relevo. A fusão destes conceitos, muito diferentes, resultou nas figuras híbridas: os parques de conservação no meio urbano, os bosques cercados e os parques lineares em beira de rios ou lagoas. Estas novas categorias de parques urbanos prescindem do uso de lazer, que, em alguns casos, é apenas possibilidade futura.

Isto talvez revele que o desejo que moveu os poderes legislativo e executivo não foi exatamente pelo parque com suas apropriações para o lazer. A demanda foi pela reserva de áreas com recursos vegetais remanescentes para conter a urbanização e reverter processos de degradação das águas e ecossistemas de modo geral. 0 parque foi o instrumento, precário, para a realização desta vontade difusa.

Ainda que os parques tenham sido cada vez mais respostas a questões ambientais, mesmo parques sem elementos naturais significativos poderão ser definidos como tais - caso do parque do Aeroporto Tempelhof, em Berlim, limitado à pista e gramado. Parques construídos em antigos conjuntos fabris e outros parques contemporâneos europeus são muitas vezes bastante construídos, cobertos por pisos secos. 0 Parque Minhocão representa a ideia de parque de asfalto. Uma grande contribuição do século XX para o conceito de parque urbano foi associar a função de lazer à conservação de recursos naturais - estratégia benéfica para ambos propósitos.

Em favelas, ou conjuntos habitacionais construídos para substituí-las parcialmente, como no caso do Parque do Sapé, em São Paulo, a presença de recursos naturais - rio e árvores - mostra-se tímida. 0 rio, canalizado e ainda poluído, está em condição intermediária entre o canal de esgoto e o rio de fato. A vegetação plantada ainda 
não se desenvolveu, e não se tem garantias de que terá condições para atingir a maturidade. Em contextos áridos, a presença tímida de recursos naturais pode ser valorizada e percebida pela população como um contraste à condição urbana.

A sensação de isolamento do meio urbano, típica do parque, nem sempre é interessante em contextos de conjuntos habitacionais. A transparência aumenta a sensação de segurança. 0 parque na periferia, com apropriações de lazer, pode proporcionar a sensação de isolamento do urbano e enquadrar-se no conceito de parque do século XX - assim como pode ser mais transparente e contar com menor presença de recursos naturais.

Assim, a partir desta produção do século XXl, adota-se como definição de parque: o parque urbano contemporâneo brasileiro é um espaço público, que se insere ou que tangencia malhas urbanas. É figura urbana híbrida que resultou na fusão dos conceitos de parque urbano, destinado à recreação de massa, com o parque natural, destinado à conservação ambiental. Da fusão destes conceitos surgiram parques como grandes reservas no meio urbano; pequenos bosques em áreas periféricas e parques lineares de beira de rio.

A associação simultânea da conservação e do uso de lazer - seja este de massa ou em trilhas de baixo impacto - não é condição fundamental para a definição de parque no presente momento, embora seja desejável. Esta associação é uma estratégia economicamente racional e desejável, que contribui com a viabilização e a existência de espaços para fruição social, ao mesmo tempo em que protege os recursos naturais - bosque, rio, praia, pedra ou vista da paisagem.

0 terreno deve ser de posse do poder público e a gestão deve ser pública, seja através de conselho gestor ou outros meios, que busquem estabelecer e pactuar regras de uso, plano de manejo e condições de manutenção entre as instâncias públicas e a sociedade.

Estes novos tipos apresentam questões de apropriação e manutenção desafiadoras para a gestão pública nos próximos anos. 


\section{Implicações}

430 LabHab/FAUUSP, ao analisar as categorias de parques na legislação, faz diagnóstico semelhante. Afirma que, na forma que se encontra, não se estabelece uma conceituação de Sistema de Áreas Verdes estruturada "[...] em partes que compõem um todo, com funções especificas e diferentes gradações de conservação e preservação ambiental. Tampouco as categorias definidas no PDE correspondem às funções que devem ser abarcadas, 0 que sugere que seja feito um aprofundamento na definição dessas categorias, na sua relação com o zoneamento, inclusive revisando sobreposições ou desenhos de áreas. Tudo isso pode ser feito através de um novo documento, eventualmente através de lei especifica".

Projeto "Pesquisa e análise de aplicação de instrumentos em planejamento urbano ambiental no município de São Paulo". Produto 3. Relatório - Instrumentos de Planejamento Urbano-Ambiental do Sistema Municipal de Planejamento. São Paulo: LabHab/FAUUSP, SVMA, junho de 2006. Mimeo. p. 25-28. In: WHATELY, Marussia; SANTORO, Paula Freire; GONÇALVES, Bárbara Carvalho; GONZATTO, Ana Maria. Parques urbanos municipais de São Paulo: subsídios para a gestão. São Paulo: Instituto Socioambiental, 2008.

440 arquiteto Sun Alex defende, na Prefeitura de São Paulo, que os projetos de parques sejam feitos a partir da capacidade de construção e manutenção do poder público, e que a manutenção seja a linha mestra da organização do departamento de parques. Reunião para apresentação do Projeto do Parque Leopoldina Villas-Bôas, em 02/12/2015.

\section{Da desvantagem de criar categorias híbridas}

A impossibilidade de categorizar os parques com precisão é ruim para o planejamento, a gestão e a manutenção $0^{43}$. Se a gestão fosse diferente, e a manutenção mais sistemática, talvez a nomenclatura se mostrasse menos aberta. Mas a dinâmica das transformações nas últimas décadas foi muito veloz, sendo preciso discutir a manutenção deste momento em diante.

Uma vez que reconhecemos a impossibilidade de tratar todos os parques de uma mesma forma, as estruturas de gestão e manutenção não devem se guiar pelas necessidades de cada logradouro para solucionar questões de apropriação e programar estratégias de manutenção. As novas categorias devem ser estruturadas a partir da organização para a manutenção. ${ }^{44}$

II. Da vantagem de criar categorias hibridas

A partir do momento em que os parques passaram a ser vistos como peças do sistema de espaços livres, pode-se experimentar novas formas de articulação de espaços livres.

Bacias de detenção/retenção podem (e devem) ser associadas a parques. Faixas de Domínio de Dutos/ Linhas de Transmissão de Energia também têm este potencial. Estacionamentos desocupados no final de semana, terrenos vazios, campus universitários, todos podem ter seus usos reinventados e serem articulados em novos sistemas. 


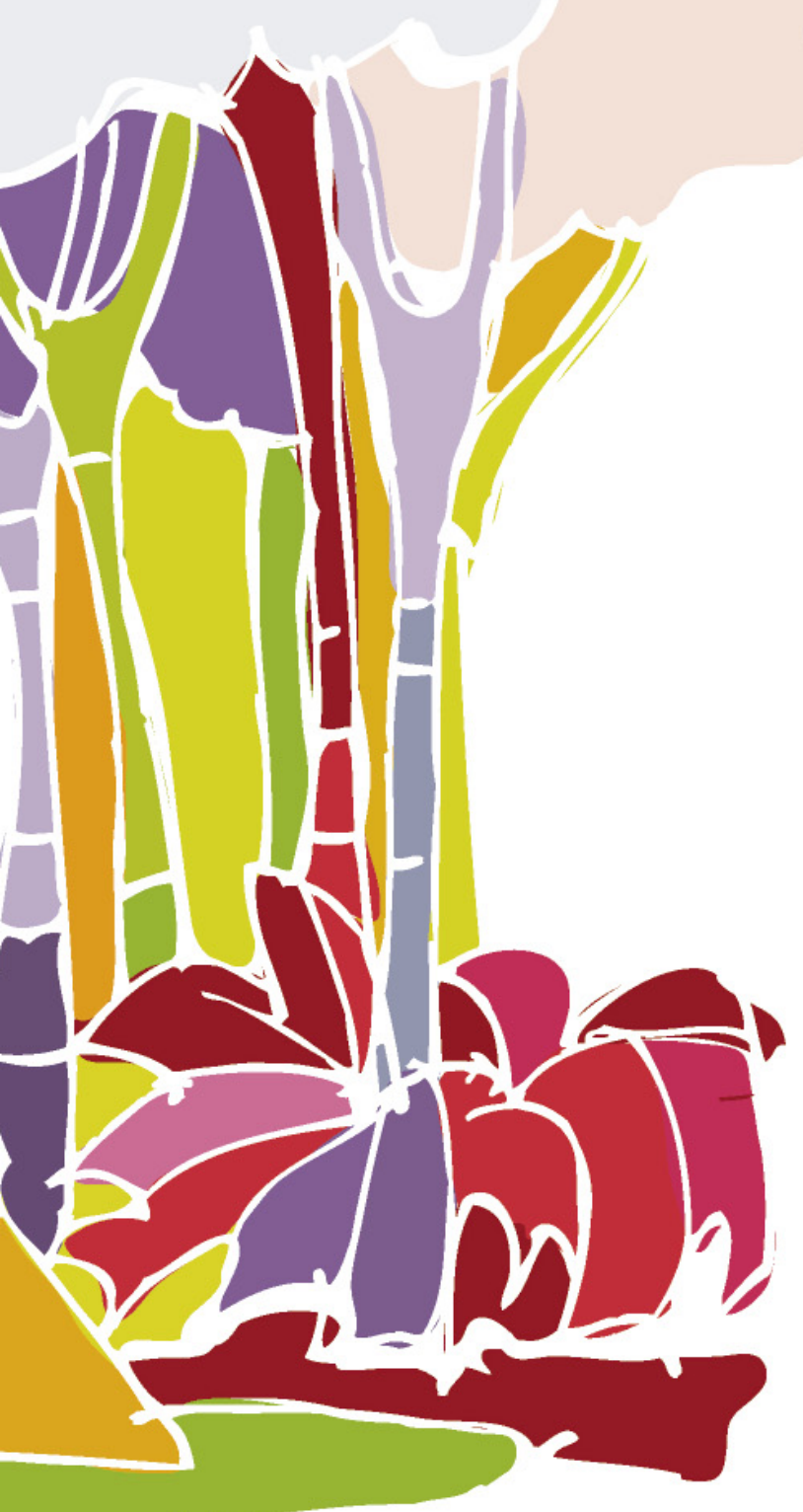




\subsection{Agentes}

No século $X X 1$, os parques foram implantados com significativa quantidade nas cidades brasileiras, pois preservam o meio ambiente ao mesmo tempo em que valorizam bairros, ampliam possiblidades de lazer e atendem interesses imobiliários e políticos de diferentes grupos e forças sociais.

A criação de parques tanto pode derivar de planos urbanos atentos à distribuição equilibrada dos equipamentos urbanos (caso das cidades de Campo Grande e Rio Branco), como pode ser fruto de políticas e programas públicos de administrações que os locam onde conseguem viabilizá-los ou, ainda, de ações pontuais públicas ou privadas que aproveitam uma conjunção favorável.

0 planejamento urbano mais abrangente, desenvolvido em gabinete, tem cada vez menos espaço nas cidades. São poucos os eventos que têm conseguido mobilizar de forma coordenada as forças políticas e econômicas envolvidas na construção das cidades. Em todas as oficinas do Quapá-SEL, parte do trabalho é a identificação dos principais agentes da transformação urbana e seus investimentos nas cidades. 0 mapeamento das ações destes agentes revela vetores de expansão e aponta tendências de transformação.

Os principais agentes construtores da forma urbana são ${ }^{1}$ :

- governo federal: atua especialmente através de linhas de crédito e programas como o Minha Casa Minha Vida (MCMV), que tem dado os parâmetros urbanísticos da expansão urbana por todo país. $A$ locação de hidroelétricas, aeroportos, universidades federais (entre
10 professor João Meyer, da FAUUSP, foi responsável por desenvolver a metodologia de identificação de agentes para as oficinas do Quapá-SEL. Uma lista completa inclui muitos outros agentes, como corretores, rentistas de aluguel etc. Mas esta simplificação é suficiente para um diagnóstico rápido e, ao mesmo tempo, bastante satisfatório. 
outras grandes instalações) e a legislação ambiental também têm muito impacto nas transformações;

- governo estadual: através da construção de rodovias e avenidas, ordenação de sistemas de transporte como trens e metrô, locação de centros administrativos, culturais, polos industriais, comerciais e parques (entre outras ações). A construção de rodovias tem grande impacto nas transformações urbanas. Por outro lado, a atuação das instâncias de planejamento metropolitano mostra-se pouco efetiva;

- prefeitura: é o agente público mais ativo nas cidades, atuando principalmente através da legislação urbana, que zoneia a cidade e estabelece parâmetros construtivos. Grandes empreendimentos dependem de aprovações da prefeitura, e as permissões e limitações à construção fazem diferença para o construtor-investidor. A prefeitura regula os transportes público e particular, implementa vias, ciclovias e parques;

- empresas de base imobiliária: responsáveis por empreendimentos imobiliários de toda a natureza;

- empresas sem base imobiliária: como as grandes indústrias, os shopping centers e as instituições de ensino, geram demanda e promovem investimentos que podem estimular ou inibir empreendimentos imobiliários; acabam condicionando a potência e a direção dos vetores de crescimento da cidade;

- população: constrói e amplia casas, com um pavimento a mais ou a ocupação total do lote. Altera a forma da cidade.

0 poder público atua nas cidades através dos investimentos públicos infraestruturais, da legislação urbanística e das articulações destes com os investimentos privados.

A população e os urbanistas não são capazes de direcionar ou limitar as transformações urbanas, que ocorrem velozmente. Em 2016, na campanha popular pela criação do parque Augusta em São Paulo, as pessoas lamentavam a verticalização e a falta de qualidade urbana e de áreas verdes. A luta pela criação de parques é, em parte, a materialização da resistência à urbanização. 


\section{Antecedentes}

Em trabalho anterior ${ }^{2}$, analisamos cinco programas de criação de espaços públicos, entre 1980 e 2005, e as motivações da criação. 0 Projeto Rio Cidade, no Rio de Janeiro (1993-2003) foi responsável pela requalificação de ruas comerciais em centros de bairro em toda a cidade. A repercussão foi muito boa junto à população, pois eram espaços tomados por carros e camelôs, com uso muito intenso. As intervenções passaram a ser sistematicamente solicitadas pelos comerciantes dos bairros. 0 prefeito e arquiteto, Luiz Paulo Conde, elegeu-se, em boa parte, por conta do sucesso do programa.

Em 2005, o programa encolheu e a Prefeitura do Rio de Janeiro encampou projetos mais ambiciosos, associados à Copa do Mundo (2014) e às Olimpíadas (2016). Com exceção das obras de mobilidade e das calçadas do Porto Maravilha, as novas infraestruturas - museus e instalações esportivas - eram mais caras e muito menos úteis para o cotidiano do carioca. 2.01 2.02

Em São Paulo a administração municipal de 2000-2005 teve dois programas de criação de espaços públicos: o Centros-de-Bairro, que requalificou praças com caminhos, bancos, brinquedos, quadras, flores, árvores e palmeiras em subcentros periféricos; e os Centros Educacionais Unificados (CEUs), espaços escolares amplos e de qualidade que permitem a apropriação pela comunidade de salas, teatros, piscinas, playgrounds. 0 primeiro programa não teve a visibilidade do segundo, pois, apesar de procurar intervir em centros de bairros populosos, significou a requalificação de cerca de 50 logradouros em um universo de quase 3 mil praças. 2.03 2.04

O Programa Viva-Bairro (1996-2002), em São Luiz do Maranhão, objetivou a qualificação de praças para as festas do boi e o carnaval. Eram espaços já intensamente utilizados, muitos com piso de terra. O governo do Estado promoveu a construção de pisos coloridos, bancos, mesas e quiosques por toda a cidade. Foi uma ação de sucesso, porque veio para atender demandas já existentes. A apro- 
CAPÍTULO 2. GESTÃO DE OPORTUNIDADES
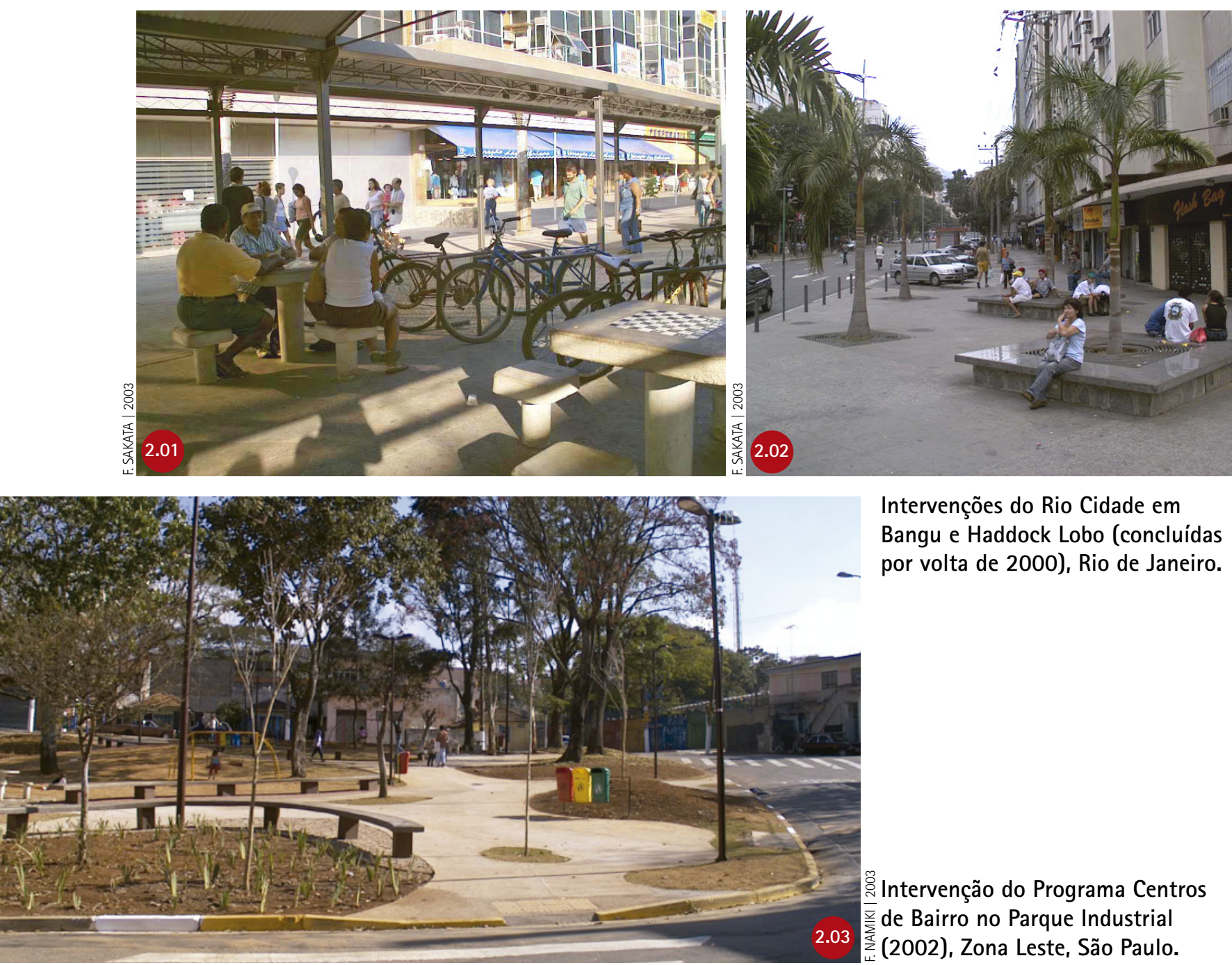

Intervenções do Rio Cidade em Bangu e Haddock Lobo (concluídas por volta de 2000), Rio de Janeiro.

Intervenção do Programa Centros de Bairro no Parque Industrial (2002), Zona Leste, São Paulo.

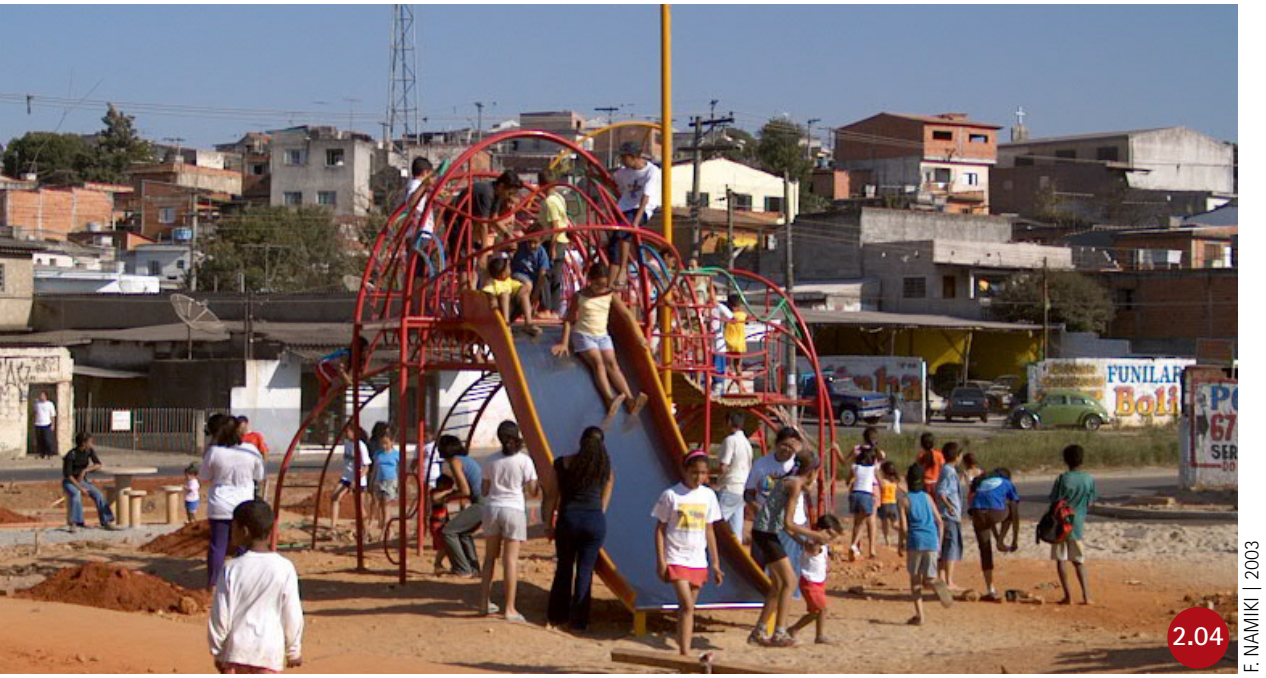

Obras de implantação brinquedo "Jacaré", do Programa Centros de Bairro em 2003, na Praça Bassano del Grapa, na Vila Carrão, Zona Leste, São Paulo. As subprefeituras não tiveram condições de conservar os brinquedos que duraram, sem manutenção alguma, não mais que três anos. 

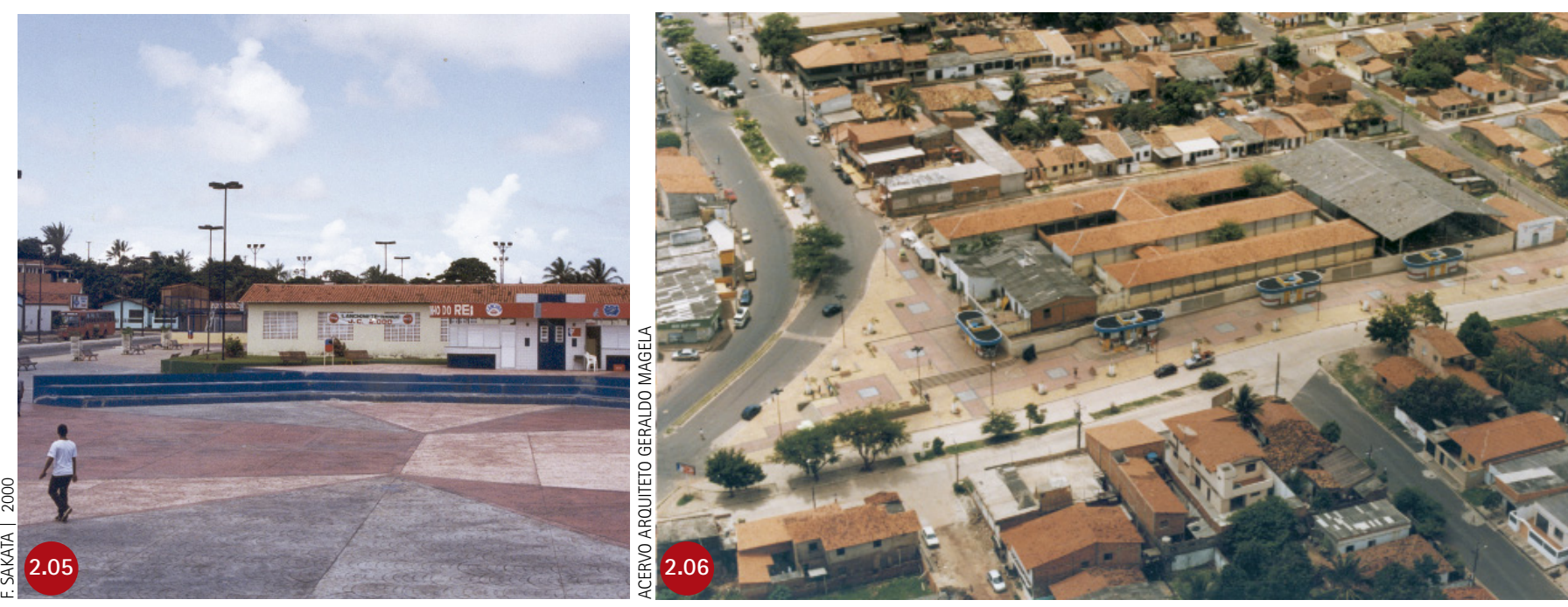

À esquerda, o Viva Angelim (1996) e à direita, o Viva-Anjo da Guarda (1996), do programa Viva-Bairros, São Luís do Maranhão.
Em Salvador foi analisado um conjunto de parques multicoloridos feitos nos anos 1990, em paralelo com a intervenção no Pelourinho (1993). Com corrimãos de inox e coberturas de lonas brancas, distribuíam-se no percurso entre o Pelourinho e o aeroporto, no sentido da orla do Atlântico - mais valorizada pelas elites do que a orla da Baía de Todos os Santos. As principais motivações eram a propaganda turística e a representação do poder político no espaço da cidade.

Por fim, estudou-se o caso dos parques de Curitiba. Os primeiros foram feitos, segundo técnicos do planejamento local, como uma forma de prevenir enchentes, mas passaram a ser muito frequentados e foram apresentados como símbolos de qualidade de vida, o que ajudaria a cidade a atrair indústrias e trabalhadores qualificados. Depois do Bosque do Papa (1980), os parques foram feitos sempre com modo temático, chegando a um por ano. Todos na zona norte de Curitiba, têm relação com o mercado imobiliário: além de impedir a ocupação por favelas e a desvalorização das terras, seus terrenos - especialmente os últimos deste conjunto de parques dos anos 1990 - foram negociados com empreendedores locais. Cedia-se a área de preservação em troca da valorização das terras vizinhas para empreendimentos. Havia o entendimento de que os proprietários não poderiam ser penalizados em relação à preservação ambiental ou não colaborariam com ela quando preciso. Mas não se tratava, na ocasião, do grande capital imobiliário transnacional. 


\section{A nova escala do capital imobiliário}

A partir dos anos 1980, o padrão de acumulação capitalista sofre profundas transformações. Em escala mundial, a matriz de organização de riquezas passa a ser o mercado financeiro, o que impõe uma nova organização das políticas públicas tanto nos países desenvolvidos quanto nos subdesenvolvidos. ${ }^{3}$

Até os anos 2000, predominavam no Brasil, como investidores imobiliários, as famílias proprietárias de terras e aqueles com quem se associavam. As elites locais coordenavam as incorporações, construções e vendas. A partir deste período, surgem grandes empresas com capital na bolsa de valores, que haviam captado crédito de fundos públicos, projetando-se nacional e internacionalmente. Ocorreu uma significativa mudança de escala no capital imobiliário.

A crise fiscal do Estado, associada à reestruturação da apropriação do dinheiro em circulação no sistema financeiro mundial, implicou na inflexão do reconhecimento de direitos e na oferta estatal de bens e serviços públicos. Caminhava-se para a distribuição universalizada das políticas públicas, mas o jogo se inverteu: o orçamento público e os fundos financeiros do Estado deixavam de ser responsáveis pelo bem-estar da população, limitando-se a atender demandas localizadas e ao fomento da economia de mercado. Para alguns autores, o orçamento fiscal do Estado passa a ser direcionado também para garantir a rentabilidade de aplicações financeiras de investidores privados. A provisão de moradias sociais, compreendida como parte dos direitos fundamentais, migrou para a lógica dos mercados, articulando-se com a arquitetura financeira dos novos padrões de acumulação do capital. ${ }^{4}$

A criação de parques públicos não deixou de ser entendida como papel do poder público, mas já não havia recursos financeiros disponíveis para isto nos orçamentos e fundos do Estado. Foi, entretanto, um período de prosperidade econômica, com créditos públicos para construção e compra de imóveis e expansão do mercado imobiliário privado. A expansão dos parques está relacionada a este processo e foi viabilizada de duas formas:
3 Luciana Royer aponta as consequências deste novo arranjo capitalista para a provisão de habitação no Brasil. As consequências para produção de espaços públicos aparecem nos estudos do Quapá-SEL.

ROYER, Luciana de Oliveira. Financeirização da política habitacional: limites e perspectivas. 2009. 194 f. Tese (Doutorado em Arquitetura e Urbanismo) - Faculdade de Arquitetura e Urbanismo, Universidade de São Paulo, São Paulo, 2009.

4 Idem. 
- em terrenos próximos de grandes empreendimentos residenciais e comerciais, com recursos dos empreendimentos - como ações de compensação ambiental que, ao mesmo tempo, valorizavam os imóveis para a venda;

- em bairros periféricos, fora do eixo de expansão imobiliária, com recursos de termos de compensação de shopping centers, torres comerciais ou mesmo de obras públicas de infraestrutura, transferidos para fundos públicos.

A municipalidade passou a capturar recursos da iniciativa privada através de Termos de Compromisso Ambiental (TCA) e de Termos de

Edifícios em torno do Parque Ajustamento de Conduta (TAC). Recursos estes que o próprio poder Chácara Paraíso (2013), em Vitória. público havia repassado às grandes empresas do setor na forma de

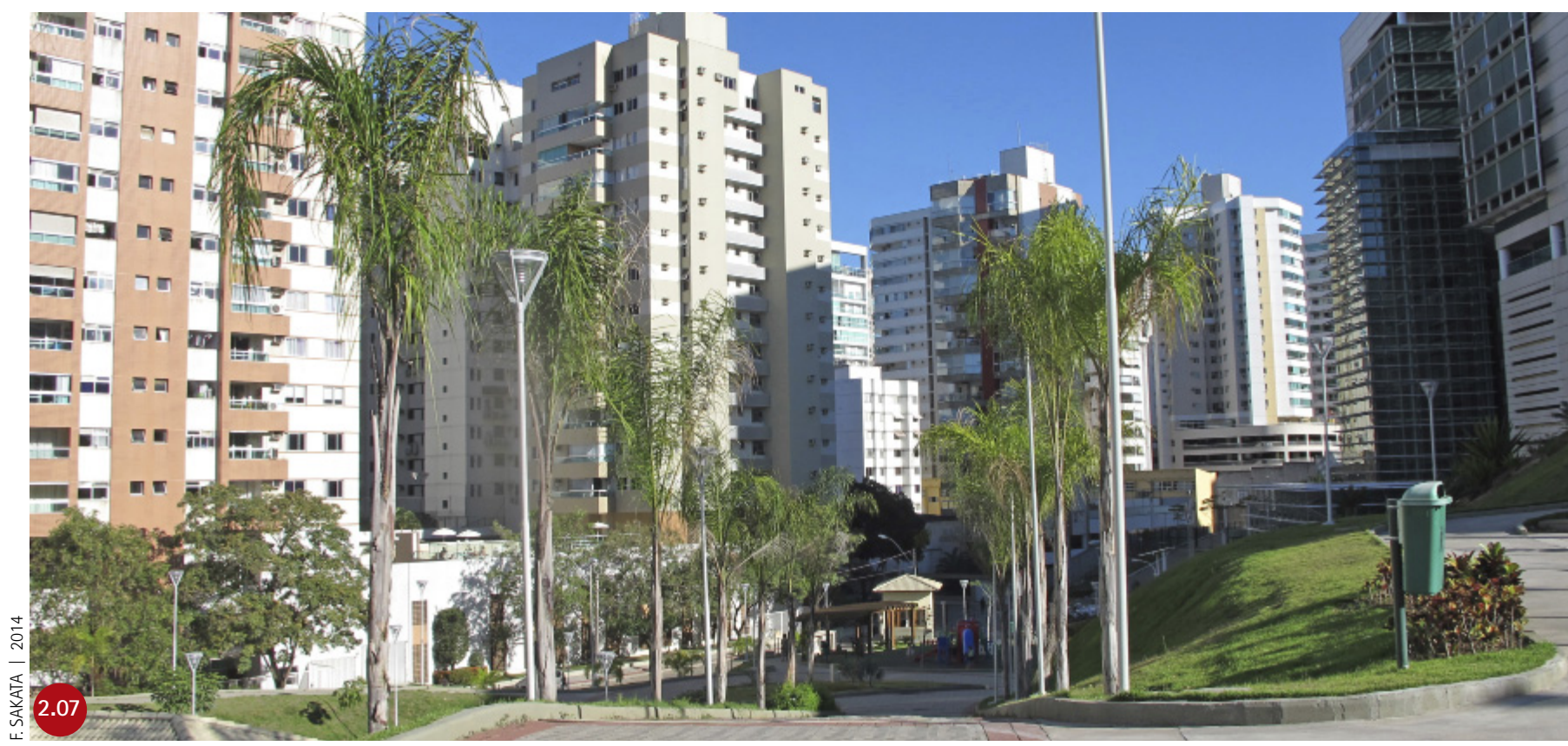

crédito. Isto financiou a criação de parques e de obras viárias de diversos portes no entorno dos empreendimentos. (2.07)

Até 2013 a economia brasileira se manteve crescendo, com baixo desemprego e baixa inadimplência, e a liberação do crédito imobi-

5 Foram financiados 529,8 mil imóveis - alta de 17\% em relação aos 453,2 mil em 2012.

Disponivel em: <https://revista.zapimoveis.com.br/confira-uma-linha-do-tempo-sobre-a-venda-de-imoveis-no-brasil/>. liário se expandiu. Em 2013 os números dos imóveis financiados bateram recordes, atingindo $\mathrm{R} \$ 109,2$ bilhões $-32 \%$ a mais do que no ano anterior. Mas, neste mesmo ano, a demanda começa a cair, situação que se agravou em 2015, com a retração da demanda, dos créditos, de todo o setor. ${ }^{5}$ 


\subsection{Arranjos para a criação de parques}

A valorização do meio ambiente e a necessidade de espaços para caminhadas e corridas em prol da saúde física e mental aumentaram positivamente o significado dos parques na visão das pessoas. Isto foi capitalizado tanto pelo mercado imobiliário quanto pelas administrações públicas, sendo eles apresentados como contribuição ao enfrentamento dos problemas ambientais das cidades por muitas gestões ou empreendimentos, ações louváveis e eficientes.

Mas, entre a vontade de criar um parque e a sua inauguração, muitos recursos e articulações são necessários. Para que obras complexas sejam concluídas a tempo de serem inauguradas, secretarias e concessionárias de serviços públicos precisam trabalhar integradas. Os gabinetes de prefeitos e governadores precisam comumente estar diretamente envolvidos para vencer a falta de articulação. Isso tudo depois de resolvida a questão da propriedade ou da posse da terra. GRÁFICO 2.G1

Em São Paulo o Programa 100 parques, executado entre 2008 e 2012, representou um segundo salto na criação de parques na cidade, cerca de trinta anos após o primeiro, elevando o número de parques municipais oficiais de 34, em 2005, para 102 em 2012. A valorização de ações relacionadas ao meio ambiente garantiu a destinação de recursos e, ao menos no discurso, o papel principal que estes equipamentos urbanos passaram a ter foi o ambiental. A função social dos parques como equipamentos de lazer ficou em segundo plano. Neste mesmo período, o governo do estado também abriu parques de grande porte na capital, como o parque do Belém (2012), na zona leste, em uma área que por mais de 100 anos abrigou instituições disciplinares para jovens infratores ${ }^{6}$. 2.08

Os principais mecanismos para captura de recursos financeiros na cidade de São Paulo foram os TCAs e os TACs. O TCA é celebrado entre o poder público municipal e empreendedores, e resulta da negociação de contrapartidas nos casos de autorização para supressão de espécies arbóreas. A compensação inicialmente deveria ser paga em exemplares arbóreos, mas já não haveria o que fazer com
6 Entre 1902 a 2005, funcionaram o Instituto Disciplinar, Colônia Correcional e a Fundação Estadual para o Bem-Estar do Menor (Febem). A antiga Febem do Tatuapé chegou a atender mais de 1.800 jovens. Hoje estão sendo atendidos em centro menores, com capacidade para no máximo 60 jovens, o que facilita sua ressocialização. 0 parque possui área total de $210.000 \mathrm{~m}^{2}$, sendo $14.000 \mathrm{~m}^{2}$ de área construida.

FUNDAÇÃO CASA. Governo de SP inaugura novo Parque do Belém. 26/01/2012. Disponivel em: <http://fundacaocasa. sp.gov.br/View.aspx?title=governo-de-sao-paulo-inaugura-novo-parque-no-tatuapectd=1381> 
Origem fundiária dos terrenos onde foram implantados parques municipais paulistanos até 2017 . feita por Matheus Casimiro. Este autor observou que muitas áreas se tornaram públicas via desapropriação ou com a transferência de uma gleba para o município em decorrência da Lei de Loteamento e que não necessariamente eram terrenos bem localizados ou com relações urbanas interessantes com o entorno para o uso como parques públicos. $^{7}$
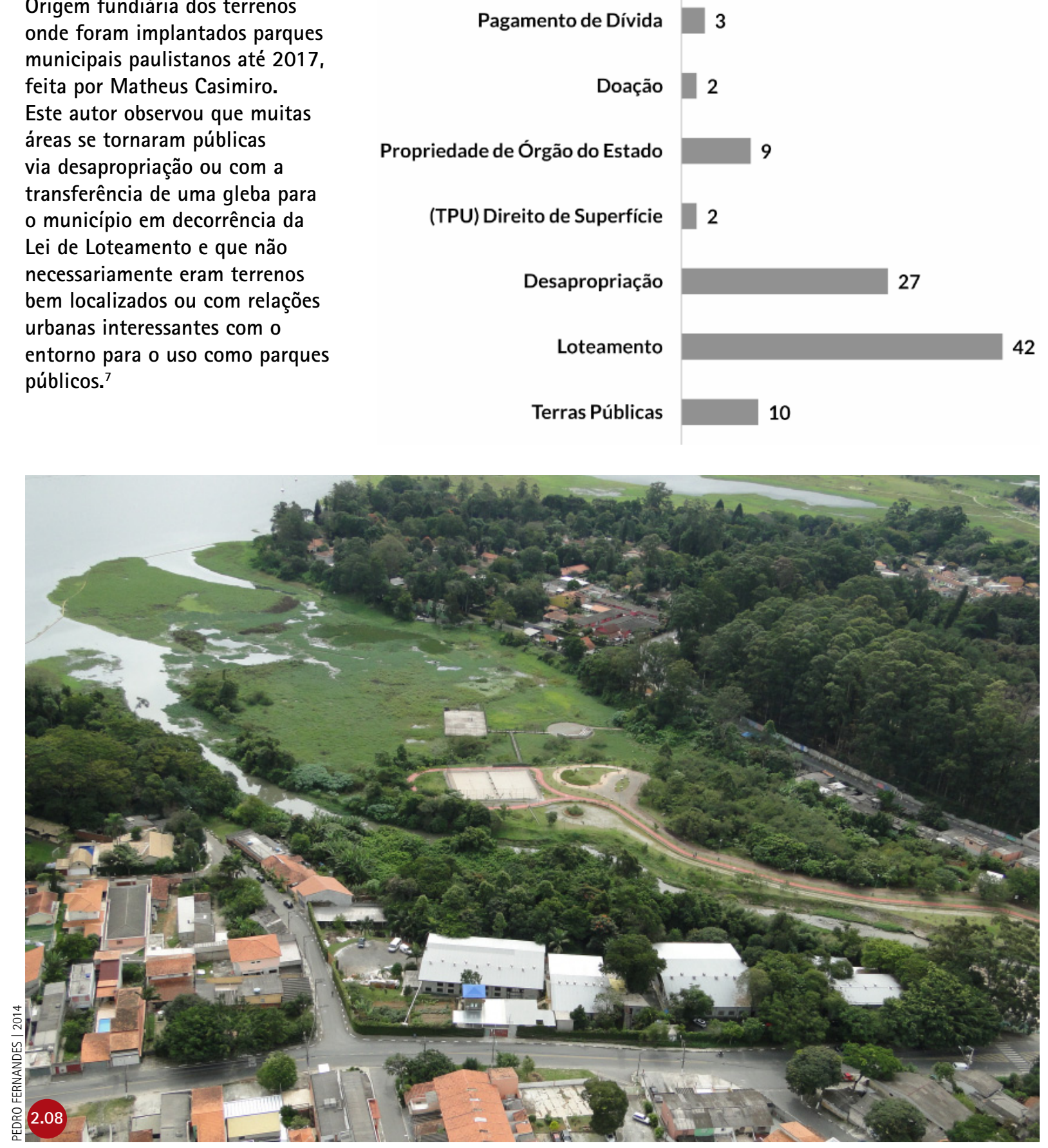

7 CASIMIRO, Matheus de Vasconcelos. A invenção e reinvenção do parque público paulistano: um olhar sobre a produção municipal. Dissertação (Mestrado em Arquitetura e Urbanismo) - Faculdade de Arquitetura e Urbanismo, Universidade Presbiteriana Mackenzie, São Paulo, 2018.
Parque Linear São José (2008), São Paulo. Feito como estratégia para ampliar as opções de lazer para a população local e evitar ocupações irregulares na orla da Represa Guarapiranga. Está localizado junto ao Parque Nove de Julho. 
tantas mudas. Assim, admitia-se converter o valor destas em obras e serviços, como projetos ou obras de recuperação e requalificação de áreas verdes, algo muito mais vantajoso para o poder público. 0 TAC funciona como uma multa, firmado quando um dano ambiental já foi causado. Outros instrumentos também poderiam financiar o programa, como a venda de potencial construtivo e as doações, mas não foram muito utilizados. ${ }^{8}$

O Parque do Cordeiro, na Zona Sul paulistana, começou a ser viabilizado em 2001, quando o uso de compensações ambientais era incipiente. Ainda trocavam-se árvores suprimidas por mudas de árvores. A atuação da Sociedade Amigos do Jardim Petrópolis e dos Estados (Sajape) foi fundamental para garantir que os recursos de compensação de empreendimentos no bairro fossem direcionados para este parque. Mesmo com a pressão, parte dos recursos foi direcionada para outras frentes, revelando a disputa pelos mesmos, que, como não são previstos pelo orçamento do poder público, não têm destinação definida. Os recursos iniciais, neste caso, foram suficientes para o início das obras, de movimentação do terreno e implantação dos pisos, mas o plantio das árvores foi feito antes da parte civil. Inversões nas etapas da obra, por descompasso entre as fontes de recursos, são difíceis de administrar. As obras também demoraram para começar porque o vigia do terreno, funcionário da prefeitura, vendeu-o por R\$200 mil, o que gerou um imbróglio que durou cerca de dois anos. Os custos para concluir a obra foram assumidos pelo município, através da Subprefeitura de Santo Amaro. ${ }^{9}$

Em 2017 as verbas de compensação ambiental ainda provocam disputas. No Espírito Santo, houve, inclusive, uma disputa pelo termo de compensação no valor de $\mathrm{R} \$ 730$ mil relativo à obra de aprofundamento do porto de Tubarão/Vale. Os jornais de Vitória anunciaram que a prefeitura "perdeu" o termo para um parque estadual em Guarapari. ${ }^{10}$

No Distrito Federal o Programa Brasília, Cidade Parque, criado em 2011 pela Secretaria do Meio Ambiente e Recursos Hídricos (Semarh), também contou com verbas de compensações ambientais. Teve como meta construir 72 parques ecológicos, que foram demarcados. ${ }^{11}$ Ocorreram muitos investimentos, contudo, dos 72 parques, apenas cerca da metade chegaram a ter condições de uso.
8 DEVECCHI, Alejandra Maria. Programa 100 Parques para São Paulo. Apresentação sem data. Acesso em: 10/07/2015. Disponivel em: <http://site.sabesp.com.br/ uploads/file/audiencias_sustentabilidade/ prog_100parques_sp_12aud.pdf>.

Segundo WHATELY: "O Plano Diretor Estratégico (PDE) de 2002 estabeleceu instrumentos urbanístico-ambientais, seguindo os preceitos do Estatuto da $\mathrm{Ci}$ dade, como, por exemplo, o que determina como finalidades para aplicação do Direito de Preempção a criação de espaços públicos de lazer e áreas verdes e a criação de unidades de conservação, ou proteção de outras áreas de interesse ambiental (Lei Federal 10.257/01, Art. 26, inciso VI e VII). São estes instrumentos: Transferência de Potencial Construtivo; Áreas de Intervenção Urbana; Direito de Preempção; Concessão Urbanística; Licenciamento ambiental; Termo de Compromisso Ambiental (TCA); Termo de Compromisso de Ajuste de Conduta Ambiental; Zoneamento ambiental; Avaliação Ambiental Estratégica; Planos de bairro." WHATELY, Marussia; SANTORO, Paula Freire; GONÇALVES, Bárbara Carvalho; GONZATTO, Ana Maria. Parques urbanos municipais de São Paulo: subsídios para a gestão. São Paulo: Instituto Socioambiental, 2008.

9 A história está relatada em: COELHO, Leonardo L. Compensação ambiental: uma alternativa para viabilização de espaços livres públicos para lazer e convívio na cidade de São Paulo. 2008 209 p. Dissertação (Mestrado - Área de Concentração: Paisagem e ambiente) Faculdade de Arquitetura e Urbanismo, Universidade de São Paulo, São Paulo, 2008.

10 COUZEMENCO, Fernanda. Vitória perde R\$ 730 em compensação ambiental. Século Diário. Vitória. 28/11/2017. Disponivel em: <http://seculodiario.com. br/36744/10/vitoria-perde-r-730-mil-de-compensacao-ambiental-e-sinha-laurinha-requer-o-valor-para-setiba>.

11 Disponivel em: <http://www. cidades.df.gov.br/noticias/item/2837-compensa\%C3\%A7\%C3\%A30-ambiental-aumenta-quantidade-de-parques-no-df-em-mais-de-1000.html>. 12/03/2014 
Nem todos os recursos de compensação provêm de empreendimentos privados. Metade das compensações ambientais relacionadas aos parques em São Paulo originou-se pelo licenciamento de obras do próprio poder público, sobretudo obras viárias, canalizações e instalação de infraestrutura urbana. Assim, os recursos para parques são em boa parte provenientes do próprio poder público, que os havia destinado para infraestrutura. Em consequência da supressão de árvores, os recursos são transferidos para o sistema de espaços livres.

Sem orçamentos ou fundos públicos para parques, os representantes do poder público foram guiados a atrair recursos financeiros que estavam nas mãos de empresas privadas ou fundos para financiar suas ações. As intervenções do poder público passaram a se caracterizar, cada vez mais, como ações pontuais, que se concretizam pela combinação do apoio político com o 'aproveitamento' de uma lei, norma ou verba. A realidade é operada no possível, no atendimento das questões mais imediatas, no aproveitamento dos recursos momentaneamente disponíveis. A impossibilidade de atender amplas demandas da população e a necessidade de capturar recursos levam a concluir que, no período entre 2000 e 2015, a expressão mais apropriada para o trabalho dos prefeitos e secretários é gestão de oportunidades.

Por todo o país a criação de parques foi vinculada às oportunidades, seja na forma de obter terras ou capital humano e financeiro. Os recursos de compensações ambientais ou parcerias com empreendimentos residenciais privados e públicos foram o expediente mais comum para implantar parques. 1sto, por si, não é um fato ruim. Sendo os parques úteis para a sociedade, no presente ou no futuro, criá-los com recursos circulantes captados do mercado imobiliário terá sido uma justa ação redistributiva da renda.

A maior parte dos parques foi concebida e gerida pelo poder público, mas houve parques concebidos e geridos por empreendedores imobiliários, o que desonera a máquina pública e pode ser vantajoso para todos. Foi visto, ainda, o caso dos parques de mineradoras, concessionárias de água, e há outros de grandes empresas, cuja atividade impacta o meio ambiente, como forma de compensação e propaganda. Uma propaganda que contribui com a cidade e que tem utilidade para as pessoas. 


\subsection{Motivações}

No Capítulo 1 os parques foram categorizados por suas características físicas e sua relação com a cidade. Apresentam-se, neste Capítulo, categorias de parques pela motivação de sua criação, o que tem muito a ver com o agente promotor. As categorias não são estanques, até porque há vários agentes, sendo comum que 0 parque seja criado pela conjunção de várias razões simultâneas.

\section{Parques que projetam a imagem das cidades}

As grandes obras nos espaços mais visíveis da cidade - centros, bairros ricos ou faixas de orla - tendem a projetar sua imagem entre habitantes e turistas. É o caso do Mangal das Garças, em Belém. Conforme a envergadura, inovação ou repercussão, também ganham projeção pelo mundo, como o Parque Madrid-Río e o Parque Olímpico de Londres. 2.09

Em 2012, no contexto da candidatura às Olimpíadas de 2018, a Prefeitura do Rio de Janeiro inaugurou o Parque Madureira, na zona norte da cidade - que, ao contrário da zona sul, é carente de arborização e áreas de lazer. 0 parque Madureira tem sido um enorme sucesso e, como parque linear, cresceu em comprimento ao longo dos anos. Em 2016 estimava-se que recebia 25 mil visitantes por final de semana. Todo o corolário de qualidade ambiental em voga para as construções civis foi aplicado e divulgado no Parque Madureira - sistema de irrigação controlado por sensores, edificações com paredes e tetos verdes, energia solar, coleta de resíduos com separação de recicláveis, reuso de água, pisos permeáveis, lâmpadas LED -, que recebeu o primeiro certificado de qualidade ambiental AQUA atribuído a um espaço público brasileiro. 0 plantio de árvores e palmeiras de espécies nativas foi considerado uma ação de recuperação da fauna e flora da região.

Depois de ampliado, chegou a $255.000 \mathrm{~m}^{2} \mathrm{em} 2016$; quando abriu, tinha $109.000 \mathrm{~m}^{2}$ e 1,3 quilômetro de extensão. Apesar de ser cheio de atrações, era um parque pequeno - que foi anunciado pela prefeitura (e isto repetido por toda a imprensa e todos os sites) como "o 
0 Queen Elizabeth Olympic Park foi fechado após as Olimpíadas de 2012 e reaberto em 2014, assim como muitas das instalações esportivas. A área escolhida, a leste de Londres, era conhecida pelas indústrias desativadas $\mathrm{e}$ foi recuperada para a cidade e 0 mercado imobiliário. Há gramados, playgrounds, ciclovia, pedalinhos no rio e um escultórico escorregador gigante, o AcelorMittal Orbit.

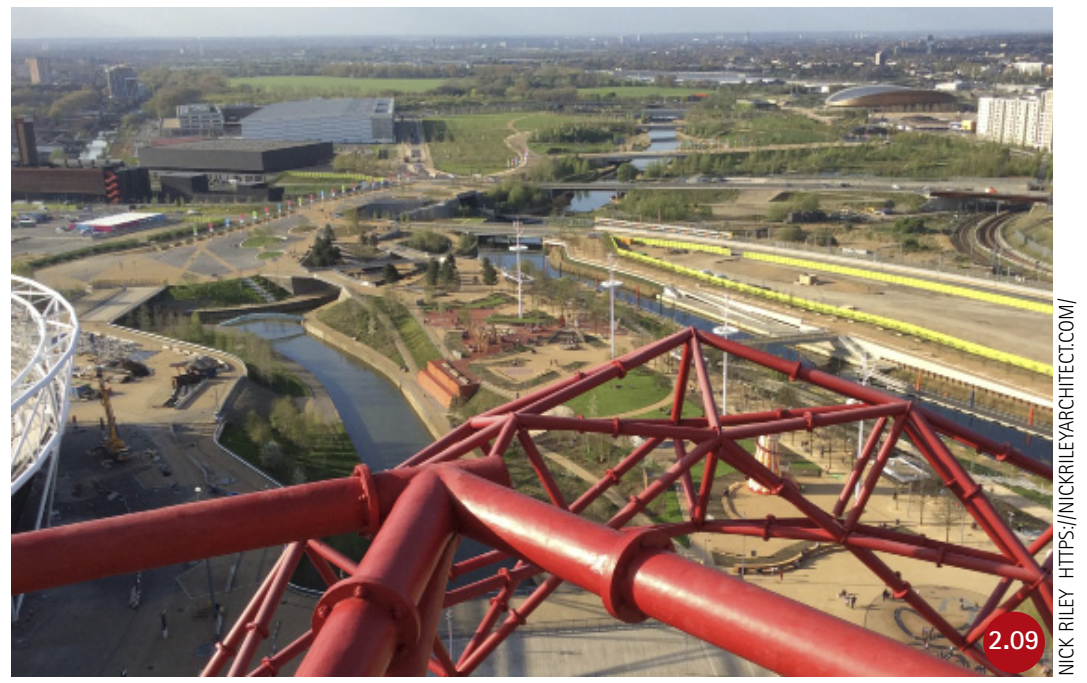

Em Belém o Parque Mangal das Garças (2005) foi criado pelo Governo do Pará para a revitalização de áreas às margens do rio Guamá, nas franjas do centro histórico de Belém, com o pressuposto de aproveitar as condições paisagísticas da área. Com projeto elegante e obra impecável, o Mangal das Garças foi apropriado pela população, inclusive como cenário para fotos, e tornou-se um de seus principais pontos turísticos.

Parque Madureira (2005), Rio de Janeiro. Idealizado pela Secretaria Municipal de Obras da prefeitura, tinha como diretriz um programa de educação socioambiental. Sua lista de atrações é grande e inclui pistas de skate, cascatas para banho e um palco com capacidade para uma bateria de escola de samba De fato, é uma ação de provisão de lazer na periferia, mas a propaganda se apoiou na qualidade ambiental.
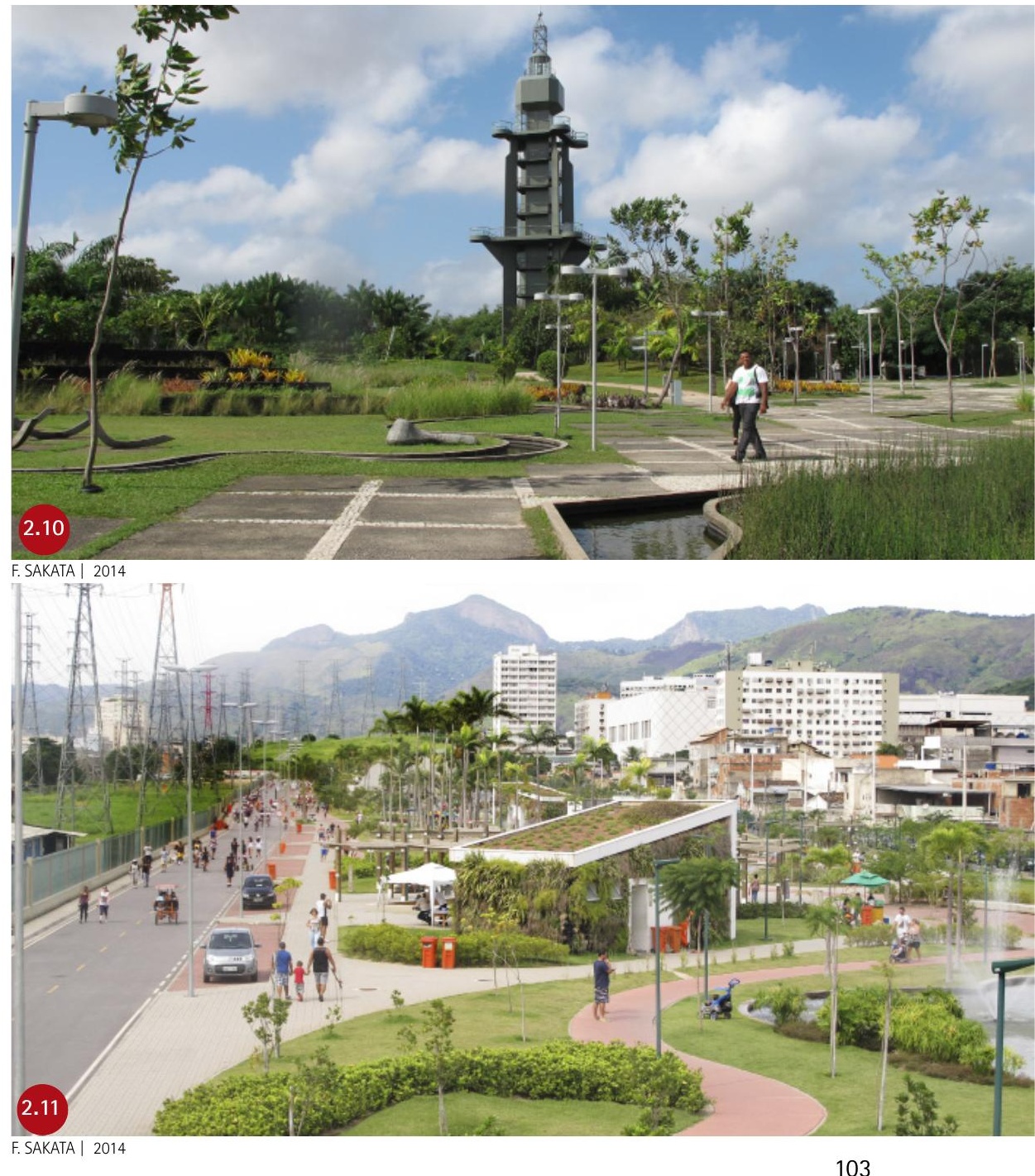
terceiro maior da cidade, menor apenas que o Parque do Flamengo e a Quinta da Boa Vista”. O Parque do Flamengo é realmente muito maior, contando com 1.301.306 m²; a Quinta possui $378.000 \mathrm{~m}^{2}$. Apenas para citar dois outros parques cariocas, observa-se que o Bosque da Barra tem $500.000 \mathrm{~m}^{2}$, e o Parque lage, $522.000 \mathrm{~m}^{2}$. Até o Campo de Santana, com seus $155.200 \mathrm{~m}^{2}$, considerado pequeno, é maior que o Madureira quando inaugurado. A informação sobre o tamanho do Parque Madureira era falsa, e ninguém a contestou, mesmo observando que estava mais perto de ser o terceiro menor.

Em obras de espaços livres públicos, em região tão carente de infraestrutura, as paredes e tetos verdes são detalhes, com contribuição ambiental bastante questionável, mas o papel social do parque é inegável e inestimável. 0 sucesso foi tão grande que, em 2017, o prefeito da cidade anunciou que o Campo Grande, outra área carente da cidade, ganharia em 2019 um 'Parque Madureira.'12

\section{Propaganda política}

Tudo que um político faz, sejam ajustes fiscais, sejam inaugurações de hospitais tem consequências e objetivos eleitorais, algo inerente ao sistema. Não é diferente no caso dos parques. A criação do parque da Juventude em São Paulo envolveu também a questão de remediação da imagem da gestão política. Foi implantado no terreno do Complexo Penitenciário do Estado de São Paulo (1956), o maior da América Latina, chegando a alojar mais de oito mil presos. Em 1992 uma rebelião terminou no massacre de 111 presos, fato que marcou o noticiário e a memória de todos e levou à decisão de desativar o presídio, que foi parcialmente demolido em 2002, em implosões que foram marcos simbólicos. Em 1999 o governo do Estado promoveu um concurso público para a concepção do projeto arquitetônico do parque, e o projeto vencedor foi executado com qualidade. É um caso de parque para provisão de lazer e equipamentos culturais. 0 equipamento que desvalorizava a área passou a valorizá-la, mudando a dinâmica imobiliária dos bairros ao redor e reparando a imagem da administração pública, estigmatizada pelo massacre. 2.12.13 -janeiro/2017-10-11/campo-grande-vai-ganhar-um-parque-madureira.html 
Parque da Juventude (2003), São Paulo. 0 projeto paisagístico de Rosa Kliass, vencedor do concurso, contemplou as três grandes áreas hoje existentes no parque: contemplativa (parte central), institucional (na parte inferior da foto vê-se trecho do piso e dos edifícios da biblioteca e da escola técnica, concluídos em 2007) e esportiva. Foi mantida na área a penitenciária feminina.
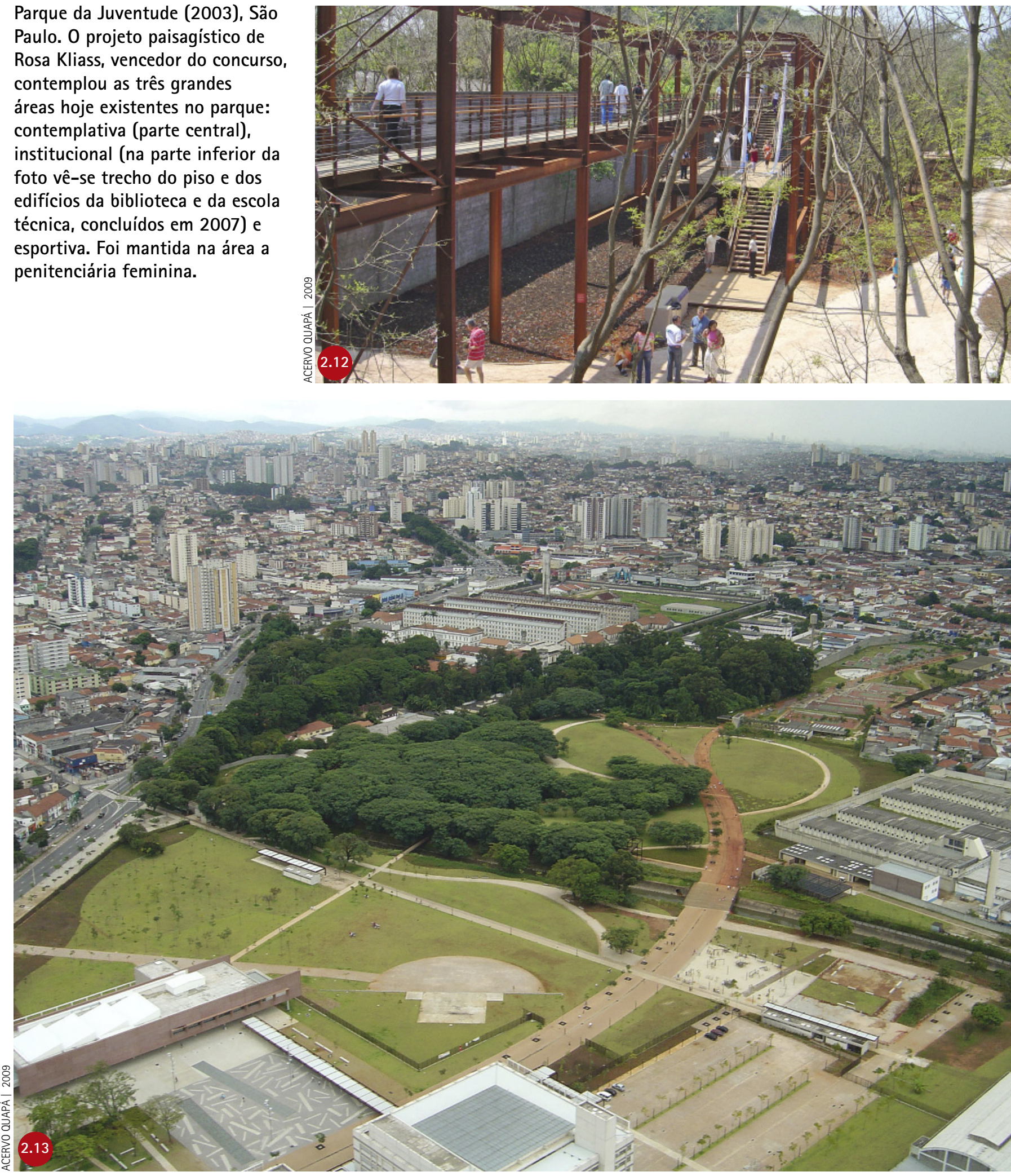


\section{Parques como ação de propaganda de empresas}

0 Piscinão de Ramos (2001), no Rio de Janeiro, foi um grande sucesso de público e mídia e repercutiu positivamente na imagem do governador. A obra foi paga e mantida pela Petrobrás, empresa estatal que iria instalar dois grandes filtros para melhorar a condição da água na poluída Baía da Guanabara como forma de compensação ambiental. Teve-se a ideia de jogar a água filtrada em uma grande e rasa piscina com fundo de areia antes que voltasse para a baía. Todo o entorno desta piscina, que é cercada pela favela de Ramos, foi tratado para o lazer de famílias de rendas baixas e apropriado por moradores de diversos bairros da Zona Norte do Rio de Janeiro. 2.14

A mineradora Vale que, como a Petrobrás, tem o seu negócio calcado na exploração de recursos naturais, mantém dois parques botânicos, um em Vitória (2004) e outro em São Luís do Maranhão (2008), e um parque zoobotânico (1985), dentro da Floresta Nacional de Carajás, no Pará, com onças e outros animais da fauna brasileira. 2.15

Em São Paulo, a Companhia de Saneamento Básico do Estado (Sabesp) iniciou em 2014 a implantação de três parques em terrenos que abrigavam reservatórios nos bairros Butantã, Mooca e Cangaíba. As áreas já pertenciam à concessionária de águas e, qualificadas para o lazer, passaram a funcionar como uma forma de propaganda, transmitindo a imagem de uma empresa preocupada com o bem-estar público. 0 projeto e a obra são mais sofisticados que o padrão usual dos parques da prefeitura de São Paulo, ou mesmo do Estado. O Parque Sabesp Butantã (2015) é muito pequeno $\left(10.000 \mathrm{~m}^{2}\right)$, ocupando um terreno muito íngreme e abrigando três grandes reservatórios d'água que armazenam 15 milhões de litros e atendem 18 bairros $^{13}$. 0 mais alto deles foi iluminado à noite com uma luz azul-espacial. Os reservatórios mais baixos foram embalados com mensagens do gênero "cuide bem da água". Assim, os parques são públicos, mas o agente promotor é um ente meio-público-meio-privado, uma empresa mista de capital aberto, que tem o governo do Estado de São Paulo como principal acionista (50,3\%). 2.16
13 Sabesp. População do Butantã recebe novo espaço de lazer e práticas esportivas. 27/07/2015. Disponível em: <http://site. sabesp.com.br/site/imprensa/noticias- detalhe. aspx? secaold $=65$ ctid $=6638>$. 
Piscinão de Ramos (2001), Rio de Janeiro, foi o primeiro parque em favela a ter uso metropolitano.

Parque Zôobotânico Vale (1985), em Carajás (PA), é parte da criação da imagem corporativa.

Parque Sabesp Butanta (2015), São Paulo. A rampa que funciona também como circuito de caminhada. Na parte mais alta, três decks metálicos vermelhos são mirantes para a paisagem.
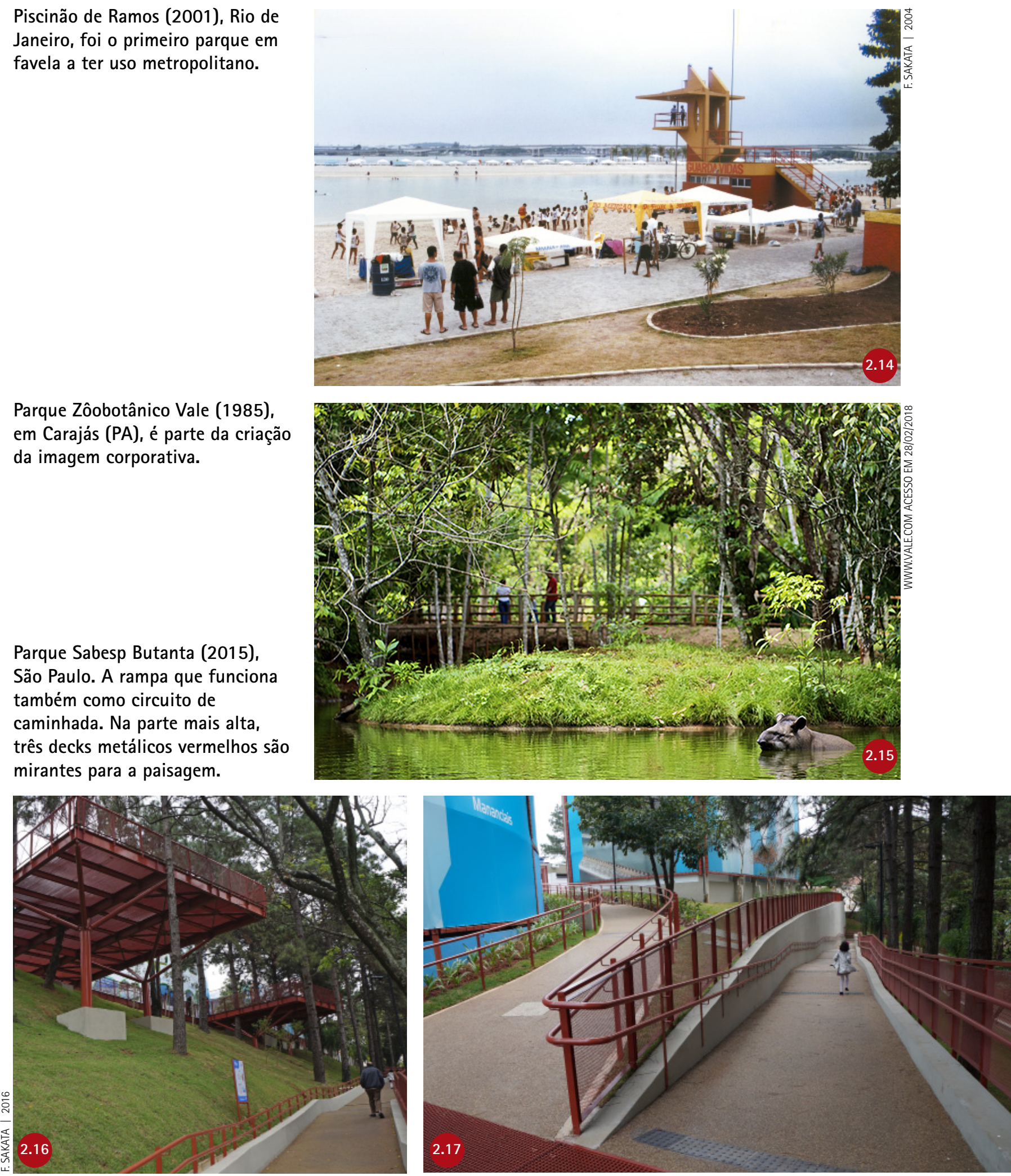


\section{Operações consorciadas para valorização imobiliária}

0 Regent's Park, de Londres, é o primeiro caso de parque público associado à venda de imóveis de alta renda no entorno. Nos Estados Unidos, o Central Park não foi pago por empreendimentos a ele associados, mas favoreceu muito a ocupação dos bairros ao redor. A obra recebeu críticas pelos custos exorbitantes mas desde o início o parque foi muito frequentado pela população e promoveu as vendas ao seu redor. 0 padrão dos apartamentos é mais luxuoso nas quadras ao longo do parque, diminuindo conforme aumenta a distância.

Os parques parisienses à margem do rio Sena, La Villette (1987), André-Citröen (1992) e Bercy (1993), são os elementos centrais de operações urbanas de grande envergadura. Ao mesmo tempo em que projetam a imagem de uma cidade inovadora e economicamente forte, reestruturaram áreas industriais antigas, próximas dos limites da cidade, transformando-as em bairros agradáveis e valorizados, com funções residenciais, comerciais e de serviços. Estes parques são feitos para oferecer aos bairros vizinhos espaços atrativos de lazer, recreação e uma nova identidade, que contribua para sua valorização. ${ }^{14}$

Uma nova operação urbana nos mesmos moldes inaugurou, em 2007, o primeiro trecho de outro parque, concluído em 2017: o Parc Clichy-Batignolles Martin Luther King, no limite noroeste de Paris. ${ }^{15}$ Esses parques são intervenções planejadas no sistema de espaços públicos urbanos, que dão continuidade ao trabalho de Haussmann no século XIX. Os imensos canteiros de obras que se estabelecem são administrados por sociedades de economia mista, que articulam a prefeitura ou o estado francês ao capital privado. São operações que representam ganhos para o grande capital e o governo, mas também incrementam a paisagem da cidade. 2.18 2.1920

Caso similar ao Central Park, o Parque do Ibirapuera, em São Paulo, foi feito em área de expansão urbana e, nos anos 2000, os lançamentos de apartamentos mais caros de São Paulo foram vendidos nas suas proximidades. 0 empreendimento The Place, em torno do parque, lançado em 2010, tem duas torres de 33 andares e apartamentos com quatro dormitórios e de cinco a oito vagas para au108
14 https://123i.uol.com.br/condominio-2bcd94d2b.html, valor de estimativa médio atualizado em 07/11/2017

16 Sobre o contexto da criação e os projetos destes parques, ver: SERPA, Ângelo. Paisagem em movimento: o Parque André-Citröen de Paris. Paisagem Ambiente. São Paulo: FAUUSP, p. 137 - 162, 2004. Ele mostra também que são construidos apartamentos para o aluguel social, mas a gentrificação acontece. Atualmente, a maior porcentagem de habitações de caráter social (82\%) está em municipios vizinhos da região metropolitana parisiense.

17 Explicações sobre os requintados detalhes do projeto paisagístico deste parque em: <http://equipement.paris.fr/ parc-clichy-batignolles-martin-luther-king-2817>. 


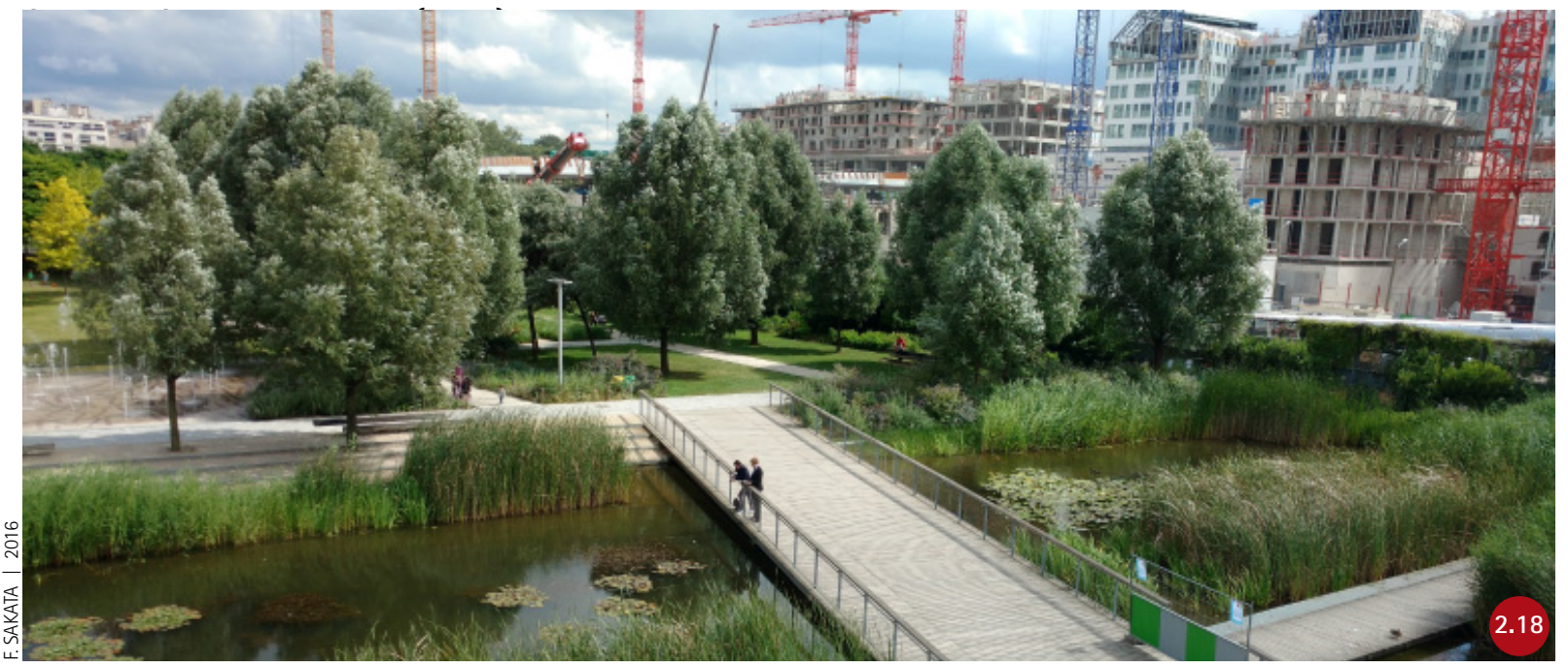

Parc Clichy-Batignolles - Martin Luther King (2007-2015), em Paris. Como Bercy, Andre Citroen e La Villette, o parque em Batignolles é o centro de uma grande operação urbana que converte uma antiga área industrial e um bairro de alta qualidade para a comércio e habitação.
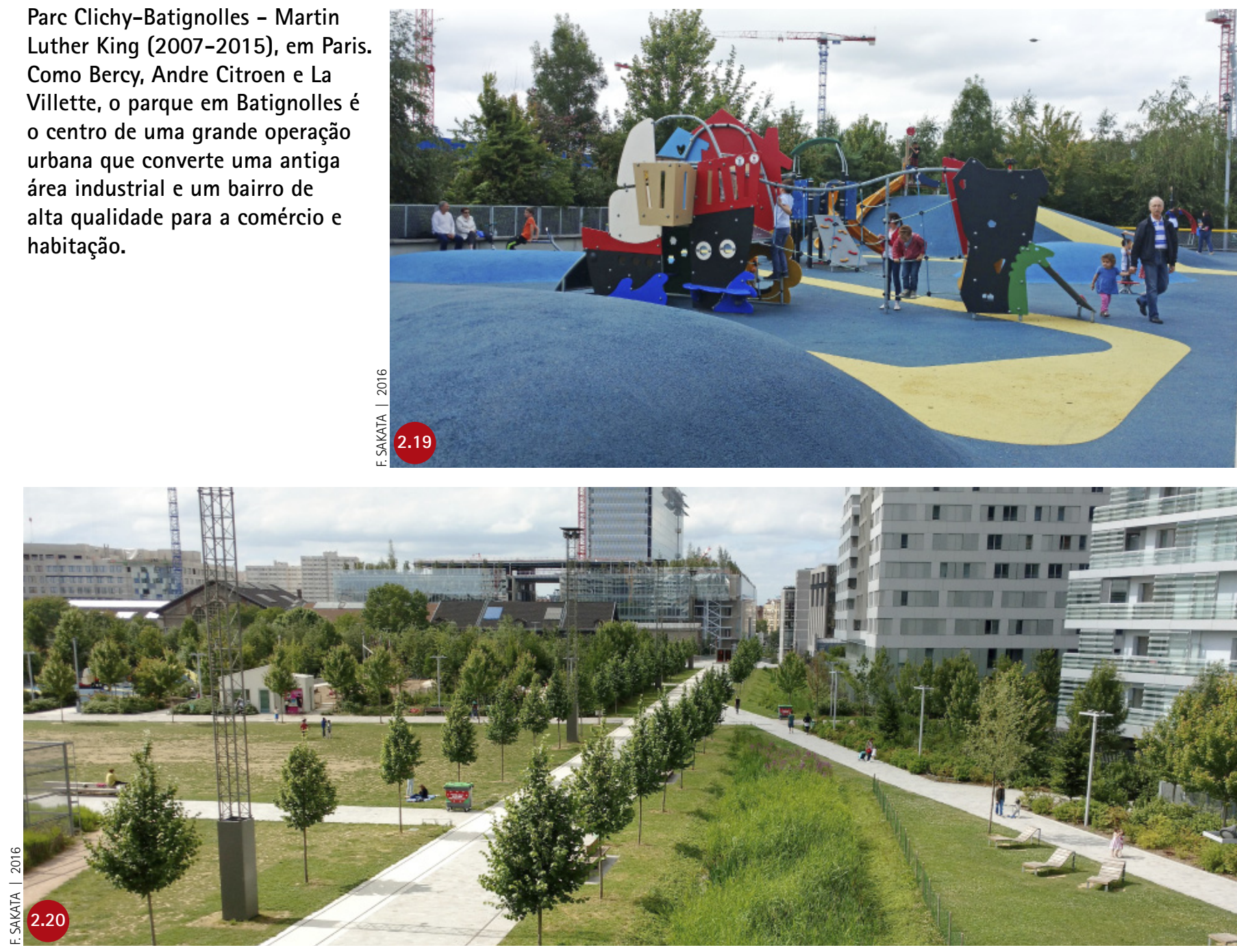


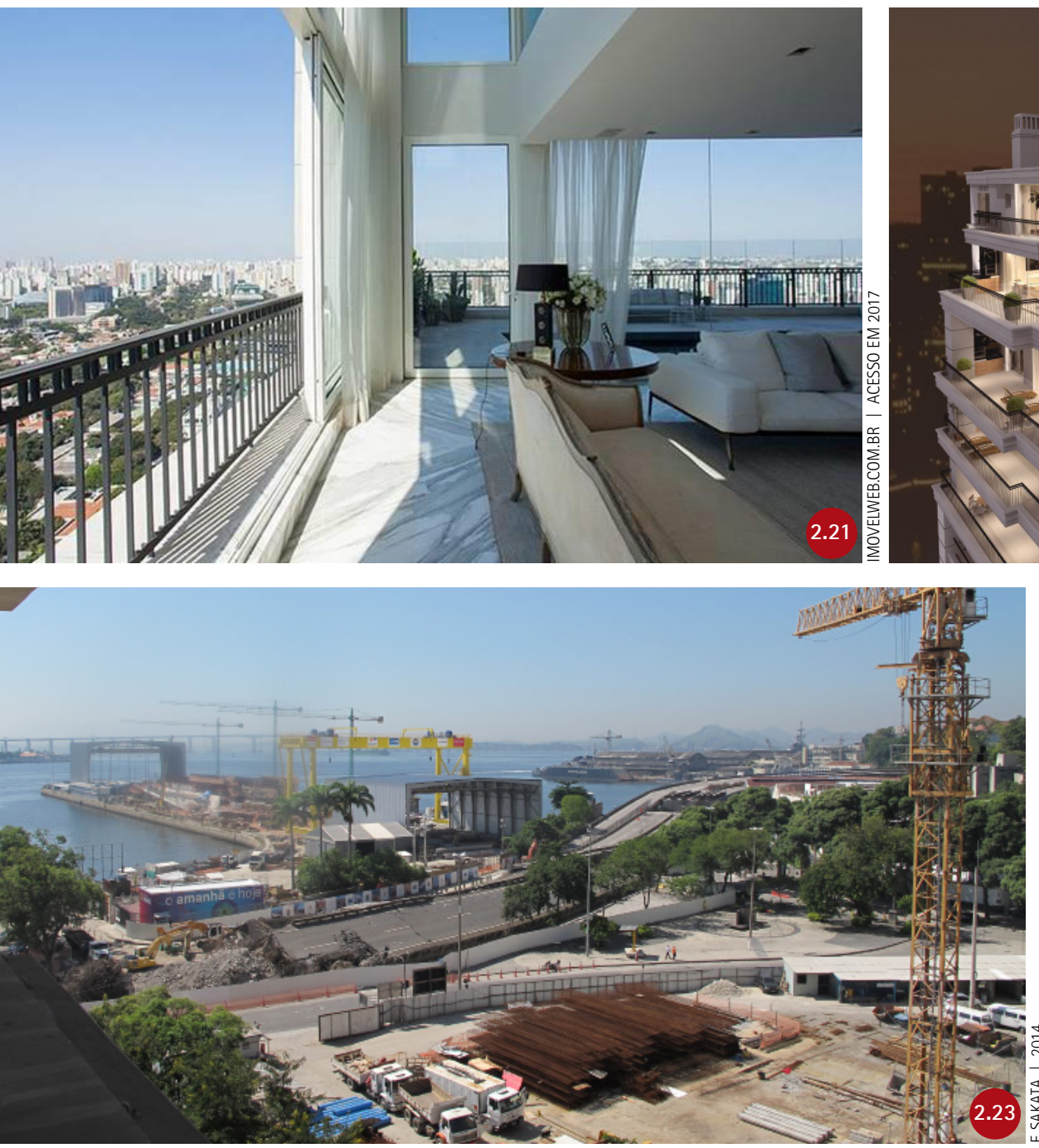

The Place (2010), empreendimento em torno do Parque do Ibirapuera (1954), em São Paulo.

Porto Maravilha (2016) no Rio de Janeiro em obras em 2014, com a demolição da Via Perimetral. Entre as áreas livres executadas está a praça em frente ao Museu do Amanhã, edifício com arquitetura vistosa e exposições tecnológicas sobre meio ambiente. A questão ambiental foi introduzida, na obra, por meio virtual.

A praça do Museu do Amanhã se articula com o Boulevard Olímpico (ou Orla Conde) que soma $3,5 \mathrm{~km}$ de extensão. 
tomóveis. As unidades de $470 \mathrm{~m}^{2}$ têm valor estimado, em 2017, entre $R \$ 9$ e $R \$ 12$ milhões ${ }^{16}$. Os valores maiores correspondem aos apartamentos mais altos, com a vista mais nobre da cidade. (2.21) O Porto Maravilha, no Rio de Janeiro, é uma operação urbana de grande porte, que articula terras e capitais públicos a interesses privados, aproveitando a realização das Olimpíadas (2016) para ganhar apoio. 0 espaço público - calçadas e um trecho da orla da Baía da Guanabara - foram tratados com infraestrutura nova, calçadas largas revestidas com material de qualidade e iluminação de LED. A apropriação que pudemos presenciar é principalmente turística mas é importante que a população local também se aproprie deles, intensa e diversificadamente. 2.23.2.

Há acordos de muitos tipos entre o poder público e os empreendedores privados. Há parques públicos concebidos junto com o empreendimento e que são, cada vez mais, pagos pelas construtoras e utilizados na propaganda como símbolo da qualidade de vida do bairro. Nas cidades brasileiras, a imagem simbólica da classe do bairro é muito importante. Garantir que o bairro seja tão nobre quanto os empreendimentos é um esforço dos empreendedores. Em São Paulo, o parque Burle Marx é fruto de acordo dos loteadores com a Prefeitura, que viabilizou o restauro de jardins que ali havia, projetados por Burle Marx, convertendo a área em parque público. Quem o mantém, a partir de recursos provenientes de eventos, venda de produtos, direitos de imagem, estacionamento, projetos e doações, é a Fundação Aron Birmann, uma Organização da Sociedade Civil de Interesse Público (OSCIP). 2.25 2.26

O Parque Jardim das Perdizes (2013) é um caso mais recente. Houve um concurso para o desenho urbano da Barra Funda e os vencedores previam edifícios de poucos andares, o que não interessou aos empreendedores, que aprovaram a proposta do parque público, desenhado com um formato alongado, e as torres ao redor. 0 urbanista Hélio Mitica Neto foi responsável pelo desenho das quadras urbanas, locando as torres, as vias e o parque.

A relação entre os parques urbanos e as novas frentes de desenvolvimento imobiliário ficou muito clara em Goiânia, mais do que em qualquer cidade analisada. A verticalização de alto padrão com ga- 

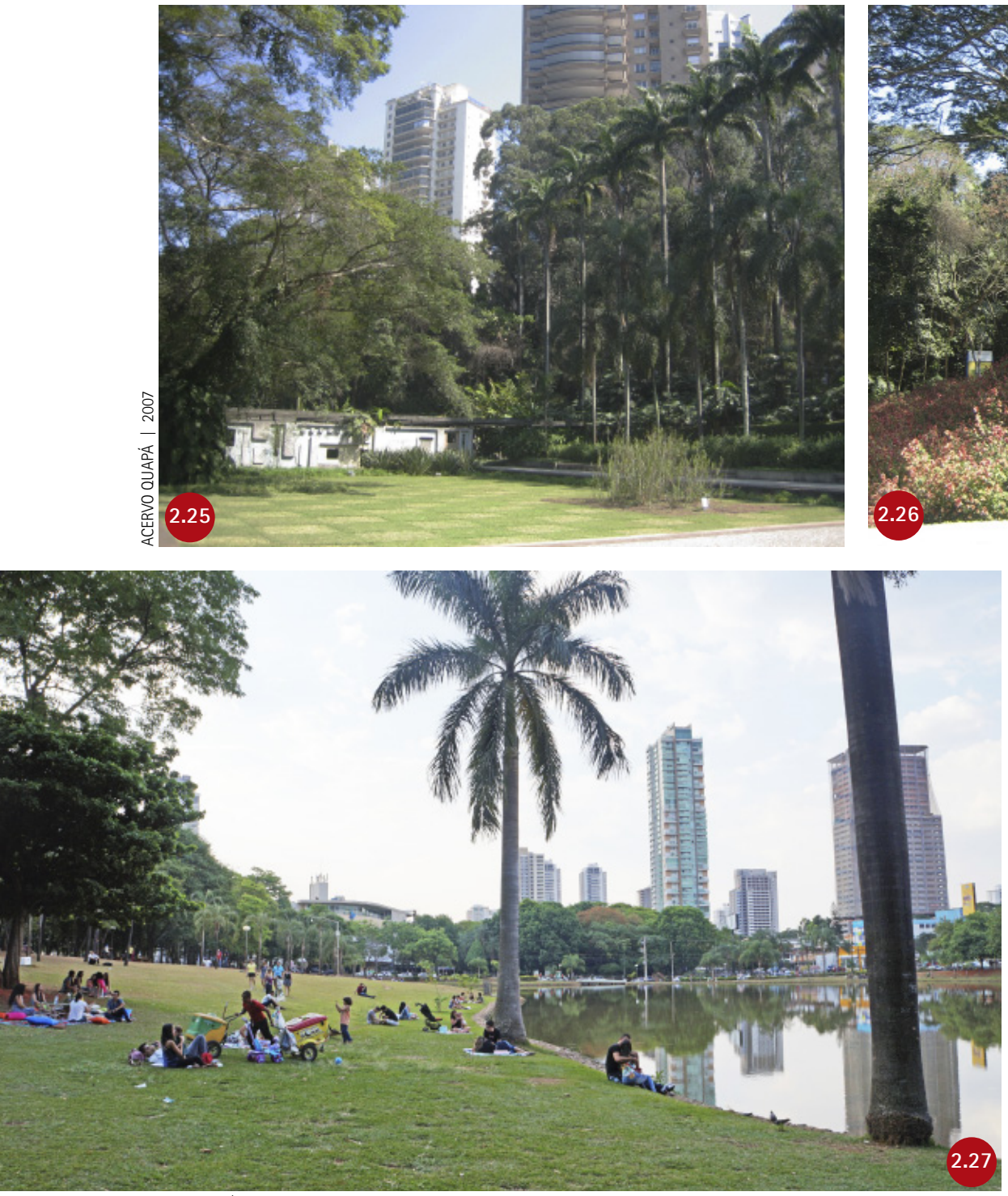

F. SAKATA | 2015

baritos expressivos, extrapolando os 40 andares, ocorreu em torno dos parques Lago das Rosas, Buritis, Vaca Brava, Flamboyant, Areião e Cascavel. Este processo foi muito intenso a partir de 2002 e se deu em período curto de tempo. Os novos parques foram projetados e feitos com mão-de-obra da Prefeitura e recursos de empreendedores. Não eram projetos caros, mas resolviam bem a estruturação dos espaços. Sem cercamentos, com a água como ponto focal e sempre com amplos gramados para o lazer. Os parques valorizaram os imóveis, como é usual nos bairros de elite, e tendem a ter manutenção adequada, porque a vizinhança assim exige. (2.27) (2.22)
Parque Burle Marx (1995), São Paulo. A mantenedora impõe restrições aos frequentadores do parque, como a proibição de bolas, bicicletas e piqueniques. 0 estacionamento é cobrado e o acesso por transporte público é difícil. 0 parque é público, mas a população em geral tem dificuldade para conhecê-lo.

Parque Vaca Brava (1996). A população aprovou e solicitou à prefeitura, novos parques nos moldes do Vaca Brava: sem cercamentos. 


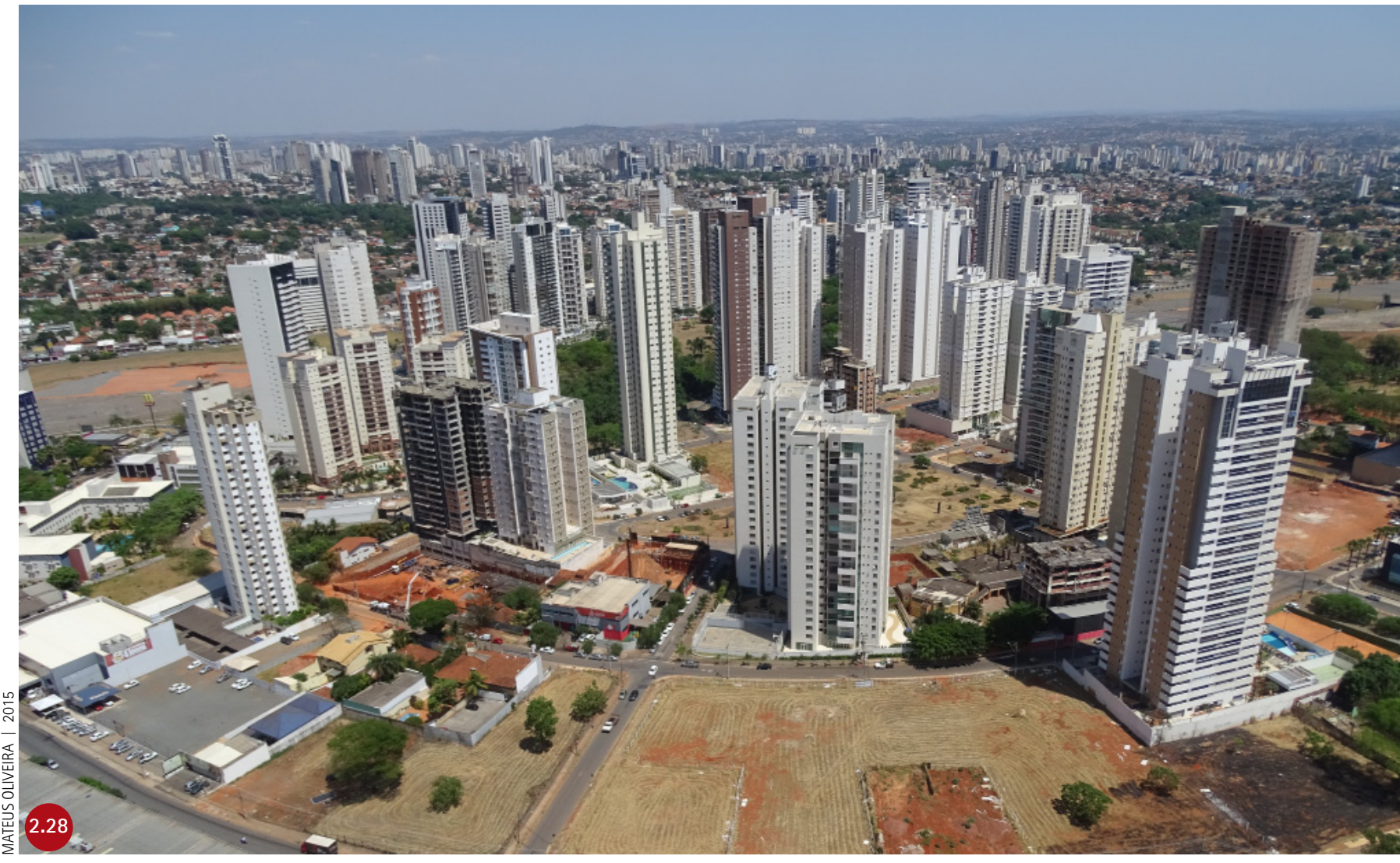

Verticalização em torno do Parque Flamboyant (bosque formado ao fundo) e da Praça das Artes. À esquerda, em torno do Lago das Rosas. É positivo associar o desenvolvimento imobiliário com o planejamento e a qualificação de espaços livres. Em Goiânia este arranjo foi mais bem sucedido que em outras cidades e ocorreu de forma seriada nos setores de expansão de alta renda, com parques sem fechamentos e muito apropriados pela população.

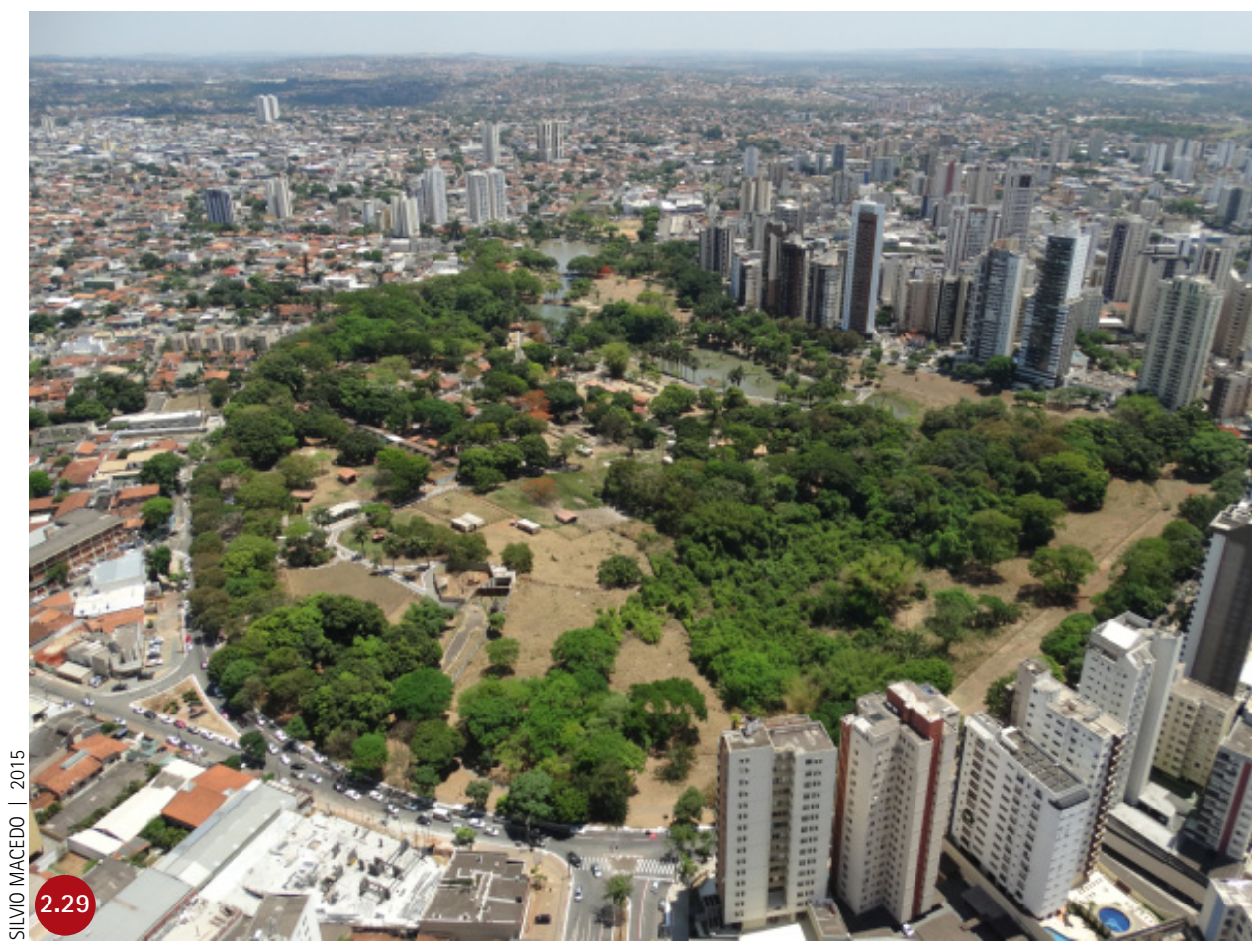


VII. Parques para valorização urbana e provisão de lazer em bairros consolidados de rendas alta, média ou baixa por demanda da população.

Parques criados por demanda da vizinhança tendem a ter apropriação desde o momento em que são abertos. Em Brasília os dois parques novos mais conhecidos e recomendados são o Bosque do Sudoeste e o Parque Olhos d'Água, que atendem a bairros de padrão médio-alto. Antes da intervenção, eram áreas sem ocupação.
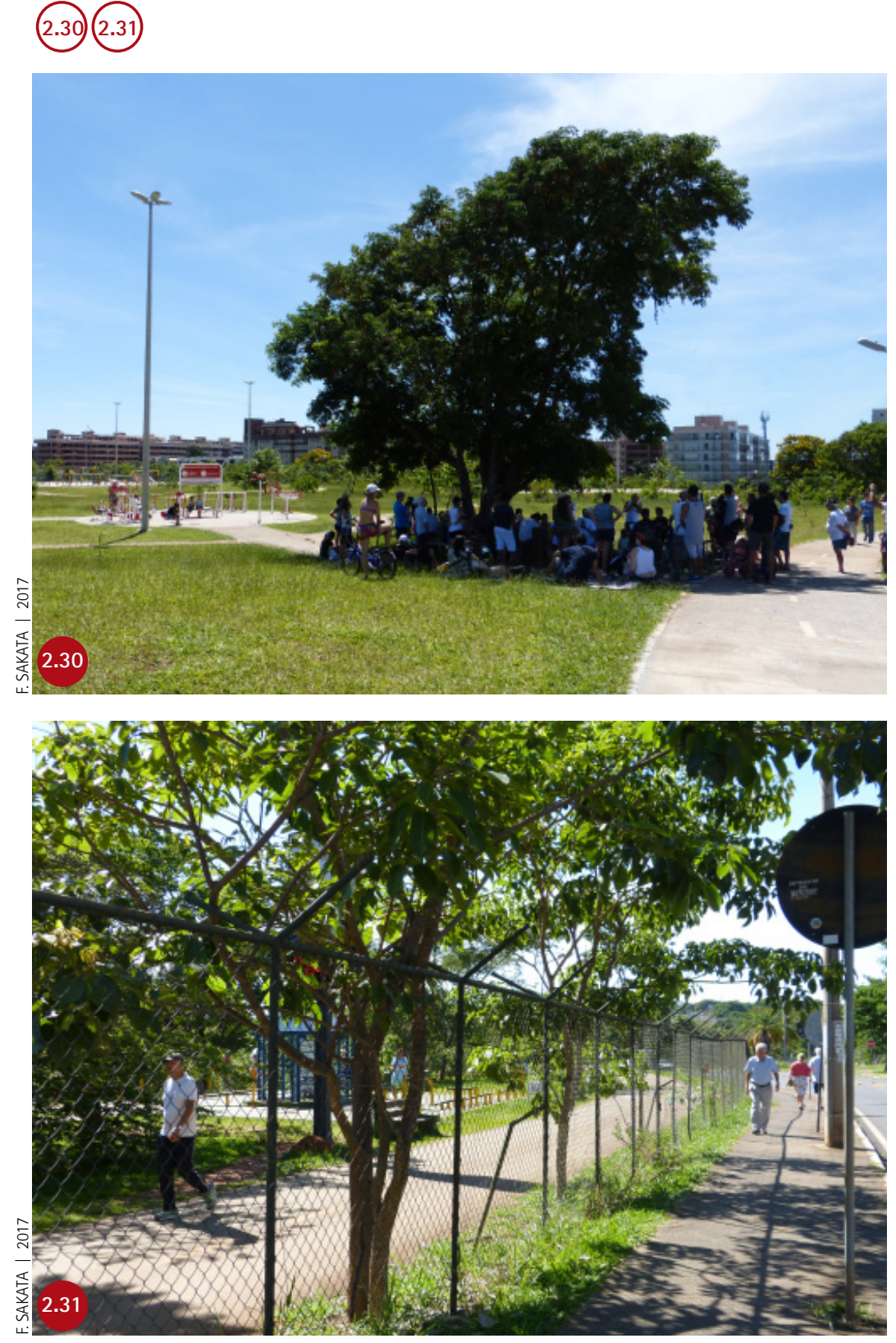

Parque Olhos D'Água. Compõe-se basicamente de percurso quase perimetral que atravessa lagoas, bosques e campos de cerrado. Bancos, cercamentos e sinalização são rústicos e foram posicionados sem um projeto arquitetônico formal. A população teria solicitado a criação do parque após um crime ter sido cometido na área. Seu uso é muito intenso para caminhadas, tanto internamente quanto nas calçadas em sua volta.

18 Disponivel em: https://www.brasil247. com/pt/247/brasilia247/97094/Sudoeste-ganha-parque-revitalizado.htm>. 
Em São Paulo, o Parque Chácara do Jockey (2016) foi o único executado e inaugurado pela prefeitura na gestão 2012-2016. Sua implantação atendia à reivindicação de mais de trinta anos dos moradores da região pela criação de um parque e ajuda a incrementar o bairro que fica ao lado de duas avenidas de tráfego muito intenso. Neste período, não foram abertos parques, mas uma rede de ciclovias foi demarcada em vias por toda a cidade, e avenidas importantes foram abertas para o lazer da população aos domingos. ${ }^{18}$

Parque Chácara do Jockey (2014), São Paulo, projetado pelo corpo técnico do Departamento de Parques e Áreas Verdes (Depave). A região deverá ser atendida pela extensão do Metrô e o parque será elemento de valorização.

19 São Paulo, Prefeitura. Chácara do Jockey. 14/06/2016.

Disponivel em: http://www.prefeitura. sp.gov.br/cidade/secretarias/meio_ambiente/parques/regiao_centrooeste/index. php?p=219032

20 Projeto Manuelzão. Disponivel em: $<$ https://manuelzaovaiaescola.wordpress. com/o-projeto-manuelzao/> Acesso em 15 nov. 2017

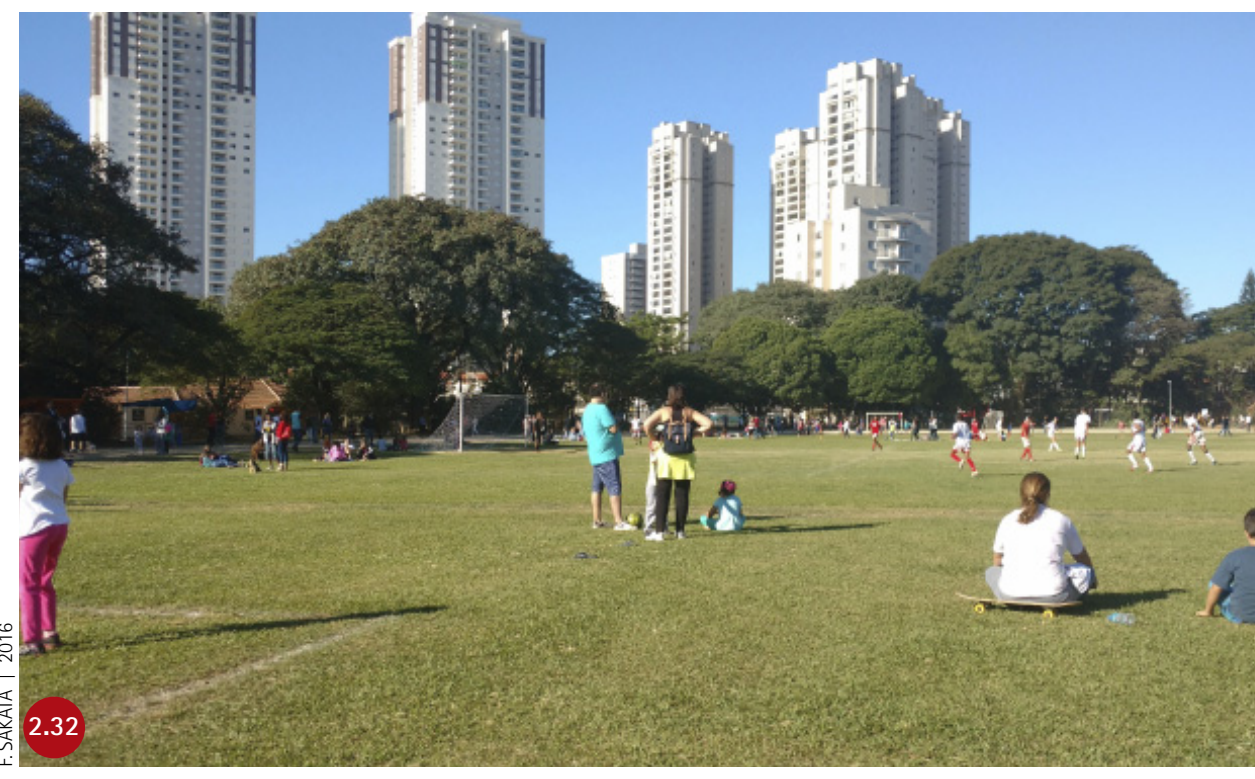

Em Belo Horizonte, os parques Nossa Senhora da Piedade (2008) e Primeiro de Maio (2008) foram feitos em bairros modestos, depois de grande mobilização da população, determinante para a construção dos parques. A organização dos moradores se deu a partir da criação de uma comissão representada por vizinhos, alunos e professores da Escola Municipal Hélio Pellegrino, em 1999. Esse grupo buscou parceria com o Projeto Manuelzão, uma iniciativa de professores da Faculdade de Medicina da Universidade Federal de Minas Gerais (UFMG), que visava a implementação das melhorias ambientais como forma de promover a saúde. ${ }^{19}$ Os parques foram criados pela prefeitura em 2008, através de um programa de recuperação ambiental, que previu intervenções no sistema viário, na drenagem pluvial e no esgotamento sanitário, e a implantação do 
CAPITULO 2. GESTÃO DE OPORTUNIDADES

parque. São parques-modelos, tanto para a recuperação de córregos quanto de desenho e manutenção (em 2017). São simultaneamente equipamentos de drenagem, preservação, lazer e qualificação do bairro. 2.33 2.34 2.35 PARQUE NOSSA SENHORA DA PIEDADE: PÁGINA 280.

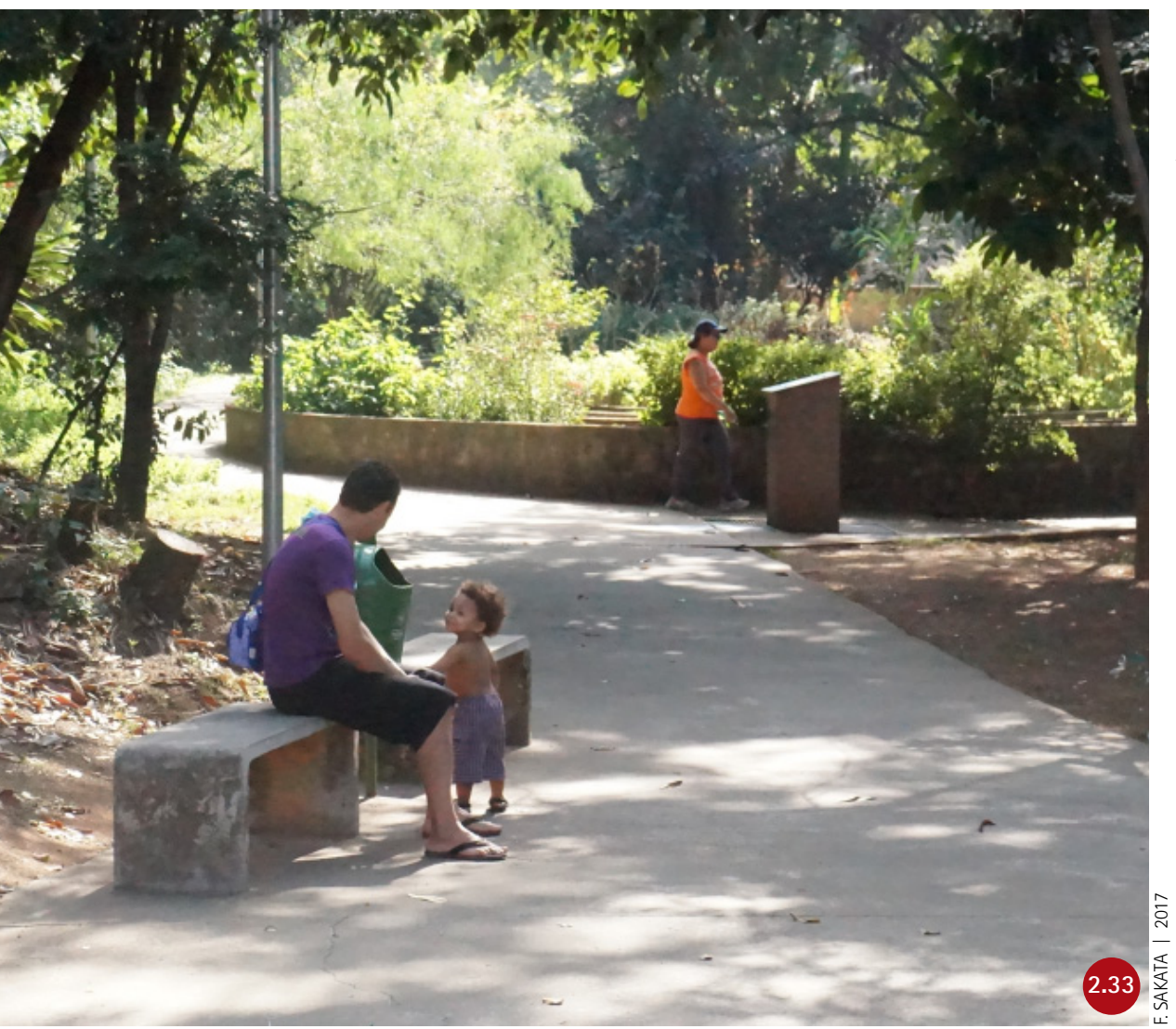

Parque Primeiro de Maio, Belo Horizonte. Considerado símbolo do Programa de Recuperação Ambiental de Belo Horizonte, concretiza a transformação de um terreno baldio, com esgoto a céu aberto, em um espaço de lazer com ambiente preservado.
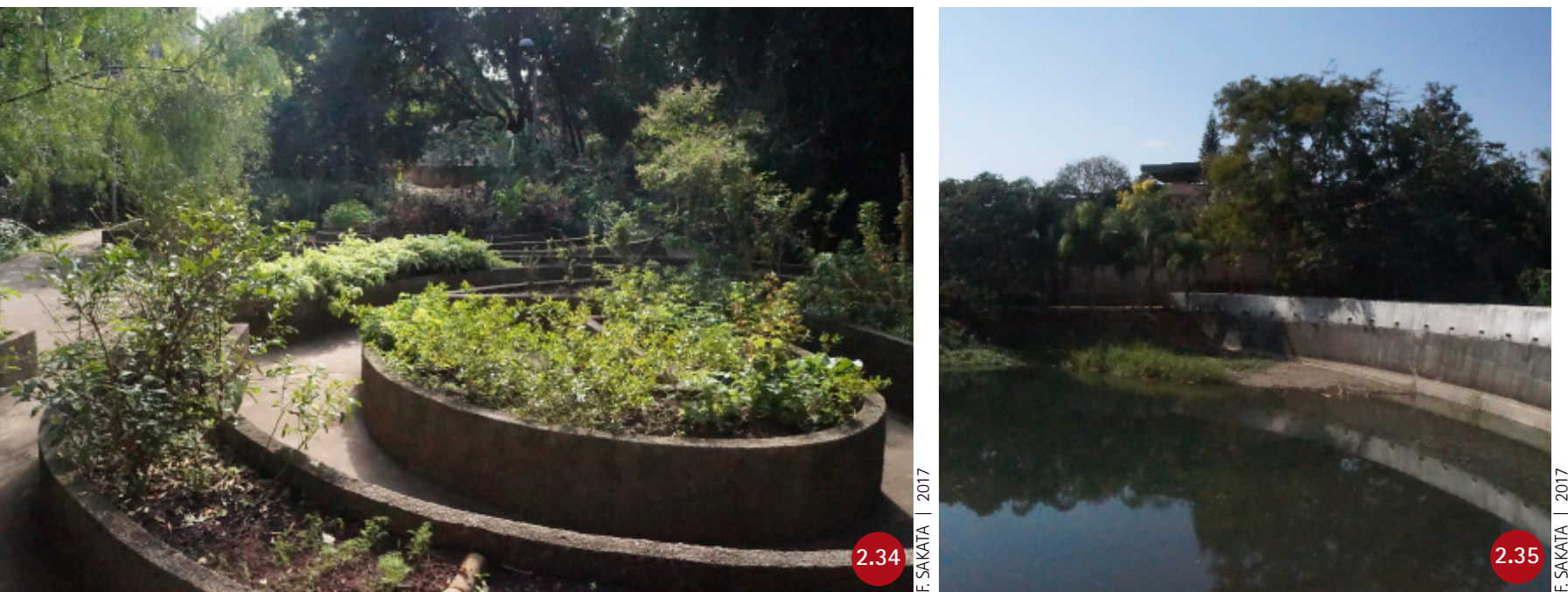


\section{Parques oriundos de programas habitacionais}

A criação das APPs urbanas deixou claro que o poder público precisava tomar providências mais efetivas em relação aos córregos urbanos ocupados por moradias em condições precárias e de risco. Em São Paulo, o Programa 100 parques encampou uma política de implantação de parques lineares ao longo de rios, córregos e represas, e a SVMA associou-se à Secretaria Municipal de Habitação (Sehab) para as remoções e a construção de novas moradias, tratamento dos canais e desenho dos espaços livres. Galender e Campos $^{20}$ destacam ainda os casos dos parques lineares implantados apenas pela Sehab, e que passam a ser classificados como parques apenas quando entregues e quando têm sua gestão transferida para a SVMA. Os parques em áreas que eram favelas são uma forma de prevenir que as áreas voltem a ser ocupadas.

As autoras reconhecem a imprecisão quanto à classificação dos parques lineares. Muitos são definidos como tal desde a sua gênese: é o caso dos parques linear Sapé (zona oeste), Linear Aricanduva e Tiquatira (zona leste), Linear do Fogo (zona norte) e Linear Parelheiros (zona sul). Outros, como o Cantinho do Céu (zona sul) e o Consciência Negra (zona leste) não têm seus nomes oficializados como parque linear no Guia de Parques Municipais (2014), mas assim são reconhecidos. Já os parques Praia São Paulo e Prainha (zona sul), apesar de igualmente localizados em orla de represa, não são apresentados como lineares. ${ }^{21}$

21 Participaram do Programa a SVMA e a Secretaria de Infraestrutura Urbana (Siurb), com a supervisão de obras de implantação; a Secretaria Municipal de Coordenação de Subprefeituras para projeto e implantação de parques de menor porte através de repasse de recursos da SVMA; a Sehab para suporte em relação a questões habitacionais.

GALENDER, Fany; CAMPOS, Ana Cecilia M. de Arruda. Ações públicas em São Paulo voltadas para recuperação dos corpos d'água: percepção e apropriação. Texto apresentado no III Seminário APPs Urbana, Belém, 2014.

22 Idem.

\section{Provisão de lazer na periferia}

O Centro de Esportes Radicais, em São Paulo, é uma obra exclusiva de provisão de lazer na periferia para jovens, e não se apropriou do discurso ambiental, nem da nomenclatura parque. De modo geral, os outros exemplos de ações de provisão de lazer na periferia receberam denominação de parques, como os parques Radical de Deodoro e o Madureira, no Rio de Janeiro, ou o Parque Cantinho do Céu em São Paulo. Este último, resolve questões ambientais, urbanísticas e, também, a questão do lazer. 2.36 2.372.39 
CAPÍTULO 2. GESTÃO DE OPORTUNIDADES
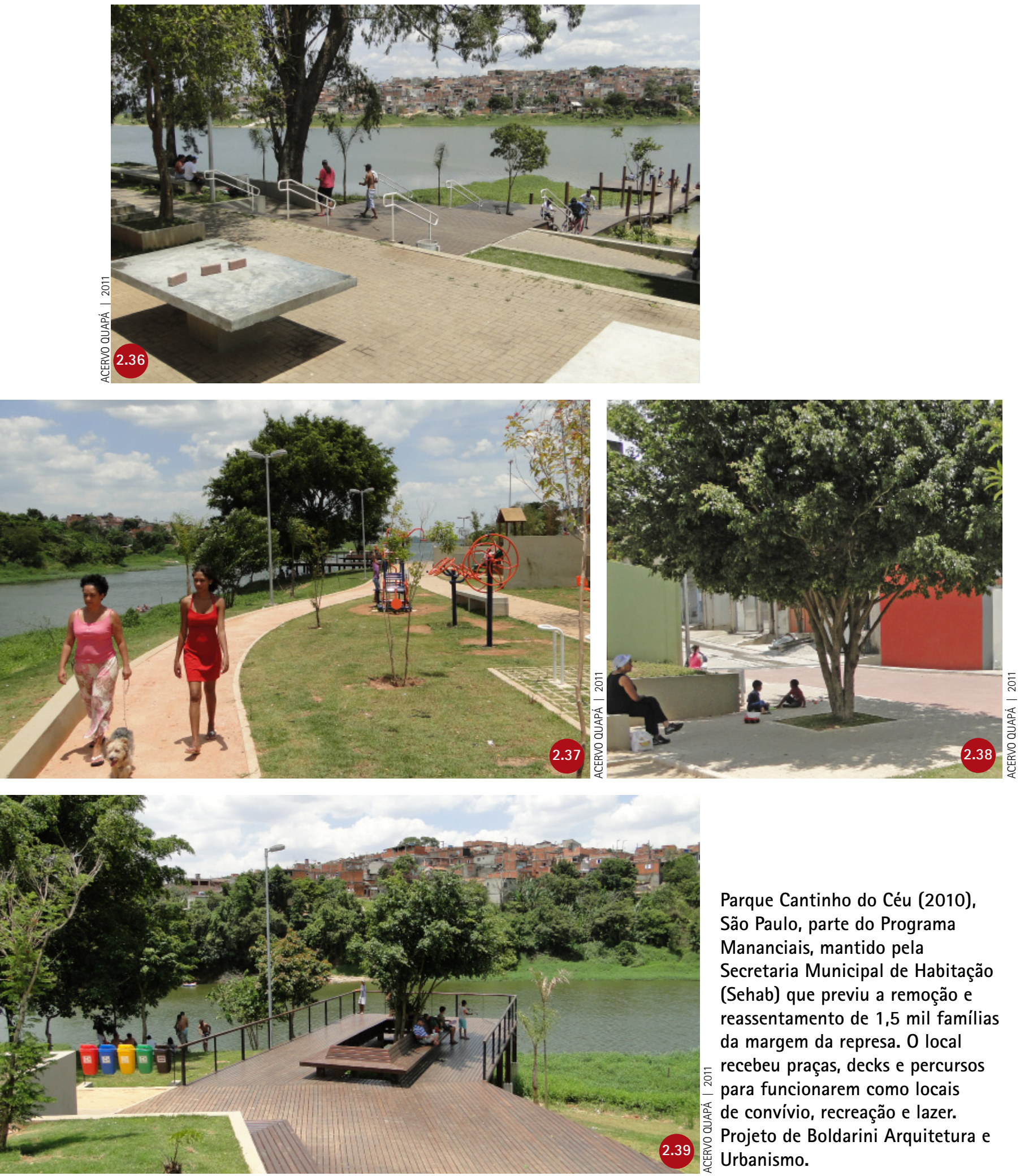

Parque Cantinho do Céu (2010), São Paulo, parte do Programa Mananciais, mantido pela Secretaria Municipal de Habitação (Sehab) que previu a remoção $e$ reassentamento de 1,5 mil famílias da margem da represa. 0 local recebeu praças, decks e percursos para funcionarem como locais de convívio, recreação e lazer. Projeto de Boldarini Arquitetura e Urbanismo. 
23 Eduardo Jorge Martins, secretário municipal do Verde e Meio Ambiente, responsável pelo Programa 100 parques, de São Paulo, explica o caso: "[...] os parques passaram a ser pensados não apenas como urbanismo ou equipamento de lazer e contemplação, mas como parte de um todo sistêmico que é a cidade. Exemplo disso é a implantação de parques na orla da Represa Guarapiranga, dentro da chamada Operação Defesa das Águas, que tem como objetivo evitar ocupações irregulares que coloquem ainda mais em risco nossos mananciais de abastecimento. No extremo-sul do municipio, onde se localizam as represas Billings e Guarapiranga, estão sendo implantados vários parques. Assim também na zona norte, no limite da Serra da Cantareira, a implantação de parques lineares mostra-se fundamental para estabelecer uma barreira à ocupação." WHATELY, Marussia; SANTORO, Paula Freire; GONÇALVES, Bárbara Carvalho; GONZATTO, Ana Maria. Parques urbanos municipais de São Paulo: subsídios para a gestão. São Paulo: Instituto Socioambiental, 2008, p. 15.

24 COELHO, Leonardo L.; SAKATA, Francine. Parques e proteção ambiental no vetor oeste da região metropolitana de São Paulo. X Colóquio Quapá- SEL, Brasilia, 2015.

\section{Parques como figura criada pela lei para conter a urbanização}

Os parques têm sido demarcados para garantir áreas de preservação e prevenir ocupações irregulares, sejam de moradias de baixa ou alta renda. Entre os objetivos do Programa 100 parques, de São Paulo (2008-2012), estavam construir um banco de terras públicas com potencial para a prestação de serviços ambientais e iniciar um plano de adaptação ao novo cenário de mudanças climáticas. Prioritariamente, a implantação dos parques se daria na borda da Cantareira, das represas Billings e Guarapiranga, além das nascentes do Aricanduva. A principal meta declarada era evitar ocupações irregulares que colocassem em risco os mananciais de abastecimento. ${ }^{22}$

A demarcação de parques cumpre papel importante na proteção das áreas. Coelho ${ }^{23}$, que estudou os municipios do Vetor Oeste da Região Metropolitana de São Paulo (RMSP), verificou que entre as áreas identificadas como 'superfícies protegidas', há: parques urbanos (municipais ou estaduais), reservas e áreas classificadas de acordo com o Sistema Nacional de Unidades de Conservação como Unidades de Proteção Integral ou Uso Sustentável. Embora existam no vetor mecanismos legais, abrangendo aproximadamente a metade da área correspondente à soma dos municípios estudados, os parques e as unidades de proteção correspondem à pequena porcentagem (135 km²), 31\% do total das zonas ambientalmente protegidas. Isto significa que existe estoque expressivo de áreas ambientalmente frágeis no vetor, que ainda são passiveis de serem conservadas e mais bem articuladas com as áreas urbanizadas existentes. 0 maior problema das superfícies protegidas é a falta de gestão. De todas as unidades de proteção, apenas os parques que se caracterizam como urbanos têm alguma estrutura de administração e conseguem alguma efetividade na proteção dos recursos naturais. Na prática as demais áreas de conservação e preservação legalmente estabelecidas na região estão desprotegidas. 2.40 2.41 


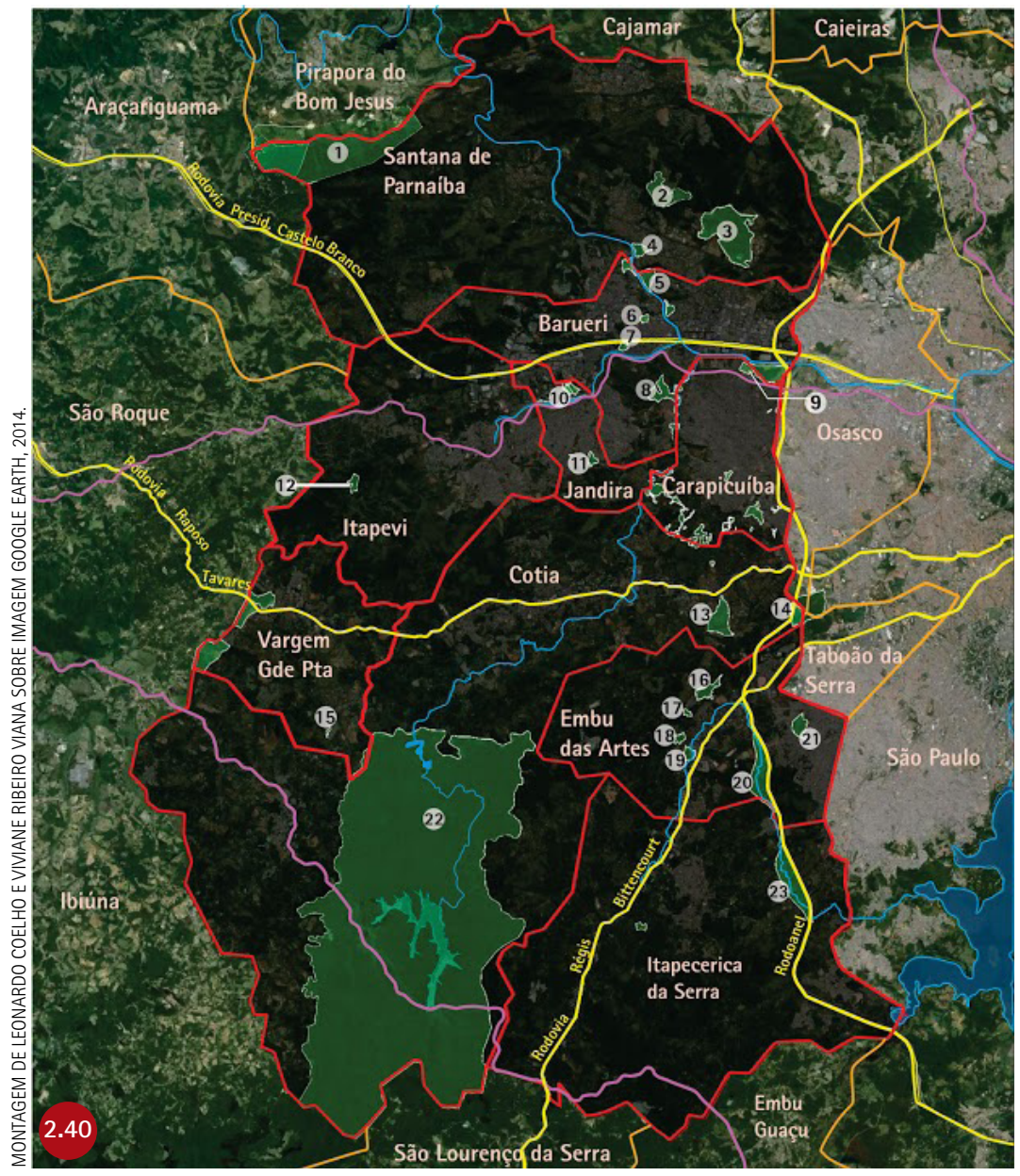

Superficies protegidas

1 Área Natural Tombada do Boturuna

2 Reserva Gênesis

3 Reserva Biológica Tamboré

4 Parque Lagoa do Bacuri

5 Parque Ecológico do Tietê Centro

de Lazer llha do Tamboré

6 Parque Municipal Dom Jose

7 Parque da $3^{a}$ Idade

8 Área do Exército

9 Parque Estadual Gabriel Chucre/ Parque da Lagoa

10 Área de Lazer do Trabalhador

11 Portal Ecológico

12 RPPN Sitio Ryan

13 Parque CEMUCAM

14 Parque Tizo

15 Parque Lagoa do Agreste

16 APA Prado Rangel

17 Fonte dos Jesuitas

18 APA Lagoa dos Principes

19 Parque Francisco Rizzo

20 Parque Rodoanel - Embu da Artes

21 APA Santa Tereza

22 Reserva Morro Grande

23 Parque Compensatório Rodoanel

- Limite municipios Vetor Oeste

- Demais municipios RMSP

- Rodovias

- Principais corpos d'água

- Linha férrea

Casario

Superfícies protegidas dos municípios do Vetor Oeste da Região Metropolitana de São Paulo.
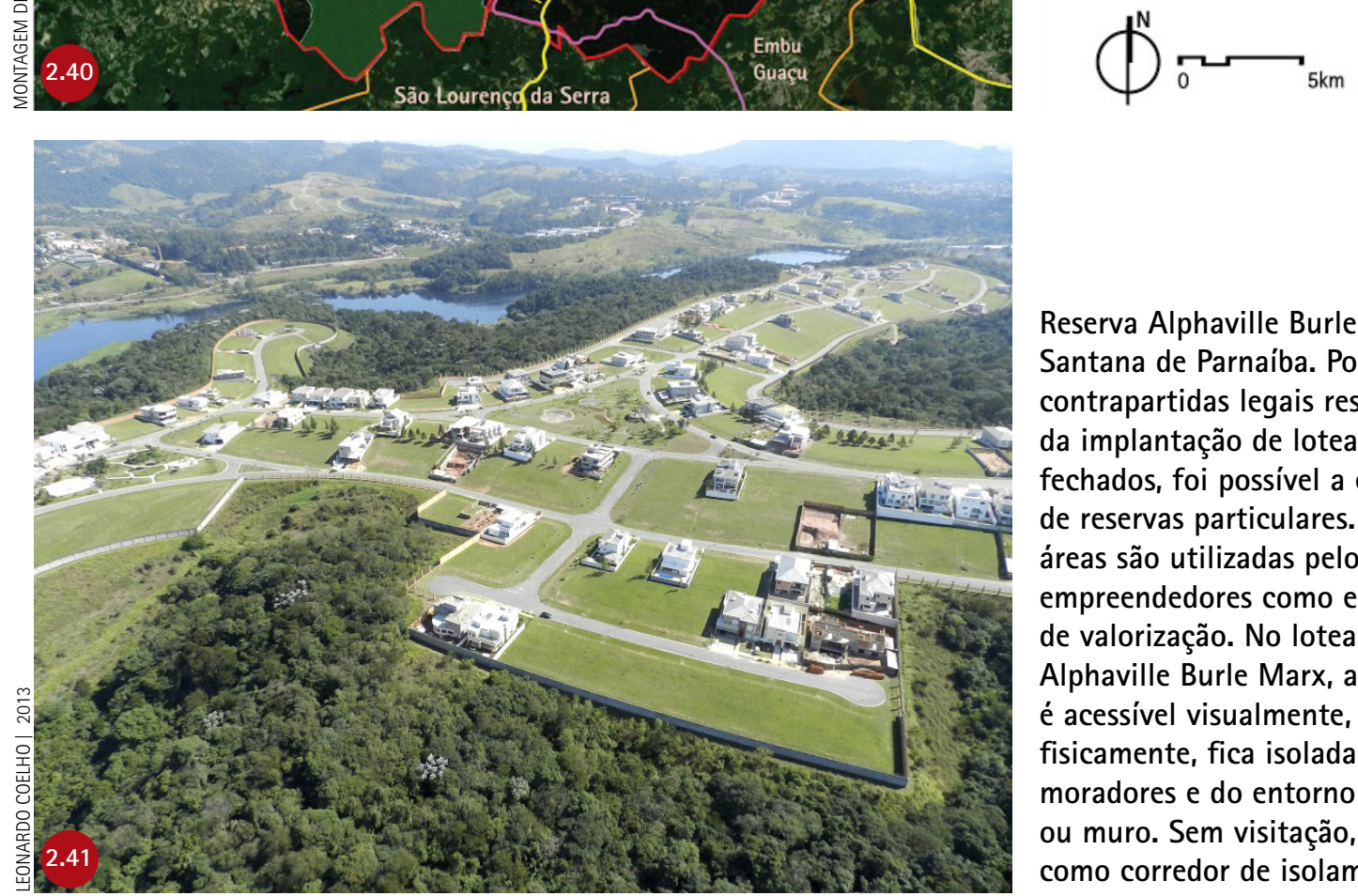

Reserva Alphaville Burle Marx, Santana de Parnaíba. Por meio de contrapartidas legais resultantes da implantação de loteamentos fechados, foi possível a criação de reservas particulares. Essas áreas são utilizadas pelos empreendedores como elementos de valorização. No loteamento Alphaville Burle Marx, a mata é acessível visualmente, mas, fisicamente, fica isolada dos moradores e do entorno por cerca ou muro. Sem visitação, funciona como corredor de isolamento. 


\section{Parques que são ações de planejamento}

Rios e parques lineares também foram a espinha dorsal de grandes projetos urbanísticos que são verdadeiras ações de planejamento urbano, como os Programas Viva Barigui (Curitiba), Prosamim (Manaus) e Macambira-Anicuns (Goiânia).

A Operação Urbana Água Espraiada, em São Paulo, visa requalificar o entorno da avenida Jornalista Roberto Marinho, que faz a continuação das pontes estaiadas construídas sobre a marginal Pinheiros; fazer uma extensão via túnel até a rodovia dos Imigrantes; instalar o monotrilho sobre a via expressa; retirar a favela sobre o córrego Jabaquara, reassentando as famílias; e reurbanizar o córrego Jabaquara com um parque linear. É um projeto rodoviarista, Operação Urbana Cohsorciada Água Espraiada. que está sendo implantado (2018) na contramão do que está sendo feito pelo mundo, de demolir viadutos e trocar vias-expressas por espaços de pedestres. 0 parque linear parece ter sido colocado, neste caso, como uma forma de amenizar a ação, principalmente a remoção das moradias. 0 eixo estruturador é a obra viária. (2.42)

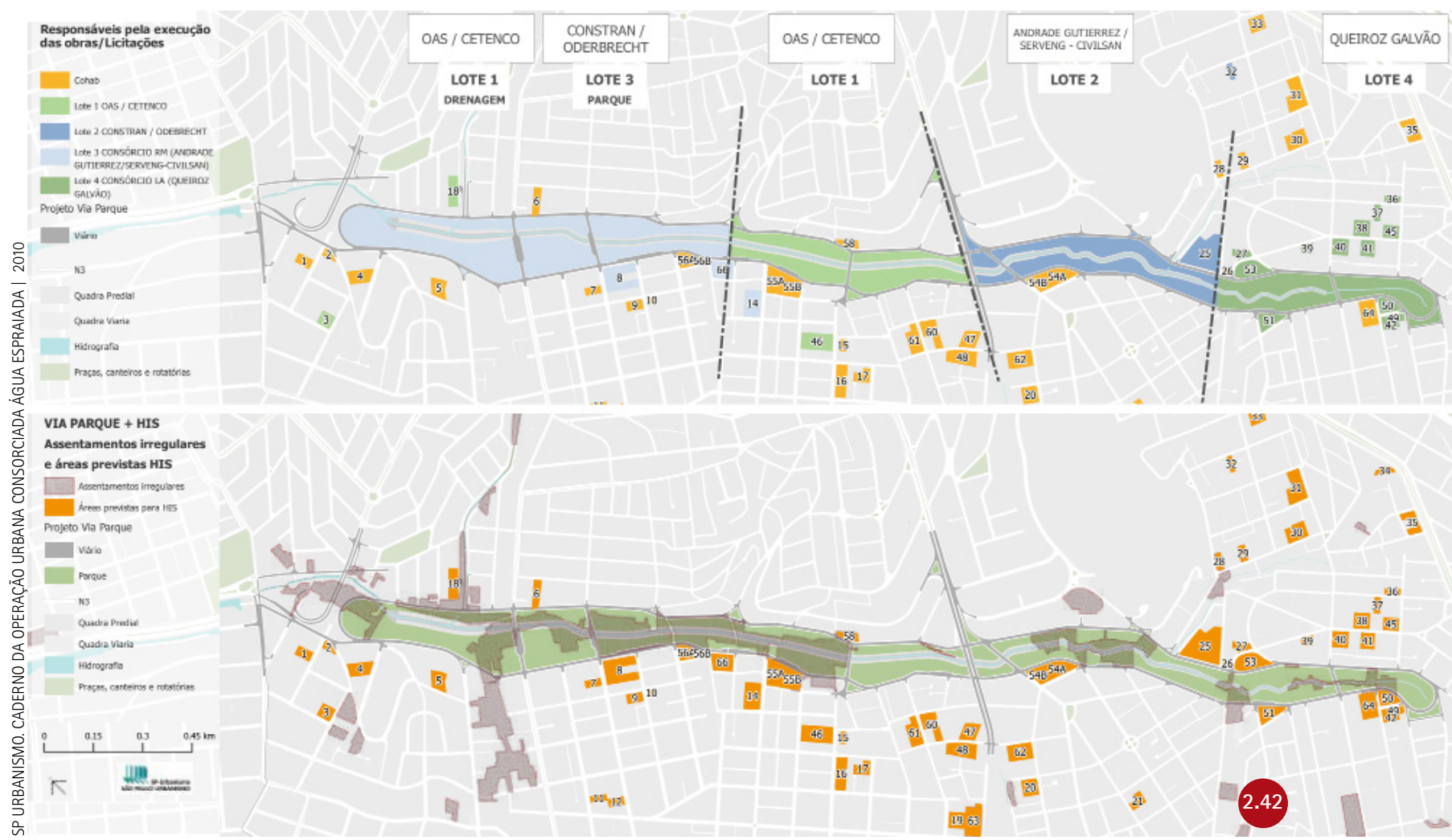


Em Curitiba, em 2007, teve início o Programa Viva Barigui, que a partir de 2012 foi chamado de Rio Parque. Consiste em um conjunto de ações que visam à implantação de parque linear com 45 quilômetros de extensão, que se estende por 25 bairros da cidade, integrando parques tradicionais - Barigui, Tingui e Tanguá - a novos núcleos de lazer e conservação ambiental, através da recuperação de áreas degradadas e ocupadas por favelas. 0 plano envolve ações setoriais, incluindo a remoção e o reassentamento de famílias de baixa renda, saneamento da bacia e desassoreamento do canal, recuperação da vegetação nativa e estabilização das margens e implantação de infraestrutura de lazer ao longo da orla do Barigui. Foi desenvolvido de forma global, mas sua implantação ocorreria por trechos, conforme a capacidade de realizá-los. Foi feito o parque Cambuí (2008) e, a partir de 2013, a gestão municipal priorizou a implantação de todo o programa, inaugurando os parques Guairacá (2014), Mané Garrincha (2014), Bosque dos Mundiais (2014), Vista Alegre (2015), Reserva do Bugio (2015), Mairi (2016) e Yberê (2016). 2.43
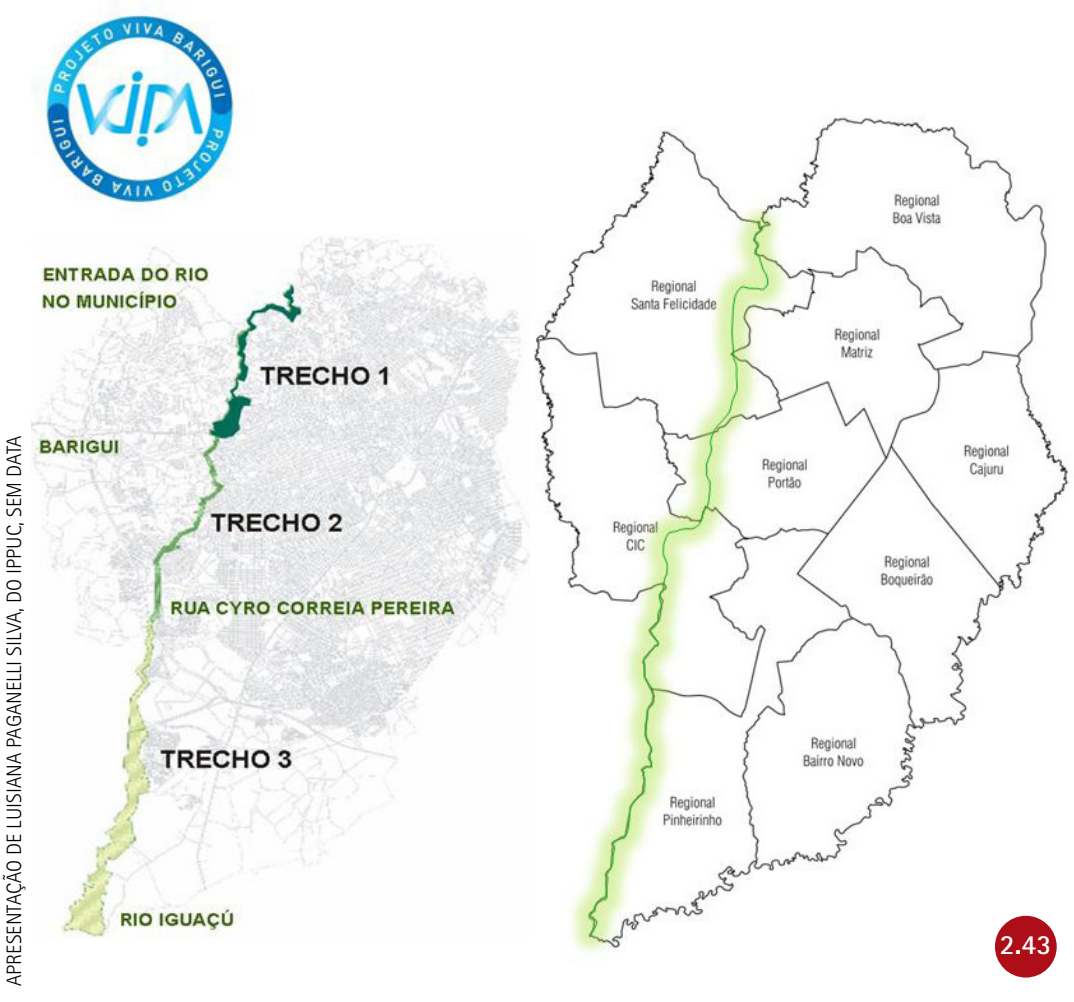

Programa Viva Barigui. Foram previstas obras de infra-estrutura para consolidar o Parque Linear do Rio Barigüi, interligando parques, bosques e áreas de lazer já existentes com novas unidades de conservação. 
A área de intervenção do Prosamim em 2012: em verde, Parque Residencial Manaus; azul, Parque Bittencourt; amarelo, Parque Jefferson Péres; laranja, Parque Mestre Chico; vermelho, Parques Residenciais Jefferson Péres e Gilberto Mestrinho.
0 Programa de Recuperação Ambiental e Social dos lgarapés de Manaus (Prosamim) teve início em 2006 e consiste na recuperação dos igarapés (pequenos rios) nas áreas centrais da cidade. 0 programa envolve obras de infraestrutura de saneamento e drenagem, canalizações e desassoreamento dos canais, remoções e reassentamentos de grande número de famílias que moravam em palafitas, implantação de obras viárias e o conjunto de espaços livres à beira d'água. Todas essas ações fazem parte de uma única obra, com recursos específicos e gestão centralizada, ligada ao gabinete do governador, coordenando diferentes setores da administração pública. $^{24}$ (2.44)

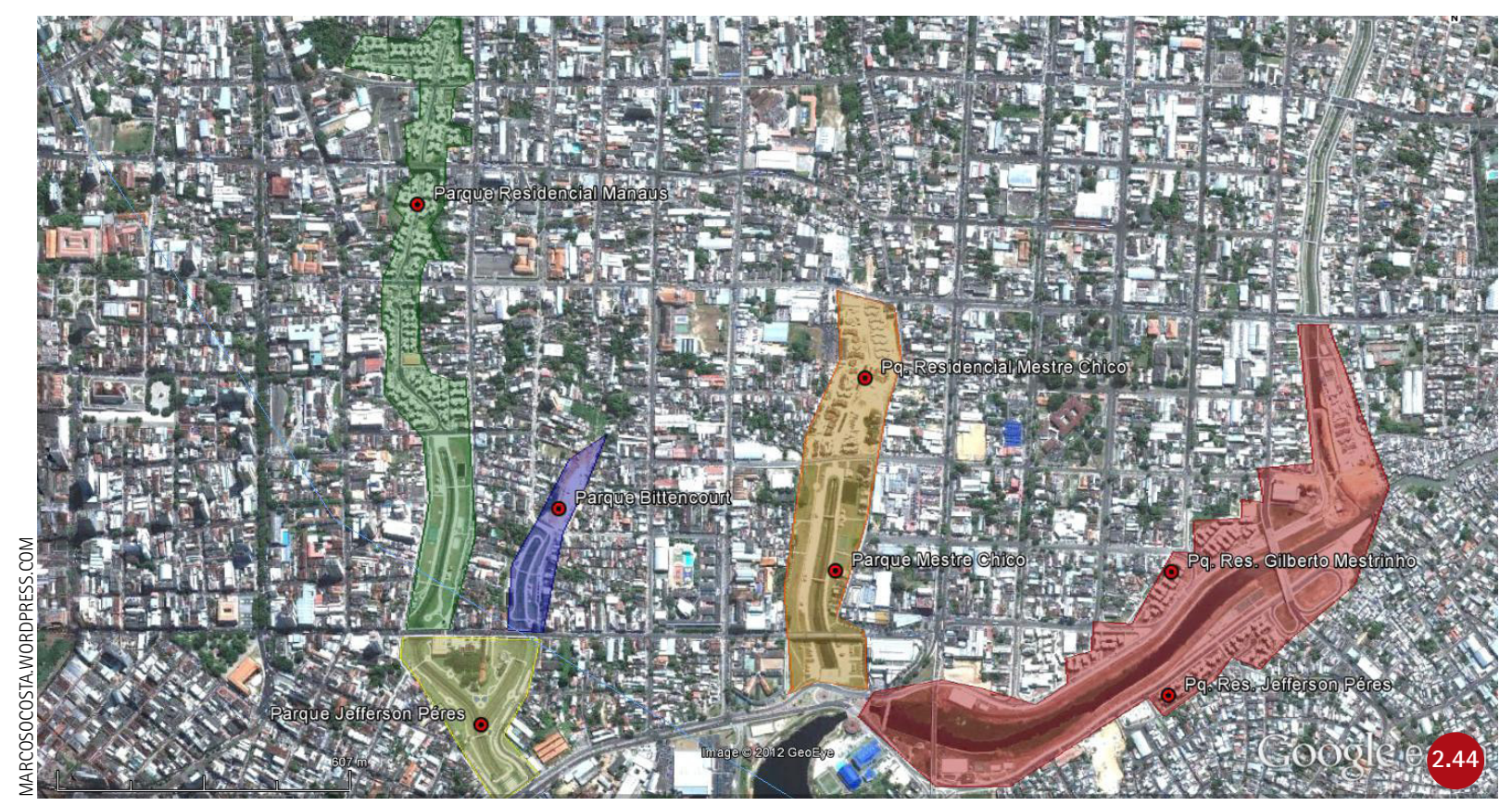

25 Conrado Blanco de Souza apresenta, como "projetos de grande abrangência", o Prosamim, de Manaus, e o Rio-parque, de Curitiba, em um trabalho sobre legislação, projetos e desafios para orlas fluviais.

SOUZA, Conrado Blanco de. APPs fluviais urbanas e sistemas de espaços livres: uma análise da influência do Código Florestal na forma das cidades brasileiras. 2015. 165 p. : il. Dissertação (Mestrado - Área de Concentração: Paisagem e. Ambiente) - Faculdade de Arquitetura e Urbanismo, Universidade de São Paulo. São Paulo, 2015.
O Prosamim é o grande programa de intervenção urbana do Brasil deste período, que contempla a questão urbana, habitacional e ambiental de forma ampla, multidisciplinar. Além dos espaços públicos criados, mais de 60 mil pessoas foram assistidas. 0 Prosamim recebeu críticas: não foi capaz de reassentar toda a população removida e, para as obras, áreas de igarapés foram aterradas, inclusive nascentes. Segundo o Professor Marcos 0. Costa (FAAP/SP), as críticas não invalidam o processo mas devem ser o ponto de partida para uma avalição mais profunda, que permitirá a correção e a maior 
CAPÍTULO 2. GESTÃO DE OPORTUNIDADES
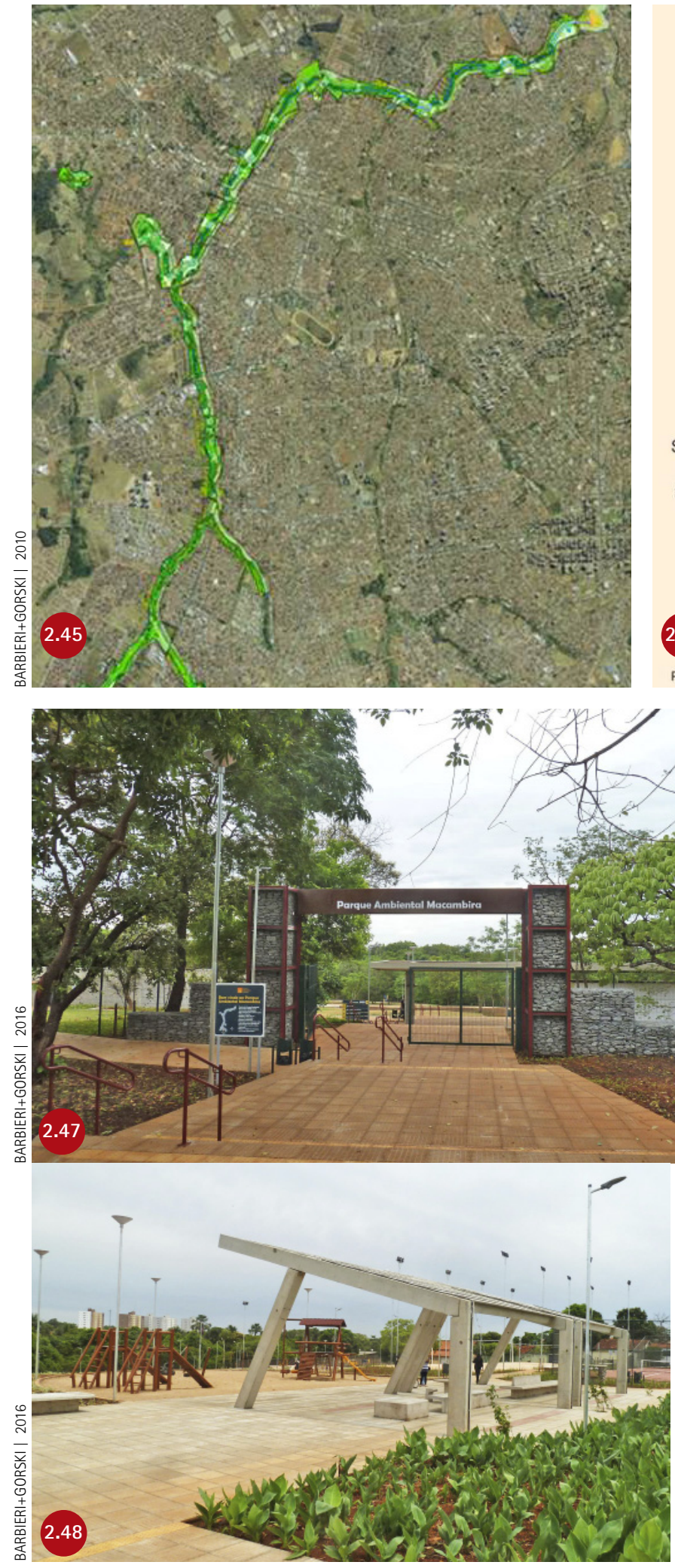

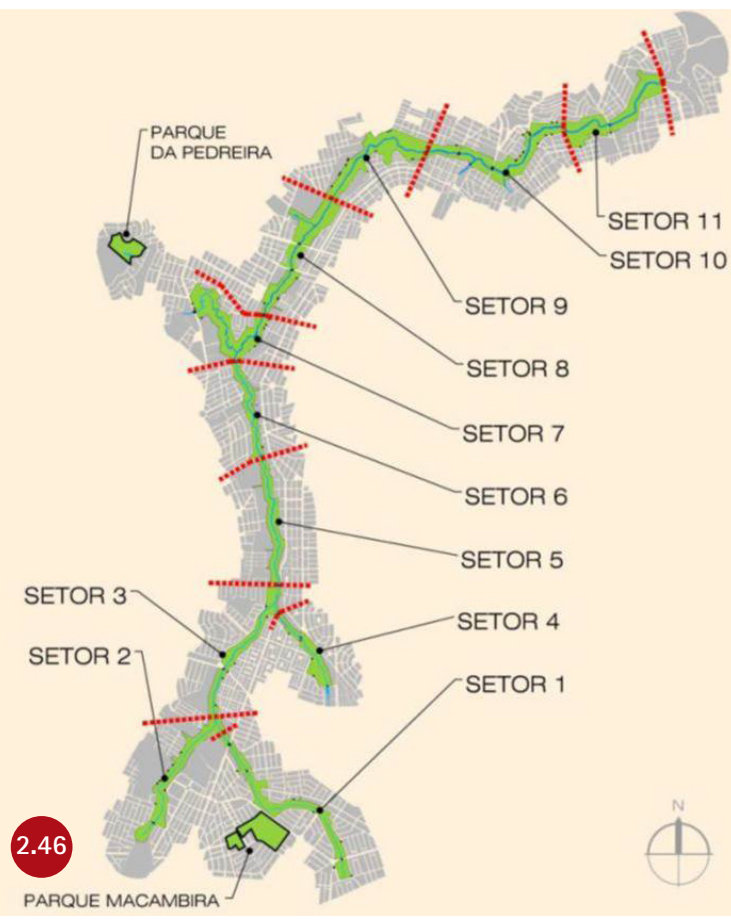

O plano completo para o Parque Macambira-Anicuns e o trecho inaugurado no Setor Faiçalville. Os núcleos de equipamentos de lazer e sedes de convivência comunitária assumem diferentes configurações conforme as características dos bairros. 
qualificação das intervenções futuras. 0 Prosamim é um paradigma para uma nova metodologia de intervenção em cidades brasileiras. ${ }^{26}$

Outro parque linear de grande porte é o Macambira-Anicuns, em Goiânia, projetado em parceria por Barbieri+Gorski, Rosa Kliass e o Grupo 4. Totaliza 24 quilômetros de extensão e engloba dois parques ‘convencionais', o Parque da Pedreira e o Parque Macambira. 0 intuito do parque é recuperar o rio, que tem recebido esgoto e entulho. A área, convertida em parque, seria um benefício para 131 bairros relativamente densos percorridos pelo projeto. Este parque é um exemplo de ação de planejamento urbano através de parques. Em 2015 teve dois pequenos trechos inaugurados. (2.45) 2.46 2.47 


\section{Quadro-síntese das categorias de parques pela motivação de sua realização}

\begin{tabular}{|c|c|c|}
\hline Motivação principal & Características & Exemplos \\
\hline $\begin{array}{l}\text { Ação sistemática de criação de } \\
\text { parques já previstos em planos }\end{array}$ & $\begin{array}{l}\text { Reservados no plano da cidade e que } \\
\text { vão sendo equipados numa ação mais } \\
\text { ou menos sistemática das prefeituras }\end{array}$ & $\begin{array}{l}\text { Campo Grande, Rio Branco e } \\
\text { Curitiba }\end{array}$ \\
\hline Para projetar a imagem da cidade & $\begin{array}{l}\text { Projetam imagens para valorização } \\
\text { urbana para propaganda da cidade, } \\
\text { política, turismo }\end{array}$ & $\begin{array}{l}\text { Parque Mangal das Garças, Parque } \\
\text { Madureira }\end{array}$ \\
\hline $\begin{array}{l}\text { Como propaganda da gestão de } \\
\text { governo }\end{array}$ & $\begin{array}{l}\text { Quando a melhoria da imagem da } \\
\text { administração foi o principal objetivo }\end{array}$ & Parque da Juventude \\
\hline Como propaganda de empresa & $\begin{array}{l}\text { Ações institucionais para mostrar } \\
\text { preocupação com qualidade de vida e } \\
\text { meio ambiente }\end{array}$ & $\begin{array}{l}\text { Parques da Sabesp, em São Paulo, } \\
\text { ou da Vale, em Vitória e São Luís }\end{array}$ \\
\hline $\begin{array}{l}\text { Operações consorciadas ou } \\
\text { parcerias para valorização } \\
\text { imobiliária }\end{array}$ & $\begin{array}{l}\text { Parques que projetam imagens de } \\
\text { "qualidade de vida" no bairro para } \\
\text { incrementar vendas }\end{array}$ & Jardim das Perdizes, em São Paulo \\
\hline $\begin{array}{l}\text { Lazer e qualificação ambiental em } \\
\text { bairros consolidados de camadas } \\
\text { alta, média ou baixa }\end{array}$ & $\begin{array}{l}\text { Quando bem geridos, também } \\
\text { acarretam valorização }\end{array}$ & Bosque do Sudoeste, em Brasília \\
\hline Associados à habitação social & $\begin{array}{l}\text { Requalificação de córrego com favela } \\
\text { e provisão de lazer }\end{array}$ & $\begin{array}{l}\text { Parque Cantinho do Céu e Parque } \\
\text { do Sapé, em São Paulo }\end{array}$ \\
\hline $\begin{array}{l}\text { Provisão de lazer na periferia } \\
\text { prioritariamente }\end{array}$ & & $\begin{array}{l}\text { Centro de Esportes Radicais, Parque } \\
\text { Madureira, parques do Idoso, } \\
\text { Criança e Juventude em Manaus }\end{array}$ \\
\hline $\begin{array}{l}\text { Para preservação ambiental ou } \\
\text { como reserva natural, com o lazer } \\
\text { em segundo plano }\end{array}$ & Bosque, rio, lago ou outro recurso & $\begin{array}{l}\text { Programa } 100 \text { parques, em São } \\
\text { Paulo; Parques de Brasilia; Parque } \\
\text { das Dunas, em Salvador }\end{array}$ \\
\hline $\begin{array}{l}\text { Como ações de planejamento } \\
\text { urbano para qualificação da } \\
\text { paisagem, melhorias viárias, da } \\
\text { provisão de lazer etc. }\end{array}$ & & $\begin{array}{l}\text { Macambira-Anicuns, Prosamim, } \\
\text { Rio-Parque (Barigui) }\end{array}$ \\
\hline
\end{tabular}




\section{DistRIBUIÇÃO PELO ESPAÇO URBANO}

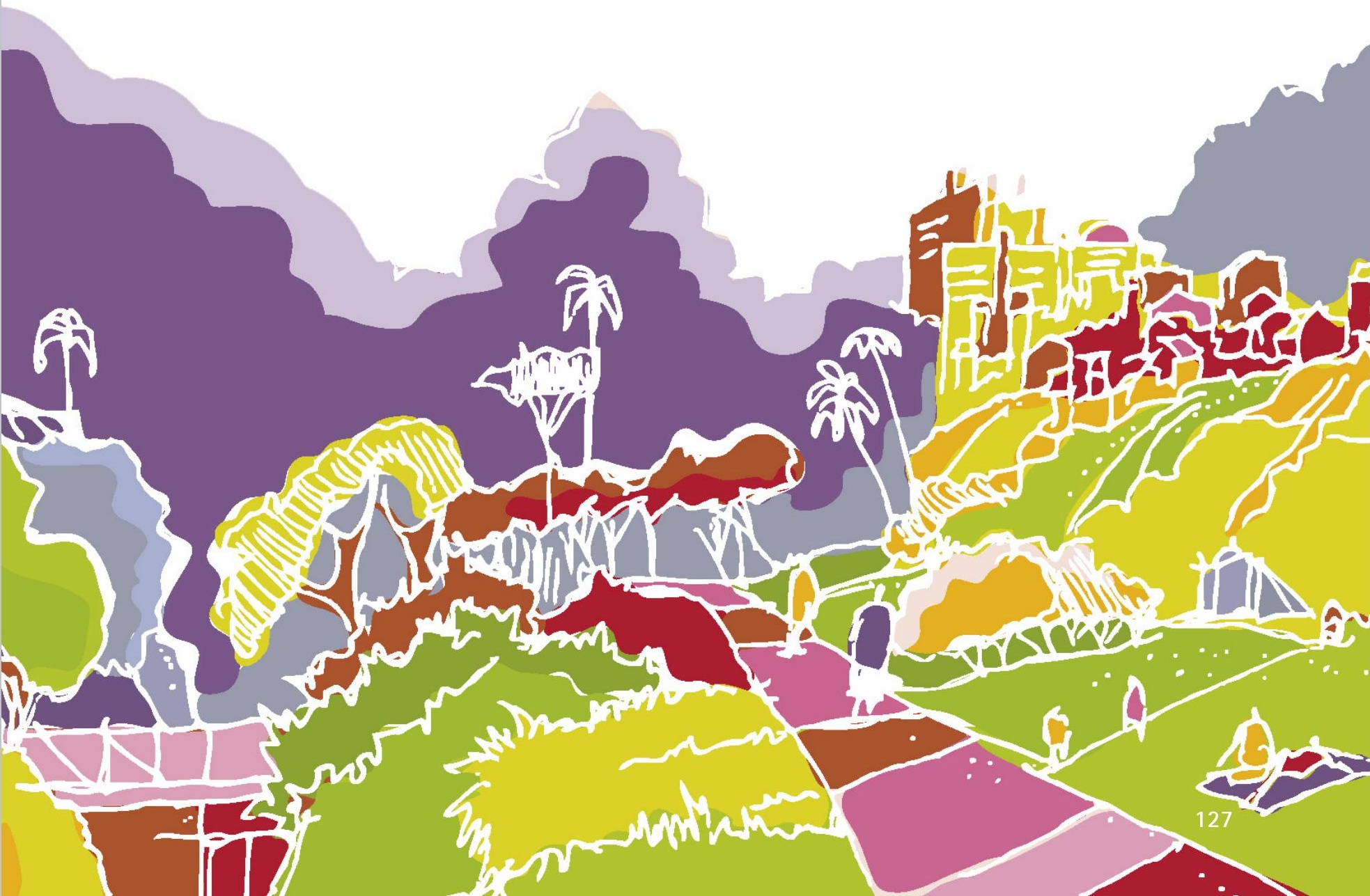




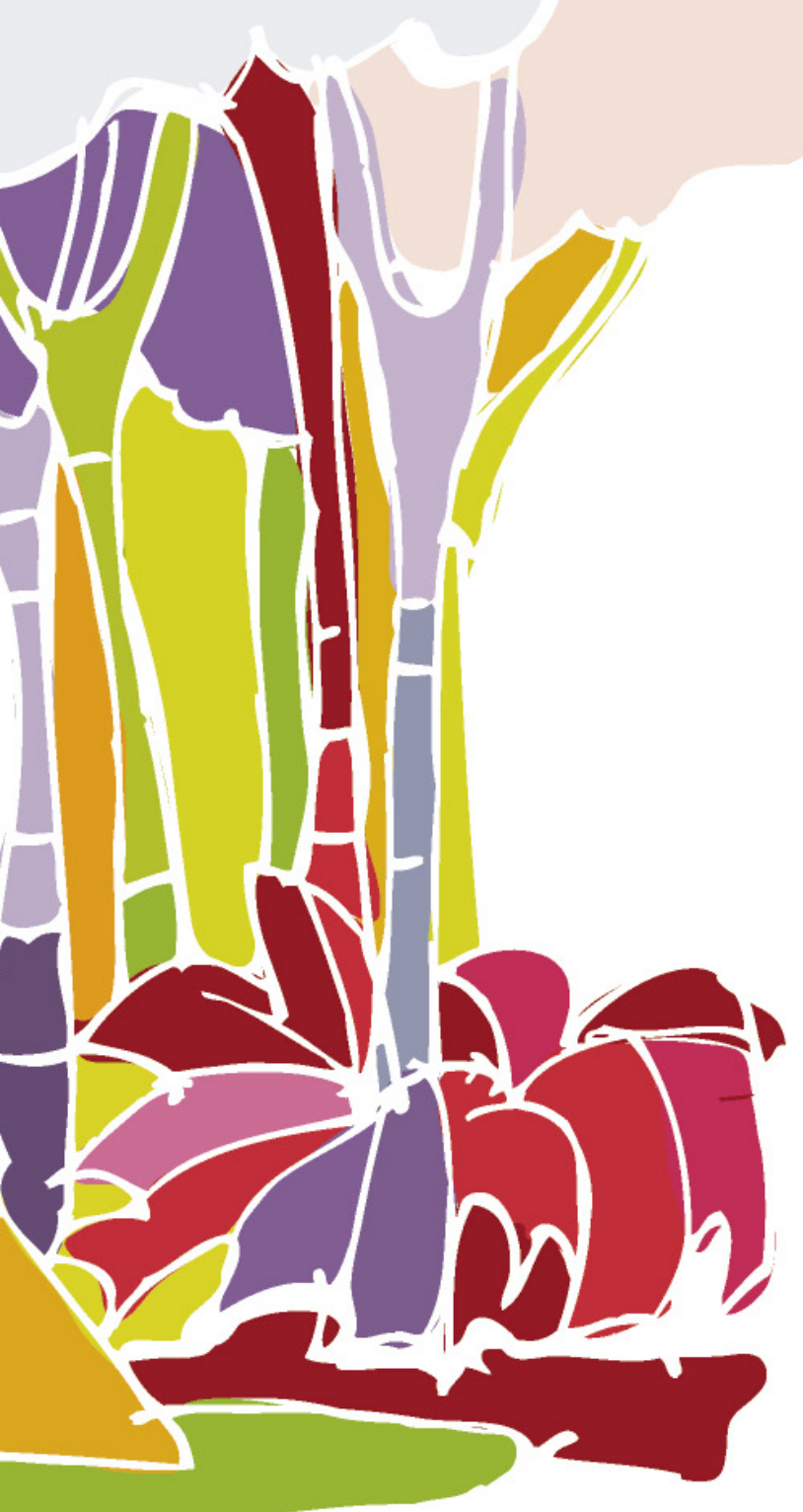




\subsection{Quadro geral}

As metrópoles brasileiras seguem padrões de estruturação territorial segregadores. Há bairros ricos e bairros pobres muito demarcados, representando os extremos da pirâmide social. E há vastos tecidos mistos nos quais o mercado imobiliário busca pontualmente criar "ilhas de prosperidade", ou seja, demarcar trechos com a imagem de que são mais bem servidos de infraestrutura e mais sofisticados que o entorno, a fim de alavancar vendas e garantir a rentabilidade dos investimentos. Espaços livres tratados e parques podem ser ferramentas para esta qualificação simbólica.

Nos bairros tradicionais, as cidades crescem por consolidação, isto é, ocupando terrenos disponíveis, ou por substituição das construções existentes por novas. Nas últimas décadas, os terrenos ociosos das grandes cidades tornaram-se cada vez mais escassos; os que existem são públicos e têm sido reivindicados pela população e o Estado para a preservação de recursos vegetais e hídricos ou para o lazer.

Nas bordas do tecido, estão os terrenos sobre os quais as cidades crescem por adição. No século XXI, os maiores problemas socioambientais das metrópoles não estão mais nos municípios-sede, mas nos municípios em torno deles, que formam uma espécie de periferia da capital. Há ocupações irregulares e grandes loteamentos sendo construídos, por exemplo, sobre as dunas nos municípios vizinhos de Fortaleza e agressões ambientais ao rio Cocó sendo toleradas nos municípios que atravessa. Mas, quando se trata do rio ou das dunas dentro do município de Fortaleza, há forte mobilização para que as qualidades paisagísticas sejam conservadas. 


\section{Da distribuição dos equipamentos de lazer}

0 aparelhamento de infraestruturas é desigual pelo território das cidades, inclusive a provisão de espaços livres. As porções mais ricas são mais servidas de espaços livres tratados, tanto em qualidade como em quantidade. Mas, nas últimas décadas, foram implantados - nas principais capitais do interior - muito novos parques em bairros tradicionalmente mal servidos por espaços livres tratados. A distribuição não se deu equitativamente e não aconteceu em todos esses bairros, porém houve esforços para diminuir as desigualdades.

No grupo de pesquisa Quapá-SEL, entende-se que o sistema de espaços livres da cidade é uma infraestrutura urbana sistêmica e essencial, sendo que o provimento de espaços livres qualificados para o lazer é uma atribuição do poder público.

Os indices numéricos que informam a quantidade de $\mathrm{m}^{2}$ verdes por habitante, ou mesmo de lazer por habitante, não fornecem bons retratos da realidade. Eles podem mostrar se as áreas verdes ou de lazer existem ou inexistem, sua quantidade, mas não mostram se são acessiveis ou se têm qualidade para o uso. 0 Parque Ecológico do Tietê (1982), em São Paulo, é uma área verde de 14 milhões de $m^{2}$, mas possui acesso limitado ao sul por rodovia e linha férrea e, ao norte, por outra rodovia. Sua entrada é praticamente inacessível e desconhecida pela população. Em relação à provisão de lazer, pouco contribui para ampliar de fato as opções na Zona Leste da cidade.

Em Recife, Pedroso e Silva' ${ }^{1}$ fizeram um levantamento, em 2011, dos parques e suas estruturas para esporte e recreação. Contaram nove parques em uma cidade com 94 bairros e constataram a ausência de equipamentos em determinadas regiões. Mesmo naquelas onde havia parques, a relação de $\mathrm{m}^{2}$ por habitantes apresentava-se muito baixa de acordo com indicadores europeus. Na Região Norte, que não possuía parques, era próxima dos parques da Região Noroeste, a mais bem equipada. Às vezes, quem morava no extremo de uma determinada região estava distante dos parques de sua própria região.
1 PEDROSO, Carlos Auguro Mulatinho de Queiroz; SILVA, Felipe Francisco Pereira da. Equipamentos de esporte e lazer na cidade: planejamento dos parques urbanos do Recife, PE, Brasil. Revista Digital EFDeportes. Buenos Aires, Ano 16, n. 158, julho de 2011.

Disponivel em: $<h t t p: / / w w w . e f d e p o r t e s$. com/efd 158/equipamentos-de-esporte-e-lazer-na-cidade.htm>. 
Os mapas - com parques, vias estruturais, tipologias morfológicas e renda -, aliados a outras informações sobre qualidade e apropriação dos espaços de lazer, são as melhores ferramentas para avaliar relações, sobreposições e carências de espaços de lazer.

No comércio varejista, a construção de um shopping ou a distribuição dos pontos de venda de uma rede de lojas é antecedida por pesquisas de renda, padrão de consumo, composição do comércio já existente na região, raio de movimento das vias etc. - um esforço para garantir maior possibilidade de acerto.

0 raio de atendimento de um equipamento pode ser marcado no mapa com um círculo, porém é mais preciso considerar variáveis como obstáculos (rios e pistas expressas), alternativas de percursos, meios de transporte, tempo que se leva para chegar, percursos tradicionais etc. Para o provimento de espaços livres tratados para o lazer, o poder público idealmente consideraria os outros elementos já existentes no sistema e poderia assumir que um equipamento complementa o outro. Articulando-se os espaços livres, racionaliza-se o sistema e a população é mais bem atendida.

Mas, na distribuição recente dos parques, a localização se deu onde havia terrenos vagos públicos ou onde a oportunidade fosse criada. Não teve relação direta com a demanda, entretanto, poderia ter a definição do programa de atividades. É possível estudar o perfil da vizinhança, o que existe e o que falta na área, para compreender melhor as possibilidades de complementação dos equipamentos urbanos. A gestão e a manutenção podem contribuir para corrigir eventuais distorções ao longo do tempo. 


\section{Mapas e tabelas}

A seguir, são apresentados, por cidade, tabelas e mapas com a localização dos parques existentes antes e depois de 2000. Foram produzidos dois mapas para cada cidade:

- dos parques anteriores e posteriores a 2000, com marcação das principais vias e áreas verticalizadas (em roxo) - que costumam ser densas (ainda que menos densas que os bairros pobres e horizontais) ${ }^{2}$ e apresentar maior dinâmica de transformação. Nelas, o valor do solo é maior.

- dos parques e da renda: cada ponto corresponde ao setor censitário; as rendas menores estão em amarelo; as maiores, em preto. Este conjunto de mapas nos permitiu concluir que os parques mais conhecidos e melhor equipados e mantidos estão localizados em bairros de rendas mais elevadas mas o poder público implantou novos parques (2000-2017) em junto a rendas baixas, médias e altas.

Para Vitória, Goiânia, Curitiba e Brasília foram também produzidos os mapas:

- dos parques e das transformações urbanas (por adição, consolidação ou substituição) - sobre bases elaboradas por Rafael Pegoraro e Victória Ribeiro. ${ }^{3}$ Os parques criados entre 2000-2017 nas cidades em questão não se relacionaram especialmente com nenhum tipo especifico de transformação.

Devido à utilização das bases do Quapá-SEL neste trabalho não estão contempladas as regiões metropolitanas, apenas os municípios-sede.

As listagens de parques foram compostas a partir de sites, levantamentos acadêmicos, guias de parques, de bairros e jornais, porém as fontes sempre são incompletas e nem sempre coerentes entre si. Por exemplo: os seis parques inaugurados em Curitiba na última gestão administrativa não constam no site da prefeitura em 2018. Cada vez que revisávamos as tabelas e os mapas, encontrávamos parques novos. Aqueles parques que existem em decreto, mas são desconhecidos pela população, tendem a não constar na comunicação oficial e a não estar listados aqui.

Com isto obtivemos os seguintes resultados:
2 CARVALHO, Sidney. Análise comparativa das paisagens urbanas de São Paulo, Rio de Janeiro e Distrito Federal no início do século XXI: forma urbana e sistema de espaços livres no Brasil contemporâneo. 2018. 334 p. Tese (Doutorado em Arquitetura e Urbanismo) - Faculdade de Arquitetura e Urbanismo, Universidade de São Paulo, São Paulo, 2018.

3 PEGORARO, Rafael Lopez. Transformação urbana no Brasil: estudo de cinco centros urbanos. Relatório Científico Final. São Paulo: Fapesp, 2017. Processo Fapesp: 2015/04226-9

RIBEIRO, Victória Mendes. Uso e ocupação recente de áreas pouco adensadas e suas áreas livres no espaço urbano brasileiro: o caso das cidades de Anápolis, Uberlândia, Palmas, Brasília, Cuiabá e Goiânia. São Paulo: FAUUSP, 2018. Processo Fapesp: 2016/21205-8. 
Quadro: dados da população e o incremento no número e área de parques públicos nas cidades estudadas

\begin{tabular}{|c|c|c|c|c|c|c|c|c|c|c|}
\hline MUNICÍPIO & \begin{tabular}{|l|} 
população \\
censo 2000
\end{tabular} & $\begin{array}{l}\text { no. de } \\
\text { parques } \\
\text { até } \\
2000\end{array}$ & $\begin{array}{l}\text { área de } \\
\text { parques } \\
\left(\mathrm{m}^{2}\right) \text { até } \\
2000\end{array}$ & $\begin{array}{l}\text { população } \\
\text { estimada } \\
\text { em } 2017\end{array}$ & $\begin{array}{l}\text { área de } \\
\text { parques } \\
\left(\mathrm{m}^{2}\right) \text { acresc. } \\
2000-2017\end{array}$ & $\begin{array}{l}\text { no. de } \\
\text { parques } \\
\text { acresc. } \\
2000- \\
2017\end{array}$ & $\begin{array}{l}\text { área de } \\
\text { parques } \\
\left(\mathrm{m}^{2}\right) \text { total } \\
\text { em } 2017\end{array}$ & $\begin{array}{l}\text { no. de } \\
\text { parques } \\
\text { total } \\
\text { em } \\
2017\end{array}$ & $\begin{array}{l}\text { frota de } \\
\text { veículos } \\
\text { em } 2016\end{array}$ & $\begin{array}{l}\text { PIB per } \\
\text { capita } \\
2015 \\
(\mathrm{R} \$)\end{array}$ \\
\hline SÃO PAULO & 10.434 .252 & 40 & 26.112 .671 & 12.106.920 & 8.893 .204 & 76 & 35.005 .821 & 116 & 7.602 .325 & $54.357,81$ \\
\hline $\begin{array}{l}\text { BELO } \\
\text { HORIZONTE }\end{array}$ & 2.238 .526 & 29 & 4.842 .266 & 2.523 .794 & 2.893 .647 & 33 & 7.735 .913 & 62 & 1.711 .139 & $34.910,13$ \\
\hline GOIÂNIA & 1.093 .007 & 3 & 301.130 & 1.466 .105 & 5.188 .953 & 39 & 5.490 .083 & 42 & 1.104 .064 & $32.594,32$ \\
\hline $\begin{array}{l}\text { DISTRITO } \\
\text { FEDERAL }\end{array}$ & 2.051 .146 & 21 & 32.159 .489 & 3.039 .444 & 86.544 .338 & 12 & 118.703 .827 & 33 & 1.654 .667 & $73.971,05$ \\
\hline VITÓRIA & 292.304 & 8 & 2.579 .129 & 363.140 & 469.259 & 5 & 3.048 .388 & 13 & 192.469 & $64.744,84$ \\
\hline CURITIBA & 1.587.315 & 30 & 18.045 .935 & 1.908 .359 & 10.069 .685 & 22 & 28.115 .620 & 52 & 1.514 .424 & $44.624,32$ \\
\hline $\begin{array}{l}\text { CAMPO } \\
\text { GRANDE }\end{array}$ & 663.621 & 4 & 1.744 .261 & 874.210 & 5.654 .832 & 13 & 7.399 .093 & 11 & 532.950 & $28.417,05$ \\
\hline MANAUS & 1.405 .835 & 1 & 420.500 & 2.130 .264 & 855.220 & 13 & 1.275 .720 & 14 & 652.548 & $32.592,94$ \\
\hline RECIFE & 1.422 .905 & 9 & 618.138 & 1.633 .697 & 3.380 .766 & 5 & 3.998 .904 & 14 & 655.660 & $29.701,32$ \\
\hline $\begin{array}{l}\text { RIO DE } \\
\text { JANEIRO }\end{array}$ & 5.857 .904 & 30 & 59.308 .996 & 6.520 .266 & $47.817 .660^{*}$ & 12 & 107.126 .656 & 42 & 2.673 .915 & $49.527,98$ \\
\hline SALVADOR & 2.443.107 & 9 & 6.320 .000 & 2.953 .986 & 920.000 & 3 & 7.240 .000 & 12 & 847.844 & $19.812,07$ \\
\hline FORTALEZA & 2.141 .402 & 6 & 139.217 & 2.627 .482 & 11.570 .000 & 2 & 11.709 .217 & 8 & 1.011 .472 & $22.092,58$ \\
\hline BELÉM & 1.280 .614 & 4 & 14.137 .000 & 1.452 .275 & 86.000 & 2 & 14.223 .000 & 6 & 415.618 & $20.340,21$ \\
\hline $\begin{array}{l}\text { PORTO } \\
\text { ALEGRE }\end{array}$ & 1.360 .590 & 11 & 2.727 .600 & 1.484 .941 & 370.600 & 3 & 3.098 .200 & 13 & 851.150 & $46.122,79$ \\
\hline SOMA & 34.272 .528 & 205 & 169.456 .332 & 38.561 .089 & 190.114 .164 & 240 & 360.170 .442 & 438 & & \\
\hline
\end{tabular}

* Sem área do Parque Natural Municipal Jardim do Carmo.

Tabela elaborada por Francine Sakata e Caroline Ribeiro a partir dos dados sobre parques que contam no capítulo 3 deste trabalho.
Buscamos somar números dos parques na área urbana abertos à fruição humana, mesmo aqueles que são prioritariamente de conservação. Com exceção de Porto Alegre em que foram somados apenas os parques tradicionais. Foram desconsiderados, sempre que possivel, os parques sem nenhum acesso público. Assim, este número não representa as soma das áreas protegidas mas das áreas de parques no município com acesso público.

É preciso fazer a ressalva que a somatória das áreas totais dos parques como áreas de uso público é um dado sem grande significado: não significa que a população tenha acesso fácil a eles, nem que eles têm qualidade de fato para o lazer. Pequenos parques podem ser muito úteis para a população, como equipamentos de lazer, e grandes parques podem ser, na prática, desconhecidos. Nesta soma também faltam os calçadões de praia.

Fontes de dados população e PIB disponiveis em: <https://ww2.ibge.gov.br/home/estatistica/populacao/censo2000> e <https://cidades.ibge.gov.br>. Frota: disponivel em: $<$ http://www.denatran.gov.br/frota2016.htm>. 


\subsection{São Paulo}

Até 2005 havia seis parques estaduais com usos de lazer no município de São Paulo (Horto Florestal, Villa-Lobos, Fontes do Ipiranga, Ecológico do Tietê, Ecológico do Guarapiranga e Água Branca), sendo ele responsável por 34. Nos dez anos seguintes, o governo do Estado criou três grandes parques na capital: Juventude, Belém e Parque Tizo - atual Jequitibá, criado em 2006 devido à pressão popular, em implantação desde 2011, com áreas em São Paulo, Osasco e Cotia, porém ainda não aberto ao público em fevereiro de 2018. O Parque Villa-Lobos foi ampliado e houve a criação do Parque Cândido Portinari em área contígua. A prefeitura implantou cerca de 70 parques através do Programa 100 parques. $^{4}$

No Plano Diretor de 2002 da cidade de São Paulo, não havia o desenho da distribuição de áreas verdes, nem a previsão de implantação (o mesmo ocorreu no de 2015). Havia a consideração de que a rede hídrica é estruturadora da urbanização, e foram criados instrumentos para a captação de recursos do meio ambiente. 0 Programa 100 parques, então, escolheu as localizações para implantação dos parques no programa embasado na identificação de áreas públicas existentes que tivessem maior porte, ambientalmente frágeis (com recursos a preservar), produtoras de água ou em fundos de vale, principalmente concentradas nos extremos sul e norte do município. A identificação pela SVMA era feita por fotos aéreas, sobrevoos e visitas a campo. As subprefeituras também podiam inscrever áreas para parques. À medida que o programa era executado, novas áreas eram acrescentadas e outras consideradas inviáveis, porque dependiam de desapropriação e desocupação - o que requeria recursos incompativeis com o orçamento. Os parques lineares seriam o principal eixo de ação do Programa, mas, na prática, a grande maioria dos parques foi criada sobre áreas disponíveis, e não em fundos de vale, pois a recuperação das áreas dependia de grande número de desapropriações. ${ }^{5}$

Tanto na Zona Norte como na Zona Sul, há ainda extensas áreas de floresta com gestão ainda não equacionada. 0 programa de criação de parques (2008-2012) demarcou como de Utilidade Pública (DUPs) vários terrenos nas bordas do Parque da Serra da Cantareira,
4 Segundo dados da Prefeitura, a cidade possuia 34 parques municipais em 2005 (nove na Zona Sul; nove na Zona Centro-Oeste; sete Zona Leste; oito na Zona Norte e um no município de Cotia), que somavam 15 milhões de $\mathrm{m}^{2}$ de área protegida municipal. Em 2012, quando o programa foi descontinuado, havia 102 parques, aproximadamente 50 milhões de $\mathrm{m}^{2}$. Neste trabalho, contamos 71 novos parques municipais entre 2005 e 2014.

5 TAKAESU, Luciana Satiko. Parques urbanos de São Paulo. 2012. Monografia - Faculdade de Arquitetura e Urbanismo, Universidade de São Paulo, São Paulo, 2012. 
6 SANDRE, Adriana F. O planejamento ambiental à luz da Ecologia da Paisagem: estudo aplicado da zona de amortecimento do Parque Estadual da Cantareira. 2017. 235 f. Dissertação (Mestrado em Ciências) - Faculdade de Arquitetura e Urbanismo, Universidade de São Paulo, São Paulo, 2017. na Zona Norte, para que fossem comprados pela municipalidade nos anos seguintes. Se convertidos em parques, teriam o papel de área de amortecimento para a Cantareira, mas não foram pagos no período dos cinco anos previstos, sendo os decretos extintos. Um dos únicos parques concretizados na Zona Norte foi o do Canivete, com mata ciliar em processo de recuperação. Entretanto, formou-se uma nova favela na área, denominada Tribo, enquanto a "Fazendinha”, já existente e também em área de risco, se adensou. 0 Parque Brasilândia, com ordem para criação desde 2012 e uma comunidade organizada lutando por sua criação, sofre também com o avanço das ocupações por favelas em sua parte norte - o que provocou a poluição de nascentes, do córrego da Onça e da cachoeira. Além disso, teve um trecho loteado para casas de classe média. 0 parque inclui duas áreas particulares ainda não judicialmente adquiridas pela municipalidade e um trecho que é propriedade da Companhia de Desenvolvimento Habitacional e Urbano (CDHU). Na área da Barrocada, além do desmatamento e da pressão de ocupação, ocorre deposição clandestina de lixo e entulho e exploração de recursos minerais. ${ }^{6}$

A Zona Norte tem potencial para a criação de um conjunto de parques urbanos de recreação e lazer especialmente nas franjas da urbanização da Zona Norte com a serra da Cantareira. Entretanto, quanto mais ao norte, mais fragmentado o tecido urbano, razão pela qual não tem sido possível estruturá-los nestas bordas para a visitação de massa - caso do Parque Estadual do Jaraguá e do Parque Municipal Anhanguera. Os parques mais frequentados são justamente os localizados mais ao sul da Zona Norte, próximos da Marginal Tietê, no caminho entre esta região e as outras porções da cidade. 3.013.02 3.03

Na Zona Sul as represas seguem pouco acessíveis como equipamento público, todavia existem projetos para as orlas, os waterfronts paulistanos, que têm grande potencial para apropriação. A prefeitura conseguiu reservar áreas importantes, como os parques Bororé, Varginha e ltaim, com recursos da compensação ambiental do licenciamento do trecho sul do Rodoanel. Até 2018 faltavam funcionários e recursos para gerir as áreas, mas a criação das reservas foi um avanço. Nas franjas das zonas Norte e Sul, a urbanização é fragmentada e de difícil acesso. A relação das pessoas que moram 
nestas franjas com os espaços livres não é a mesma das que moram nas áreas centrais. A presença da natureza representa um incômodo para muitas pela ausência dos serviços públicos - e as bordas das metrópoles são um desafio para a sociedade. 3.11) (3.12)

No Centro-Sul e Oeste, regiões onde a renda da população é mais alta, houve, entre 2008 e 2014, grandes investimentos imobiliários, que detectaram a possibilidade de criar tipologias com torres e térreos equipados com piscinas, quadras, playgrounds, etc. nos espaços de grandes galpões sem funções específicas. Estes empreendimentos muitas vezes geraram espaços públicos frutos de parcerias público-privadas que os valorizam. Tem havido um esforço velado para que estes espaços sirvam preferencialmente aos empreendimentos que lhes dão suporte. 3.07 3.08 3.09 3.10)

Do total de parques criados pelo município, 24 são parques lineares. Nagano, que estudou o caso dos parques lineares da Zona Leste, relata que muitos não possuem boa localização para a apropriação, pois são remanescentes de loteamentos e não têm visibilidade pela rua. Os parques que receberam equipamentos de lazer não tiveram um trabalho de acompanhamento de avaliação pós-implantação. Um ano depois de inaugurados alguns já não tinham mais os mobiliários, brinquedos e até a areia do playground, levados pela população. $^{7}$

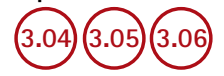

$\mathrm{Na}$ Zona Leste, a distribuição de espaços livres equipados para o lazer de massa possui as seguintes características:

- o Parque Ecológico do Tietê tem área extensa e de difícil acesso. As barreiras físicas somam-se à falta de informação, sinalização e atrativos para a apropriação social. Este parque é a prova de que o índice de área verde por habitante pode ser um número sem significado para o cotidiano das pessoas;

- o Parque do Carmo, em Itaquera, apresenta grande porte, sendo muito frequentado;

- em outros bairros da região, há parques de pequeno e médio porte, contudo grandes trechos da Zona Leste não contam com equipamentos de lazer de massa;

- os parques com melhor infraestrutura - o Parque Estadual do Belém e o Parque Municipal Piqueri - são bastante próximos, junto dos bairros com a melhor renda da região;
7 Nagano documentou a criação dos parques lineares entre 2006 e 2015 , estudando os casos dos parques Canivete, Guaratiba e Itaim Paulista.

NAGANO, Wellington T. Parque Linear Itaim como Espaço Livre Público. 2017. 93

f. Memorial de Qualificação (Mestrado em Arquitetura e Urbanismo) - Faculdade de Arquitetura e Urbanismo, Universidade de São Paulo. São Paulo, 2017. 

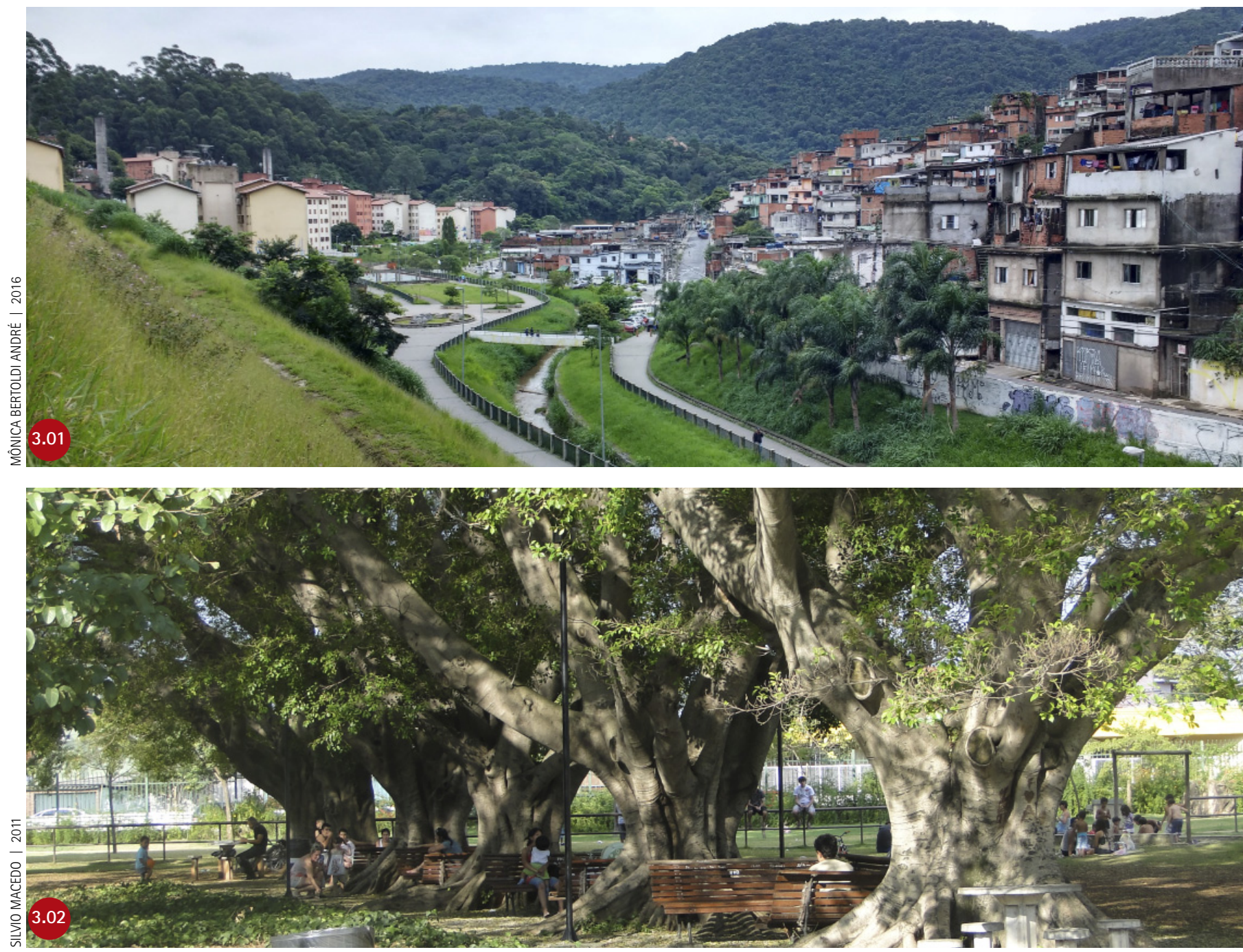

Parques na Zona Norte. Acima, Parque Linear Canivete (2010), na franja da cidade. Meio e à direita, Parque Vila Guilherme - Trote, próximo à Marginal Tietê. Estes são dois parques vizinhos, de 1988 e 2007, respectivamente, que a população reconhece como sendo um único.

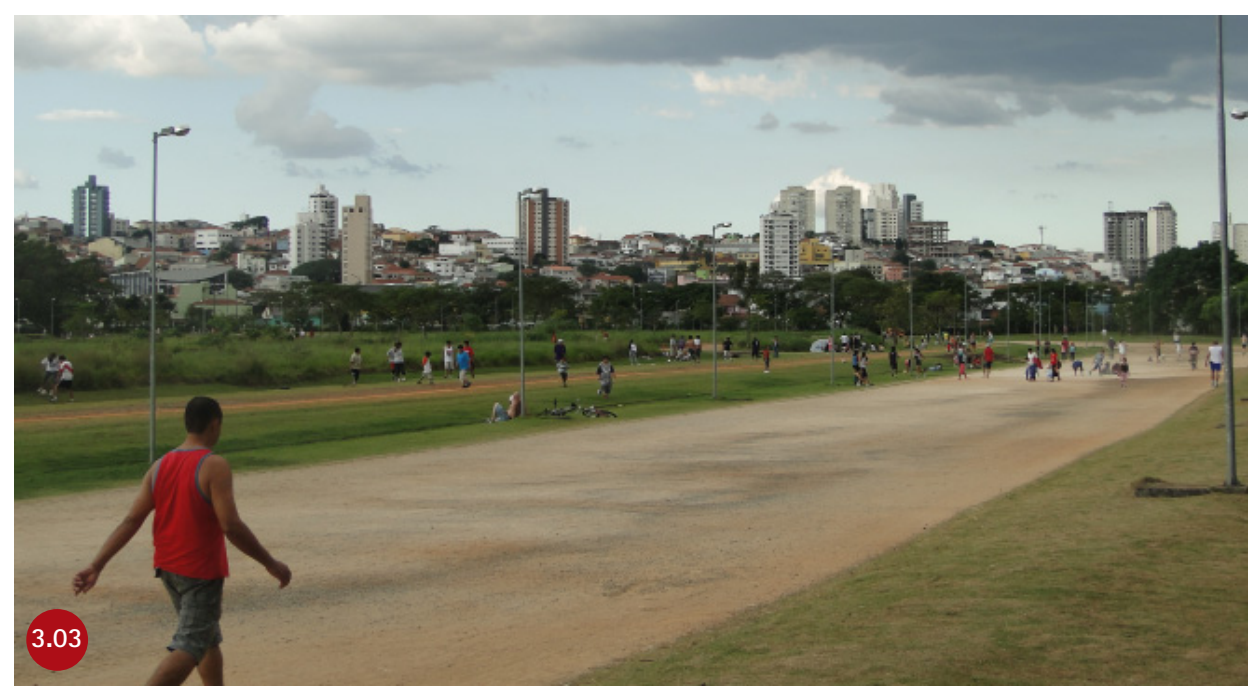



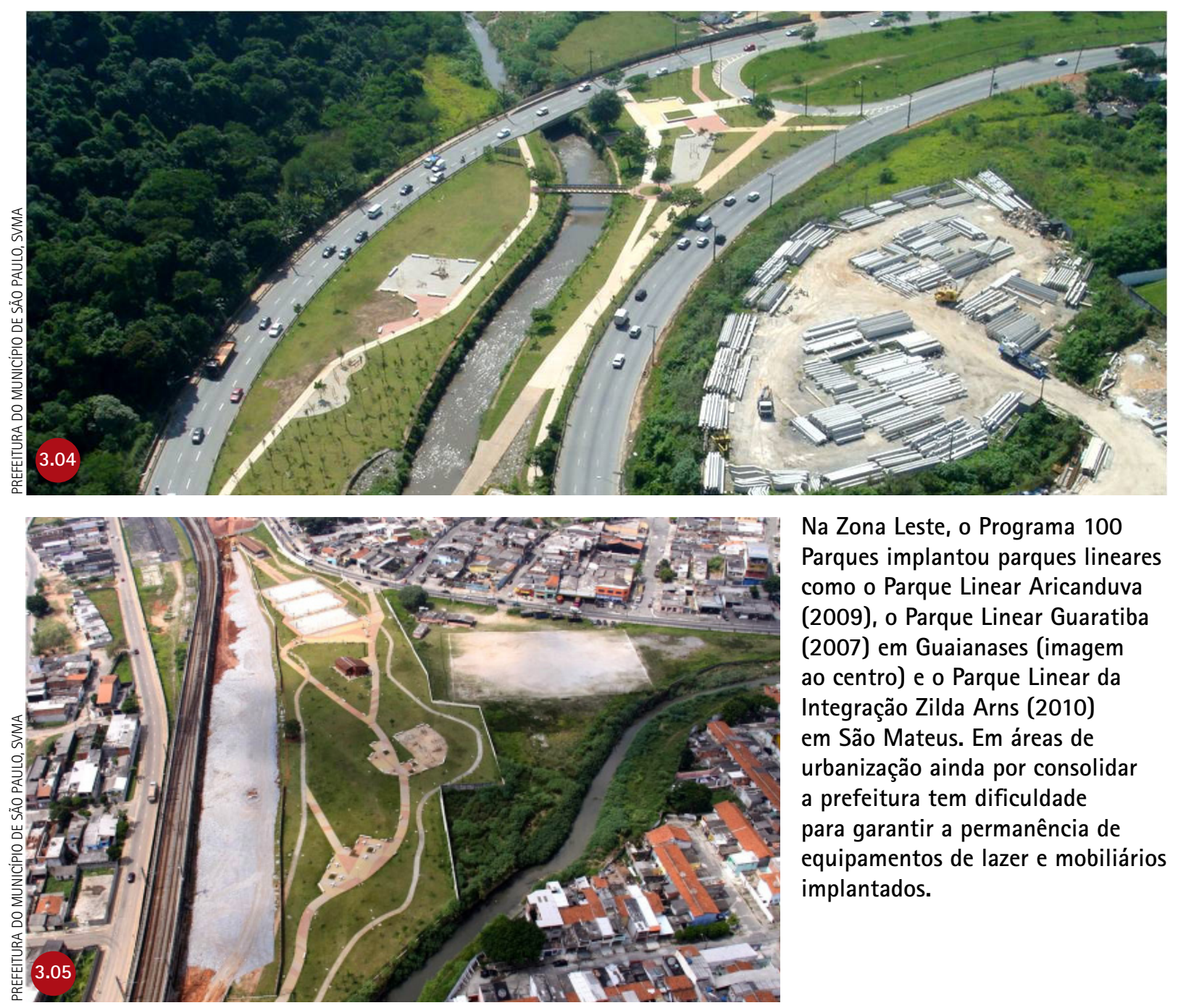

Na Zona Leste, o Programa 100 Parques implantou parques lineares como o Parque Linear Aricanduva (2009), o Parque Linear Guaratiba (2007) em Guaianases (imagem ao centro) e o Parque Linear da Integração Zilda Arns (2010) em São Mateus. Em áreas de urbanização ainda por consolidar a prefeitura tem dificuldade para garantir a permanência de equipamentos de lazer e mobiliários implantados.

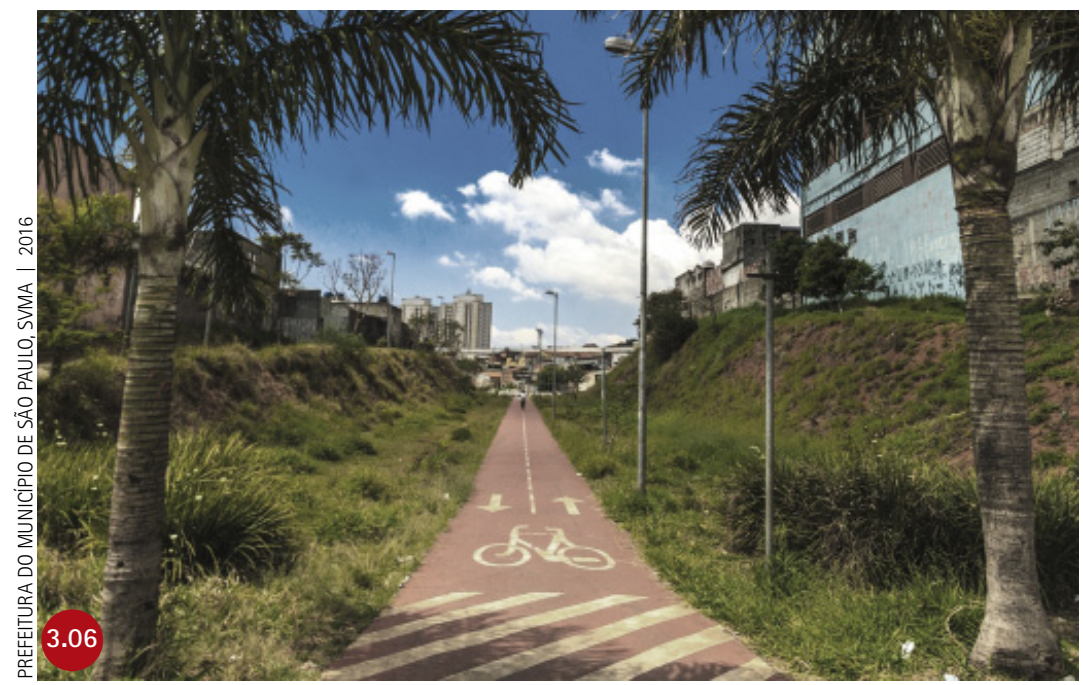



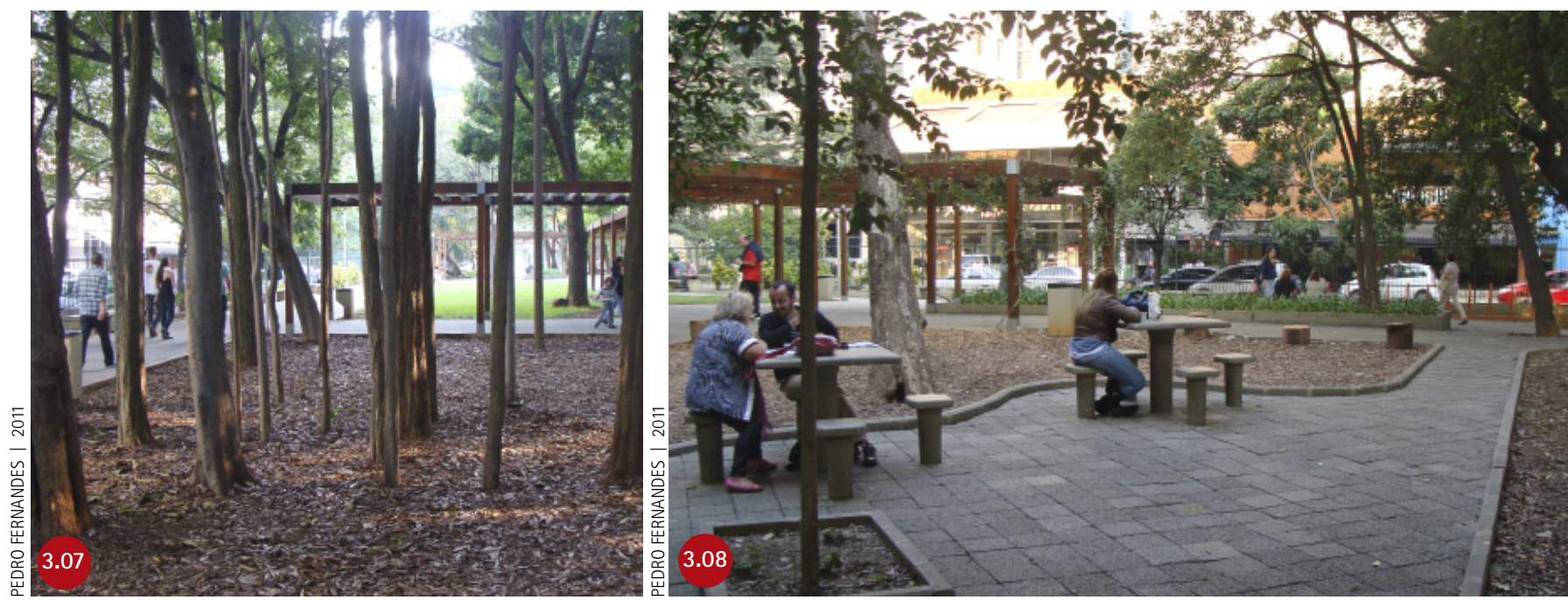

Na Zona Centro-Oeste, dois parques muito centrais e muito pequenos. Acima, Parque Mario Covas (2010), na Avenida Paulista, com $5.396 \mathrm{~m}^{2}$, segue o corolário da sustentabilidade que vigorava entre os técnicos da prefeitura na ocasião: vegetação preservada, pisos permeáveis, mobiliário de fácil manutenção. À direita, o Parque Zilda Natel (2009), no Sumaré, tem $2.426 \mathrm{~m}^{2}$ e tem programa de atividades focado principalmente no skate.
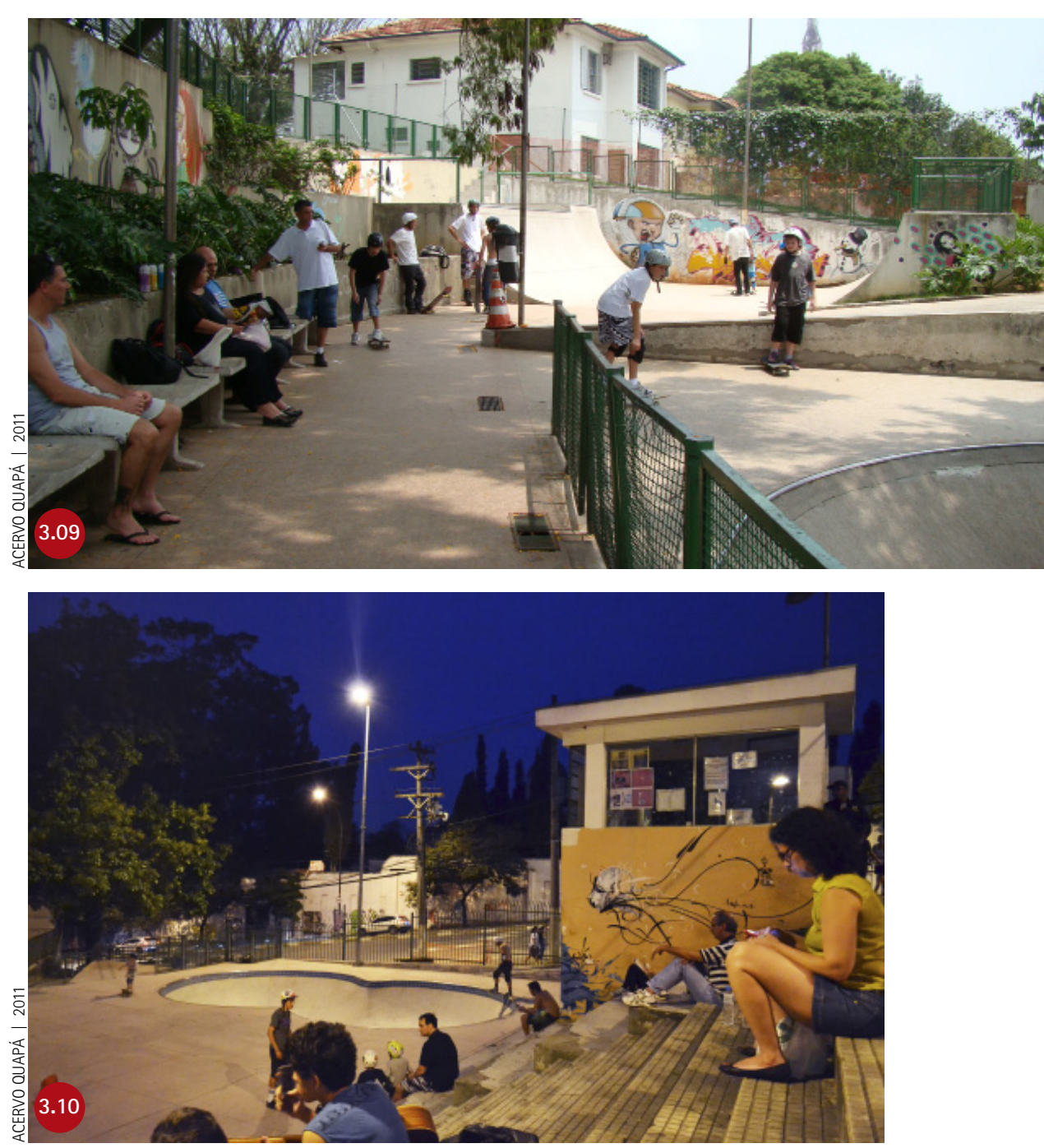
CAPÍTULO 3. DISTRIBUIÇÃO PELO ESPAÇO URBANO

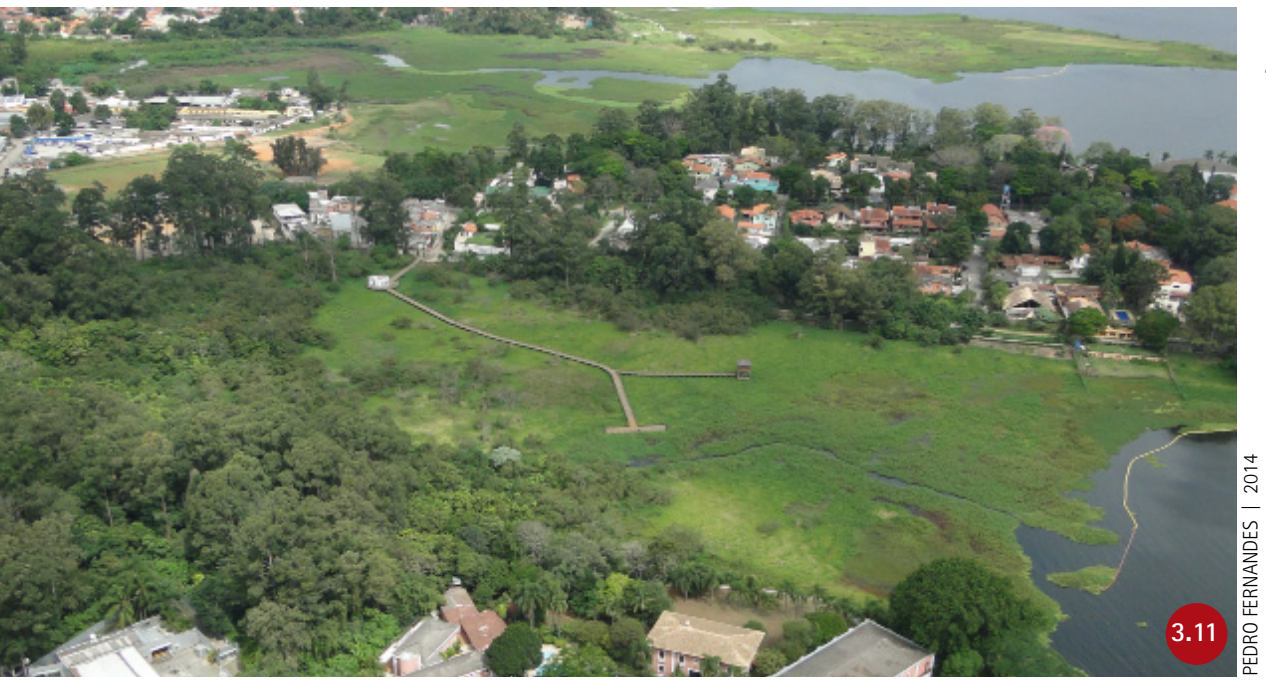

Parque Linear Castelo, Parque Jacques Cousteau (2009) e Parque

Praia de São Paulo (2009). Os parques na Zona Sul, às margens da Guarapiranga, recebem frequentadores do entorno próximo mas são desconhecidos pelo restante da população.
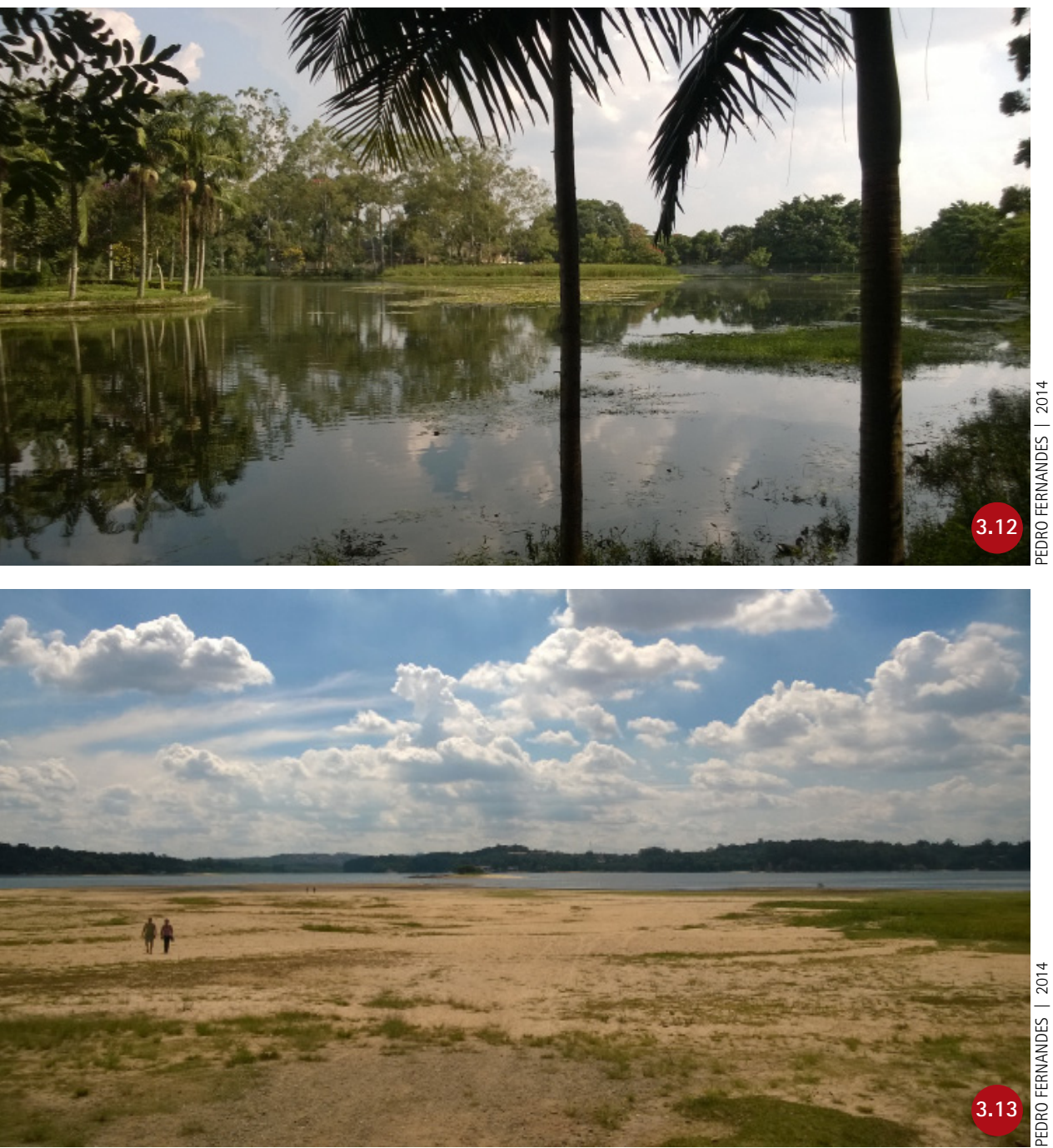
- Na falta de áreas disponíveis para implantação de parques, uma solução alternativa às custosas desapropriações, são os parques lineares e as ciclovias. Na região foram feitos o Parque Linear do Córrego Tiquatira e a ciclovia sob o viaduto ao longo da Avenida Salim Farah Maluf. Estes equipamentos são estreitos e extensos, fazendo vizinhança com muitas quadras e atendendo grande número de pessoas, com custo baixo de implantação se comparado ao de desapropriar uma grande área.

Neste contexto, a criação de parques pelo Programa 100 parques nos terrenos que existiam foi positiva, mesmo a municipalidade ainda não tendo condições de tratá-los a contento. Foi louvável o fato de o Programa (que não visou ao atendimento das áreas centrais) realizar a distribuição dos parques na periferia. Os novos parques espalharam-se em áreas tradicionalmente pouco atendidas, ocupando espaços com remanescentes de bosques ou rios degradados. Entretanto, a distribuição não é homogênea.

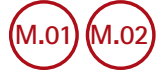

Após o Programa 100 parques, houve um esforço para a implantação de ciclovias por toda a cidade. Algumas foram mais bem localizadas, tornando-se mais úteis; outras, improvisadas e perigosas. Um único parque foi aberto entre 2012 e 2016, o Parque Chácara do Jockey, na Zona Oeste.

8 Parques estaduais na cidade de São Paulo anteriores a 2000: Água Branca, Alberto Löfgren (Horto Florestal), Ecológico do Guarapiranga, Ecológico do Tietê, Jardim Botânico e Fontes do Ipiranga. Após 2000: Belém e Cândido Portinari (junto do Villa-Lobos). Não foi contado o Parque Pomar Urbano, na Marginal do Rio Pinheiros, por não ser propriamente um parque, mas uma área de recuperação ambiental e paisagística às margens do canal do Rio Pinheiros. Na RMSP existem ainda sob gestão do Estado os parques: Várzea do Embu-Guaçu (2013), Professor Aziz Ab'Saber (2016); Chácara Baronesa (2013), em Santo André; Gabriel Chucre (2012), em Carapicuiba; Jequitibá, ou Tizo (com as obras paralisadas). Entrevista com Ana Lucia de Faria Burjato, assessoria técnica da Coordenadoria de Parques Urbanos da Secretaria do Estado de Meio Ambiente.
0 conjunto de parques sob a gestão do Estado $^{8}$ compreende equipamentos de maior porte e abrangência de atendimento maior em relação aos geridos pelo município. São bastante frequentados os parques: Villa-Lobos/Cândido Portinari (500 mil visitantes/mês); Água Branca (250 mil visitantes/mês); Juventude (150 mil visitantes/mês); Alberto löfgren (110 mil visitantes/mês), e mesmo o Ecológico do Guarapiranga (25.600 visitantes/mês), considerando a região em que se localiza. Os parques do Belém (45 mil visitantes) mês) e o Ecológico do Tietê têm capacidade para mais frequentadores, mas provavelmente devido à dificuldade de acesso, apresentam baixa frequência. Os parques municipais, com exceção do lbirapuera e o do Carmo, apresentam abrangência de público mais de vizinhança, havendo alguns com dimensões e inserção urbana mais similares às de praças. 


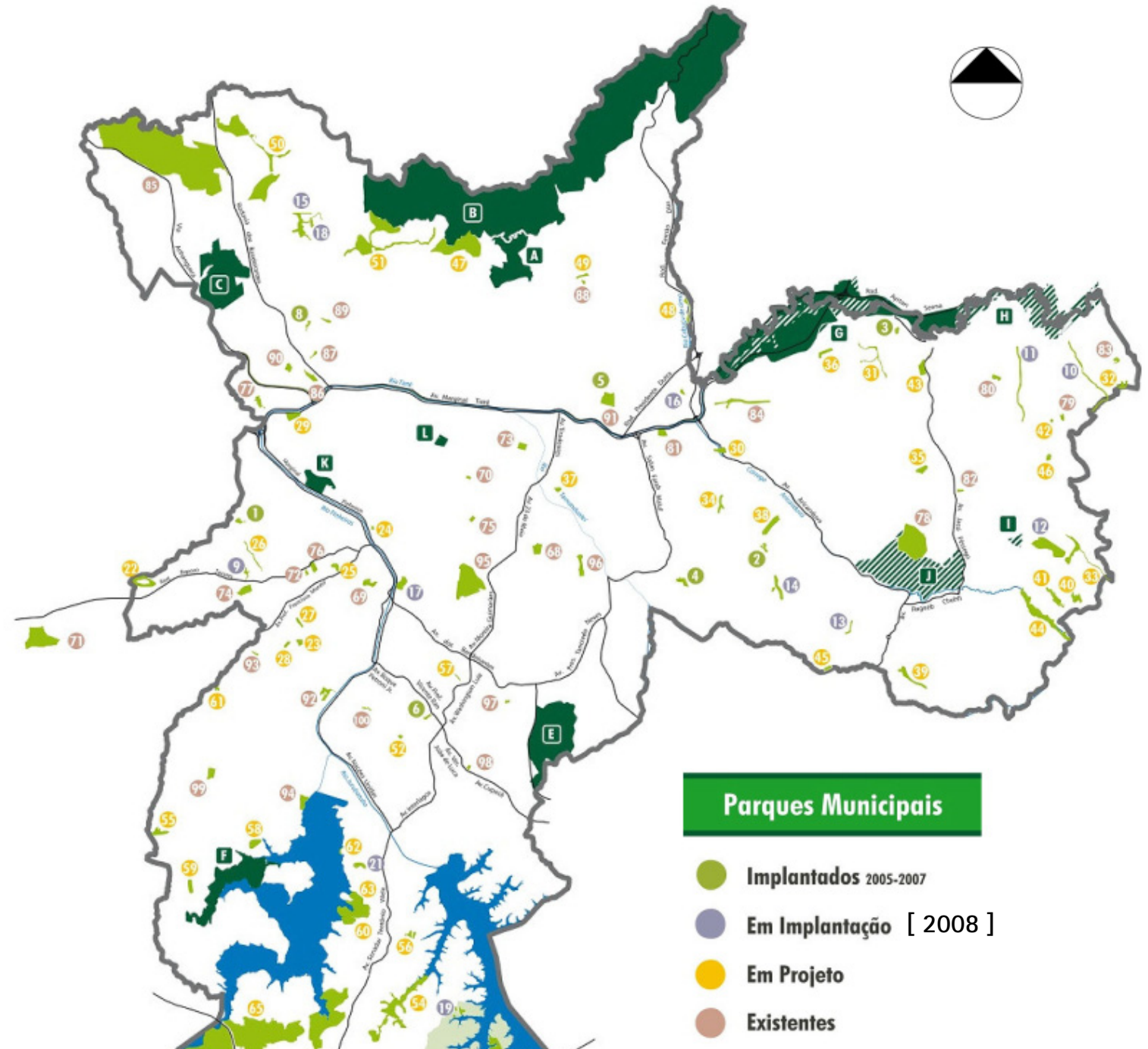

Programa 100 parques para São Paulo - Cartaz de divulgação da SVMA, 2008. Em verde escuro, os parques estaduais.

Este mapa sugere ampla cobertura do território municipal por parques. Luciana Satiko elaborou um modelo (página oposta) com o raio de atendimento esperado para cada parque $e_{\text {, mesmo se fossem }}$ incluídos os parques estaduais (em roxo), observa-se que há vastos trechos da malha urbana desatendidos. Este modelo, assim como os índices de $\mathrm{m}^{2}$ por habitante, têm limitações. Fatores como qualidade do parque, a existência de outros espaços livres e equipamentos de lazer, manutenção, seguraça, facilidade de acesso e eventos de animação fazem muita diferença. 


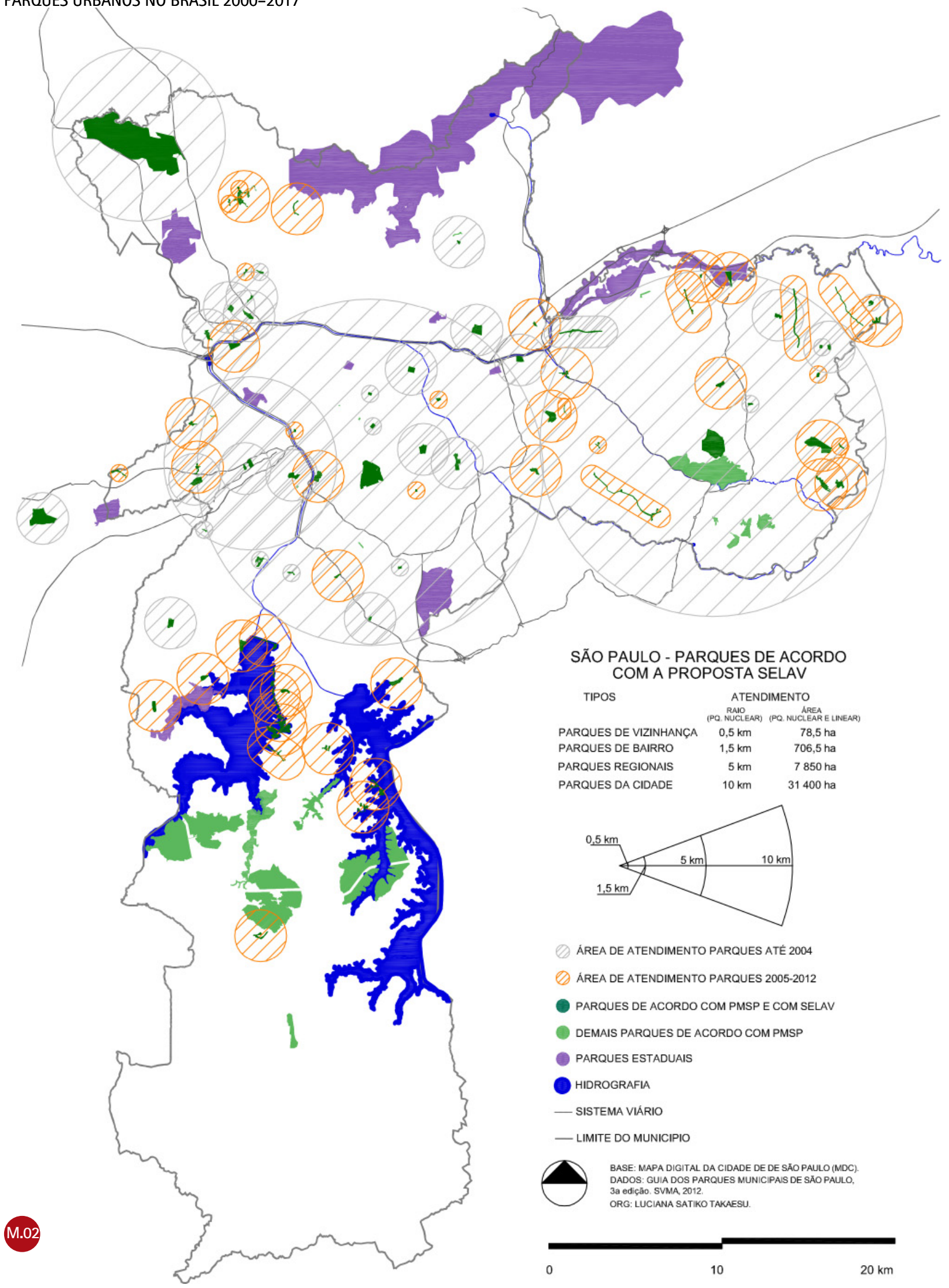




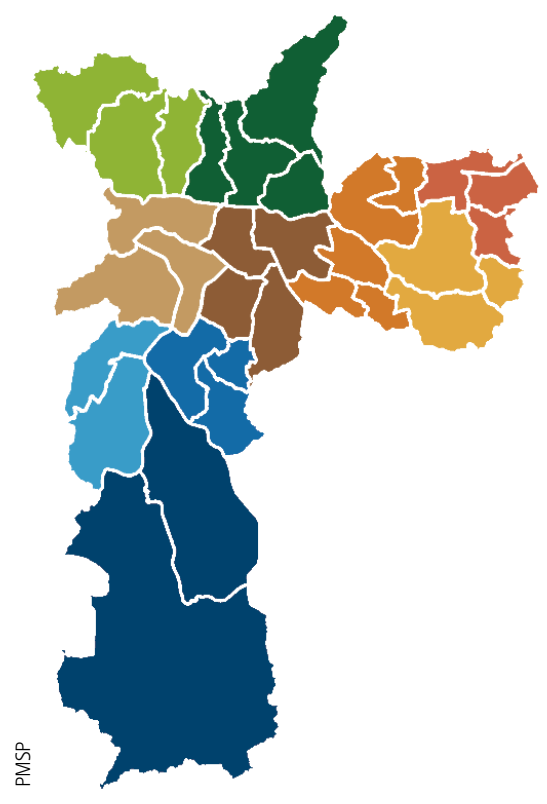

São Paulo, Zoneamento. Cada secretaria municipal adota sua própria divisão do município. Na tabela a seguir, usamos o zoneamento em Departamentos de Gestão Descentralizada (DGD), adotado em 2017 pela SVMA, que faz sentido para avaliar como as partes da cidade são servidas por parques. Curiosamente, alguns parques da Zona Leste se localizam na divisão Zona Centro-Oeste 2.

Norte 1

Norte 2

Centro-0este 1

Centro-0este 2

Leste 1

Leste 2

Leste 3

Sul 1

Sul 2

Sul 3

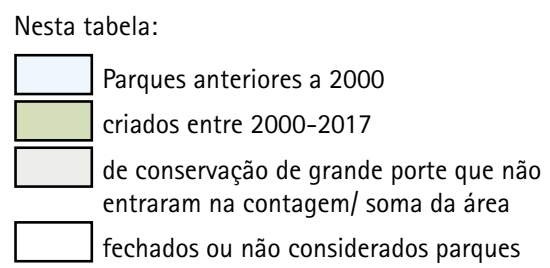

\begin{tabular}{|c|c|c|c|c|c|}
\hline \multicolumn{6}{|l|}{ SÃO PAULO } \\
\hline PARQUE & BAIRRO / SUBPREF. & ÁREA $\left(\mathrm{m}^{2}\right)$ & CRIAÇÃO & INAUG. & OBS. \\
\hline \multicolumn{6}{|c|}{ NORTE 1 (PERUS, PIRITIBA-JARAGUÁ, FREGUESIA-BRASILÂNDIA) } \\
\hline ESTADUAL DO JARAGUÁ & Pirituba/ Jaraguá & 4.926 .800 & & 1961 & CONSERVAÇÃO \\
\hline ANHANGUERA & Perus & 9.622 .280 & & 1979 & CONSERVAÇÃO \\
\hline SÃO DOMINGOS & Pirituba/ Jaraguá & 79.100 & & 1979 & \\
\hline PIRITUBA - RODRIGO DE GÁSPERI & Pirituba/ Jaraguá & 36.000 & & 1982 & \\
\hline JARDIM FELICIDADE & Pirituba/ Jaraguá & 26.200 & & 1990 & \\
\hline CIDADE DE TORONTO & Pirituba/ Jaraguá & 126.200 & & 1992 & \\
\hline JACINTHO ALBERTO & Pirituba/ Jaraguá & 37.600 & 2003 & 2007 & \\
\hline LINEAR DO FOGO & Pirituba/ Jaraguá & 39.365 & & 2008 & \\
\hline PINHEIRINHO D'ÁGUA & Pirituba/ Jaraguá & 250.306 & 2006 & 2009 & \\
\hline LINEAR CANIVETE & $\begin{array}{l}\text { Jd. Damasceno / Brasilândia } \\
\text { - Freguesia do Ó }\end{array}$ & 46.000 & 2009 & 2010 & \\
\hline SENHOR DO VALE & Pirituba/ Jaraguá & 22.800 & 2010 & 2011 & \\
\hline \multicolumn{6}{|c|}{ NORTE 2 (JAÇANÃ-TREMEMBÉ, SANTANA-TUCURUVI, CASA VERDE-CACHOEIRINHA, V. MARIA-V. GUILHERME) } \\
\hline ESTADUAL DA CANTAREIRA & Horto Florestal & 79.160 .000 & & 1962 & $\begin{array}{l}\text { CONSERVAÇÃO. } \\
\text { NÃO TEM } \\
\text { NÚCLEOS DE } \\
\text { VISITAÇÃOO. }\end{array}$ \\
\hline $\begin{array}{l}\text { ESTADUAL ALBERTO LOEFGREEN - HORTO } \\
\text { FLORESTAL }\end{array}$ & Horto Florestal & 1.870 .000 & & 1986 & ESTADUAL \\
\hline LIONS CLUBE TUCURUVI & Tucuruvi & 21.000 & 1982 & 1987 & \\
\hline VILA GUILHERME & Vila Maria / Vila Guilherme & 26.000 & & 1988 & \\
\hline DA JUVENTUDE & Santana & 240.000 & & 2003 & ESTADUAL \\
\hline TROTE & Vila Maria / Vila Guilherme & 134.000 & 2005 & 2007 & \\
\hline SENA & Jaçanã / Tremembé & 27.960 & 2003 & 2009 & \\
\hline
\end{tabular}




\begin{tabular}{|c|c|c|c|c|c|}
\hline PARQUE & BAIRRO / SUBPREF. & ÁREA $\left(\mathrm{m}^{2}\right)$ & CRIAÇÃO & INAUG. & OBS. \\
\hline TENENTE BRIGADEIRO FARIA LIMA & $\begin{array}{l}\text { Pq. Novo Mundo / V. Maria - } \\
\text { Guilherme }\end{array}$ & 50.259 & 2006 & 2009 & \\
\hline \multicolumn{6}{|l|}{ LESTE 1 (ITAQUERA, SÃO MATEUS, CIDADE TIRADENTES) } \\
\hline DO CARMO - OLAVO EGYDIO SETÚBAL & Itaquera & 1.500 .000 & & 1976 & \\
\hline RAUL SEIXAS & Itaquera & 33.500 & & 1989 & \\
\hline SANTA AMÉLIA & Jd. das Oliveiras / Itaquera & 29.653 & & 1991 & \\
\hline JARDIM SAPOPEMBA - NILO COELHO & São Mateus & 44.303 & & 2009 & \\
\hline NATURAL MUNICIPAL FAZENDA DO CARMO & Parque do Carmo & 4.498 .086 & 2009 & & FECHADO \\
\hline VILA DO RODEIO & $\begin{array}{l}\text { Inácio Monteiro / Cidade } \\
\text { Tiradentes }\end{array}$ & 622.113 & 2004 & 2009 & \\
\hline LINEAR CONSCIÊNCIA NEGRA & Cidade Tiradentes & 123.609 & 2008 & 2009 & \\
\hline LINEAR DA INTEGRAÇÃO ZILDA ARNS & São Mateus & 237.238 & 2008 & 2010 & \\
\hline DA CIÊNCIA & Cidade Tiradentes & 178.657 & 2008 & 2011 & \\
\hline LINEAR RIO VERDE & Itaquera & 56.013 & & 2012 & \\
\hline ATERRO DO SAPOPEMBA & São Rafael / São Mateus & 304.477 & 2009 & 2012 & \\
\hline NEBULOSAS & São Mateus & 44.930 & 2010 & 2013 & \\
\hline JARDIM DA CONQUISTA & $\begin{array}{l}\text { Jd. da Conquista / São } \\
\text { Mateus }\end{array}$ & 208.000 & 2011 & 2013 & \\
\hline LINEAR GUABIROBEIRA MOMBAÇA & Jd. Nova Vitória/ São Mateus & 264.700 & 2011 & 2013 & \\
\hline \multicolumn{6}{|c|}{ LESTE 2 (ERMELINO MATARAZZO, PENHA, ARICANDUVA-FORMOSA-CARRÃO, VILA PRUDENTE, SAPOPEMBA) } \\
\hline $\begin{array}{l}\text { CERET - CENTRO ESPORTIVO, RECREATIVO E } \\
\text { EDUCATIVO DO TRABALHADOR } \\
\text { (Antigo PET - Parque Estadual dos Trabalhadores) }\end{array}$ & Vila Formosa / Aricanduva & 286.000 & & 1973 & $\begin{array}{l}\text { PASSOU } \\
\text { EM } 2008 \\
\text { PARA SECR. } \\
\text { ESPORTES }\end{array}$ \\
\hline ECOLÓGICO DO TIETÊ & Cangaiba / Penha & 14.000 .000 & & 1982 & ESTADO \\
\hline $\begin{array}{l}\text { LINEAR TIQUATIRA ENG. WERNER EUGÊNIO } \\
\text { ZULAUF }\end{array}$ & Penha & 194.500 & 1987 & & \\
\hline $\begin{array}{l}\text { ERMELINO MATARAZZO - DOM PAULO EVARISTO } \\
\text { ARNS }\end{array}$ & $\begin{array}{l}\text { Jardim Belém / Ermelino } \\
\text { Matarazzo }\end{array}$ & $5.565,00$ & 2005 & 2005 & \\
\hline LINEAR IPIRANGUINHA & Ipiranguinha / Aricanduva & 19.360 & & 2007 & $\begin{array}{l}\text { SIMILAR À } \\
\text { PRAÇA }\end{array}$ \\
\hline LINEAR RAPADURA & Aricanduva / Vila Formosa & 18.600 & 2007 & 2008 & \\
\hline $\begin{array}{l}\text { VILA PRUDENTE - ECOLÓGICO PROF. LYDIA } \\
\text { NATALIZIO DIOGO }\end{array}$ & Vila Prudente & 80.488 & 2007 & 2008 & \\
\hline LINEAR ARICANDUVA - VIADUTO BADRA & Av. Aricanduva & 65.274 & 2008 & 2009 & \\
\hline VILA SILVIA - CANGAÍBA & Penha & 5.040 & 2008 & 2009 & \\
\hline LINEAR MONGAGUÁ FRANCISCO MENEGOLO & Ermelino Matarazzo & 52.825 & 2007 & 2011 & \\
\hline LINEAR RIBEIRÃO ORATÓRIO & Vila Prudente / Sapopemba & 30.979 & 2008 & 2013 & \\
\hline SABESP CANGAÍBA & Cangaiba & 12.300 & & 2015 & SABESP \\
\hline \multicolumn{6}{|l|}{ LESTE 3 (SÃO MIGUEL, ITAIM PAULISTA, GUAIANASES) } \\
\hline ECOLÓGICO CHICO MENDES & $\begin{array}{l}\text { Vila Curuçá Velho / Itaim } \\
\text { Paulista }\end{array}$ & 61.600 & & 1989 & \\
\hline CHÁCARA DAS FLORES & Itaim Paulista & 41.737 & 1996 & 2002 & \\
\hline LINEAR ITAIM & Itaim Paulista & 68.154 & 2006 & 2008 & \\
\hline $\begin{array}{l}\text { VILA JACUÍ UNIDADE DE LAZER ENGENHEIRO } \\
\text { ANTONIO ARNALDO DE QUEIROZ E SILVA } \\
\text { (LINEAR) }\end{array}$ & $\begin{array}{l}\text { União de Vila Nova / São } \\
\text { Miguel }\end{array}$ & 171.000 & 2007 & 2008 & \\
\hline LINEAR GUARATIBA & Guaianases & 22.199 & 2007 & 2009 & \\
\hline
\end{tabular}


CAPÍTULO 3. DISTRIBUIÇÃO PELO ESPAÇO URBANO

\begin{tabular}{|c|c|c|c|c|c|}
\hline PARQUE & BAIRRO / SUBPREF. & ÁREA $\left(\mathrm{m}^{2}\right)$ & CRIAÇÃO & INAUG. & OBS. \\
\hline LINEAR ÁGUA VERMELHA & Jd. Miragaia / Itaim Paulista & 116.180 & $\begin{array}{l}2001 / \\
2004\end{array}$ & 2009 & \\
\hline $\begin{array}{l}\text { LAJEADO - IZAURA PEREIRA DE SOUZA } \\
\text { FRANZOLIN }\end{array}$ & Lajeado / Guaianases & 14.206 & 2008 & 2010 & \\
\hline QUISSISSANA & Itaim Paulista & 26.921 & 2008 & & É FECHADO. \\
\hline $\begin{array}{l}\text { LINEAR VILA JACUÍ - UNIDADE DE LAZER ENG. } \\
\text { ANTÔNIO ARNALDO DE QUEIROZ SILVA }\end{array}$ & São Miguel & 137.579 & 2009 & 2010 & $\begin{array}{l}\text { ADM. PELO } \\
\text { DAEE (ESTADO) }\end{array}$ \\
\hline DAS ÁGUAS & $\begin{array}{l}\text { Cidade Kemel / Itaim } \\
\text { Paulista }\end{array}$ & 74.013 & 2007 & 2011 & \\
\hline MUNICIPAL JARDIM PRIMAVERA & São Miguel & 230.000 & 2002 & 2012 & $\begin{array}{l}\text { ANTIGO } \\
\text { ATERRO. } \\
\text { IMPLANTADO. } \\
\text { EM } 2008 \text { ESTÁ } \\
\text { FECHADO. }\end{array}$ \\
\hline ECOLÓGICO CENTRAL DO ITAIM & Itaim Paulista & 23.129 & 2011 & 2012 & \\
\hline \multicolumn{6}{|c|}{ CENTRO OESTE 2 (SÉ, MÓOCA, IPIRANGA, VILA MARIANA) } \\
\hline JARDIM DA LUZ & Luz/ Sé & 113.400 & & 1825 & \\
\hline TRIANON - TENENTE SIQUEIRA CAMPOS* & Cerqueira César & 48.600 & & 1892 & $\begin{array}{l}\text { SUBPREF. } \\
\text { PINHEIROS }\end{array}$ \\
\hline ACLIMAÇÃO & Aclimação/ Sé & 126.535 & & 1892 & \\
\hline INDEPENDÊNCIA & Ipiranga & 161.300 & & 1909 & \\
\hline BUENOS AIRES & Higienópolis/ Sé & 25.000 & & 1916 & \\
\hline IBIRAPUERA & Vila Mariana & 1.584 .000 & & 1954 & \\
\hline $\begin{array}{l}\text { ESTADUAL DAS FONTES DO IPIRANGA (PARQUE } \\
\text { DO ESTADO) }\end{array}$ & Ipiranga & 5.260 .000 & & 1969 & $\begin{array}{l}\text { INCLUI ZOO, } \\
\text { JD. BOTÂNICO }\end{array}$ \\
\hline PIQUERI & Tatuapé & 97.200 & & 1978 & \\
\hline TATUAPÉ (PRAÇA LIONS CLUBE PENHA) & Mooca & 17.769 & & $\begin{array}{l}\text { Anos } \\
1980\end{array}$ & $\begin{array}{l}\text { ANTES: PRAÇA. } \\
\text { VIROU PARQUE } \\
\text { EM } 2014\end{array}$ \\
\hline PREFEITO MÁRIO COVAS & Bela Vista & 5.396 & 2008 & 2010 & \\
\hline BENEMÉRITO JOSÉ BRAZ & Brás & 26.568 & 2008 & 2011 & \\
\hline ESTADUAL DO BELÉM - MANOEL PITTA & Belém & 210.400 & & 2012 & ESTADUAL \\
\hline CASA MODERNISTA & Vila Mariana & 12.607 & 2010 & 2012 & \\
\hline SABESP RADIALISTA FIORI GIGLIOTTI & Mooca & 21.200 & & 2014 & SABESP \\
\hline \multicolumn{6}{|l|}{ CENTRO OESTE 1 (PINHEIROS, LAPA, BUTANTÃ) } \\
\hline DA ÁGUA BRANCA & Perdizes & 136.765 & & 1929 & ESTADUAL. \\
\hline $\begin{array}{l}\text { PÔR DO SOL (PRAÇA CORONEL CUSTÓDIO } \\
\text { FERNANDES PINHEIROS) }\end{array}$ & Alto de Pinheiros & 31.343 & & $1968-$ & $\begin{array}{l}\text { PRAÇA ATÉ } \\
2015\end{array}$ \\
\hline ALFREDO VOLPI & Morumbi & 142.400 & & 1971 & \\
\hline VILA DOS REMÉDIOS & Vila Jaguara & 103.382 & 1978 & 1979 & \\
\hline PREVIDÊNCIA & Butantã & 91.500 & & 1979 & \\
\hline RAPOSO TAVARES & Butantã & 195.000 & & 1980 & \\
\hline LUIZ CARLOS PRESTES & Butantã & 27.100 & & 1988 & \\
\hline VILLA-LOBOS & Alto de Pinheiros & 732.000 & & 1994 & ESTADUAL. \\
\hline COLINA DE SÃO FRANCISCO & Vila São Francisco & 49.063 & 2002 & 2007 & \\
\hline POVO - MÁRIO PIMENTA CAMARGO & Pinheiros & 133.547 & 2006 & 2008 & \\
\hline LINEAR SAPÉ & Rio Pequeno & 26.240 & 2006 & 2009 & \\
\hline
\end{tabular}




\begin{tabular}{|c|c|c|c|c|c|}
\hline PARQUE & BAIRRO / SUBPREF. & ÁREA $\left(m^{2}\right)$ & CRIAÇÃO & INAUG. & OBS. \\
\hline VICTOR CIVITA & Pinheiros & 13.600 & 2007 & 2008 & \\
\hline ZILDA NATEL & Sumaré & 2.426 & 2008 & 2009 & \\
\hline $\begin{array}{l}\text { JULIANA DE CARVALHO TORRES (COHAB RAPOSO } \\
\text { TAVARES) }\end{array}$ & Butantã & 16.476 & 2008 & 2010 & $\begin{array}{l}\text { CALÇADA EM } \\
\text { TORNO DE } \\
\text { ÁREA VERDE }\end{array}$ \\
\hline LINEAR DAS CORUJAS & Sumarezinho & 2.000 .000 & 2008 & 2010 & \\
\hline CÂNDIDO PORTINARI & Alto de Pinheiros & 121.670 & & 2013 & $\begin{array}{l}\text { ESTADUAL. } \\
\text { EXTENSÃO DO } \\
\text { VILLA-LOBOS }\end{array}$ \\
\hline JARDIM DAS PERDIZES & Água Branca & 40.000 & & 2013 & \\
\hline CHÁCARA DO JOCKEY & Butantã & 143.531 & & 2016 & \\
\hline JEQUITIBÁ (TIZO) & $\begin{array}{l}\text { São Paulo, divisa com Cotia, } \\
\text { Osasco, Taboão }\end{array}$ & 1.308 .319 & 2006 & - & $\begin{array}{l}\text { ESTADUAL. } \\
\text { FECHADO. }\end{array}$ \\
\hline $\begin{array}{l}\text { ECOLÓGICO DE CAMPO CERRADO DR. ALFRED } \\
\text { USTERI }\end{array}$ & Butantã & 13.090 & 2008 & - & FECHADO \\
\hline LEOPOLDINA ORLANDO VILLAS-BÔAS & Vila Leopoldina & 55.000 & & 2010 & $\begin{array}{l}\text { FECHADO. } \\
\text { PARTE ANEXA } \\
\text { É DA SABESP. }\end{array}$ \\
\hline \multicolumn{6}{|l|}{ SUL 1 (CAMPO LIMPO, M'BOI MIRIM) } \\
\hline SANTO DIAS & Campo Limpo & 157.800 & & 1991 & \\
\hline BURLE MARX & Morumbi & 189.000 & & 1995 & $\begin{array}{l}\text { GESTÃO } \\
\text { PRIVADA }\end{array}$ \\
\hline EUCALIPTOS & Morumbi & 17.500 & 1995 & 1995 & \\
\hline LINEAR FEITIÇO DA VILA - MOENDA VELHA & Capão Redondo & 38.124 & 2007 & 2015 & \\
\hline \multicolumn{6}{|l|}{ SUL 2 (JABAQUARA, SANTO AMARO, CIDADE ADEMAR) } \\
\hline NABUCO & Jabaquara & 31.000 & & 1979 & \\
\hline CONCEIÇÃO - LINA E PAULO RAIA & Vila Guarani & 15.621 & 1980 & 1980 & \\
\hline SEVERO GOMES / GRANJA JULIETA & Granja Julieta & 34.900 & & 1989 & \\
\hline CORDEIRO MARTIN LUTHER KING & Chácara Monte Alegre & 34.965 & 2005 & 2007 & \\
\hline LINEAR INVERNADA & Campo Belo & 6.400 & 2007 & 2012 & \\
\hline \multicolumn{6}{|l|}{ SUL 3 (CAPELA DO SOCORRO, PARELHEIROS) } \\
\hline GUARAPIRANGA (MUNICIPAL) & M'Boi Mirim & 147.176 & & 1974 & \\
\hline SANTO DIAS & Capão Redondo & 134.000 & & 1992 & \\
\hline ECOLÓGICO DO GUARAPIRANGA & Jardim Riviera & 2.500 .000 & & 1999 & ESTADUAL \\
\hline LINEAR PARELHEIROS & Jd. Novo Parelheiros & 25.120 & 2005 & 2007 & \\
\hline M'BOI MIRIM & Jardim Ângela & 190.000 & 2008 & 2010 & \\
\hline RIBEIRÃO CAULIM & Parelheiros & 9.678 & 2010 & 2012 & \\
\hline LINEAR PARELHEIROS & Estrada da Colônia & 18.076 & 2007 & 2007 & \\
\hline SHANGRILÁ & Grajaú & 82.000 & 2003 & 2008 & \\
\hline JARDIM HERCULANO & Jd. Herculano & 76.800 & 2005 & 2009 & \\
\hline $\begin{array}{l}\text { LINEAR SÃO JOSÉ (ORLA DA REPRESA DE } \\
\text { GUARAPIRANGA) }\end{array}$ & $\begin{array}{l}\text { Vila São José / Capela do } \\
\text { Socorro }\end{array}$ & 95.183 & 2007 & 2008 & \\
\hline $\begin{array}{l}\text { LINEAR NOVE DE JULHO (ORLA DA REPRESA DE } \\
\text { GUARAPIRANGA) }\end{array}$ & Cidade Dutra & 537.514 & 2008 & 2008 & \\
\hline $\begin{array}{l}\text { CASTELO (DUTRA) (ORLA DA REPRESA DE } \\
\text { GUARAPIRANGA) }\end{array}$ & Capela do Socorro & 103.337 & & 2008 & \\
\hline JACQUES COUSTEAU & Interlagos & 67.326 & 2008 & 2009 & \\
\hline
\end{tabular}




\begin{tabular}{|c|c|c|c|c|c|}
\hline PARQUE & BAIRRO / SUBPREF. & ÁREA $\left(\mathrm{m}^{2}\right)$ & CRIAÇÃO & INAUG. & OBS. \\
\hline $\begin{array}{l}\text { PRAIA DE SÃO PAULO (ORLA DA REPRESA DE } \\
\text { GUARAPIRANGA) - NÚCLEO DO SOL }\end{array}$ & Capela do Socorro & 17.965 & & 2009 & \\
\hline GUANHEMBU & Capela do Socorro & 71.920 & 2008 & 2009 & \\
\hline MUNICIPAL M'BOI MIRIM & Jd. Ângela & 195.000 & & 2010 & \\
\hline $\begin{array}{l}\text { BARRAGEM DO GUARAPIRANGA (ORLA DA } \\
\text { REPRESA DE GUARAPIRANGA) }\end{array}$ & Jd. Guarapiranga & 88.584 & 2009 & 2010 & \\
\hline LINEAR CANTINHO DO CÉU & Grajaú & 59.566 & 2009 & 2012 & \\
\hline JARDIM PRAINHA & $\begin{array}{l}\text { Jd. Monte Verde / Capela do } \\
\text { Socorro }\end{array}$ & 93.092 & 2008 & 2012 & \\
\hline LINEAR DO RIBEIRÃO COCAIA & Grajaú & 48.947 & 2008 & 2012 & $\begin{array}{l}\text { SITE SVMA: } \\
\text { ÁREA DE } \\
1.261 .516 \mathrm{M}^{2}\end{array}$ \\
\hline RIBEIRÃO CAULIM - SÃO RAFAEL & Parelheiros & 9.687 & & 2012 & \\
\hline SETE CAMPOS & Cidade Ademar & 83.267 & 2008 & 2012 & \\
\hline NATURAL MUNICIPAL CRATERA DA COLÔNIA & Parelheiros & 526.584 & 2007 & - & FECHADO \\
\hline $\begin{array}{l}\text { LINEAR CASTELO (ORLA DA REPRESA DE } \\
\text { GUARAPIRANGA) }\end{array}$ & $\begin{array}{l}\text { Rua Zeferino Borges Barreto, } \\
260\end{array}$ & 103.337 & 2008 & & \\
\hline CEU TRÊS LAGOS & Jardim São Pedro & 34.133 & 2009 & - & $\begin{array}{l}\text { BOSQUE JUNTO } \\
\text { AO CEU, SEM } \\
\text { EQUIPAMENTOS. }\end{array}$ \\
\hline HORTO DO IPÊ & Horto do Ipê & 132.000 & 2010 & - & $\begin{array}{l}\text { ÁREA } \\
\text { ABERTA. NÃO } \\
\text { IMPLANTADO. }\end{array}$ \\
\hline NATURAL MUNICIPAL BORORÉ & Capela do Socorro & 1.932 .687 & 2012 & - & FECHADO \\
\hline NATURAL MUNICIPAL ITAIM & Parelheiros & 4.793 .841 & 2012 & - & FECHADO \\
\hline NATURAL MUNICIPAL JACEGUAVA & Parelheiros & 2.760 .000 & 2012 & - & FECHADO \\
\hline ALTOS DA BARONESA & Jardim Ângela & 24.428 & 2012 & - & FECHADO \\
\hline NATURAL MUNICIPAL VARGINHA & Grajaú & 4.211 .461 & 2012 & - & FECHADO \\
\hline
\end{tabular}

*Parque Trianon em Cerqueira Cesar, Subprefeitura Pinheiros; Parque Mário Covas a duas quadras, em Bela Vista - ambos na Av. Paulista. Aqui foram colocados juntos, na Zona Centro Oeste 2.

Quando não foi encontrada a data de inauguração, mas o parque está instalado, considerou-se a data da criação como a data da inauguração.

Tabela montada por Francine Sakata e Caroline Ribeiro, a partir de dados de 2018 de Matheus Casimiro e Ana Lucia de Faria Burjato (Secretaria de Estado do Meio Ambiente - SMA) e dos sites <http://www.prefeitura.sp.gov.br>; <http://www.saopaulo.sp.gov.br>; $<$ www.ambiente.sp.gov.br>; <www.areasverdesdascidades.com.br>; do Google Earth e do Google Street View. As informações divergem conforme a fonte e nem sempre é simples localizá-los no mapa.

Um dos parques municipais paulistanos é o Cemucam, no municipio de Cotia - por isso excluido desta listagem.

Dos Programa 100 parques, foram contados 68 parques implantados (descontadas as 2 praças que já estavam com a área demarcada e a estrutura física existente e que passaram, neste periodo, a ser geridas como parques). Os parques lineares são cerca de 25.

No total foram contados 40 parques implantados e abertos à visitação antes de 2000 e 76 entre 2000-2017 (inclusos Anhanguera, Cantareira e Jaraguá e as 2 praças que já estavam implantadas e que passaram a ser geridas como parques), somando 116 parques implantados.

Destes 116, são 9 estaduais (Parque do Estado que inclui o Zoo e o Jardim Botânico, Horto, Água Branca, Ecológico do Tietê, Ecológico do Guarapiranga, Villa-Lobos, Candido Portinari, Belém, Juventude). Os quatro últimos são posteriores ao ano 2000. municipais são 107.

Em relação às áreas dos parques urbanos (consideramos por terem áreas abertas, por exemplo, Horto Florestal, Ecológico do Tietê e Parque do Estado e parte do Parque Anhanguera (400.000m²) mas desconsideramos Cantareira e Jaraguá e os parques fechados). 


\section{M.04 SÃO PAULO | ZONA NORTE}

Parques na malha urbana

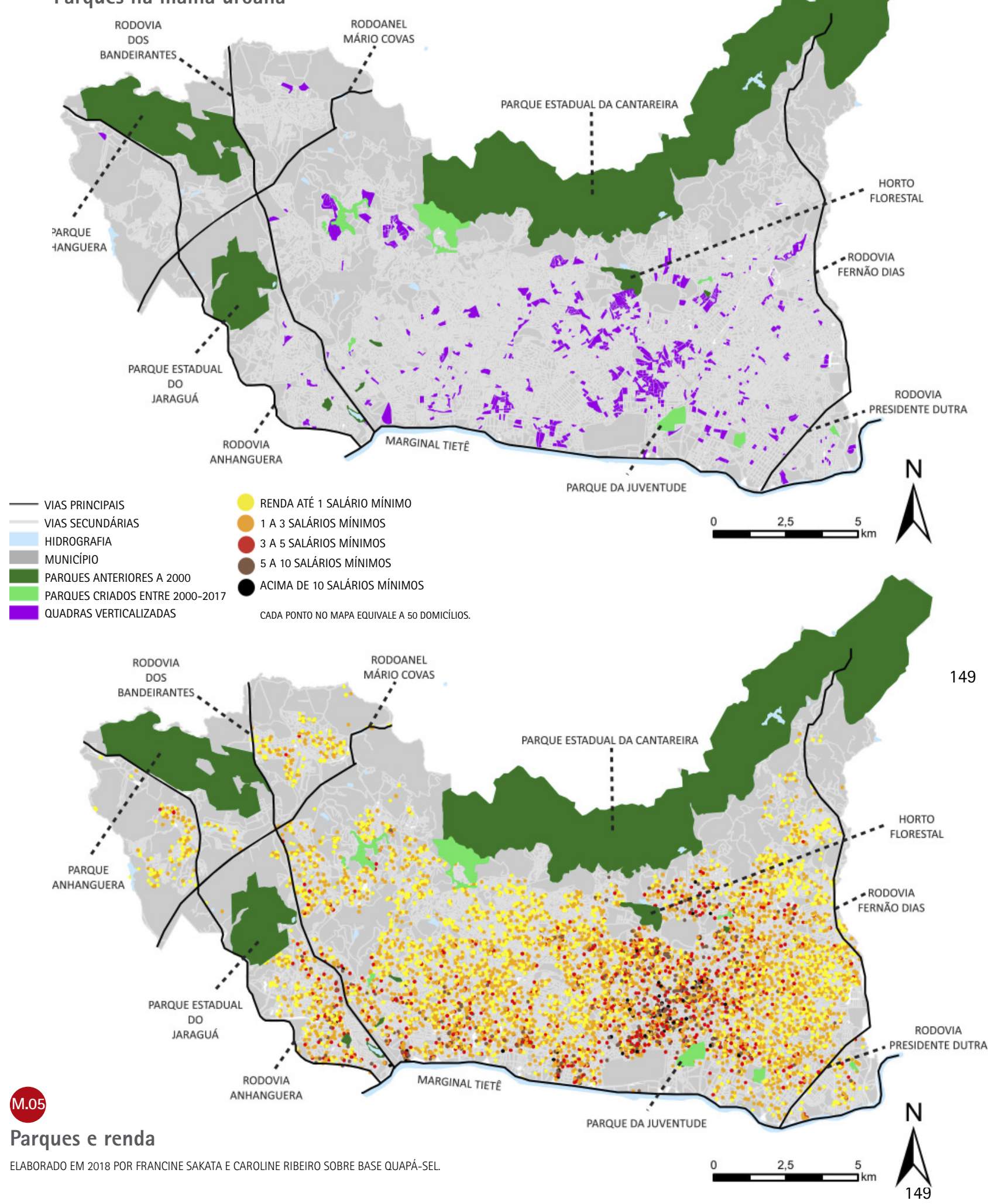




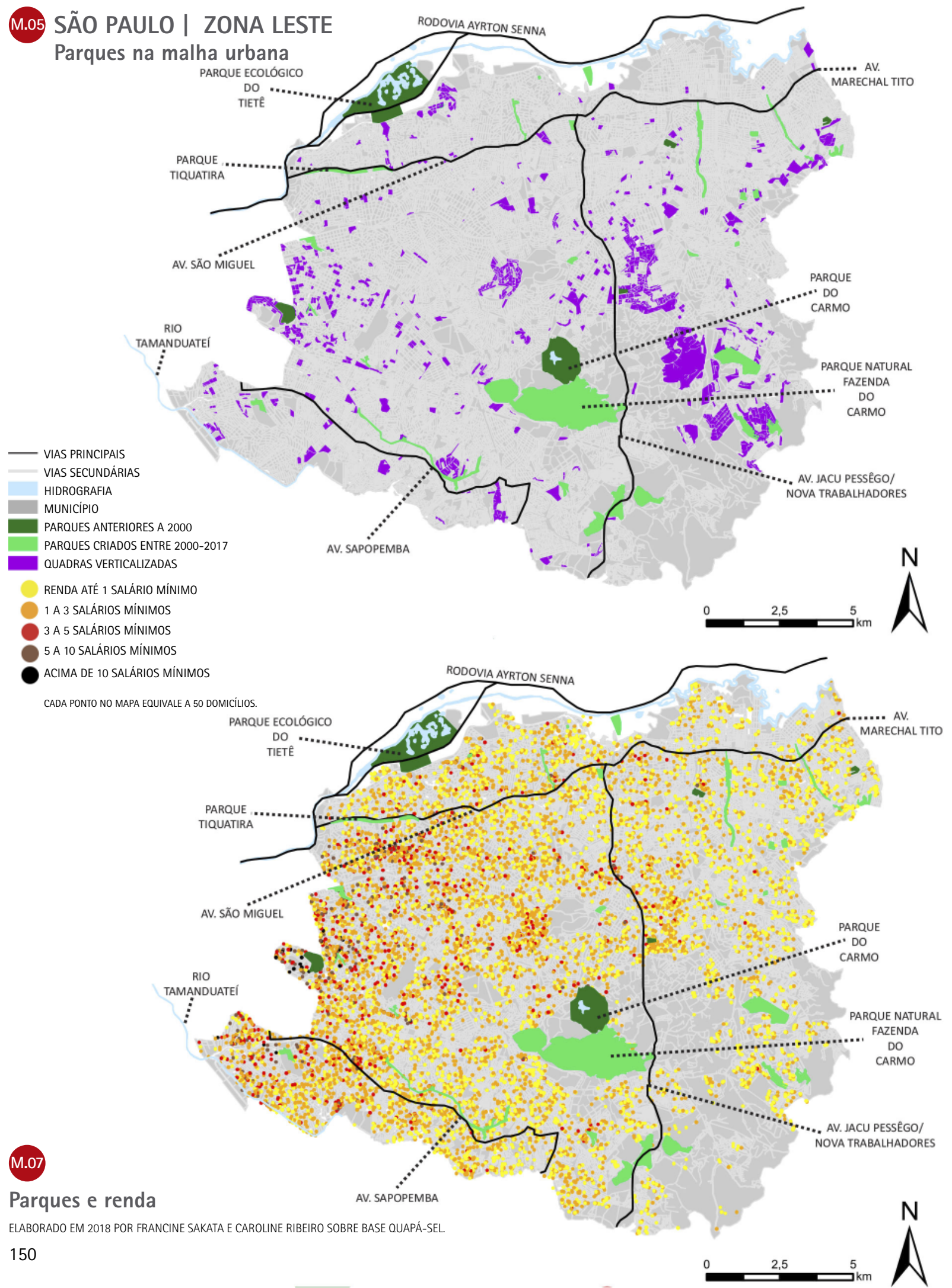



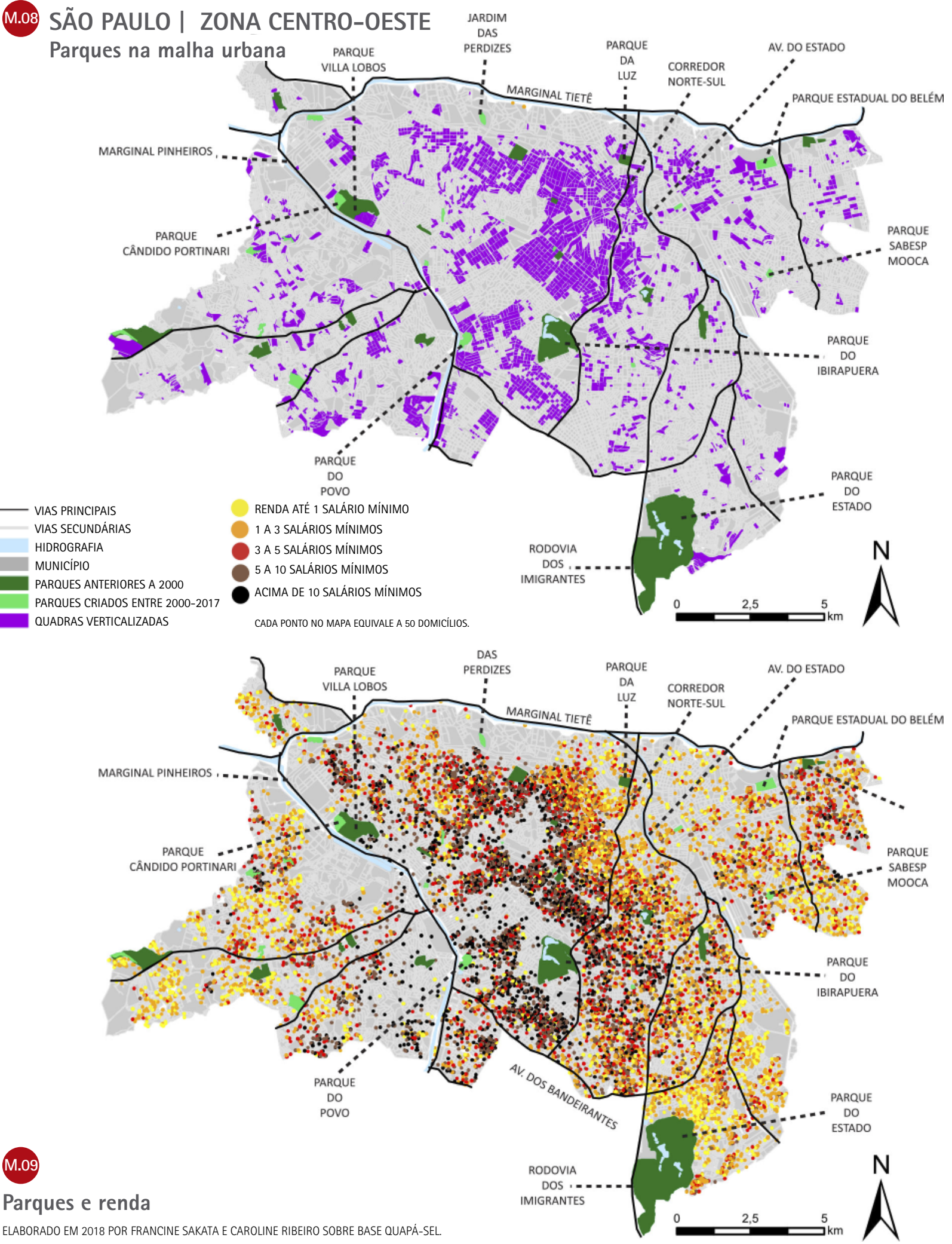
CAPITULO 3. DISTRIBUIÇÃO PELO ESPAÇO URBANO
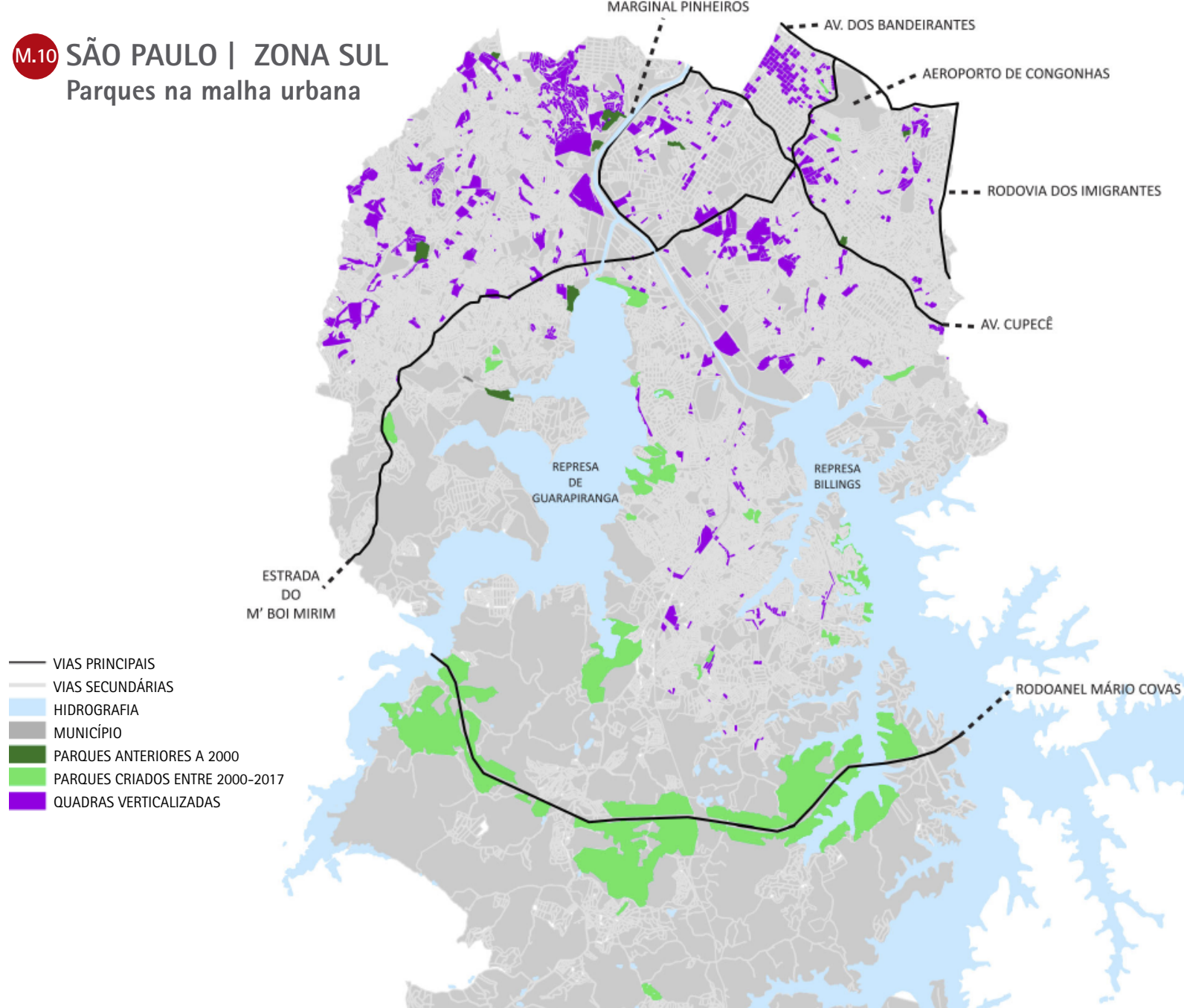

ELABORADO EM 2018 POR FRANCINE SAKATA E CAROLINE RIBEIRO SOBRE BASE QUAPÁ-SEL. 

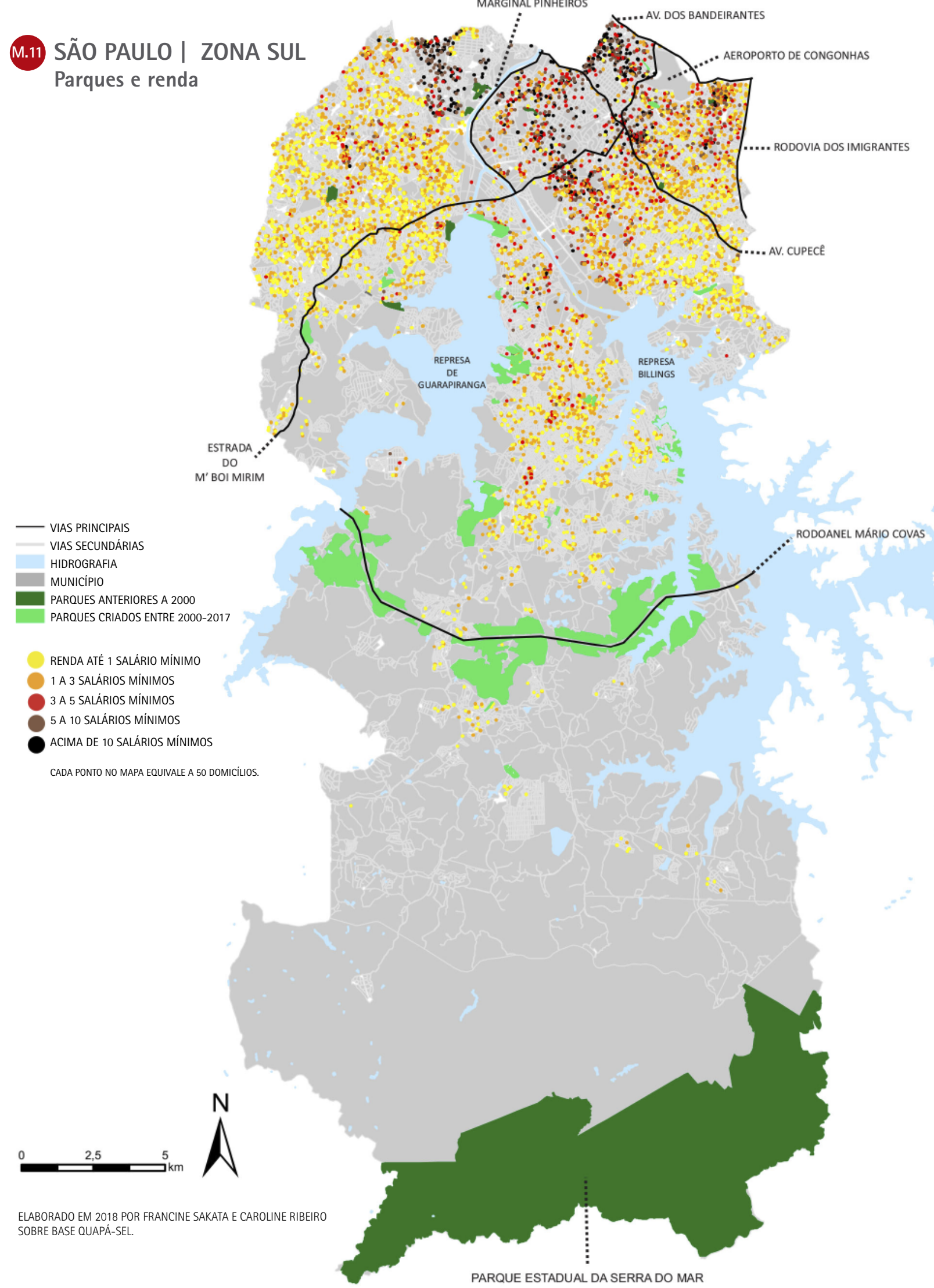


\subsection{Belo Horizonte}

Belo Horizonte apresentou um boom na criação de parques nos anos 1990, por todas as regiões do município - processo que se repetiu na década seguinte. Assim, em 2018 todas as regiões possuem parques. Ainda que não suficientes e que haja variações na qualidade da infraestrutura e manutenção, há parques em toda a cidade, alguns pouco conhecidos e frequentados. Entre 1975 e 1979, foi desenvolvido o Programa Metropolitano de Parques Urbanos pela Superintendência de Desenvolvimento da Região Metropolitana de Belo Horizonte (Plambel), que criou um ambiente favorável para a preservação ambiental, contudo muitas áreas eram particulares e ainda não havia estrutura administrativa e instrumentos legais para ações de porte relacionadas a parques. Isto foi incrementado ao longo dos anos. Em 1990 a Lei Orgânica do Município reforçou a missão de proteger o meio ambiente e as paisagens naturais notáveis; prevenir e controlar a degradação ambiental; criar parques, reservas e UCs de forma que as áreas verdes nunca sejam inferiores a $12 \mathrm{~m}^{2}$ por habitante e sejam distribuidas equitativamente por administração regional. Entre 1991 e 1992, a prefeitura, por meio da Secretaria Adjunta de Meio Ambiente (SMMA), iniciou vários projetos que resultaram na criação de novos parques. Em 2002 o Programa BH Verde seguiu o trabalho e levantou todos os espaços livres de propriedade pública destinados a parques, praças e Áreas de Preservação Permanente (APPs), conjunto que o próprio poder público desconhecia. ${ }^{9}$

0 Parque Municipal Américo Renné Giannetti (1897) reinou como o único da cidade, até que foi implantado o Parque Julien Rien (1978), e pouco depois o Parque das Mangabeiras (1982), com projeto de Roberto Burle Marx - todos na Regional Centro-Sul. Um parque foi executado na região Nordeste, o Professor Guilherme Lage (1982). ${ }^{10}$

Entre 1995 e 1996, o Departamento de Parques e Jardins criou o Programa Parque Preservado, coordenado por Marieta Cardoso Maciel, com a meta de transformar as áreas destinadas legalmente aos parques - que, sem projetos, se transformavam em depósitos de 154
9 COSTA, Stäel Alvarenga Pereira et al. Os espaços livres na paisagem de Belo Horizonte. Paisagem e Ambiente. São Paulo: FAUUSP, n. 26, 2009, p. 51-72.

10 MEDEIROS, Mirelli B. Parques urbanos em Belo Horizonte: a evolução de uma paisagem cultural. Colóquio Íbero-americano Paisagem Cultural, Patrimônio e Projeto, 3, Belo Horizonte, 15 a 17 de setembro de 2014. 
Parque Lagoa do Nado (1994), na Regional Pampulha, oferece programa de atividades amplo.
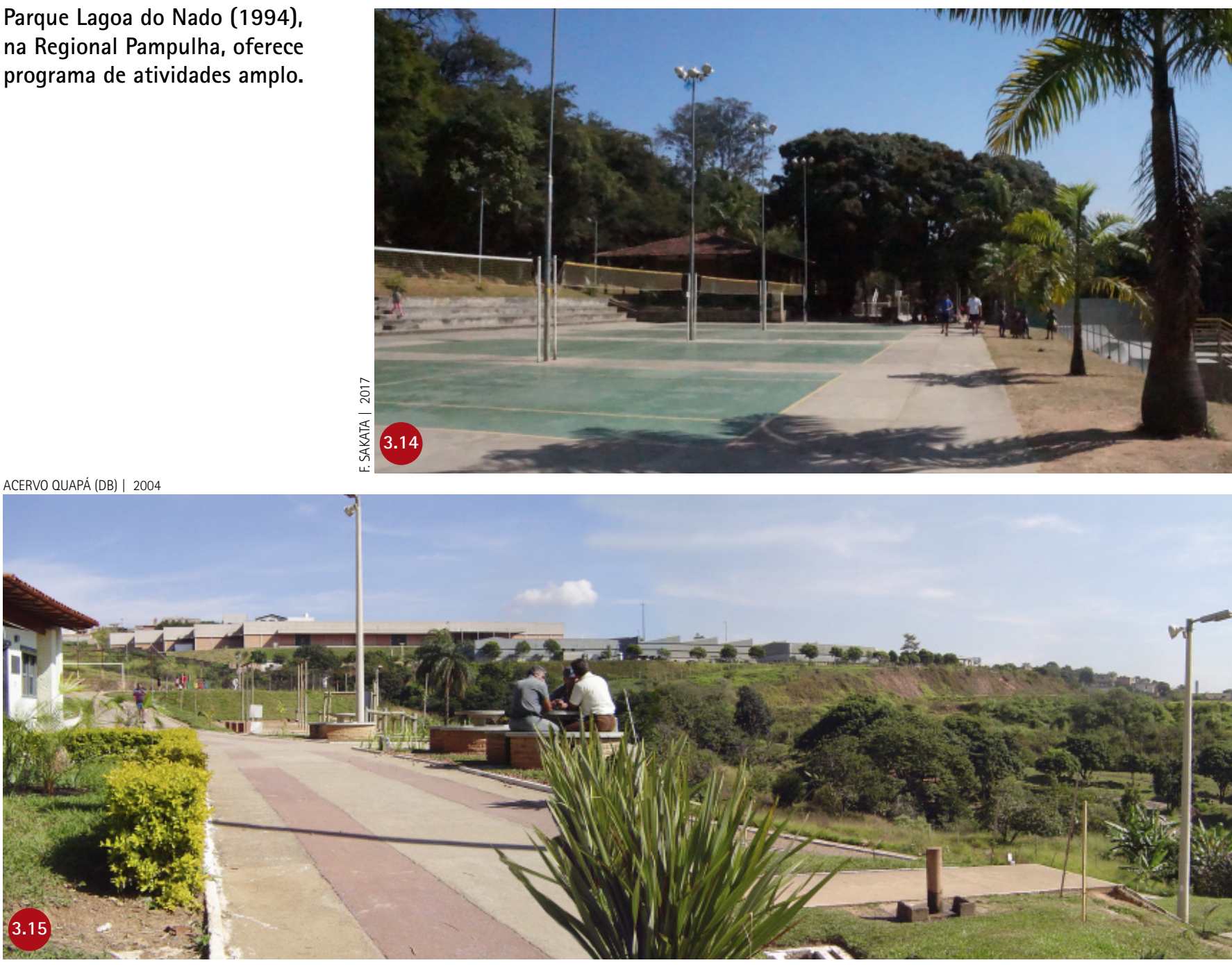

Parque Vila Pinho (2000), na Regional Barreiro. Grande número de parques aliou preservação ambiental com provisão de lazer em bairros de rendas médias e baixas.

Parque Cenáculo (2005), Regional Venda Nova. Ao lado de conjunto habitacional, consiste em bosque com caminhos. Programa de usos ameno e visitação esparsa.

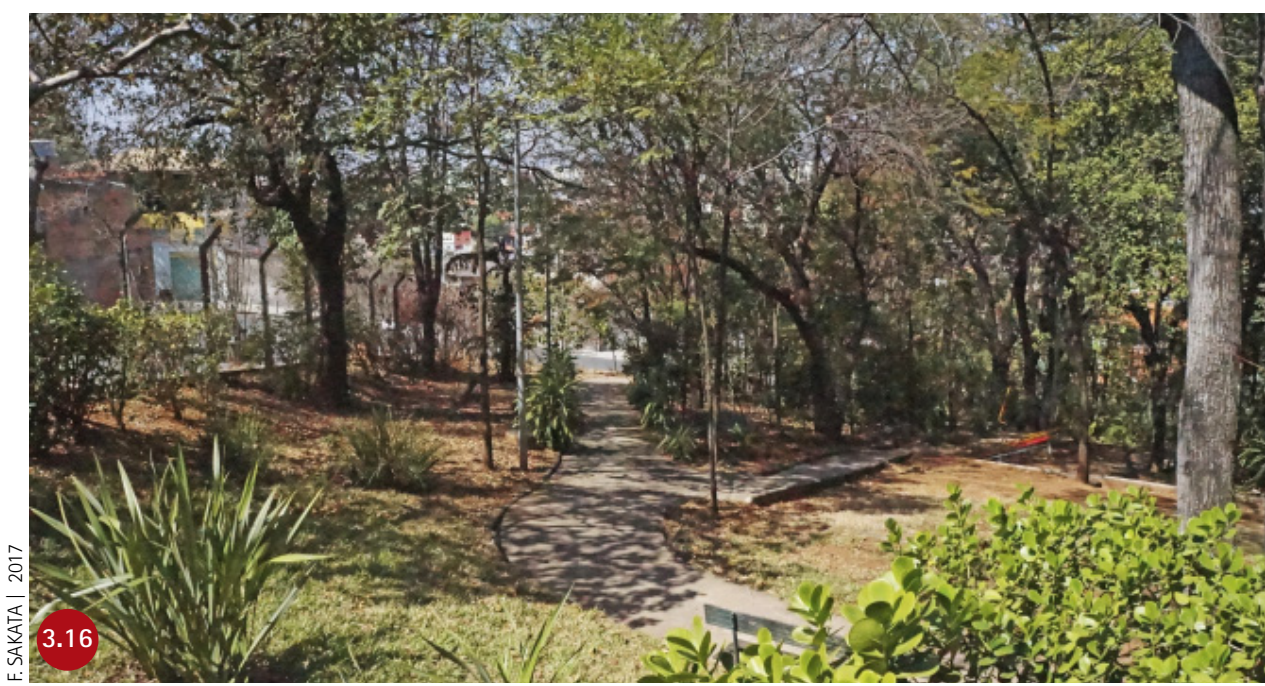


lixo, bota-fora, abrigo de marginais e invasões. 0 programa previu a instalação de um ambiente-núcleo em cada parque com um piso, bancos, mesinhas, barra para alongamento, um pequeno conjunto de brinquedos (escorregador, gangorra e tanque de areia) e, eventualmente, uma guarita para atendimento imediato ao público e posterior elaboração do projeto. Nos casos em que este já existia, o ambiente-núcleo era posicionado de forma a não interferir na implantação do projeto original. Com esta estratégia, a população se envolveu nos processos de criação, operacionalização e gestão. Assim, quando os nove parques foram implantados, já estavam sendo apropriados. ${ }^{11}$

Muitas das áreas onde foram implantados ao longo da década de 1990 já eram destinadas a esta finalidade. A implantação foi feita posteriormente, conforme conveniências política e econômica e pela mobilização social. A intervenção nos parques como medida compensatória em licenciamentos ambientais contribuiu para agilizar a implantação e a gestão das áreas públicas. ${ }^{12}$

A mobilização social parece ter continuado como motor da implantação de parques em Belo Horizonte nos anos 2000. Vários foram criados a partir de solicitações da população e a implantação dos equipamentos de lazer foi definida nos orçamentos participativos municipais, como no caso do Parque Ecológico Vida e Esperança do Tirol.

$\mathrm{Na}$ listagem feita para este trabalho, foram identificados cerca de dez parques aguardando tratamento e pelo menos cinco - solicitados pela população - fechados, sem a demanda de implantação de usos de lazer. Criado em 2002 nos bairros Santa Lúcia e Belvedere (Região Centro-Sul), por solicitação da vizinhança de alta renda, o Parque das Nações é um exemplo desta situação: não tem equipamentos e não é aberto.

Medeiros ${ }^{13}$ destaca que há no municipio predomínio de parques menores que $20.000 \mathrm{~m}^{2}$, sendo a região Centro Sul a que possui a maior área de parques efetivamente implantados, $3.741 .600 \mathrm{~m}^{2}$, e de parques não implantados, $309.000 \mathrm{~m}^{2}$. Nela se encontram o Parque das Mangabeiras, o maior da capital, e o Américo Renné
11 Os parques implantados foram: Alexander Brandt, Parque do Bairro Planalto, Orlando de Carvalho Silveira, Parque Ecológico Renato Azeredo, Parque Escola Jardim Belmonte, Marcus Pereira de Melo e Aggeo Pio Sobrinho.

MACIEL, Marieta Cardoso. Programa Parque Preservado. Paisagem e Ambiente. São Paulo: FAUUSP, n. 15, dez/2001, p. 103-126.

12 Idem.

13 MEDEIROS, Mirelli B. Parques urbanos em Belo Horizonte: a evolução de uma paisagem cultural. Colóquio Íbero-americano Paisagem Cultural, Patrimônio e Projeto, 3, Belo Horizonte, 15 a 17 de setembro de 2014. 
No Parque Jacques Cousteau (1999), Edanise Guimarães Reis, chefe de Departamento na Fundação de Parques Municipais, criou composições sofisticadas com a vegetação $\mathrm{e}$, ao mesmo tempo, buscou a participação da população para consolidar o uso.

0 Parque Cassia Eller (2000) foi pago por compensações ambientais e associado à valorização dos empreendimentos. Essa associação não foi tão comum em Belo Horizonte. Na imagem abaixo, de 2011, o parque estruturado há uma década e as torres em construção.
Giannetti, o mais antigo. Em seguida, considerando a área de parques implantados, aparece a Regional Oeste, com 1.024.400 $\mathrm{m}^{2} \mathrm{e}$ a Regional Pampulha, com $799.580 \mathrm{~m}^{2}$. Encontra-se também uma área significativa de parques não implantados $\left(277.100 \mathrm{~m}^{2}\right)$.

0 fechamento do Parque Alexander Brandt, em 2017, revela que há dificuldades na gestão dos parques. Por outro lado, o cuidado que se percebe nos parques Nossa Senhora da Piedade, Primeiro de Maio, Conjunto Estrela Dalva e muitos outros, denota a preocupação da população com estes espaços livres.

F. SAKATA $\mid 2017$

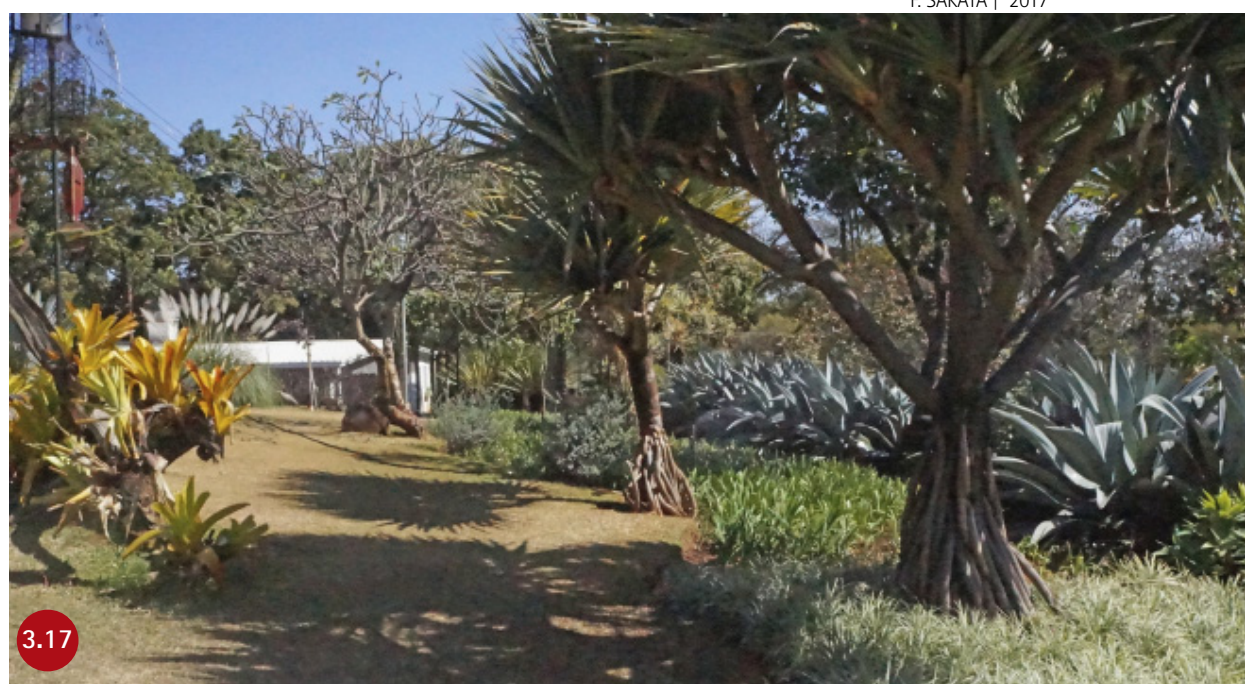

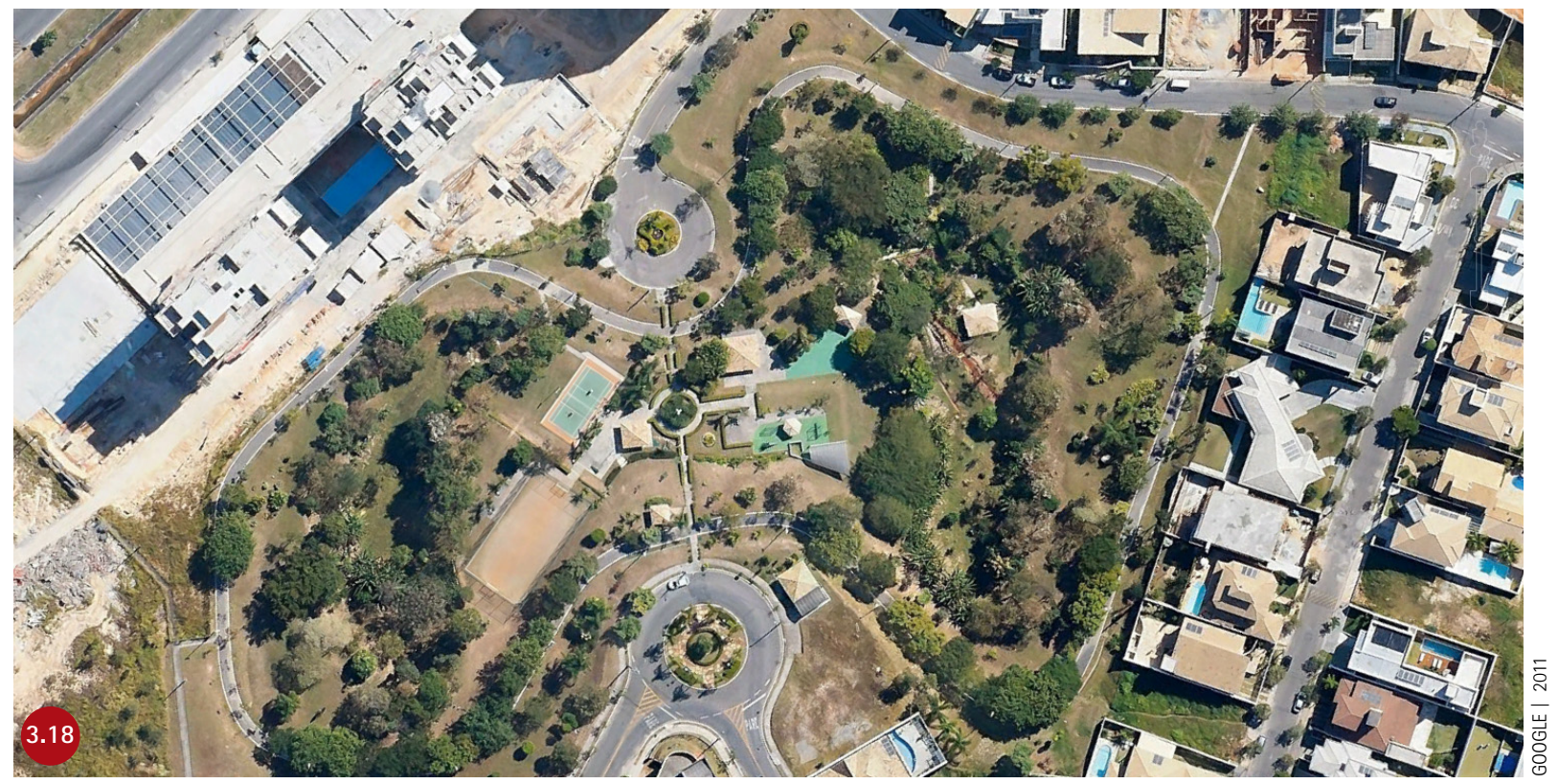




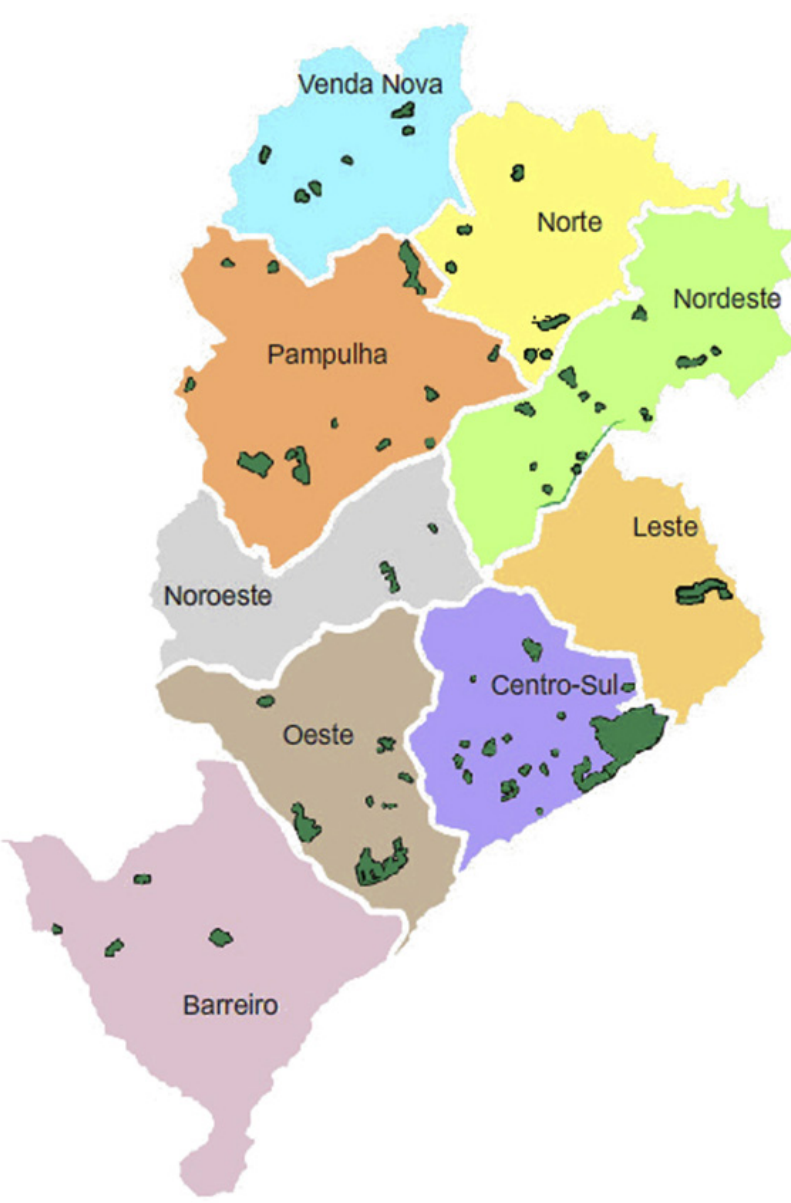

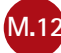

Regionais de Belo Horizonte ${ }^{14}$

14 Disponivel em: <http://portalpbh.pbh. gov.br/pbh/ecp/comunidade.do?evento $=p$ ortlet\&tpldPIc=ecpTaxonomiaMenuPortal Etapp $=$ fundacaoparqueEttax $=8263 \&$ tlang $=$ pt_BR\&tpg $=5521 \& t \operatorname{taxp}=0 \&$ >
Nesta tabela:

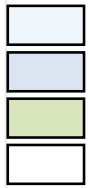

Parques anteriores a 1990 criados entre 1990-1999 criados entre 2000-2017 não implantados e, por isso, não contabilizados

\begin{tabular}{|c|c|c|c|c|}
\hline \multicolumn{5}{|l|}{ BELO HORIZONTE } \\
\hline PARQUE & BAIRRO & ÁREA $\left(\mathrm{m}^{2}\right)$ & CRIAÇÃO & INAUG. \\
\hline \multicolumn{5}{|l|}{ REGIONAL BARREIRO } \\
\hline $\begin{array}{l}\text { PARQUE ECOLÓGICO ROBERTO BURLE MARX (PARQUE } \\
\text { DAS ÁGUAS) }\end{array}$ & FLAVIO MAROUES LISBOA & 171.850 & - & 1994 \\
\hline $\begin{array}{l}\text { PARQUE CARLOS DE FARIA TAVARES (PARQUE VILA } \\
\text { PINHO) }\end{array}$ & SANTA CECILIA & 79.260 & 1992 & 2000 \\
\hline PARQUE ECOLÓGICO PADRE ALFREDO SABETTA & TEIXEIRA DIAS & 53.900 & 1999 & 2003 \\
\hline PARQUE ECOLÓGICO VIDA E ESPERANÇA DO TIROL & MARILÂNDIA JATOBÁ & 27.000 & & 2012 \\
\hline \multicolumn{5}{|l|}{ REGIONAL CENTRO-SUL } \\
\hline PARQUE MUNICIPAL AMÉRICO RENNÉ GIANNETTI & CENTRO & 229.730 & - & 1897 \\
\hline PARQUE MUNICIPAL JULIEN RIEN & ANCHIETA & 16.150 & - & 1978 \\
\hline PARQUE MUNICIPAL DAS MANGABEIRAS & MANGABEIRAS & 2.300 .000 & 1966 & 1982 \\
\hline PARQUE MUNICIPAL ROSINHA CADAR & SANTO AGOSTINHO & 7.610 & - & 1994 \\
\hline PARQUE JUSCELINO KUBITSCHEK & COMITECO & 32.000 & 1990 & 1995 \\
\hline PARQUE MUNICIPAL MATA DAS BORBOLETAS & SION & 41.100 & - & 1995 \\
\hline PARQUE MARCUS PEREIRA DE MELO & SÃO LUCAS & 3.669 & - & 1996 \\
\hline $\begin{array}{l}\text { PARQUE JORNALISTA EDUARDO COURI } \\
\text { (BARRAGEM SANTA LÚCIA) }\end{array}$ & VILA PARIS & 90.605 & - & 1996 \\
\hline
\end{tabular}




\begin{tabular}{|c|c|c|c|c|}
\hline PARQUE & BAIRRO & ÁREA $\left(\mathrm{m}^{2}\right)$ & CRIAÇÃO & INAUG. \\
\hline ÁREA DAS NASCENTES DA BARRAGEM SANTA LÚCIA & SANTA LÚCIA & 4.000 & 1997 & Não é aberto \\
\hline PARQUE PAULO BERUTTI & SÃO BENTO & 29.000 & 1998 & Não impl. \\
\hline PARQUE PROFESSOR AMÍLCAR VIANNA MARTINS & CRUZEIRO & 17.320 & - & 2000 \\
\hline $\begin{array}{l}\text { ÁREA DO VERTEDOURO BARRAGEM SANTA LÚCIA } \\
\text { (BOSOUE COLIBRI) }\end{array}$ & SANTA LÚCIA & 8.000 & & 2000 \\
\hline PARQUE MOSTEIRO TOM JOBIM & LUXEMBURGO & 6.100 & - & 2001 \\
\hline PARQUE DAS NAÇÕES & SANTA LÚCIA / BELVEDERE & 110.000 & 2002 & Não é aberto \\
\hline PAROUE FORT LAUDERDALE & MANGABEIRAS & 170.000 & 2003 & Não impl. \\
\hline PARQUE ECOLÓGICO SANTO ANTÔNIO & SANTO ANTÔNIO & 35.580 & - & 2008 \\
\hline PARQUE OLINTO MARINHO COUTO (BOSQUE SÃO BENTO) & SÃO BENTO & 44.000 & 2010 & Não é aberto \\
\hline PARQUE DA SERRA DO CURRAL & MANGABEIRAS & 404.560 & 1997 & 2012 \\
\hline \multicolumn{5}{|l|}{ REGIONAL LESTE } \\
\hline PARQUE LINEAR DO VALE DO ARRUDAS & CAETANO FURQUIM & 41.000 & & 1990 \\
\hline \multicolumn{5}{|l|}{ REGIONAL NORDESTE } \\
\hline PARQUE PROFESSOR GUILHERME LAGE & SÃO PAULO & 120.000 & - & 1982 \\
\hline $\begin{array}{l}\text { PAROUE ECOLÓGICO E CULTURAL PROFESSOR MARCOS } \\
\text { MAZZONI }\end{array}$ & UNIÃO & 18.346 & - & 1990 \\
\hline PARQUE DA MATINHA & UNIÃO & 14.890 & - & 1991 \\
\hline PARQUE ESCOLA JARDIM BELMONTE & BELMONTE & 57.300 & - & 1996 \\
\hline PARQUE ECOLÓGICO RENATO AZEREDO & PALMARES & 92.700 & & 1996 \\
\hline PARQUE ORLANDO DE CARVALHO SILVEIRA & GRAÇA & 26.900 & - & 1996 \\
\hline PARQUE ESCOLA JARDIM BELMONTE & JD. BELMONTE & 57.600 & & 1996 \\
\hline $\begin{array}{l}\text { PARQUE MUNICIPAL ISMAEL DE OLIVEIRA FÁBREGAS } \\
\text { (ANTIGA PRAÇA DO BOWL) }\end{array}$ & NOVA FLORESTA & 9.525 & - & 1999 \\
\hline PARQUE LINEAR AV. JOSÉ CÂNDIDO DA SILVEIRA & CIDADE NOVA & 51.200 & & 2006 \\
\hline PARQUE FERNÃO DIAS & FERNÃO DIAS & 27.000 & & 2009 \\
\hline PARQUE FERNÃO DIAS PARQUE SOL & FERNÃO DIAS & 25.100 & 2002 & 2008 \\
\hline PARQUE ECOLÓGICO E CULTURAL VITÓRIA & JD. VITÓRIA & 101.000 & & Não impl. \\
\hline PARQUE HUGO FUROUIM WERNECK & JD. VITÓRIA & 13.240 & 2010 & Não impl. \\
\hline PARQUE ECOLÓGICO JARDIM VITÓRIA & JD. VITÓRIA & Não localizado & & 2013 \\
\hline PARQUE GOIÂNIA & GOIÂNIA & 13.430 & & Não impl. \\
\hline \multicolumn{5}{|l|}{ REGIONAL NOROESTE } \\
\hline PARQUE ECOLÓGICO DO BAIRRO CAIÇARA & ALTO CAIÇARAS & 11.500 & - & 1996 \\
\hline $\begin{array}{l}\text { PARQUE MARIA DO SOCORRO MOREIRA (PARQUE DO } \\
\text { AEROPORTO) }\end{array}$ & JARDIM MONTANHÊS & 108.900 & - & 2000 \\
\hline \multicolumn{5}{|l|}{ REGIONAL NORTE } \\
\hline PARQUE DO BAIRRO PLANALTO & PLANALTO & 27.500 & - & 2002 \\
\hline PARQUE NOSSA SENHORA DA PIEDADE & AARÃO REIS & 67.880 & - & 2008 \\
\hline PARQUE PRIMEIRO DE MAIO & PRIMEIRO DE MAIO & 33.700 & & 2008 \\
\hline PARQUE VILA CLÓRIS & VILA CLÓRIS & 9.000 & 2008 & Não é aberto \\
\hline $\begin{array}{l}\text { PARQUE ECOLÓGICO E CULTURAL JARDIM DAS } \\
\text { NASCENTES (PAROUE MADRI) }\end{array}$ & MADRI & 29.000 & & $\begin{array}{l}\text { Depois de } \\
2008 .\end{array}$ \\
\hline PARQUE ESTADUAL SERRA VERDE & NOVA YORK & 1.420 .000 & 2007 & \\
\hline
\end{tabular}




\begin{tabular}{|c|c|c|c|c|}
\hline PARQUE & BAIRRO & ÁREA $\left(\mathrm{m}^{2}\right)$ & CRIAÇÃO & INAUG. \\
\hline \multicolumn{5}{|l|}{ REGIONAL OESTE } \\
\hline PARQUE MUNICIPAL AGGEO PIO SOBRINHO & BURITIS & 324.870 & - & 1996 \\
\hline PARQUE JACQUES COUSTEAU & BETÂNIA & 365.216 & - & 1999 \\
\hline $\begin{array}{l}\text { PARQUE ECOLÓGICO NOVA GRANADA (PARQUE DO } \\
\text { LIXÃO) }\end{array}$ & NOVA GRANADA & 41.580 & & 1998 \\
\hline PARQUE HALLEY ALVES BESSA & ESTRELA DALVA & 6.300 & & 1998 \\
\hline PARQUE DA VILA PANTANAL & BURITIS & 10.000 & & 2000 \\
\hline PARQUE BANDEIRANTE SILVA ORTIZ & ESTORIL & 11.740 & - & 2002 \\
\hline PARQUE DO CONJUNTO ESTRELA DALVA & ESTRELA DALVA & 12.000 & - & 2002 \\
\hline PARQUE ECOLÓGICO PEDRO MACHADO & SANTA MARIA & 5.997 & - & 2006 \\
\hline PAROUE VILA SANTA SOFIA & SANTA SOFIA & 4.640 & & 2008 \\
\hline PARQUE DA RESERVA ECOLÓGICA DO BAIRRO ESTORIL & ESTORIL & 15.340 & 2012 & Não é aberto \\
\hline \multicolumn{5}{|l|}{ REGIONAL PAMPULHA } \\
\hline PARQUE MUNICIPAL FAZENDA LAGOA DO NADO & ITAPOÃ & 324.000 & - & 1994 \\
\hline PARQUE MUNICIPAL URSULINA DE ANDRADE MELO & CASTELO & 309.615 & - & 1996 \\
\hline PARQUE ELIAS MICHEL FARAH & OURO PRETO & 6.850 & - & 1998 \\
\hline PARQUE DO CONFISCO & CONJ. CONFISCO & 27.000 & & 1999 \\
\hline PARQUE CÁSSIA ELLER & JD. PARQUETÁ & 28.000 & & 2000 \\
\hline PARQUE ECOLÓGICO DA PAMPULHA & PAMPULHA & 300.000 & - & 2004 \\
\hline PARQUE VENCESLI FIRMINO DA SILVA & ALIPIO DE MELO & 23.990 & & 2009 \\
\hline PARQUE JARDIM MONTANHÊS & JD. MONTANHÊS & 10.000 & & 2008 \\
\hline PARQUE MUNICIPAL DO BAIRRO TREVO & TREVO & 23.940 & & 2012 \\
\hline PARQUE UNIVERSITÁRIO & UNIVERSITÁRIO & 30.840 & & 2012 \\
\hline PARQUE DONA CLARA & D. CLARA & 15.000 & & 2013 \\
\hline $\begin{array}{l}\text { PARQUE FERNANDO SABINO (PARQUE FAZENDA DA } \\
\text { SERRA) }\end{array}$ & OURO PRETO & 178.880 & & Não impl. \\
\hline PARQUE ECOLÓGICO E CULTURAL ENSEADA DAS GARÇAS & TREVO & 38.000 & 2003 & Não impl. \\
\hline PARQUE ECOLÓGICO BREJINHO & SÃO FRANCISCO & 57.600 & 2007 & Não impl. \\
\hline \multicolumn{5}{|l|}{ REGIONAL VENDA NOVA } \\
\hline PARQUE ALEXANDER BRANDT & LUAR DE MINAS & 15.100 & - & 1996 \\
\hline PARQUE DO CONJ. HAB. DA LAGOA & LAGOA & 22.000 & 1999 & Não impl. \\
\hline PARQUE DO BAIRRO JARDIM LEBLON & LEBLON & 11.300 & & 2001 \\
\hline PARQUE JOSÉ DAZINHO PIMENTA (CENÁCULO) & CENÁCULO & 11.000 & & 2005 \\
\hline PARQUE JOSÉ LOPES DOS REIS (BALEARES) & EUROPA & 21.860 & - & 2008 \\
\hline PARQUE ESPORTIVO TELÊ SANTANA & RIO BRANCO & 30.600 & & 2008 \\
\hline
\end{tabular}

Do total de 80 parques, 62 estão abertos ao público em 2017. Havia 4 até 1990 na capital. Na década de 1990, foram implantados 25 parques (na tabela, em azul). Entre 2000 e 2015, foram 33 parques. Outros 18 foram criados, mas ou não foram implantados ou são áreas de conservação sem demanda para o lazer - e seguem fechados.

Tabela montada por Francine Sakata e Caroline Ribeiro com dados do folheto "Parques Municipais de Belo Horizonte", da Fundação de Parques Municipais da Prefeitura de Belo Horizonte, obtido em 2017, e do site da prefeitura: <http://portalpbh.pbh.gov.br>. Foi acrescido o Parque Estadual Serra Verde. As áreas e datas foram obtidas no site da prefeitura ou estimadas pelas imagens do Google Earth. 


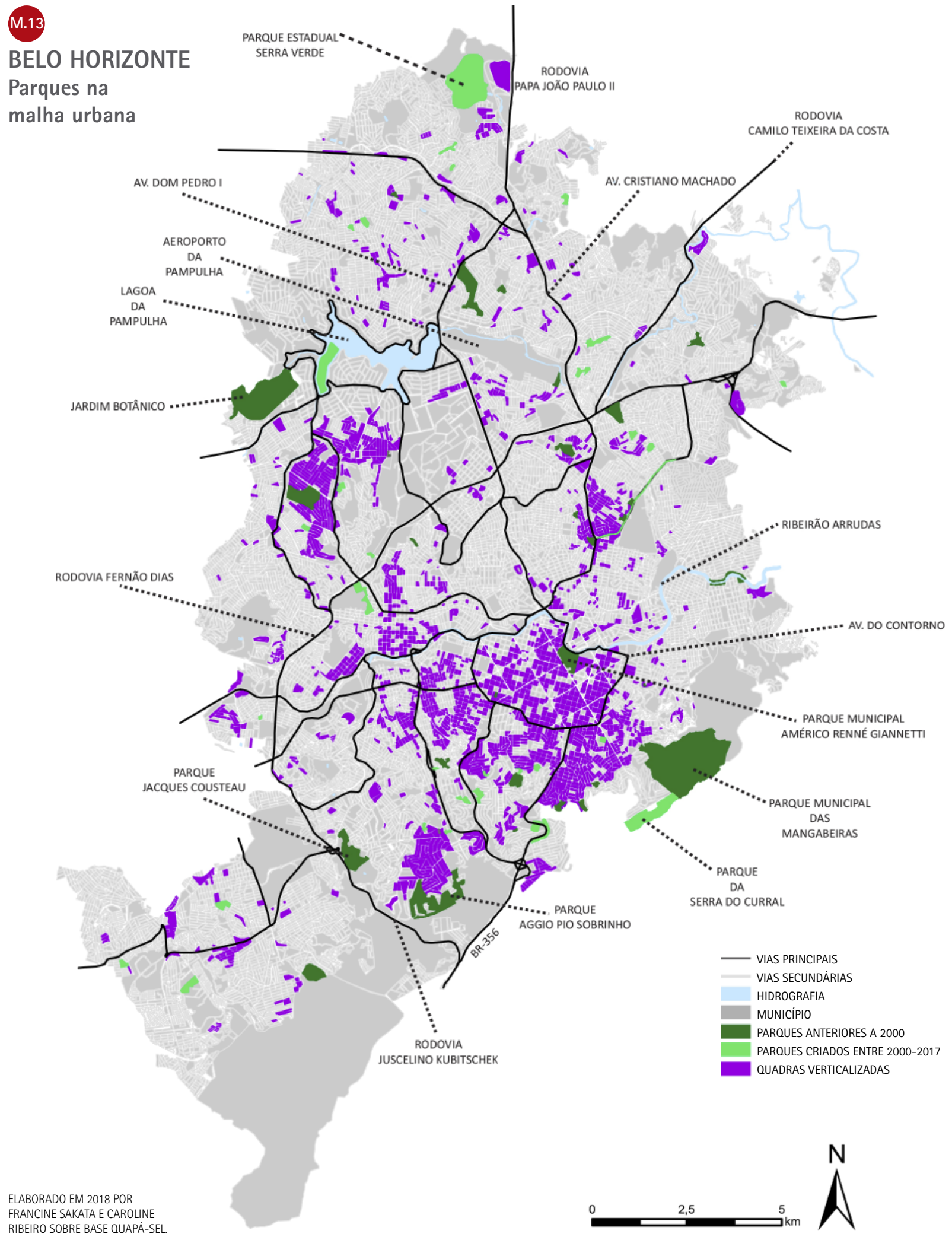


CAPITULO 3. DISTRIBUIÇÃO PELO ESPAÇO URBANO

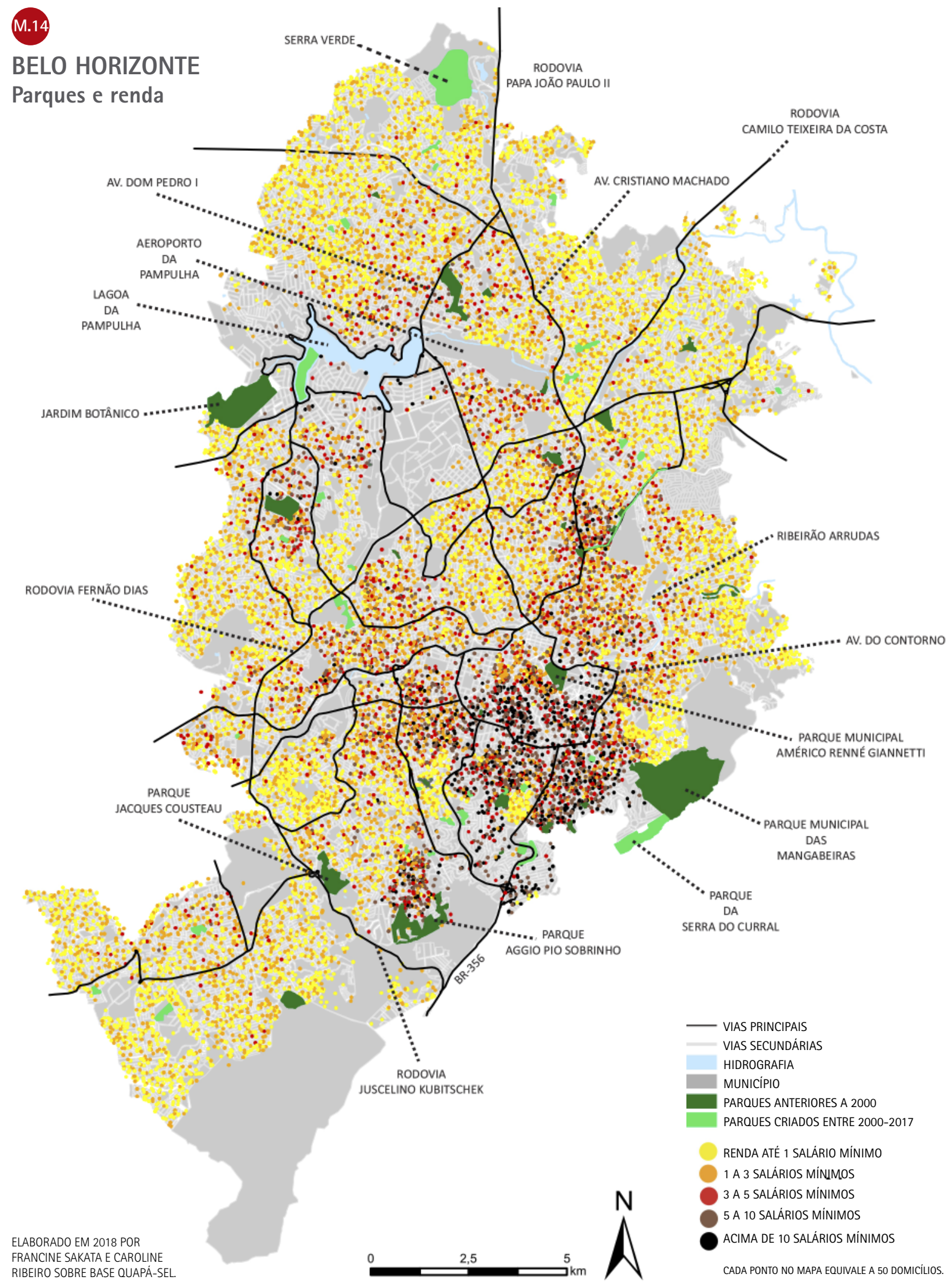




\subsection{Goiânia}

15 As 190 áreas foram checadas via Google Earth. Pelo menos dez das que a prefeitura não considerava como parques implantados estão equipadas com algum mobiliário, o que sugere que estejam sendo utilizadas como parques.

16 No site da prefeitura, o texto informava: "Para Goiânia possuir o título de capital brasileira com melhor qualidade de vida, pelo Instituto Brasil Américas não foi por acaso. [...] Goiânia é a capital brasileira que possui o maior número de $\mathrm{m}^{2}$ de áreas verdes por habitante. Conforme 0 levantamento da Agência Municipal do Meio Ambiente (Amma), Goiânia tem $94 \mathrm{~m}^{2}$ de áreas verdes de cada cidadão. A capital goiana fica em segundo lugar, uma vez que a campeã mundial é a cidade de Edmonton, no Canadá, com um quantitativo de $100 \mathrm{~m}^{2}$ de área verde por habitante. De acordo com a Organização das Nações unidas (ONU), é recomendável que uma cidade tenha pelo menos $12 \mathrm{~m}^{2}$, ou seja, Goiânia supera a meta com um indice de sete vezes mais áreas verdes." Disponivel em: <http://www4. goiania.go.gov.br/portal/goiania. asp?s=2\&tt=conctcd=1265>. Acesso em: $01 / 02 / 2018$.
Em Goiânia, mais de 190 áreas foram decretadas parques nos últimos vinte anos, especialmente APPs. Até 2015, segundo dados da prefeitura, 32 foram tratadas mas, segundo o levantamento ${ }^{15}$ realizado para este trabalho, foram 42. Apenas entre os anos de 2002 e 2007, foram feitos 15 destes 42 parques. A prefeitura usou-os na propaganda oficial: "Goiânia, a capital brasileira com melhor qualidade de vida”. ${ }^{16}$

Prefeitura e empreendedores imobiliários uniram-se para implantar parques que poderiam alavancar os lançamentos residenciais de alto padrão nos setores ao sul da cidade e, assim, foram feitas parcerias para a criação de parques. 0 primeiro projeto da equipe da prefeitura envolvida neste processo, coordenada pela arquiteta Yara Hasegawa, foi o Parque Vaca Brava, em área de expansão imobiliária, o Setor Bueno. A requalificação do terreno do parque era urgente devido ao processo de erosão. Fizeram-se caminhos, bancos, lixeiras, parques infantis e a estação de ginástica adicional. A fiação foi estabelecida de forma subterrânea e ampliou-se a capacidade do sistema de drenagem das ruas do entorno, pois se trata de fundo de vale. Um trecho do sistema viário, que não tinha utilidade, foi anexado à área, aumentando-a. 0 parque foi mantido aberto, isto é, sem cercamento. Este conjunto de práticas se tornou referência para os projetos seguintes. 3.19 3.20

A equipe de funcionários da prefeitura efetuou inicialmente o levantamento das áreas e o plano de ação. Assim, quando a Secretaria de Meio Ambiente se tornou agência, a AMMA, houve condições para a implantação sequencial de parques, uma vez que os técnicos tiveram mais autonomia financeira sobre o fundo que recebia os recursos de TAC. 3.25 3.26

A população, quando solicitava parques à prefeitura, pedia que fossem sempre abertos, como o Parque Vaca Brava, em oposição aos parques Areião, Buritis e Bosque das Rosas, cercados ou parcialmente cercados. 3.21 3.22 (3.23) (3.29) 
Parque Areião (1996). Como em vários parques, os vendedores de côco disponibilizam poltronas nas calçadas aos clientes.

A infraestrutura hídrica

(contenções, desníveis, o jato de aeração do lago e pontes para travessia) foi aproveitada como recurso paisagístico.
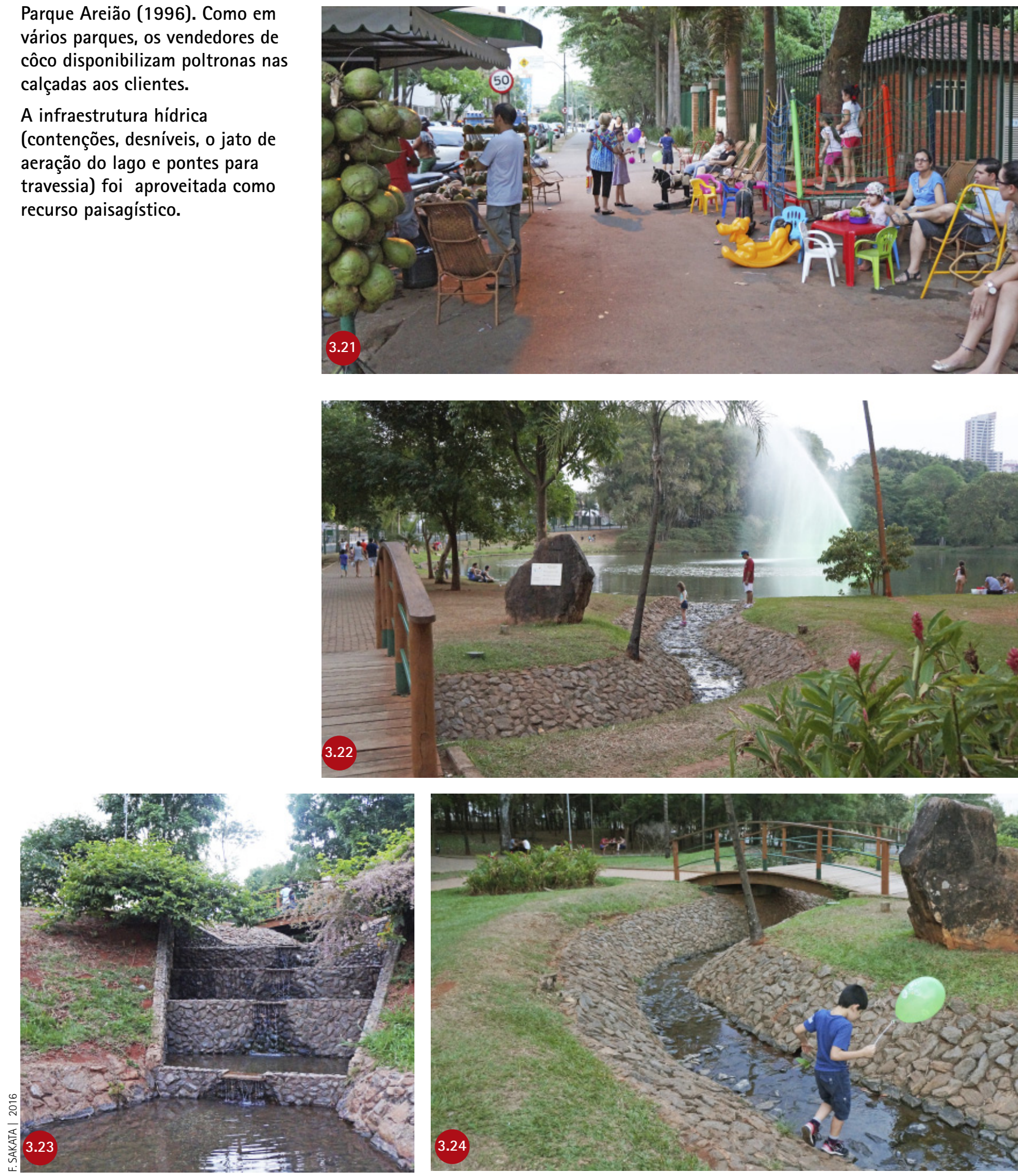


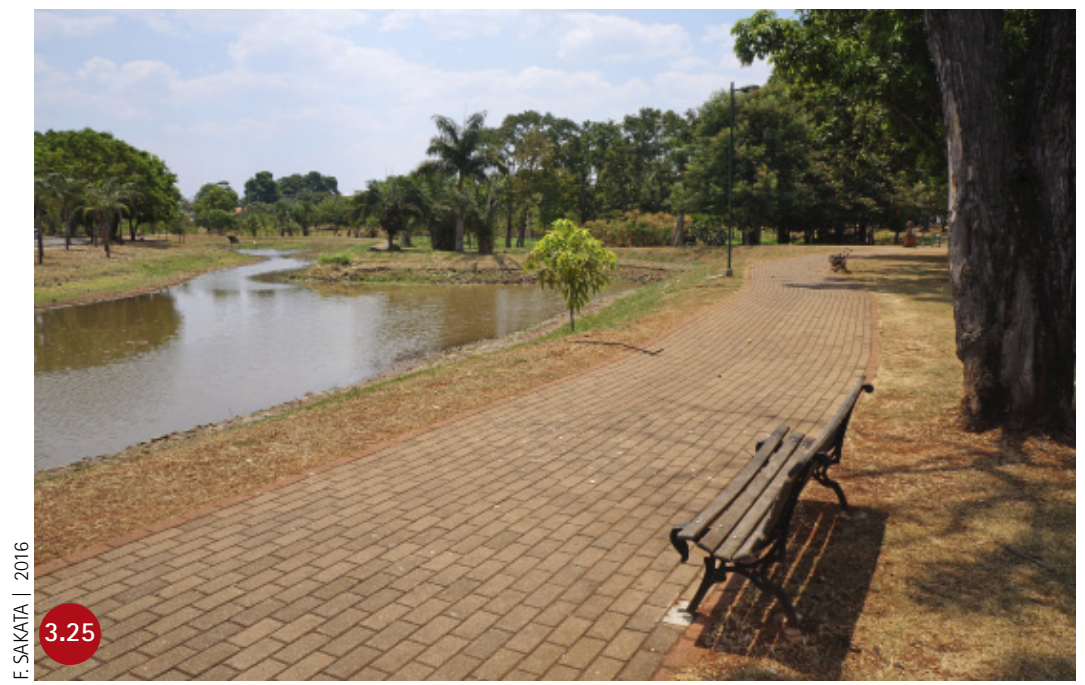

0 Parque Beija-Flor (2007), em bairro de casas de alto padrão, foi criado, segundo Hasegawa, por meio do esforço conjunto da prefeitura e da comunidade do entorno. Havia interesse em resolver o conflito na área, que estava sendo ocupada irregularmente. A obra foi executada com equipe e recursos do município. Para viabilizar o pergolado, reutilizou-se a madeira que havia sobrado de outras obras.

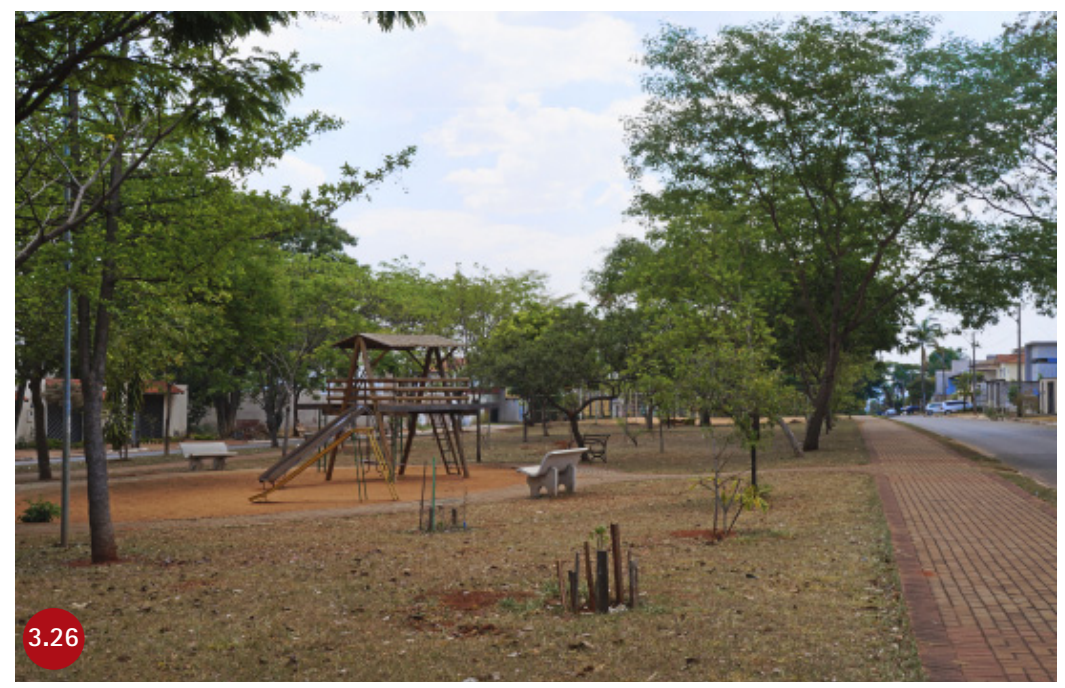

A população, vendo as intervenções da AMMA, pediu o projeto nos mesmos moldes para o Bosque do Café (2007), um canteiro central convertido em área de preservação por conta da flora. 0 projeto é simples: pista de caminhada, espaços de estar para contemplação e piqueniques.

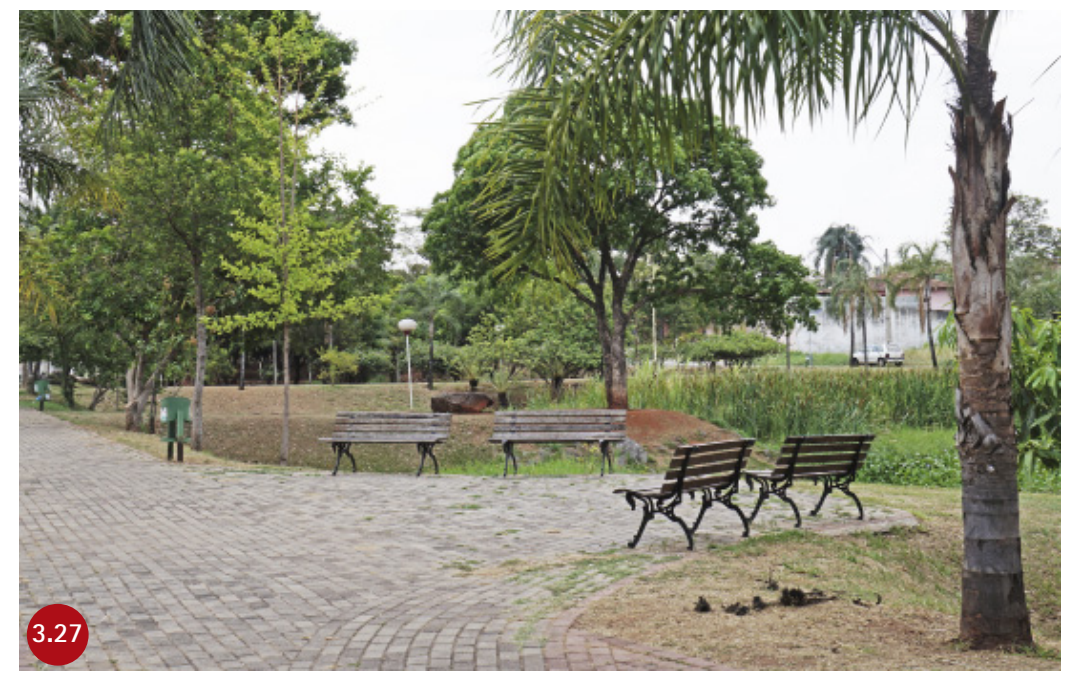


Parque Lago das Rosas (1940) é o mais antigo da cidade e inclui em sua área o Zoológico (foto abaixo). Sua presença valorizou as terras no seu entorno. Foi revitalizado em 2015.

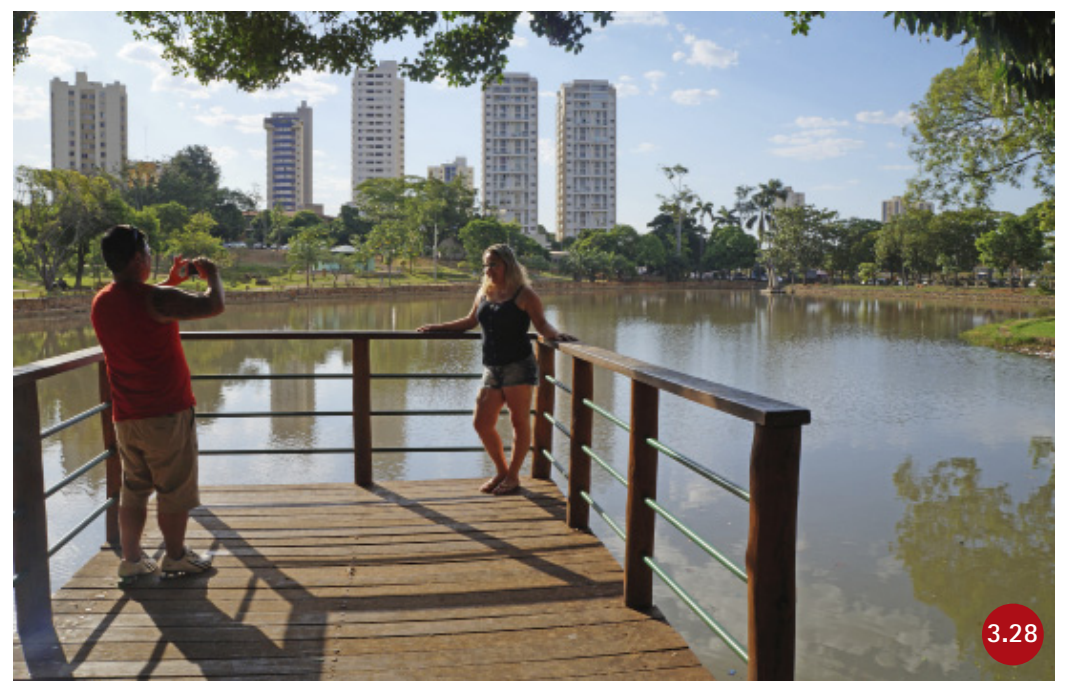

Abaixo, área no Jardim Curitiba decretada como parque e incorporada ao loteamento fechado do Programa MCMV.
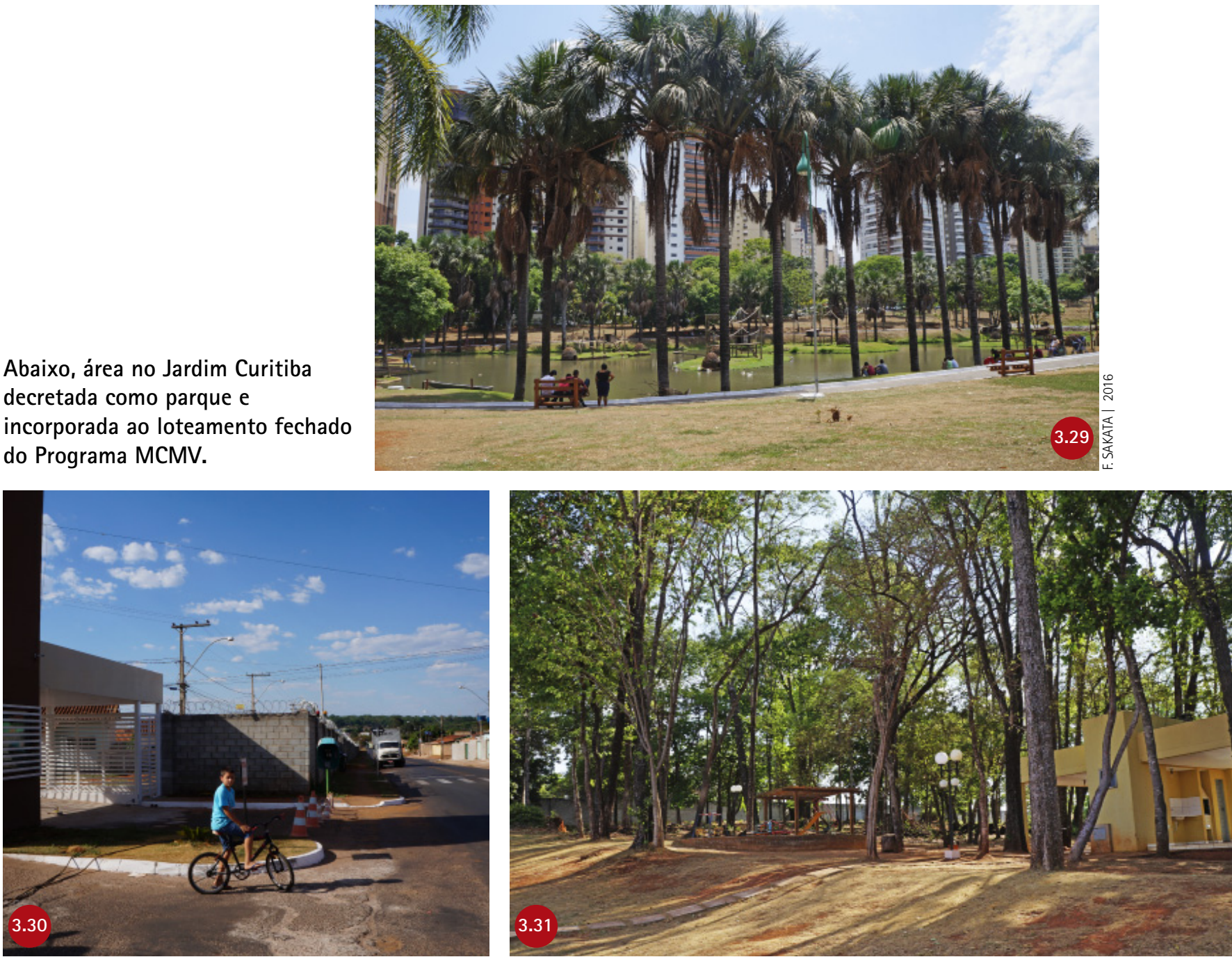
CAPITULO 3. DISTRIBUIÇÃO PELO ESPAÇO URBANO

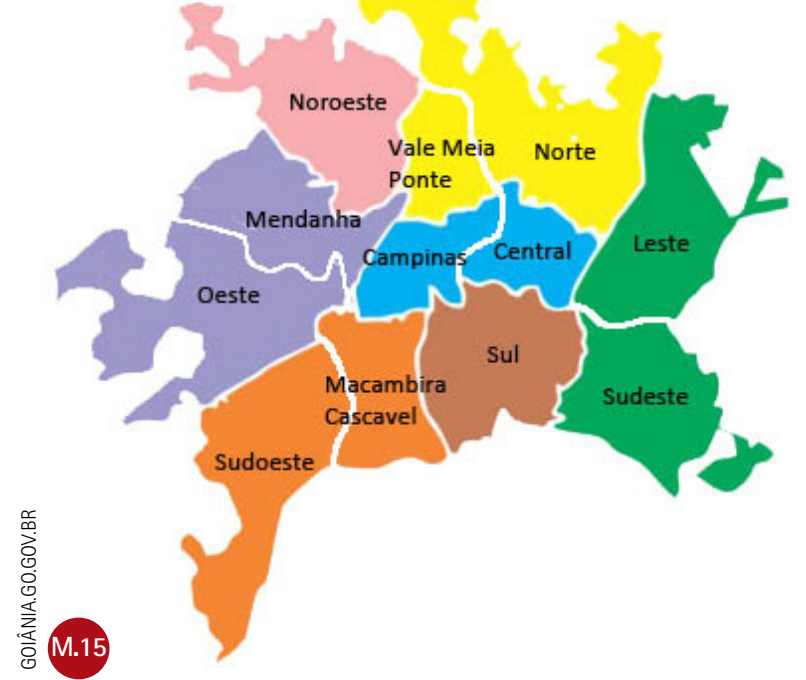

Regiões de Goiânia utilizadas nesta tabela.

Nesta tabela:

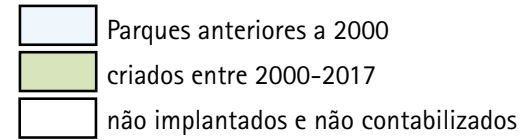

\begin{tabular}{|c|c|c|c|}
\hline \multicolumn{4}{|l|}{ GOIÂNIA } \\
\hline PARQUE & ÁREA $\left(\mathrm{m}^{2}\right)$ & CRIAÇÃO & INAUG. \\
\hline \multicolumn{4}{|l|}{ CENTRAL } \\
\hline LAGO DAS ROSAS & 315.000 & 1938 & \\
\hline BOSOUE DOS BURITIS & 124.800 & 1938 & \\
\hline BOTAFOGO & & 1938 & \\
\hline \multicolumn{4}{|l|}{ CAMPINAS } \\
\hline CAMPININHA DAS FLORES & 31.152 & 2007 & 2011 \\
\hline MOOCA & 10.372 & 2000 & Não impl. \\
\hline VILA SÃO JOSÉ EXTENSÃO & 36.040 & 2002 & Não impl. \\
\hline \multicolumn{4}{|l|}{ CASCAVEL E MACAMBIRA } \\
\hline CASCAVEL & 287.850 & 1996 & 2009 \\
\hline BOSQUE MACAMBIRA & 533.000 & 1997 & 2015 \\
\hline \multicolumn{4}{|l|}{ LESTE } \\
\hline $\begin{array}{l}\text { BOSOUE JOSÉ } \\
\text { EDUARDO NASCIMENTO } \\
\text { (AMENDOEIRAS) }\end{array}$ & 28.321 & 2000 & 2000 \\
\hline CLÉA BORGES & 20.412 & 2001 & 2001 \\
\hline ÍNDIA DIACUÍ & 23.477 & 1978 & 2008 \\
\hline BOUGAINVILLE & 37.413 & 1994 & 2008 \\
\hline PRATA & 6.304 & 1995 & Não impl. \\
\hline RECANTO DAS MINAS GERAIS & 106.000 & 1995 & Não impl. \\
\hline SONHO VERDE & 22.674 & 1998 & Não impl. \\
\hline $\begin{array}{l}\text { JARDIM DAS AROEIRAS } \\
\text { (BURACÃO) }\end{array}$ & 14.919 & 1998 & Não impl. \\
\hline OLINDA & 60.858 & 1999 & Não impl. \\
\hline ARUANÃ PARK & 12.036 & 2000 & Não impl. \\
\hline BELO HORIZONTE & 14.823 & 2002 & Não impl. \\
\hline HAVAÍ & 10.133 & 2003 & Não impl. \\
\hline $\begin{array}{l}\text { JARDIM NOVO MUNDO } \\
\text { (EXTENSÃO) }\end{array}$ & 7.591 & 2003 & Não impl. \\
\hline VALE DO ARAGUAIA & 133.601 & 2004 & Não impl. \\
\hline \multicolumn{4}{|l|}{ MENDANHA } \\
\hline RECANTO DAS GRAÇAS & 13.945 & 1992 & 2004 \\
\hline PAROUE CLARISSA & 13.945 & 2004 & 2004 \\
\hline LEBLON I & 27.575 & 1996 & Não impl. \\
\hline PARQUE REAL & 20.248 & 1998 & Não impl. \\
\hline SOLAR VILLE I & 41.104 & 1998 & Não impl. \\
\hline SOLAR VILLE II & 18.182 & 1998 & Não impl. \\
\hline CIDADE VERDE I & 28.896 & 2000 & Não impl. \\
\hline CIDADE VERDE II & 9.994 & 2000 & Não impl. \\
\hline LEBLON II & 25.297 & 2000 & Não impl. \\
\hline MIGUEL ABDALA & 29.937 & 2000 & Não impl. \\
\hline
\end{tabular}




\begin{tabular}{|c|c|c|c|}
\hline PARQUE & ÁREA $\left(\mathrm{m}^{2}\right)$ & CRIAÇÃO & INAUG. \\
\hline BARRA DA TIJUCA & 20.521 & 2003 & Não impl. \\
\hline NOVO PETRÓPOLIS & 4.866 & 2004 & Não impl. \\
\hline MENDANHA & 85.179 & 2006 & Não impl. \\
\hline \multicolumn{4}{|l|}{ NOROESTE } \\
\hline BOSQUE ESTRELA DALVA I & 266.599 & 1998 & 1998 \\
\hline OTÁVIO LÚCIO & 267.475 & 2000 & 2001 \\
\hline BOSOUE BOA VISTA & 17.894 & 2004 & 2004 \\
\hline CURITIBA & 392.212 & 2004 & 2008 \\
\hline FONTE NOVA & 76.420 & 2004 & 2008 \\
\hline NOVA ESPERANÇA & 32.900 & 1996 & Não impl. \\
\hline RECANTO DO BOSOUE I & 131.669 & 1997 & Não impl. \\
\hline RECANTO DO BOSQUE II & 24.266 & 1997 & Não impl. \\
\hline ESTRELA D'ALVA II & 45.300 & 1998 & Não impl. \\
\hline DAS HORTÊNCIAS & 10.871 & 1998 & Não impl. \\
\hline MORADA DO SOL & 4.340 & 1999 & Não impl. \\
\hline PRIVÊ NORTE & 9.376 & 1999 & Não impl. \\
\hline HELOU & 10.360 & 2003 & Não impl. \\
\hline BOSQUE DO PAMA & 58.240 & 2004 & Não impl. \\
\hline MORRO DA CASCALHEIRA & 161.375 & 2004 & Não impl. \\
\hline LINEAR CURITIBA & 314.138 & 2004 & Não impl. \\
\hline PARQUE BOA VISTA & 100.739 & 2004 & Não impl. \\
\hline CURITIBA IV & 256.884 & 2004 & Não impl. \\
\hline MANSÕES PARAÍSO & 22.993 & 2004 & Não impl. \\
\hline FLORESTA I & 696.201 & 2004 & Não impl. \\
\hline FLORESTA II & 64.580 & 2004 & Não impl. \\
\hline SÃO CARLOS & 168.703 & 2004 & Não impl. \\
\hline RESERVA SÃO DOMINGOS & 445.605 & 2004 & Não impl. \\
\hline VITÓRIA & & 2004 & Não impl. \\
\hline \multicolumn{4}{|l|}{ NORTE } \\
\hline NOSSA MORADA & 26.307 & 1999 & 2005 \\
\hline BEIJA-FLOR & 27.800 & 1952 & 2006 \\
\hline JOSÉ EDUARDO & 28.321 & 2000 & 2006 \\
\hline LIBERDADE & 10.922 & 1997 & 2007 \\
\hline BOSQUE DO CAFÉ & 19.260 & 2007 & 2007 \\
\hline ITATIAIA & 97.952 & 2008 & 2008 \\
\hline LEOLÍDIO DI RAMOS CAIADO & 123.900 & 2009 & 2010 \\
\hline VALE DOS SONHOS & 29.531 & 2010 & 2011 \\
\hline PARQUE DOS CISNES & 31.457 & 1998 & Não impl. \\
\hline NOSSA MORADA & 26.307 & 1999 & Não impl. \\
\hline MATINHA & 68.316 & 2000 & Não impl. \\
\hline
\end{tabular}

\begin{tabular}{|c|c|c|c|}
\hline PARQUE & ÁREA $\left(\mathrm{m}^{2}\right)$ & CRIAÇÃO & INAUG. \\
\hline SÍTIO DE RECREIO CARAÍBAS & 70.327 & 2000 & Não impl. \\
\hline VALE DA SERRA & & 2001 & Não impl. \\
\hline ANTONIO BARBOSA & 7.941 & 2002 & Não impl. \\
\hline VALE DOS SONHOS II & 29.531 & 2004 & Não impl. \\
\hline VALE DOS SONHOS I & 29.531 & 2016 & Não impl. \\
\hline \multicolumn{4}{|l|}{ OESTE } \\
\hline NOVA AURORA & 10.363 & 2001 & 2003 \\
\hline TAQUARAL & 109.655 & 2006 & 2006 \\
\hline JERIVÁ & 21.933 & 2008 & 2010 \\
\hline GOIÁ II & 12.117 & 1995 & Não impl. \\
\hline ELDORADO OESTE & 26.391 & 1996 & Não impl. \\
\hline CAROLINA CÂNDIDA CABRAL & 19.581 & 1997 & Não impl. \\
\hline CAROLINA PARK & 9.180 & 1999 & Não impl. \\
\hline GOIÁ IV & 34.423 & 2000 & Não impl. \\
\hline LUANA PARK & 8.066 & 2000 & Não impl. \\
\hline $\begin{array}{l}\text { VENERANDO DE FREITAS } \\
\text { BORGES }\end{array}$ & 48.200 & 2000 & Não impl. \\
\hline EVERALDO DE SOUZA & 146.544 & 2002 & Não impl. \\
\hline SÃO MARCOS & 136.905 & 2002 & Não impl. \\
\hline $\begin{array}{l}\text { SETOR DAS NAÇÕES } \\
\text { EXTENSÃO }\end{array}$ & 6.310 & 2002 & Não impl. \\
\hline SÃO JOSÉ & 48.265 & 2002 & Não impl. \\
\hline NUNES DE MORAIS I & 22.770 & 2003 & Não impl. \\
\hline JARDIM SÃO JOSÉ & 35.730 & 2003 & Não impl. \\
\hline ELDORADO OESTE EXTENSÃO & 17.127 & 2004 & Não impl. \\
\hline ESTRELA NOVA & 26.783 & 2004 & Não impl. \\
\hline VILLAGE MARINGÁ & 10.866 & 2004 & Não impl. \\
\hline ANA MORAES & 7.762 & 2006 & $\begin{array}{l}\text { Loteam. } \\
\text { fechado }\end{array}$ \\
\hline DOM RAFAEL & 35.313 & 2006 & Não impl. \\
\hline PORTINARI & 46.040 & 2006 & Não impl. \\
\hline $\begin{array}{l}\text { VICENTE RODRIGUES DE } \\
\text { OLIVEIRA }\end{array}$ & 327.348 & 2007 & Não impl. \\
\hline MORRO DOS MACACOS & 408.686 & 2008 & Não impl. \\
\hline BOSQUE DO LAGO & 13.495 & 2008 & $\begin{array}{l}\text { Loteam. } \\
\text { fechado }\end{array}$ \\
\hline CONDOMÍNIO DO LAGO & 166.553 & 2008 & Não impl. \\
\hline \multicolumn{4}{|l|}{ PARQUE INDUSTRIAL } \\
\hline $\begin{array}{l}\text { JOÃO CARLOS FERNANDES } \\
\text { DE OLIVEIRA (PARQUE DA } \\
\text { LAGOA) }\end{array}$ & 38.347 & 1954 & 2008 \\
\hline
\end{tabular}


CAPÍTULO 3. DISTRIBUIÇÃO PELO ESPAÇO URBANO

\begin{tabular}{|c|c|c|c|}
\hline PARQUE & ÁREA $\left(\mathrm{m}^{2}\right)$ & CRIAÇÃO & INAUG. \\
\hline \multicolumn{4}{|l|}{ SUDESTE } \\
\hline VILLE DE FRANCE & 32.637 & 2001 & 2004 \\
\hline SABIÁ & 32.111 & 1997 & 2007 \\
\hline CARMO BERNARDES & 639.109 & 1992 & 2009 \\
\hline BOSOUE DAS LARANJEIRAS & 76.950 & 2010 & 2010 \\
\hline ALPHAVILLE FLAMBOYANT & 356.256 & 2000 & $\begin{array}{l}\text { Loteam. } \\
\text { fechado }\end{array}$ \\
\hline PORTAL DO SOL I & 84.926 & 2000 & $\begin{array}{l}\text { Loteam. } \\
\text { fechado }\end{array}$ \\
\hline PORTAL DO SOL II & 35.591 & 2000 & $\begin{array}{l}\text { Loteam. } \\
\text { fechado }\end{array}$ \\
\hline ATENAS & 49.850 & 2002 & $\begin{array}{l}\text { Loteam. } \\
\text { fechado }\end{array}$ \\
\hline PARIS & 121.246 & 2002 & $\begin{array}{l}\text { Loteam. } \\
\text { fechado }\end{array}$ \\
\hline GOIÂNIA GOLF CLUBE & 129.684 & 2003 & $\begin{array}{l}\text { Loteam. } \\
\text { fechado }\end{array}$ \\
\hline MILÃO & 116.009 & 2004 & $\begin{array}{l}\text { Loteam. } \\
\text { fechado }\end{array}$ \\
\hline VALE DAS BRISAS & 31.604 & 2005 & Não impl. \\
\hline ARCO VERDE & 13.719 & 2006 & $\begin{array}{l}\text { Loteam. } \\
\text { fechado }\end{array}$ \\
\hline RECANTO DOS BURITIS & 337.704 & 2006 & $\begin{array}{l}\text { Loteam. } \\
\text { fechado }\end{array}$ \\
\hline VALÊNCIA & 44.655 & 2008 & $\begin{array}{l}\text { Loteam. } \\
\text { fechado }\end{array}$ \\
\hline VERONA & 31.474 & 2008 & $\begin{array}{l}\text { Loteam. } \\
\text { fechado }\end{array}$ \\
\hline \multicolumn{4}{|l|}{ SUDOESTE } \\
\hline BALIZA & 21.599 & 2001 & 2001 \\
\hline BERNARDO ELIS & 76.585 & 2010 & 2012 \\
\hline VILLAGE VENEZA & 28.852 & 1995 & Não impl. \\
\hline CENTER VILLE & & 1997 & Não impl. \\
\hline ELI FORTE & 23.207 & 1997 & Não impl. \\
\hline GRANVILLE & & 1997 & Não impl. \\
\hline SOLAR SANTA RITA I & 4.702 & 1997 & Não impl. \\
\hline SOLAR SANTA RITA II & 12.004 & 1997 & Não impl. \\
\hline GRAJAÚ & 12.970 & 1999 & Não impl. \\
\hline MADRE GERMANNA II & 19.145 & 1999 & Não impl. \\
\hline MADRI & 67.561 & 1999 & $\begin{array}{l}\text { Loteam. } \\
\text { fechado }\end{array}$ \\
\hline RIO VERDE & 19.145 & 1999 & Não impl. \\
\hline SOLAR BOUGAINVILLE I & 22.546 & 1999 & Não impl. \\
\hline SOLAR BOUGAINVILLE II & 7.522 & 1999 & Não impl. \\
\hline VEREDAS DOS BURITIS & 24.303 & 1999 & Não impl. \\
\hline ANDRÉIA CRISTINA & 10.130 & 2000 & Não impl. \\
\hline VILA LUCIANA & 19.219 & 2000 & Não impl. \\
\hline
\end{tabular}

\begin{tabular}{|c|c|c|c|}
\hline PARQUE & ÁREA $\left(\mathrm{m}^{2}\right)$ & CRIAÇÃO & INAUG. \\
\hline BALIZA & 21.599 & 2001 & Não impl. \\
\hline ORIENTVILLE & 15.000 & 2001 & Não impl. \\
\hline TALISMÃ & 3.357 & 2002 & Não impl. \\
\hline ANTONIO CRISPIM & 89.513 & 2003 & Não impl. \\
\hline JARDIM ALPHAVILLE & 17.952 & 2003 & Não impl. \\
\hline PIRACANJUBA & 85.094 & 2003 & Não impl. \\
\hline SANTA FÉ & 28.568 & 2003 & Não impl. \\
\hline CAMPOS DOURADOS & 15.721 & 2004 & Não impl. \\
\hline FIDÉLIS & 11.020 & 2004 & Não impl. \\
\hline ELDORADO & 7.592 & 2005 & Não impl. \\
\hline LISBOA & 99.646 & 2005 & Não impl. \\
\hline AQUÁRIOS II & 6.253 & 2006 & Não impl. \\
\hline CAPÃO DA MATA & 45.581 & 2006 & Não impl. \\
\hline REAL CONQUISTA & 326.991 & 2006 & Não impl. \\
\hline IPANEMA & 64.492 & 2007 & Não impl. \\
\hline JOSÉ CRISPIM BORGES & 45.386 & 2008 & Não impl. \\
\hline \multicolumn{4}{|l|}{ SUL } \\
\hline AREIÃO & 34.531 & 1992 & 1996 \\
\hline JARDIM BOTÂNICO & 1000.000 & 1978 & 2001 \\
\hline VACA BRAVA & 77.760 & 1999 & 2005 \\
\hline FLAMBOYANT & 130.000 & 2000 & 2007 \\
\hline AREIÃO II & 34.531 & 2002 & Não impl. \\
\hline \multicolumn{4}{|l|}{ VALE DA MEIA PONTE } \\
\hline FLORES II & 15.351 & 1997 & 2004 \\
\hline ITAMARACÁ & 56.606 & 2004 & 2004 \\
\hline GENTIL MEIRELLES & 445.605 & 2004 & 2008 \\
\hline IONE MARTINS DO CARMO & 19.968 & 1996 & Não impl. \\
\hline MORRO DO ALÉM & 47.027 & 1997 & Não impl. \\
\hline BALNEÁRIO & 95.879 & 2000 & Não impl. \\
\hline GUAREMA & 31.880 & 2000 & Não impl. \\
\hline HUGO DE MORAES II & 20.234 & 2000 & Não impl. \\
\hline MARABÁ & 18.061 & 2000 & Não impl. \\
\hline LICARDINO REY & 19.286 & 2001 & Não impl. \\
\hline FLORES I & 81.849 & 2004 & Não impl. \\
\hline URIAS A. TAVARES & 214.081 & 2004 & Não impl. \\
\hline CRISTINA EXTENSÃO & 17.184 & 2006 & Não impl. \\
\hline MORUMBI & 47.554 & 2006 & Não impl. \\
\hline
\end{tabular}

Os parques não implantados ou incorporados a loteamentos fechados não foram marcados nos mapas.

Tabela elaborada por Felipe Neres para este trabalho, a partir de informações da prefeitura e conferência no Google Earth. 


\section{M.16 GOIÂNIA}

Parques na malha urbana

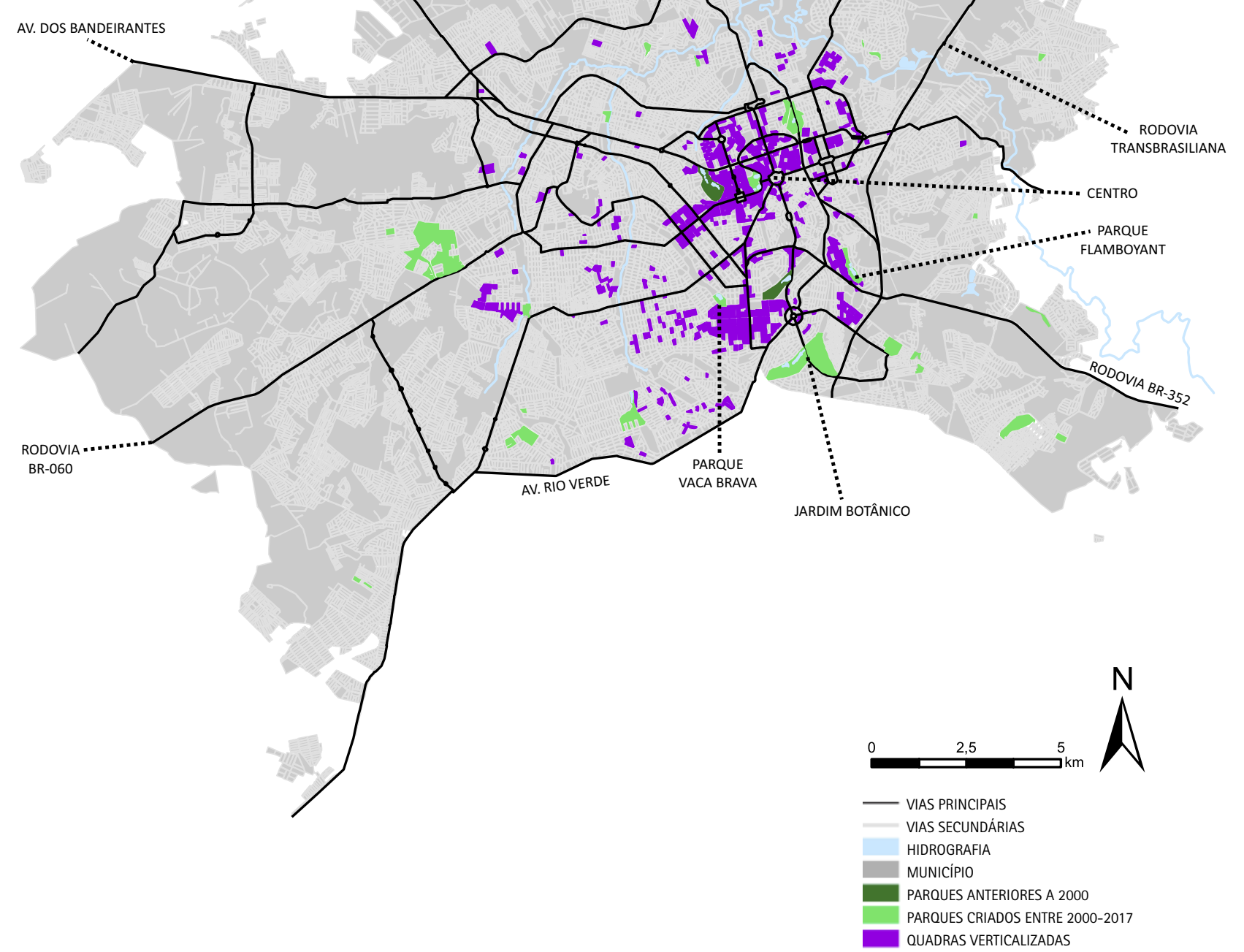




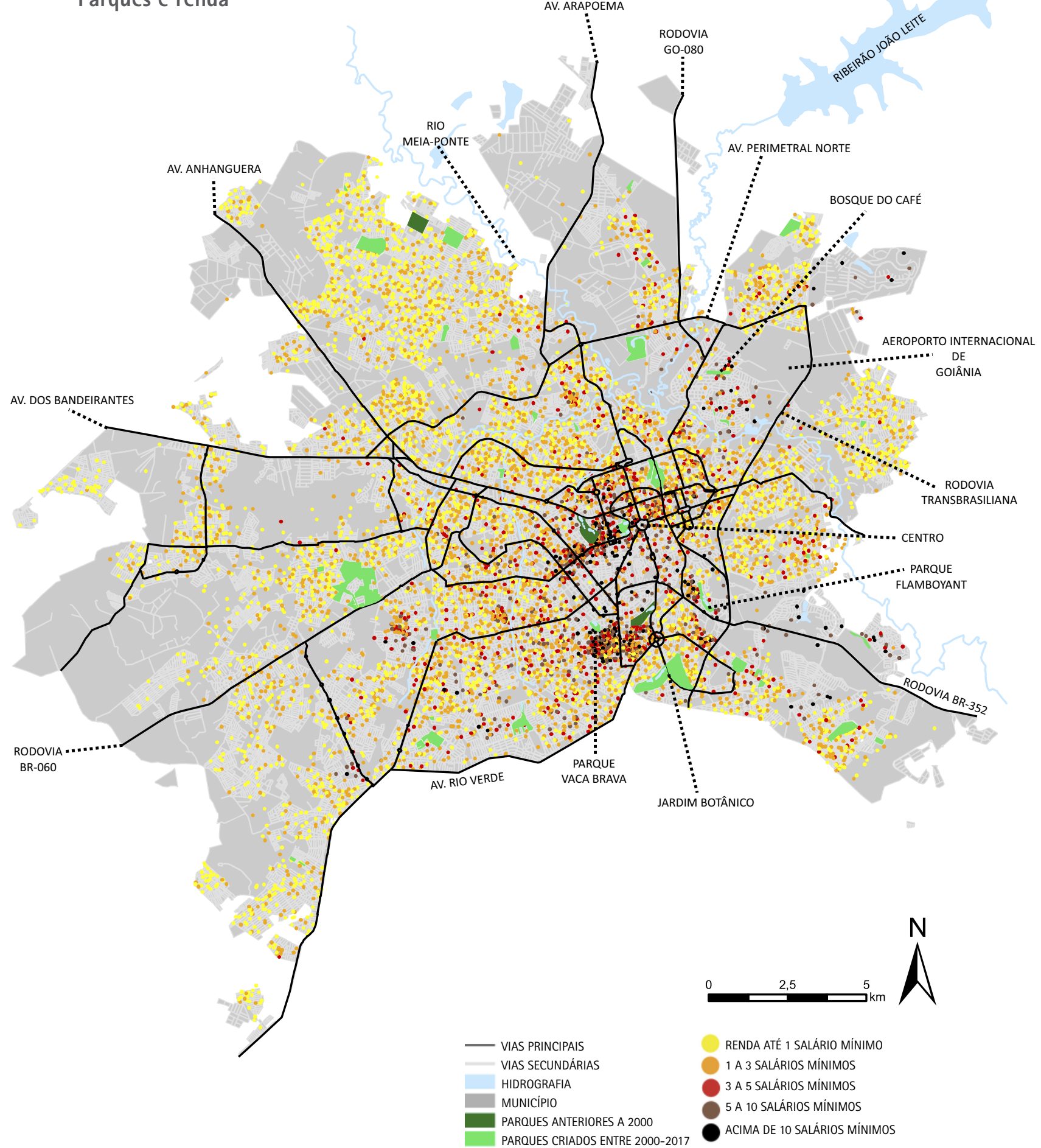


s

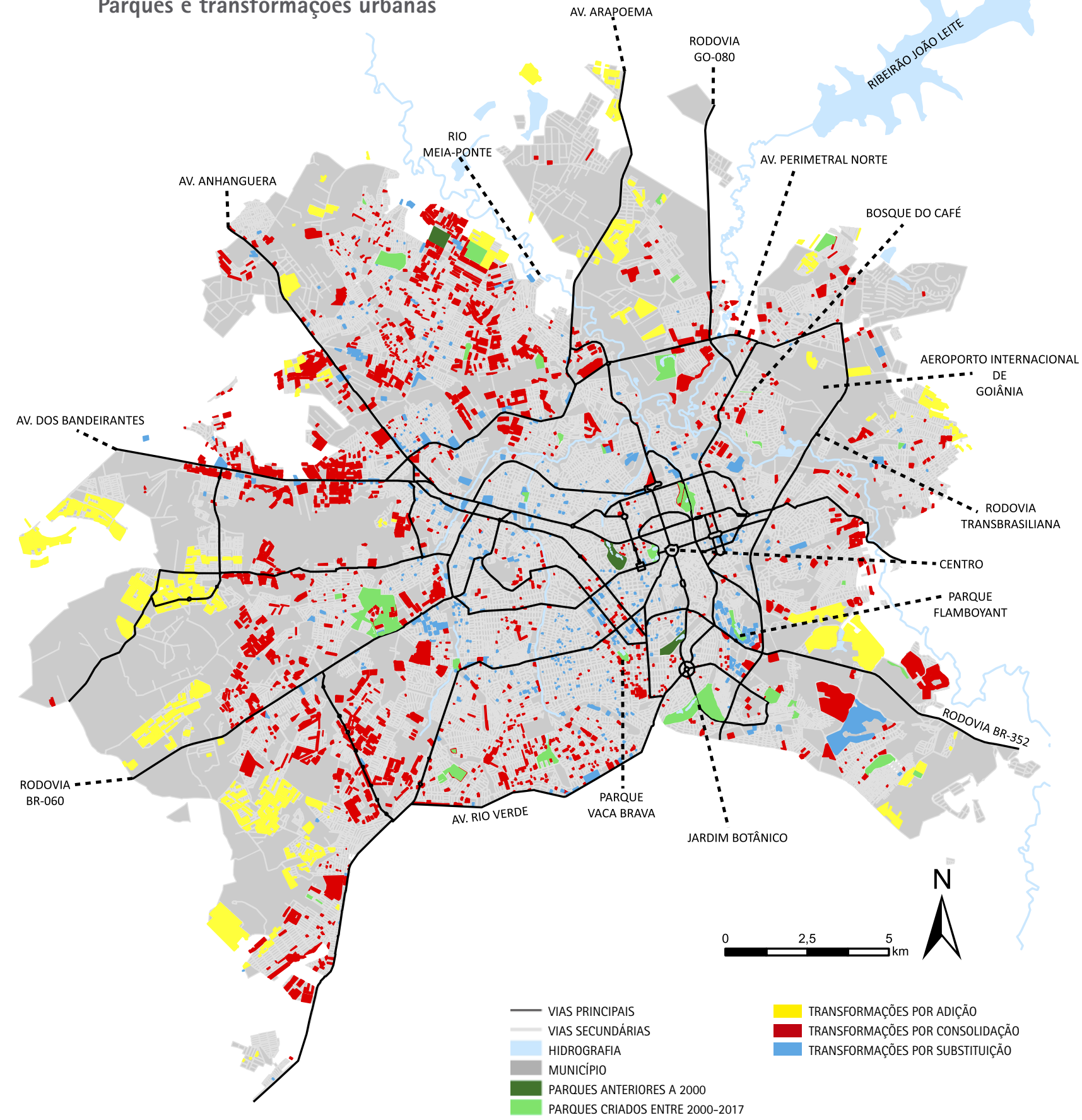




\subsection{Distrito Federal}

Brasília era uma cidade-parque na aparência, por conta dos canteiros generosos dos quais brotaram os palácios e os blocos de apartamentos, mas os usos de lazer destas áreas verdes eram limitados. Ao longo dos anos 2000, foi se consolidando uma cidade-parque também na apropriação. As mangueiras e outras árvores (exóticas ao cerrado) plantadas após a fundação da cidade estão adultas. 0 Lago Paranoá foi despoluído e abriga variados esportes náuticos. Proliferam pistas de caminhada e decks à beira d'água. Confirmando a demanda e o interesse da população por atividades recreativas ao ar livre aos domingos, as pistas do Eixão e seus canteiros laterais abrigam usos de parque como piqueniques, brinquedos infláveis, aulas de skate.

Cerca de 60\% da população mora fora do Plano Piloto, que concentra as áreas tratadas e apropriadas pelo lazer - e também os empregos. A população moradora nos arredores do Plano é obrigada a fazer um deslocamento pendular: de manhã, da periferia para o centro; no final do dia, de volta para a periferia. Para Schvarsberg (Universidade de Brasília - UnB) ${ }^{18}$, a Região Metropolitana de Brasília passa por processo de metropolização $360^{\circ}$, isto é, a consolidação do anel de munícipios-dormitório ao redor do Plano Piloto. Os fluxos na direção sul são os mais intensos, seguidos daqueles nas direções oeste e norte. Existem também fluxos pendulares na direção leste, menos expressivos. 0 resultado são grandes congestionamentos nos horários de pico.

A consolidação do Plano Piloto como espaço das elites desde a fundação da cidade trouxe, segundo Giuliana de Freitas (UnB) ${ }^{19}$, a necessidade de delimitar as áreas de ocupação popular. Assim, as cidades-satélite foram criadas dispersas pelo Distrito Federal, distantes do Plano Piloto, em geral localizadas junto das rodovias. Essa política criou grandes vazios urbanos - porções consideráveis de território predominantemente desocupadas, cercadas por áreas urbanizadas.

As políticas de ocupação das cidades-satélite visaram ao atendimento das camadas mais pobres através de programas habitacio-
18 Tiago REGUEIRA, Tiago e VESPE, Giovanni. Relatório da Oficina Quapá-SEL Brasilia, de 04 a 06/11/2015. 
20 Grupo de Trabalho Sistemas de Espaços Livres, formado por Camila Gomes, Caroline de Lima, Gabriela Maia, Giovanni Vespe, Giuliana Brito.

REGUEIRA, Tiago e VESPE, Giovanni. Relatório da Oficina Quapá-SEL Brasilia, de 04 a 06/11/2015. nais e lotes baratos; a classe média ficou com poucas opções para aquisição de moradia. Poucos programas visaram ao atendimento dessa demanda, como: a Área Octogonal Sul e o Setor Sudoeste, nos anos 1980; o bairro de Águas Claras, surgido nos anos 1990; o bairro Noroeste, que começou a ser construído em 2009. Assim, loteamentos irregulares de padrão médio e médio-alto surgiram ao redor do Plano Piloto como solução para a classe média, com terrenos mais baratos e próximos das áreas de emprego. Atualmente, três sistemas estruturam a forma urbana do Distrito Federal: o Plano Piloto, o anel de loteamentos horizontais já consolidados que o cerca e os novos eixos de expansão, sobretudo ao longo dos vetores Oeste, Sudoeste e Nordeste.

Os sistemas de espaços livres do Distrito Federal são muito diferentes entre si. 0 Plano Piloto e os bairros em torno do Lago Paranoá configuram-se como ilha e possuem grande oferta de espaços de recreação e uso público. As demais malhas urbanas, em geral, também contam com áreas verdes institucionais - mas sem tratamento. O Plano Piloto apresenta vias de muitas faixas e espaços generosos para a circulação de pedestres. Em Águas Claras, o adensamento populacional se deu com verticalização massiva, com vias insuficientes e calçadas por vezes inexistentes. ${ }^{20}$

Nos últimos vinte anos, a expansão da demanda por espaços de lazer e preservação da vegetação impulsionou a criação de novos parques. A ação mais visível, consequência desta pressão, foi a ampliação dos espaços públicos na orla do Lago Paranoá, com a desocupação de terrenos públicos que há muito estavam incorporados aos terrenos particulares das mansões construídas às margens do lago. Uma das atribuições da Agência de Fiscalização do Distrito Federal (Agefis), através do programa Território da Gente, foi promover a desobstrução das margens do Paranoá. Desmanchar jardins e decks particulares para reincorporá-los ao patrimônio público é uma ação complicada e rara no Brasil. Neste caso, resultou na ampliação da área pública de lazer. 3.32 3.33

Durante a Oficina Quapá-SEL Brasília, no esforço de reconhecimento e categorização dos parques, fez-se uma divisão baseada na função principal de cada um, resultando em quatro tipos: 1) recre- 


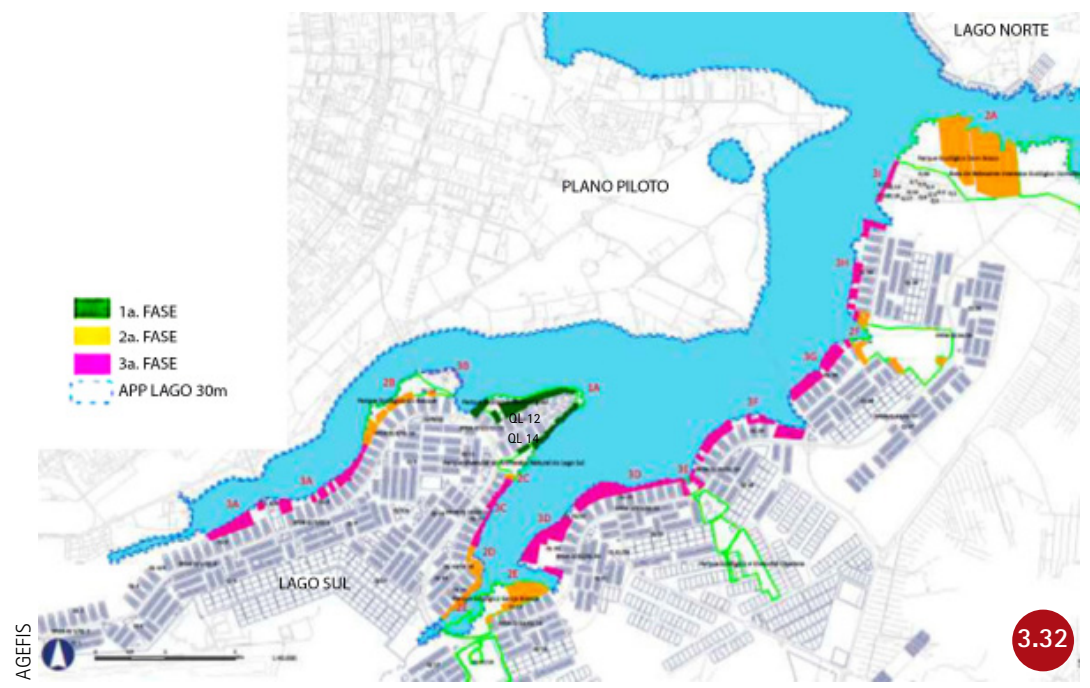

Em 2017, foi lançado o concurso para Masterplan da Orla pelo Projeto Orla Livre para a faixa desobstruída na 1a. fase.
Reintegração de posse dos terrenos públicos ao longo do Lago Paranoá. Apresentada por Rubens Amaral (Agefis) na Oficina Quapá-SEL 2015.

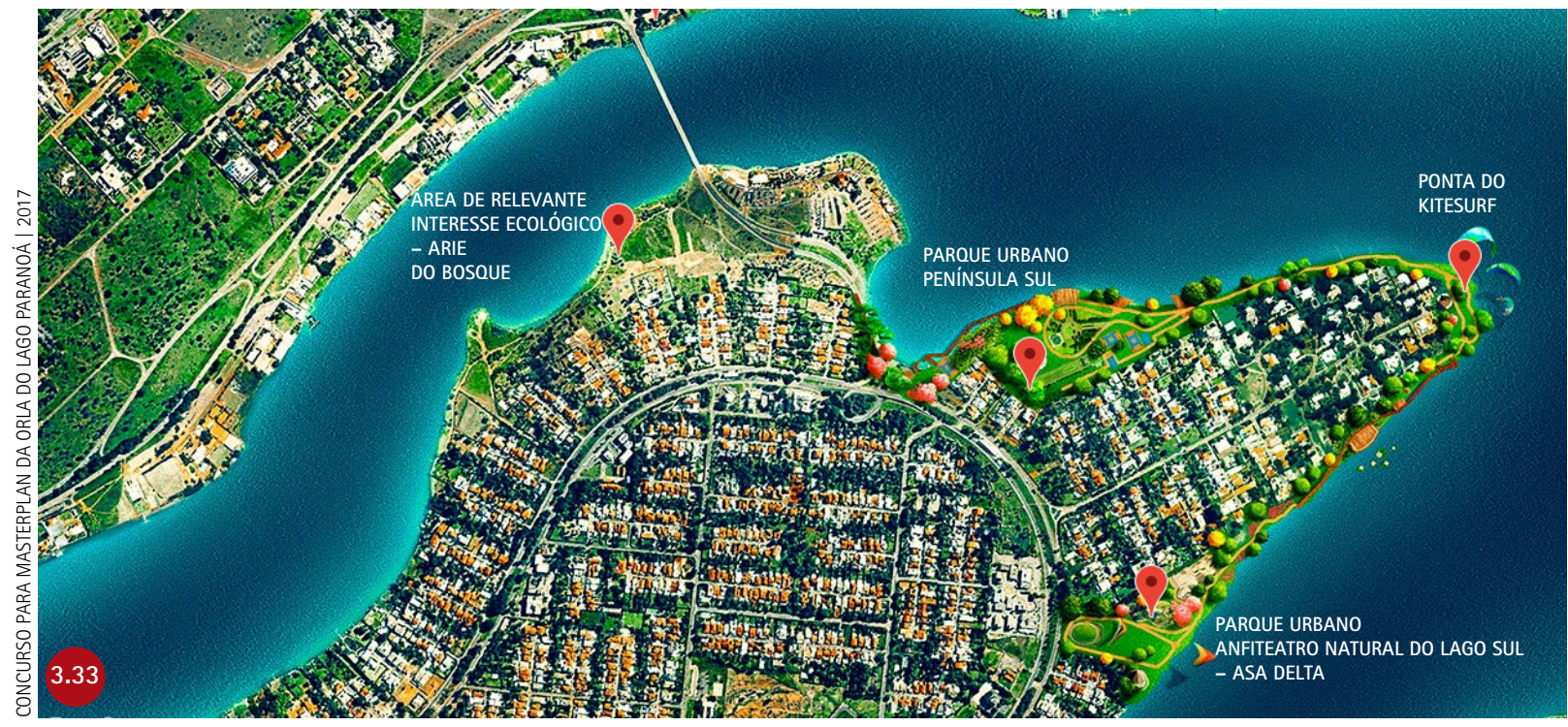

ativos, como o Parque Multifuncional da Asa Norte; 2) esportivos, como o Ecológico Três Meninas e o Taguaparque; 3) de conservação, como o Parque Nacional; 4) mistos, como o Parque da Cidade, o Jequitibá e o Ecológico Saburo Onoyama. 0 grupo identificou 27 parques implantados, três em construção e 43 não implantados. (3.34) 3.35 (3.36) 3.3.3.

Na mesma época, o Instituto Brasília Ambiental (lbram) informa que o Distrito Federal possui 72 parques ecológicos e urbanos (sem distinguir os dois tipos), além de outras 22 UCs de proteção integral ou de uso sustentável. Entre os 72 parques, apenas 33 constam 
Parque de Uso Múltiplo da Asa Norte, próximo da ponte entre a Asa Norte e o Lago Norte. A presença da água foi aproveitada para estruturar um espaço de lazer sem cercamento.
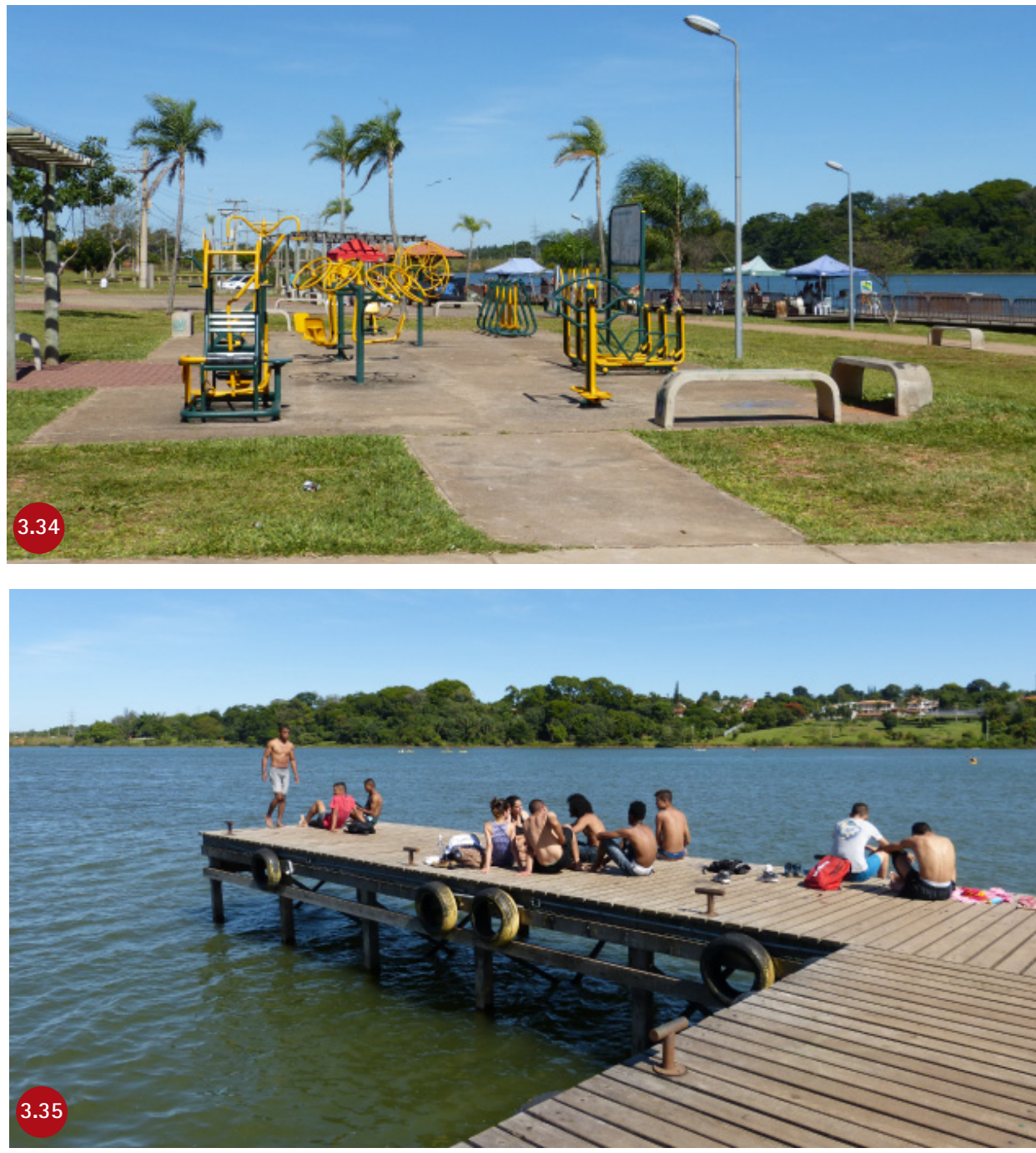

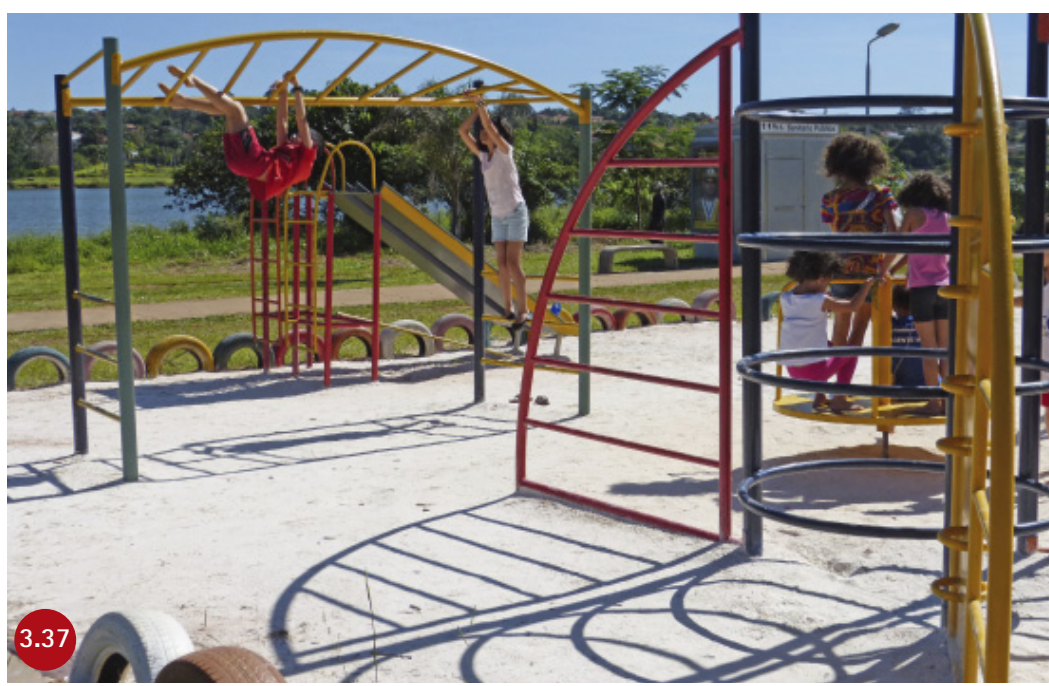


no Guia de Parques do Distrito Federal ${ }^{21}$, pois foram "[...] considerados em condições de receber visitantes que buscam espaço para realizar atividades físicas, de lazer ou simplesmente contemplação da natureza”.

Neste trabalho, através de imagens do Google, foram checados os 78 parques do Distrito Federal. Desconsiderando os que não têm sinais de fruição pública e também o Parque das Copaíbas, que apresenta parte da sua área invadida, restaram 30 parques.

Parte dos parques contou com verbas de compensação ambiental do Programa Brasília, Cidade Parque ${ }^{22}$. 0 processo de criação sequencial dos parques começou com a identificação, em mapa, de áreas que poderiam ser conservadas, sem qualquer relação com as demandas de uso da população. Essa proposta ganhou corpo entre técnicos e dirigentes, e assim os parques foram sistematicamente criados.

Segundo o lbram, os parques possuem em média 1\% de área destinada a atividades de lazer, 58\% para vegetação nativa e $41 \%$ de áreas degradadas (destas, 60\% podem ser recuperadas).

Faltam recursos e pessoal para a manutenção. Foi relatada a existência de um carrinho para transportar pessoas com deficiência em um dos parques, mas não havia funcionário para guiá-lo. Assim, em 2014 começaram a ser buscados modelos de gestão compartilhada para que os parques se tornassem replicáveis e sustentáveis em longo prazo $^{23}$. No Cerrado as equipes de manutenção lidam com problemas adicionais: os incêndios. Quando o Cerrado era abundante, as queimadas faziam parte da dinâmica ecológica e a regeneração podia demorar. Estando este ecossistema em extinção, as queimadas são um grave problema, e tem-se os parques como parte da solução.

Em 2014 a criação de novos parques declinou; em 2017 foi realizado o Concurso Nacional de Arquitetura para os parques Central e Sul de Águas Claras. Embora tivesse já recebido algum investimento, o Parque Águas Claras ainda não é um parque completo, com projeto que lhe confira identidade e valorize os apartamentos de Águas Claras. 3.40
22 Parques considerados implantados no âmbito do Programa Brasilia, Cidade Parque, com verbas de compensação ambiental: Parque dos Jequitibás; Parque Asa Sul; Parque Ecológico Ezechias Heringer; Parque Bosque do Sudoeste; Parque Ecológico Águas Claras; Parque do Areal; Parque Ecológico Dom Bosco; Parque Ecológico Três Meninas; Parque Olhos D'Água; Parque Ecológico Saburo Onoyama; Parque Lago do Cortado. As compensações também financiaram investimentos no Jardim Botânico de Brasilia.

Disponivel em: <http://www.ibram.df.gov. br/component/content/article/297.html>

23 Evento Parques do Brasil, promovido por Arq. Futuro em São Paulo, 7/10/2014. Painel Compensação ambiental: os compromissos com o desenvolvimento urbano, com Ricardo Birmann, presidente da Urbanizadora Paranoazinho S/A e Nilton Reis, presidente do Ibram/DF. Disponivel em: <http://arqfuturo.com.br/ encontros/post/623>. 
Parque Olhos D'Água. Compõe-se basicamente de percurso quase perimetral que atravessa lagoas, bosques e campos de cerrado. Bancos, cercamentos e sinalização são rústicos e posicionados sem um projeto arquitetônico formal. A população se mobilizou pela sua criação após um crime ocorrido na área. Tem uso muito intenso para caminhadas, tanto na parte interna quanto nas calçadas ao seu redor. 0 projeto é pouco perceptível: o mobiliário, por exemplo, não foi selecionado e posicionado a partir de um projeto completo arquitetônico e paisagístico.

O Parque Águas Claras (2009) tem um desenho simples, aquém do Parque da Cidade. Sua requalificação valorizaria todo este bairro.
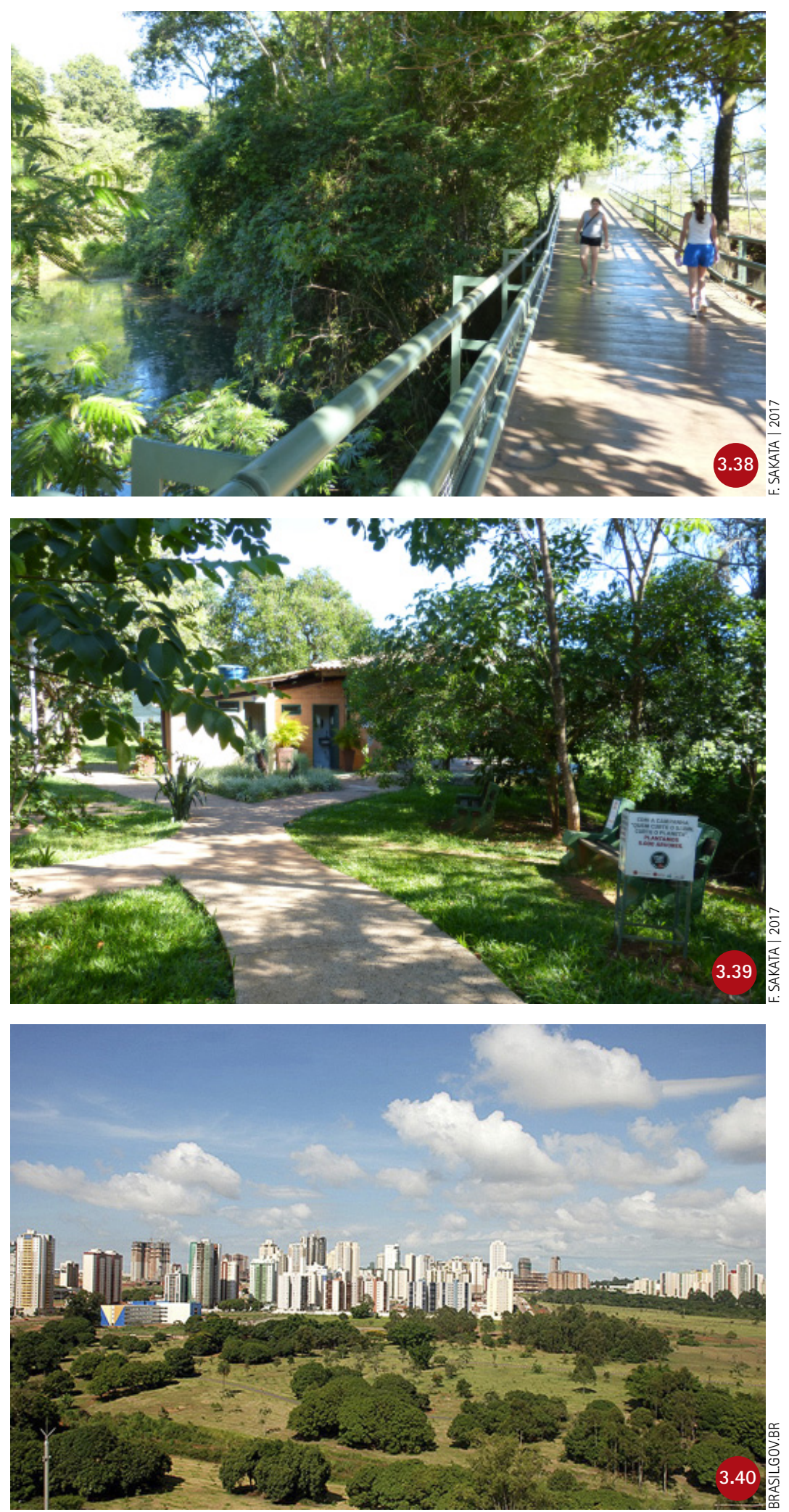
CAPÍTULO 3. DISTRIBUIÇÃO PELO ESPAÇO URBANO

\begin{tabular}{|c|c|c|c|c|}
\hline \multicolumn{5}{|l|}{ DISTRITO FEDERAL } \\
\hline PARQUE & REGIÃO & ÁREA $\left(\mathrm{m}^{2}\right)$ & CRIAÇÃO & ABERTURA \\
\hline JARDIM ZOOLÓGICO DE BRASÍLIA & CANDANGOLÂNDIA & 1.041 .592 & & 1957 \\
\hline NACIONAL DE BRASÍLIA & ZONA INDUSTRIAL & 423.555 .400 & & 1961 \\
\hline JARDIM BOTÂNICO DE BRASÍLIA & CORREGO RONCADOR & 4.682 .957 & 1961 & 1985 \\
\hline DONA SARAH KUBITSCHEK (PARQUE DA CIDADE) & ASA SUL & 3.936 .842 & 1974 & 1974 \\
\hline TRÊS MENINAS & SAMANBAIA & 461.765 & & 1993 \\
\hline OLHOS D'ÁGUA & ASA NORTE & 255.262 & 1994 & 1994 \\
\hline DOS JEQUITIBÁS & SOBRADINHO & 200.110 & 1994 & 1998 \\
\hline AREAL & ÁGUAS CLARAS & 50.528 & & 1994 \\
\hline ECOLÓGICO DE SÃO SEBASTIÃO & SÃO SEBASTIÃO & 170.669 & & 1994 \\
\hline VEREDINHA & BRAZLÂNDIA & 690.632 & & 1994 \\
\hline RECREATIVO DO SETOR O & CEILÂNDIA & 160.968 & & 1995 \\
\hline DAS AVES & ASA SUL & 1.017 .788 & & 1996 \\
\hline ONOYAMA & TAQUATINGA & 1.410 .248 & & 1996 \\
\hline RECREATIVO DO GAMA & TAQUATINGA & 1.360 .000 & 1961 & * \\
\hline RECREATIVO SUCUPIRA & PLANALTINA & 1.304 .212 & & 1996 \\
\hline ECOLÓGICO CANELA DE EMA & SOBRADINHO & 5.250 .000 & & 1997 \\
\hline VIVENCIAL DO RIACHO FUNDO & RIACHO FUNDO II & 3.727 .879 & & 1997 \\
\hline PARQUE RECREATIVO DO N. BANDEIRANTE & CANDANGOLÂNDIA & 47.231 & & 1997 \\
\hline VIVENCIAL ANFITEATRO DO LAGO SUL & LAGO SUL & 84.336 & & 1998 \\
\hline $\begin{array}{l}\text { ECOLÓGICO E VIVENCIAL DA LAGOA JOAQUIM DE } \\
\text { MEDEIROS }\end{array}$ & PLANALTINA & 383.743 & & 1998 \\
\hline ECOLÓGICO DOM BOSCO & LAGO SUL & 1.688 .052 & 1999 & 1999 \\
\hline ECOLÓGICO PENÍNSULA SUL & LAGO SUL & 140.000 & & 2003 \\
\hline TAGUAPARQUE & VICENTE PIRES & 1.063 .920 & 1999 & 2009 \\
\hline ECOLÓGICO DO PEQUIZEIRO & PLANALTINA & 7.869 .666 & 1999 & * \\
\hline ECOLÓGICO DE ÁGUAS CLARAS & ÁGUAS CLARAS & 681.262 & 2000 & 2009 \\
\hline ECOLÓGICO DAS GARÇAS & LAGO NORTE & 96.395 & 2002 & * \\
\hline ECOLÓGICO DE TORORÓ & CACHETA & 5.340 .842 & 2002 & * \\
\hline LAGO DO CORTADO & TAQUATINGA & 1.087.010 & 2002 & * \\
\hline USO MULTIPLO DO LAGO NORTE & LAGO NORTE & 379.375 & 2002 & * \\
\hline MULTIUSO DA ASA SUL & ASA SUL & 271.468 & * & 2011 \\
\hline BOSOUE DO SUDOESTE & SUDOESTE & 6.686 há & * & 2013 \\
\hline RECREATIVO DO SUCUPIRA & PLANALTINA & 1.244 .400 & 1996 & 2014 \\
\hline URBANO E VIVENCIAL DO GAMA & SETOR NORTE & 520.000 & * & 2017 \\
\hline
\end{tabular}

*Não encontrado

Tabela elaborada por Caroline Ribeiro para este trabalho, a partir de informações do Guia de Parques do GDF com conferência no Google Earth através da qual outros parques foram encontrados.
Nesta tabela:

\begin{tabular}{l}
$\square$ Parques anteriores a 2000 \\
\hline$\square$ criados entre $2000-2017$
\end{tabular} 
M.19 DISTRITO FEDERAL

Parques na malha urbana

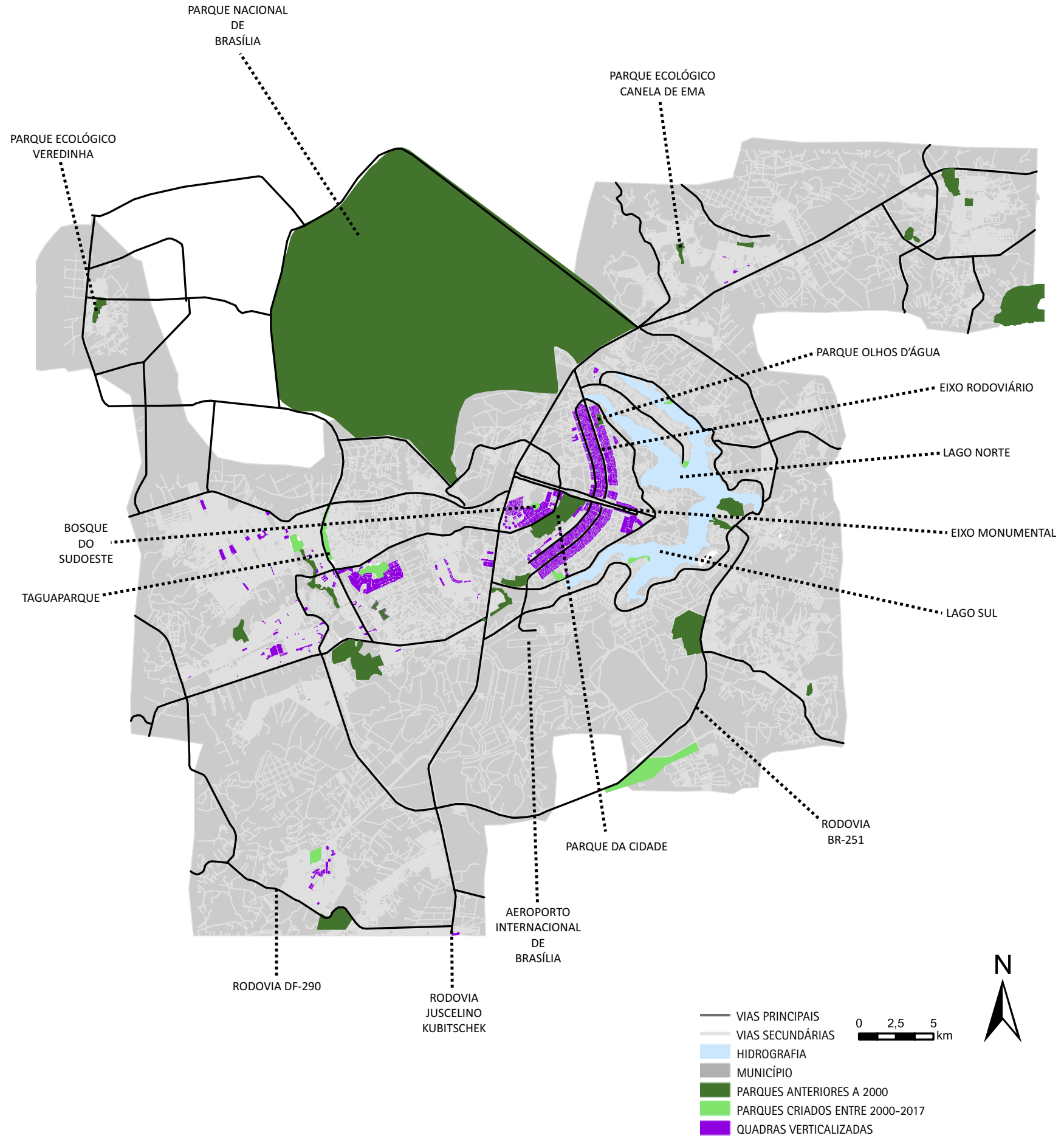


M.20 DISTRITO FEDERAL

Parques e renda

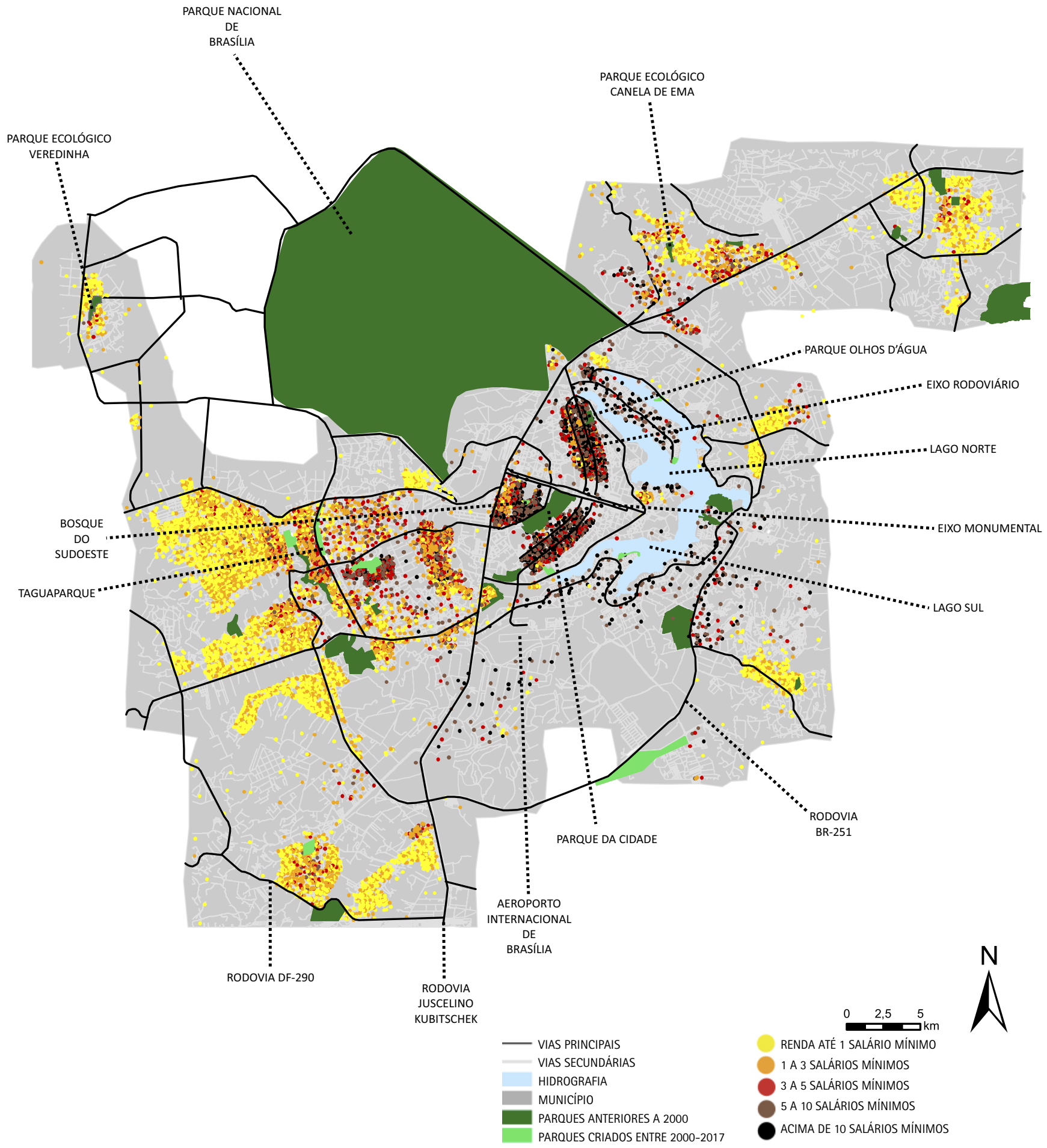


M.21 DISTRITO FEDERAL

Parques e transformações urbanas

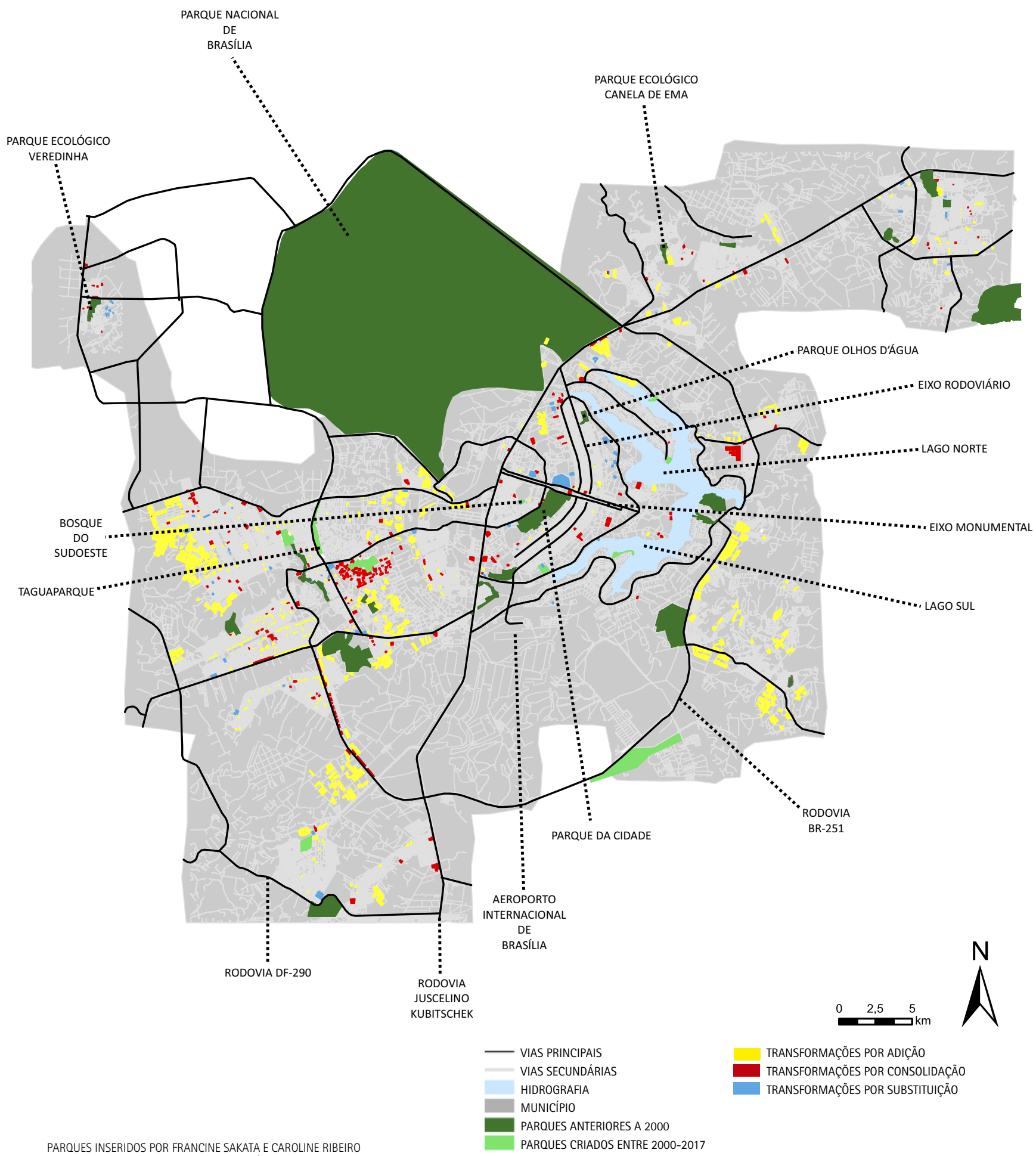




\subsection{Curitiba}

0 Instituto de Pesquisa e Planejamento de Curitiba (lppuc) foi criado para desenvolver o Plano Diretor de 1966 - cuja estrutura institucional foi mais importante que o próprio plano -, contando com o apoio dos prefeitos ao longo de sucessivas administrações. 0 grande símbolo desse planejamento urbano é o transporte coletivo, mas na década de 1990 também ganhou destaque o sistema de parques, bosques e ciclovias, estruturado para reter a água das chuvas, que causava enchentes, prevenir a ocupação desordenada dos mananciais e servir como espaços para o lazer da população. Os parques passaram a ser muito utilizados para a prática de atividades físicas, visando à saúde e ao bem-estar, e contribuíram para a valorização imobiliária do setor da cidade onde se concentraram. A municipalidade passou a investir no city marketing, tendo os parques como ícones da qualidade de vida aliada à preservação ambiental. A cada ano um novo parque era criado, possuindo temas como homenagem aos italianos, alemães, portugueses etc. ${ }^{24}$

Muitas mudanças aconteceram na década de 2000: novos produtos imobiliários, loteamentos de alto padrão, assentamentos informais, empresas se instalando na região metropolitana etc. De acordo com Silva, as favelas cresceram em número de habitantes, se adensaram se expandiram ao norte, numa coroa da urbanização periférica junto às APAs, e também ao sul. Há muitos núcleos com menos de 50 unidades, que escapam dos levantamentos oficiais que consideram aglomerado subnormal aqueles com mais de 51 unidades. ${ }^{25}$ Nos anos 2000, são feitos conjuntos do MCMV, sobretudo no sul de Curitiba e em São José dos Pinhais, em áreas periféricas, distantes dos transportes públicos da cidade.

Em relação aos espaços livres, há duas grandes APAs, lguaçu e Passaúna, opostas no território, e muitos bosques de matas remanescentes dentro do município. Os parques são mais numerosos e mais bem distribuídos na região norte e um pouco no sudeste, e há extensa área sem parques até a proximidade do grande Parque Regional do lguaçu e do Jardim Zoológico. As praças e os "jardinetes" (termo local para praças) ${ }^{26}$ estão distribuídos por todo território e a periferia ainda conta com muitas canchas de futebol. ${ }^{27}$
24 SAKATA, Francine. Paisagismo urbano: requalificação e criação de imagens. São Paulo: Edusp, 2011.

25 SILVA, Madianita Nunes da. A dinâmica de produção dos espaços informais de moradia e o processo de metropolização em Curitiba. 2012. 259f. Tese (Doutorado em Geografia) - Faculdade de Geografia, Universidade Federal do Paraná, Curitiba, 2012.

260 Decreto 427/1983, que define critérios para denominação de áreas públicas ajardinadas, define jardinete como áreas de até $2.500 \mathrm{~m}^{2}$. As praças são definidas pelo mesmo Decreto como áreas com mais de $2.500 \mathrm{~m}^{2}$. Alessandro Rosanelli, da Universidade Federal do Paraná, ressalva que existem praças oficiais com área menor.

27 CUSTÓRIO, Vanderli et al. Relatório Oficina Quapá-SEL Curitiba, 10 a 11 de junho de 2015. 
28 ROMANUS, Luciana Evans. Sistemas de Espaços Livres na Região Metropolitana de Curitiba. 2016. Relatório Científico. São Paulo: CNPq, 2016.

29 Disponivel em: <http://www.curitiba. pr.gov.br/noticias/prefeito-gustavo-fruet-inaugura-parque-ybere-no-campo-de-santana/40738>.
Nos anos 2000, a SMMA criou o Sistema de Unidades de Conservação e o Código Florestal de Curitiba. 0 sistema reconhece ${ }^{28}$ :

- Parques de Conservação: de propriedade do município com área mínima de 10 hectares;

- Parques Lineares: áreas de propriedade pública ou privada,

- Parques de Lazer: de propriedade do município, com pelo menos 10 hectares, destinados ao lazer e com características naturais de interesse à proteção;

- Reservas Biológicas: de propriedade pública ou privada,

- Bosques Nativos Relevantes: de propriedade particular com restrições à ocupação;

- Bosques de Conservação: de propriedade do município, menores que 10 hectares, destinados à "manutenção da qualidade de vida";

- Bosques de Lazer: de propriedade do município com área inferior a 10 hectares, destinados à proteção de recursos naturais com predominância de uso público ou lazer;

- Específicas: unidades de conservação como Jardim Botânico, Pomar Público, Zoológico e Nascentes.

Outra categoria de espaço público criada pela prefeitura é o Eixo de Animação, que engloba um conjunto de canteiros e praças configurando um parque linear. 0 mais famoso é o da Rua Schiller, sobre um rio tamponado na década de 1970, quando foi projetado com o nome original de Jardim Ambiental 2.

Salvo as ruas, os demais espaços livres públicos são geridos pela pela SMMA. São cerca de 30 parques, 16 bosques, um jardim botânico, inúmeras praças e jardinetes e bosques públicos cercados, não abertos à visitação. Há também 15 Reservas Particulares do Patrimônio Natural (RPPNs), sob a responsabilidade dos proprietários.

Curitiba tem um projeto de grande envergadura em andamento, o Programa Rio Parque de Conservação Barigui, composto por quatro parques e quatro bosques existentes e seis parques inaugurados pela gestão municipal de 2013-2016 com recursos da Prefeitura e do Fundo Francês de Desenvolvimento - Guairacá (2014): Mané Garrincha (2014), Bosque dos Mundiais (2014), Vista Alegre (2015), Reserva do Bugio (2015), Mairi (2016) e Yberê (2016).

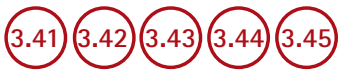


A Reserva do Bugio possui área de 827 milhões de $\mathrm{m}^{2}$ no limite entre os municípios de Curitiba, Araucária e Fazenda Rio Grande. No discurso do poder público, três pilares sustentam a criação deste grande parque linear: melhora a qualidade da água da bacia, ajuda a evitar enchentes e previne ocupações irregulares. ${ }^{29}$

Os parques dos anos 2000 foram implantados especialmente ao longo do Barigui, de norte a sul do município, em operações que envolveram a remoção de ocupações de baixa renda. Nos anos 1990 , eles predominaram na zona norte da cidade e seus projetos foram costurados em torno de temas folclóricos que favoreciam a apropriação turística. Nos anos 2000, os projetos foram desenhados mais sóbrios, sem temas, privilegiando a questão ambiental e a distribuição de caminhos e de equipamentos de lazer que não exijam manutenção sofisticada.

As administrações dos municípios vizinhos também buscam criar parques. São José dos Pinhais criou o Parque São José em 2011 e o nomeou como seu o primeiro parque por conta do programa esportivo mas já contava com o Parque da Fonte, que tem características de reserva de mata e que, desde 1999, sedia anualmente uma atração folclórica: a casa do papai noel.
A Reserva do Bugio (2015) congrega três unidades de conservação e se distribui pelos municípios de Araucária, Curitiba e Fazenda Rio Grande, em trechos dos rios Iguaçu, Barigui e Maurício.

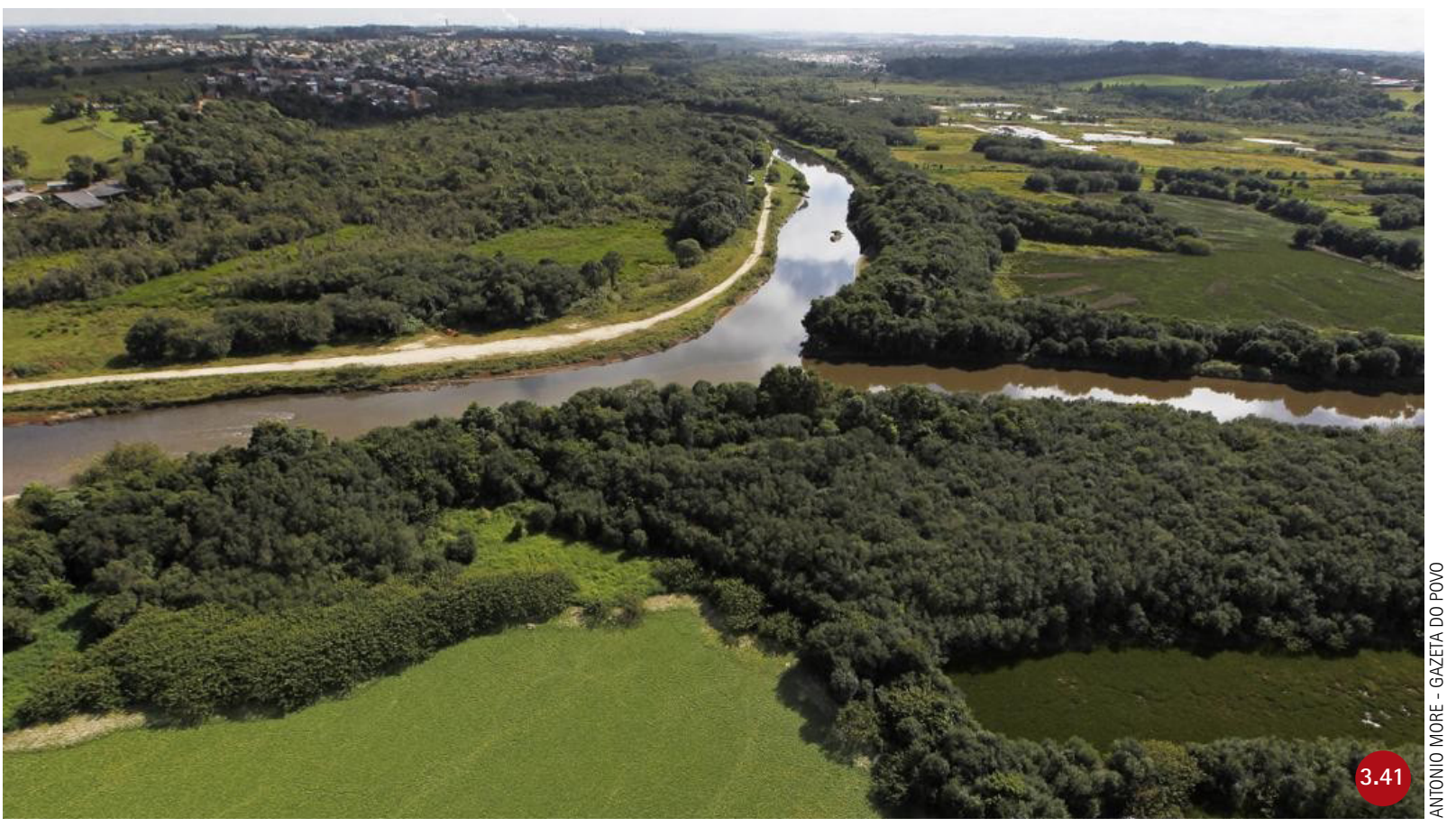


Parque Linear do Rio Barigui com o Parque Guairacá em projeto.
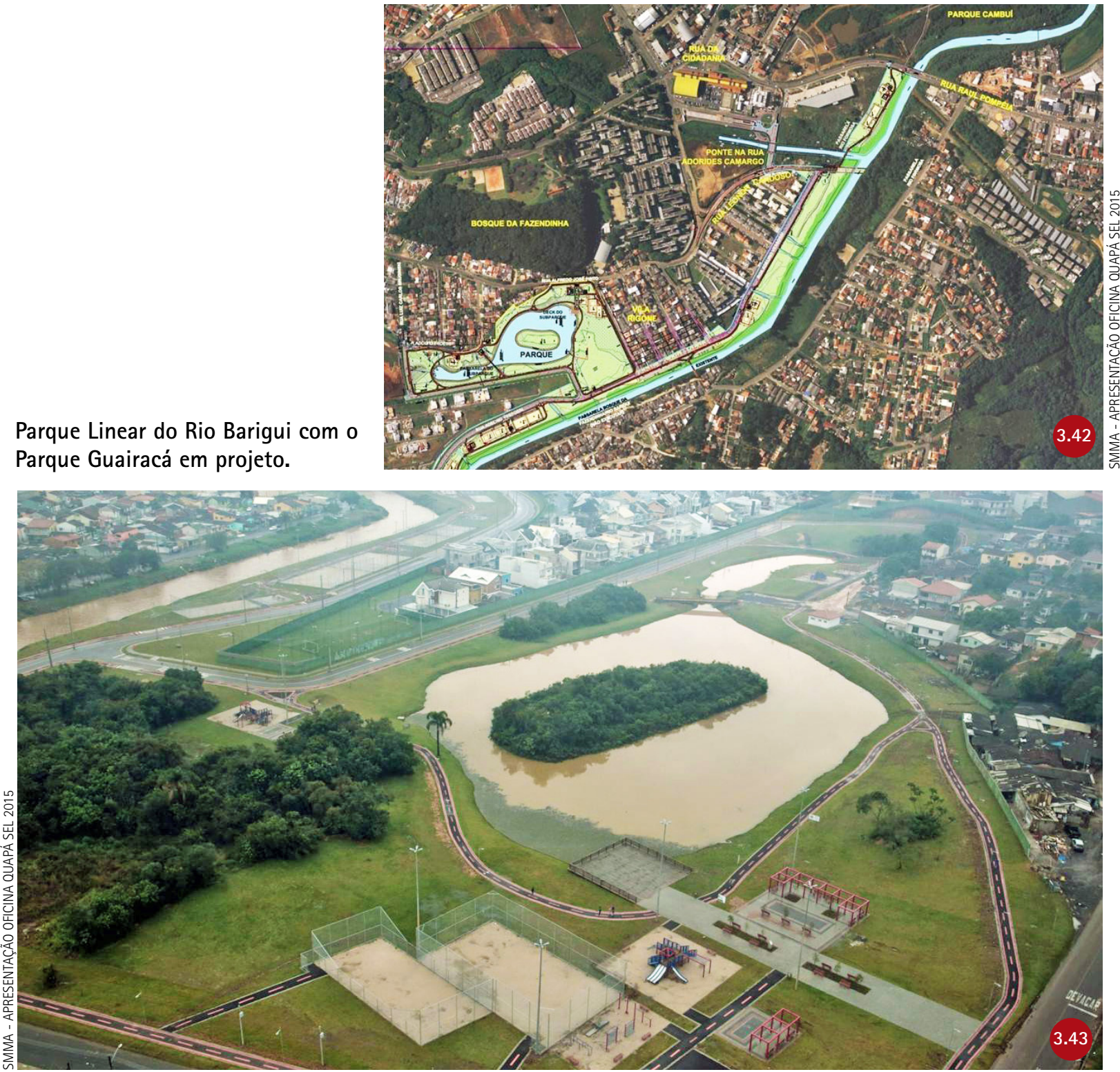

Parque Guairacá (2016), com $118.178 \mathrm{~m}^{2}$, incluiu a relocação de famílias que moravam na área e a implantação de equipamentos de lazer. Não há temas folclóricos mas foi feita trilha didática, que começa no deck sobre o lago, com placas sobre a importância de nascentes e banhados.

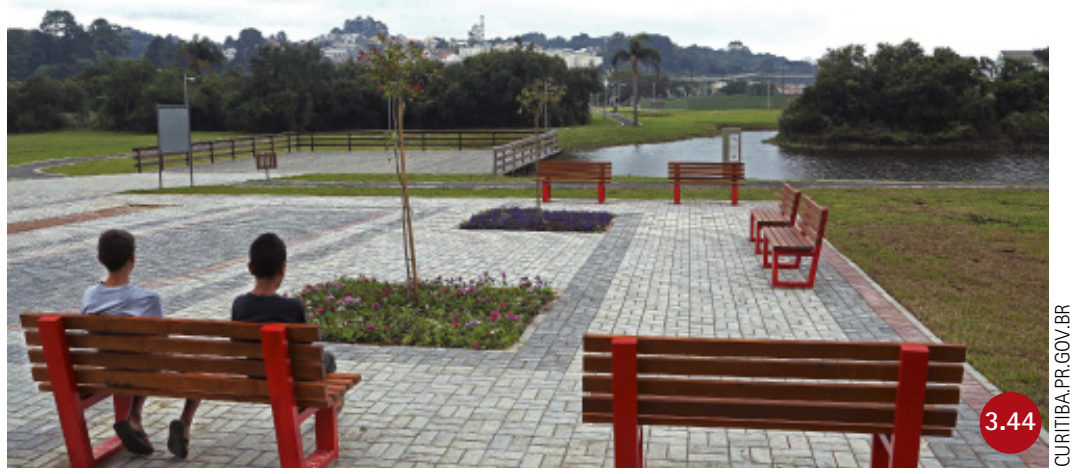


Nesta tabela:

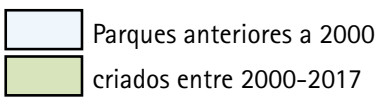

Curitiba, divisão administrativa.

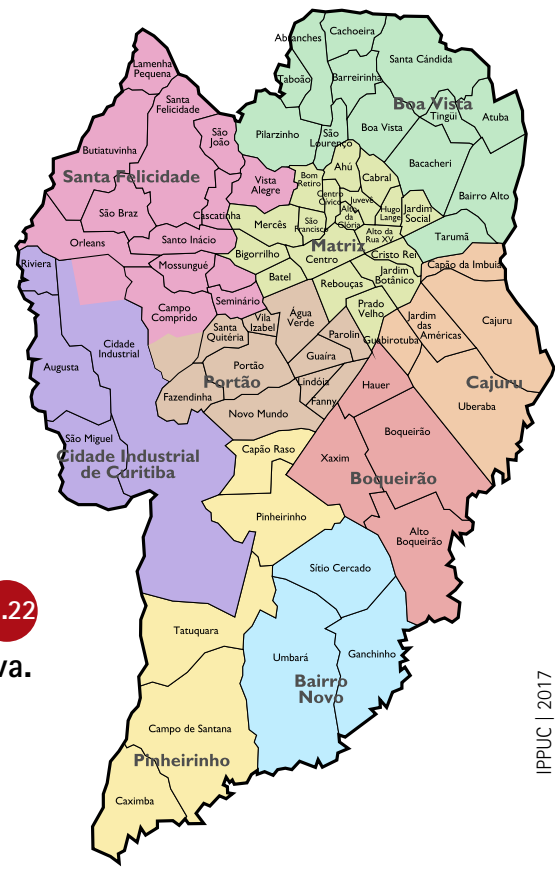

\begin{tabular}{|c|c|c|c|}
\hline \multicolumn{4}{|l|}{ CURITIBA } \\
\hline PARQUE & BAIRRO & ÁREA $\left(\mathrm{m}^{2}\right)$ & INAUG \\
\hline \multicolumn{4}{|l|}{ MATRIZ } \\
\hline PASSEIO PÚBLICO & CENTRO & 79.100 & 1886 \\
\hline VELÓDROMO MUNICIPAL & JARDIM BOTÂNICO & 256.257 & 1979 \\
\hline BOSQUE JOÃO PAULO II & CENTRO CIVICO & 77.946 & 1980 \\
\hline JARDIM BOTÂNICO & JARDIM BOTÂNICO & 278.000 & 1991 \\
\hline BOSQUE DE PORTUGAL & JARDIM SOCIAL & 57.453 & 1994 \\
\hline PARQUE GOMM & BATEL & 10.000 & 2016 \\
\hline \multicolumn{4}{|l|}{ SANTA FELICIDADE } \\
\hline PARQUE BARIGUI & MERCÊS & 1.106 .932 & 1972 \\
\hline BOSOUE DOUTOR JOÃO CARLOS HARTLEY GUTIERREZ & VISTA ALEGRE & 28.482 & 1986 \\
\hline PARQUE TINGUI & BUTIATUVINHA & 92.017 & 1994 \\
\hline BOSOUE ITALIANO & BUTIATUVINHA & 92.017 & 1993-1996 \\
\hline BOSQUE ALEMÃO & VISTA ALEGRE & 42.979 & 1996 \\
\hline BIODIVERSIDADE URBANA SANTA PAULA & SANTO INÁCIO & 11.000 & 2010 \\
\hline BOSQUE DA VISTA ALEGRE & VISTA ALEGRE & 119.985 & 2015 \\
\hline \multicolumn{4}{|l|}{ BOA VISTA } \\
\hline PARQUE DO BARREIRINHA & BARREIRINHA & 118.299 & 1972 \\
\hline PARQUE SÃO LOURENÇO & SÃO LOURENÇO & 268.250 & 1972 \\
\hline BOSOUE DOUTOR MARTIN LUTERO & BOA VISTA & 37.185 & 1974 \\
\hline PARQUE GENERAL IBERÊ DE MATTOS & BACACHERI & 141.007 & 1988 \\
\hline PARQUE DAS PEDREIRAS & PILARZINHO & 101.149 & 1990 \\
\hline BOSQUE DO PILARZINHO & PILARZINHO & 27.214 & 1991 \\
\hline BOSQUE ZANINELLI - UNILIVRE & PILARZINHO & 53.426 & 1992 \\
\hline
\end{tabular}


CAPÍTULO 3. DISTRIBUIÇÃO PELO ESPAÇO URBANO

\begin{tabular}{|c|c|c|c|}
\hline PARQUE & BAIRRO & ÁREA $\left(\mathrm{m}^{2}\right)$ & INAUG \\
\hline PARQUE TANGUÁ & TABOÃO & 166.816 & 1996 \\
\hline PARQUE MUNICIPAL NASCENTES DO BELÉM & CACHOEIRA & 84.597 & 2001 \\
\hline PARQUE NATURAL MUNICIPAL ATUBA & ATUBA & 123.199 & 2004 \\
\hline BOSQUE IRMÃ CLEMENTINA & BAIRRO ALTO & 26.956 & 2008 \\
\hline BOSQUE PROFESSOR ERWIN GRÖGER & ABRANCHES & 3.000 & 2010 \\
\hline \multicolumn{4}{|l|}{ CAJURU } \\
\hline $\begin{array}{l}\text { CENTRO POLIESPORTIVO DIRCEU JOSÉ GUIMARÃES } \\
\text { (PARQUE DOS PELADEIROS) }\end{array}$ & CAJURU & 360.080 & 1981 \\
\hline PARQUE IGUAÇU & UBERABA & 8.922 .984 & 1978 \\
\hline BOSQUE DO CAPÃO DA IMBUIA & CAPÃO DA IMBUIA & 44.916 & 1981 \\
\hline PARQUE LINEAR CAJURU & CAJURU & 155.035 & 2003 \\
\hline BIODIVERSIDADE URBANA MERCÚRIO & CAJURU & 73.181 & 2014 \\
\hline BIODIVERSIDADE URBANA ENG. RENATO RIBEIRO CARDOSO & UBERABA & 6.958 & 2016 \\
\hline \multicolumn{4}{|l|}{ PORTÃO } \\
\hline BOSQUE DA FAZENDINHA & FAZENDINHA & 72.952 & 1995 \\
\hline PARQUE CAMBUÍ & FAZENDINHA & 125.903 & 2008 \\
\hline BOSQUE DOS MUNDIAIS & PORTÃO & 9.000 & 2014 \\
\hline PARQUE GUAIRACÁ & FAZENDINHA & 118.178 & 2014 \\
\hline PARQUE LINEAR DO BARIGUI & FAZENDINHA & 276.763 & 2017 \\
\hline \multicolumn{4}{|l|}{ BOQUEIRÃO } \\
\hline BOSOUE REINHARD MAACK & HAUER & 93.168 & 1989 \\
\hline \multicolumn{4}{|l|}{ BAIRRO NOVO } \\
\hline BOSQUE DOS 300 ANOS & SITIO CERCADO & 15.000 & 1993 \\
\hline PARQUE DO SEMEADOR & SITIO CERCADO & 25.378 & 1997 \\
\hline PARQUE LAGO AZUL & GANCHINHO & 227.152 & 2008 \\
\hline BOSQUE SAMBAQUI & UMBARÁ & 130.847 & 2011 \\
\hline \multicolumn{4}{|l|}{ CIDADE INDUSTRIAL DE CURITIBA } \\
\hline PARQUE DO PASSAÚNA & AUGUSTA & 5.018 .883 & 1991 \\
\hline PARQUE CAIUÁ & CIDADE INDUSTRIAL & 55.565 & 1994 \\
\hline PARQUE DIADEMA & CIDADE INDUSTRIAL & 112.802 & 1994 \\
\hline PARQUE DOS TROPEIROS & SÃO MIGUEL & 123.447 & 1994 \\
\hline BOSOUE DO TRABALHADOR & CIDADE INDUSTRIAL & 360.315 & 1996 \\
\hline BOSQUE SÃO NICOLAU & CIDADE INDUSTRIAL & 21.757 & 2000 \\
\hline PARQUE TULIO VARGAS & CIDADE INDUSTRIAL & 53.157 & $2006 / 2009$ \\
\hline PARQUE MANÉ GARRINCHA & CIDADE INDUSTRIAL & 120.000 & 2014 \\
\hline PARQUE MAIRI & CIDADE INDUSTRIAL & 43.000 & 2016 \\
\hline \multicolumn{4}{|l|}{ TATUQUARA } \\
\hline RESERVA DO BUGIO & TATUQUARA & 8.000 .000 & 2015 \\
\hline PARQUE YBERE & CAMPO DE SANTANA & 238.000 & 2016 \\
\hline
\end{tabular}


M.23 CURITIBA

Parques na malha urbana PARque

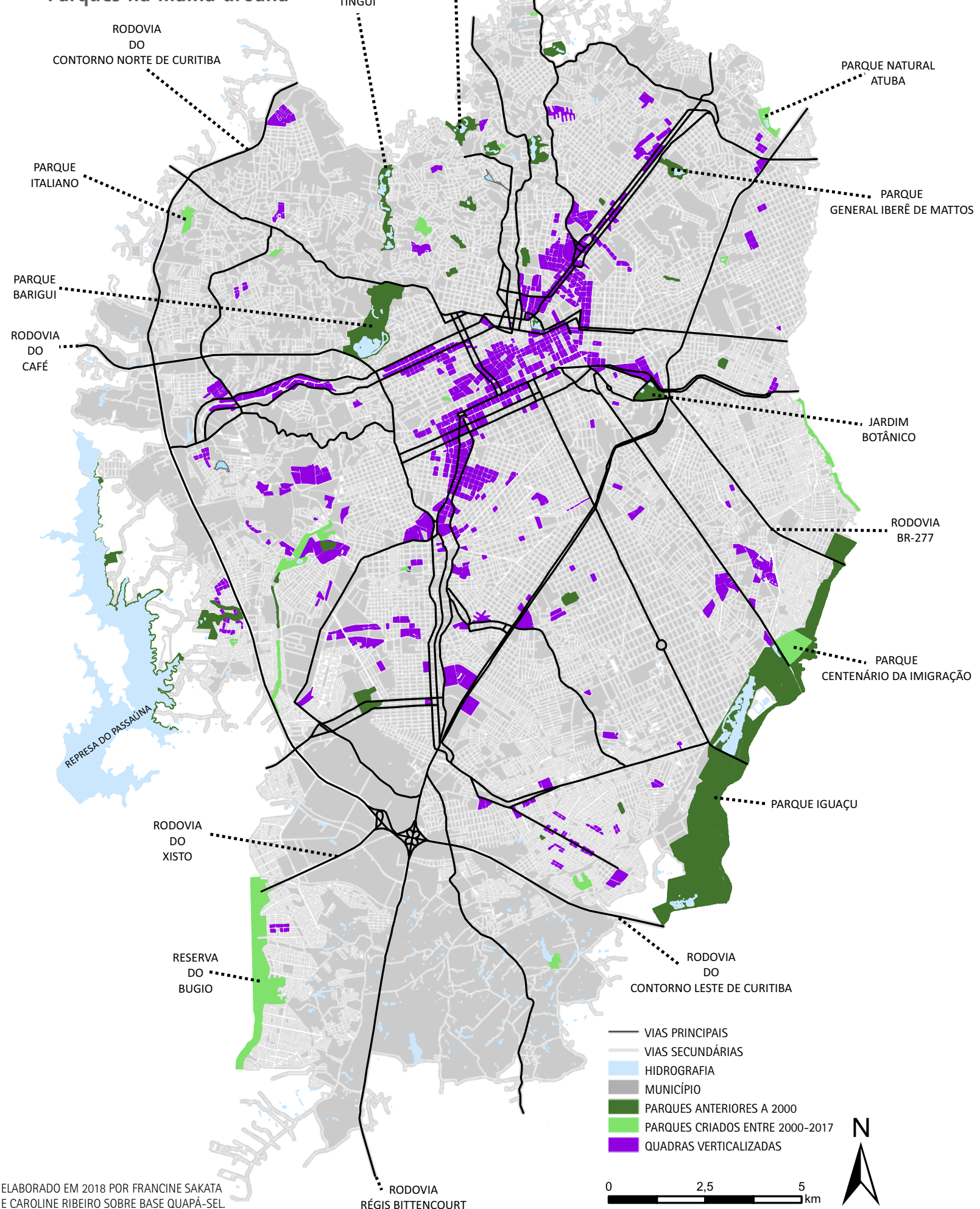




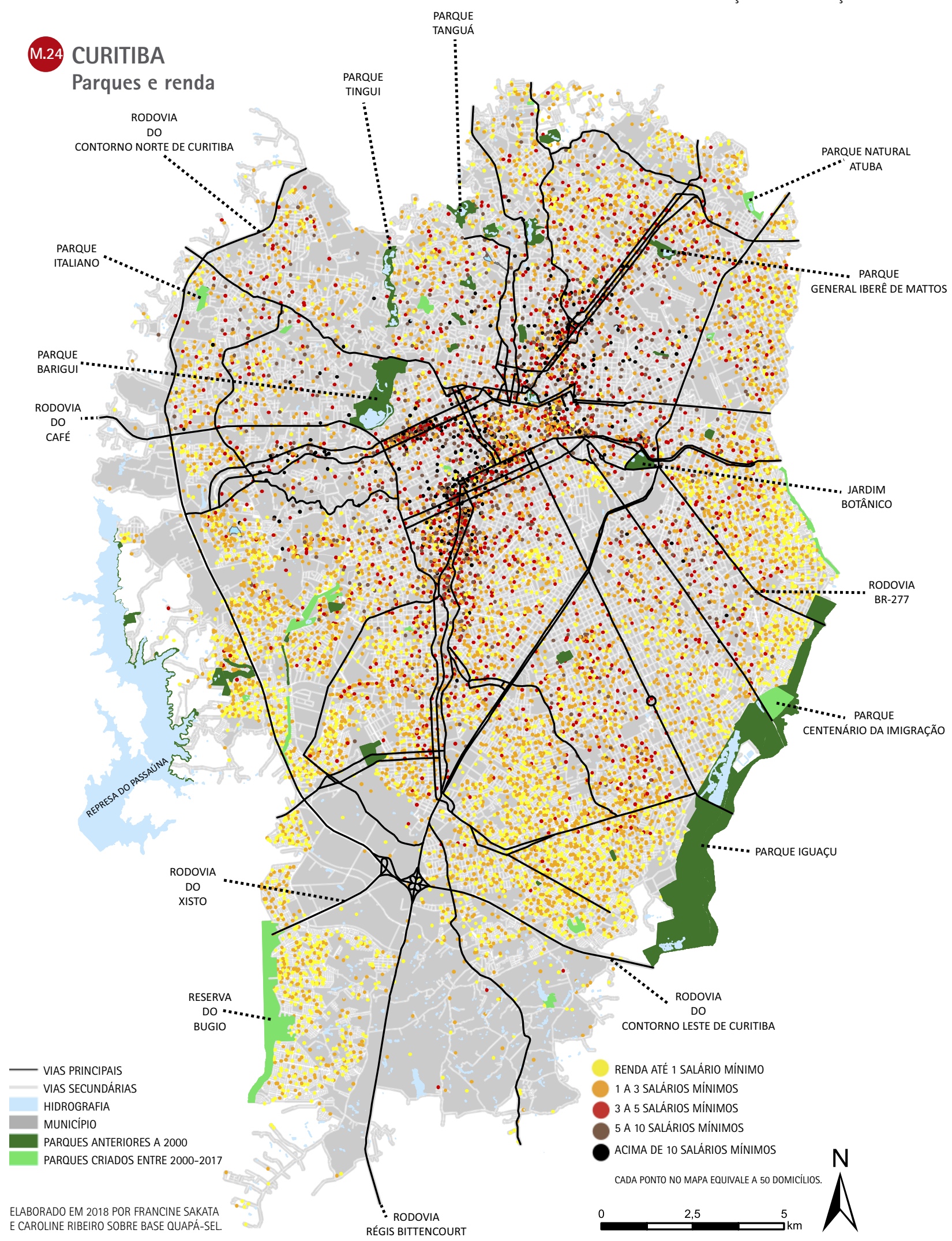




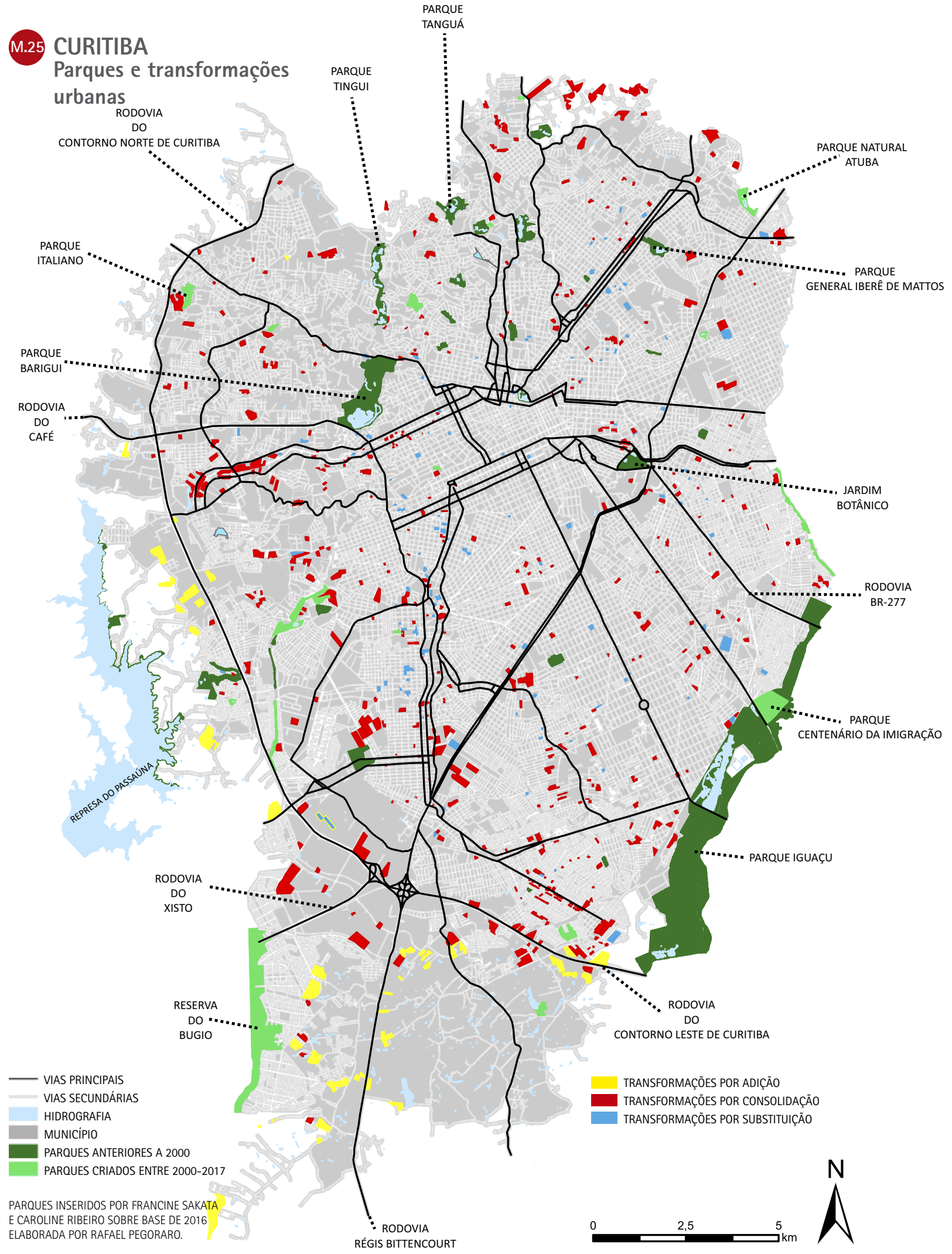




\subsection{Campo Grande}

Na maior parte da sua história, a ocupação urbana de Campo Grande foi direcionada por planos urbanísticos, o que é incomum no Brasil. Os planos de maior importância para a formação do Sistema de Espaços Livres Públicos de Recreação e de Conservação foram o Plano de Complementação Urbana (1979) e o Plano Diretor (1995). Este efetivou o desenho do sistema de áreas livres. Segundo Gutemberg Weingartner ${ }^{30}$, os instrumentos previstos na Lei do Uso do Solo e no Plano Diretor, como o guia de diretrizes urbanísticas, contribuíram para mitigar os efeitos das descontinuidades administrativas, assegurando a manutenção dos objetivos dos planos conforme a cidade crescia.

No Plano Diretor de 1995, foram definidas treze áreas especiais de interesse ambiental, três delas na zona rural. Na criação dos parques de conservação dentro do perímetro urbano, um dos critérios foi a implantação de pelo menos um parque por região. A possibilidade do desenvolvimento de atividades recreativas ou prática esportiva, sem que isso comprometesse a função de conservação, foi outro aspecto considerado. Estabeleceram-se seis tipos de parques: 1) destinados exclusivamente à recreação; 2) destinados exclusivamente à conservação; 3) recreativos e de conservação; 4) recreativos e culturais; 5) históricos; 6) mistos, com funções recreativa, cultural e de conservação. 3.50

Para Weingartner, os Parques de Conservação, considerando a paisagem de Campo Grande, poderiam ser subdivididos em dois tipos: implantados nas cabeceiras dos córregos e implantados nos fundos de vale. Os primeiros, por conta de serem impostas restrições à visitação, atendem demanda pequena da população; os de fundo de vale, de morfologia mais alongada, são mais acessiveis e atendem muitos frequentadores.

Apesar dos planos, o crescimento espraiado de Campo Grande, associado à falta de gestão específica dos espaços públicos, acarretou a formação do sistema de espaços livres públicos também disperso e fragmentado, tornando-os mais suscetíveis à invasão de terras públicas.
300 trabalho de Weingartner apresenta o histórico da ocupação de Campo Grande e seus espaços livres, apresentando o contexto da criação e dos projetos dos principais parques e praças.

WEINGARTNER, Gutemberg. A construção de um sistema: os espaços livres públicos de recreação e de conservação em Campo Grande, MS. 2008. 192 p. Tese (Doutorado em Arquitetura e Urbanismo) - Faculdade de Arquitetura e Urbanismo, Universidade de São Paulo, São Paulo, 2008. 

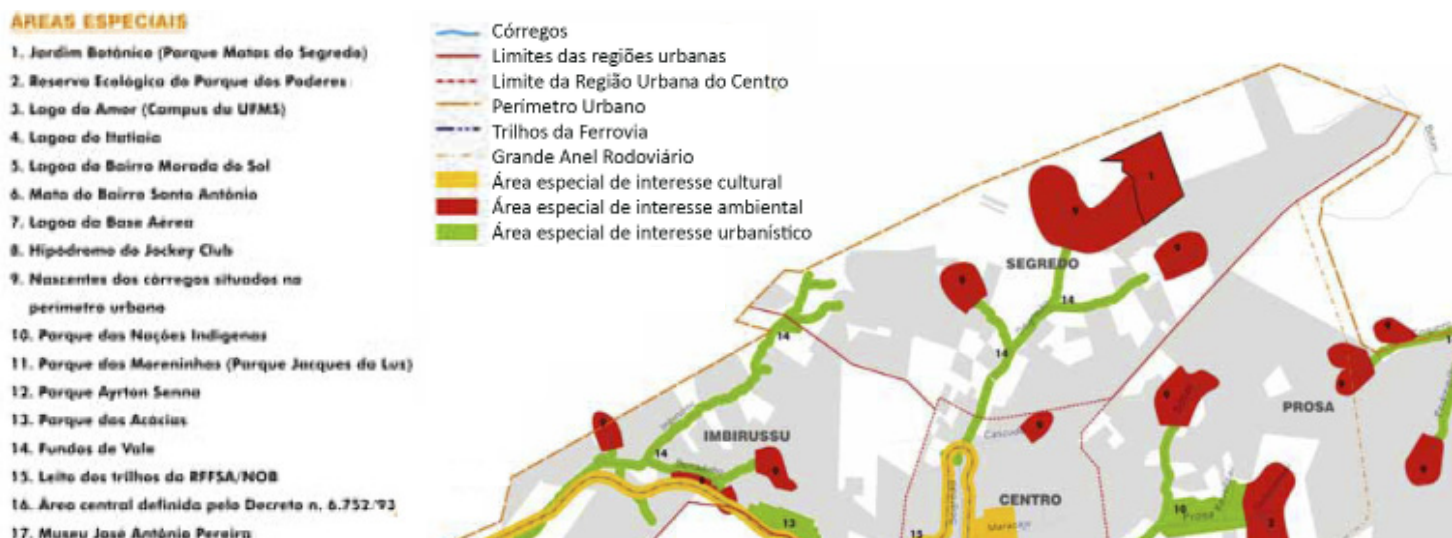

1. Nastenter dos córregos stunder na

11. Porque des Moreninhes (Prarque decques de (vi)

12. Porque Artion Senee

11. Marque des Acasias

12. Leate des trithes de errsanos

14. Ares central definida pelo Decreto n, 0.732 .03

17. Museu Jase Amtinie Pereira

\subsection{0}

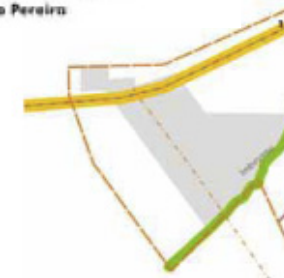

Plano Diretor de 1995. Delimitação das 13 áreas especiais de interesse urbanístico e ambiental. Para locá-las foram utilizadas recomendações da Carta de Drenagem. No perímetro urbano, um critério adicional para locação era haver pelo menos um parque por região urbana.

Fonte: WEINGARTNER, Gutemberg (2008).

31 LEMOS, Isabela et al. Relatório Oficina Quapá-SEL Campo Grande, 10 a 14 de abril de 2018, Universidade Federal do Mato Grosso do Sul - UFMS.
0 poder público municipal tem mostrado dificuldade para implantar, gerir e manter os espaços livres públicos para o lazer. Na Oficina Quapá SEL de Campo Grande ${ }^{31}$, os pesquisadores da Universidade Federal do Mato Grosso do Sul relataram que as praças são em grande quantidade mas predominam as praças não qualificadas, sem intenção de projeto, portanto sem possibilidade de apropriação coletiva e pública. Há praças qualificadas, com manutenção e equipamentos de ginástica e playgrounds padronizados e há outros tipos de espaços livres públicos: áreas residuais provenientes de desmembramento de glebas, canteiros centrais com larguras generosas frequentemente ocupados para caminhada e áreas residuais da implantação de sistemas viários. Partes dos terrenos sem qualificação, públicos e privados, tem sido apropriadas como campos de futebol informais que encontram-se espalhados em toda a cidade. 
Os logradouros demarcados como parques também são numerosos mas se apresentam, em sua maioria, sem qualificação. 0 poder público, conforme o interesse e as condições, os qualifica ao longo do tempo. 0 fato das áreas estarem reservadas é uma vantagem em relação a outras cidades.

Alguns dos parques que receberam investimento público têm sido amplamente utilizados. No entorno de parques como os parques das Nações Indígenas (1987), Sóter (2004) e Linear do Bandeira tem havido intenso processo de verticalização, predominando empreendimentos para camadas de rendas altas. 3.51 3.52 3.53

O Parque Ayrton Senna (1994) conta com equipamentos e programa esportivo nem sempre associado a parques públicos: ginásio, academia, piscinas, salas de ginástica e dança. 0 parque está inserido no Bairro Aero Rancho, um dos bairros mais adensados da cidade, com uma população de rendas médias e baixas. (3.54)

Entre os mais recentes destacamos o Parque Linear do Lagoa e a Orla Morena. 0 Linear do Lagoa foi inaugurado em 2011 com a abertura da Av. Lúdio Martins Coelho, que atravessa toda a região urbana do Lagoa. São cerca de $10 \mathrm{~km}$ de extensão. 0 parque apresenta nascentes, cursos d'água ainda preservados (Buriti, Zardo e Siriema) e trechos de matas ciliares. Não foram construídos muitos equipamentos de lazer mas, basicamente, pista de caminhada. ciclovias e planos gramados.

Orla Morena é um calçadão de $2,5 \mathrm{~km}$ de extensão no canteiro que divide as duas pistas da avenida Noroeste e é considerada parque. Em 2005, com a retirada dos trilhos da Noroeste do Brasil, houve a necessidade de estruturação do espaço. 0 projeto foi concluído em dezembro de 2010, atendendo uma demanda antiga da população daquela região por espaços livres para atividades de recreação, cultura, esporte e lazer. A feira livre existente no bairro Cabreúva ganhou espaço adequado no projeto, além de infraestrutura básica (energia elétrica e água). Ao longo dos $2,5 \mathrm{~km}$ da orla encontram-se equipamentos como quadras esportivas, pistas de skate, pista ciclável, arena de eventos, equipamentos para exercícios físicos. Para lsabela Lemos (Quapá), a Orla Morena é favorecida, em relação à Orla 

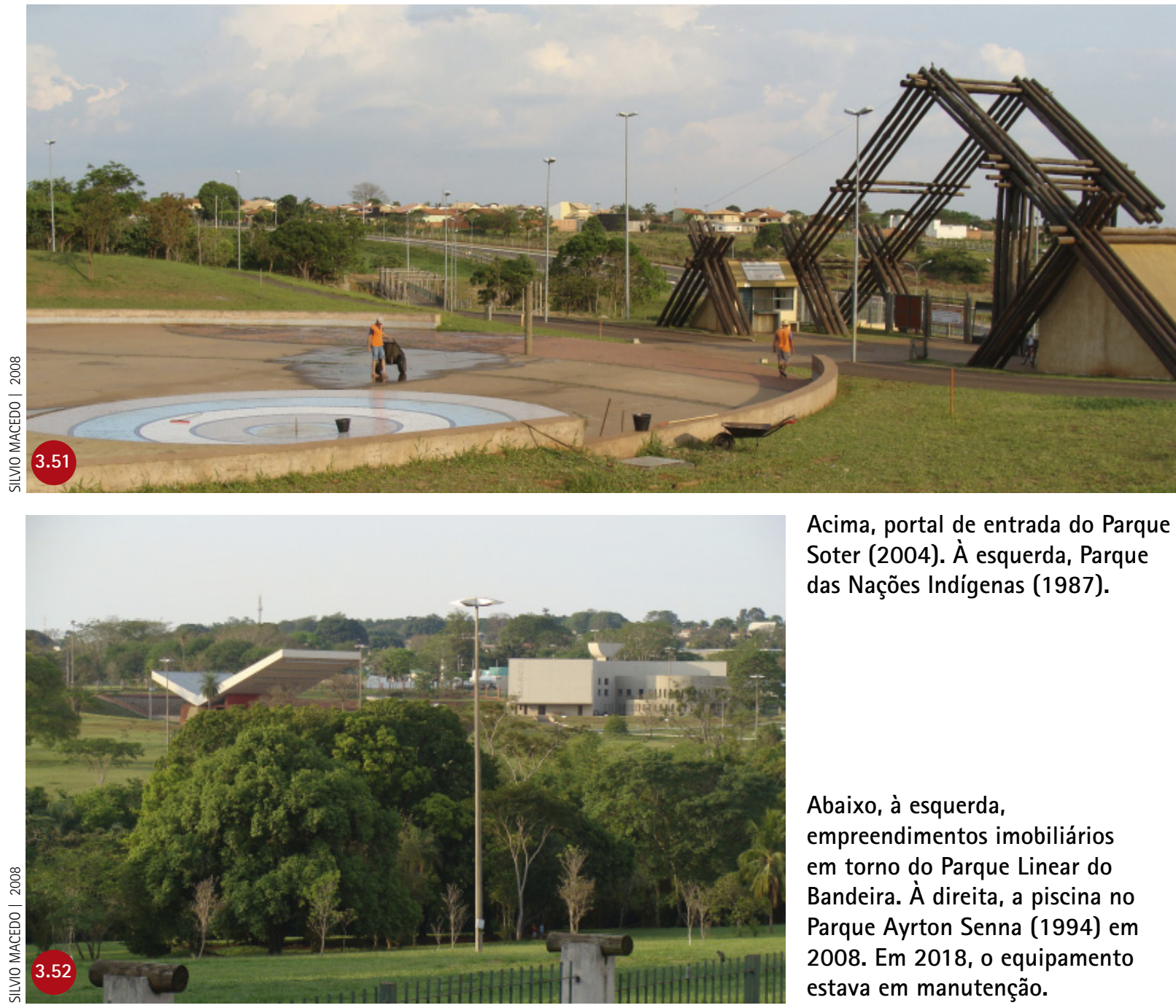

Acima, portal de entrada do Parque Soter (2004). À esquerda, Parque das Nações Indígenas (1987).

Abaixo, à esquerda, empreendimentos imobiliários em torno do Parque Linear do Bandeira. À direita, a piscina no Parque Ayrton Senna (1994) em 2008. Em 2018, o equipamento estava em manutenção.
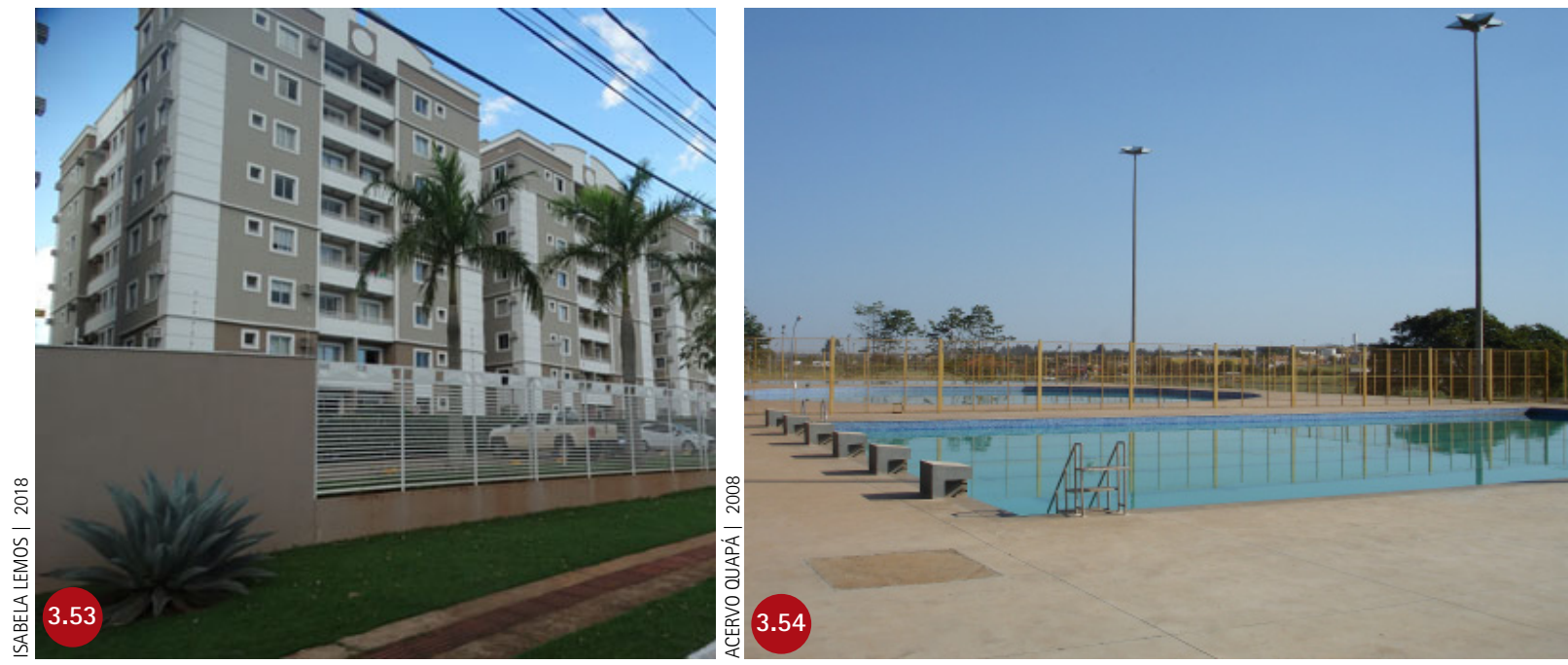
Ferroviária, com a qual a Orla Morena poderia se conectar, pois não tem as mesmas extensas faixas de empenas cegas que deixam o pedestre com a sensação de insegurança. 3.54A. 3.54B
Orla Morena (2010), parque no canteiro que divide as duas pistas da avenida Noroeste, tem atraído toda a população para lazer, passeios e feiras.
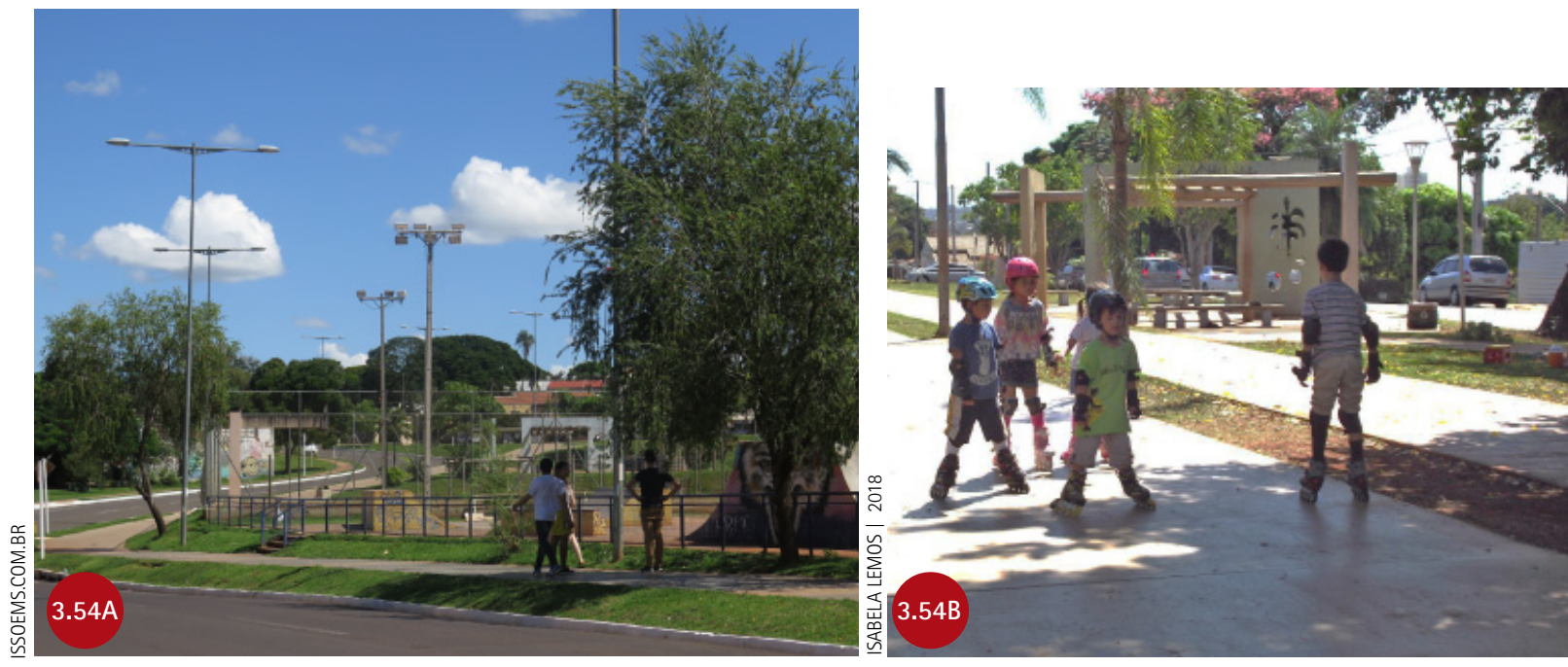

\begin{tabular}{|c|c|c|c|c|}
\hline \multicolumn{5}{|l|}{ CAMPO GRANDE } \\
\hline PARQUE & REGIÃO & ÁREA $\left(\mathrm{m}^{2}\right)$ & CRIAÇÃO & INAUG \\
\hline $\begin{array}{l}\text { HORTO FLORESTAL (Parque Florestal Antônio } \\
\text { Albuquerque) }\end{array}$ & Amambai & 60.000 & * & 1923. Revitalizado em 1993 \\
\hline PARQUE DOS PODERES & Jardim Veraneio & 174.261 & * & 1983 \\
\hline PARQUE DAS NAÇÕES INDÍGENAS & Jardim Veraneio & 1.190 .000 & * & 1987 \\
\hline PAROUE AYRTON SENNA & Conj. Aero Rancho & 320.000 & * & 1994 \\
\hline PAROUE ECOLÓGICO ANHANDUÍ & Vila São Vicente & 180.042 & * & 2000 \\
\hline PAROUE ESTADUAL MATA DO SEGREDO & Mata do Segredo & 1.780 .000 & 2000 & 2001 \\
\hline PARQUE TARSILA DO AMARAL & Jardim Vida Nova & 21.220 & * & Entre 2002 e 2006 \\
\hline PARQUE JACQUES DA LUZ & Cidade Morena & 450.000 & * & 2003 (reinaugurado) \\
\hline PARQUE ECOLÓGICO DO SÓTER & Mata do Jacinto & 220.000 & * & 2004 \\
\hline PARQUE LINEAR DO SÓTER & Monte Carlo & 150.000 & 2003 & \\
\hline PARQUE LINEAR DO LAGOA & Jardim Leblon & 970.000 & & 2011 \\
\hline PARQUE LINEAR DO IMBIRUSSU & José Abrão & ${ }^{*}$ & & 2011 \\
\hline PAROUE LINEAR DO SEGREDO & Monte Castelo & $\begin{array}{r}381.000 \\
(4,5 \mathrm{~km} \text { extensão) } \\
\end{array}$ & & 2011/ retomada em 2018 \\
\hline PARQUE LINEAR DO CABAÇA & Vila leda & $\begin{array}{r}124.000 \\
(1,5 \mathrm{~km} \text { extensão }) \\
\end{array}$ & & 2010 \\
\hline PARQUE ESTADUAL DO PROSA & Jardim Veraneio & 1.352 .570 & 2002 & 2007 (reinaugurado) \\
\hline ORLA MORENA & Jardim Cabreúva & 56.000 & ${ }^{*}$ & 2010 \\
\hline PARQUE LINEAR DO BANDEIRA & Rita Vieira/ V. S. Eugenio & $*$ & & 2017 \\
\hline
\end{tabular}

Tabela elaborada por Caroline Ribeiro para este trabalho a partir de informações da prefeitura. 


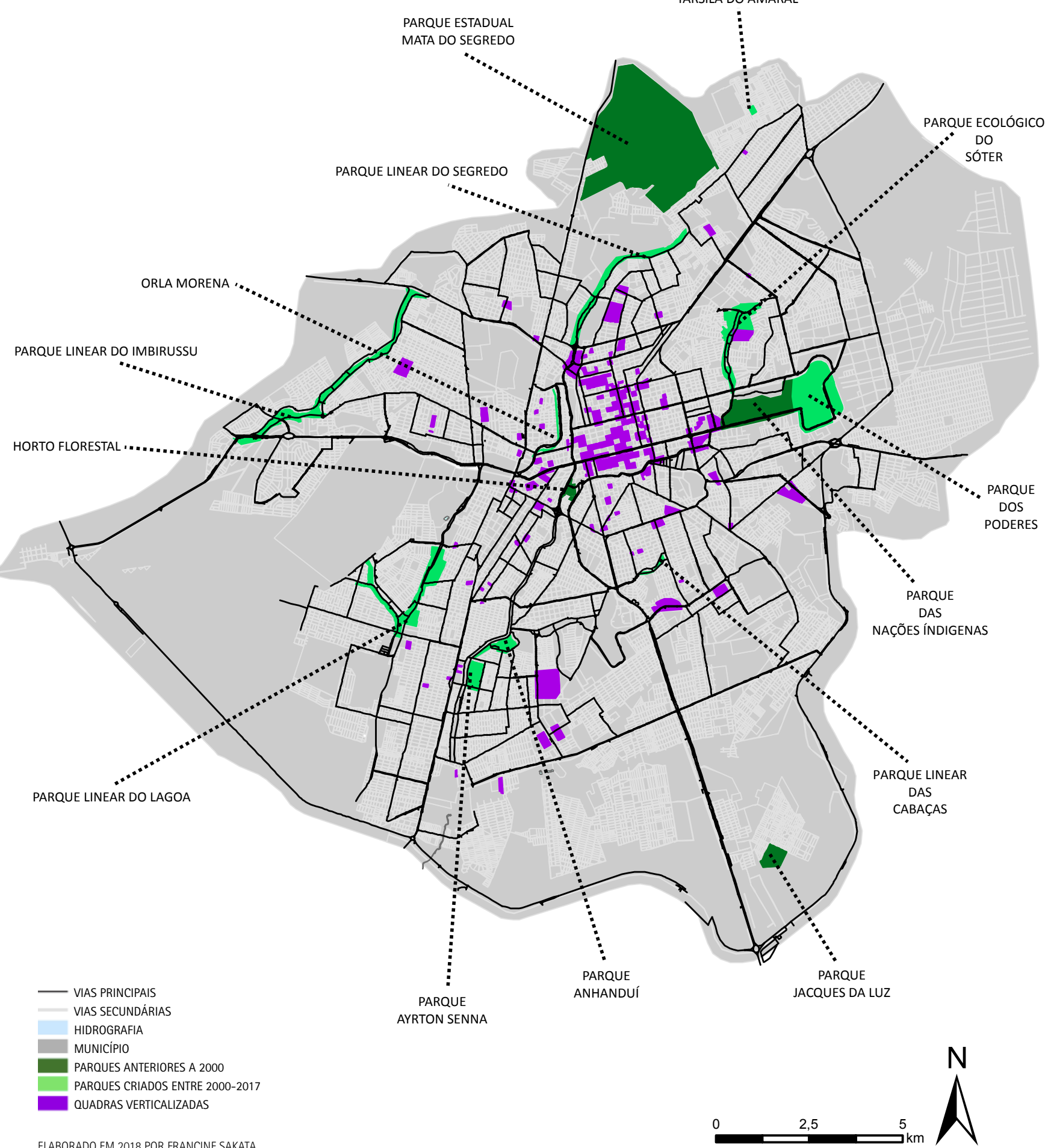



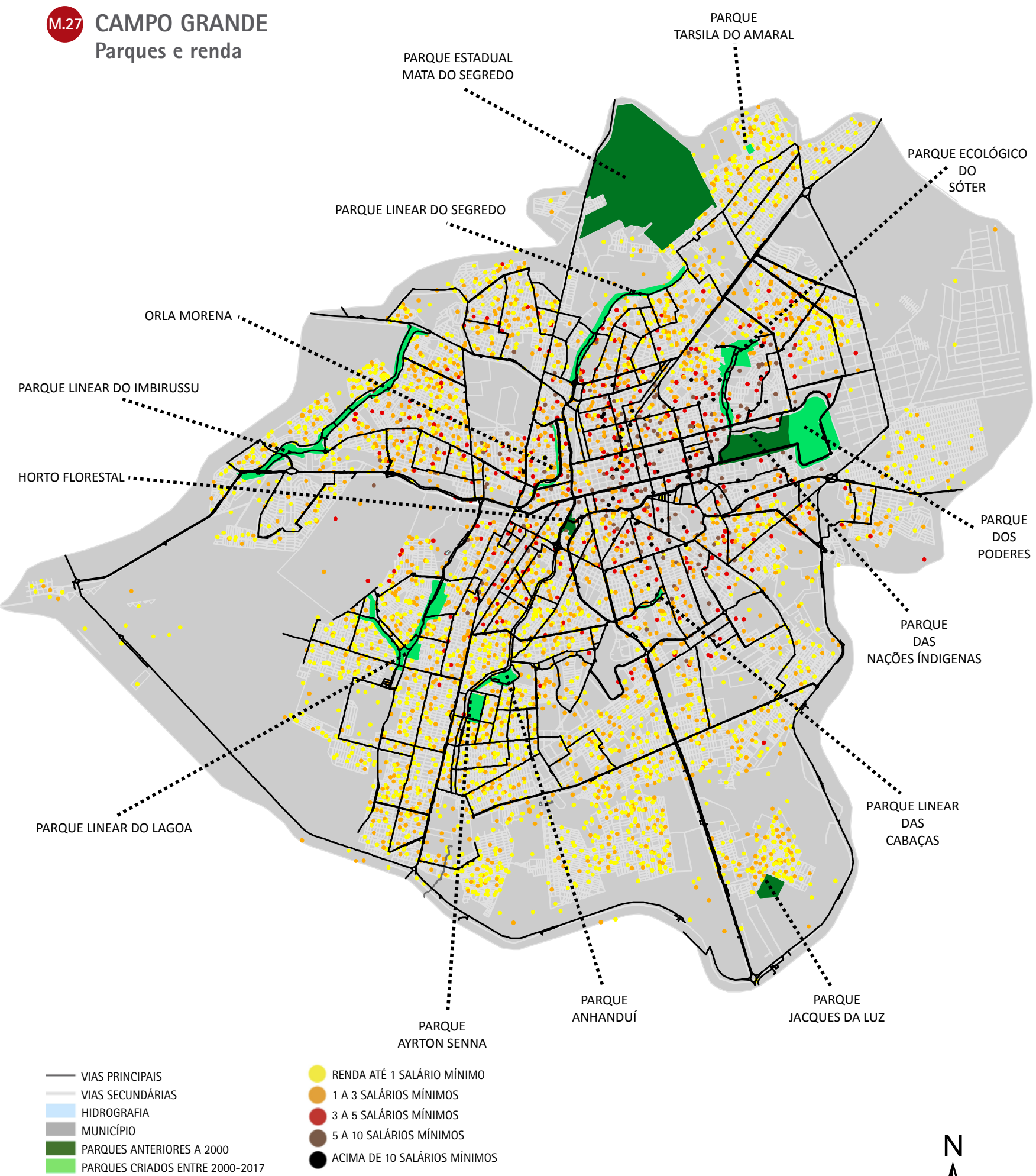

PARQUES CRIADOS ENTRE 2000-2017

CADA PONTO NO MAPA EQUIVALE A 50 DOMICILIOS. 


\subsection{Manaus}

Manaus não contava com parques até 1989, mas havia um centro de lazer e de encontros comunitários, o Centro Social Urbano do Parque Dez (1977), não denominado parque, mas com usos de parque. Feito pela prefeitura a partir da demanda da população por espaços de lazer, abriga quadras, dois campos de futebol, duas piscinas, dois anfiteatros, academia, escola e delegacia, além de sediar eventos esportivos e festas folclóricas.

O município recebeu o Parque do Mindu (1989), uma novidade em termos de projeto, com passarelas de madeira suspensas para
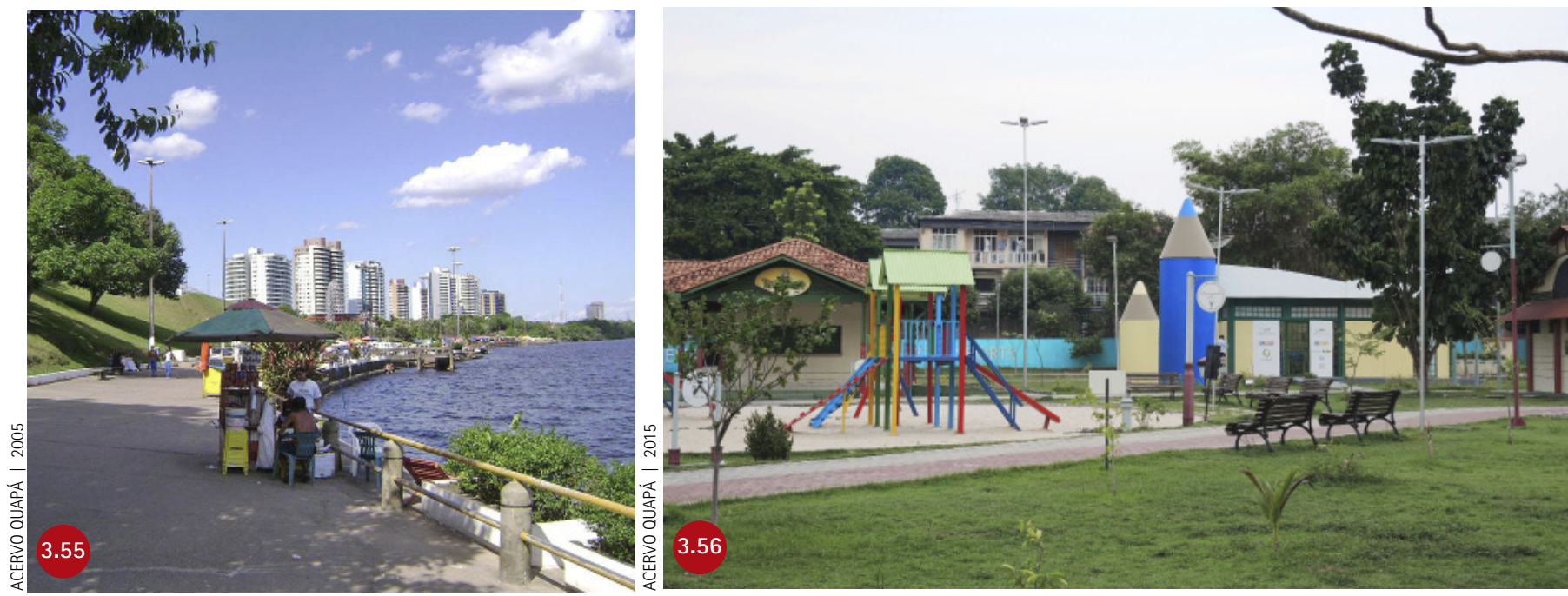

Acima, Calçadão da Ponta Negra, Parque dos Bilhares (2006) e, à direita, Parque da Juventude Ajuricaba Mascarenhas (2016).

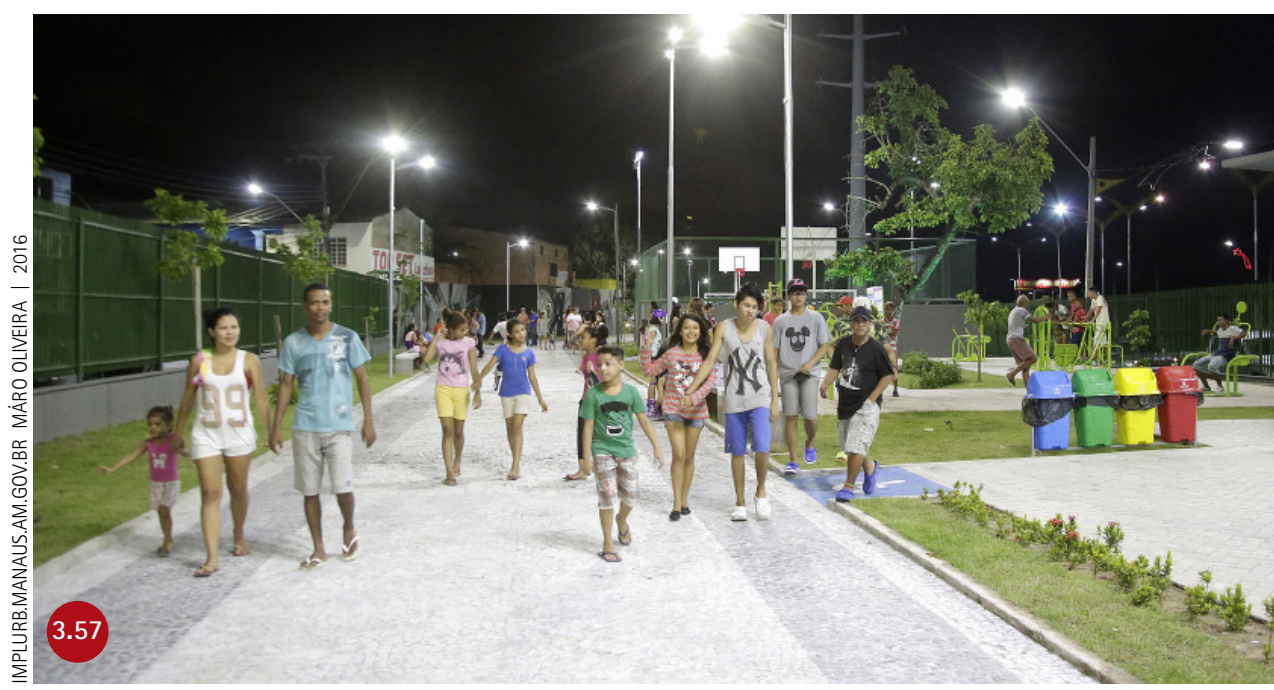


percorrer um trecho de mata amazônica. Nos anos 1990, foi construído o Calçadão da Ponta Negra ao longo de $2 \mathrm{~km}$ da orla do Rio Negro, dotando este espaço de anfiteatro, quadras de esportes e bares que foi revitalizado em 2010. A Ponta Negra é moradia de camadas de alta renda e cartão postal da cidade. 3.55

Em 2016 criou-se o Parque dos Bilhares (2006) às margens do lgarapé do Mindu, com funções simultâneas de valorizar a cidade, servir como espaço de lazer e conservar o meio ambiente. Manaus também foi responsável pela criação dos parques do ldoso (2002) e da Criança (2011) - ações de provisão de lazer em áreas tradicionalmente não atendidas, que conferiam usos a terrenos 'ociosos'. (3.56) O Parque da Juventude Ajuricaba Mascarenhas (2016) foi feito também em terrenos públicos que estavam sem destinação. Como os parques de esportes radicais em outras cidades, o Parque da Juventude foi bem recebido, e outro foi criado, o Parque da Juventude Titio Barbosa. Em 2017 foi considerada a criação de um terceiro na Zona Norte. As possibilidades de implantação do projeto estavam sendo avaliadas, em 2017, por técnicos da (Semmas) junto com representantes de empresas incorporadoras locais, o que sugere a busca por parcerias público-privadas. ${ }^{31}$ (3.57)

Em paralelo a estas ações, a partir de 2006 o governo do Estado conduziu o Programa Ambiental e Social dos lgarapés de Manaus (Prosamim), que substituiu as palafitas junto dos igarapés por conjuntos residenciais. As obras envolveram saneamento e drenagem, canalizações, descontaminação e desassoreamento dos canais, remoções, reassentamentos e a construção de moradias no local articuladas por espaços livres de várias categorias. Nem toda a população relocada foi acomodada.

A primeira fase do programa, o Prosamim 1 (2006), visava à recuperação da bacia do Educando, que inclui os igarapés Manaus, Bittencourt, Mestre Chico, Quarenta e Cachoeirinha. A fase 11, iniciada em 2008 e inaugurada em 2009, visava à bacia do lgarapé do São Raimundo, que incluiu os igarapés do Cajual e de Manaus, onde foi criado o Parque Kako Caminha. A fase 111, iniciada em 2012 e prevista para ser concluída em 2020, está intervindo na bacia do lgarapé de São Raimundo.
31 Disponivel em: <http://www. portalmarcossantos.com.br/2017/07/21/ prefeitura-de-manaus-estuda-implantacao-de-novo-parque-da-juventude-na-cidade-nova/>. 

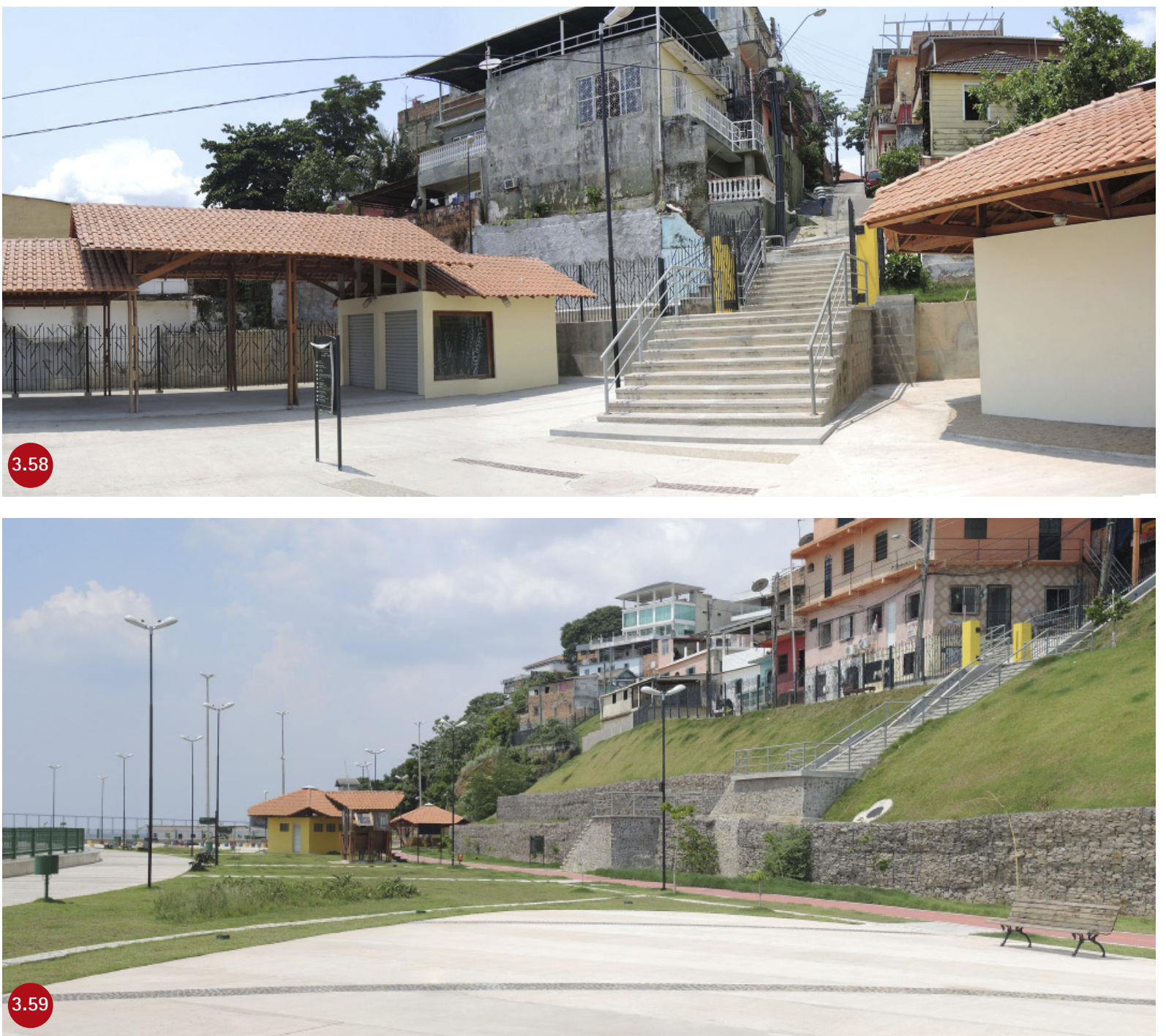

Parque Rio Negro (2015), na orla do Rio Negro no bairro São Raimundo, zona Oeste de Manaus. 0 complexo de lazer e cultura é o novo cartão postal da cidade.

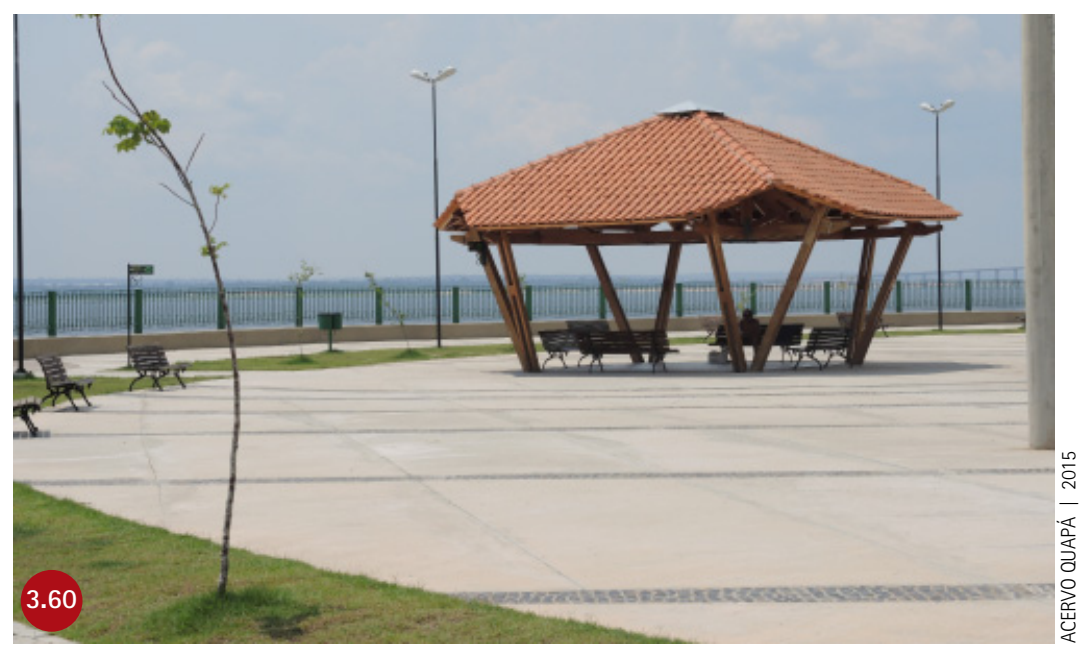


Nesta tabela:

\begin{tabular}{l}
\hline \\
\hline \\
\hline \\
\hline \\
criados entre $2000-2017$
\end{tabular}

\begin{tabular}{|c|c|c|c|c|c|}
\hline PARQUE & REGIÃO & $\begin{array}{l}\text { ÁREA } \\
\left(\mathrm{m}^{2}\right)\end{array}$ & CRIAÇÃO & INAUG. & OBS. \\
\hline PAROUE MUNICIPAL DO MINDU & CENTRO SUL & 420.500 & 1988 & 1989 & $\begin{array}{l}\text { UC com trilhas, biblioteca, auditório, orquidário, } \\
\text { equipamentos. }\end{array}$ \\
\hline PARQUE DO IDOSO & $\begin{array}{l}\text { N. SRA. DAS } \\
\text { GRAÇAS }\end{array}$ & 11.000 & 2001 & 2002 & Piscina, ginásio, auditório, pista de caminhada. \\
\hline PARQUE ESTADUAL SUMAÚMA & CIDADE NOVA & 510.000 & 2003 & 2003 & UC com trilhas, biblioteca, playground. \\
\hline PAROUE DOS BILHARES & CHAPADA & 60.000 & 2006 & 2006 & $\begin{array}{l}\text { Biblioteca, quadras poliesportivas, campo de } \\
\text { futebol de areia, pista de skate, playgrounds, } \\
\text { anfiteatro, equipamentos de ginástica, teatro de } \\
\text { arena. }\end{array}$ \\
\hline LAGOA DO JAPIIM & JAPIIM I E II & 41.000 & 2008 & 2008 & $\begin{array}{l}\text { Academia, pista de caminhada, quadra de areia } \\
\text { poliesportiva, pista de skate. }\end{array}$ \\
\hline $\begin{array}{l}\text { PARQUE SENADOR JEFFERSON } \\
\text { PERES - PROSAMIM I }\end{array}$ & CENTRO & 53.421 & 2006 & 2009 & $\begin{array}{l}\text { Playground, quadras poliesportivas, academia ao } \\
\text { ar livre. }\end{array}$ \\
\hline $\begin{array}{l}\text { PAROUE DESEMBARGADOR } \\
\text { PAULO JACOB - PROSAMIM I }\end{array}$ & CENTRO & 52.000 & 2006 & 2009 & $\begin{array}{l}\text { Recuperação do Igarapé Manaus. Ciclovia, } \\
\text { quiosques, quadra poliesportiva, caminhada. }\end{array}$ \\
\hline PARQUE CIDADE DA CRIANÇA & CENTRO-SUL & 19.637 & 2009 & 2011 & $\begin{array}{l}\text { Antigo horto florestal. } \\
\text { Cinema, biblioteca, playgrounds. }\end{array}$ \\
\hline $\begin{array}{l}\text { PARQUE DO LARGO MESTRE } \\
\text { CHICO - PROSAMIM I }\end{array}$ & CACHOEIRINHA & 57.000 & 2006 & 2012 & $\begin{array}{l}\text { Recuperação do Igarapé Mestre Chico e Ponte } \\
\text { Benjamin Constant. Ciclovia, quiosques, quadra } \\
\text { poliesportiva, pista de caminhada }\end{array}$ \\
\hline PARQUE ESTADUAL RIO NEGRO & SÃO RAIMUNDO & 36.590 & 2014 & 2015 & $\begin{array}{l}\text { Pista para caminhada, mirantes, quiosques, praças, } \\
\text { academia ao ar livre, playground. }\end{array}$ \\
\hline $\begin{array}{l}\text { PARQUE DA JUVENTUDE } \\
\text { AJURICABA MASCARENHAS }\end{array}$ & SÃO JOSÉ & 5.000 & 2015 & 2016 & $\begin{array}{l}\text { Espaço ocioso convertido em espaço de lazer. } \\
\text { Pista de skate, playground, academia ao ar livre, } \\
\text { streetball. }\end{array}$ \\
\hline $\begin{array}{l}\text { PARQUE CACIMBAS - } \\
\text { PROSAMIM III }\end{array}$ & SÃO RAIMUNDO & 6.966 & 2015 & 2016 & $\begin{array}{l}\text { Recuperação do Igarapé das Cacimbas. Quadra de } \\
\text { areia, playgrounds, academia ao ar livre. }\end{array}$ \\
\hline $\begin{array}{l}\text { PARQUE IGARAPÉ DO SESC } \\
\text { PROSAMIM III }\end{array}$ & ALVORADA & 22.690 & 2015 & 2016 & $\begin{array}{l}\text { Recuperação do igarapé do SESC. Playground, } \\
\text { academia ao ar livre. }\end{array}$ \\
\hline $\begin{array}{l}\text { PARQUE DA JUVENTUDE TITIO } \\
\text { BARBOSA }\end{array}$ & CENTRO-SUL & 9.916 & 2015 & 2017 & $\begin{array}{l}\text { Espaço ocioso convertido em espaço de lazer. Pista } \\
\text { para caminhada, skate, playground, quadra de } \\
\text { futebol, academia ao ar livre. }\end{array}$ \\
\hline
\end{tabular}

Tabela elaborada por Caroline Ribeiro para este trabalho, a partir de informações da prefeitura, do programa Prosamim e de conferência no Google Earth através da qual outros parques foram encontrados. 


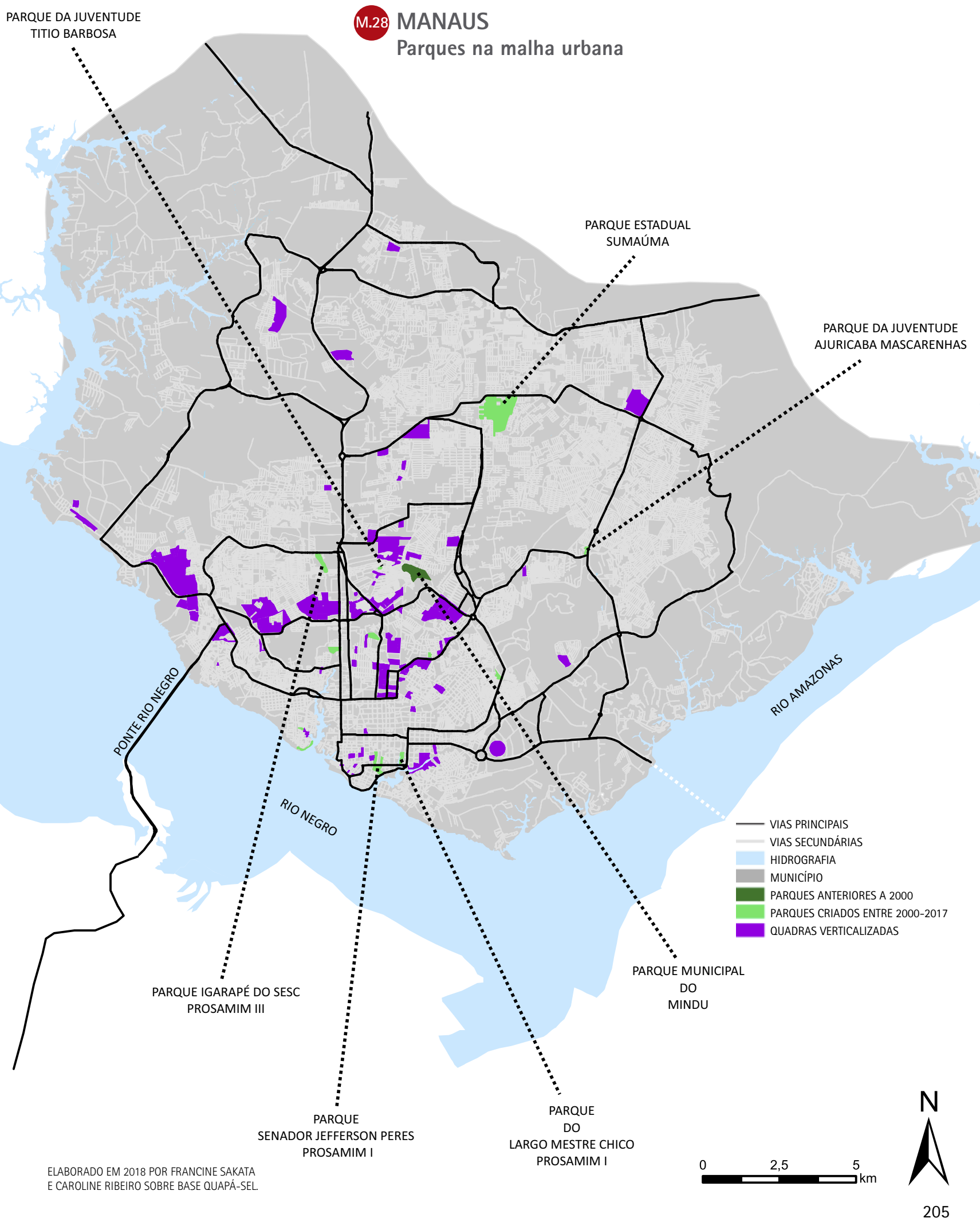




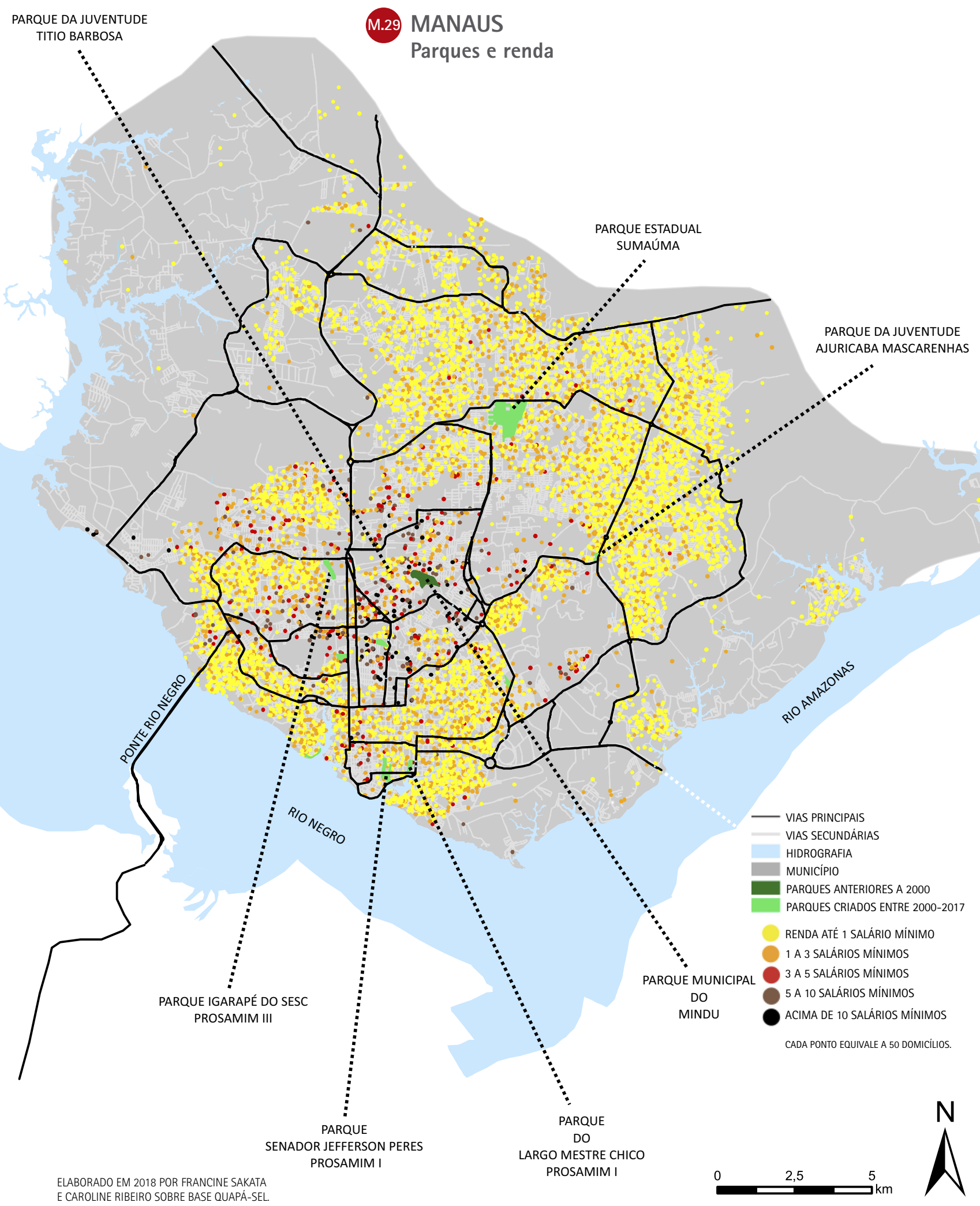




\subsection{Vitória}

Vitória é uma das três ilhas-capitais do país, junto com Florianópolis e São Luís. 0 mar é estrutural na organização desses territórios. A malha urbana extensa forma um conjunto com uma única dinâmica: a conurbação formada por Vitória, Serra, Cariacica e Vila Velha. A economia volta-se para atividades portuárias, indústria, comércio, prestação de serviços e turismo de negócios. A capital capixaba conta com dois portos: o de Vitória e o de Tubarão, que, junto com vários outros do Estado, formam o maior complexo portuário do país.

Nos últimos dez anos, houve melhorias infraestruturais de porte que induziram a ocupação do território, a redução de áreas verdes e a valorização da terra. As transformações foram de tal monta que até o contorno do canal marítimo foi alterado. 0 Governo Federal investiu na duplicação da BR-101, na ampliação do aeroporto, do Porto de Vitória e no MCMV, que estimulou forte periferização. A Federação também criou uma grande UC - a Área de Proteção Ambiental (APA) de Costa das Algas. O Governo Estadual foi responsável pela construção das rodovias leste-Oeste, Cariacica-Vila Velha, o contorno de Jacaraípe (entre outras). Às prefeituras restou desenvolver projetos complementares nessa produção do espaço urbano. $^{32}$

32 Outras frentes de investimento apontadas foram: a região do Ceasa (Cariacica), um polo de uso misto em transformação que recebeu um shopping center; o estádio Cleber Andrade (Cariacica); a Avenida Civit (Serra); o Portal de Manguinhos (Serra), com equipamentos urbanos - faculdades, hospitais e shoppings; o entorno do Shopping Boulevard (Vila Velha); a Enseada do Suá (perto do Shopping Vitória); polo tecnológico e faculdades (Goiabeiras); condomínios como o Morar Bem (região Sul de Vila Velha); o loteamento Alphaville (Serra).

Os dados sobre Vitória foram extraídos do Relatório da Oficina Quapá-SEL II Vitória, 1 a 4/9/2014, desenvolvido por Vanderli Custódio, Verônica Garcia Donoso e Patrícia Eiko Aguchiku.
De modo geral, os bairros mais nobres estão situados ao norte e ao leste, e os mais carentes a oeste. Camburi, ao norte, foi o que mais recebeu investimentos imobiliários. A produção de loteamentos fechados de casas e edifícios de alto e médio padrão foi intensa. Os loteamentos fechados - em geral localizados em áreas ambientalmente frágeis e com boas qualidades paisagísticas - concentraram-se em Serra e Vila Velha. Criaram-se muitos espaços livres associados aos loteamentos, privados e também públicos, em parcerias. Um vetor econômico de crescimento muito forte são os sítios industriais das siderúrgicas e mineradoras. Além das transformações no território, a expansão das indústrias gerou Termos de Compensação Ambiental (TCAs) que deram suporte à criação de parques e 


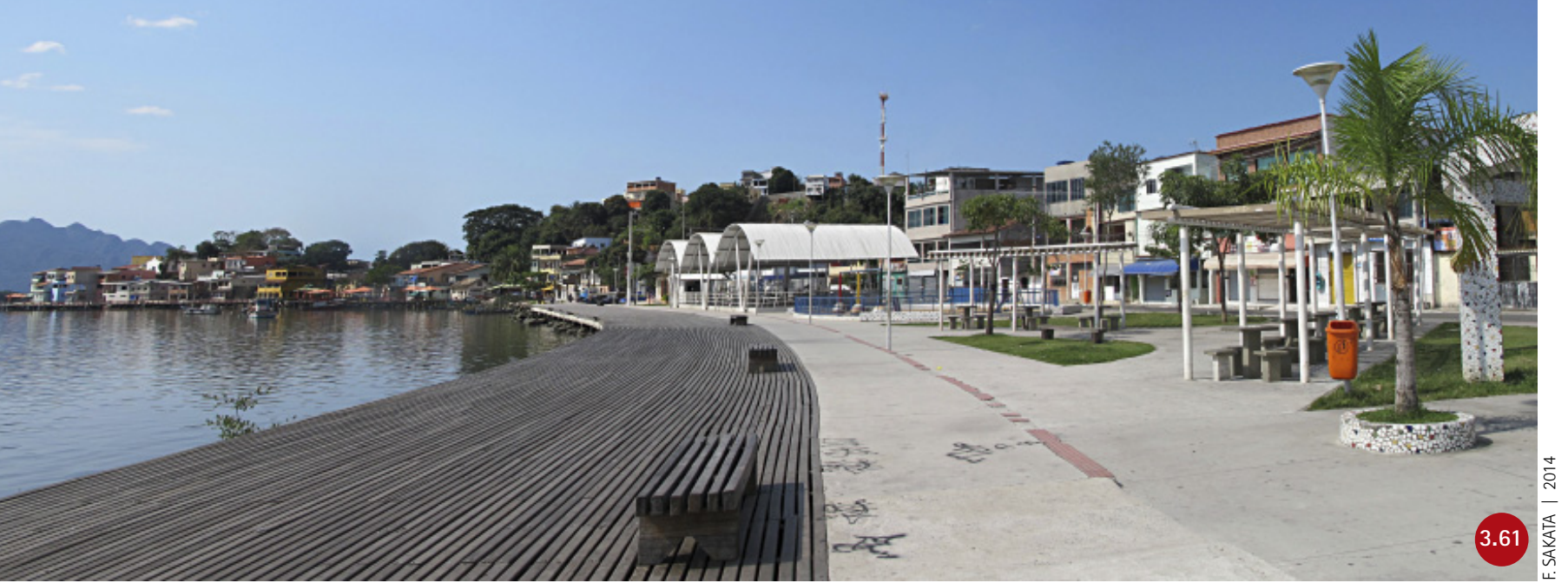

áreas de proteção e à melhoria dos parques existentes ${ }^{33}$. Um dos parques criados com recursos de compensações ambientais em bairro de expansão do mercado imobiliário foi o Chácara Paraíso. E um dos requalificados foi o da Pedra da Cebola. 3.62 3.63 3.65)

Uma dezena de UCs em Vitória, Vila Velha e Serra receberam recursos de compensação do licenciamento ambiental da ampliação da produção de bobinas de aço da Arcelor-Mittal Tubarão. ${ }^{34}$ Esta verba de grandes empresas não cessou repentinamente como ocorreu com a dos empreendimentos imobiliários devido à crise econômica em 2014. A Vale também criou e mantém como ação ambiental e de propaganda o Parque da Vale.

Para a prefeitura, parques urbanos são aqueles "despossuídos de atributos naturais" e parques naturais são os de preservação, em que as apropriações sociais se limitam a trilhas e mirantes. Entretanto, o Parque Natural Municipal do Tabuazeiro (1996), por ser oriundo de antigo sítio agrícola, é dos mais equipados para o lazer: possui campo de futebol society, quadra poliesportiva, playground, viveiro e horta. Em Vitória os parques são muito diversos: há parques apenas com trilhas, um para apreciar animais da fazenda, outro para tartarugas. Funções esportivas não são a ênfase.

As praias são o grande parque de Vitória. Na porção mais central do território, acabam faltando equipamentos de lazer e esporte, mas, de modo geral, os parques da cidade apresentam-se muito bem cuidados, fato incomum nas capitais litorâneas.
A orla da Ilha das Caieiras, à beira do mangue, recebeu tratamento paisagístico para o esporte e extensa faixa de deck à beira d'água. A comunidade, de baixa renda, se uniu para promover os pequenos restaurantes do bairro e passou a receber visitantes de todas as partes da cidade, produzindo requalificações urbana e social.

33 Disponivel em: <http://www.vitoria. es.gov.br/noticia/melhorias-no-parque-da-fonte-grande-vao-atrair-ainda-mais-visitantes-26238>.

34 Esta compensação foi anunciada em $\mathrm{R} \$ 15$ milhões.

Disponivel em:<https://iema.es.gov. $\mathrm{br} /$ compensacao-ambiental-beneficia-unidades-de-c>. 

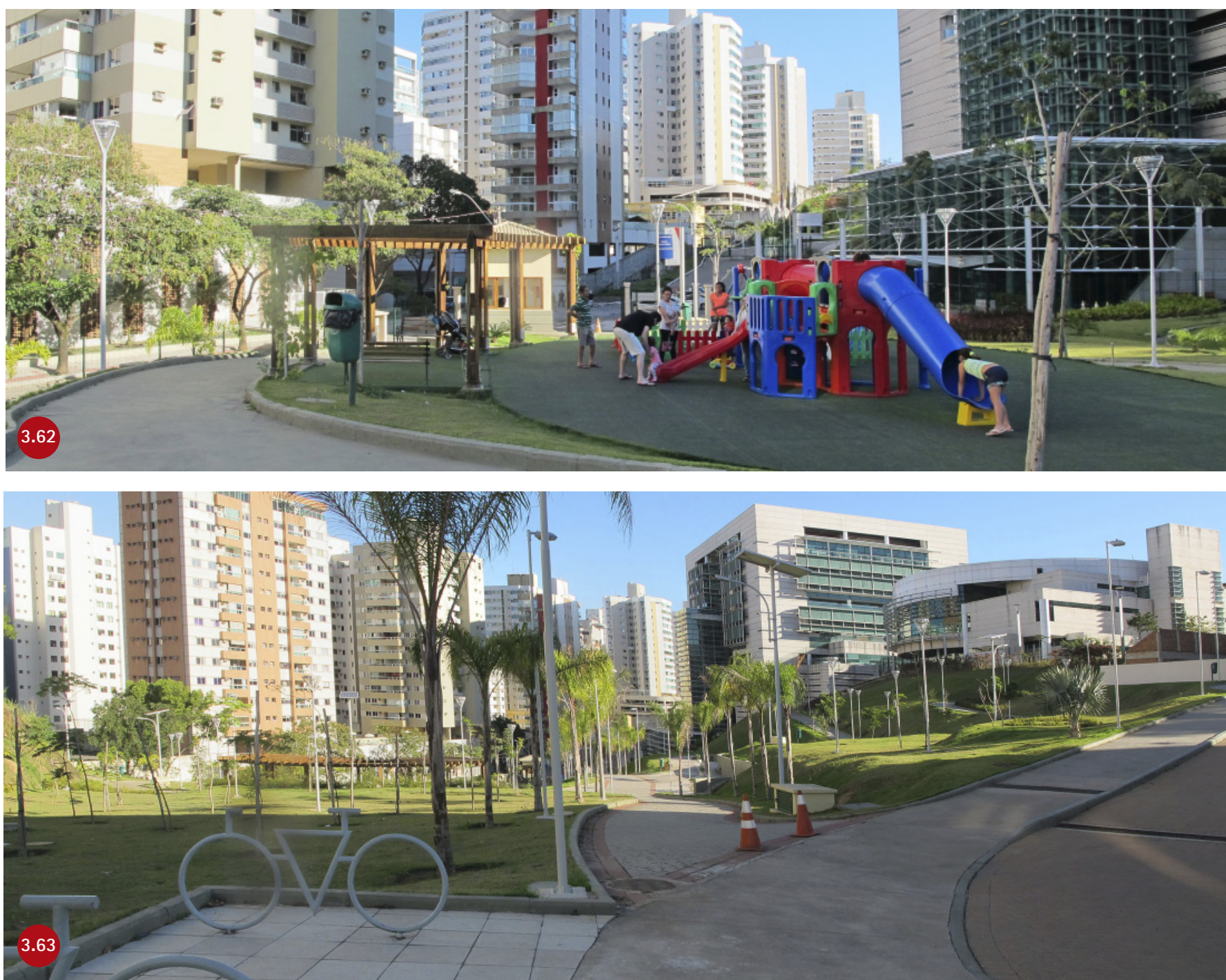

Parque Chácara Paraíso (2013), um parque pequeno $\left(15.000 \mathrm{~m}^{2}\right) \mathrm{em}$ vetor de expansão imobiliária. 0 projeto faz uma ligação agradável entre a rua mais baixa e a mais alta. Única ressalva é ter colocado uma edificação inexpressiva no centro do parque.

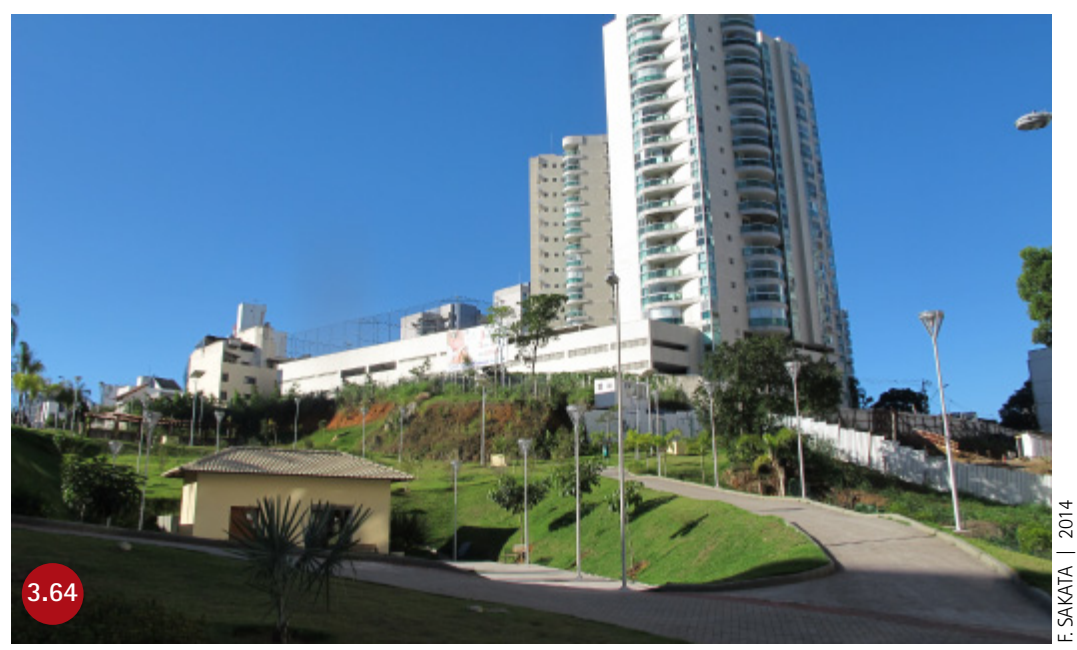


M.30 VITÓRIA

Parques na malha urbana

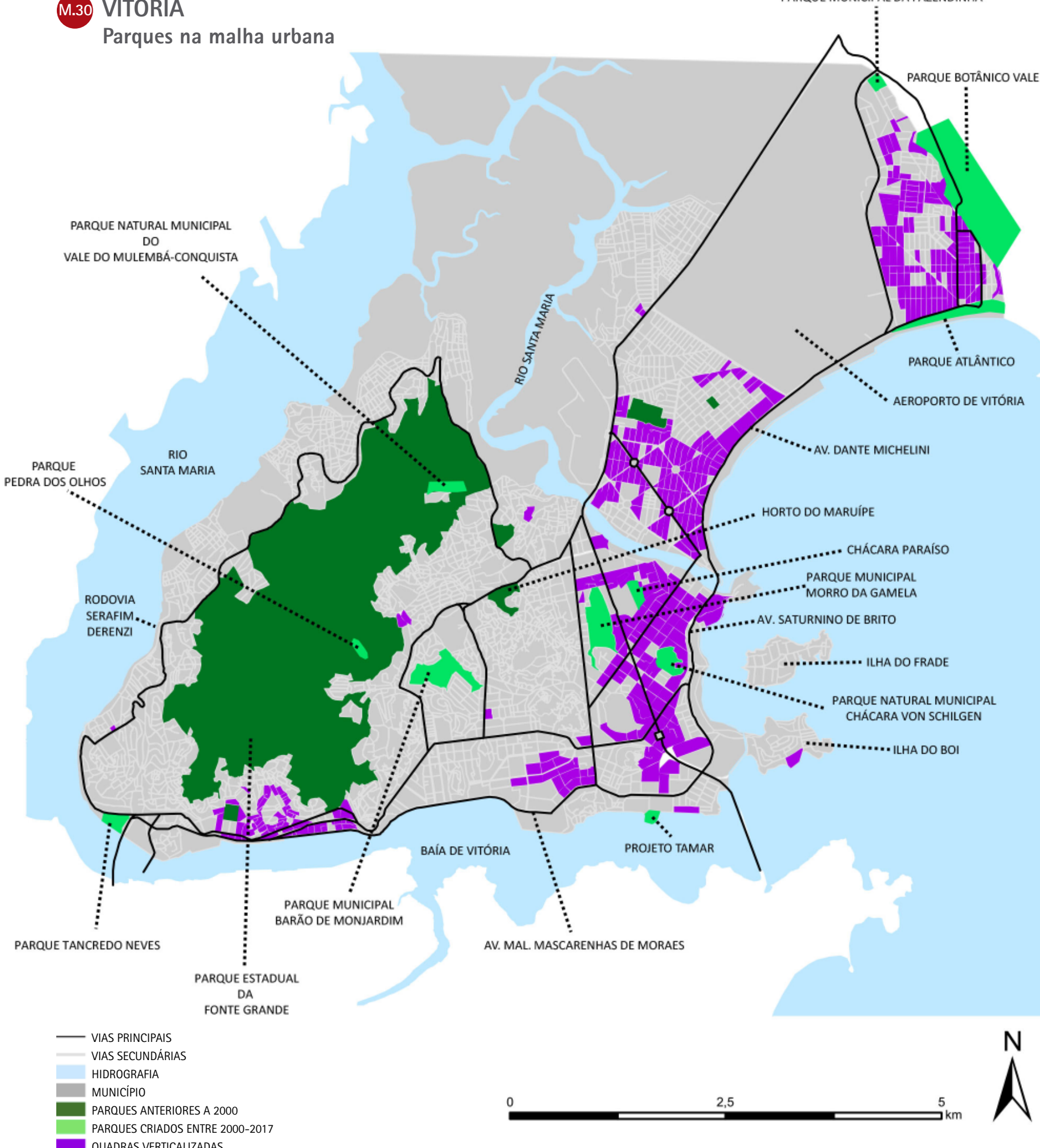




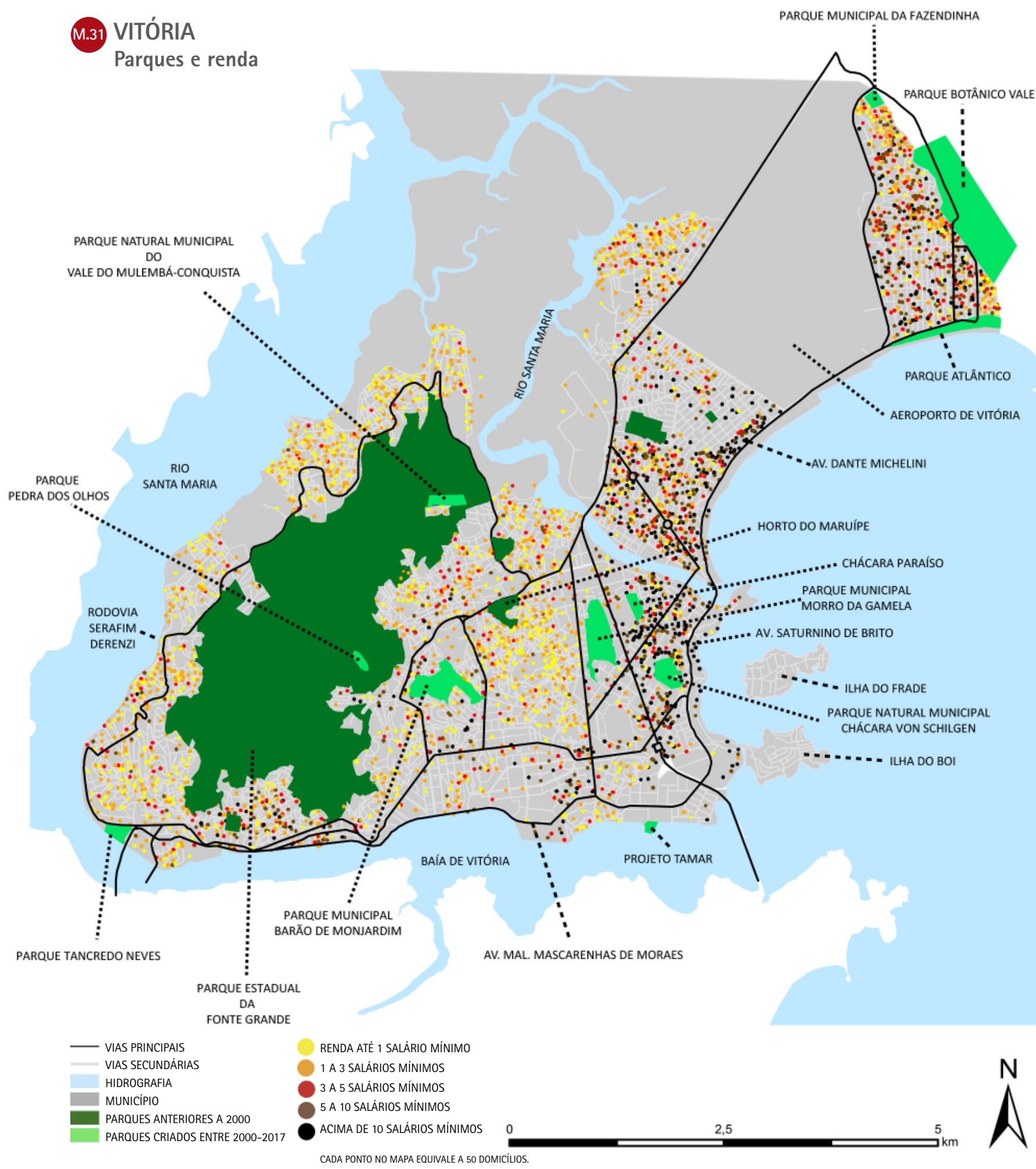


M.32 VITÓRIA

Parques e transformações urbanas

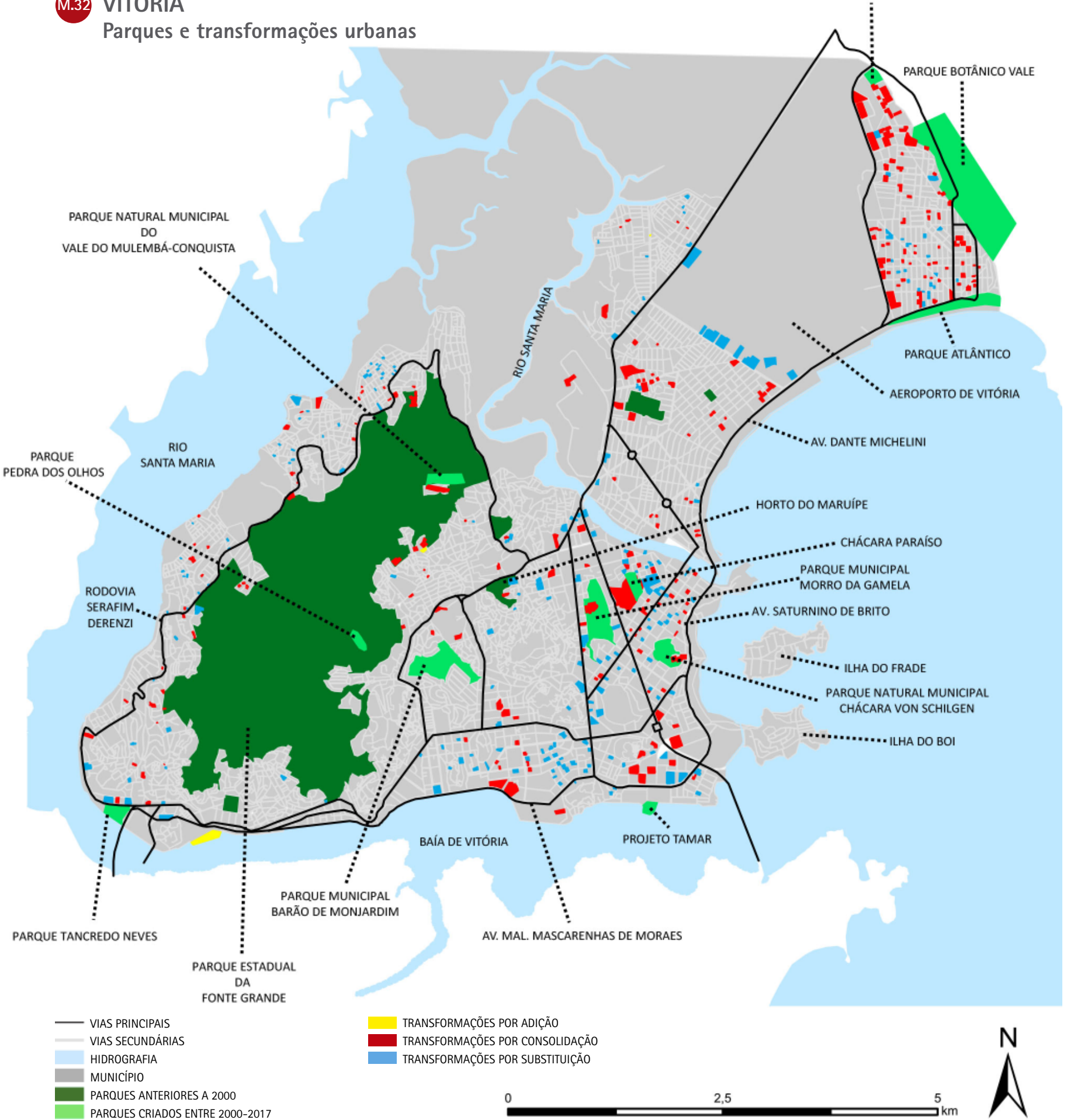




\subsection{Recife}

Em Recife a mancha urbana está contida pelos morros e áreas vegetadas das UCs, pelo rio e a orla marítima. 0 território é "encharcado", sendo a água o suporte peculiar do município, criando um cordão verde a oeste da cidade. A paisagem é predominantemente horizontal, as ruas são estreitas e a mobilidade muito difícil, agravada pela pouca oferta de transportes de massa. ${ }^{35}$ Ainda que exista mistura entre bairros ricos e pobres na cidade, o Rio Capibaribe pode ser considerado divisor de classes: na margem direita, ficam os pobres; na esquerda, onde se concentra o grosso da infraestrutura, os ricos ${ }^{36}$.

Nos anos de 1980, cinco parques foram criados: da Jaqueira, Santana, Arnaldo Assunção (no bairro do Engenho do Meio), do Forte (no Cordeiro) e o Robert Kennedy (no Ipsep). Os dois mais procurados pela população da cidade (e não apenas do entorno), o da Jaqueira e o Santana, tiverem origem em proposta que incluía outros parques ao longo do Rio Capibaribe, mas acabaram sendo executados apenas estes, em bairros de rendas mais altas. Nos seguintes surgem também muitas praças, para atender à demanda da população por espaços de recreação e esportes. ${ }^{37}$ No bairro de Casa Amarela, o Sítio da Trindade é um espaço de lazer importante, criado nos anos 1950, a partir da conversão do sítio histórico, que abriga o Forte Real do Bom Jesus do século XVIl, em parque público. 3.66

Na Oficina Quapá SEL em 2014 foram identidicados vetores de expansão para oeste, sul e norte de Recife, em territórios dos municípios vizinhos da região metropolitana. A verticalização se concentra na beira-mar e no "arco da elite", havendo ênfase do poder público em investimentos neste setor. Uma medida para amenizar a verticalização foi a Lei dos 12 Bairros $^{38}$, que criou restrições para grandes empreendimentos, mas a verticalização continuou se espraiando por estes bairros e pelos vizinhos. Há resistências: em 2012, no eixo leste, foi apresentado o projeto Novo Recife, um plano imobiliário concebido por consórcio de empreiteiras para a construção de doze torres acompanhadas de espaços livres privados e públicos ao longo do Cais José Estelita, na área central da cidade. Diferentes setores da sociedade se opuseram com veemência por meio do Movimento Ocupe Estelita (MOE).
35 CUSTÓDIO, Vanderli; TÂNGARI, Vera. Relatório Oficina Quapá-SEL I/ Recife 13 e 14 de novembro de 2014.

36 Palestra Paisagem cultural do Recife: caminhos a percorrer, de Evelyne Labanca, Instituto Pelópidas Silveira - Prefeitura Municipal do Recife. In: CUSTÓDIO, Vanderli; TÂNGARI, Vera. Relatório Oficina Quapá-SEL II Recife - 13 e 14 de novembro de 2014.

37 CARNEIRO, Ana Rita Sá; SILVA, Aline de Figueirôa; GIRÃO, Pricylla Amorim. Os espaços verdes na história do Recife. Paisagem e Ambiente. São Paulo: FAUUSP, n. 19, 2004, p. 67-82, 200.

38 Doze bairros passaram a integrar a chamada Área de Reestruturação Urbana (ARU): Derby, Espinheiro, Graças, Aflitos, Jaqueira, Parnamirim, Santana, Casa Forte, Poço da Panela, Apipucos, Monteiro e parte da Tamarineira - todos na Zona Norte. 
39 FELIPE, Max. Um parque à espera de mais frequentadores. Diário de Pernambuco, 24/03/2016. Disponivel em: <http://www.impresso.diariodepernambuco.com.br/app/noticia/cadernos/ vida-urbana/2016/03/24/interna_vidaurbana,140698/um-parque-a-espera-de-mais-frequentadores.shtml>.

40 Os autores calcularam o indice de $\mathrm{m}^{2}$ de áreas de lazer por habitante em cada uma das cinco Regiões Político- Administrativas (RPAs). Os resultados variam de 0 a 0,92 - todos considerados fracos com base em um indicador europeu.

40 PEDROSO, Carlos Auguro Mulatinho de Queiroz; SILVA, Felipe Francisco Pereira da. Equipamentos de esporte e lazer na cidade: planejamento dos parques urbanos do Recife, PE, Brasil. Revista Digital EFDeportes. Buenos Aires, Ano 16, n. 158, julho de 2011. Disponivel em: <http://www. efdeportes.com/efd158/equipamentos-de-esporte-e-lazer-na-cidade.htm>
No vetor de expansão urbana ao norte foram criados, com gestão da prefeitura, o Parque Tamarineira, e com gestão do Estado, a Requalificação da Via Norte, o Parque da Macaxeira, o projeto de Renaturalização do Rio Beberibe, o projeto Prómetrópole (ao longo do Rio Beberibe, contemplando empreendimentos do MCMV). Ainda no Eixo Norte, há o projeto da Estação Apipucos, um conjunto residencial de alto padrão. A prefeitura inaugurou nesta região o Parque Apipucos Maximiano Campos (2012), junto ao açude de Apipucos que, apesar de equipado, tem pouca visitação ${ }^{39}$. 3.66

A partir de 2011, surgem quatro novos parques: Apipucos (2012) e caiara (2011), ambos ao longo do Capibaribe; o Macaxeira (2014) e o Dona Lindu (2011) na orla de Boa Viagem; e são revitalizados o Arraial do Bom Jesus (2013) e o Santana (2014). São parques para a provisão de lazer, com quadras, pistas, playgrounds e equipamentos de ginástica. 0 Parque da Macaxeira, o maior da cidade, com campo de futebol, quadras poliesportivas, playbrounds, pistas para caminhada e bicicleta é considerado uma ação do poder público para compensar a concentração de parques públicos em áreas de altas rendas. Ele atende comunidades com alta densidade populacional e rendas inferior. 0 Dona Lindu é o único à beira-mar, no bairro de Boa Viagem, e se estrutura em torno de dois edifícios cilíndricos projetados por Oscar Niemeyer. É dotado de área de eventos, mas os usos esportivos são predominantes. Pedroso e Silva ${ }^{40}$ observaram que os parques da Jaqueira e Dona Lindu, por se localizarem em bairros nobres, são mais conservados e contêm equipamentos de melhor qualidade. (3.68)

A calçada à beira-mar é o parque urbano linear, mas há espaços livres públicos tratados em algumas partes da cidade. 0 grupo reunido na Oficina Quapá-SEL em 2014 dividiu a cidade do Recife em áreas pelo grau de atendimento de espaços livres públicos tratados para o lazer. 0 setor entre a Avenida Norte e o Rio Capibaribe e a orla de Boa Viagem são bem atendidos; o miolo central, medianamente atendido. As demais áreas não foram consideradas atendidas.

Em 2016 foi feito para Recife um projeto de grande abrangência, propondo um parque de 30 quilômetros ao longo do Rio Capibaribe - que é a somatória, segundo os autores do projeto, dos parques existentes, 65 vias-parques, 30 alamedas, 45 ciclovias para se chegar ao parque e 12 passarelas para cruzar o rio. Do conjunto 
41 Disponivel em: <http://www.leiaja. com/noticias/2015/03/11/patrimonio-do-recife-parque-dos-manguezais-esta-esquecido/>. de praças e espaços de convivência previstos, foi feito, em 2017, o Jardim do Baobá.

Nos manguezais e várzeas, há potencial para novos e futuros parques. Um já foi criado em Decreto, o Parque dos Manguezais, maior reserva de mangue em área urbana, ao sul da cidade. Cercado por comunidades de pescadores que vivem em palafitas, desde 1965 é área considerada de preservação ambiental - elevada à categoria de Parque em 2004. 0 projeto de sua criação, que não evoluiu, previa oceanário, mirantes, píeres e torres de observação científica e turística. A área segue ameaçada por lixo e esgoto. A cada dois meses, a Empresa de Manutenção e Limpeza Urbana (Emlurb) retira mais de 20 toneladas de lixo das áreas de mangue que não foram levadas pela maré. Falta saneamento básico em mais de $70 \%$ do Recife. $^{41}$ (3.69

\begin{tabular}{|c|c|c|c|c|}
\hline \multicolumn{5}{|l|}{ RECIFE (PE) } \\
\hline PARQUE & REGIÃO & ÁREA $\left(\mathrm{m}^{2}\right)$ & CRIAÇÃO & INAUG. \\
\hline PARQUE TREZE DE MAIO & JAQUEIRA & 69.000 & Cerca de 1890 & 1939 \\
\hline $\begin{array}{l}\text { PARQUE ESTADUAL DOIS IRMÃOS } \\
\text { (abriga o Zoológico) }\end{array}$ & CÓRREGO DO JENIPAPO & 172.900 & 1916 & 1939 \\
\hline $\begin{array}{l}\text { ARRAIAL VELHO DO BOM JESUS (PARQUE SÍTIO DA } \\
\text { TRINDADE) }\end{array}$ & CASA AMARELA & 64.750 & - & 1952 \\
\hline PARQUE DA JAQUEIRA & TAMARINEIRA & 74.500 & - & 1985 \\
\hline $\begin{array}{l}\text { PARQUE ARNALDO ASSUNÇÃO (inicialmente tratado por } \\
\text { Praça) }\end{array}$ & ENGENHO DO MEIO & & & $\begin{array}{r}1987 \\
\text { (revitalizado em } \\
2012 \text { ) }\end{array}$ \\
\hline ARRAIAL NOVO DO BOM JESUS (PAROUE DO FORTE) & CORDEIRO & 30.321 & & 1988 \\
\hline JARDIM BOTÂNICO DO RECIFE & CURADO & 100.000 & $\begin{array}{r}1960 \\
\text { (Parque Zoobotânico } \\
\text { do Curado) }\end{array}$ & 1979 \\
\hline $\begin{array}{l}\text { PARQUE ROBERT KENNEDY (PRAÇA DA JUVENTUDE OU } \\
\text { DO SARGENTO) }\end{array}$ & IPSEP & 18.000 & & Anos 1980 \\
\hline PARQUE SANTANA ARIANO SUASSUNA & SANTANA & 71.500 & & $\begin{array}{r}\text { Anos } 1980 \\
\text { (revitalizado em } \\
\text { 2014) }\end{array}$ \\
\hline PARQUE DOS MANGUEZAIS & PINA & 3.200 .000 & 2004 & - \\
\hline PARQUE DONA LINDU & BOA VIAGEM & 27.166 & - & $\begin{array}{r}2008 / 2011\left(1^{\mathrm{a}}\right. \\
\text { etapa) }\end{array}$ \\
\hline PAROUE DO CAIARA & IPUTINGA & 72.000 & - & 2011 \\
\hline PAROUE APIPUCOS MAXIMIANO CAMPOS & APIPUCOS & 12.900 & - & 2012 \\
\hline PARQUE URBANO DA MACAXEIRA & MACAXEIRA & 68.700 & - & 2014 \\
\hline
\end{tabular}

Tabela elaborada por Caroline Ribeiro para este trabalho, a partir de informações de informações da prefeitura, Google Earth e outras fontes.

Nesta tabela:

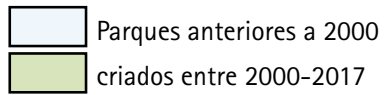




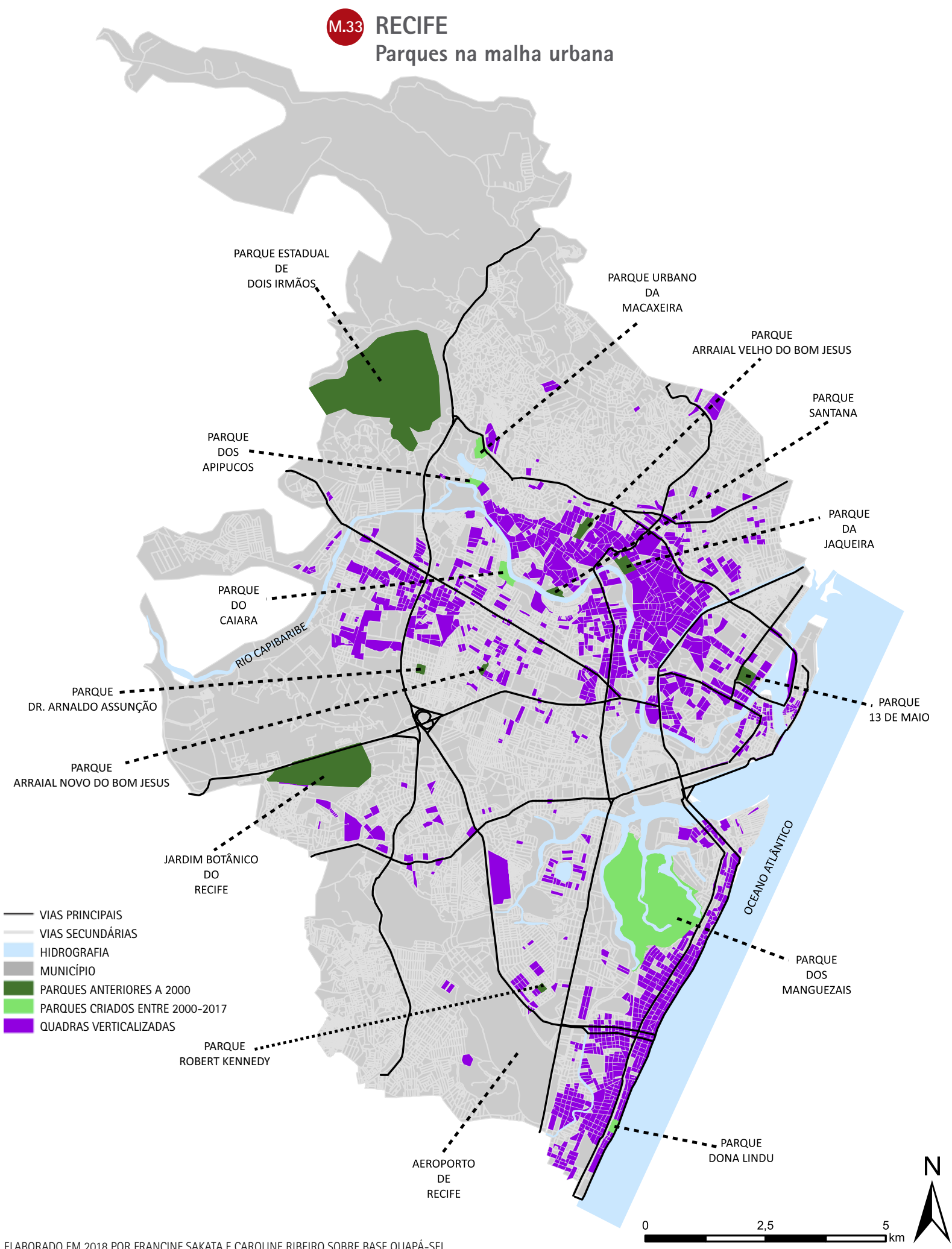




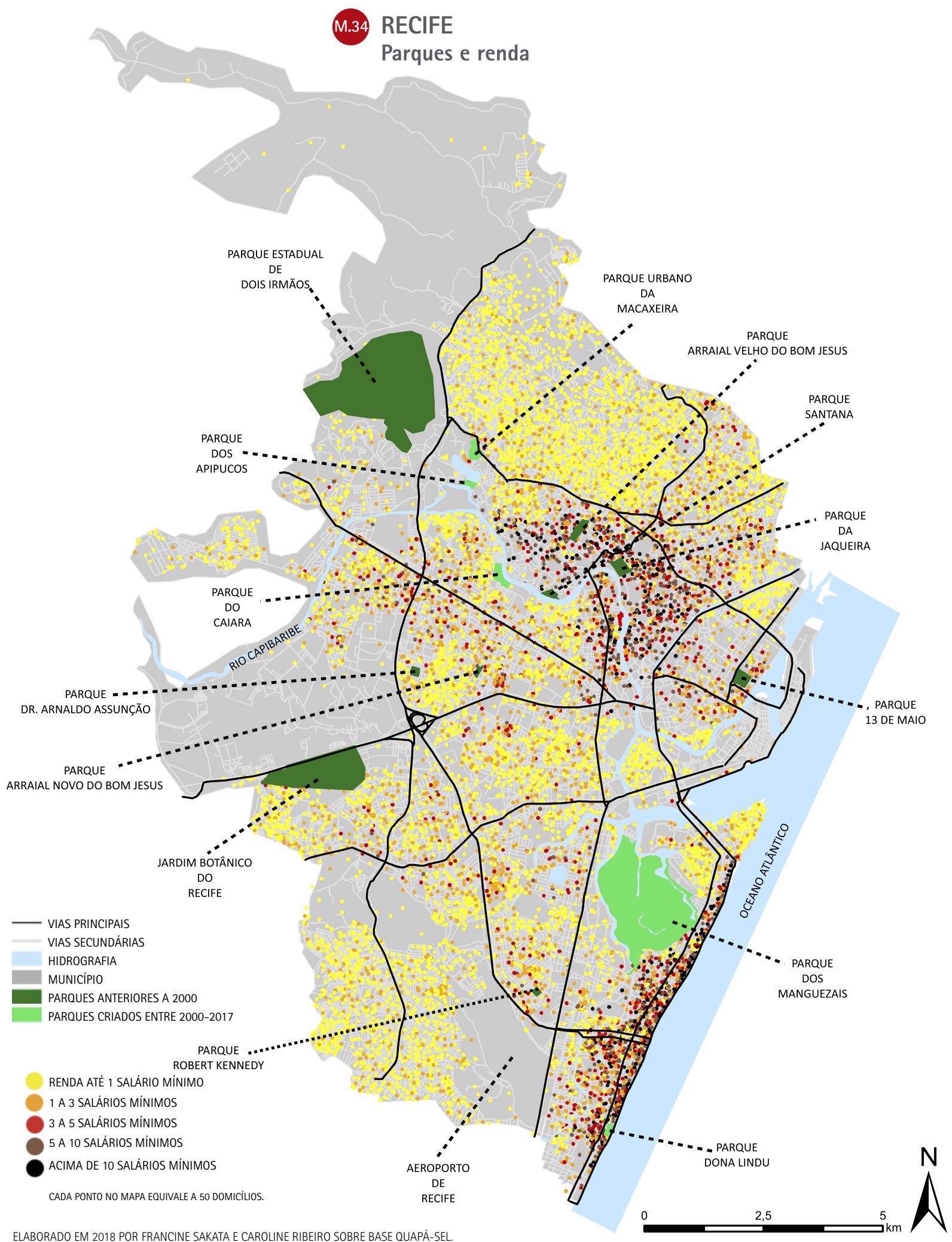




\subsection{Rio de Janeiro}

No século XXl, diversos investimentos públicos - na circulação, construção de centros esportivos, incremento das orlas, urbanização de favelas etc. - transformam a cidade. Para os grandes proprietários e investidores, a Barra da Tijuca e arredores são importantes polos de negócios e comércio. Já a região central e a Zona Sul foram se consolidando, mais uma vez, como polos de negócios e turismo. 0 extremo oeste (Baía de Sepetiba) foi alterado com o porto e os investimentos em siderurgia. 0 Rio de Janeiro habitado pela elite e conhecido pelos turistas é o das zonas Central e Sul, porém a maioria da população vive fora dessas regiões e relativamente distante do mar. Para os bairros populares localizados atrás dos maciços, a moldura da cidade são os morros. ${ }^{42}$

A produção do Minha Casa Minha Vida, sobretudo na Zona Oeste do Rio de Janeiro, foi intensa, com mais de 100 empreendimentos. A cidade se adensou, mais do que se expandiu, embora existam muitas áreas prontas para expansão na Barra da Tijuca e no Recreio dos Bandeirantes.

No sentido Leste-Oeste, margeando a orla, há muitas praças. Nos locais onde há concentração de praças não há parques e vice-versa. Na llha do Governador, há muitas praças e parques. A praia é, sem dúvida, o principal espaço livre da cidade, muito apropriado pela população. Atualmente, o Rio de Janeiro conta com 30 parques urbanos, o que é pouco para as dimensões da cidade. ${ }^{43}$

A gestão das áreas é feita pela Fundação Parques e Jardins (FPJ), uma das instituições mais antigas da Prefeitura, criada em 1893. A FPJ é responsável pela arborização da cidade, construção e manutenção em praças, instalação de mobiliário urbano e pelo planejamento, paisagismo, projetos, reflorestamento pela administração dos parques, assim como pelas regras que regulam o espaço físico das praças, parques e podas. ${ }^{44}$ Ainda que sejam muitas as atribuições, até o início dos anos 2000 a manutenção da vegetação na cidade poderia ser considerada boa e a dos elementos construídos era mais irregular. As dificuldades aumentaram e as concessões para
42 CUSTÓDIO, Vanderli. Relatório Oficina Quapá-SEL II Rio de Janeiro (RJ), 5 e 6 de dezembro de 2016.

43 Idem.

44 Disponivel em: <http://www.rio.rj.gov. br/web/fpj/estrutura $>$. 
a gestão privada dos parques mais visitados têm sido consideradas. Para o Parque Tom Jobim, foi feito o modelo jurídico considerando que há legislação municipal ou estadual ou federal incidindo sobre cada elemento. 0 Parque Nacional da Floresta da Tijuca, o trecho onde está o Corcovado, teve sua exploração concedida ao grupo Cataratas. Segundo o Instituto Chico Mendes de Conservação da Biodiversidade (1CMBio), os parques nacionais do Estado do Rio de Janeiro são os "laboratórios" brasileiros de práticas de gestão de áreas protegidas. (3.70 3.72

No período que analisamos neste trabalho, destacamos:

- a ampliação das áreas de conservação ou sua conversão em parques como forma mais efetiva de preservação. 0 Plano Diretor de 1992 havia definido a criação de UCS como instrumento da Política de Meio Ambiente e a Secretaria Municipal de Meio Ambiente (SMAC) desenvolveu estudos técnicos para a criação de novas unidades, regulamentação e implantação das UCs existentes. Em 2004, um Decreto Federal ampliou os limites do Parque Nacional da Tijuca de 33 para 39,51 km², incorporando locais como o Parque Lage, Serra dos Pretos Forros e Morro da Covanca. ${ }^{45}$ Em 2011, estudos para regulamentação das (Aparus) do Complexo Cotunduba - São João apontaram a possibilidade de criação de uma Unidade Conservação de Proteção Integral e, com a mobilização da sociedade local, foi criado o Parque Natural Municipal Paisagem Carioca; ${ }^{46}$

- Dois parques novos foram criados com muita qualidade para o lazer de massa: o Parque Madureira e o Parque Radical de Deodoro, que não foram feitos como obras cotidianas, mas como especiais, fora do escopo da FPJ. Para Silvio Macedo, áreas pertencentes ao exército podem ser vistas como espaços de espera que permitirão politicas públicas para os espaços livres de edificação no futuro; ${ }^{47}$ 3.71

45 Disponivel em: <http://www.parquedatijuca.com.br/\#historia>

46 Disponivel em: <http:// www.rio.r.j.gov.br/web/smac/ exibeconteudo?id=2812667 $>$. Atualizado em 26 jan. 2010.

47 Idem.

- Entre as obras mais "cotidianas" relacionadas a parques, foi feita a remodelação do Parque Recanto do Trovador, na Vila Isabel em 2011, e do Parque Machado de Assis, no Morro do Pinto, Zona Portuária do Rio de Janeiro, em 2013. Este último é parte do complexo do reservatório do Morro do Pinto, terceiro maior reservatório de água do municipio e serve como principal centro de lazer de doze mil moradores em seus arredores. 


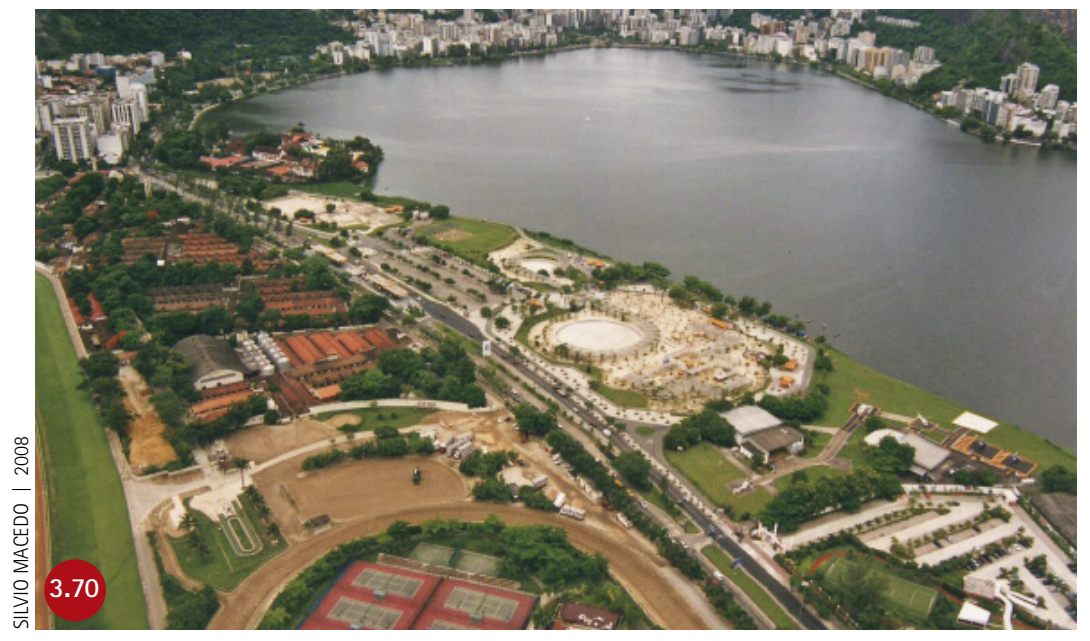

Parque Tom Jobim (1994) em torno da Lagoa Rodrigo de Freitas. Demonstra a boa oferta de espaços públicos na Zona Sul.

0 Parque Madureira (2012) foi a proposta do poder público de diminuir a defasagem de espaços de lazer na Zona Norte com um único equipamento de altíssima qualidade.
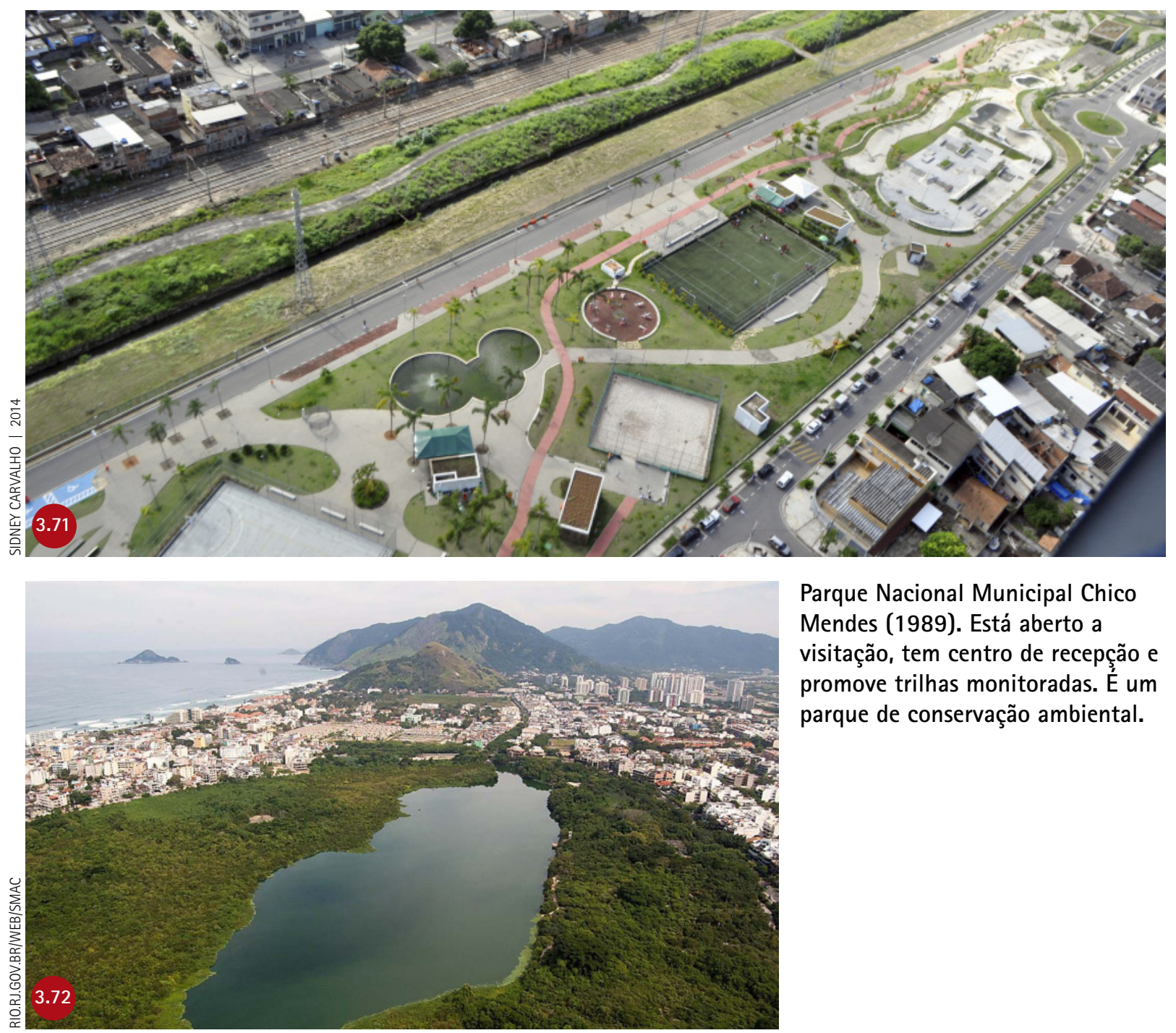

Parque Nacional Municipal Chico Mendes (1989). Está aberto a visitação, tem centro de recepção e promove trilhas monitoradas. É um parque de conservação ambiental. 
M.35 Rio de Janeiro. Divisão por zonas.

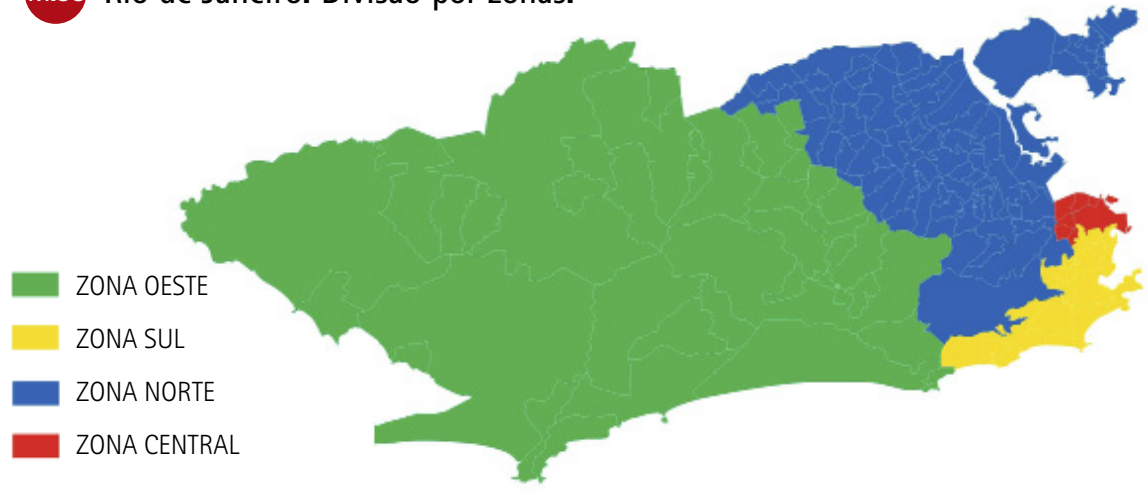

\begin{tabular}{|c|c|c|c|c|}
\hline \multicolumn{5}{|l|}{ RIO DE JANEIRO (RJ) } \\
\hline PARQUE & LOCALIZAÇÃO & ÁREA $\left(\mathrm{m}^{2}\right)$ & INAUG. & $\begin{array}{l}\text { CLASSIF. } \\
\text { PELA FPJ }\end{array}$ \\
\hline \multicolumn{5}{|l|}{ ZONA NORTE } \\
\hline PARQUE ESTADUAL DO GRAJAÚ & GRAJAÚ & 550.000 & 1978 & UC \\
\hline PARQUE NACIONAL DA TIJUCA & ALTO DA BOA VISTA & 39.584 .700 & 1967 & UC \\
\hline PARQUE MARCELLO DE IPANEMA & JARDIM GUANABARA & 130.000 & 1995 & URBANO \\
\hline PARQUE ORLANDO LEITE & CASCADURA & 13.000 & 1982 & URBANO \\
\hline PARQUE POETA MANUEL BANDEIRA & СОСОТÁ & 70.000 & 1978 & URBANO \\
\hline PARQUE ARI BARROSO & PENHA & 40.703 & 1964 & URBANO \\
\hline $\begin{array}{l}\text { PARQUE CORREDOR ESPORTIVO DA ILHA DO } \\
\text { GOVERNADOR }\end{array}$ & MONERÓ & 17.603 & 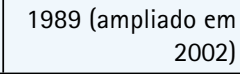 & URBANO \\
\hline PARQUE ESPORTIVO DA MARÉ & MARÉ & 100.000 & 1999 & URBANO \\
\hline $\begin{array}{l}\text { PARQUE AMBIENTAL DA PRAIA DE RAMOS } \\
\text { (PISCINÃO DE RAMOS) }\end{array}$ & RAMOS & & 2001 & \\
\hline PARQUE NATURAL MUNICIPAL JARDIM DO CARMO & VILA COSMOS & & 2001 & \\
\hline PARQUE RECANTO DO TROVADOR & VILA ISABEL & 41.260 & $\begin{array}{r}\text { Remodelação: } \\
2011 \\
\end{array}$ & URBANO \\
\hline PARQUE MADUREIRA & MADUREIRA & 113.000 & 2012 & \\
\hline PARQUE ESTADUAL MENDANHA & BANGU & 43.981 .000 & 2013 & \\
\hline PARQUE RADICAL DE DEODORO & DEODORO & 500.000 & 2015 & \\
\hline $\begin{array}{l}\text { PARQUE MUNICIPAL URBANO DA SERRA DA } \\
\text { MISERICÓRDIA }\end{array}$ & $\begin{array}{l}\text { COMPLEXO DO ALEMÄO, INHAÚMA, } \\
\text { ENGENHO DA RAINHA, TOMÁS } \\
\text { COELHO, VILA KOSMOS, PENHA, } \\
\text { OLARIA E RAMOS }\end{array}$ & 2.409 .100 & $\begin{array}{l}\text { Criado em } 2010 . \\
\text { Não implantado. }\end{array}$ & URBANO \\
\hline \multicolumn{5}{|l|}{ ZONA OESTE } \\
\hline BOSOUE DA BARRA & BARRA DA TIJUCA & 530.000 & 1983 & UC \\
\hline PARQUE ESTADUAL DA PEDRA BRANCA & VARGEM GRANDE & 125.000 .000 & 1984 & \\
\hline PARQUE NATURAL MUN. DE GRUMARI & GRUMARI & 9.663 .200 & 1986 & \\
\hline PARQUE NATURAL MUN. CHICO MENDES & RECREIO & 436.400 & 1989 & \\
\hline PARQUE AMBIENTAL MELLO BARRETO & BARRA DA TIJUCA & 60.000 & 1994 & \\
\hline
\end{tabular}


CAPITULO 3. DISTRIBUIÇÃO PELO ESPAÇO URBANO

\begin{tabular}{|c|c|c|c|c|}
\hline PARQUE & LOCALIZAÇÃO & ÁREA $\left(\mathrm{m}^{2}\right)$ & INAUG. & $\begin{array}{l}\text { CLASSIF. } \\
\text { PELA FPJ }\end{array}$ \\
\hline PARQUE NATURAL MUN. DA FREGUESIA & FREGUESIA & 303.300 & 1992 & \\
\hline PARQUE NATURAL MUN. DE MARAPENDI & RECREIO & 2.478 .500 & 1978 & \\
\hline PARQUE NATURAL MUN. DA PRAINHA & GRUMARI & 1.469 .300 & 1999 & \\
\hline PARQUE FAZENDA DO VIEGAS & SENADOR CAMARÁ & 84.900 & 1999 & URBANO \\
\hline $\begin{array}{l}\text { PARQUE NATURAL MUN. DA SERRA DA CAPOEIRA } \\
\text { GRANDE }\end{array}$ & GUARATIBA & 209.000 & 2002 & \\
\hline PARQUE PINTO TELES & VILA VALOUEIRE & 30.000 & 2003 & URBANO \\
\hline PARQUE NATURAL MUN. DA CIDADE & GÁVEA & 467.000 & 2008 & \\
\hline \multicolumn{5}{|l|}{ ZONA CENTRAL } \\
\hline PASSEIO PÚBLICO & LAPA & 33.600 & 1880 & URBANO \\
\hline CAMPO DE SANTANA & CENTRO & 155.000 & 1880 & URBANO \\
\hline QUINTA DA BOA VISTA & SÃO CRISTÓVÃO & 560.500 & 1905 & URBANO \\
\hline PAROUE MACHADO DE ASSIS & SANTO CRISTO & 21.260 & 2013 (reinaug.) & URBANO \\
\hline CAMPO DE SÃO CRISTÓVÃO & SÃO CRISTÓVÃO & 13.510 & $\begin{array}{r}1906 \\
\text { Pavilhão: anos } 1950 \\
\end{array}$ & URBANO \\
\hline \multicolumn{5}{|l|}{ ZONA SUL } \\
\hline $\begin{array}{l}\text { PARQUE DO FLAMENGO (PARQUE BRIG. EDUARDO } \\
\text { GOMES) }\end{array}$ & FLAMENGO & 1.219 .700 & 1965 & URBANO \\
\hline PARQUE EDUARDO GUINLE & LARANJEIRAS & 24.750 & Por volta de 1940 & URBANO \\
\hline PARQUE DA CIDADE & GÁVEA & 470.000 & 1939 & \\
\hline PARQUE ESTADUAL DA CHACRINHA & COPACABANA & 130.000 & 1984 & \\
\hline PARQUE GAROTA DE IPANEMA & IPANEMA & 28.270 & 1978 & URBANO \\
\hline PARQUE LAGE & JARDIM BOTÂNICO & 520.000 & 1957 & \\
\hline PARQUE YITZHAK RABIN & BOTAFOGO & 43.800 & 1965 & URBANO \\
\hline PARQUE PENHASCO DOIS IRMÃOS & LEBLON & 391.900 & 1992 & \\
\hline $\begin{array}{l}\text { PARQUE TOM JOBIM (COMPREENDE PARQUES } \\
\text { CANTAGALO, DAS TABOAS E BRIG. FARIA LIMA) }\end{array}$ & LAGOA & 100.000 & 1994 & URBANO \\
\hline $\begin{array}{l}\text { PARQUE NATURAL MUN. JOSÉ GUILHERME } \\
\text { MEROUIOR }\end{array}$ & LAGOA & 829.000 & 2000 & \\
\hline PARQUE NATURAL MUN. DA FONTE DA SAUDADE & LAGOA & 22.200 & 2000 & \\
\hline PARQUE NATURAL MUN. PAISAGEM CARIOCA & COPACABANA & 1.598 .200 & 2013 & \\
\hline
\end{tabular}

Segundo a Secretaria Municipal de Meio Ambiente - SMAC, em 2011, o Município contava com 93 Áreas Protegidas, sendo 35 Parques, 26 APAs e duas Áreas de Proteção Ambiental e Recuperação Urbana (Aparu) que correspondiam a 1.182,30 km² ou 26,99\% da área total do municipio.

No site da prefeitura constam como urbanos os 22 parques anotados na tabela. Tabela montada por Francine Sakata e Caroline Ribeiro a partir de dados da Fundação Parques e Jardins e da SMAC. Disponiveis em: <http://www.rio.rj.gov.br/web/fpj/ parques-urbanos> e <http://www.rio.rj.gov.br/web/smac/exibeconteudo?id=2812667>.
Nesta tabela:

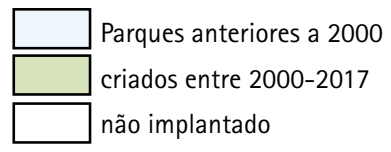


M.36 RIO DE JANEIRO

Parques na malha urbana

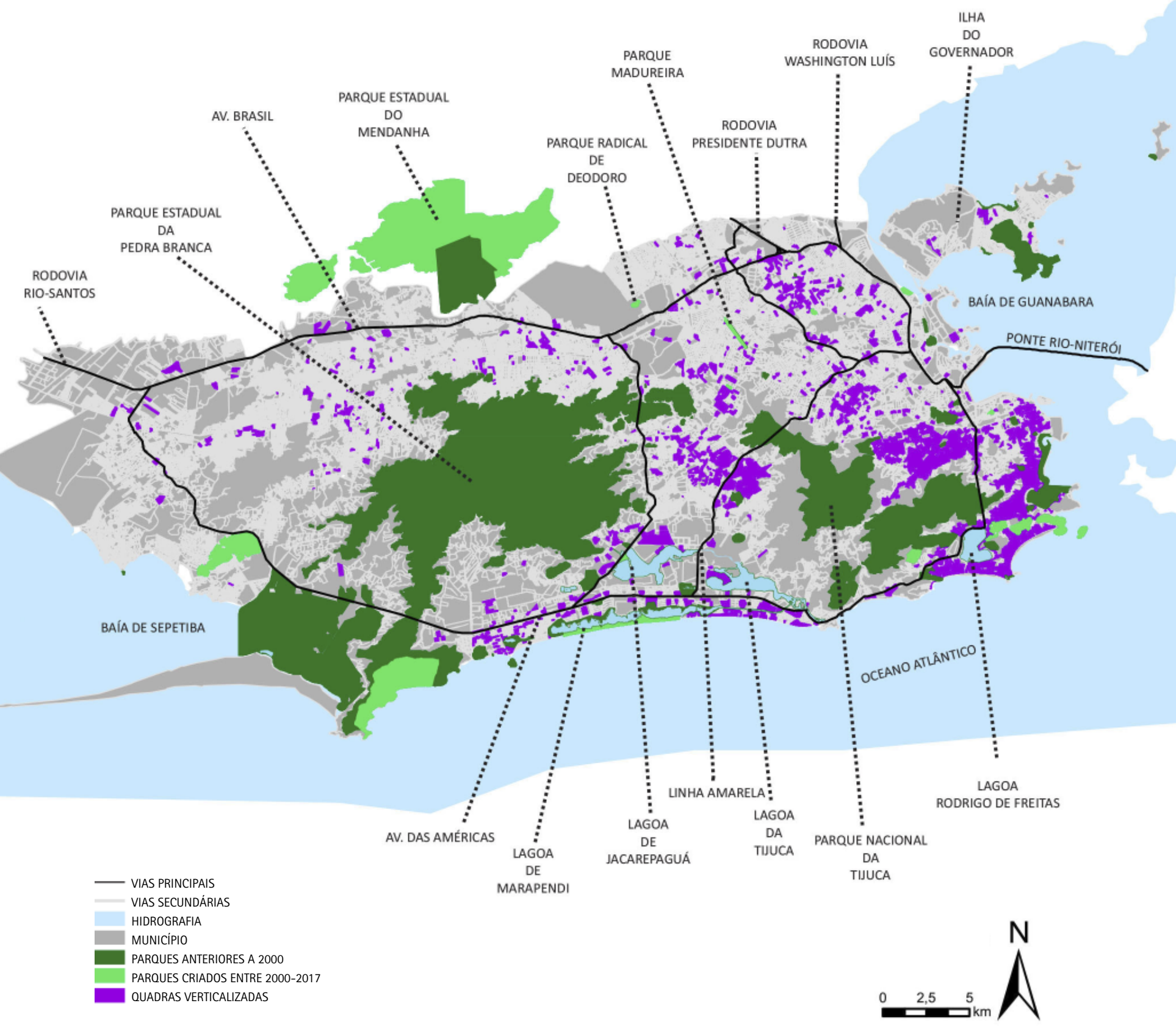




\section{M.37 RIO DE JANEIRO}

Parques e renda

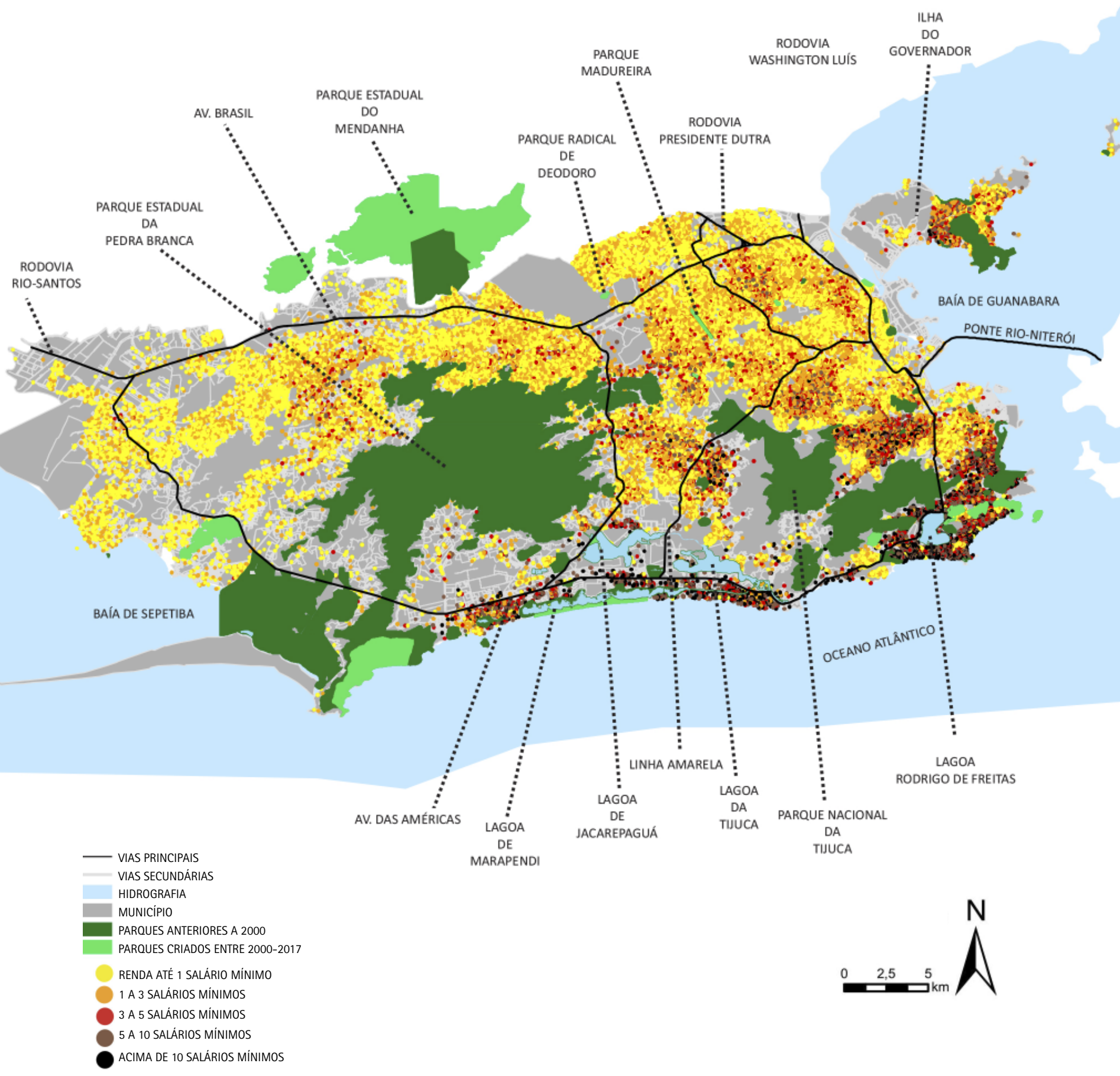

CADA PONTO NO MAPA EQUIVALE A 50 DOMICILIOS. 


\subsection{Salvador}

Na Oficina Quapá-SEL ${ }^{48}$ de Salvador, em 2014, fez-se o diagnóstico de que o crescimento urbano se mostra tanto espraiado como compacto, dos pontos altos para os baixos. A expansão da verticalização é caracterizada por altas taxas de impermeabilização. A expansão viária está sendo incrementada com a construção de vias perpendiculares aos quatro eixos viários principais - duas rodovias, as paralelas e a via da orla. 0 pedestre tem sido pouco contemplado nestas expansões. Há muito investimento público e imobiliário ao longo dos principais eixos de trânsito rápido, como shoppings, faculdades, áreas corporativas e centros administrativos.

0 mercado imobiliário concentrou lançamentos ao longo da Avenida Paralela, no eixo Barra-Graça, em Ondina e Itapuã. Os apartamentos na Barra, na Graça e na Boca do Rio são valorizados porque estão no vetor histórico de expansão das camadas de renda mais alta, mas a presença de remanescentes dos cursos hídricos e das manchas de mata é um chamariz para as vendas. A Mata da Aeronáutica e a dos terrenos de outras associações atléticas não são parques e nem são públicos, entretanto são associados à qualidade de vida e compõem a imagem destes bairros. 3.75

A cidade possui forma peninsular e extensas faixas de orlas distintas: a do Atlântico é mais aberta e valorizada, embora os tecidos urbanos sejam mistos; a da Bahia de Todos os Santos é a de ocupação mais antiga e a mais popular. 3.73

A maioria dos parques - Pituaçu, Abaeté, Zoobotânico Getúlio Vargas, Costa Azul, Jardim dos Namorados - foram propostos e geridos pelo governo do Estado, através da Companhia de Desenvolvimento Urbano do Estado da Bahia (Conder). Nos anos 1990, uma sequência de parques foi criada ao longo da orla: Abaeté (1993); Costa Azul (1997); das Esculturas (1998) - ainda na Baía de

48 CUSTÓDIO, Vanderli. Relatório Oficina Quapá-SEL II Salvador, 1 a 4 de junho de 2014.

49 SAKATA, Francine. Paisagismo urbano: requalificação ou criação de imagens. São Paulo: Edusp, 2011.
Todos os Santos; Jardim dos Namorados (1999) e Aeroclube (1999). Todos foram feitos com a intenção de incrementar a imagem da cidade e valorizar a orla especialmente para o turismo..$^{49} 0$ Parque do Abaeté ainda possui o mérito de preservar dunas e a lagoa do Abaeté, de grande significado cultural. 3.80 3.81 
50 Disponivel em: <http://varelanoticias. com.br/leitor-denuncia-sujeira-e-mau-cheiro-no-dique-do-tororo-conder-esclarece/>

51 Palestra de Tânia Scofield, Diretora da Fundação Mário Leal Ferreira, da Prefeitura de Salvador. CUSTÓDIO, Vanderli. Relatório Oficina Quapá-SEL I/ Salvador, 1 a 4 de junho de 2014.

52 Barracas de praia - entre o mito e a realidade. Arquitextos. Portal Vitruvius, jan. 2008. Disponivel em: <http://www. vitruvius.com.br/revistas/read/arquitextos/08.092/171>.

53 VERA, L. A. R.; LADEIRA, R.; COSTA, A. $S$. A retirada das barracas de praia da orla de Salvador na perspectiva de turistas e moradores. Caderno Virtual de Turismo. Rio de Janeiro, v. 13, n. 3, dez 2013, p. 308-323.

Disponivel em: <http://www.ivt.coppe. ufrj.br/caderno/index.php/caderno/article/ view/780/375>.
O Parque do Aeroclube nunca teve apropriação significativa e foi demolido por volta de 2008. Em seu lugar, foi projetado o Parque dos Ventos, por Ciça Gorski e Rosa Kliass, cujas obras foram iniciadas e abandonadas. (3.78)

0 Dique do Tororó (1998) se destaca por não ter partido da premissa da valorização turística. A população se mobilizou pela sua despoluição, passando a fazer caminhadas ao seu redor. 0 espaço foi estruturado e recebeu decks e grandes esculturas, que valorizaram a cidade. Quando o foco é o morador, a cidade também se qualifica para o turista e de forma mais verdadeira, mais permanente. Entretanto, em 2017, há relatos de mau cheiro no local. A Secretaria do Meio Ambiente da Bahia informa que a administração do Dique do Tororó é realizada pela prefeitura; a Secretaria Municipal de Manutenção diz que a manutenção cabe ao Governo do Estado, e a CONDER esclarece que o espelho d'água é responsabilidade da União (que não conta com estrutura para isto), cabendo a ela apenas a retirada do lixo e manutenção dos aeradores. ${ }^{50}$

Em 2014 a prefeitura reformou o Parque da Cidade, sob sua gestão, com a substituição de muros por portões e gradil; recuperação das quadras, pistas, ciclovia e sinalização; e a implantação de pistas de skate. Também foram reformados e construídos novos playgrounds, o Anfiteatro Dorival Caymmi, e foi montada a Praça Confúcio. A Guarda Municipal passou a funcionar 24h no parque. A prefeitura, afirma, assim, seu papel também na gestão de parques. 3.80

As orlas seguem como os principais espaços públicos da cidade. Nos anos 2000, a opção do poder público foi qualificar os pontos da orla de maior movimento e visibilidade, das barracas e dos restaurantes. 0 programa municipal específico para a requalificação da orla fez intervenções de desenho urbano na Barra, Rio Vermelho, Ribeira e ltapuã, regulando o tráfego, completando a infraestrutura e repavimentando pisos. Em alguns pontos da Avenida Oceânica, optou-se pelo tráfego compartilhado ${ }^{51}$. A partir de 2002, buscou-se substituir as barracas de praia de madeira e piaçava por quiosques padronizados. ${ }^{52}$ Em 2010 elas foram demolidas por ordem judicial. ${ }^{53}$ A substituição das barracas e a remoção dos pescadores causaram polêmicas, pois opõem os usos tradicionais populares e o sustento 
das pessoas que ali trabalham à concepção da orla mais limpa, turística e elitizada.

Entre 2000 e 2015 criaram-se poucos espaços públicos, porém é recorrente a requalificação de praças nas áreas mais antigas. Os três parques novos criados no período - São Bartolomeu, Jardim Botânico de Salvador e Parque das Dunas - têm problemas de gestão. Os dois primeiros estão em vizinhanças de rendas média e baixa e contêm muitos trechos de mata. 0 Parque das Dunas apresenta uma área muito extensa, delimitada para conter a urbanização sobre as dunas, e sem programas de atividade consistentes: a fruição se restringe às trilhas, às visitas guiadas, organizadas pela Universidade Livre das Dunas e Restinga de Salvador (Unidunas), e à possibilidade de tirar fotografias. Em 2014 a prefeitura criou o Projeto Cidade Verde Perto, com o objetivo de requalificar estes parques e também o Parque da Cidade. ${ }^{54}$

Conforme cresce a mancha urbana, as áreas verdes diminuem significativamente, o que é perceptível nos mapas de desenvolvimento da cidade. Contudo, ainda há muitas áreas passíveis de preservação e aproveitamento, como áreas públicas de lazer. Junto com o professor Silvio Soares Macedo (FAUUSP/Quapá), chegou-se à conclusão de que, apesar dos problemas, Salvador é uma cidade de muitas possibilidades.
540 Projeto Cidade Verde Perto também tem como objetivo estabelecer parcerias público-privadas para a adoção de praças e rever o plano de arborização urbana.

Palestra de José A. Saraiva, da Secretaria da Cidade Sustentável e Inovação (Secis), Prefeitura de Salvador.

CUSTÓDIO, Vanderli. Relatório Oficina Quapá-SEL II Salvador, 1 a 4 de junho de 2014.

Dique do Tororó (1998) e Parque Solar Boa Vista (1980).
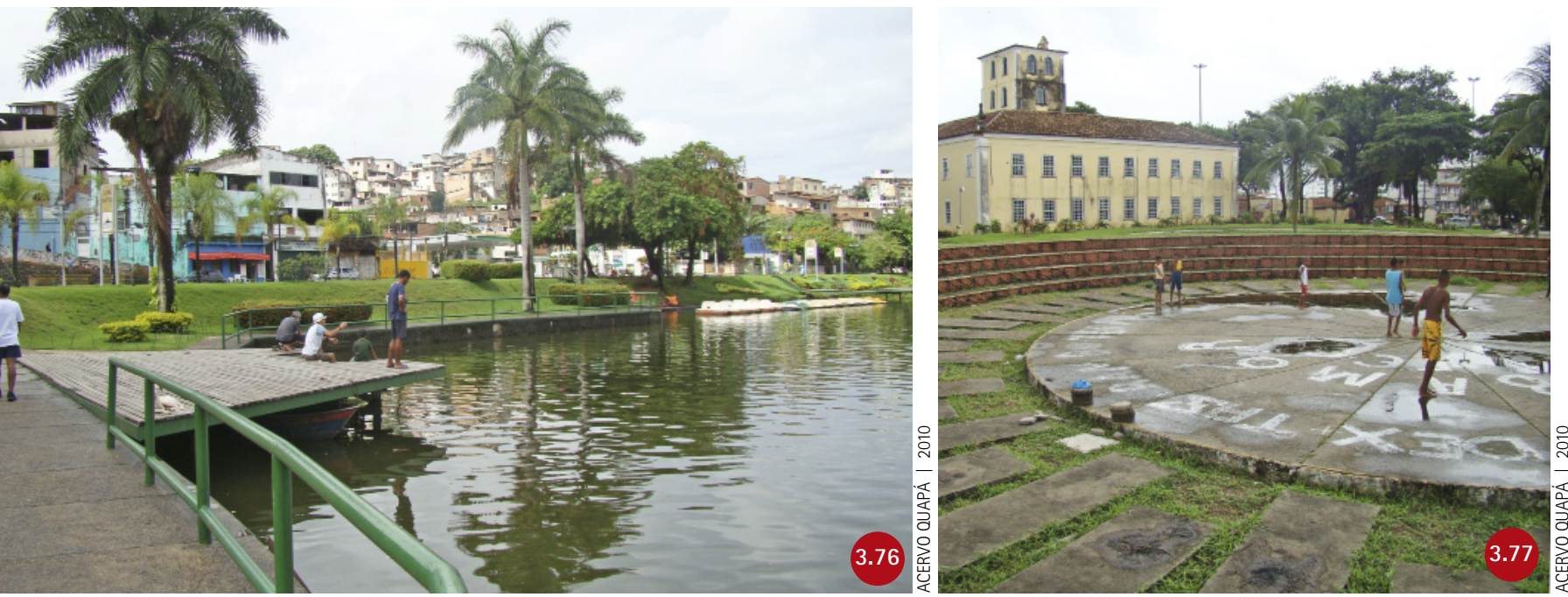
Terreno que já foi do Parque do Aeroclube (1999), ao lado de Shopping, que foi demolido em 2014. Novo parque foi projetado para o terreno, o Parque dos Ventos mas as obras, em 2017, estão interrompidas.

Parque da Cidade Joventino Silva (1975), o grande parque municipal, renovado em 2014 para melhorar as condições de uso.

Parque Costa Azul (1997), projeto de José Tabacow para a orla atlântica. Presta-se também à apropriação turística, uma vez que se localiza no caminho entre 0 aeroporto e o Pelourinho.
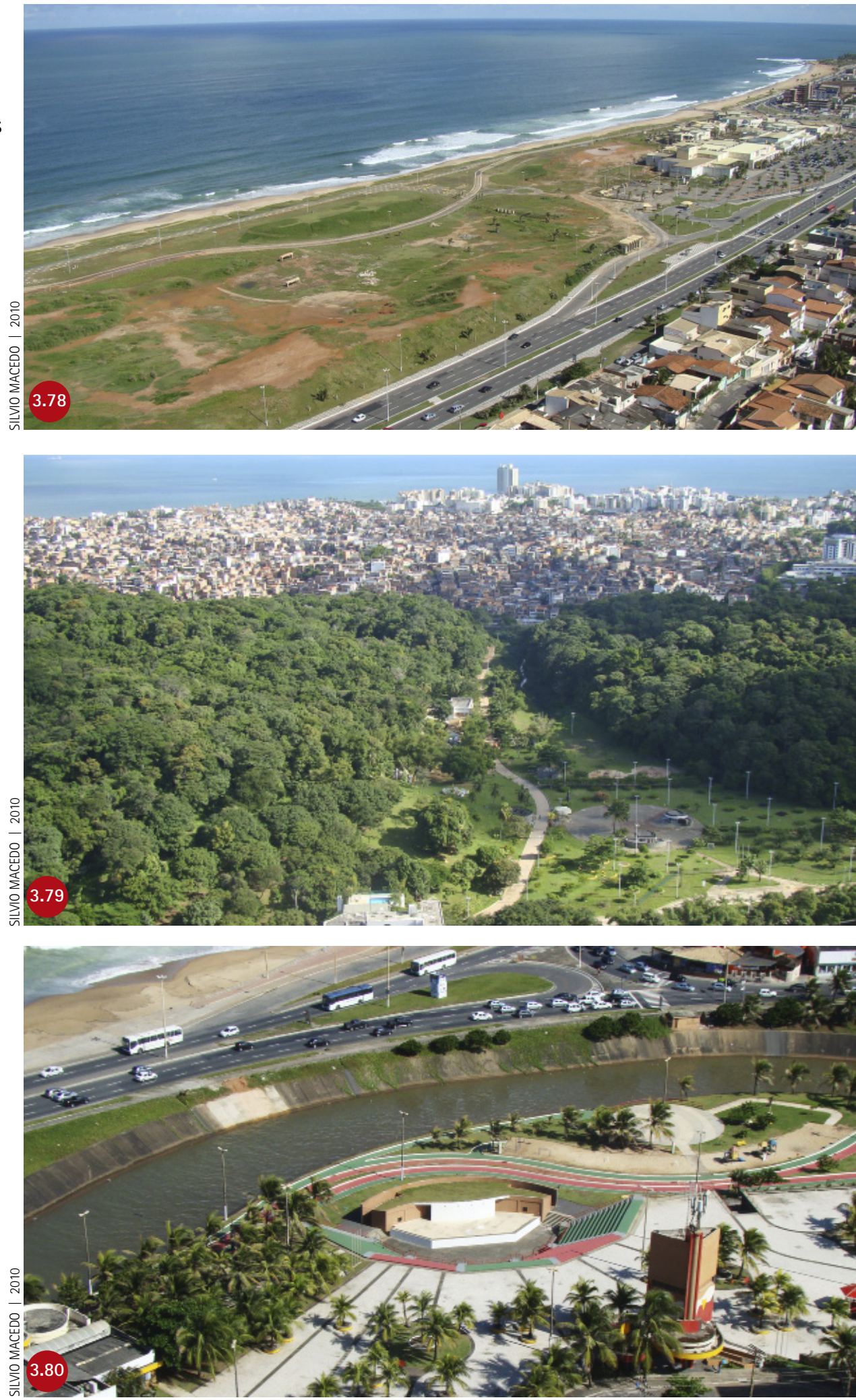


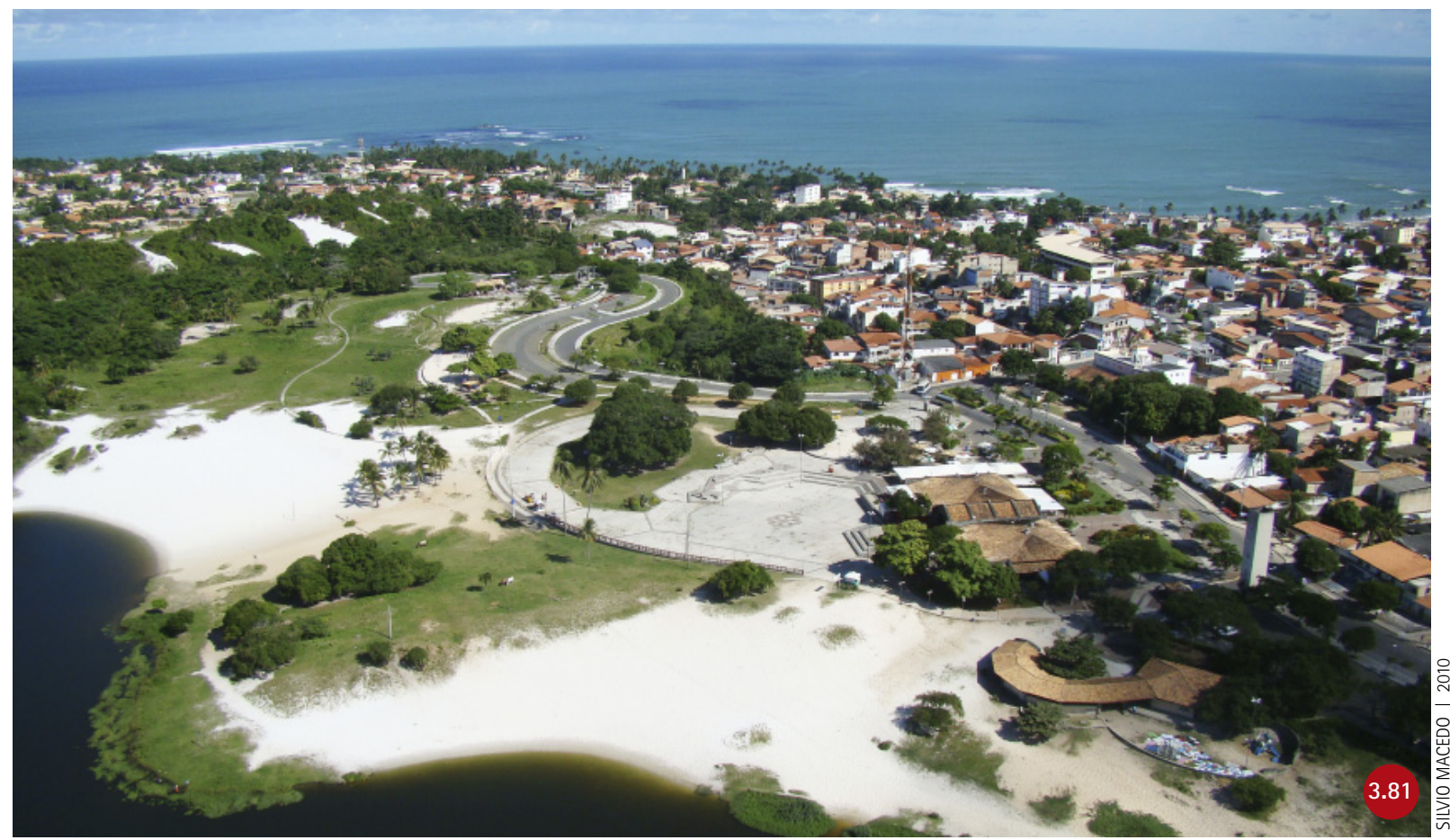

Parque Metropolitano do Abaeté (1993), um dos grandes parques criados por iniciativa do governo do estado.

\begin{tabular}{|c|c|c|c|c|}
\hline \multicolumn{5}{|l|}{ SALVADOR } \\
\hline PARQUES PÚBLICOS & REGIÃO & ÁREA $\left(\mathrm{m}^{2}\right)$ & CRIAÇÃO & INAUG. \\
\hline ZOOBOTÂNICO GETÚLIO VARGAS & ONDINA & 700.000 & 1958 & 1958 \\
\hline PARQUE METROPOLITANO DO PITUAÇU & PITUAÇU & 4.500 .000 & 1973 & 1973 \\
\hline PARQUE JOVENTINO SILVA (PARQUE DA CIDADE) & PITUBA & 720.000 & 1973 & $\begin{array}{r}1975 \\
\text { (reforma em 2014) }\end{array}$ \\
\hline PARQUE SOLAR BOA VISTA & ENG. VELHO DE BROTAS & 20.000 & 1980 & 1980 \\
\hline PARQUE METROPOLITANO DO ABAETÉ & ITAPUÃ & 2.250 .000 & 1993 & 1993 \\
\hline PARQUE COSTA AZUL & COSTA AZUL & 55.000 & 1995 & 1997 \\
\hline PARQUE DAS ESCULTURAS & DOIS DE JULHO & 53.000 & & 1998 \\
\hline DIQUE DO TORORÓ & $\begin{array}{l}\text { TORORÓ/ ENG.VELHO DE } \\
\text { BROTAS/ GARCIA }\end{array}$ & 110.000 & & 1998 \\
\hline JARDIM DOS NAMORADOS & PITUBA & 150.000 & 1960 & 1999 (reforma) \\
\hline JARDIM BOTÂNICO DE SALVADOR & SÃO MARCOS & 170.000 & 2002 & 2004 \\
\hline PARQUE DAS DUNAS & STELLA MARIS & 6.000 .000 & 2008 & 2008 \\
\hline SÃO BARTOLOMEU & PIRAJÁ & 750.000 & 1975 & 2014 \\
\hline
\end{tabular}

Tabela montada por Francine Sakata e Caroline Ribeiro.

Nesta tabela:

\begin{tabular}{l}
$\square$ Parques anteriores a 2000 \\
\hline$\square$ criados entre 2000-2017 \\
\hline$\square$ de conservação, sem fruição pública
\end{tabular}


Parques na malha urbana

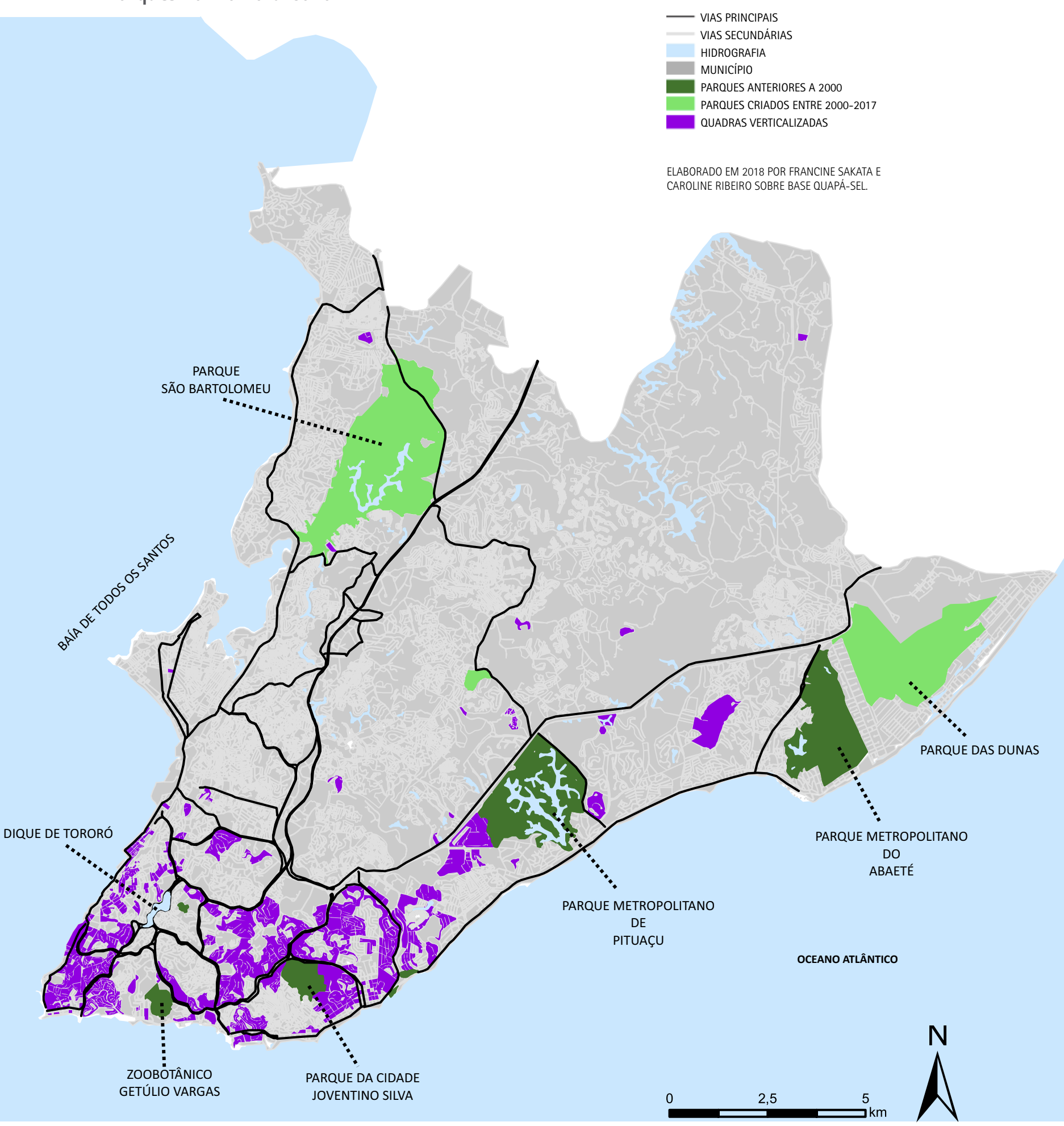


CAPÍTULO 3. DISTRIBUIÇÃO PELO ESPAÇO URBANO

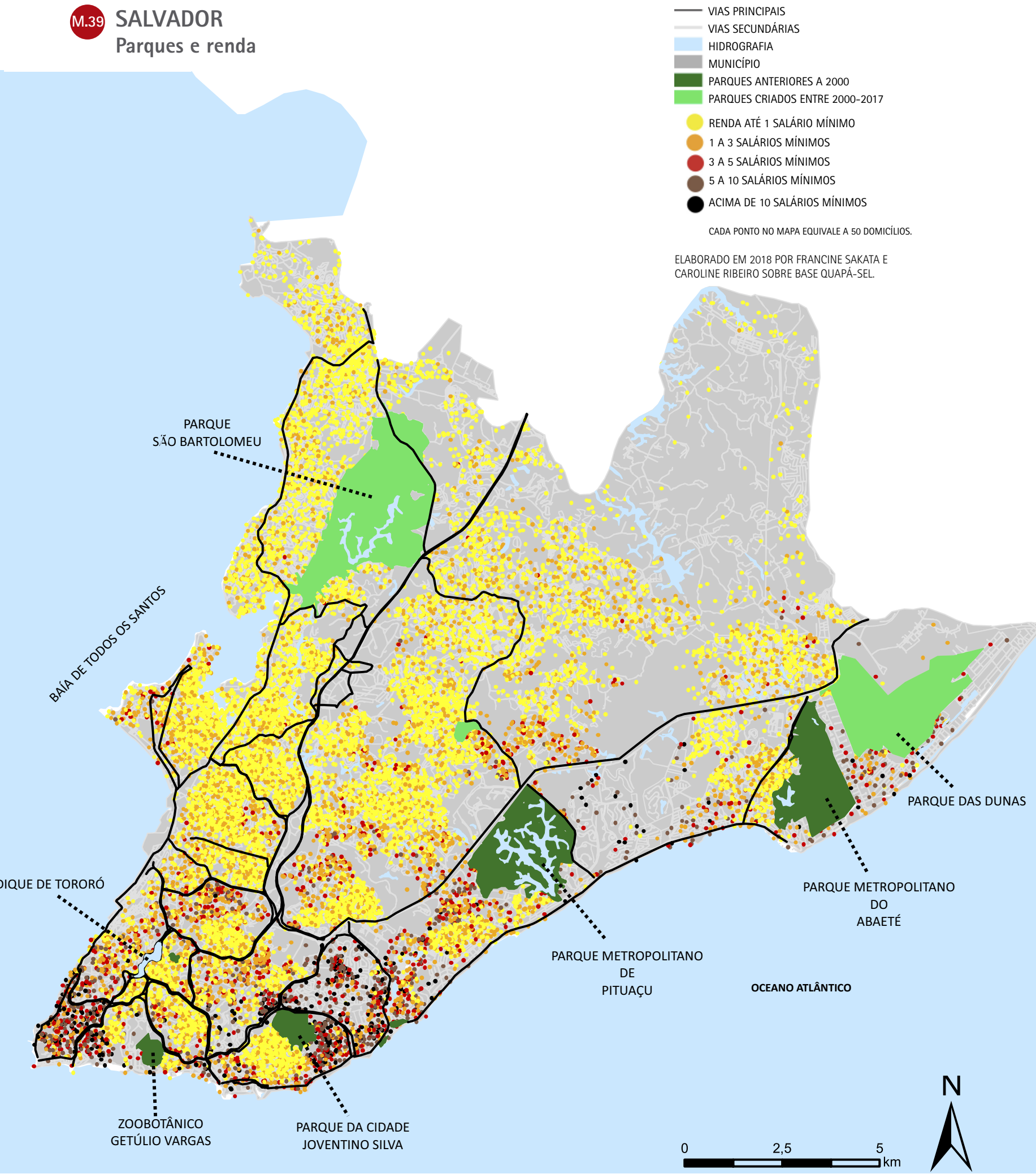




\subsection{Fortaleza}

Ainda que tenha havido muita discussão sobre o Parque do Cocó, não foram implantados novos parques entre 2000 e 2015. Houve a sobrequalificação da orla, por meio de obras como o aquário, reformas do calçadão da Praia de Iracema e o Mercado do Peixe. As praias são o espaço de lazer por excelência e em várias delas há barracas com mesas para as famílias, piscinas e toboáguas. Há praias próximas a Fortaleza que contam com o mar de um lado da faixa de areia e a lagoa do outro. E existe a cultura de uso da praça, pois a cidade tem muitas praças intensamente apropriadas para contemplação, recreação ou ginástica e que são utilizadas inclusive à noite, quando o clima é mais ameno e agradável. Nos anos 1990, houve um programa de implantação de grandes praças com equipamentos esportivos, chamado Polos de Lazer.

Em 2002, no livro Parques urbanos no Brasil (2003), Macedo e Sakata apresentaram os parques Alagadiço Novo ou Polo de Lazer Sargento Hermínio (1980), do Opaiá (feito por volta de 1980), do Pajeú (1993), Parque Adahil Barreto ou Antigo Cocó (1980), da Costa Oeste (1992), do Parreão (1993), Rio Branco (1994) e o Calçadão da Praia de lracema (projeto de 1995).

Em 2016 o Polo de Lazer Sargento Hermínio foi revitalizado e está sendo considerado parte do Parque Rachel de Queiroz. O Pajeú, pequeno bosque na área central, perdeu a vegetação rasteira possivelmente pela dificuldade de manutenção. 0 Opaiá e o Parreão, em áreas periféricas, seguem íntegros, mas com manutenção irregular. Na época da sua criação, o Parreão - pioneiro como parque linear era um dos mais belos parques do país, com uma borda sinuosa de pedra para conter a água das cheias.

Os três rios perenes de Fortaleza - Cocó, Ceará e Maranguapinho - não receberam obras de canalização e têm muitos remanescentes de vegetação conservados ao longo de suas bordas. São excelentes oportunidades para parques lineares ainda não muito explorados. 0 Parque do Cocó apresenta um trecho implantado, e sua consolidação, há alguns anos, mobilizou a atenção da população, da mídia e do poder público. É vetor de expansão do mercado imobiliário de 

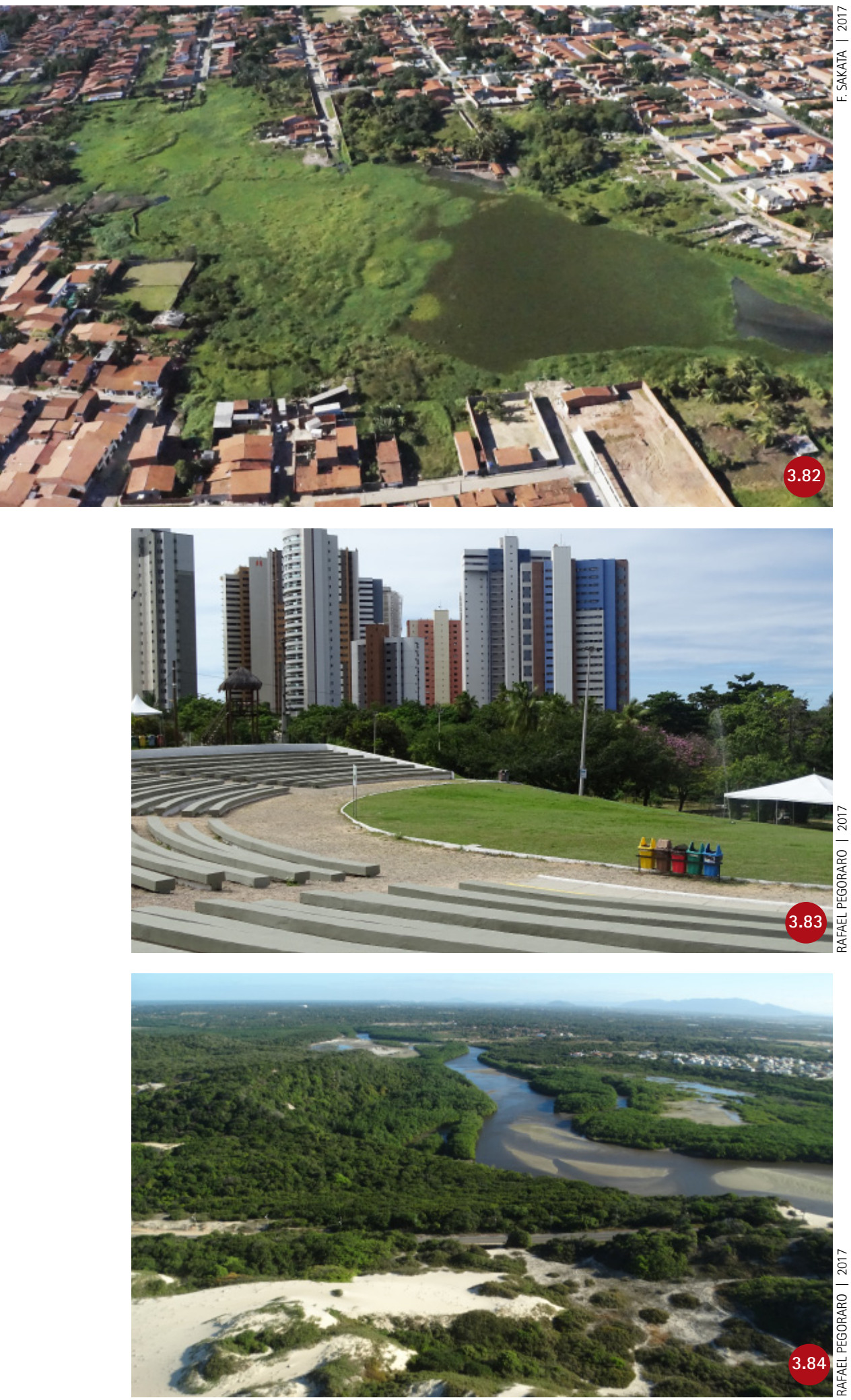

Lagoa típica de Fortaleza. 0 projeto de arruamento e loteamento ignorou a existência destes recursos naturais e agora é preciso resolver a questão da propriedade e do desenho urbano em torno da água.

Parque do Cocó, trecho implantado. As áreas restantes foram demarcadas e foram objeto de concurso de projeto em 2017.

Rio Pacoti, próximo à foz. Um desafio para Fortaleza é manter a qualidade desta paisagem, ainda bastante íntegra. 
alta renda, o que o torna interessante para o mercado imobiliário - pois valoriza os terrenos ainda disponíveis - e para a população, pois permite a criação e espaço de lazer de qualidade.

A área demarcada para o Parque do Cocó, depois de muitas discussões públicas, foi objeto de concurso em 2017. Na cerimônia de premiação, o Parque Adahil Barreto, ou Antigo Cocó, foi incorporado ao Parque do Cocó. A responsabilidade de sua gestão passou da prefeitura para o Estado.

Há em andamento, regulamentado em 2014, o projeto do Parque Rachel de Queiroz, nas margens do Rio Ceará. A previsão é de que tenha 10 quilômetros de extensão, abraçando espaços livres existentes ao longo de 14 bairros. 0 trecho mais próximo da orla também é vetor de expansão do mercado imobiliário, neste caso, de rendas médias. Uma primeira parte do parque foi implantada em 2015, em parceria com uma construtora. 0 Polo de Lazer da Avenida Sargento Hermínio e canal Dom Lustosa foram revitalizados com recursos da prefeitura. 0 Parque Raquel de Queiroz é, de fato, uma ação de planejamento. 3.86 3.87 3.88

Em 2016 um decreto transformou algumas lagoas em parques, mas a consolidação destes depende de arranjos político-econômicos, uma vez que as lagoas são privadas. Esta discussão, entretanto, ainda não teve visibilidade. 0 Parque do Cocó, de fato, centralizou os debates sobre os espaços livres urbanos. (3.82

\begin{tabular}{|l|l|r|l|l|}
\hline FORTALEZA & REGIÃO & ÁREA $\left(\mathrm{m}^{2}\right)$ & \multicolumn{1}{l|}{ CRIAÇÃO } & INAUG \\
\hline PARQUE & CENTRO & 26.717 & 37.000 & 1922 \\
\hline PARQUE DAS CRIANÇAS & MOURA BRASIL & 22.000 & 1992 \\
\hline PARQUE DA COSTA OESTE (ARENINHA) & FÁTIMA & 15.000 & 1993 \\
\hline PARQUE DO PARRẼ̃O & CENTRO & 38.500 & 1993 \\
\hline PARQUE PAJEÚ & JOAQUIM TÁVORA & 22.000 & 1994 \\
\hline PARQUE RIO BRANCO & MEIRELES & 11.552 .000 & 2018 \\
\hline PARQUE BISÃO & COCÓ & 2014 & PROJETO EM \\
\hline $\begin{array}{l}\text { PARQUE ESTADUAL DO COCÓ (INCLUI O PARQUE } \\
\text { ADAHIL BARRETO - VELHO COCÓ) }\end{array}$ & & \\
\hline
\end{tabular}

Tabela eloborada por Francine Sakata e Caroline Ribeiro. Nesta tabela: 
CAPÍTULO 3. DISTRIBUIÇÃO PELO ESPAÇO URBANO

MAYUMI HYRIE | 2017

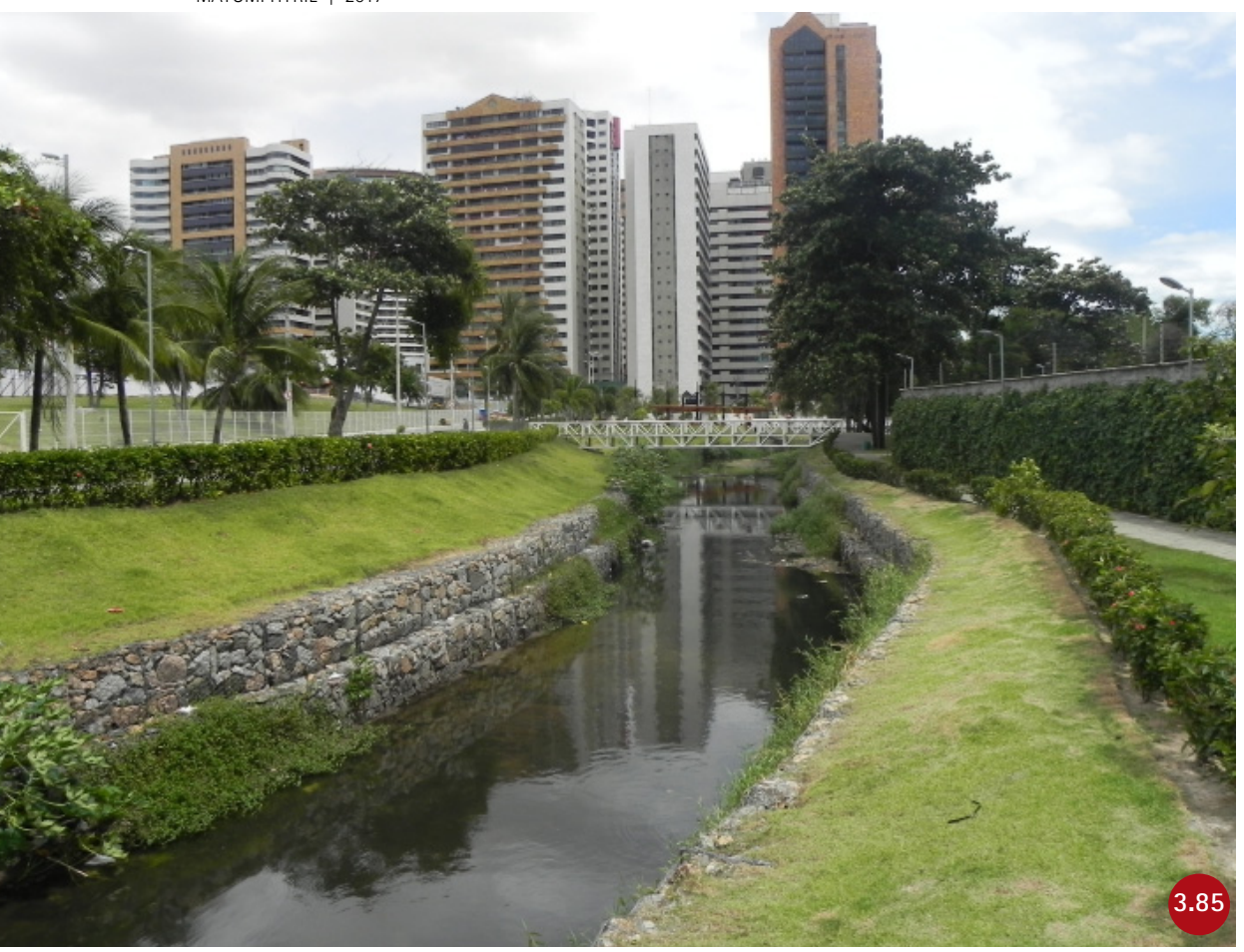

Parque Bisão (2014), em um pequeno trecho do Riacho Maceió, junto da praia, fruto de operação consorciada com uma construtora. É uma intervenção vistosa em um trecho curto, de menos de 240 metros de extensão.

Abaixo, primeiros trechos do Parque Rachel de Queiroz (2015), feitos em parceria com uma construtora, em área de rendas médias. 0 canal foi tratado e recebeu vegetação nas laterais, bancos, caminhos e iluminação. Neste trecho há caminho para pedestres de um lado do rio e rua do outro, o que ameniza os muros cegos dos edifícios. 0 projeto é simples e pode ser tomado como modelo para qualificação dos espaços urbanos à beira rio.
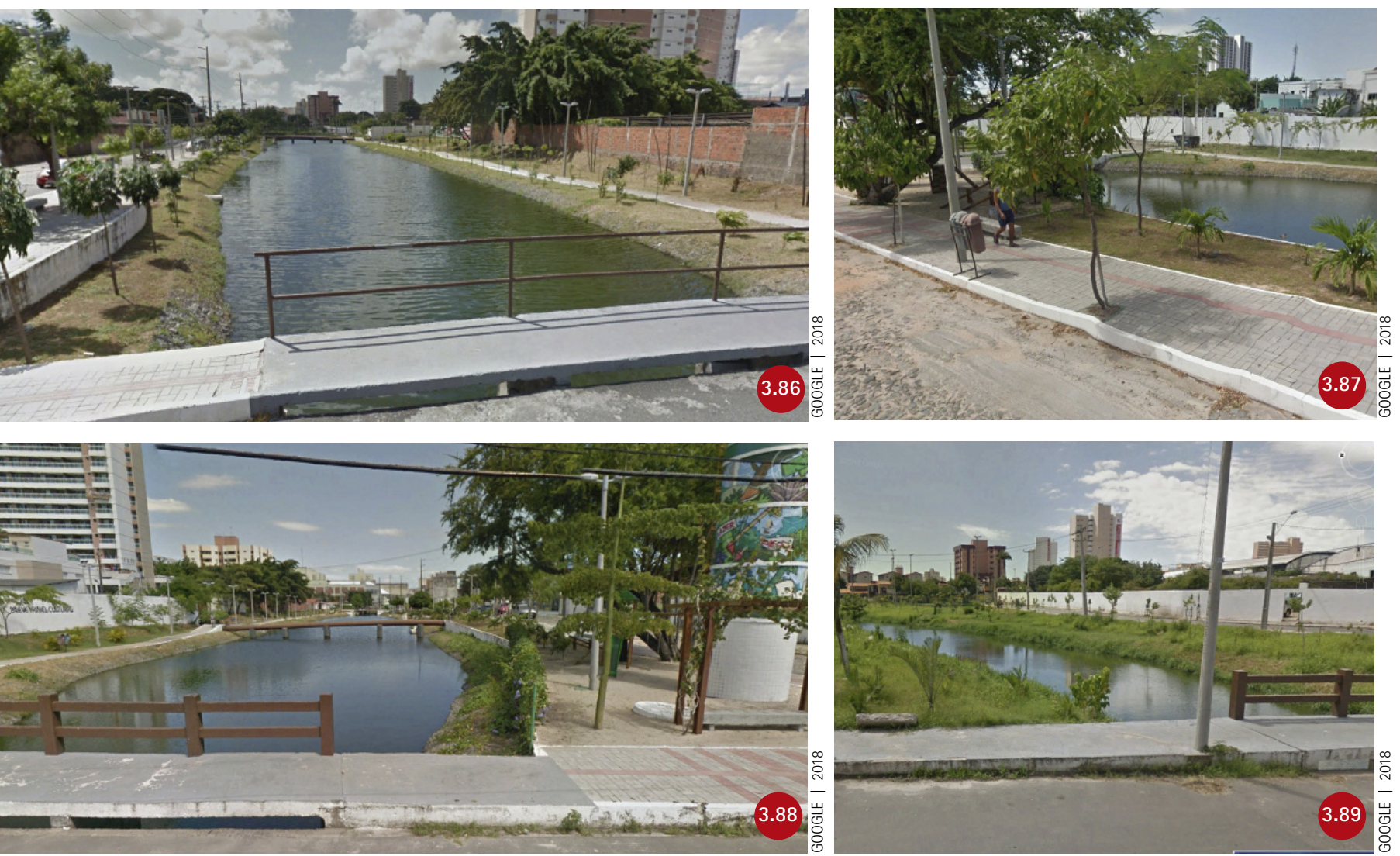
M.40 FORTALEZA

Parques na malha urbana

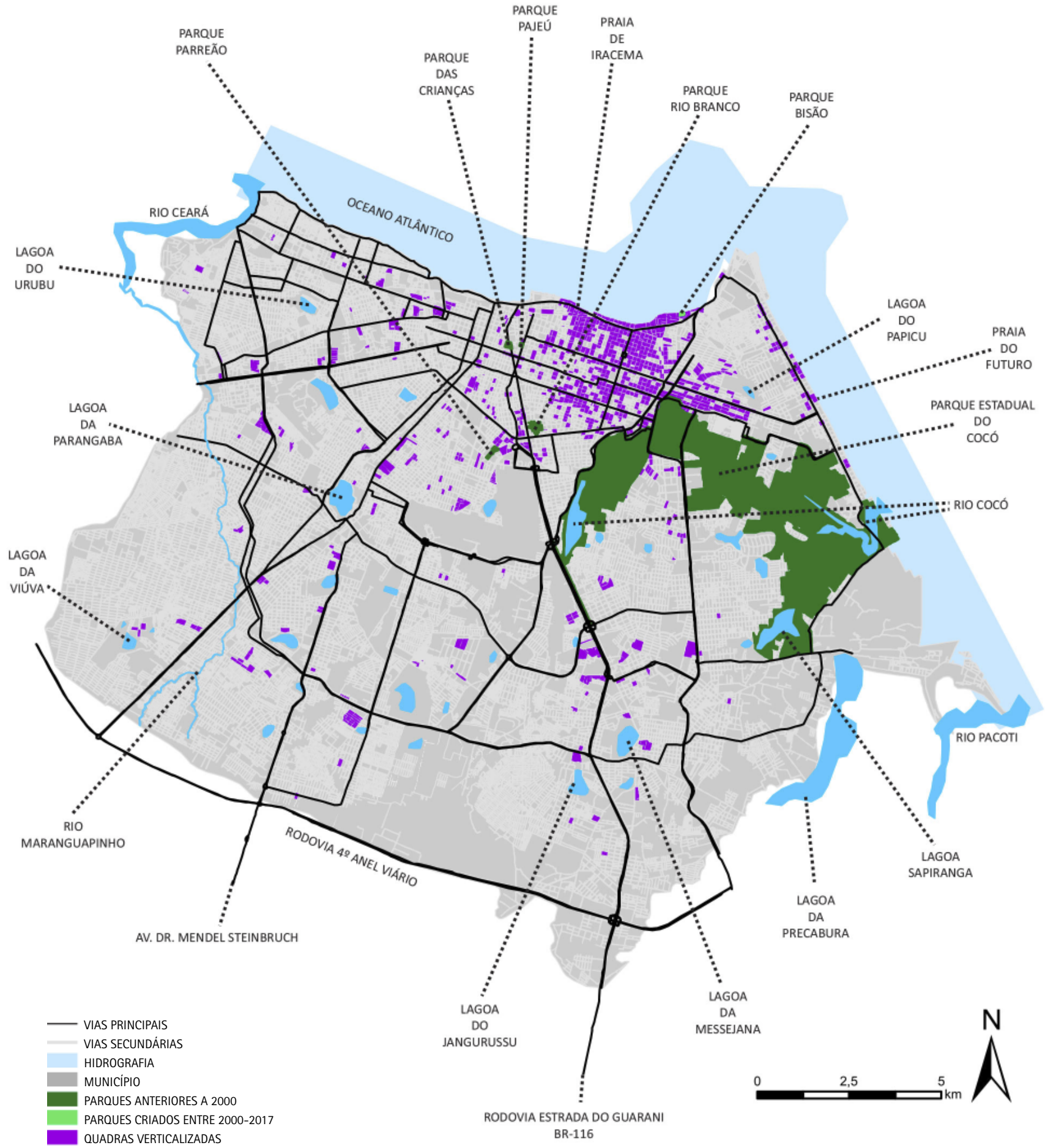


M.41 FORTALEZA

Parques e renda

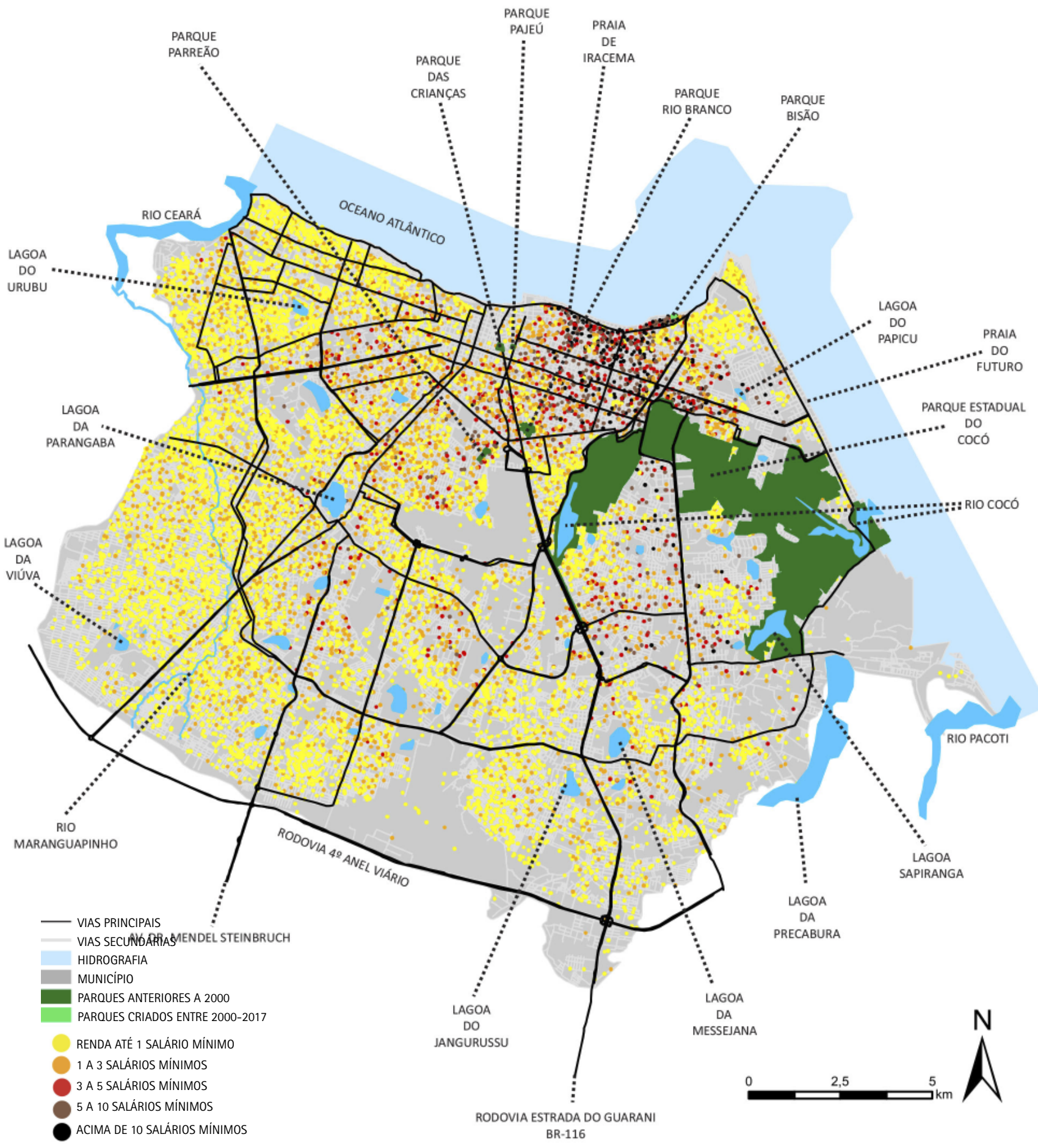

CADA PONTO NO MAPA EQUIVALE A 50 DOMICILIOS.

ELABORADO EM 2018 POR FRANCINE SAKATA E CAROLINE RIBEIRO SOBRE BASE QUAPÁ-SEL. 


\subsection{Belém}

Vista a partir do Bairro São Brás, próximo ao Parque Museu Paraense Emilio Goeldi.

Praça Frei Caetano Brandão, em frente à Igreja da Sé.
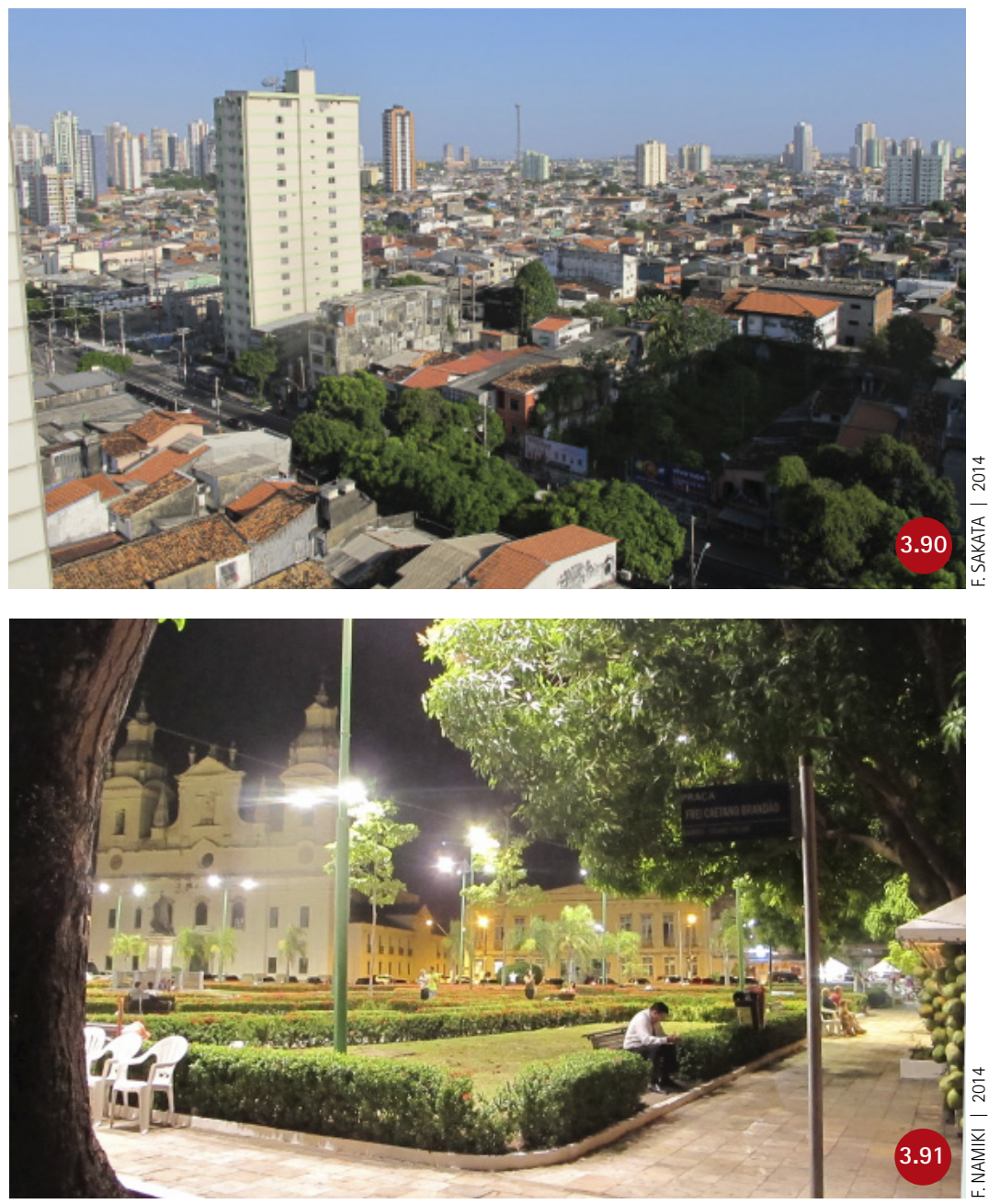

Travessa do Cruzeiro em Icoaraci, ao Norte de Belém.

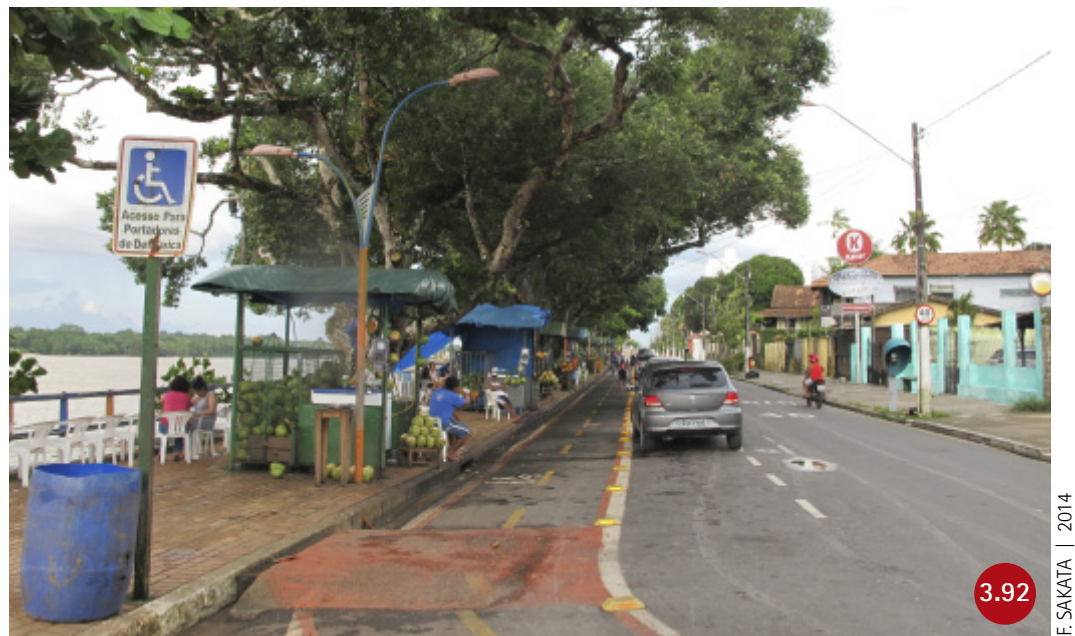


Belém está localizada em uma das maiores áreas estuarinas do mundo, para onde convergem a desembocadura de grandes e pequenos rios (Amazonas, Tocantins, Pará, Guamá). As ilhas compõem 65\% do território municipal e a parte continental, que costuma ser apreendida como "a cidade", ocupa 35\%. As ilhas têm níveis de pressão por adensamento, sendo maior quando mais bem conectada ao continente através de ponte ou transporte regular. Neste entorno insular, a vegetação tem mais presença que na porção continental, onde as transformações urbanas foram intensas e aceleradas, inclusive com supressão de vegetação, obstruções visuais e destruição de imóveis de valor histórico. ${ }^{55}$

Durante a Oficina Quapá-SEL em 2015, foi mensurado o aumento no número de domicílios na cidade entre os censos de 2000 e 2010: de aproximadamente 4 mil para cerca de 7 mil novos domicílios novos a cada ano. Uma vez que o mercado formal nunca ultrapassou 3.500 unidades entregues por ano e não tenha sido verificada a ocorrência de novas ocupações informais nesse período, supôs-se que o aumento corresponda ao adensamento de áreas de ocupação informal já existentes. ${ }^{56}$

$\mathrm{Na}$ área central, consolidou-se uma fronteira de expansão imobiliária, classificada por alguns agentes do mercado como Nova Belém, onde foram feitos condomínios verticais de médio padrão por grandes incorporadoras nacionais. Outras obras na orla do Rio Guamá - a Nova Orla - lançam a hipótese de estar se consolidando uma subcentralidade nesta área, que poderia atrair também lançamentos imobiliários de alto e médio padrão em terras urbanas que ainda não apresentam preços elevados.

Há áreas verdes tratadas como espaços públicos para uso da população na área central. As praças e os dois parques da área central e dos bairros de rendas mais altas têm boa qualidade, ainda que existam em pequena quantidade em relação à área urbanizada. Os espaços livres mais bem tratados localizam-se na orla, também com apropriação turística. Os dois novos parques da cidade e mais o Complexo Ver-o-Rio (uma espécie de praça) são espaços à beira d'água junto do centro histórico. (3.91) 3.93
55 Palestra do Prof. Dr. Eduardo Brandão, pesquisador do Laboratório de Avaliação e Medidas e membro do Movimento Orla Livre. LEITÃO, Karina et al. Relatório Oficina Quapá-SEL // Belém, 11 e 12 de maio de 2015.

56 Dados de Belém: LEITÃO, Karina et al. Relatório Oficina Quapá-SEL I/ Belém, 11 e 12 de maio de 2015. 
O Complexo Turístico Ver-o-Rio, criado entre 1997 e 2004 às margens da Baía do Rio Guajará, abriga o Memorial dos Povos Indígenas. Possui lago com pedalinhos, bar, barracas com comidas típicas, palco, playground e calçadão.

Residência ribeirinha, na outra margem do Rio Guamá.

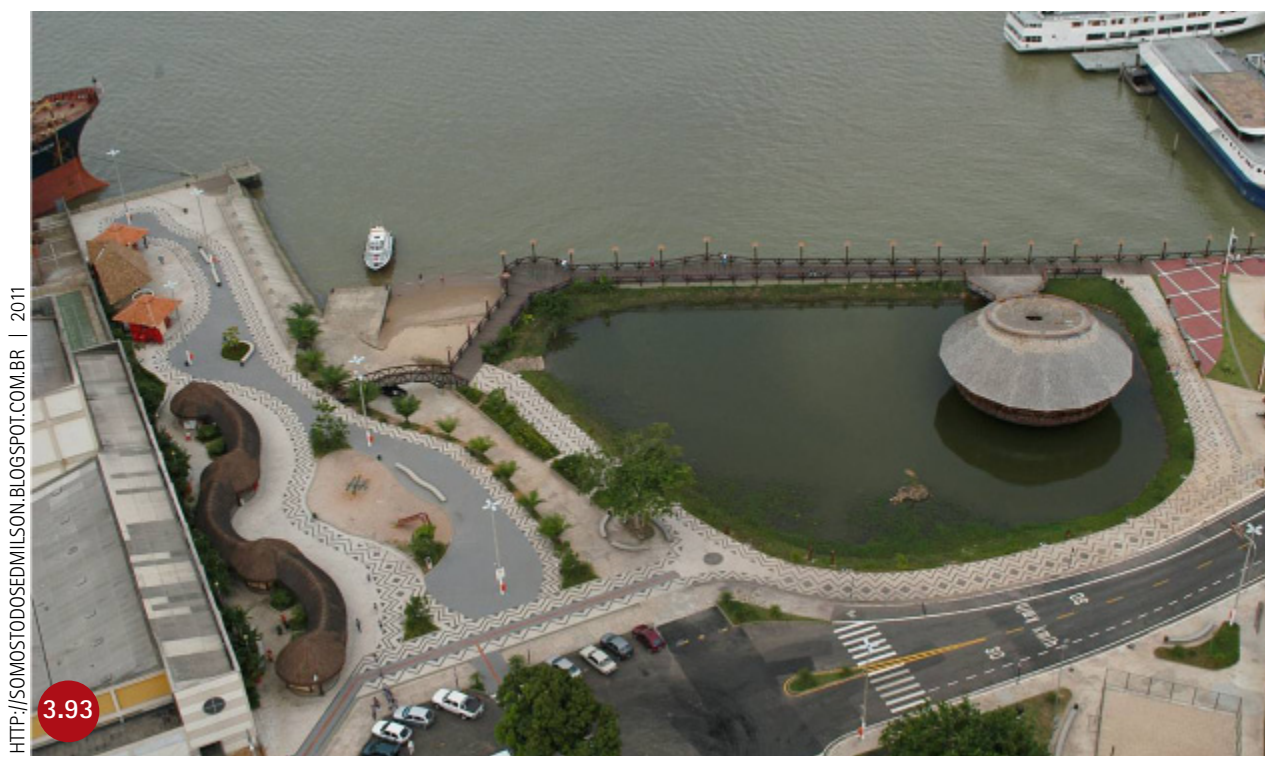

Irerês e tartaruga no Mangal das Garças.
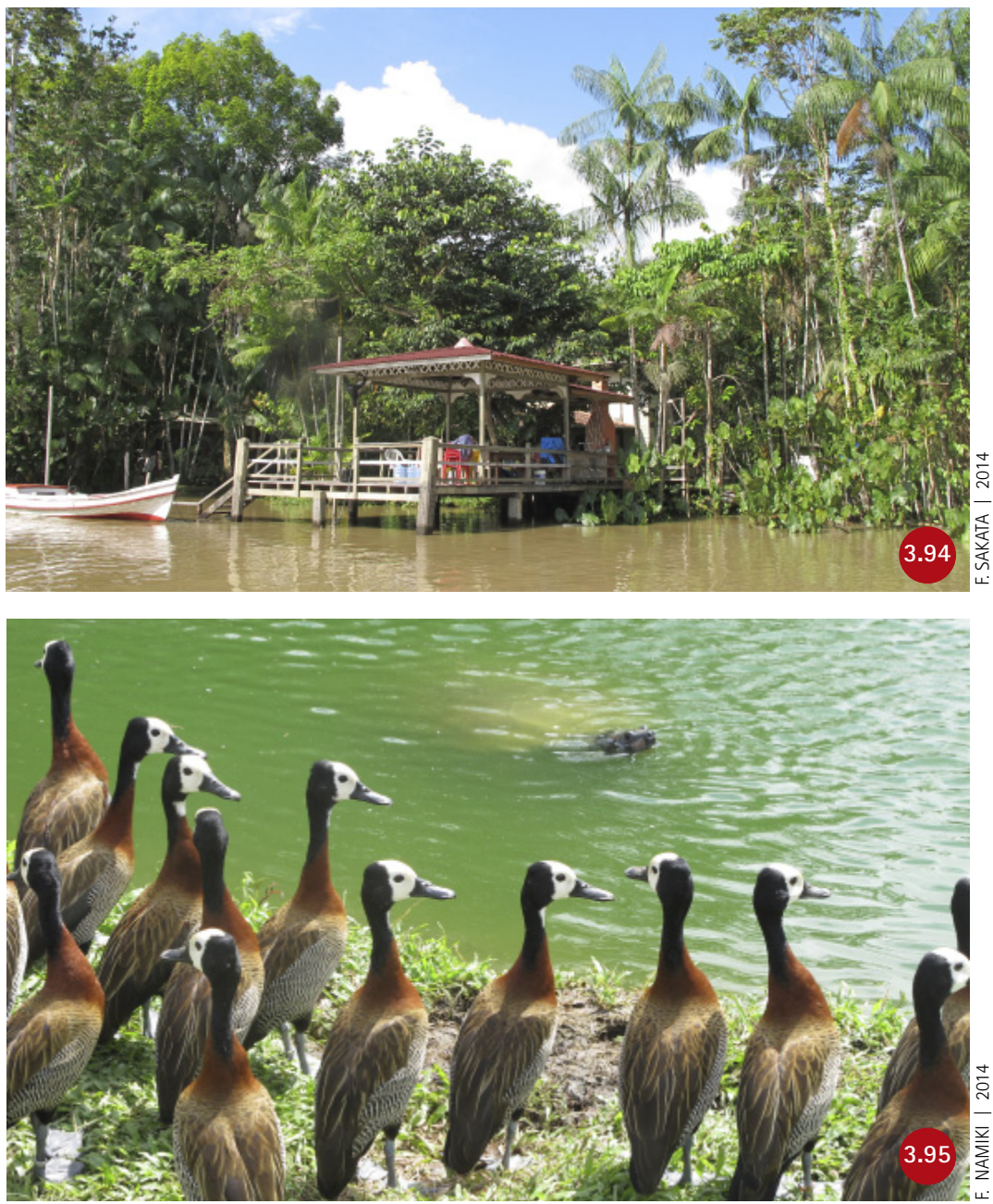
Um dos parques é o Mangal das Garças (2005), feito pelo Estado; o outro, Portal da Amazônia (2012), foi criado pela Prefeitura de Belém em parceria com uma construtora. Corresponde à urbanização de um trecho da orla com extensão de 1,5 quilômetro, com equipamentos de lazer e esporte. (3.95)

0 Parque Ambiental do Utinga, uma reserva à leste da mancha urbana, na divisa com Ananindeua, foi qualificado para caminhadas e passeios de bicicleta. 0 uso das trilhas deve ser agendado.

Há grande potencial de aproveitamento do miolo de quadras ainda vegetado de bairros como o Tapanã. Nas áreas de expansão, há fragmentos de verde em áreas reservadas para espaços públicos nos conjuntos habitacionais. Existem também áreas remanescentes das Forças Armadas, que correspondem a APPs pouco conhecidas, e áreas institucionais que coincidem com a APA Belém, nenhuma com tratamento para utilização pela comunidade. Nas áreas de ocupação informal, há grande carência de espaços livres, já que os espaços públicos disponíveis tendem a ser ocupados por moradias. Quando vazios, acumulam mato e lixo. Segundo Leitão, um tipo de espaço livre e verde apreciado pela população de baixa renda são as praias de rio e os balneários, que consistem em pequenas estruturas construídas nas margens de igarapés que permitem o banho e o lazer. Localizam-se normalmente em ilhas ou afastados da área mais urbanizada.

\begin{tabular}{|c|c|c|c|c|}
\hline \multicolumn{5}{|l|}{ BELÉM } \\
\hline PARQUE & REGIÃO & ÁREA $\left(\mathrm{m}^{2}\right)$ & CRIAÇÃO & INAUG. \\
\hline BOSOUE RODRIGUES ALVES & MARCO & 150.000 & & 1883 \\
\hline PARQUE E MUSEU EMILIO GOELDI (ZOOBOTÂNICO) & SÃO BRÁS & 52.000 & & 1895 \\
\hline PARQUE ESTADUAL DO UTINGA & LESTE & 13.930 .000 & & 1993 \\
\hline COMPLEXO VER-O-RIO & UMARIZAL & 5.000 & & entre $1997-2004$ \\
\hline PARQUE MANGAL DAS GARÇAS & CENTRO HISTÓRICO & 40.000 & & 2005 \\
\hline $\begin{array}{l}\text { PORTAL DA AMAZÔNIA (URBANIZAÇÃO DA ORLA } \\
\text { DO RIO GUAMÁ) }\end{array}$ & CENTRO HISTÓRICO & 26.000 & 2011 & 2012 \\
\hline
\end{tabular}

Tabela montada por Francine Sakata e Caroline Ribeiro.

Nesta tabela:

Parques anteriores a 2000 criados entre 2000-2017 


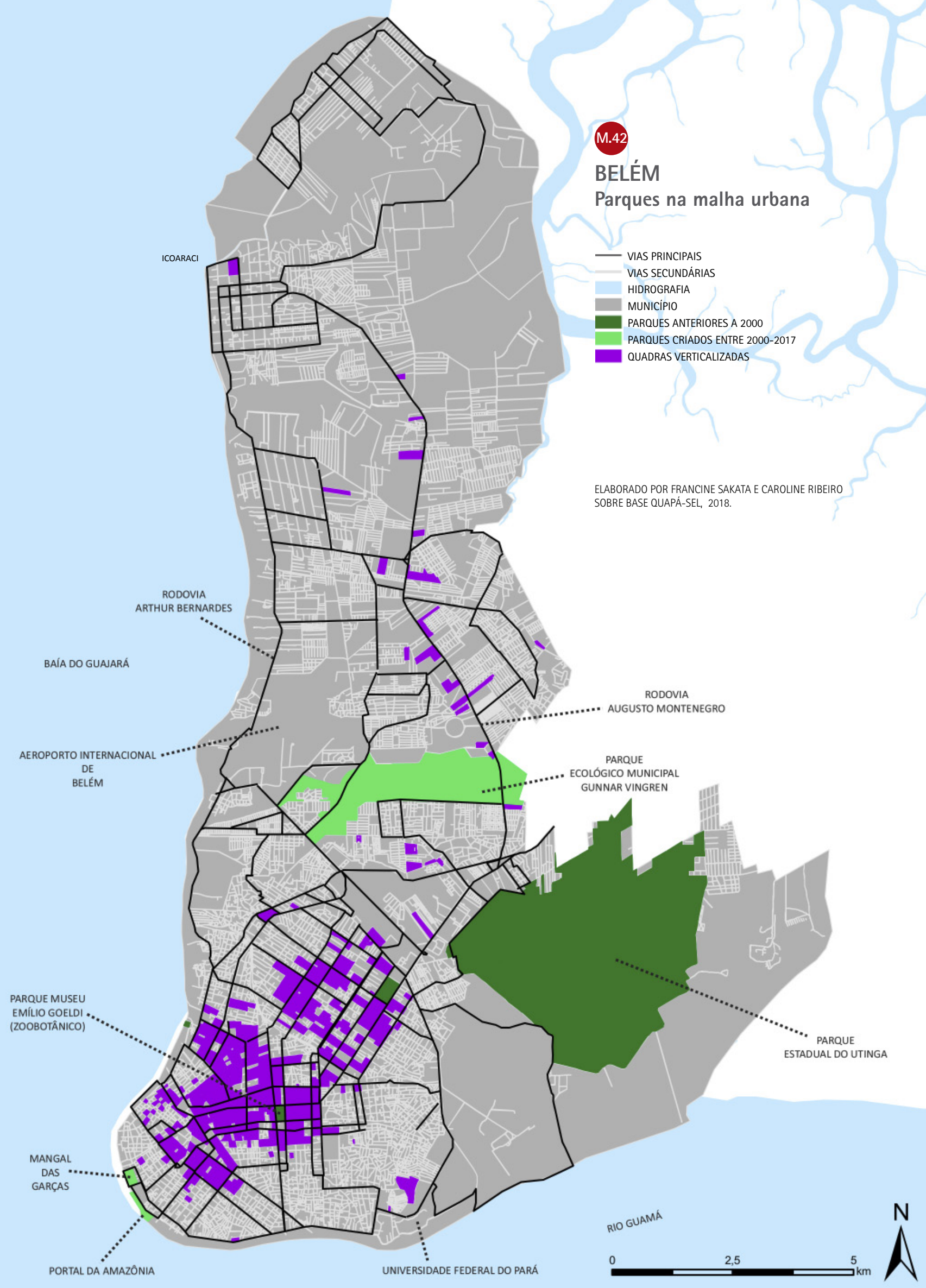




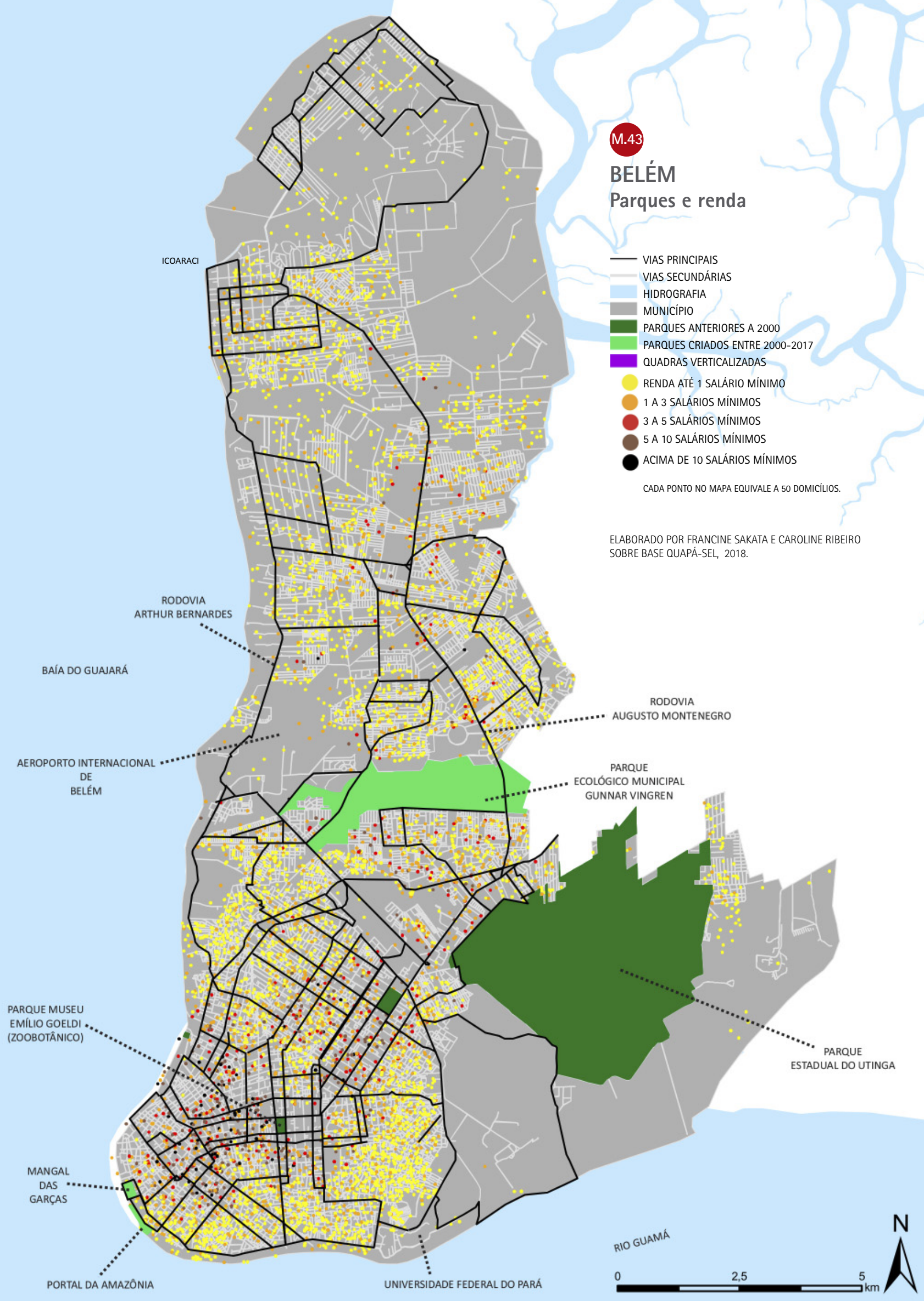




\subsection{Porto Alegre}

0 município de Porto Alegre, segundo a Secreataria Municipal do Meio Ambiente e da Sustentabilidade (SMAMS) ${ }^{57}$, conta com 8 parques urbanos, 637 praças urbanizadas e 4 unidades de conservação. Até 2017, esta secretaria era responsável pela implantação e manutenção das praças e parques de Porto Alegre. A partir deste ano, a manutenção das praças foi repassada à Secretaria de Obras e dos parques foi mantida com a SMAMS.

No entendimento dos técnicos da secretaria, os espaços públicos das praças e parques são destinados ao lazer, ao esporte, à contemplação e interação social; contribuem para o equilíbrio ambiental das cidades; são estruturadores do tecido urbano; e neles, as edificações devem ser evitadas ou minimizadas.

Para a prefeitura, os parques são áreas verdes com área superior a $100.000 \mathrm{~m}^{2}$, ainda que haja parques com área menor. São áreas com abrangência urbana, ao contrário das praças que são consideradas de abrangência local, e contam com administração própria - com sede e edificações de apoio. Assim, cada parque tem uma equipe própria de manutenção. Uma característica dos parques de Porto Alegre é que não são cercados, com exceção do Parque Germânia. A questão dos cercamentos dos parques é pauta de discussões na cidade.

Algumas unidades de preservação são áreas controladas e não tem acesso público, como o Parque Natural Municipal Morro do Osso,

57 A Oficina Quapá SEL de Porto Alegre contou com palestra e participação de Marcos B. Profes e Sergio Tomasini, da SMAMS.

SAKATA, Francine; DONOSO, Veronica; REIS, Juliana. Relatório Oficina Quapá-SEL Porto Alegre - 4 a 6 de abril de 2018, Universidade Federal do Rio Grande do Sul. FAUUSP, 2018.

58 Secretaria do Ambiente e Desenvolvimento Sustentável (Smams) do governo do Estado do Rio Grande do Sul: Disponivel em: <http://www.sema.rs.gov.br/ unidades-de-conservacao-2016-10>. o Parque Estadual Delta do Jacui e Reserva Biológica do Lami José Lutzenberger..$^{58}$

Os espaços livres de uso público no município têm surgido pricipalmente por conta da obrigação legal do empreendedor de destinar áreas públicas por ocasião do parcelamento do solo. 0 projeto deste espaço deve seguir as diretrizes da SMAMS e tem sido, em geral, executado pelo empreendedor. As áreas doadas ao município são mais compatíveis, pelo porte, com praças do que com parques. Os Termos de Compensação Ambiental não foram utilizados para construir ou equipar parques inteiros. Em Porto Alegre, até 2018, as praças não perderam protagonismo para os parques. 
0 trecho da cidade que tem recebido mais atenção e investimentos é a Orla do Rio (ou Lago) Guaíba, desde a área central até o Museu Yberê Camargo, ao sul. Há uma sequência de praças que foram revitalizadas pela prefeitura, algumas incluídas no pacote de obras para a Copa do Mundo de 2014. Será inaugurado, em 2018, um calçadão em torno da Usina do Gasômetro, projetado pela equipe do arquiteto Jaime Lerner, com terminal turístico para barcos de passeio, restaurante, bares, playground, academias ao ar livre, quadras esportivas, caminhos com arquibancadas para contemplação do pôr-do-sol, decks que se projetam sobre a água, ciclovia, jardins aquáticos, postes de iluminação altos e vistosos. Este trecho já possuía intensa apropriação para o passeio e a contemplação mas não possuía um tratamento sofisticado. (3.96

Junto à orla também está o Parque Marinha do Brasil e o Parque Maurício Sirotski, este último com apropriação eventual, em eventos itinerantes. 0 restante da Orla do Guaíba no município segue com vários graus de tratamento e de apropriação: há trechos com acesso público; trechos com o acesso pelos clubes náuticos; e trechos sem acesso público. Em frente ao Museu Yberê Camargo, uma faixa estreita tem sido intensamente utilizada (2018) para a contemplação do pôr-do-sol. Mais ao sul, no bairro Guarujá, há uma praia de areia e o calçadão de Ipanema, também com muito uso ainda que não muito largo. A praia de lpanema até os anos 1960 era balneável, situação que se modificou com a expansão da cidade.

Entre os novos parques, o Parque Gabriel Knijnik (2004) era o sítio do engenheiro que dá nome ao parque, doador da área para que fosse transformada em parque municipal. 0 acesso é difícil. Possui pomar, uma área de banhado e uma grande área de preservação. Foram construídos sanitários, coreto, playground, churrasqueiras, duas quadras de futebol, cancha de bocha, passeios e estacionamento. Do alto do mirante, atualmente fechado, era possível avistar a área rural e a área urbana de Porto Alegre. (3.97) (3.98

O Parque Germânia (2006) foi planejado e construído por uma construtora e está circundado por empreendimentos imobiliários. Ao servir como espaço de lazer para os moradores, valoriza o entorno. A ideia era justamente esta, qualificar este setor da cidade 


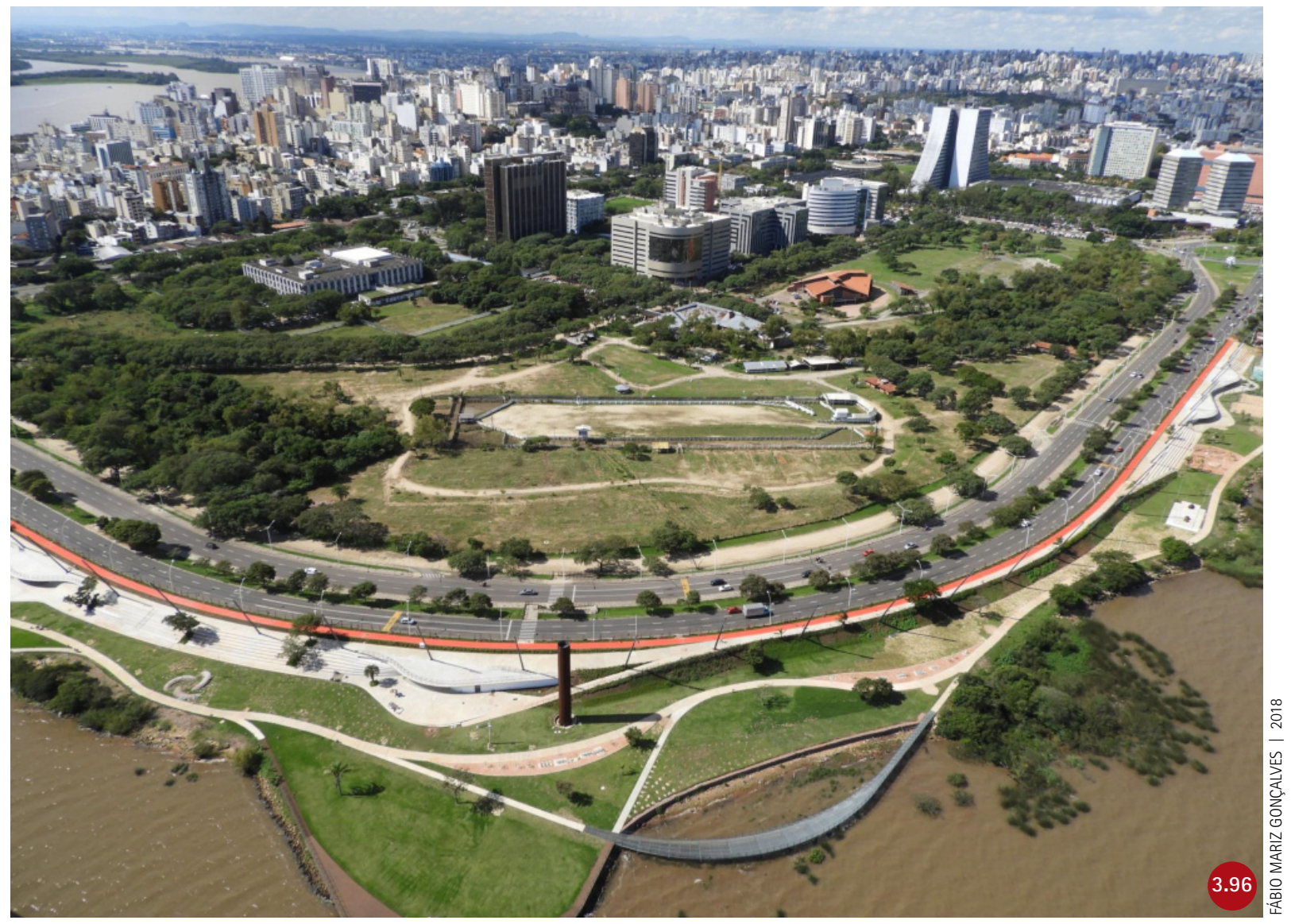

Parque Urbano da Orla do Guaíba, 1a fase, com $1.320 \mathrm{~m}$ de extensão, entre o Centro Cultural Usina do Gasômetro e a Rótula das Cuias (2018), projeto do urbanista Jaime Lerner. Aos domingos, parte da Avenida Edvaldo Pereira Paiva (Beira-Rio) fica bloqueada para automóveis. para a moradia das camadas de alta renda que resistiam em mudar das áreas tradicionais da elite na cidade, como daquela em torno do Parque Moinhos de Vento. É um parque completo, com lago, gramados, administração, quadras de tênis, vôlei, basquete e futebol de salão, cancha de bocha, playgrounds, aparelhos de ginástica, caminhos para corrida ou caminhada, jardins para descanso e contemplação da natureza e uma área de preservação. Foi anunciado por seus idealizadores como sendo o primeiro parque cercado da cidade, o que não é necessariamente uma qualidade. 3.99 3.100 3.101 Em um bairro de população de rendas mais baixas, o Parque Chico Mendes e a Praça México, quase vizinhos, são desafios para a gestão municipal. 0 primeiro tem problemas com invasões, tráfico e insegurança e a segunda foi bem apropriada e recebida pela população. 

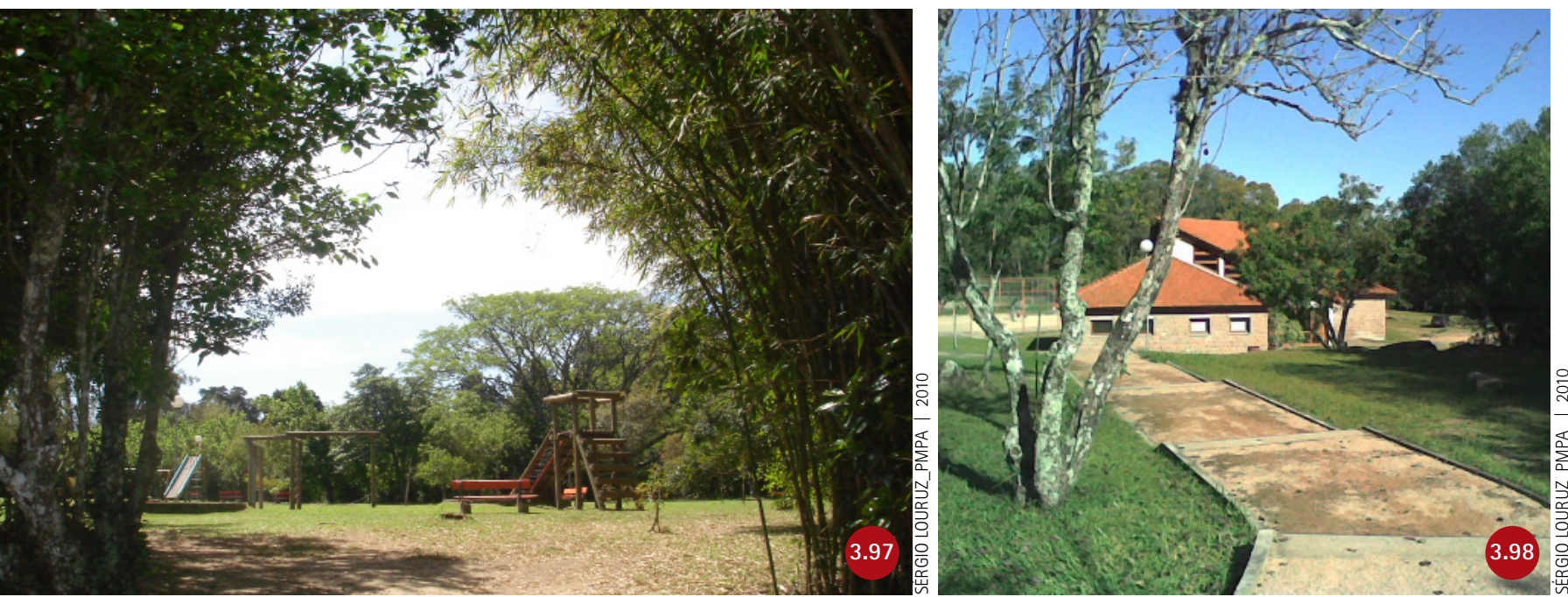

Parque Gabriel Knijnik (2004), sítio particular doado em testamento à prefeitura.

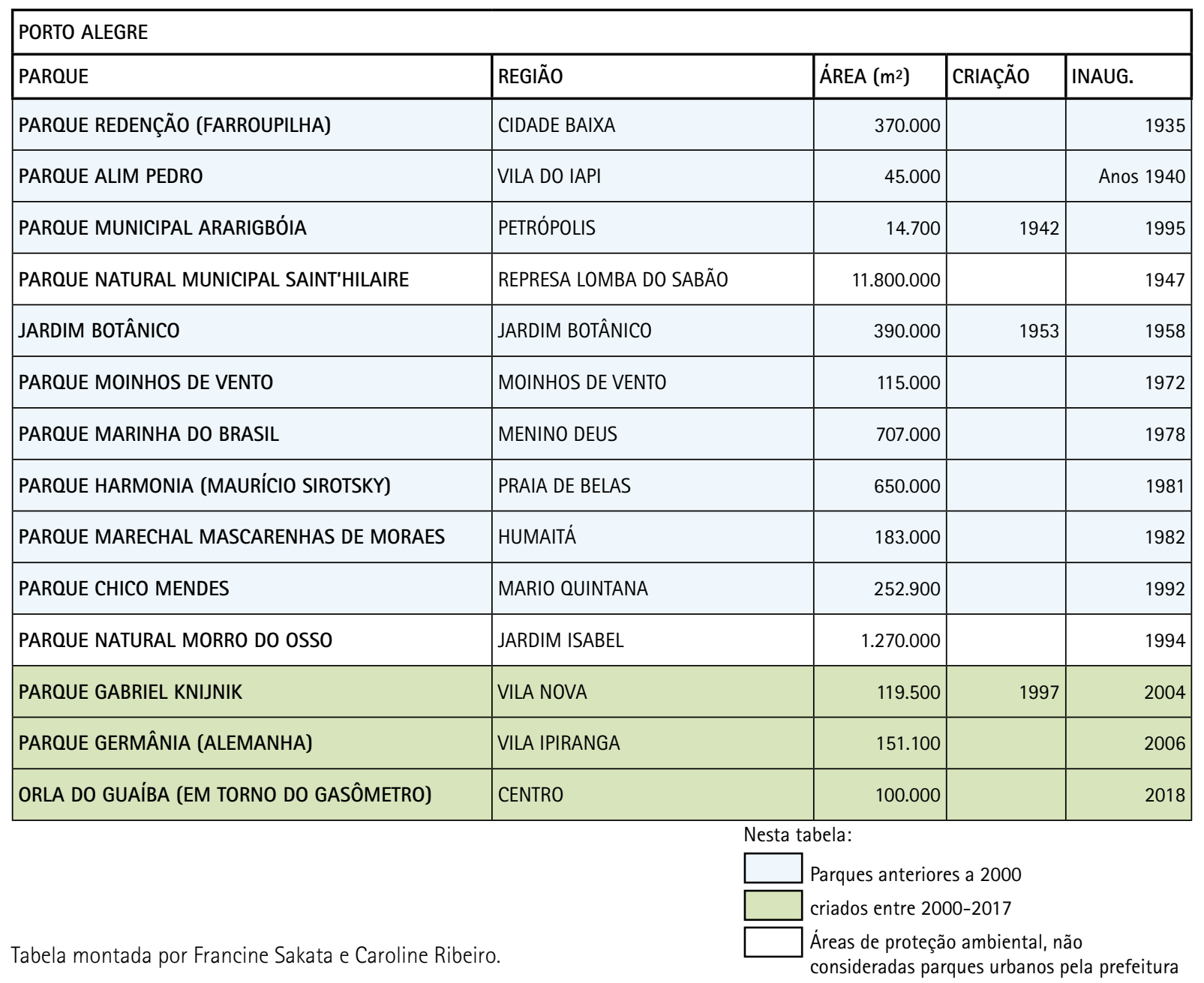


Parque Germânia (2016), com $150.000 \mathrm{~m}^{2}$. Segundo a construtora Goldsztein S/A, que concebeu 0 bairro Jardim Europa, o parque foi construído por ela e doado a Porto Alegre.
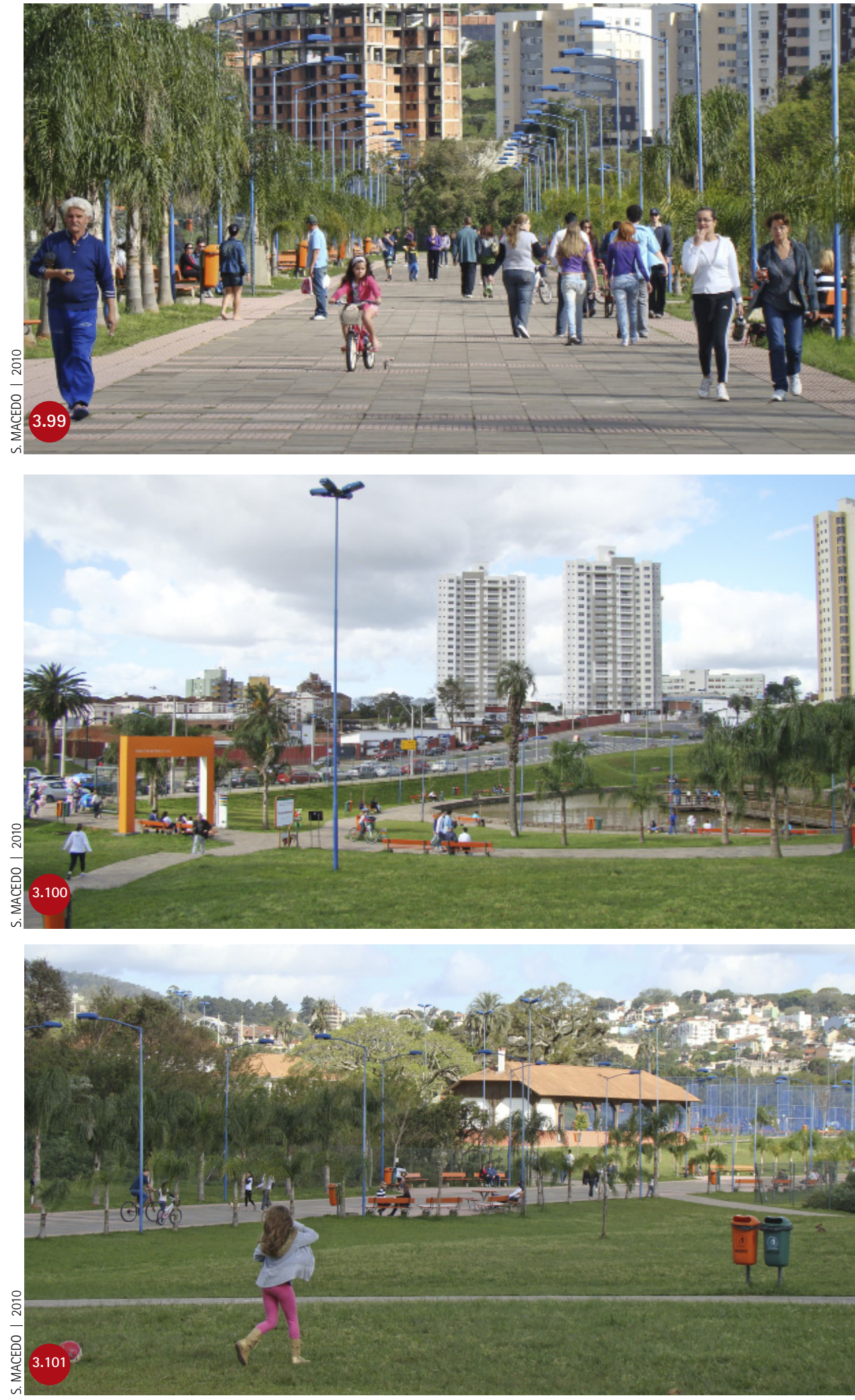
Parques na malha urbana

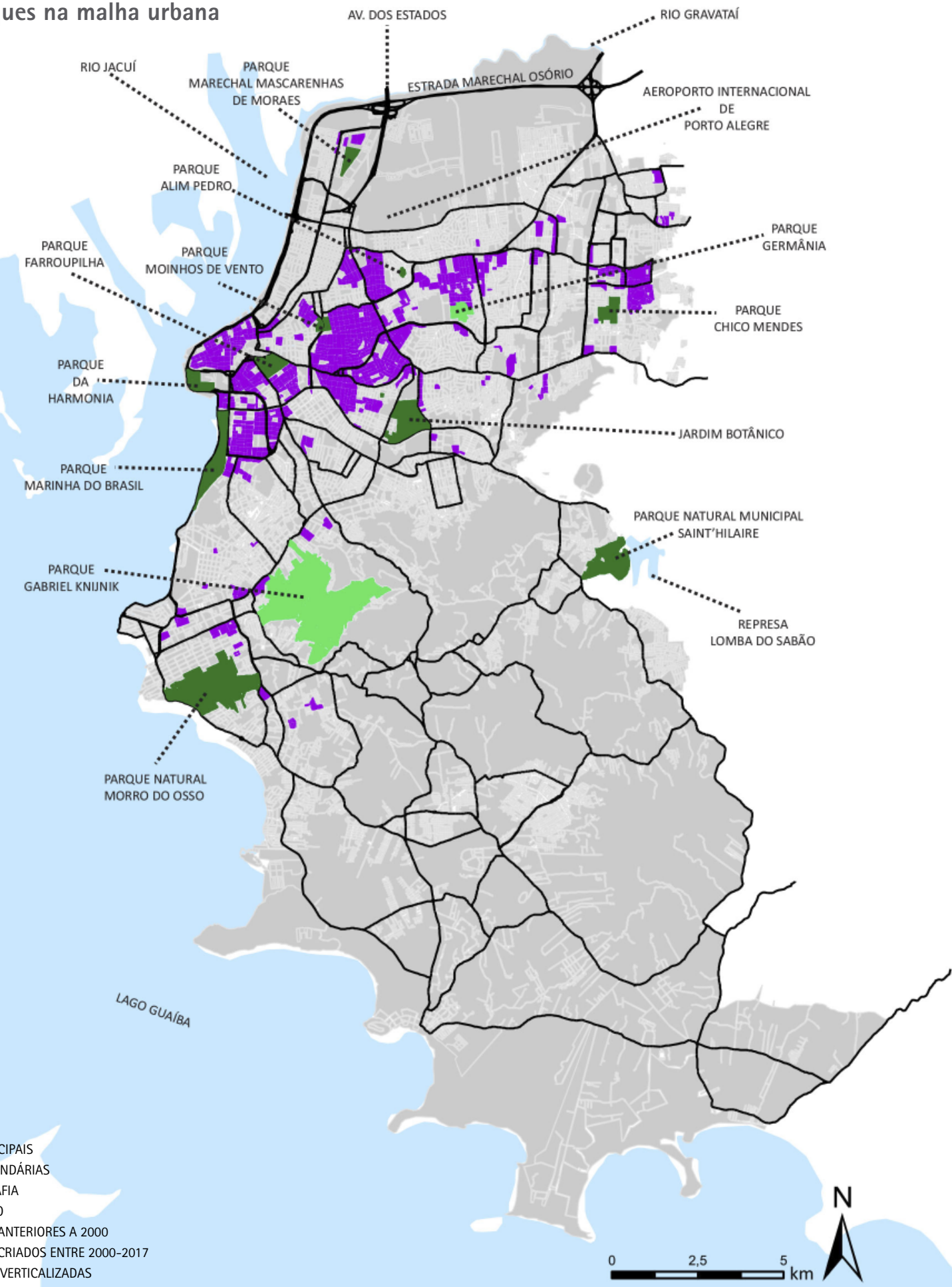


1.45 PORTO ALEGRE

Parques e renda

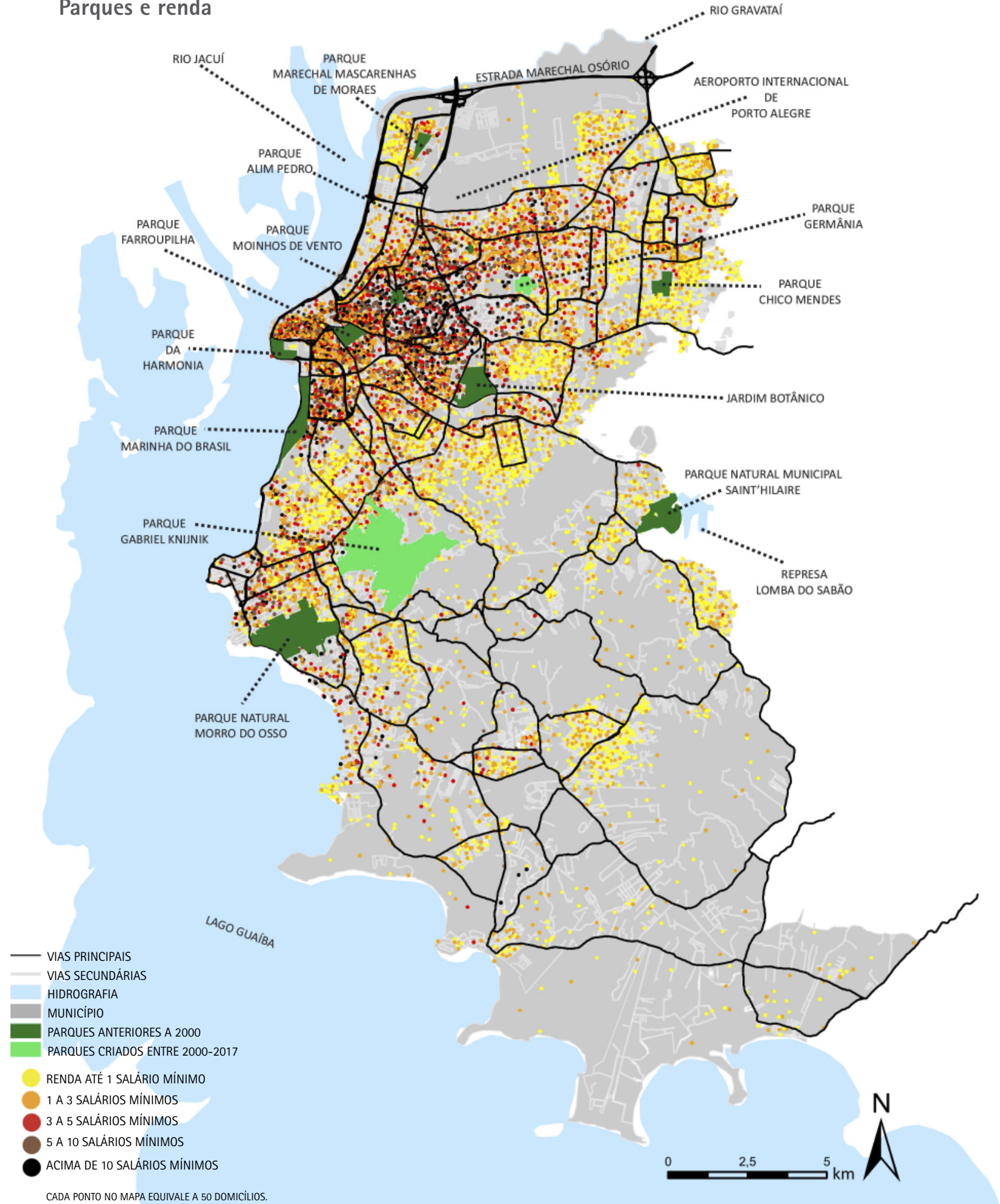

ELABORADO EM 2018 POR FRANCINE SAKATA E CAROLINE RIBEIRO SOBRE BASE QUAPÁ-SEL. 



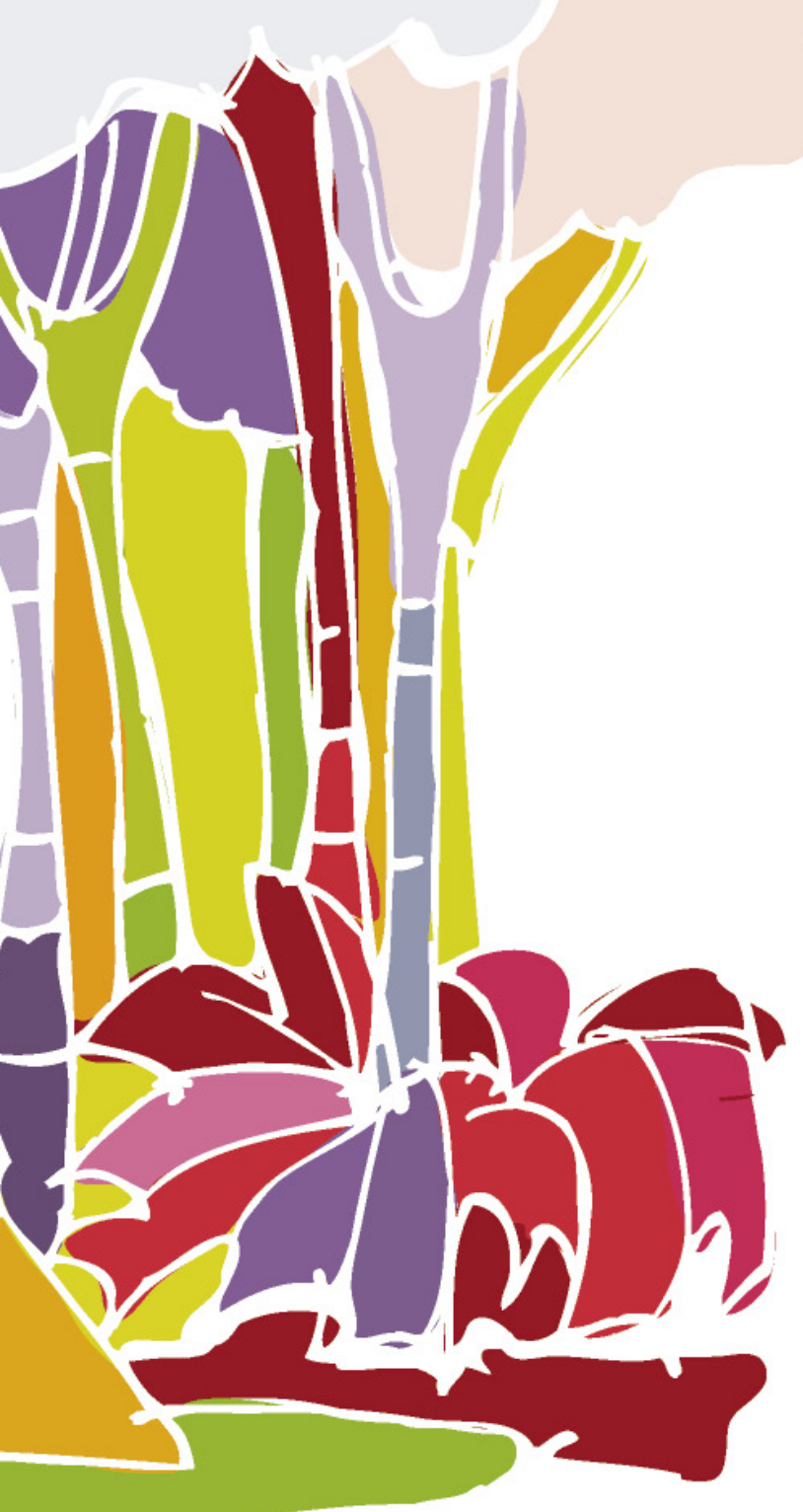


1 CRANZ, Galen; BOLAND, Michael. Defining the sustainable park: a fifth model for urban parks. Landscape Journal, 2004, 23:2-04.
Nesta tese, o parque urbano contemporâneo brasileiro foi definido como produto da mistura entre o parque urbano tradicional e o parque natural. Como causa e consequência desta fusão, os espaços urbanos públicos que não são praças ou ruas foram "batizados" de diferentes modos, e novas figuras foram disseminadas, como os parques ecológicos, os parques lineares e os bosques urbanos. Todos estes espaços são "parques”, mas diferem dos parques tradicionais quanto a usos, formas e maneiras de se relacionarem com a cidade e os recursos naturais. Em relação às estruturas e materiais utilizados, como têm sido desenhados os parques contemporâneos?

Cranz e Boland ${ }^{1}$ identificaram entre os novos parques urbanos nos Estados Unidos, a partir de 1990, os Parques Sustentáveis. São parques que podiam apenas evocar simbolismos ecológicos ou de fato restaurar sistemas ecológicos funcionais. Mas além dos novos preceitos, ou devido a eles, surgiu também uma nova estética. A prática, por exemplo, de acolher eventos espontâneos da comunidade implica em espaços com aspectos distintos daqueles nos quais isto não ocorre.

Em teoria, o parque ecológico verdadeiro deve transcender a imagem estática e desenvolver estéticas evolucionárias que incorporem a mudança ao longo do tempo. Deveria contemplar capins, arbustos e árvores crescendo sem terem sido plantados e competindo entre si, sem a ordenação da composição paisagística tradicional, porém exatamente como ocorre nos parques naturais. Contudo, segundo o levantamento de Cranz, desenhos muito abertos não foram vitoriosos nos concursos de projeto para os grandes espaços públicos. A possibilidade que ela levanta é de que desenhos sem a ordenação humana talvez não tenham sido aceitos por temor da resistência do público. 
Desenhos formais, com caminhos geometricamente traçados, também podem servir a propósitos ecológicos. Percursos pavimentados podem prevenir que as pessoas pisem em ovos de pássaros, por exemplo, o que não aconteceria em jardins pastorais, onde as pessoas andam por todo o relvado. Assim, formalmente, o Parque Sustentável identificado por Cranz é estilisticamente aberto: pode ter aparência naturalista ou formalista e busca incorporar as dinâmicas e transformações inerentes aos ambientes naturais.

Outra questão surgida como princípio nos novos parques: o projeto envolve toda a comunidade, deixa de ser domínio só dos autores, do paisagista visionário. Passa a ser criação coletiva. 0 papel do autor passa a ser o do mediador ${ }^{2}$. Mas isto não dispensa os projetos, que são necessários para a organização dos recursos e das obras ${ }^{3}$. Nos espaços do cotidiano e nos espaços em que a população busca mudar a lógica da apropriação, tomando-os para si - como nos casos do Parque Augusta e do Largo da Batata, em São Paulo, ou do Aeroporto Tempelhof, de Berlim -, surgem desenhos mais espontâneos e temporários, eventos para promover intervenções, hortas, plantios de árvores aleatórios e mobiliários reciclados, intencionando afirmar a construção coletiva.

\subsection{Parque Ecológico Brasileiro}

O conjunto dos parques criados no Brasil no século XXI pode ser considerado ecológico se levado em conta o discurso que o justifica. As explicações das decisões projetuais sempre fazem menção, de alguma forma, ao meio ambiente. 0 Parque Madureira é um exemplo de parque extremamente formal e direcionado para o lazer de massa, onde a vegetação foi utilizada como mera ornamentação. Entretanto, houve coleta da água de chuva, reciclagem de lixo e controle dos gastos energéticos, entre outros procedimentos, - que usualmente se prestam à concessão de certificação ambiental para edifícios. Assim, recebeu este "selo" e foi alardeado como ação ambiental.
2 Idem.

3 De arquitetos ou arquitetos paisagistas. No Brasil, a arquitetura paisagística é, na prática, exercida por profissionais graduados em Arquitetura e Urbanismo que se especializaram ao longo das carreiras em projetos de espaços livres. Em alguns casos, trabalham também com projetos de edificações. 
Do universo de parques pesquisados, considera-se que todos são "ecológicos" em alguma medida, porque buscaram responder a alguma questão ambiental, ou a várias. Apenas por isso não seriam diferentes dos parques criados antes deles - e, de fato, não são. Os parques sempre responderam a questões ambientais; as equipes que os projetaram tinham preocupações com o meio ambiente, sem se vangloriar por isto. Quando criado, o lbirapuera era citado pela imprensa por seus edifícios, a marquise, o obelisco. A vegetação, a permeabilidade, a amenização do clima, nada disso interessava para a opinião pública da época, nem mesmo seus autores destacavam tais questões para justificar seus projetos.

Discutir se seriam de fato ecológicos ou sustentáveis não é o propósito desta tese, mas, sim, discutir se servem à sociedade de forma ampla, apontando que os termos "ecológico", "sustentável” e "verde" comparecem em todos os discursos de quem projeta, promove ou usa parques. 0 peso destes termos parece querer reduzir a função social dos parques, colocá-la em segundo plano. Além disso, ao longo dos últimos vinte anos, esses termos foram muito associados a ações de mídia e de propaganda, o que os banalizou. Ao mesmo tempo, o significado foi realmente ampliado e, atualmente, entende-se por sustentável qualquer ação que, reconhecendo seu impacto ambiental, busque ser socialmente inclusiva, mais racional no uso dos recursos, economicamente viável, e que não envolva necessariamente o plantio de árvores. Nos anos 1990, a cidade de Curitiba usou o slogan de "Cidade Ecológica”, mas, conforme as críticas se acumulavam em relação à falta de esgoto tratado, congestionamentos e desequilíbrios sociais típicos das cidades brasileiras, o mesmo ruiu. 0 entendimento dos compromissos ecológicos superou a simples cobrança de espaços arborizados e passou a demandar a relação com a boa distribuição das infraestruturas e com um mínimo de justiça social.

Bairros 'verdes' com altos índices de espaços livres particulares e baixa densidade não são considerados mais bairros 'ecológicos', afora pela propaganda. Sua implantação demanda o terrapleno de vastas áreas e a retirada de toda a vegetação original; as obras assoreiam rios e geram mais impactos. Os bairros horizontais ainda aco- 
modam poucas pessoas, que fazem grandes deslocamentos diários de automóvel, gerando grande impacto ambiental.

Se vastas reservas naturais no meio das manchas urbanas funcionam como obstáculos obrigando grande contingente populacional a contorná-las diariamente, impedindo deslocamentos a pé, talvez estas reservas, assim opacas, não sejam a melhor resposta em termos ambientais. lsto é, reservar recursos hídricos e vegetais é importante mas os deslocamentos diários são parte da equação da cidade sustentável: da habitação ao trabalho ou à escola, à pé ou por transporte público ou particular. Áreas de moradia com baixa densidade ou isoladas no tecido urbano normalmente acarretam deslocamentos longos e transporte público ruim.

Reservar áreas por questões ambientais deve ser uma ação acompanhada pelo planejamento dos deslocamentos ao redor, dos adensamentos habitacionais, de outras relações entre esta área e a vida das pessoas ao redor. lsto não tem sido feito no país. Reservas são impostas como 'encraves' e as relações com o tecido urbano tendem a ser conflituosas, ameaçando a própria reserva.

Em síntese, do que vimos, os parques brasileiros seguiram um corolário ecológico e seus projetos, encomendados pelo poder público, têm uma ou várias das seguintes características:

- foram apresentados como ações em benefício do meio ambiente;

- foram feitos em torno de um córrego ou lagoa para preservar estes recursos;

- valorizam qualidades paisagísticas do lugar, seja água, vegetação ou relevo, para uso público, através de intervenções mais discretas, de baixo impacto e sem alto custo de execução;

- renovam áreas degradadas usadas para deposição de lixo ou entulho ou ocupadas irregularmente (ou que poderiam vir a ser);

- evitam remoções de árvores, exceto as exóticas e, em especial, exóticas invasoras;

- neles são plantadas árvores de espécies nativas, em geral de qualquer ecossistema brasileiro, mas há casos restritivos, em que são exigidas espécies locais; 
- ausência de plantio relacionado a preocupações com a composição paisagística, que ficaram para segundo plano. A ênfase recai no reflorestamento, que reduz ao mínimo o espaçamento entre as mudas, desconsiderando que árvores maiores requerem espaçamentos maiores. Isso prejudica as possibilidades de interação entre as árvores e as pessoas e frequentemente reduz os espaços gramados - as clareiras -, tão importantes quanto os bosques para o equilibrio de "vazios" e "cheios";

- retorno dos sub-bosques: as espécies arbustivas estavam em processo de banimento dos parques, para que os espaços se tornassem mais fáceis de vigiar, menos sujeitos à delinquência. Os sub-bosques, entendidos como parte dos ecossistemas, frequentemente impedem a 'transparência';

- uso de materiais mais simples e resistentes: para viabilizar a manutenção, sempre difícil, resgatam-se soluções projetuais dos parques modernos de vizinhança, da geração entre 1970 e 1980, por sua simplicidade, utilidade e facilidade de manutenção. Buscam-se materiais e mobiliários que se provaram resistentes ao longo do tempo; 4.01

- reaproveitamento de materiais de outras obras públicas - é menos princípio das instituições, e mais dos profissionais envolvidos; 4.02

- aproveitamento de caminhos, pontes e construções existentes para uso do parque; 4.03

Parque do Cordeiro (2007), São Paulo. Feito com participação popular, que também tem Ihe garantido uso, gestão e manutenção.

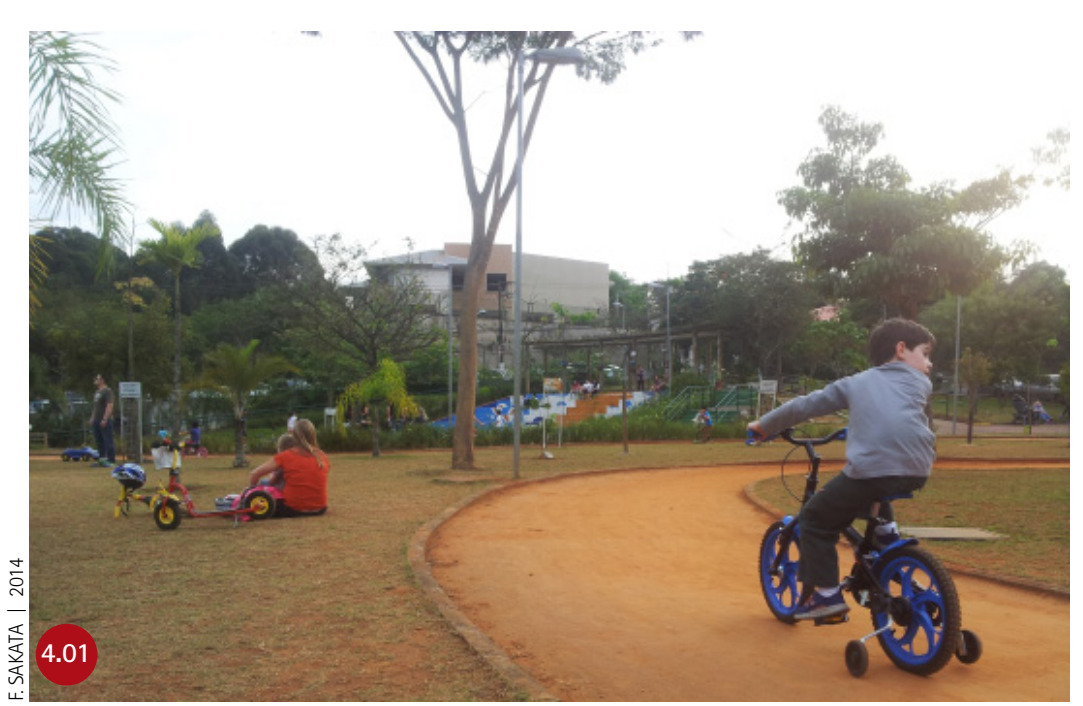


- o principal equipamento de lazer é a pista para caminhada, que articula espaços de recreação como playgrounds, equipamentos de ginástica e eventualmente uma quadra esportiva;

- jardins aromáticos ou sensoriais são pouco ecológicos, mas trazem uma ideia de ampliar a conexão das pessoas com as plantas e são empregados;

- os desenhos mais frequentes são os traçados sinuosos para os caminhos, pavimentados e acessíveis. Pisos cimentados atendem requisitos técnicos, econômicos e funcionais e são muito utilizados;

- pela mata pode haver trilhas não pavimentadas. Na prática, nem todas são mantidas abertas devido à dificuldade em vigiá-las;

- ações de educação ambiental e integração comunitária, como cursos e oficinas, são previstas para acontecerem no parque;

- mesmo os parques menores podem ter plano de manejo, como os grandes parques naturais, e zoneamento.

A propósito da produção de mudas de árvores, houve grande incremento no mercado, que precisou atender à nova demanda por mudas de espécies nativas para plantios compensatórios. Mesmo ainda sendo difícil obter algumas espécies, o circuito de mudas e sementes foi bastante ampliado.

Movimentos sociais que visam ampliar o "verde" em meio ao "cinza" das cidades, uma reivindicação normalmente associada a camadas de rendas altas e médias, surgem neste período. No Parque Candido Portinari (2013), São Paulo, desde 2016, o movimento "Floresta de Bolso" promove mutirões e adensa os bosques com o plantio de novas mudas. Os plantios são feitos sem preocupação de não criar barreiras visuais para as pessoas que umam o parque. A remoçao do lixo que eventualmente será jogado também fica prejudicada. (4.04) 0 Candido Portinari é um parque que funciona como uma extensão do Parque Villa-Lobos. Havia a previsão da construção de um teatro na área, porém o governo do Estado optou pelo parque. Em sua criação, foi aproveitado o arruamento e algumas edificações existentes, feitas originalmente para o canteiro de obras do Metrô. Assim, o parque não teve um projeto específico, mas uma adaptação ao que já havia. 0 resultado é ecológico, mas esteticamente 

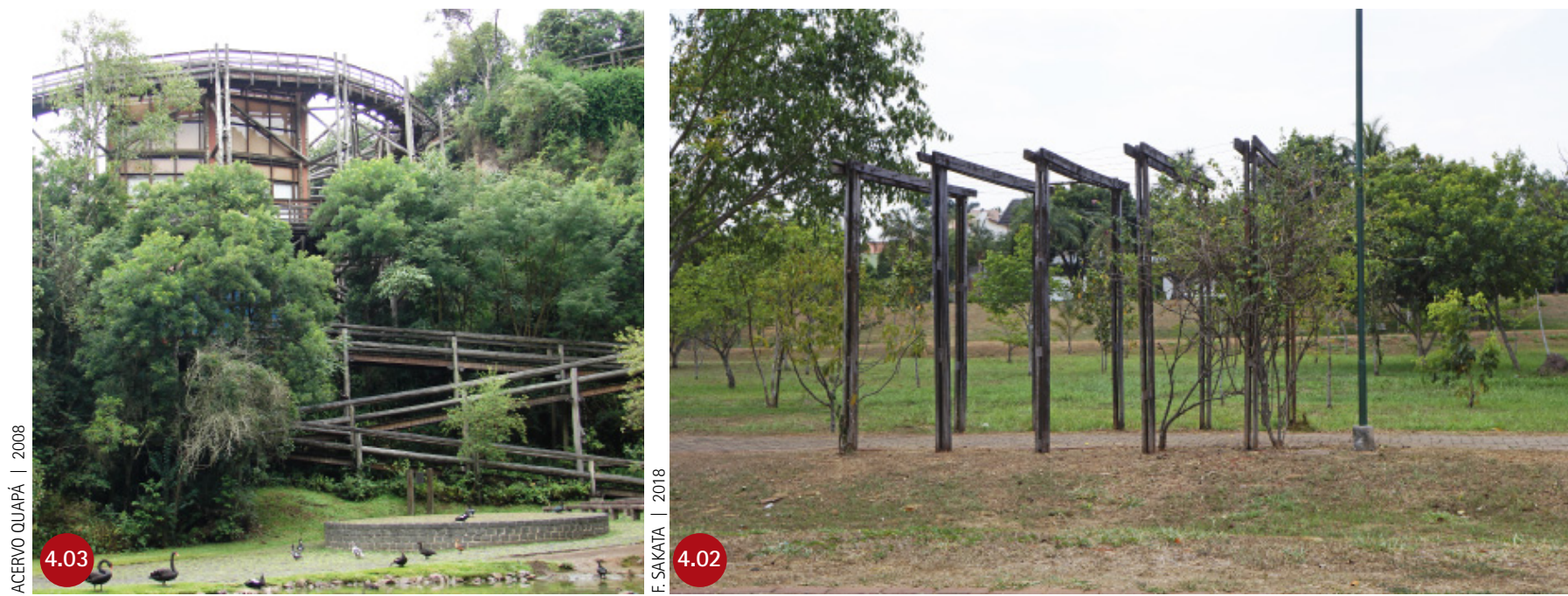

Na Universidade Livre do Meio Ambiente (1992), em Curitiba, foram aproveitados os postes de eucalipto da iluminação pública que vinham sendo trocados por postes de concreto. Acima à direita, o Parque Beija-Flor (2009), em Goiânia, no qual o pergolado foi feito com madeira aproveitada de outras obras.

Mudas plantadas em 2016 sem critérios de projeto por mutirão do movimento "Floresta de Bolso", no Parque Candido Portinari, São Paulo.

O Parque Candido Portinari (2013), São Paulo, fica em área contígua ao Parque Villa-Lobos. 0 Governo do Estado aproveitou, para o parque, arruamento e edificações feitas para o canteiro de obras do Metrô.
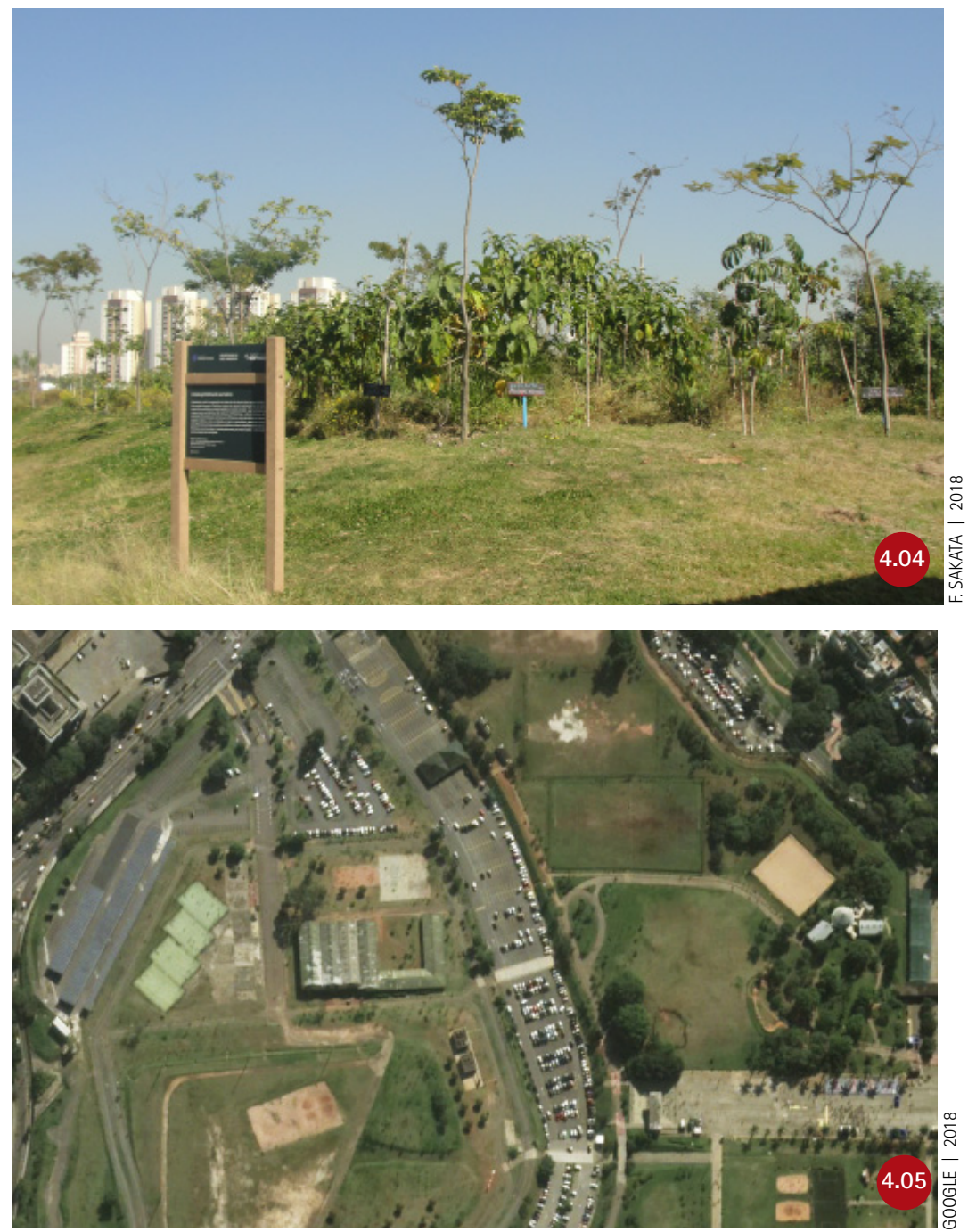
fraco: remete mais ao canteiro de obras que aos grandes parques modernos. E se trata de parque em área nobre da cidade. (4.05)

Quando aqueles que concebem o parque - poder público ou entidade civil - privilegiam o menor impacto ambiental ou a facilidade de execução como critério para o projeto ou ainda custos muito reduzidos de implantação - o projeto tende a ser deixado em segundo plano e o desenho perde força. As intenções do autor, as linhas do desenho, deixam de ser percebidas. Foi o caso do Parque Olhos d'Água, em uma área de alta renda em Brasília, que recebeu, basicamente, trilha para caminhada, bancos de concreto de desenho antiquado com proganda de lojas do entorno que foram posicionados sem critério, ora próximos, ora distantes do caminho, uma cerca metálica comum. É muito difícil discorrer sobre as intenções do autor ou das linhas de desenho deste parque.

\section{Referências projetuais}

Os parques no Brasil do século XXl pouco remetem aos parques estrangeiros; são distintos de seus pares no mundo. 0 Parque do lbirapuera (1954), em São Paulo, é uma referência de parque tradicional, com os elementos essenciais dos jardins ingleses - bosque, lago e gramados. Implantado entre bairros de alta renda da capital paulista, que se valorizam ainda mais com sua presença, é citado como principal atração turística da cidade, um exemplo da importância do parque para a valorização urbana.

Os parques de Boston projetados por Olmsted a partir de 1878, são referência em termos de articulação de áreas verdes num corredor ecológico. São pouco equipados, com baixo custo de manutenção e o duplo papel - ligado às estruturas de lazer e ao saneamento urbano. Os grandes parques de Curitiba, como o Barigui, parecem transpor o ideal de Olmsted para o Brasil. 0 mesmo ocorre com o Parque Setorial, em São José do Rio Preto (SP): projetado por Jamil Kfouri e Mirthes Baffi em 1977 área de fundo de vale, é um prolongamento da faixa de preservação dos mananciais, configurando 

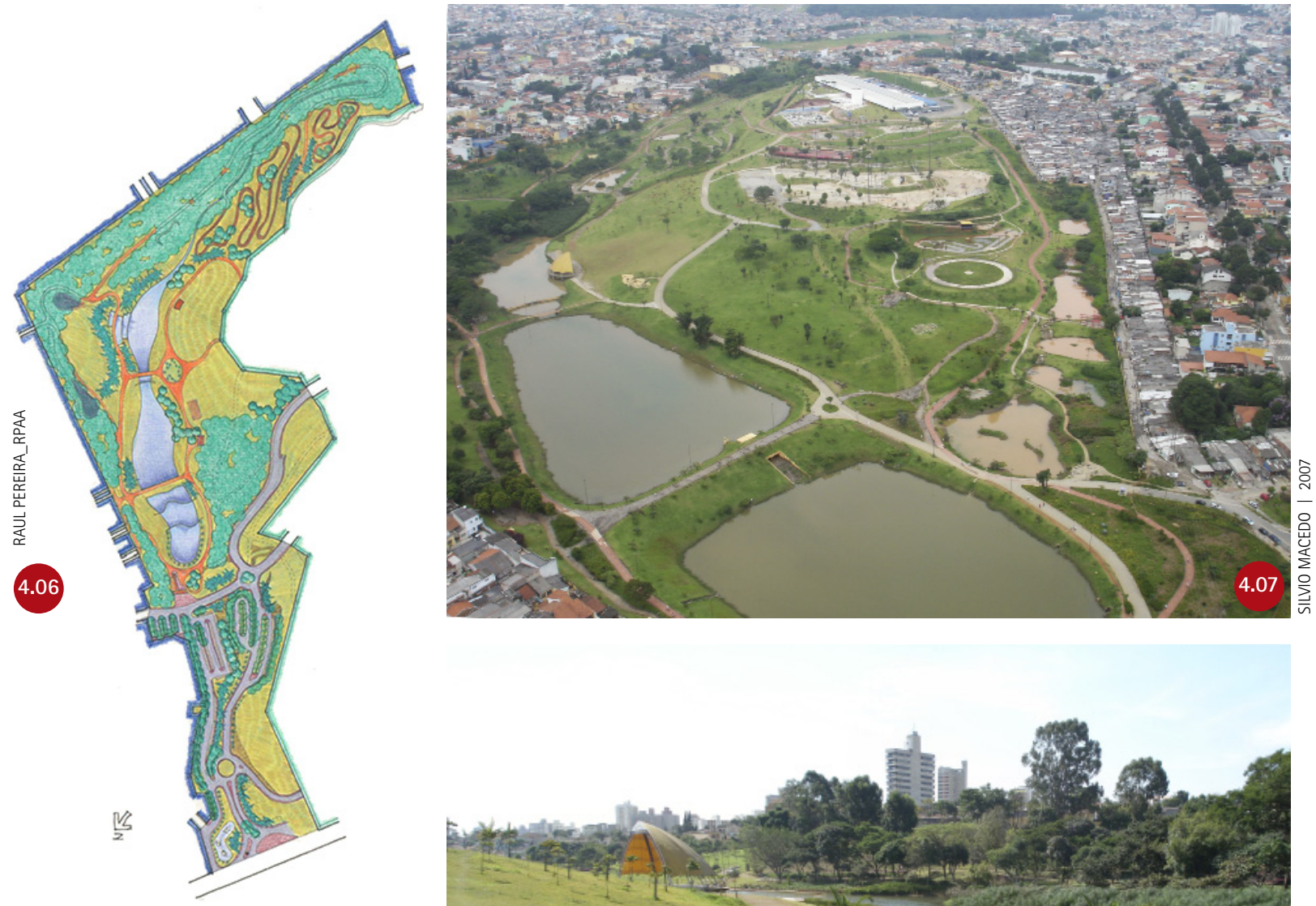

Parque Central de Santo André (SP), projeto de 2004. A obra envolveu a remoção de famílias e recuperação da rede hídrica para a infraestrutura de drenagem.
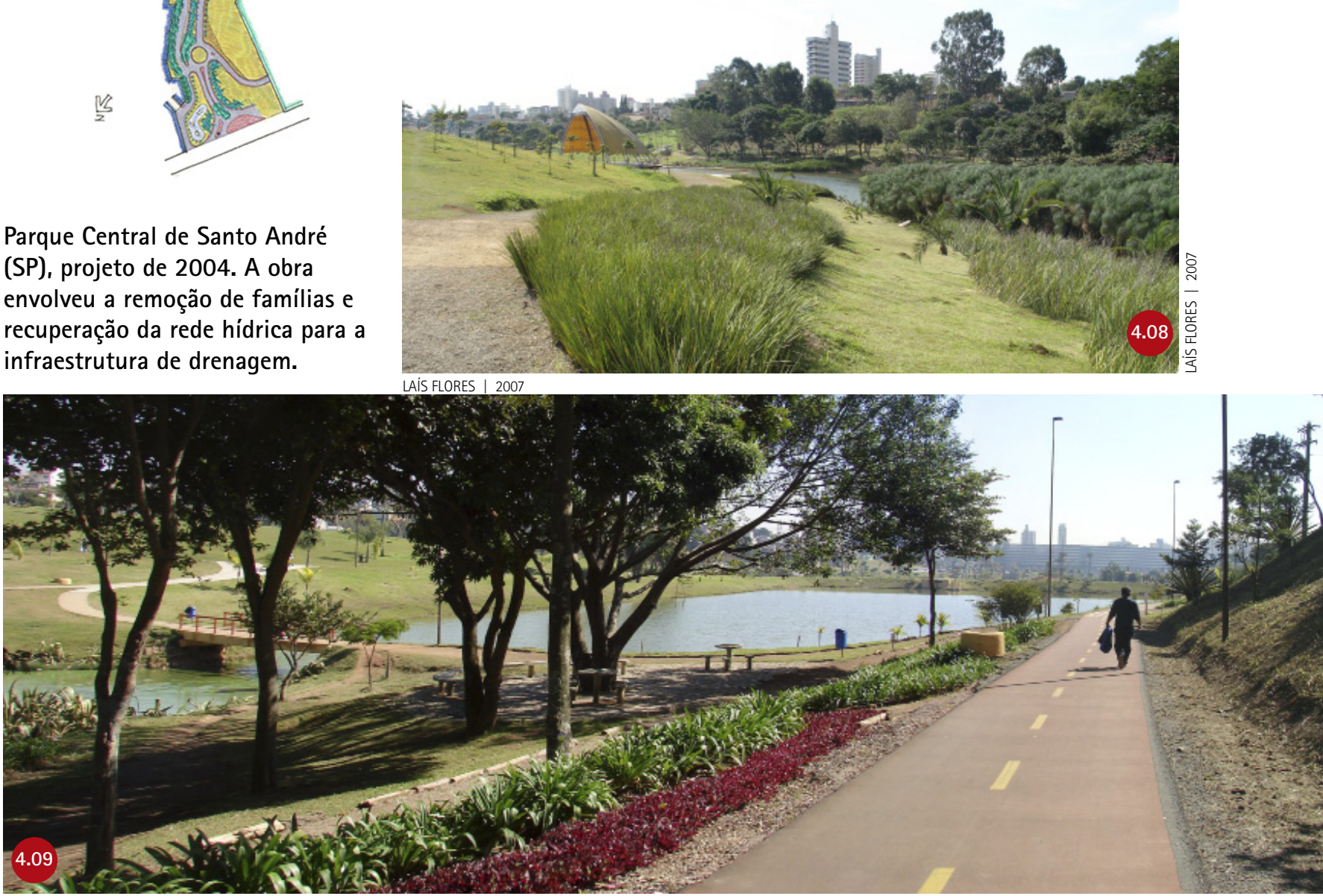
uma área verde destinada à recreação e prática de esportes, com arborização significativa bastante acessível à população.

O Parque Central de Santo André (SP), de 1992, reformado por Raul Pereira e Martha Gavião em 2004, é também um exemplo de parque implantado em área bastante densa e deteriorada, combinando recuperação ambiental e lazer. A volta dos peixes e aves para a área de nascente, tratada com a recomposição da mata ciliar, é a materialização das expectativas contemporâneas. (4.06) (4.07)(4.08) Em Salvador, o Parque do Abaeté (1993), projeto de Rosa Kliass e Luciano Fiaschi, criou um envoltório de proteção para a paisagem da lagoa e tirou partido paisagístico das dunas. Também fez uso da vegetação nativa e introduziu equipamentos de recreação, espaços para espetáculos e até o ponto de encontro das lavadeiras.

Os parques públicos e privados na Barra da Tijuca, Rio de Janeiro, projetados por Fernando Chacel e Sidney Linhares, são outra referência de projeto. Chacel chamou seu processo de trabalho de "ecogênese", principalmente devido à reintrodução de espécies vegetais nativas.

Existe um padrão ideal para parques, verificado nos parques tradicionais. Estes são espaços construídos pela elite ou gestões públicas que os criam segundo padrões da elite para promover a cidade. São parques desenhados com requinte e usufruídos por todas as camadas sociais, inclusive de vizinhanças distantes. Para o parque de vizinhança, entretanto, não há padrão predominante. 0 que se faz, comumente, é a redução do parque tradicional. Em áreas de preservação, é usual abrir um pequeno trecho para uso público, e o restante ser mantido sem maiores intervenções.

\section{Linhas de desenho}

Em Parques urbanos no Brasil (2001), Macedo e Sakata apresentam três linhas projetuais: a eclética, a moderna e a contemporânea. Há parques tradicionais ecléticos - como o Parque Farroupilha, em 
Porto Alegre; modernos, como o Aterro do Flamengo, no Rio de Janeiro, ou do Parque da Jaqueira, em Recife - ou contemporâneos, como o Parque da Juventude, em São Paulo. A população tende a avaliar os parques mais pelas possibilidades de uso e pelo cuidado da manutenção do que pelo desenho.

A linha moderna é uma reação à eclética, com o abandono dos caminhos simétricos, com bordaduras laterais, que conduziam a pontos focais com fontes. 0 modernismo adotou planos de pisos que se integravam aos espaços de estar e à distribuição de equipamentos de lazer para as massas urbanas. Os ornamentos ecléticos abolidos deram lugar a eventuais marquises, esculturas e painéis modernos. A linha contemporânea foi definida como o acréscimo de liberdade e de permissividade ao desenho moderno. Abriu caminho para espaços tematizados, referências ao passado, pisos multicoloridos, passarelas sobre a mata, bares e lojinhas. Entretanto, persiste no ideário do parque, desde o eclético, a tríade bosque, lago e gramados, emoldurada por caminhos sinuosos.

Em Paisagismo Brasileiro na Virada do Século 1990-20104, Macedo subdividiu os parques contemporâneos segundo sua estrutura formal em:

- Neoeclético: caso dos parques temáticos, caracterizados pela reintrodução de elementos típicos do passado, como quiosques, gazebos e esculturas, em meio a gramados românticos e águas tranquilas. Contudo nem o plantio nem a disposição dos elementos reproduz o passado. 0 que existe é uma intensa cenarização e equipamentos para usos contemporâneos - quadras, playgrounds, estacionamentos etc.; 4.10 4.11

- Formalista: espaços elaborados, desenhados com linhas retas ou curvas claramente expressas em planos de pisos, espelhos d'água e canteiros;

- Ambientalista: destinados, basicamente, à conservação de algum elemento natural remanescente dentro do contexto urbano, como bosques, charco, manguezal ou lagoa. Estes elementos são ladeados ou atravessados por caminhos sinuosos, ciclovias, passarelas aéreas 2012, p. 154-161. e decks. Podem também conter equipamentos de recreação; 
- Românticos ou tradicionais: tipo mais comum, que mantêm a estrutura convencional do parque ocidental e no qual o uso se desenvolve entre arvoredos e gramados. Nesta categoria se enquadram muitos projetos que aproveitam o relevo e as estruturas existentes incorporando-os aos usos do parque em desenhos "orgânicos".

Existem parques mistos, com um trecho muito tratado e o restante mantido para preservação. Estas categorizações são feitas para situar os desenhos em um contexto, mas não são rígidas e nem servem para avaliar a qualidade dos projetos. E, como já mencionamos, há projetos nos quais a intenção ou é muito tênue ou logo se perde, e nenhuma linha de desenho pode ser identificada.

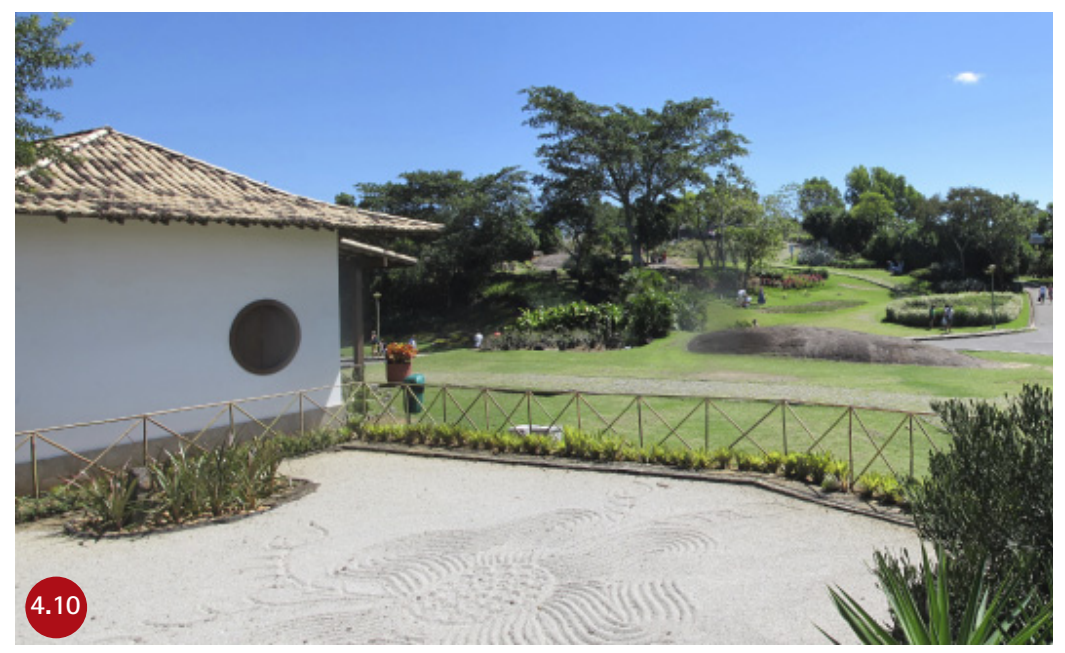

Parque Pedra da Cebola (1997), em Vitória, conta com um espaço temático, que é o jardim japonês. Em Manaus, o Bilhares (2006) foi inspirado nas memórias do tempo da borracha.

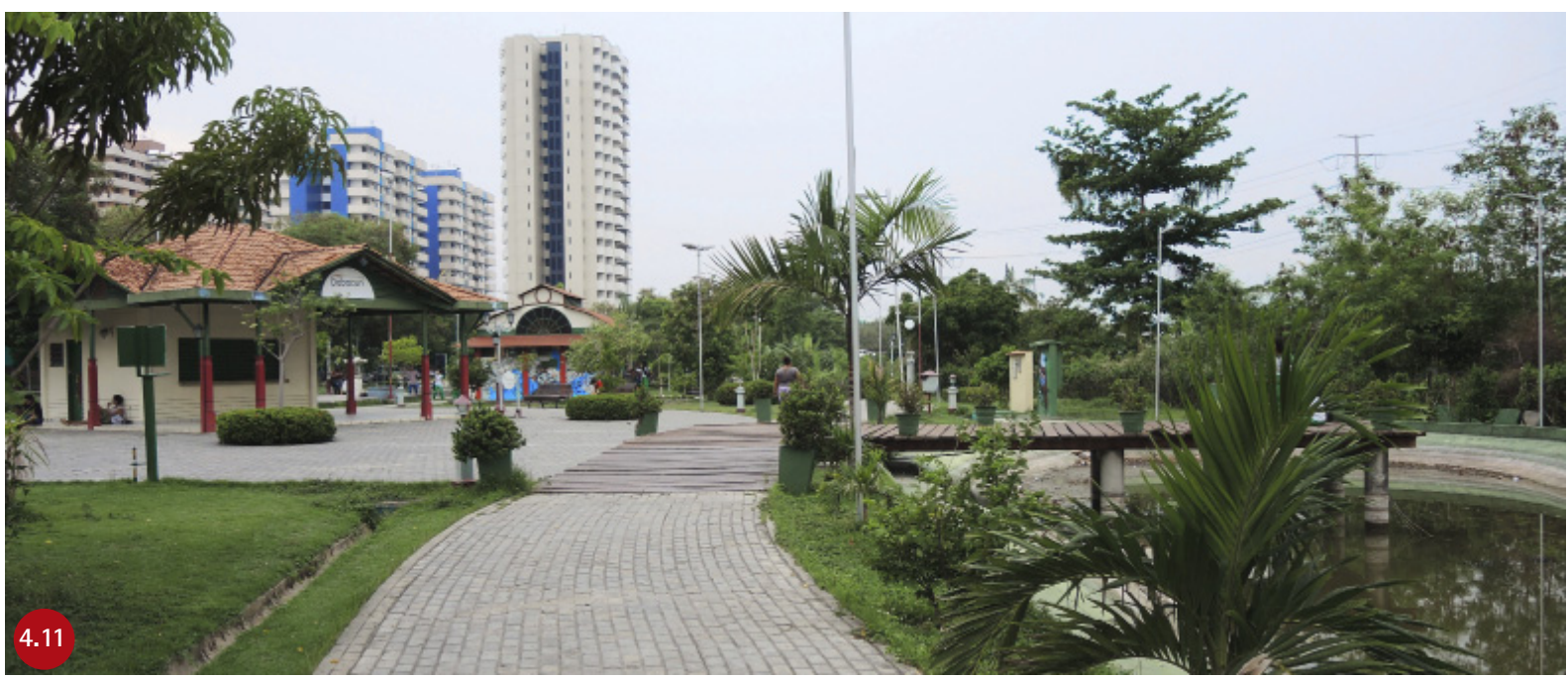




\section{Manejo e zoneamento}

Como todos os parques são considerados "ecológicos" - , os planos de manejo e zoneamento dos elementos e sistemas naturais passaram a ser incorporados aos projetos paisagísticos, com diferentes graus de consistência e pertinência.

Fato é que as leis ambientais e os técnicos das diferentes secretarias municipais frequentemente demandam estes documentos e seus procedimentos, que vão desde a garantia de pisos permeáveis para a recarga dos lençóis freáticos até faixas de recuperação de mata ciliar junto dos corpos d'água. Busca-se fazer o reflorestamento ou a recomposição florística e paisagística para a recuperação da vegetação característica da área. 0 zoneamento visa à garantia de um convívio harmonioso entre as áreas de parque típicas, visitadas diariamente, e as áreas protegidas, separadas por uma zona tampão, ou de transição. ${ }^{5}$

No terreno onde seria implantado o Parque Flamboyant, em Goiânia, os lagos existentes apresentavam solapamento das margens e grande quantidade de lixo no fundo. Por conta do assoreamento, a água apresentava-se com nível baixo, pouca oxigenação e cheirava mal em determinadas épocas do ano. Os lagos foram drenados; o

5 Não há consensos sobre o papel dos fragmentos de floresta no meio urbano e outros estudos tratam do tema. Para Roberto Sakamoto de Souza, as estratégias de conservação de fragmentos de floresta em meio urbano podem resultar em ganhos paisagísticos e de conforto urbano.

SOUZA, Roberto Sakamoto de. 0 papel das leis e das instituições para a conservação da diversidade ambiental e cultural na Baixada Santista. Tese (Doutorado). Faculdade de Arquitetura e Urbanismo da Universidade de São Paulo. São Paulo, 2018.

6 Conselho Regional de Engenharia, Arquitetura e Agronomia de Goiás. Prêmio CREA Goiás de Meio Ambiente 2007: compêndio dos trabalhos premiados. Goiânia: América, 2008. solo comprometido, removido. Em todo o perímetro do lago foram executados enrocamentos de pedra para conter o solapamento das margens.

0 projeto setorizou o parque em quatro zonas 6 : 4.12

- Zona de Uso Intensivo (ZUI): áreas que podem servir a atividades recreacionais, relativamente concentradas, com facilidades de trânsito e assistência ao público. Objetivava despertar o interesse do público para conhecimento genérico da flora e fauna nativas e das biocenoses existentes;

- Zona de Uso Restrito (ZUR): áreas necessárias à administração, manutenção, serviços, trilhas interpretativas de educação ambiental, com acesso ao público controlado. Sua concentração em pequena área objetiva minimizar o impacto ambiental; 
- Zona de Recuperação: contém áreas que sofreram considerável alteração humana. As espécies exóticas introduzidas devem ser removidas. É considerada uma zona provisória, pois, uma vez restaurada, será incorporada em uma das categorias permanentes.

- Zona de Preservação Integral (ZPI): áreas naturais, onde a intervenção humana tenha sido pequena ou mínima. Pode conter ecossistemas únicos, com espécies da flora, fauna, ou até fenômenos naturais de grande valor científico que podem tolerar ocasionalmente o uso limitado do público. Deve-se manter o ambiente natural com a mínima intervenção e facilitar o uso para educação do público.

Zoneamento do Parque Municipal Flamboyant Lourival Souza, em Goiânia.

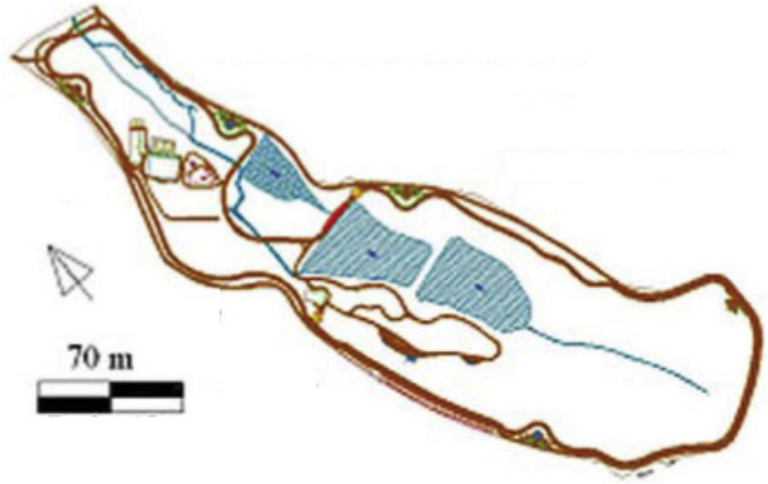

Zona de Uso Intensivo (ZUI) $22.800 \mathrm{~m}^{2}$

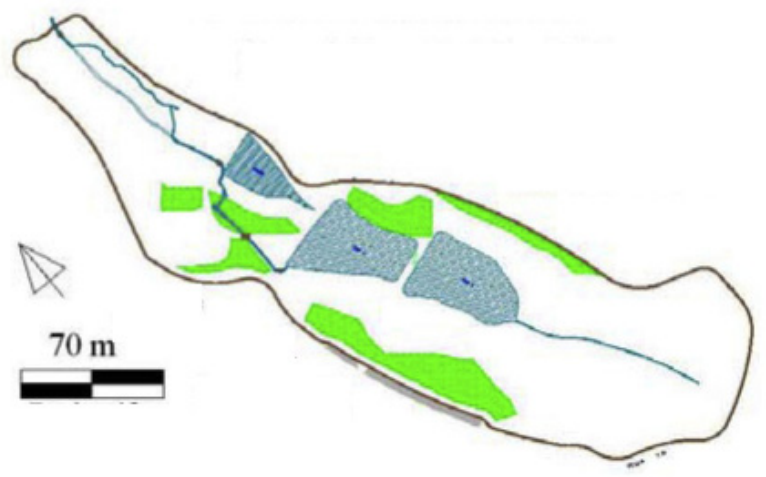

Zona de Uso Restrito (ZUR) $14.016 \mathrm{~m}^{2}$

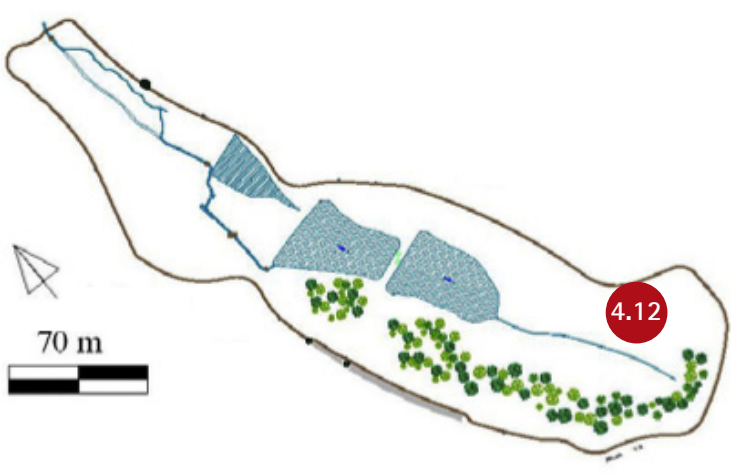

Zona de Recuperação (ZR) $18.140 \mathrm{~m}^{2}$

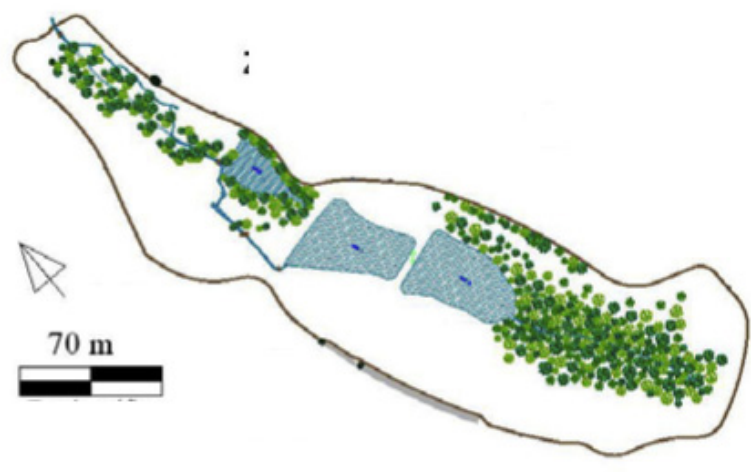

Zona de Proteção Integral (ZPI) $32.896 \mathrm{~m}^{2}$

Área total do parque $=115.000 \mathrm{~m}^{2} \quad$ Área dos lagos $=13.500 \mathrm{~m}^{2}$ 
0 plano de manejo, neste caso, se tornou ponto de partida para o projeto paisagístico. Isto é salutar, por um lado, pois é um modo de incorporar a gestão ao conceito da obra pública. 0 plano de manejo é um plano de gestão que relaciona as áreas com as intensidades de uso. Por outro lado, estes planos tendem a valorizar de sobremaneira as restrições ao público, como forma de recuperar a flora e a fauna e resgatar dinâmicas ecológicas.

Entretanto, Sakamoto de Souza ${ }^{7}$ ressalta que, quaisquer que sejam as estratégias de gestão e de desenho para manter as dinâmicas ecológicas anteriores ao processo de urbanização, elas serão sempre insuficientes para tal. Não é possível, dentro das cidades, reestabelecer todas as conexões e algumas perdas são irreversíveis. Fragmentos estreitos de florestas jamais voltarão a abrigar mamíferos de porte, por exemplo.

Se a ênfase no projeto dos parques urbanos é dada à recuperação das dinâmicas ecológicas, serão desnecessariamente sacrificadas possibilidades de apropriações sociais.

7 SOUZA, Roberto Sakamoto de. O papel das leis e das instituições para a conservação da diversidade ambiental e cultural na Baixada Santista. Tese (Doutorado). Faculdade de Arquitetura e Urbanismo da Universidade de São Paulo. São Paulo, 2018.

8 No caso do Parque da Juventude, o Governo do Estado de São Paulo realizou um concurso público. Venceram a equipe do escritório Aflalo/ Gasperini arquitetos junto com o escritório de Rosa Kliass.

9 Em função do grande volume de projetos simultaneamente em andamento, as fases de levantamento, estudos do entorno, diagnóstico e elaboração das diretrizes foram realizadas internamente; as fases de Projeto Básico Completo e Projetos Complementares (instalações elétricas, hidráulicas, estruturas etc.) foram realizadas externamente, sob a coordenação da Divisão Técnica de Projetos e Obras do Depave.

\subsection{Arquitetos paisagistas e processos de trabalho}

Os parques construídos no período analisado foram projetados por profissionais de diferentes formações, diferentes graus de preparo e experiência profissional. As variadas modalidades de contratação dos projetos e dos profissionais confirmam as grandes diferenças nas condições institucionais e de recursos para o desenvolvimento dos projetos.

Os governos do Estado de Belém e São Paulo contrataram a renomada paisagista Rosa Kliass para os projetos dos parques Mangal das Garças e da Juventude ${ }^{8}$. No Programa 100 parques (São Paulo), os técnicos do Departamento de Parques e Áreas Verdes (Depave) faziam os estudos e terceirizavam o desenvolvimento para empresas de projeto - que trabalhavam sob a supervisão do poder público, mas eram remuneradas diretamente pelas construtoras que assina- 
vam TCAs com o Depave ${ }^{9}$. Em Goiânia, muitos projetos de parques foram desenvolvidos pela própria equipe técnica da prefeitura. Para o projeto dos parques Águas Claras (Brasília) e do Cocó (Fortaleza), foram promovidos concursos públicos em 2017.

Quando os projetos são designados a profissionais de 'grife', a autonomia do projetista é maior. A exigência é de que tenham grande visibilidade, e a tendência é que a obra seja executada com rigor, acima da média para espaços públicos. Projetos de espaços públicos que acompanham empreendimentos privados tendem também a ser mais sofisticados.

0 Parque Una Pelotas (2015), em Pelotas (RS), é um empreendimento privado cujo centro é um parque público. Surgiu por sugestão do urbanista Helio Mitica, quando da encomenda de um loteamento fechado de casas. 0 urbanista propôs ao proprietário das terras um empreendimento aberto, multifuncional, com torres residenciais e comerciais, comércio e serviços no térreo e um parque público central estruturando o conjunto urbano. Segundo os autores, a ambiência urbana é o segundo elemento mais importante na hora da escolha de moradias, perdendo somente para o valor do imóvel. ${ }^{10}$

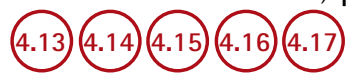

No caso dos 'projetos do cotidiano' da gestão municipal, tende a ser solicitado que se desenvolvam segundo a cultura da época e daquela instituição em questão. Para os parques paulistanos do Programa 100 parques, os técnicos da prefeitura, em geral jovens arquitetos, demandavam aos projetistas que priorizassem: primeiramente o atendimento das leis ambientais, que são bastante restritivas, especialmente na ocupação de faixas nas margens de rios, mesmo por caminhos ou playgrounds e, em segundo lugar, as normas de acessibilidade ${ }^{11}$. Em seguida, apareciam as relações com a cidade, a distribuição dos equipamentos e a qualidade das soluções. Ações adicionais para aumentar a permeabilidade do solo ou reter água de chuva, como jardins-de-chuva, eram bem-vindas.

Na fase de projeto do Parque Cohab Raposo Tavares, fase 2, os técnicos do Depave solicitaram ao projetistas da NKEtF Arquitetos Associados que todas as áreas do parque fossem acessíveis e que isto
10 AREA URBANISMO. Sucesso no planejamento de bairros verticais. 05/12/2017. Disponivel em: <http://www.areaurbanismo.com.br/blog/2017/12/5/sucesso-no-planejamento-de-bairros-verticais>.

11 A norma ABNT 9050/2004 tornou-se uma Lei Federal (Decreto n 5.296de 2004). Em São Paulo, todos os projetos públicos precisam passar pela Comissão Permanente de Acessibilidade (CPA), órgão colegiado instituído em 1996 e ligado à Secretaria Municipal da Pessoa com Deficiência e Mobilidade Reduzida (Smped). 
Parque público é centro do empreendimento Parque Una Pelotas, , em Pelotas (RS). Os urbanistas demonstraram aos investidores que seria mais interessante construir espaços públicos com equipamentos de lazer e esportes e um mix de comércios e serviços. Em 2017, foi construído o restaurante com vista para o lago para funcionar como stand de vendas.
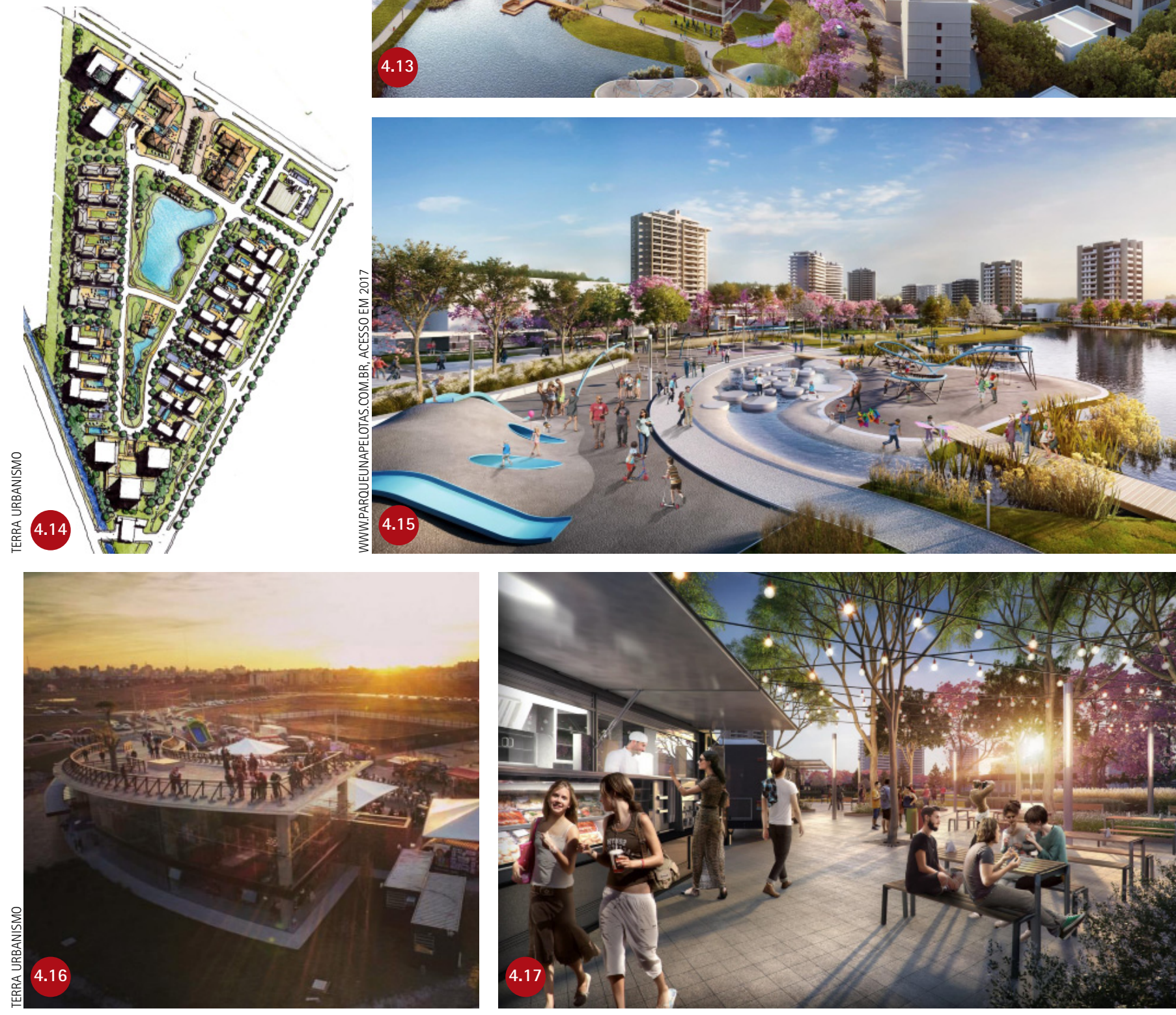


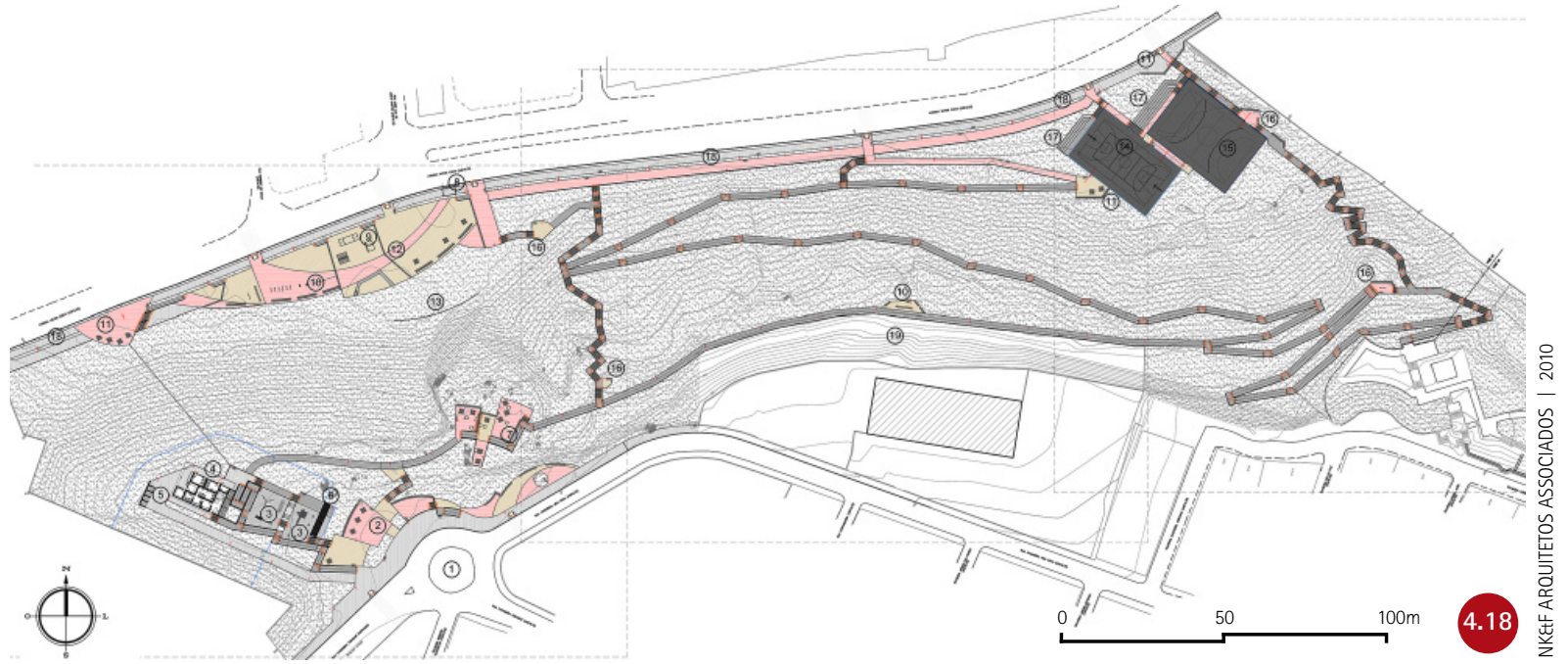

fosse feito com mínima interferência sobre o terreno. Foi necessário projetar uma passarela elevada com 633 metros de extensão, em madeira, para ligar a rua na cota mais baixa com a rua no alto. Esta passarela foi orçada em $\mathrm{R} \$ 710.000,00$ - o que correspondia a 1/4 da obra total do parque. As ruas e calçadas do entorno fazem esta ligação mas não com as declividades requeridas pela norma técnica de acessibilidade. Concluído e aprovado o projeto, nem a passarela nem o parque foram executados. (4.18

Para o projeto do Parque Linear Água Podre, o mesmo escritório desenvolveu uma proposta com caminhos sinuosos. A ideia original era alterar o desenho do canal do rio para que tivesse curvas e, com isto, minimizar o corte de árvores e melhorar o aspecto da canalização. As curvas também contribuem para retardar a velocidade da água, assim como variações na largura do leito d'água e rugosidades no fundo. 0 arquiteto Sun Alex, coordenador do projeto pela prefeitura, vetou os caminhos e bancos curvos por entender que a obra pública com estas características, sem grande visibilidade ou recursos, não conta com aparato técnico capaz de executar com qualidade caminhos e bancos curvos. Para ter qualidade mínima na obra executada, era preciso que o projeto fosse ainda mais simples.
Projeto para o Parque Cohab Raposo Tavares, fase 2. Para tornar todas as áreas acessíveis foi necessário projetar uma longa rampada. Para que a movimentação de terreno fosse mínima e não fosse necessária a derrubada de árvores, esta rampa seria elevada e construída em madeira. 


\subsection{Projetos selecionados}

Selecionamos 16 projetos de parques do período entre 2000-2017 que foram desenvolvidos completos e nos quais podemos perceber a correspondência entre o discurso e o desenho:

\section{Neoecléticos:}

Parque Mangal das Garças, Belém

Parque Senador Jefferson Peres, Manaus

\section{Românticos:}

Parque Jardim das Perdizes, São Paulo

Parque do Povo, São Paulo

Parque Belém, São Paulo

Parque Flamboyant, Goiânia

Parque Nossa Senhora da Piedade, Belo Horizonte

Parque Cordeiro, São Paulo

Parque Paraisópolis, São Paulo

\section{Formalistas:}

Parques Sabesp Butantã, São Paulo

Parque Gabriel Chucre, Carapicuiba (SP)

Bosque do Sudoeste, Brasília

Parque Madureira, Rio de Janeiro

Parque Linear do Sapé, São Paulo

Portal da Amazônia, Belém

Parque da Juventude, São Paulo

Todos podem ser considerados ambientalistas. Em um texto sobre o Parque do Cordeiro, o arquiteto Raul Pereira definiu o princípio projetual como "Paisagem revelada". Ele buscou aproveitar o plantio de árvores que já havia sido feito e optou por pisos e mobiliários feitos com técnicas tradicionais, já à disposição do construtor.

Estes desenhos românticos têm relação com a linha projetual inglesa, que recria a natureza através de lagos, morrinhos gramados e bosques. Mas há a 'tropicalização', a incorporação da natureza local, do programa de usos moderno e a busca por conviver com a economia de recursos e a gestão inconstante. Os projetos procuraram ser exequíveis e democráticos e assim demonstram assim sua qualidade e inovação. 
BELÉM

\section{Parque Mangal das Garças}

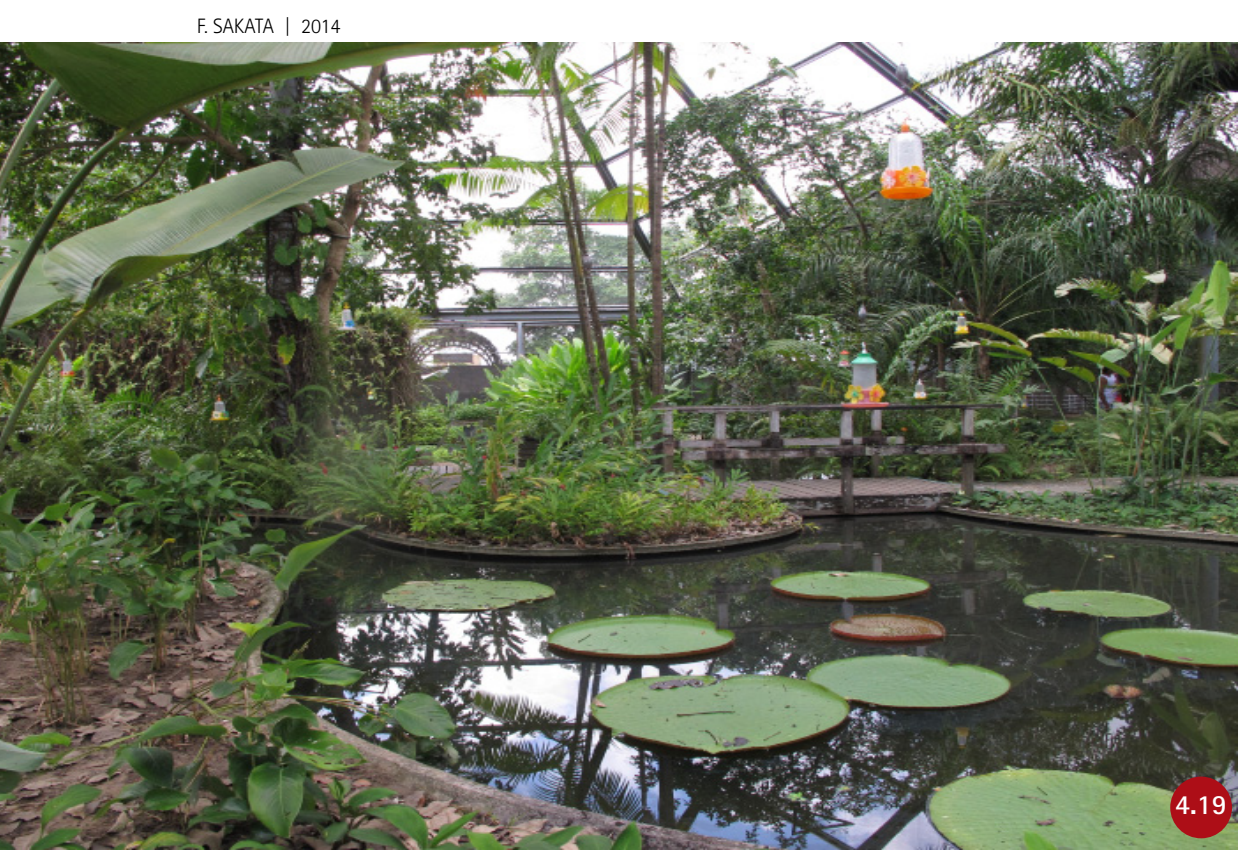

0 parque é resultado da revitalização pelo Governo do Estado de uma área de grande visibilidade da capital: junto do centro e às margens do Rio Guamá. 0 Mangal das Garças tem projeto de desenho marcante, com desenhos de piso geométricos em mosaico português e edificações que fazem referência a edifícios antigos - estufas, torres, faróis. Como um parque do século XIX, abriga famílias de patos que passeiam nos gramados. Conta também com um borboletário cenarizado, com cascatas, laguinhos e pontes. No passeio podem ser apreciadas tanto vistas para o rio quanto para a cidade. A ideia do parque é romântica: lugar de passeios, contemplação, encantamento com a natureza e seus elementos.

0 projeto de plantio apresenta as diferentes macrorregiões floristicas do Estado: matas de terra firme, matas de várzea e campos. A vegetação da beira do rio - a Aninga (Montrichardia linifera) - teve seu potencial paisagístico reconhecido por Rosa Kliass, e foi disposta formando maciços ao longo do rio, fazendo com que em alguns trechos a vista para o rio fique parcialmente oculta e, em outros, reapareça.

0 parque possui equipamentos de qualidade, que compõe a orla visivel de Belém. Não há tanta diversidade de público como em outros espaços livres do centro, mas a visitação é grande, inclusive turistica. Trata-se de um dos mais bonitos parques do período entre 2000 e 2015, rivalizando apenas com o Parque da Juventude, cujo projeto também é de Rosa Kliass.

\section{Endereço:}

R. Carneiro da Rocha, s/n, Cidade Velha

Data | 2005

Autor:

Rosa Klias

Projeto de arquitetura e fiscalização:

Paulo Chaves Fernandes, Rosário Lima, Aurélio Meira, Mariângela Melo, Sérgio Neves, Gustavo Leão, Leila Barbosa, Karla Costa

Área $\mid 40.000 \mathrm{~m}^{2}$

Atividades:

apropriado para caminhadas e recreação mas seu programa é essencialmente contemplativo

\section{Elementos:}

\section{caminhos}

museu amazônico da navegação viveiros dos pássaros borboletário 4.19 deck e mirante para o rio 4.22 farol de belém (4.23) espelhos d'água e fontes orquidário esculturas restaurante viveiro de plantas Ioja

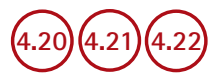



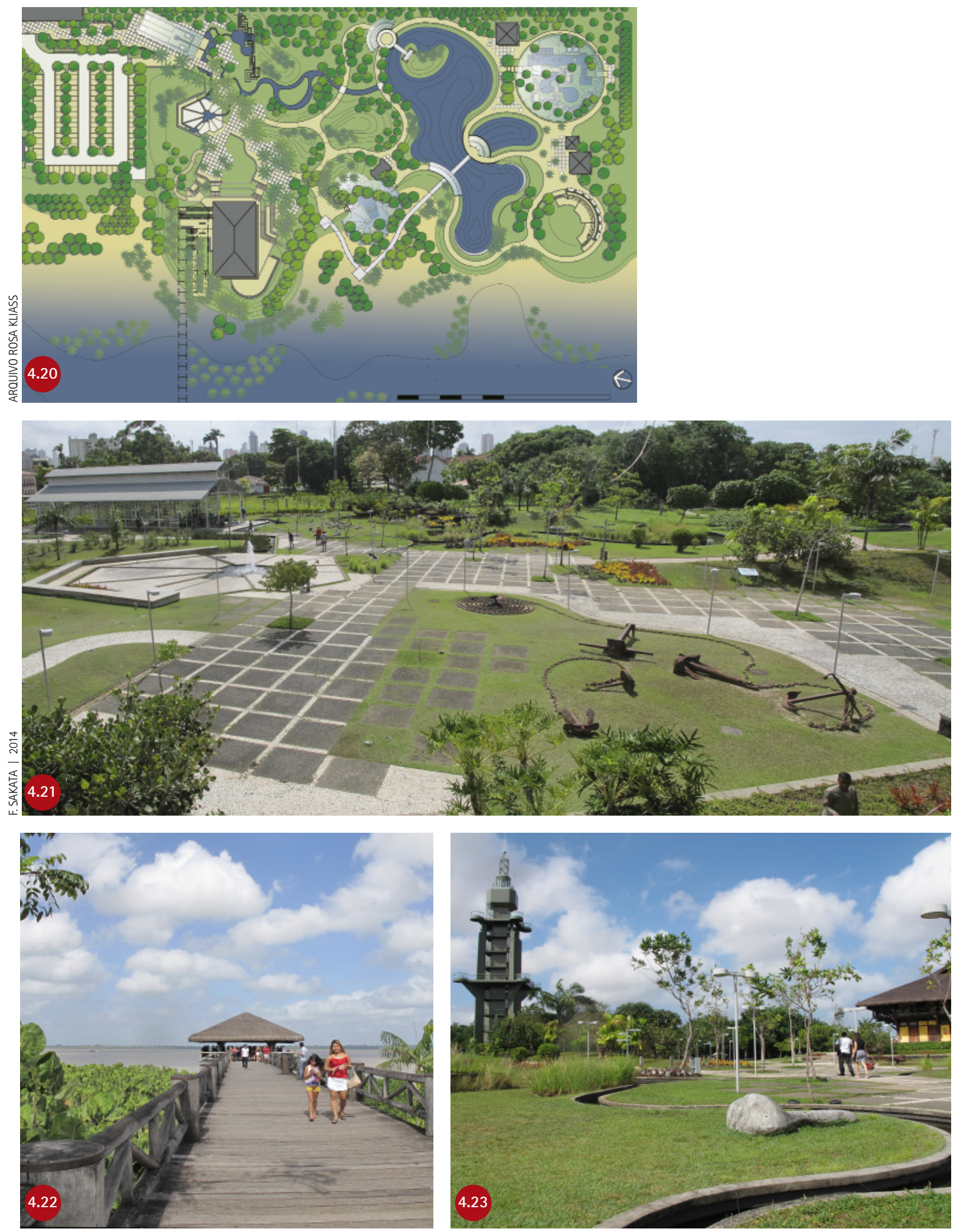
MANAUS

\section{Parque Senador Jefferson Peres}

0 parque, entregue pelo Programa Prosamim, foi feito em substituição às palafitas em uma área central de Manaus - de rendas baixa e média. 0 terreno apresenta formato de "Y" por ser o encontro de dois igarapés que deságuam no Rio Negro. Para constituir a área fez-se o aterramento parcial dos cursos de água.

0 projeto buscou oferecer aos visitantes reminiscências da história amazonense, especialmente do período econômico chamado ciclo da borracha. Há um pórtico de 10 metros de altura, voltado para Rio Negro, e pequenos quiosques dentro do parque com uma "renda" de estrutura metálica com desenhos que rememoram a Belle Epóque de Manaus.

0 Chafariz das Quimeras, monumento histórico restaurado, foi instalado no ponto onde os igarapés se encontram, a Praça dos Leões Alados. Há também as praças da Charrete e do Bonde. A bandeira do Amazonas surge no alto de um mastro de 60 metros como marca do poder público.

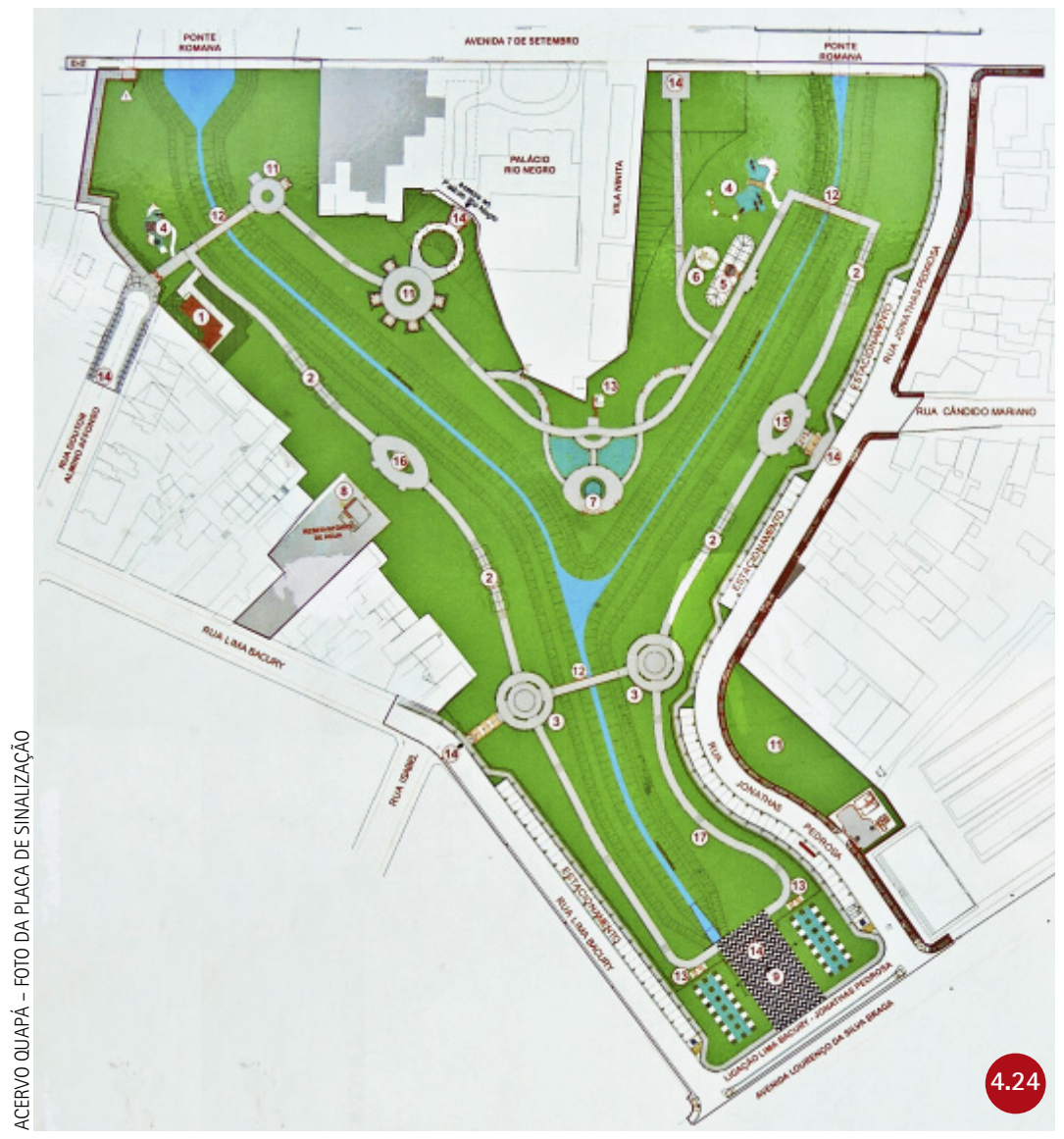

\section{Endereço:}

Av. Lorenço da Silva Braga, 1507, Centro

Data | 2009

Autor:

Informação não encontrada.

Área | $53.421 \mathrm{~m}^{2}$

\section{Atividades:}

contemplação

esportes

recreação infantil

Atividade:

esportiva

recreação infantil

contemplação

turismo

\section{Elementos:}

portal de entrada

espelho d'água

pergolado

gazebos

playground

estufa/ orquidário

sanitárrios

fonte dos leões

ponte metálica

Praça do Avião

Praça do Bonde

monumento

bandeira

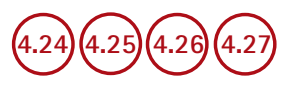



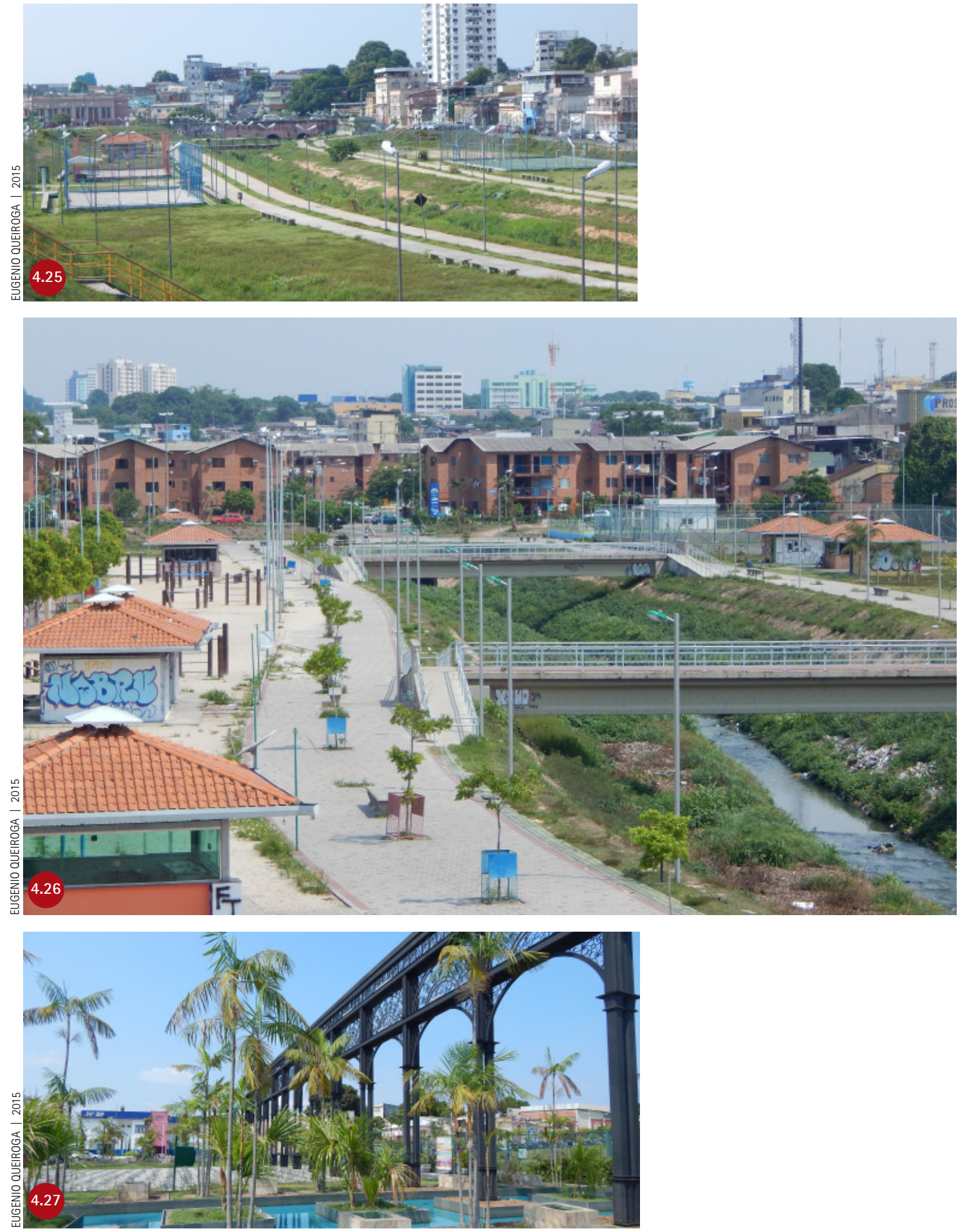
SÃO PAULO

\section{Parque Jardim das Perdizes}

0 parque foi criado com o bairro Jardim das Perdizes. Sua origem está na Operação Urbana Água Branca (1995), criada pela prefeitura para mudar o uso do bairro Barra Funda de industrial para residencial e de serviços. Os empreendedores não se interessaram pelos prédios baixos, sugeridos pelo vencedor de um concurso para a área, e criaram produtos imobiliários de grande porte, com torres.

0 parcelamento da gleba original impunha a doação de áreas verdes e institucionais. Os investidores logo perceberam que o parque valorizaria 0 empreendimento, implantado em área industrial, marcada por galpões fabris e de empresas de transportes, entremeada por casinhas simples e favelas, movimentada e com grande número de moradores pobres e em condição de fragilidade social. Contrastando com a horizontalidade dos bairros ao redor, as torres foram implantadas com varandas e vistas voltadas para o parque.

Também foram feitas no bairro calçadas mais largas e sistema de drenagem com tubos perfurados, instalados sob as calçadas. 0 projeto paisagístico privilegiou a escala e o conforto do pedestre. 0 parque urbano foi desenhado com formato ovoide, para que, além de estar no centro das torres, também servisse como elemento de conexão com o restante da cidade. É um parque pequeno, com vários ambientes ao longo de um caminho principal.

Os brinquedos e equipamentos de ginástica têm boa qualidade. Em 2016 a gestão do parque era realizada por uma associação ligada à construtora. Sua posição e o cercamento não deixam claro o fato de ser um parque público; moradores de bairros próximos ainda não o conhecem, possuindo capacidade para mais frequentadores do que tem recebido.

\section{Endereço:}

Av. Marquês de São Vicente, Perdizes

Data | 2013

Arquitetura e coordenação:

Helio Mitica, Terra Urbanismo.

Projeto paisagístico:

Tatiana Vicentini, Terra Urbanismo.

Área | $44.000 \mathrm{~m}^{2}$

\section{Atividades:}

contemplação

centro de educação ambiental

\section{Elementos:}

caminhos

ciclovia

equipamentos de ginástica

playgrounds

zona para cães

mesas de jogos

ponto de relaxamento

bebedouros

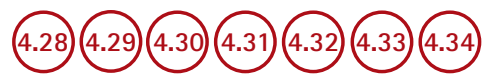

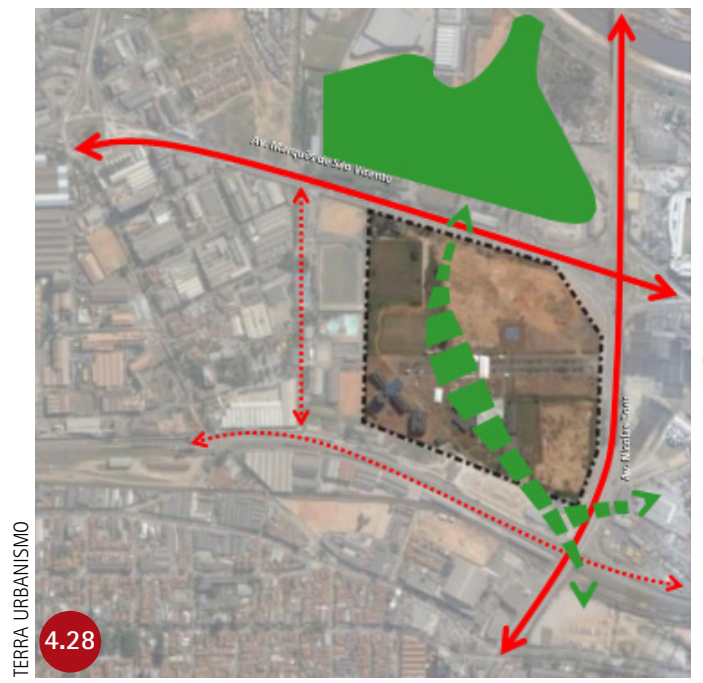

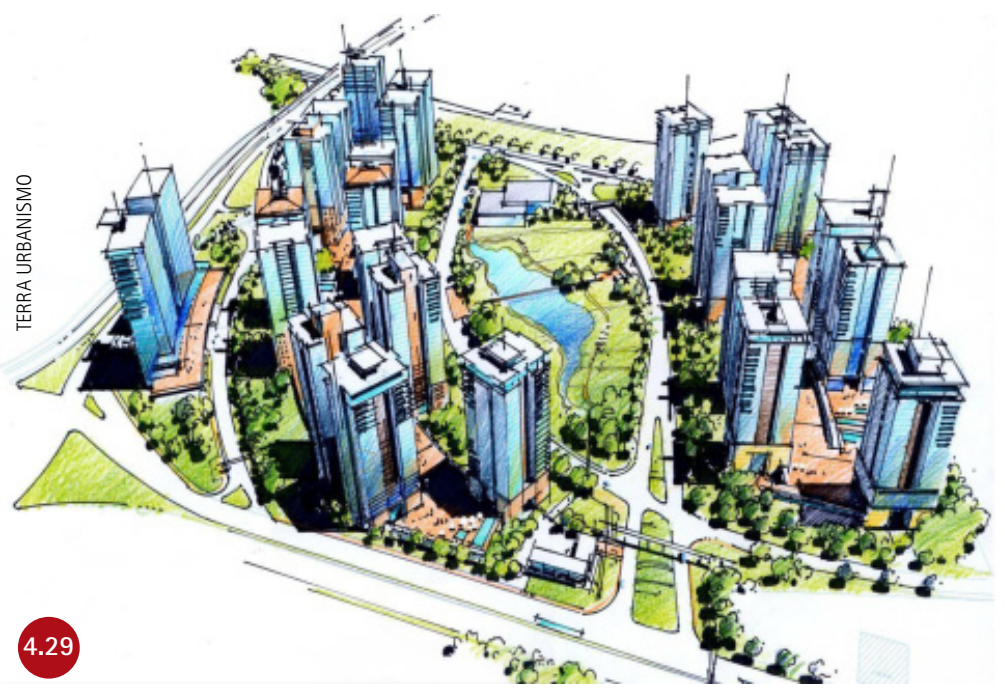



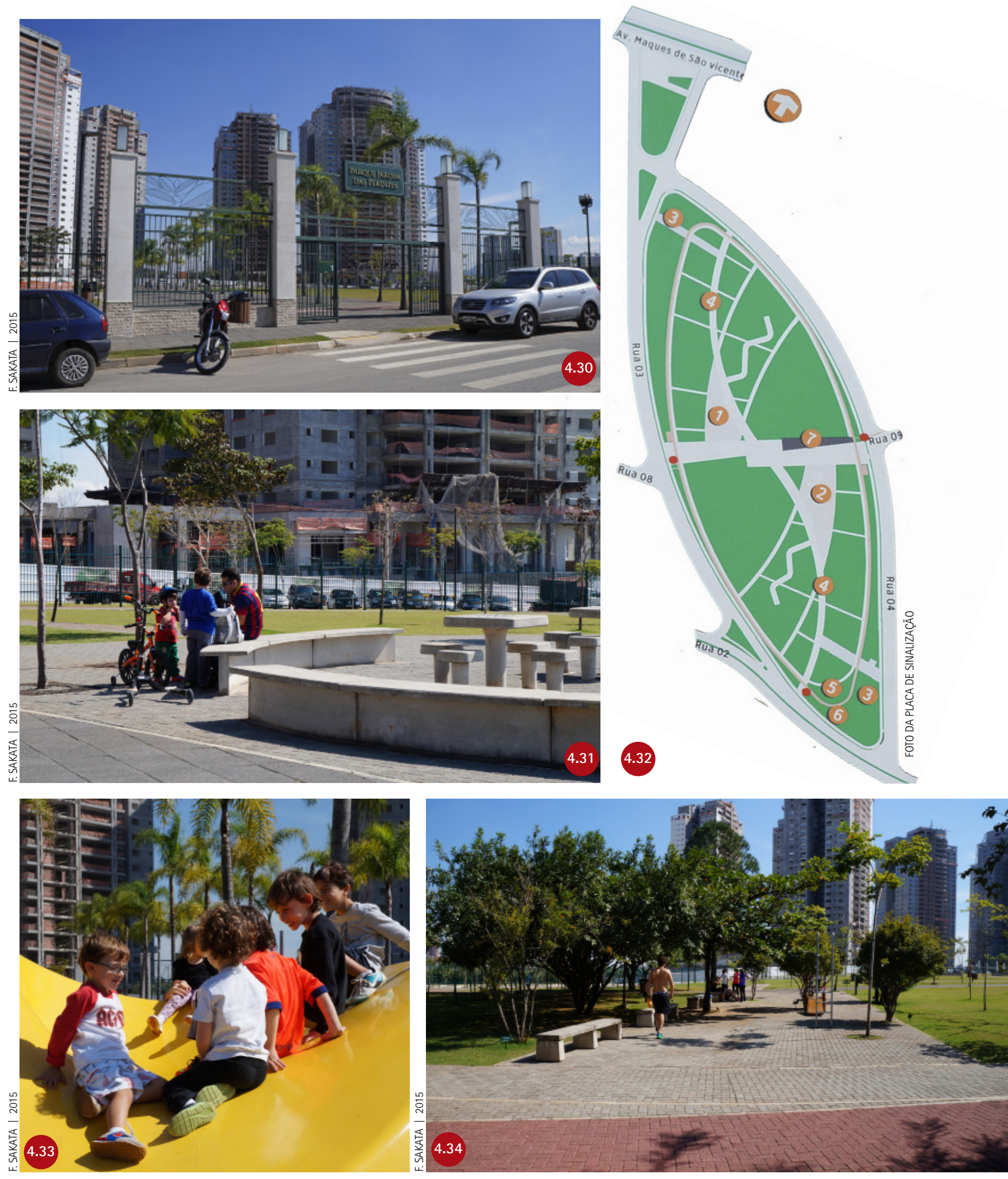
SÃO PAULO

\section{Parque do Povo (Mário Pimenta Camargo)}

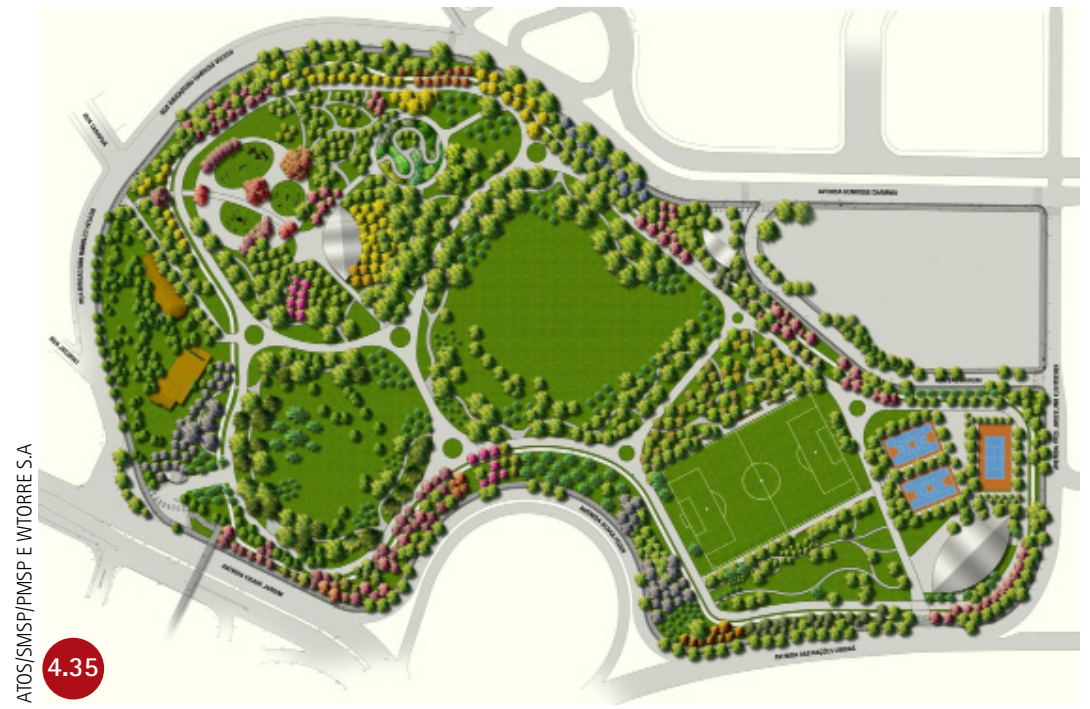

0 parque está instalado em uma área que pertencia à Caixa Econômica Federal (CEF), utilizada para a prática do futebol e que abrigava teatro e circo-escola. 0 terreno havia sido tombado em 1995, em decorrência de seu valor histórico e importância para a cultura popular - o estudo de tombamento provava que era frequentado por trabalhadores do comércio local e de restaurantes do entorno. Isto foi importante para reservar este trecho da várzea do Pinheiros, muito valorizado pelo mercado imobiliário.

Os campos de futebol deram lugar a extensos gramados usados como tapetes, contornados por caminhos, e às árvores existentes, adultas, nas bordas. Guarda semelhança com parques europeus em que as pessoas tomam sol e fazem piqueniques nos gramados. Foi feito um campo de futebol e três quadras poliesportivas.

É o parque que melhor sintetiza alguns valores do seu tempo: acessivel às pessoas com mobilidade reduzida; com jardim sensitivo para cegos; calçadas feitas com materiais de demolição; coleções botânicas reunidas em trilhas educativas.

Uma ciclofaixa demarcada com cones em algumas avenidas da cidade aos domingos e feriados liga o Parque do Povo aos parques Ibirapuera e VillaLobos, favorecendo os passeios de bibicleta entre os três parques mais frequentados pelas camadas de rendas mais altas de São Paulo. 0 Ibirapuera e o Villa-Lobos, nos finais de semana, têm público bastante diversificado enquanto o Parque do Povo, de menor porte, tem uso mais elitizado.

\author{
Endereço \\ Rua Henrique Chamma, 420, \\ Pinheiros \\ \begin{tabular}{l|l} 
Data & 2008
\end{tabular} \\ Autor \\ Projeto paisagístico: André Graziano \\ ATOS/SMSP/PMSP
}

Levantamento | 2012

Área | $133.547 \mathrm{~m}^{2}$

\section{Atividades}

contemplação

esportes

recreação infantil

\section{Elementos:}

quadras poliesportivas campo de futebol aparelhos de ginástica (inclusive para portadores de necessidades especiais) ciclovia pista de caminhada estações de ginástica jardim sensitivo sanitários portaria/ administração playground 4.39 4.40

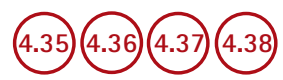



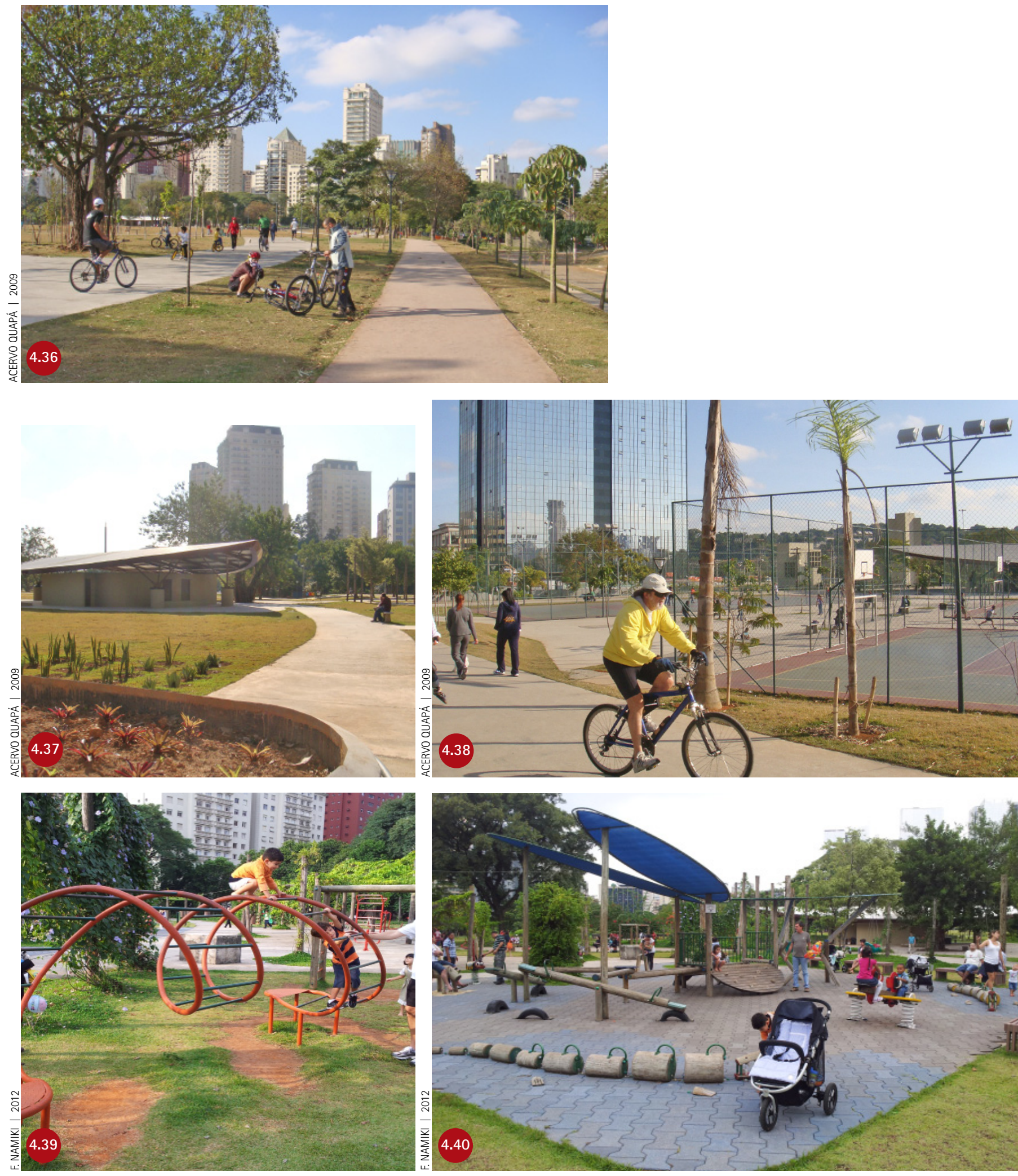
SÃO PAULO

\section{Parque Estadual do Belém}

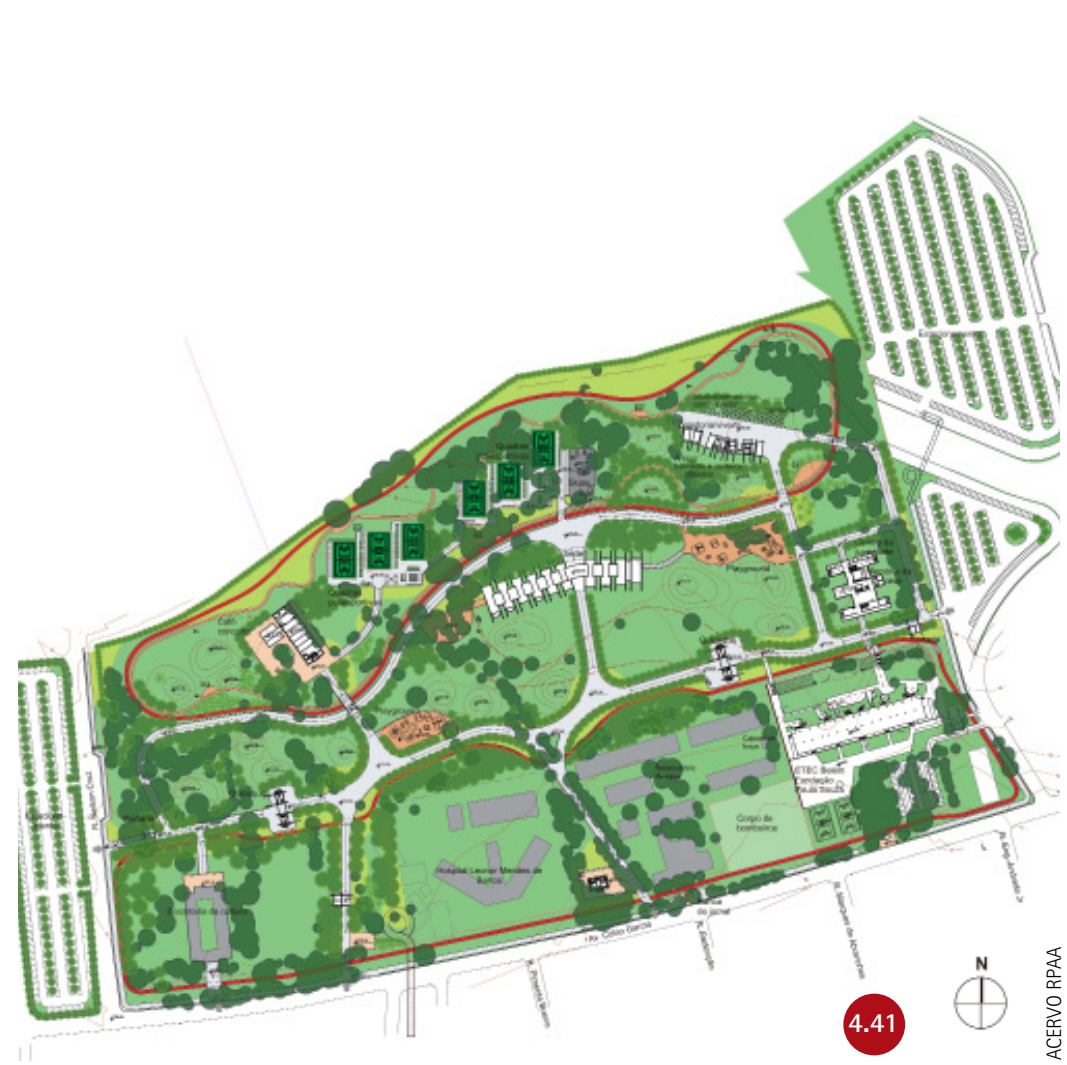

Ocupa uma área que entre 1902 e 2005 foi do Instituto Disciplinar, Colônia Correcional e Fundação Estadual para o Bem-Estar do Menor (Febem). 0 governo do Estado reformou o espaço para usos de parque com programa de atividades similar ao do Parque da Juventude, com equipamentos esportivos e culturais. Previu-se uma Escola Técnica Estadual, um café e uma biblioteca. Um edifício existente foi aproveitado para a Fábrica de Cultura, um edifício com salas para atividades culturais.

Destacam-se as novas edificações, com a telha metálica curva pintada de amarelo, fazendo às vezes de cobertura e parede, e a ponte de madeira que cruza a ciclovia por cima. Deste ponto, tem-se uma bonita vista para todo o terreno. A entrada é pouco visível, e o parque, pouco visitado - talvez por isto, talvez pela proximidade do Parque do Piqueri.

\section{Endereço:}

Avenida Celso Garcia, 2.431, Belenzinho

Data | 2012

Autor:

Projeto paisagístico: Raul Pereira Equipe: Rulian Nociti, Aline Santos, Ana Cláudia Frederico, Fernando Galvão.

Lucas das Neves, Roberto Rusche. Arquitetura: Fundação para a Pesquisa Ambiental (Fupam)

Área | $242.000 \mathrm{~m}^{2}$

\section{Atividades:}

esportes recreação infantil contemplação cursos e atividades culturais

Elementos:

rede de caminhos quadras poliesportivas quiosques

ciclovia pista de corrida pista de skate áreas para ginástica equipamentos para ginástica praças de estar playgrounds sanitários

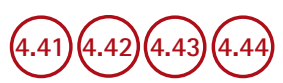



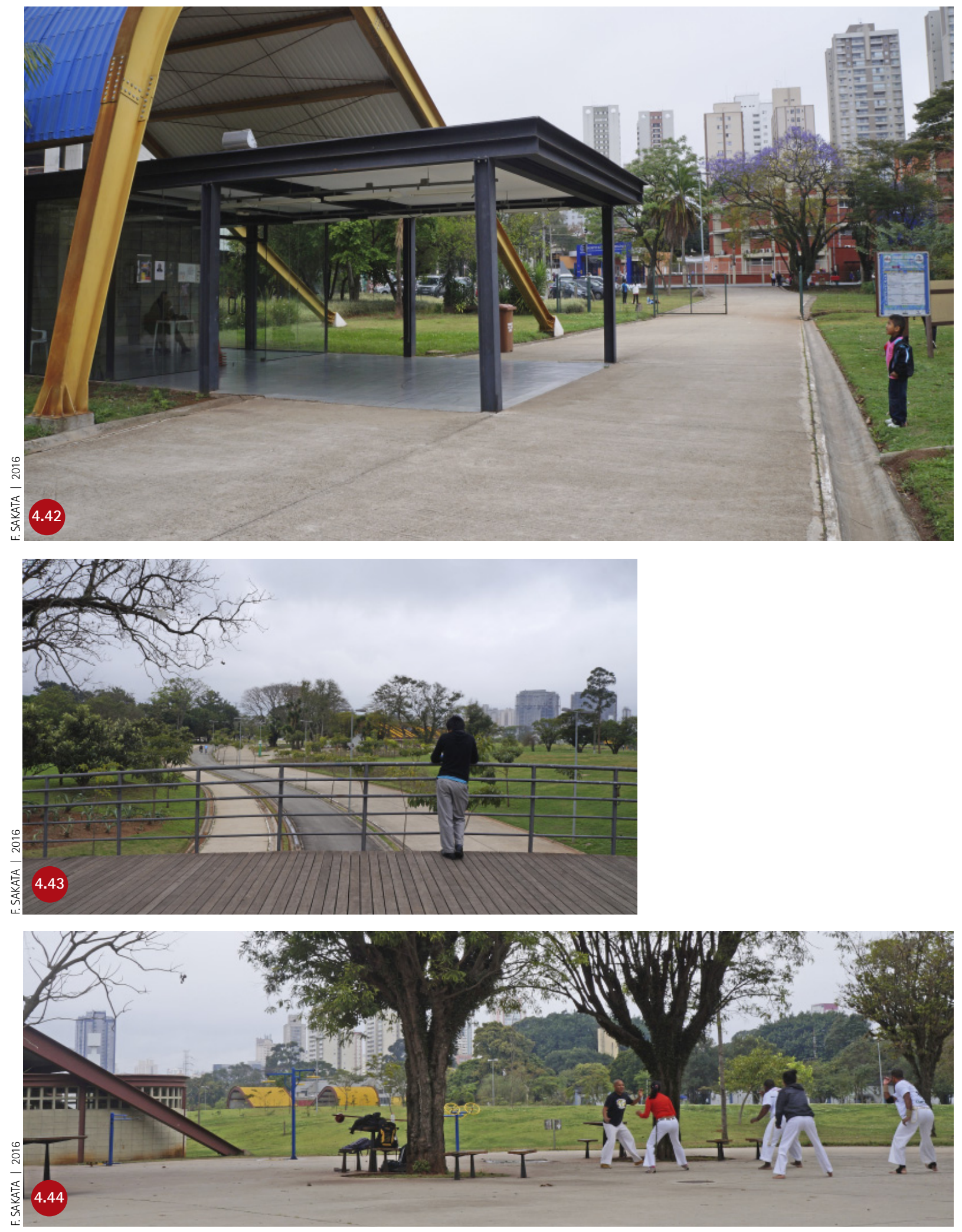

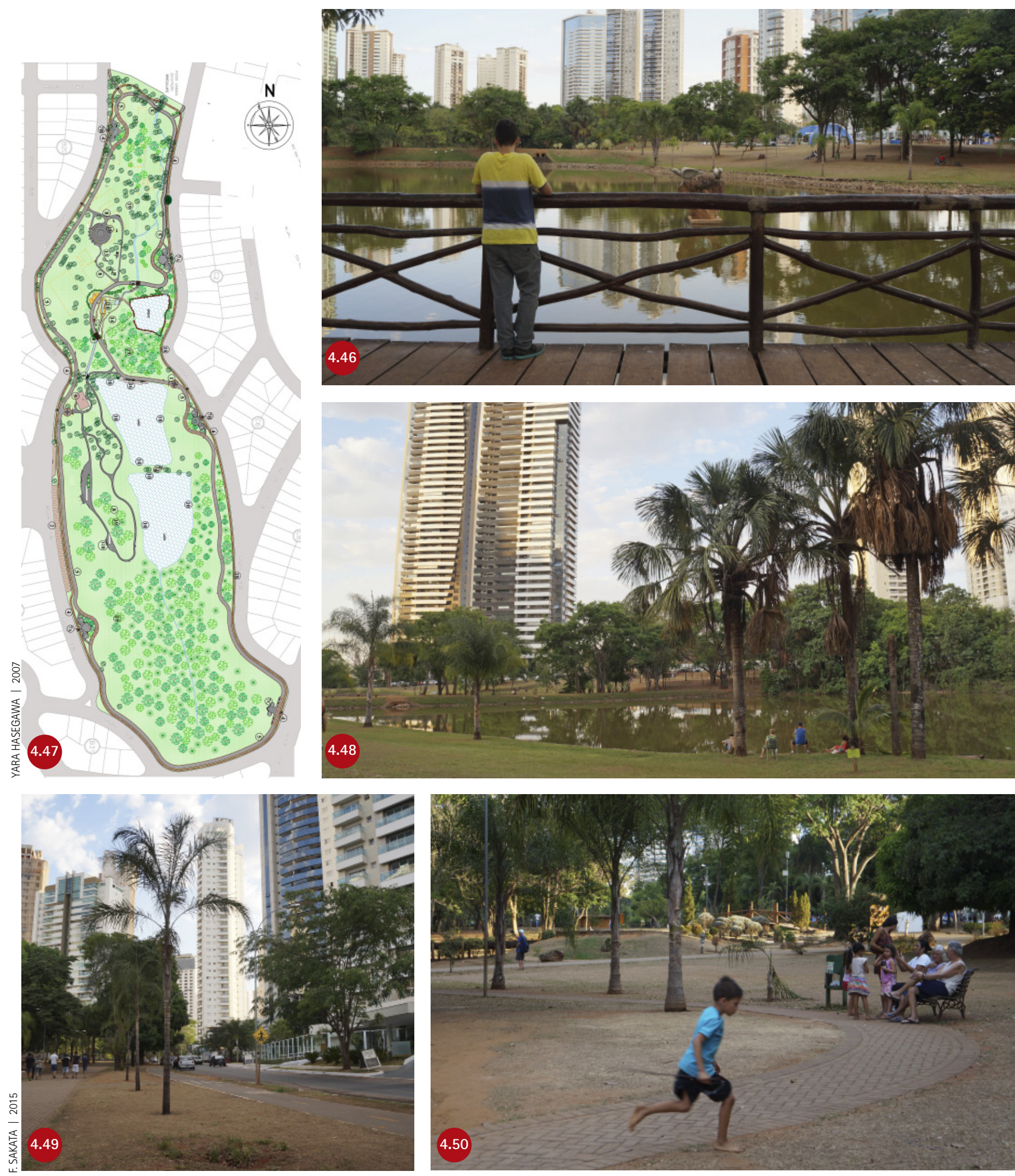


\section{BELO HORIZONTE}

\section{Parque Nossa Senhora da Piedade}

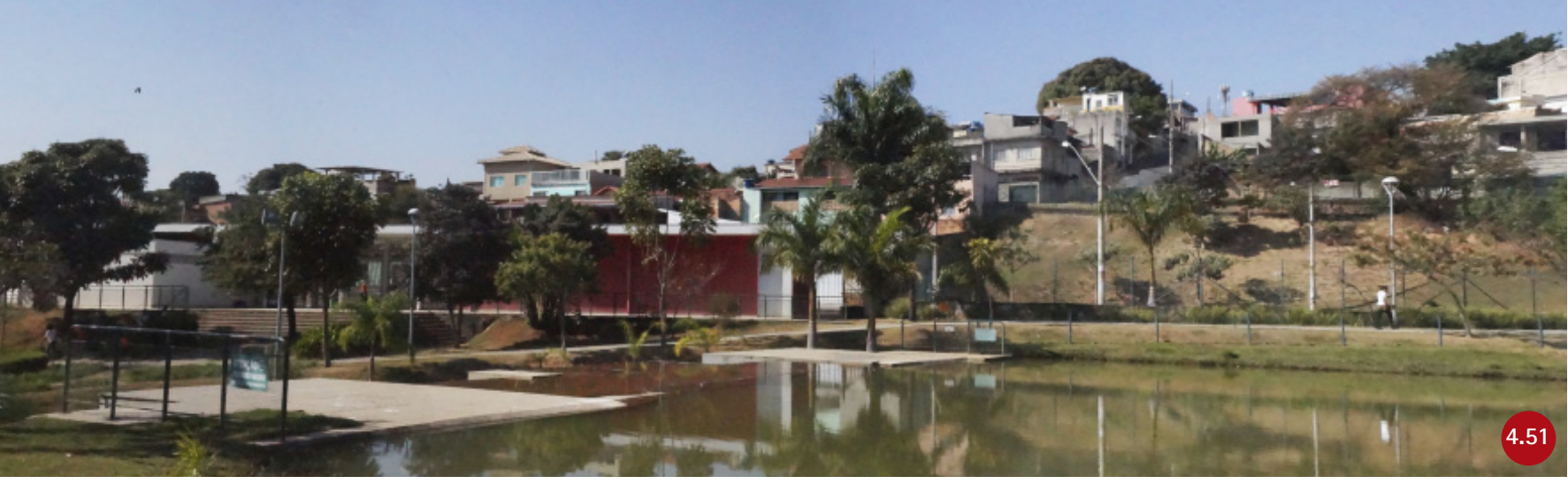

Localizado na Região Norte, sua criação ocorreu em 2008 através do Programa de Recuperação Ambiental de Belo Horizonte (Drenurbs). A participação da população local foi determinante para a sua construção, que se deu a partir da criação de uma comissão representada por moradores, alunos e professores da Escola Municipal Hélio Pellegrino e de parceria com o Projeto Manuelzão da Faculdade de Medicina da Universidade Federal de Minas Gerais (UFMG). Para esta obra, o poder público realizou 160 desapropriações de terrenos e remoção de famílias.

0 desenho do edifício, que reúne portão, portaria e salão para reuniões de moradores, mostra linhas arquitetônicas contemporâneas e marcantes, mas, segundo os projetistas, a meta são soluções menos visuais, mais duráveis e tecnicamente corretas. Chama atenção a qualidade do conjunto em uma área da cidade de renda média baixa.

Junto à entrada, o lago é uma atração que se presta, ao mesmo tempo, à contemplação bucólica e à infraestrutura. Há placas de piso que permitem chegar perto da água e cascatas, que servem para conter a vazante. Um caminho circunda este lago e estrutura o parque.

Para que não constituísse barreira para os pedestres do bairro, uma rua o atravessa transversalmente, dividindo-o em duas partes unidas por um caminho que passa por um túnel sob a rua, conectando o acesso à pista de skate, às quadras e aos equipamentos de ginástica. Palmeiras, árvores e arbustos foram dispostos ao longo do caminho, compondo maciços com intenção paisagística e não simplesmente de plantio de reflorestamento.

Os frequentadores estão sempre presentes, mas não há grande fluxo, pois trata-se de um parque para contemplação, tomar sol e levar as crianças.

\section{Endereço}

Rua Rubens de Souza Pimentel, 750, Araão Reis

Data | 2008

\section{Autor}

BEtL Arquitetura, escritório de Eduardo Beggiato e Edwiges Leal Rosa.

Levantamento | 2017

Área | $59.360 \mathrm{~m}^{2}$

Atividades

contemplação

esportes

recreação infantil

\section{Elementos}

caminhos

espelhos d'água/ lago 4.52

portaria

administração

recreação infantil

pista de skate 4.53

equipamentos de ginástica

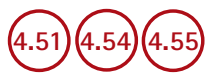



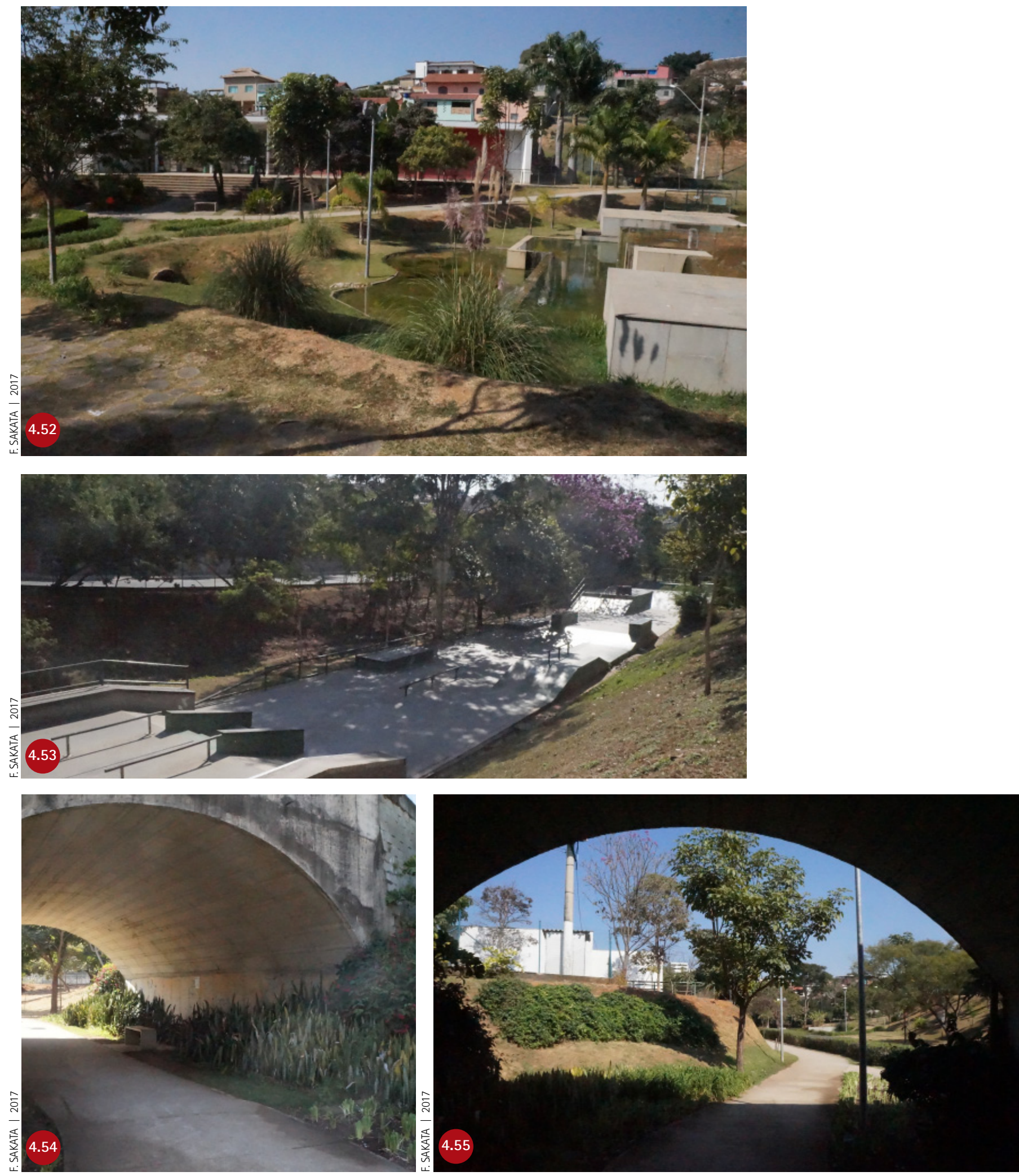


\section{SÃO PAULO \\ Parque Cordeiro Martin Luther King}

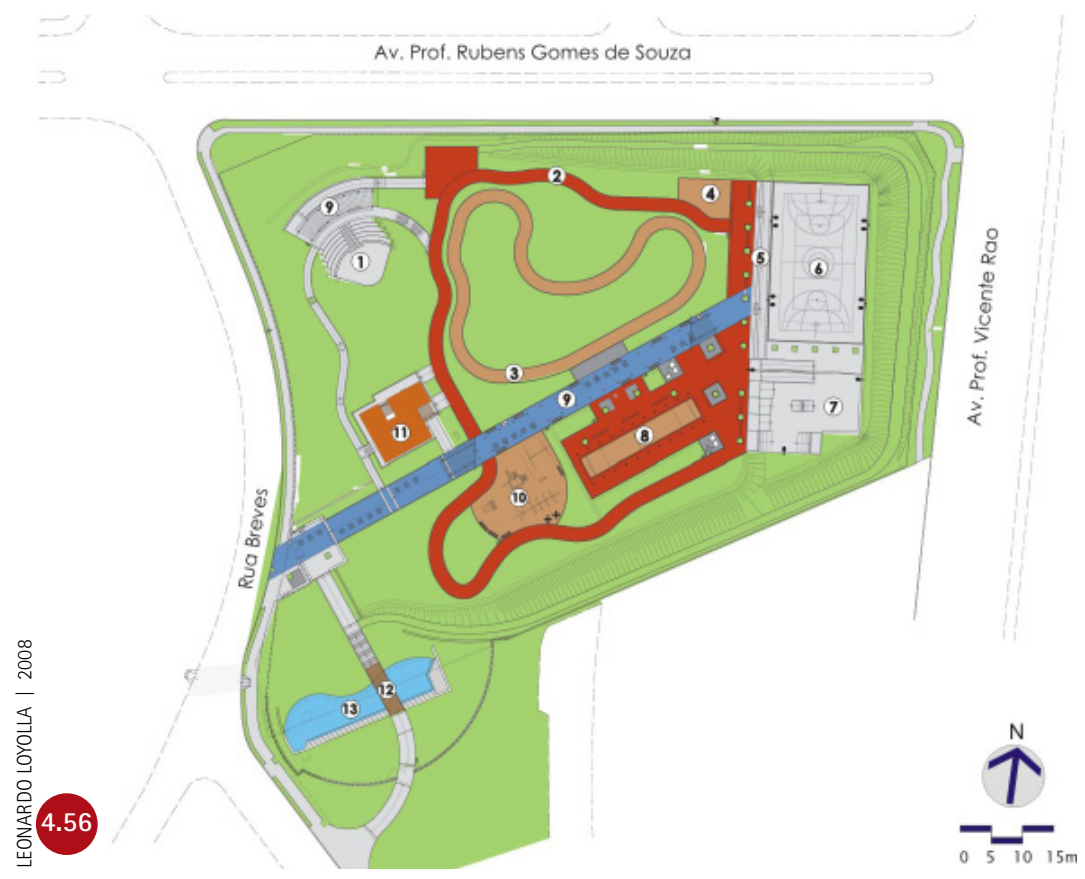

0 terreno do parque é resultante do parcelamento do bairro em 1957. Em 2000 os moradores moveram uma ação contra a prefeitura para cancelar a doação do terreno e pediram a implantação do parque. 0 entorno é predominantemente horizontal e ocupado por população de alta renda. A atuação dos moradores mostrou-se decisiva em todas as fases da obra. ${ }^{12}$

Uma rua divide a área. 0 Setor Leste, ao lado da Av. Prof. Vicente Rao, tem maior movimento de pedestres e veículos no entorno e, por isso, foi escolhido para ser implantado primeiro e concentrar os equipamentos de lazer. Para o Setor Oeste, a diretriz do projeto foi a criação de caminhos e áreas de estar para o lazer contemplativo ao longo dos bosques existentes.

0 desnivel do terreno foi ajustado com patamares e aterros, de modo a criar um grande talude separando o terreno da Av. Prof. Vicente Rao. Isto foi muito importante para resguardar a porção interna do parque do ruído de veículos. 0 parque é pequeno, mas possui muitos equipamentos, cada um configurando um ambiente: a pérgola da entrada; o teatro de arena; as pistas para bicicletinhas infantis - equipamento de muito sucesso e, ainda assim, incomum. 0 lago, um tanque retangular de cerca de $150 \mathrm{~m}^{2}$, apresenta ponte e arquibancada e proporciona a possibilidade de chegar perto da água, o que também não é frequente nos parques de vizinhança paulistanos.

Aos domingos, chega a receber cerca de 4 mil visitantes, número elevado diante do seu tamanho.

\section{Endereço}

Rua Breves, 968, Chácara Monte Alegre (Zona Sul).

Data | 2007

\section{Autor}

Raul Pereira e Núcleo da Paisagem

Foi feito estudo inicial por Salata e Orsini

Área

$35.000 \mathrm{~m}^{2}$, sendo $14.000 \mathrm{~m}^{2}$ no setor com equipamentos

\section{Atividades}

contemplação

esportes

recreação infantil

Elementos

(1) anfiteatro

(2) pista de cooper

(3) bicicross 4.57)

(4) equipamentos de ginástica

(5) arquibancada (4.59)

(6) quadras poliesportivas 4.58

(7) pista de skate

(8) cancha de bocha

(9) pergolado

(10) playground

(11) administração

(12) ponte

(13) lago 4.60

espaço pet

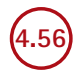

12 COELHO, Leonardo Loyolla. Compensação ambiental: uma alternativa para viabilização de espaços livres públicos para lazer e convívio na cidade de São Paulo. Dissertação (Mestrado). São Paulo: FAUUSP, 2008. 

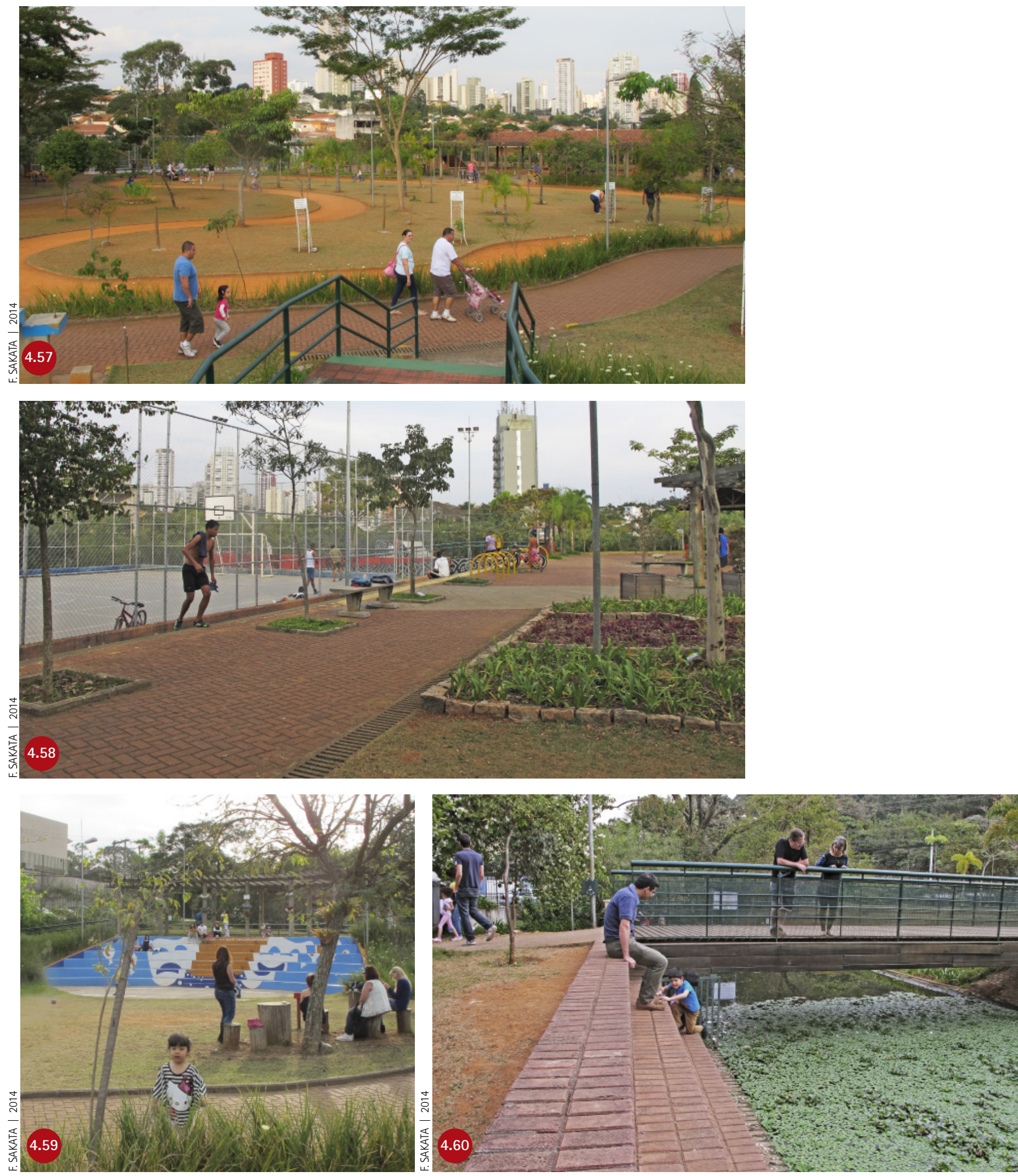


\section{SÃO PAULO}

Parque Paraisópolis

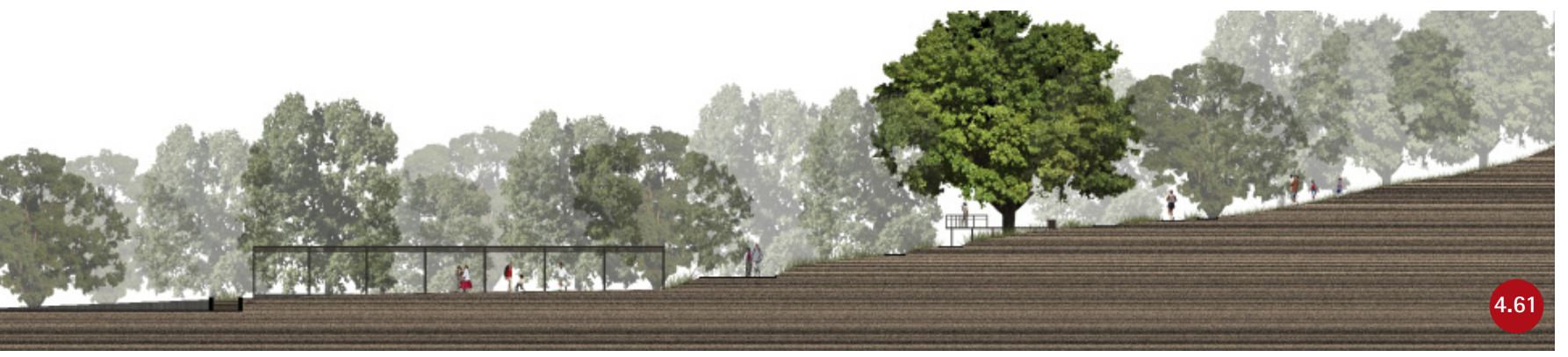

Este projeto, não executado, foi feito para área na Zona Sul de São Paulo, entre a favela de Paraisópolis e um casario de alto padrão - uma "faixa tampão" entre classes sociais distintas. Há nela nascente, curso d'água e a maior parte apresenta declividade superior a 30\%. Existem partes abertas e partes com vegetação de grande porte.

0 projeto teve como ponto de partida a conservação dos recursos naturais - água, taludes e vegetação nativa - e, ao mesmo tempo, a qualificação do lugar para receber a população. Como todos os projetos de parques, este também precisou da aprovação da Divisão de Proteção e Avaliação Ambiental (DPAA) da SVMA, que foi bastante restritiva nas intervenções nas APPs tanto na APP da nascente quanto na do córrego. Foram vetados platôs, cortes e aterros, caminhos e playground, para não alterar a estabilidade e a taxa de permeabilidade do terreno.

Assim, as edificações, caminhos, espaços de estar, mirantes e brinquedos foram distribuídos na faixa de terreno além dos 50 metros da borda da nascente. 0 círculo com raio de 50 metros que delimita a área de proteção da nascente acabou condicionando o desenho do parque. Tanto a rampa de entrada quanto o espaço de estar sob o pergolado foram desenhados curvos, a partir do limite da APP da nascente. A pérgola curva emoldura a vista para a área com foco na nascente. Três braços dessa pérgola, em balanço, reforçam essa direção.

A escadaria faz a continuação dessa linha curva. Os patamares da escada são espaços de descanso e contemplação da paisagem. Um espaço de estar com bancos curvos foi planejado em torno da figueira existente. 0 trajeto acessivel ao cadeirante recebeu tratamento mais sofisticado.

Tanto os técnicos do Depave quanto os da NKF enfatizaram a importância da possibilidade de entrar pelo portão principal na rua de baixo e sair pela rua de cima (ou vice-versa) para a consolidação do parque como espaço público, aberto a todos. Sua utilização como passagem de pedestres é positiva; o fluxo de pessoas amplia o uso do parque. Contudo, essa ligação hoje está impedida, e é possivel que tenha havido oposição à proposta pelos moradores.

\section{Endereço}

Rua Silveira Sampaio, Fazenda

Morumbi

Data | 2008

Projeto paisagístico

NKF Arquitetos Associados - Fábio

Namiki, Francine Sakata e Carlos Vaz

Coordenação

Depave/ Cláudia Montanari

Área | $36.904 \mathrm{~m}^{2}$

Atividades

contemplação

recreação infantil

Elementos

caminhos

playground

equipamentos de ginástica

administração

pérgola 4.63

decks 4.64

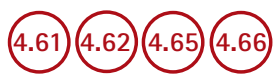



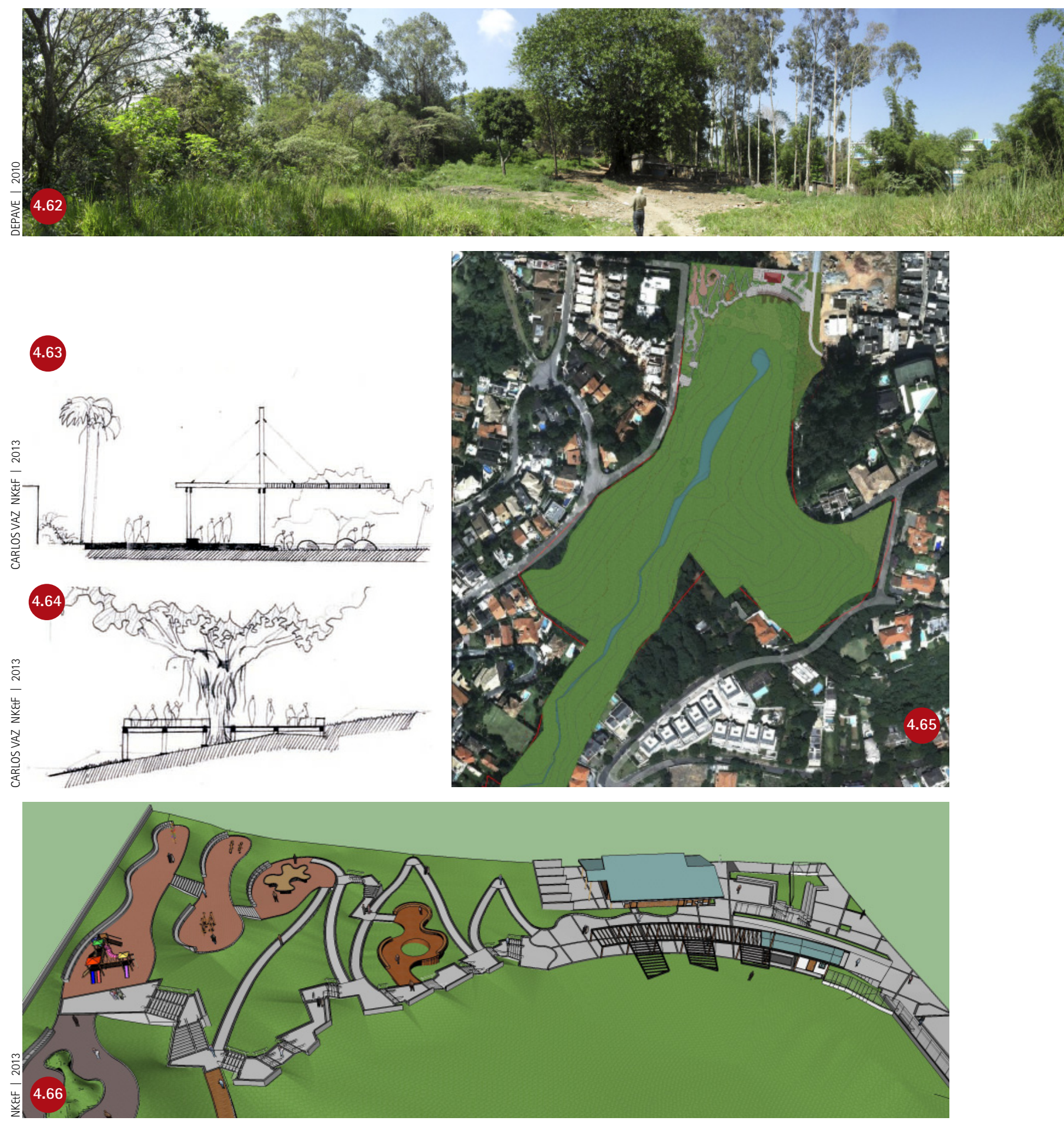
CAPÍTULO 4. DESENHOS

SÃO PAULO

\section{Parques Sabesp Butantã}

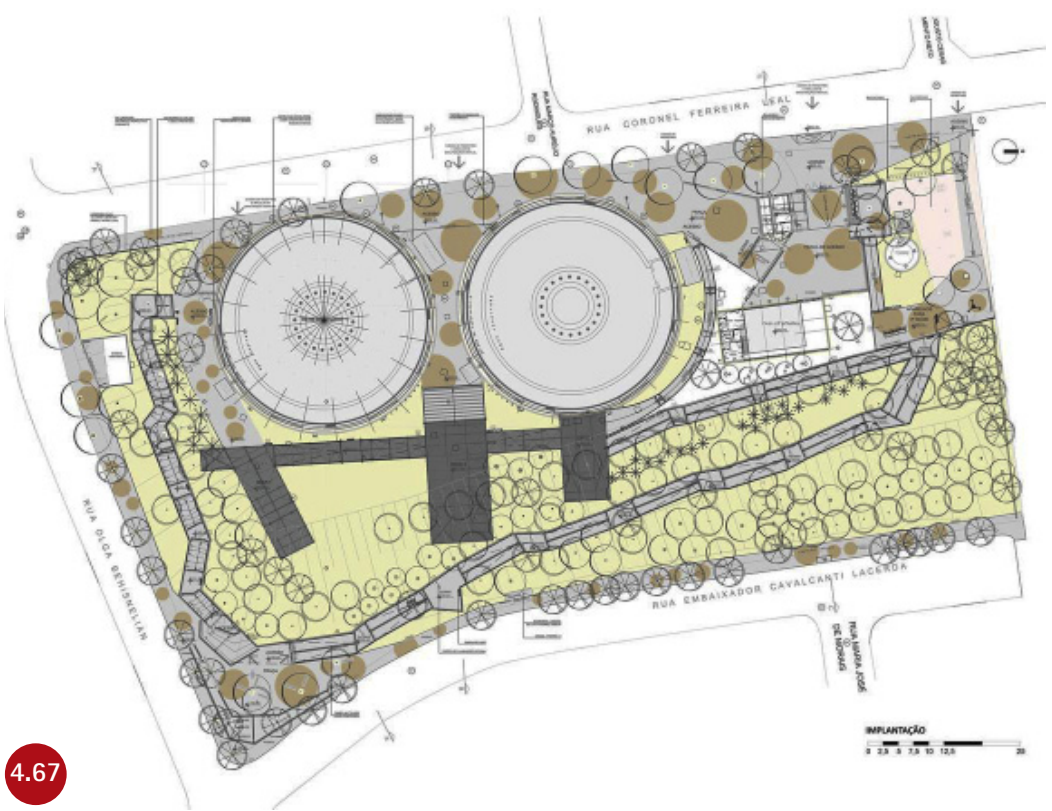

A Companhia de Saneamento Básico do Estado de São Paulo (Sabesp) teve a iniciativa de transformar três áreas, até então limitadas a cumprir a função de reservatórios de água, em espaços de uso público, dedicados à conscientização ambiental, convivência social, lazer, prática de esportes e cultura.

0 terreno do Butantã tinha aclive acentuado, duas caixas d'água baixas e cilíndricas e outra muito alta e moderna, em concreto. As caixas altas receberam iluminação noturna azul, destacando-se ainda mais como marcos na paisagem urbana. As calçadas externas foram tratadas e há espaços de estar nas entradas superior e inferior.

Os projetos dos três parques da Sabesp foram encomendados à Levisky Arquitetos, que criaram intervenções muito contemporâneas, vistosas e, ao mesmo tempo, muito leves. É o caso das passarelas e decks com piso de tela metálica vermelha que proporcionaram obras rápidas e limpas.

Os projetos valorizaram o fluxo de pedestres, a fruição, a integração com o entorno e a acessibilidade, sendo muito utilizados pelos moradores do entorno para exercícios e passeios com as crianças.

\section{Endereço:}

Rua Coronel Ferreira Leal, 309-347

Butantã

Data | 2014

\section{Autor |}

Levisky Arquitetos Estratégia Urbana, responsável: Adriana Levisky. Equipe e colaboradores: Renata Gomes, Raquel Abdian, Aline Victor, Cristiano Aprigliano, Vitória Albuquerque, Lilian Braga, Ana Carolina Angotti, Tatiana Antonelli, Rosangela do Nascimento, Karina Machado, Aline Lima, Lígia Gonçalves e Luciene Sandoval.

Projeto paisagístico (plantio): Fany Galender

\section{Área |}

$10.400 \mathrm{~m}^{2}$

\section{Atividades}

contemplação

esportes

recreação infantil

\section{Elementos}

rede de caminhos

rampas

escadas

decks-mirantes

reservatórios de água

playground

sala multiuso

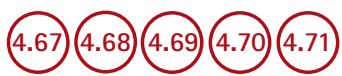



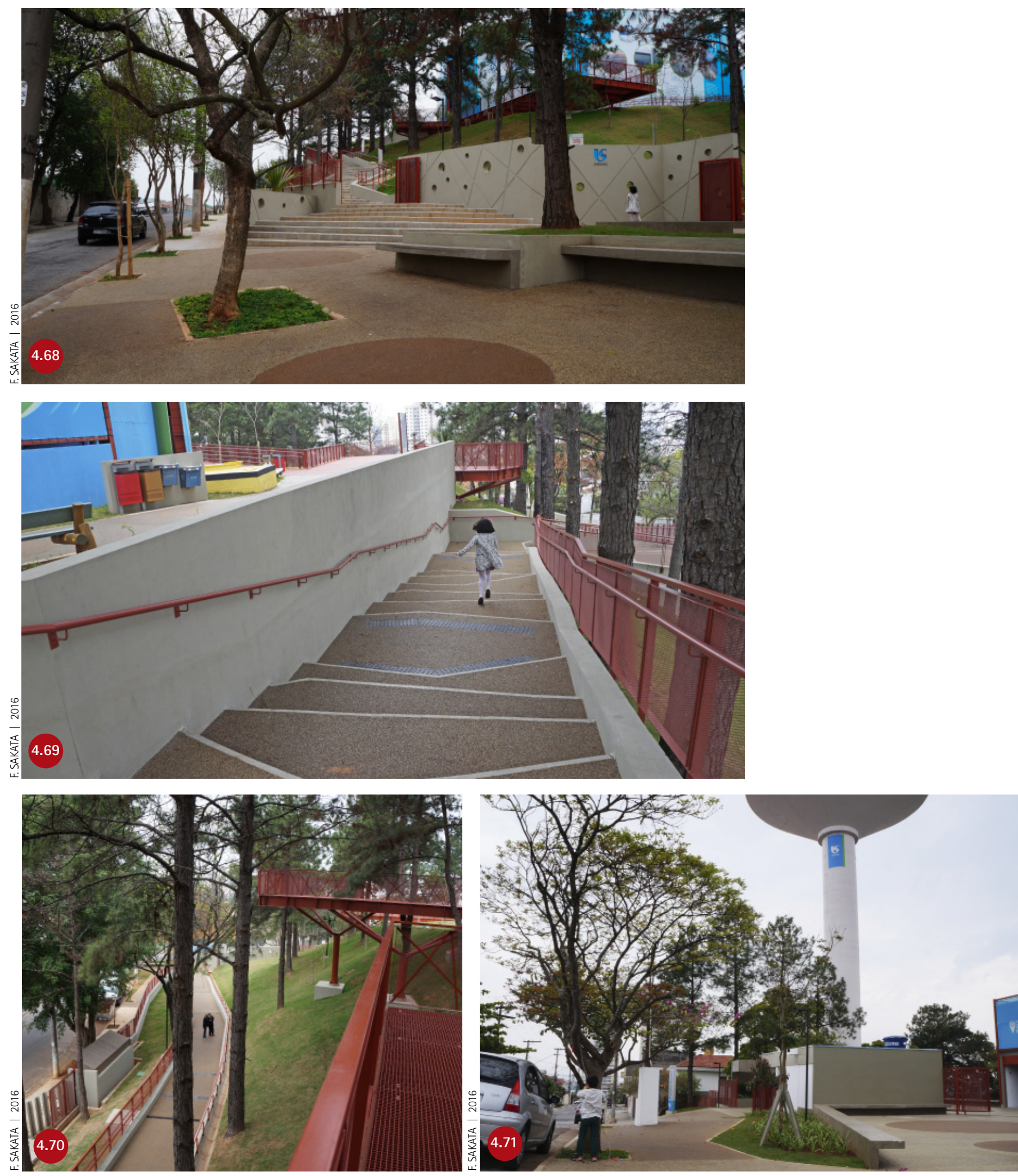
CARAPICUÍBA

\section{Parque Gabriel Chucre}

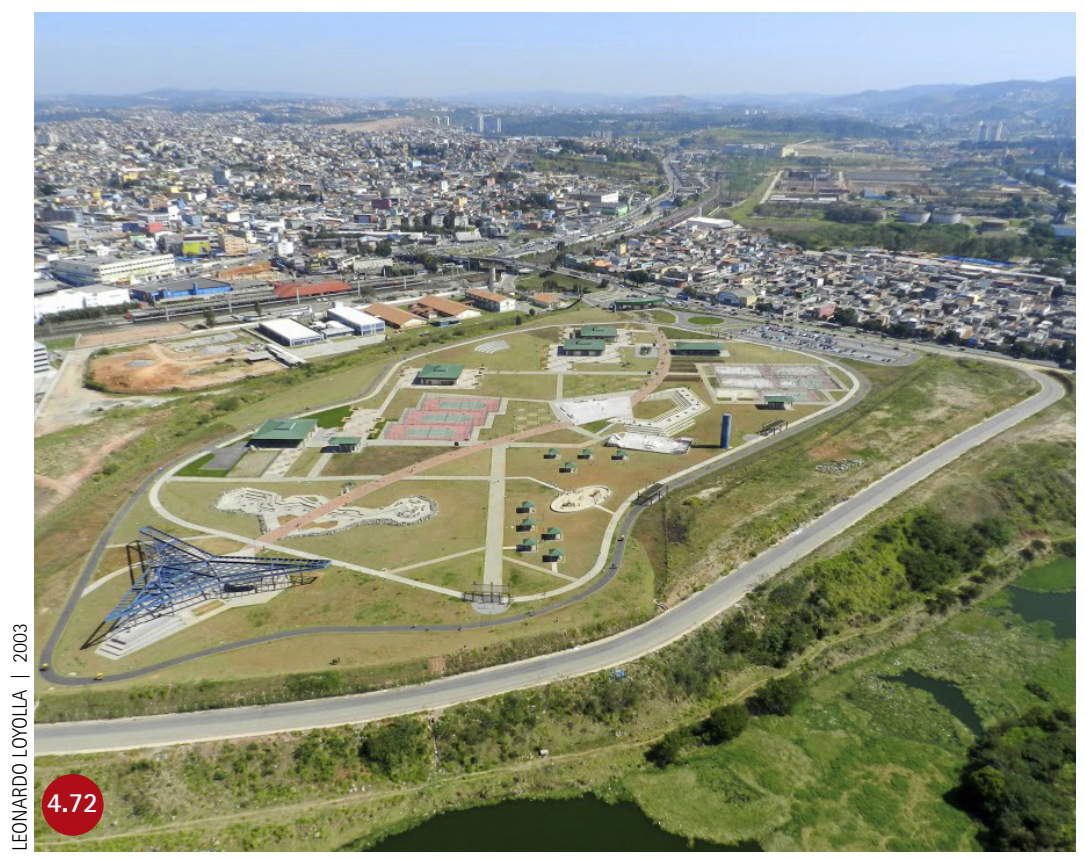

Resultado de um TAC feito pelo Ministério Público, que envolveu o Departamento de Águas e Energia Elétrica (DAEE), a Companhia de Tecnologia de Saneamento Ambiental (Cetesb), a Secretaria Estadual do Meio Ambiente, as prefeituras de Barueri e Carapicuiba e proprietários de parte do terreno. Provém do despejo de 200 mil toneladas de lama e lixo retiradas no desassoreamento do Rio Tietê e de material das obras da Linha Amarela do Metrô que foi jogado na cava de mineração que originou a Lagoa de Carapicuiba.

Os equipamentos se distribuem ao longo de um caminho central que conduz a um pergolado de formato triangular, como a proa de um navio; a pista de bicicletas e corridas circunda a área. Além dos equipamentos esportivos e edificações para atividades culturais, há um elemento escultórico, o Circuito do Tietê, que funciona como brinquedo de água, fazendo referências poéticas ao Rio Tietê. É um projeto contemporâneo, estruturado pela geometria dos pisos e caminhos e pela arquitetura das construções. 0 parque contrasta com o entorno, muito construído, homogêneo, sem marcos arquitetônicos e arborização.

Os técnicos do governo do Estado que o conservam creem que, dado o porte do parque, há potencial para atrair mais público. Nas proximidades, há estação de trem, terminal de ônibus, escolas públicas e uma unidade do Serviço Social da Indústria (Sesi).

\section{Endereço}

Av. Consolação, 505, Vila Gustavo

Correia

Data | 2012

\section{Autor}

Barbieri+Gorski - arquitetos Marcia

Cecilia Barbieri Gorski, Michel Gorski

e Patrícia Akinaga.

Área | $135.000 \mathrm{~m}^{2}$

\section{Atividades}

contemplação

esportes

recreação infantil

centro de educação ambiental

centro cultural e eventos

Unidade básica de saúde (UBS)

\section{Elementos \\ caminhos}

pérgola metálica ("proa") 4.74

pérgolas 4.77

fonte 4.76

quadras poliesportivas

circuito de skate

pista de cooper

ciclovia

três estações de ginástica

quiosques

playground

palco com arquibancada

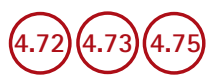



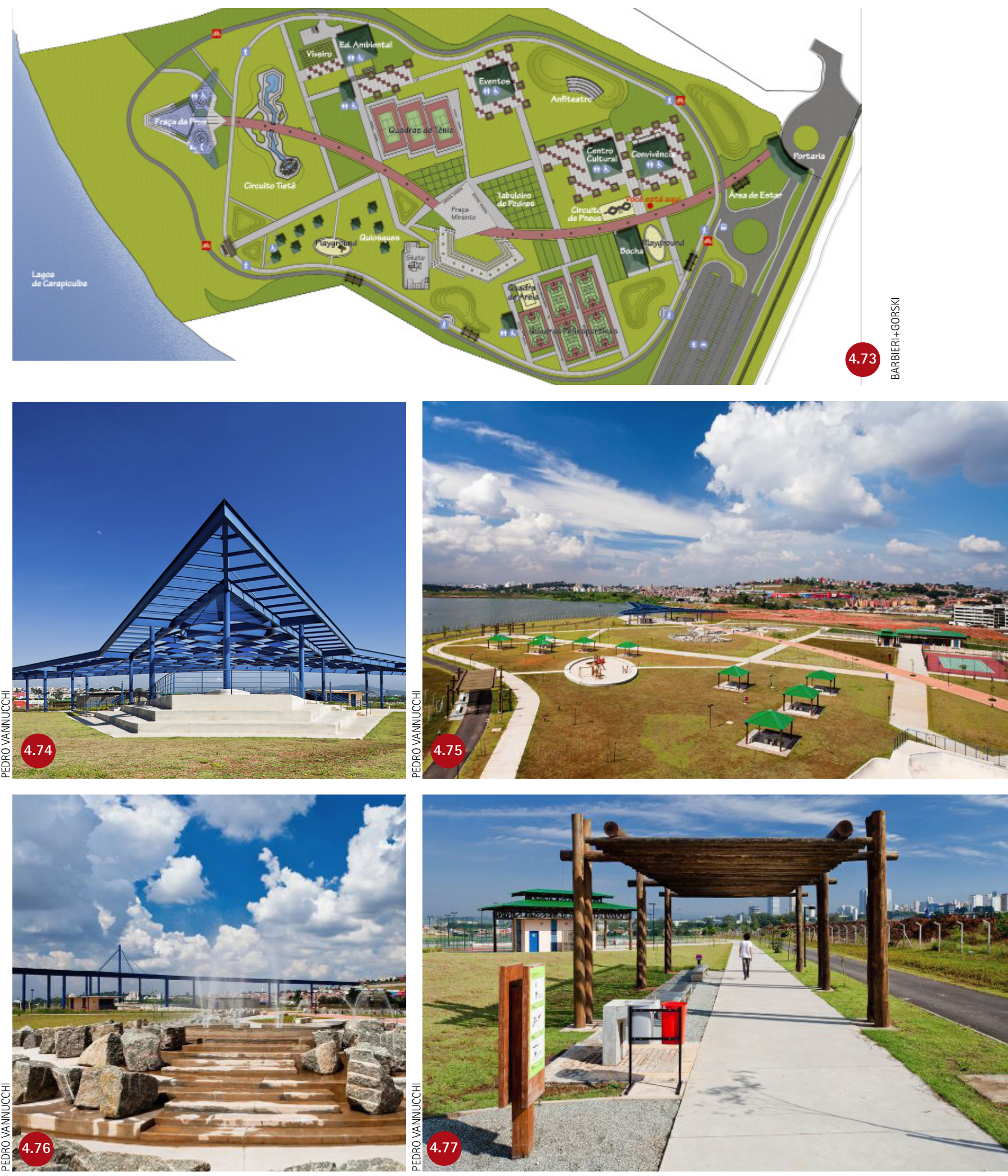
BRASÍLIA

\section{Bosque Urbano Bosque do Sudoeste}

Este é um parque cercado, voltado para uma gleba desocupada, contando com um único acesso - o que obriga os usuários do bairro a contorná-lo para entrar. A posição do acesso e o fechamento impedem que se relacione com o entorno, constitui uma barreira em contraste com a cidade, onde as superquadras são permeáveis. A pista exibe um bonito formato curvo ao longo do qual se distribuem os equipamentos de lazer.

É apropriado para usos esportivos e de lazer. São especialmente aproveitadas as sombra das poucas árvores adultas.
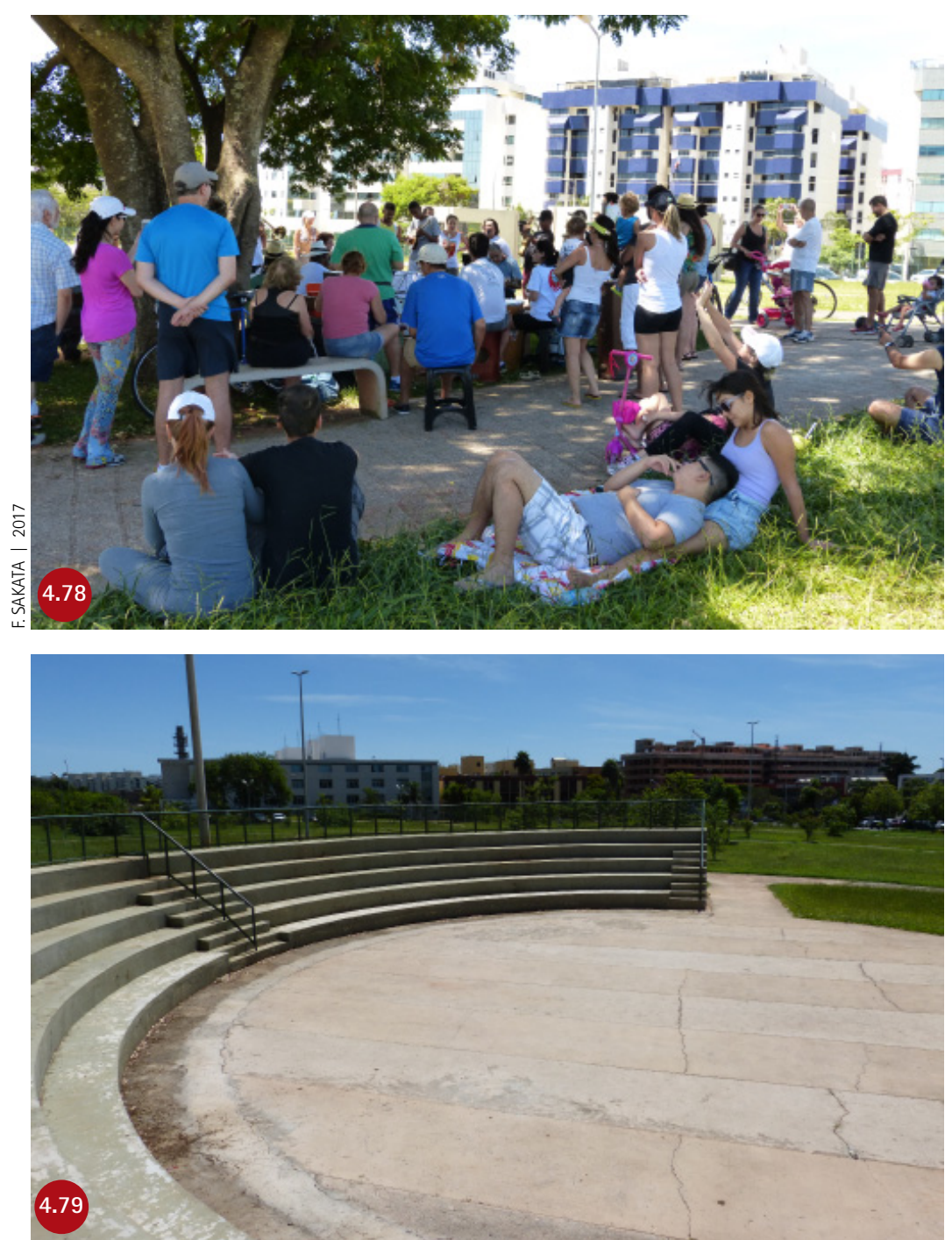

\section{Endereço}

St. Sudoeste - Cruzeiro / Sudoeste /

Octogonal

Data | 2013

Autor

os dados de autoria não foram encontrados

Área | $68.000 \mathrm{~m}^{2}$

\section{Atividades}

esportes

contemplação

centro de educação ambiental

Elementos

anfiteatro 4.79

caminhos

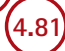

quadras poliesportivas

playground

aparelhos de ginástica 4.83

ciclovia

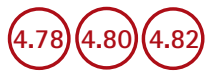



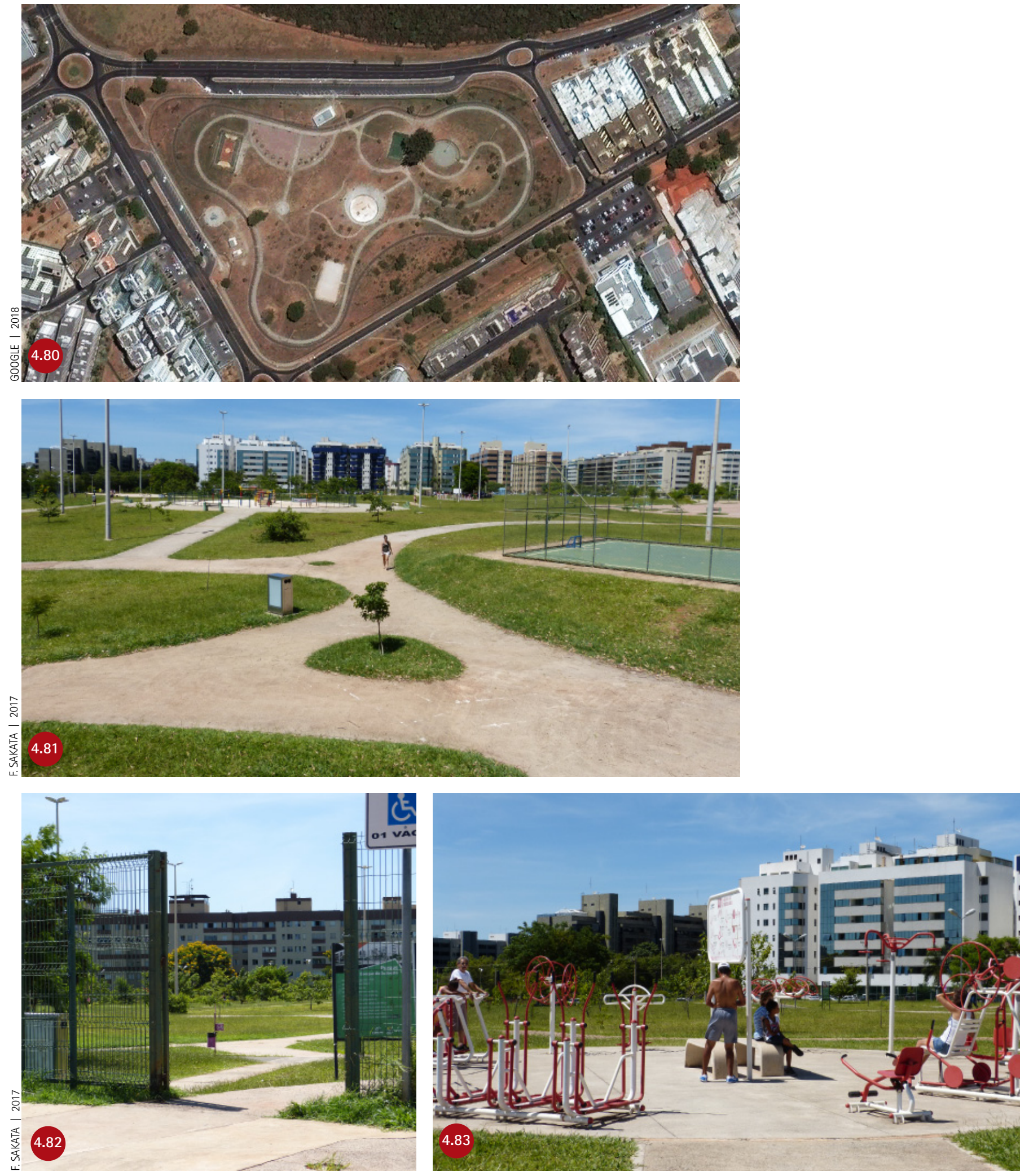


\section{Portal da Amazônia}

Trata-se de uma área de 1.200 metros de extensão de aterro, ao longo da orla do Rio Guamá e vizinha do Mangal das Garças. Uma faixa linear, ao longo de vias de tráfego, contendo faixa marginal ao rio com largura de 30 metros, canteiro central e calçada oposta. 0 projeto paisagístico foi encomendado pelo Secretário de Cultura Paulo Chaves a Eduardo Barra, que deveria buscar a valorização do sítio através do plantio de vegetação significativa e ordenada e da criação de ambientes esportivos e contemplativos, formando um conjunto semelhante a um "calçadão" ou pequeno parque linear. A obra se enquadra no Programa Ver-o-Rio, que chamou atenção da população para rios que costumam ser tratados como meras vias de transporte, dando origem à degeneração de suas margens e do próprio corpo hídrico.

0 paisagista idealizou um calçadão para instigar o visitante a percorrê-lo, mas que não pudesse ser percebido com uma única vista. Propôs, assim, um espaço contínuo, mas que se transforma ao longo da caminhada: ora mais aberto e pavimentado, ora mais vegetado e intimista, capaz de atender a atividades esportivas em grupos e conversas de casais. Foram empregados mosaicos de pedra portuguesa em branco e preto, pisos em concreto moldado in loco, decks em pranchões de madeira e gramados.

0 desenho faz referência ao perfil das margens ribeirinhas, com seus avanços e reentrâncias resultantes dos sucessivos aterros e trapiches, marcados por angulosidades e pela ausência de paralelismo. Pergolados em madeira, cobertos com placas de policarbonato sob massas de plantas trepadeiras, foram distribuídos em alguns pontos para oferecer proteção às repentinas pancadas de chuva características da região. Os desenhos de piso foram inspirados em traçados geométricos marajoaras. Foram usadas espécies nativas e palmeiras amazônicas.

0 portal é um elemento vertical que serve como "abertura" da obra e recorta um trecho da paisagem com o Guamá. Foi projetado em aço inox, com "vazios" entre os tubos, também como forma de prevenir pichações. A iluminação especial embutida no piso faz com que pareça aceso à noite.

A apropriação é intensa para o passeio e o esporte, festejos populares e shows. Porém, deixaram de ser construídos o anfiteatro, o restaurante e o tratamento do entorno. A qualidade do acabamento ficou distante do realizado na Estação das Docas. 0 autor relata que o sistema estrutural adotado para os decks obrigou sua elevação das quadras, o que gerou muretas que funcionam como barreira visual para quem passa de automóvel.
BELÉM

\section{Endereço}

Portal da Amazônia

Data

2011/2012

\section{Projeto de Paisagismo}

Eduardo Barra

Colaboração: Larissa de Aguiar, Anderson Ferreira e Cláudio Peixoto. Arquitetura: Paulo Chaves, Rosário Lima, Gustavo Leão.

Contratante

Construtora Andrade Gutierrez

Levantamento | 2014

Área | $1.200 \mathrm{~m}$ de extensão

Atividades

contemplação

centro de educação ambiental

Elementos

caminhos

decks 4.84

bancos

quiosques 4.85

portal 4.86 ciclovia 4.87 pista de corrida quadras poliesportivas quadra de areia praças de contemplação 

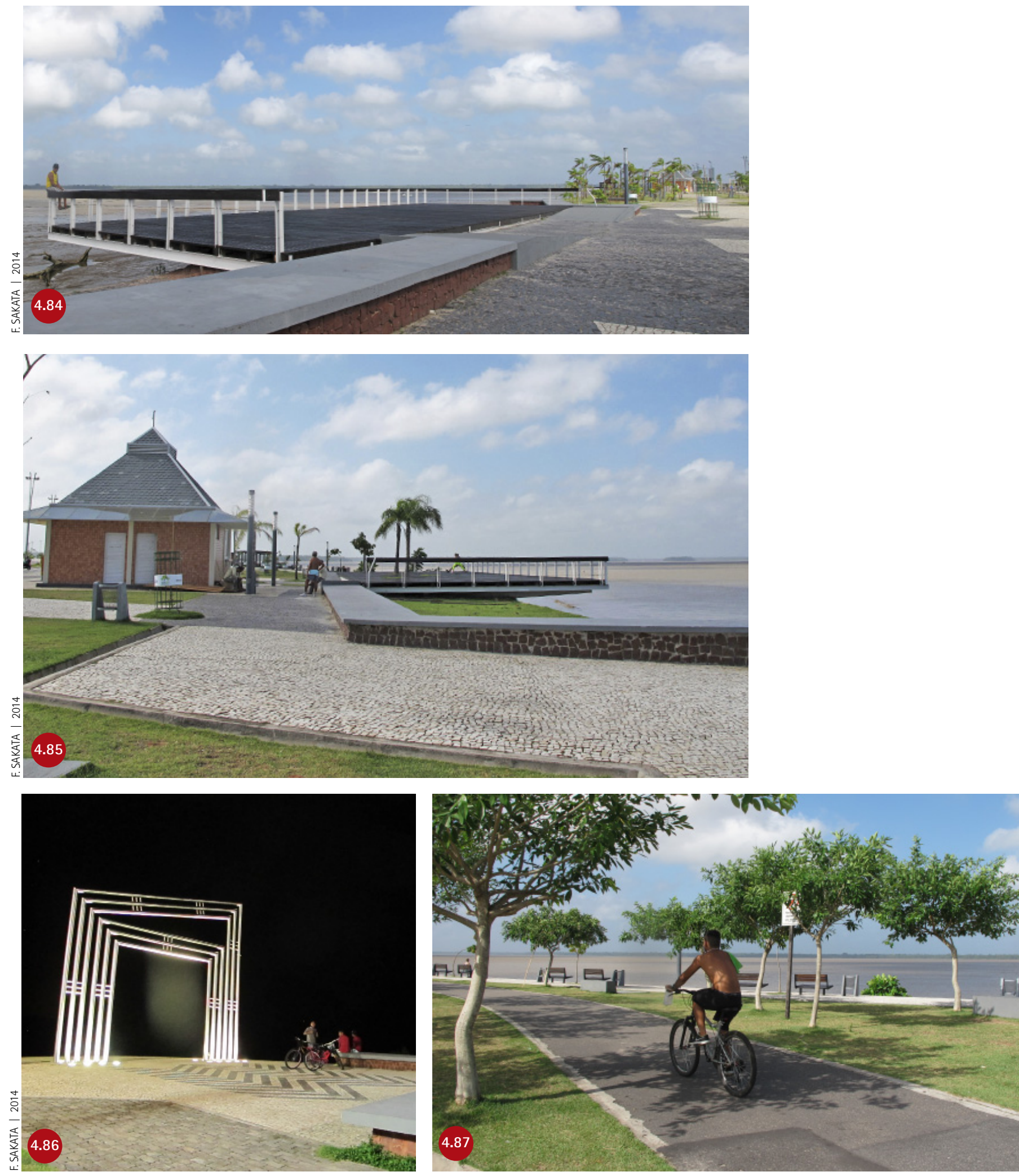


\section{Parque Madureira}

RIO DE JANEIRO

Parque linear que ocupa uma faixa de aproximadamente 80 metros de largura, conquistada a partir da faixa de proteção da linha de transmissão de energia, que corre paralelamente à linha férrea.

Implantado entre as ruas do bairro (de um lado) e a ferrovia e rede de transmissão elétrica (do outro), não tem travessias transversais por estar paralelo à grande barreira urbana constituída pelo "linhão" e pela ferrovia. Foi concebido pela prefeitura como provisão de lazer na periferia e divulgado como ação ambiental devido ao reuso da água, aos tetos verdes e à certificação da obra, que, ligada diretamente ao gabinete do prefeito, exigiu o reposicionamento das torres de transmissão e a remoção das moradias que ocupavam o terreno.

A pista de ciclistas e corredores é uma rua interna, reta e asfaltada, paralela à linha férrea. Isso livra as entradas e os demais caminhos do parque do "trânsito" mais rápido e pesado; crianças e caminhantes podem circular sem risco. Em outros parques, as pistas sinuosas de bicicleta cruzam a circulação de pedestres e, mesmo que o desenho pareça mais bonito, as condições de uso com o parque cheio são piores.

Trata-se de um parque contemporâneo, com desenho geométrico e sequência de espaços que remete mais aos térreos dos empreendimentos residenciais do que aos tradicionais parques românticos. Conforme é percorrido, os equipamentos surgem sequencialmente, como atrações ofertadas para o consumo. A obra foi executada com um esmero incomum na periferia.

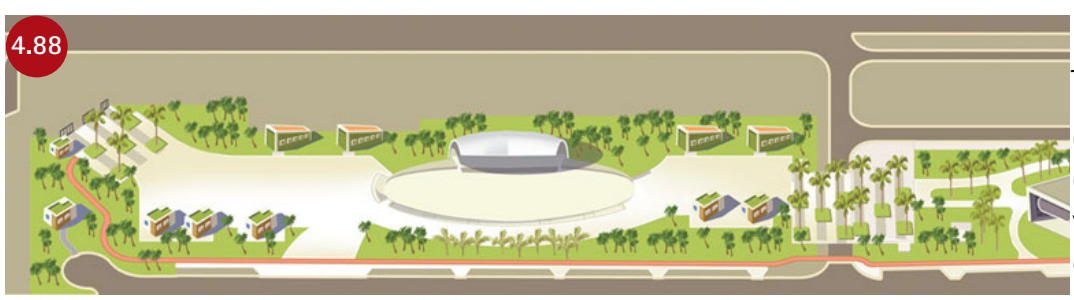

Possui muitas atrações, como pista de skate (2012) - eleita a melhor pista pública do país - com banks, bowl, ladeira para downhill e área para street em $3.850 \mathrm{~m}^{2}$. Destacam-se também cascatas d'água com degraus molhados para o banho das crianças e faixa de areia para as crianças brincarem de praia. A apropriação foi tão intensa que o parque foi ampliado até o bairro vizinho.
Endereço

Rua Soares Caldeira, 115

Bairro: Madureira

Data | 2012

Autor

Ruy Rezende Arquitetura (RRA)

Área

$1^{\text {a }}$ fase: $109.000 \mathrm{~m}^{2}$ e $1,3 \mathrm{~km}$

Em 2016, $255.000 \mathrm{~m}^{2}$ e 4,5km

Atividades

esportes

recreação infantil

eventos

contemplação

\section{Elementos}

ciclovia

estações de bicicleta

fontes

cascatas para banho 4.914 .92 tanque de areia

Skate Park

lanchonetes

muro de escalada, escola de jardinagem

playgrounds

quadras poliesportivas

campo de futebol society

vôlei de areia

ginástica

jardim das esculturas

espaço da terceira idade

jogo de bocha

mesas de jogos

tênis de mesa

jardim sensorial

Praça do Samba (palco) 4.90

Centro de Educação Ambiental

Arena carioca

Alameda rio+20

Nave do conhecimento

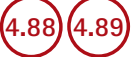



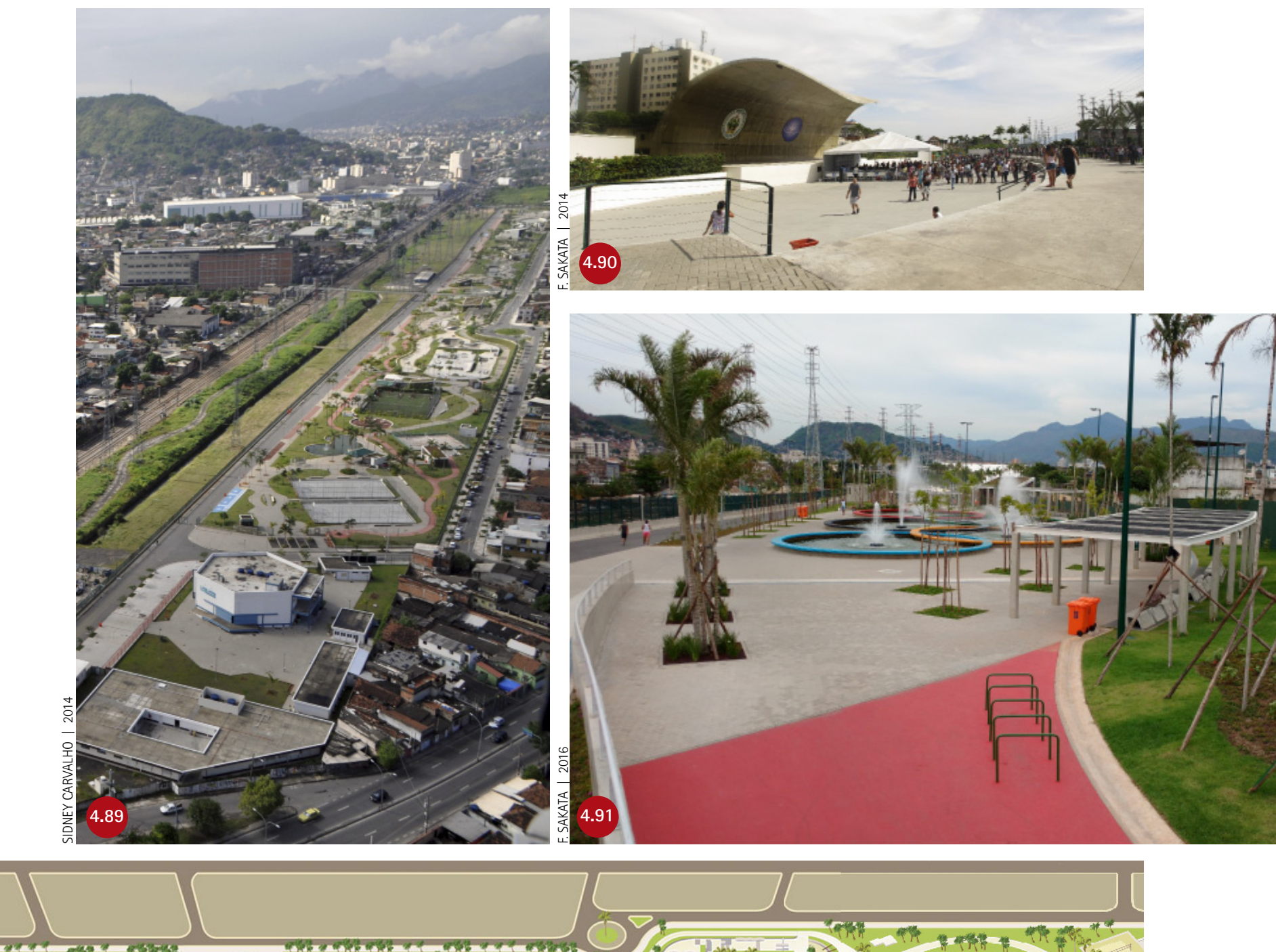

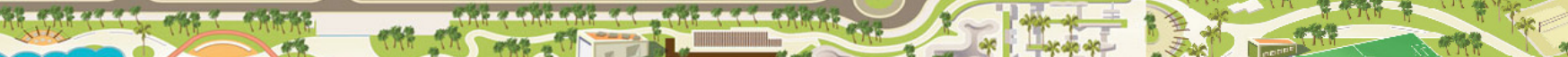

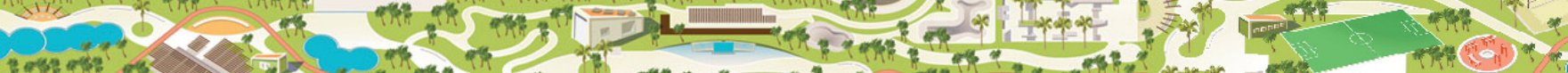
Befke

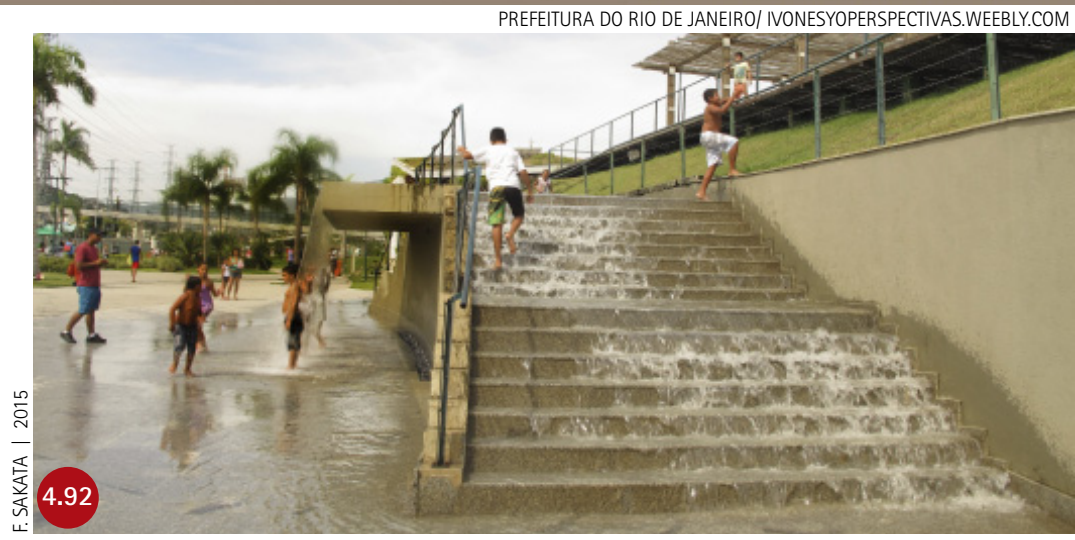




\section{Parque Linear do Sapé}

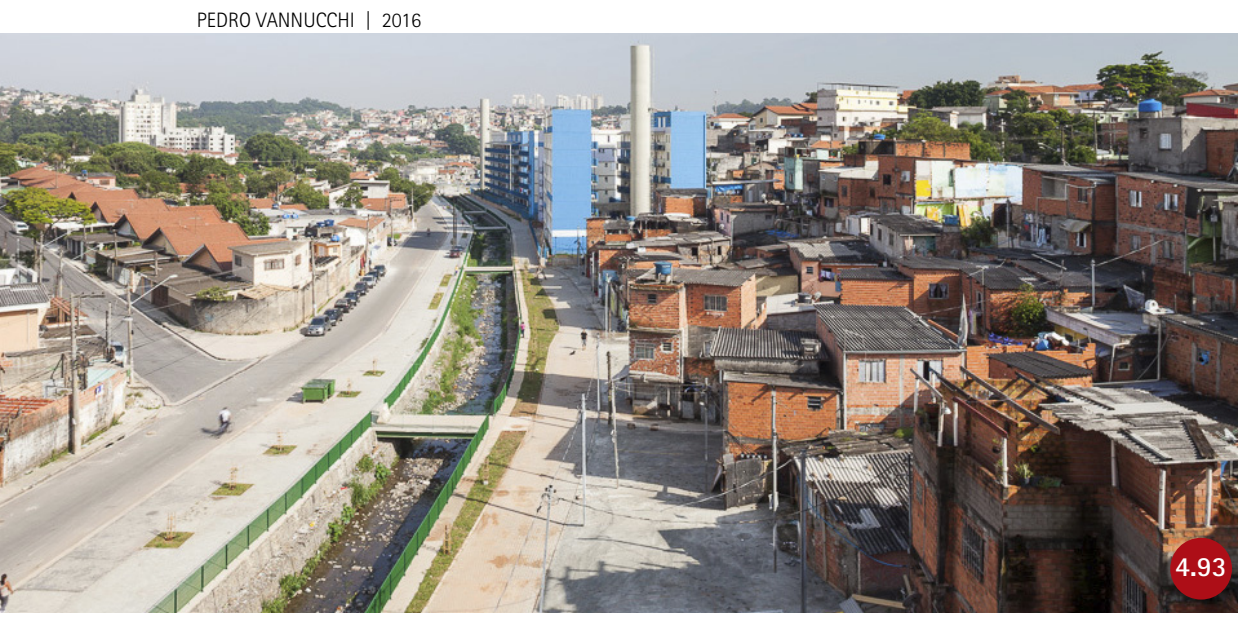

Vários trechos ao longo do Córrego do Sapé, entre a Rodovia Raposo Tavares e a Av. Escola Politécnica, encontravam-se ocupados por favela já consolidada, que foi parcialmente mantida. Em 2005, quando uma construtora gerou o TCA, o Sapé foi indicado para receber o recurso, que custeou o primeiro trecho do projeto e as contenções. A fase mais dispendiosa e complicada, a remoção da população, ficaria a cargo do poder público. Por volta de 2014, a Secretaria Municipal de Habitação seguiu com a reurbanização do Sapé e atendeu 2.500 familias, trabalhando em conjunto com a SVMA em projeto de desenho urbano, infraestrutura e habitação.

0 projeto do canal manteve o leito aberto com as laterais estruturadas em gabião. 0 rio foi tamponado por 200 metros e sobre ele estão duas quadras e a pista de skate. Em ambas margens, a área recebeu caminhos, praças de encontro, atividades de lazer e ciclovia. Foram construídas pontes para facilitar a transposição do córrego.

A grande solução urbanística deste projeto foi fazer as contenções necessárias com muretas de concreto de até 1,20 metro. As muretas, além de conter a terra, são elementos que articulam os patamares e dão unidade ao passeio sem o segregar visualmente. Acomodam jardins, escadas e rampas e, ao mesmo tempo, estabelecem o limite das edificações. Assim, o espaço público, com suas qualidades de mobilidade e lazer, chega até a borda das construções, dentro das vielas e das pequenas praças internas.

A população utiliza intensamente o parque. Mas a obra não foi realizada com zelo, encontrando-se pontas de ferro, buracos e poças pelos caminhos. Há mais lixo do que nas vizinhanças de rendas mais altas, inclusive no córrego, e o corte da grama não é regular, o que causa má impressão. Ao mesmo tempo, os edifícios construídos são transparentes, abertos para a cidade, e os espaços são intensamente apropriados.
SÃO PAULO

\section{Endereço}

Av. Waldemar Roberto, Av. Maria

Rita Balbino - Rio Pequeno, Butantã

Data | 2014

Arquitetura e coordenação

Solo Ambiente (1 $1^{\text {a fase }}$ )

Catherine Otondo e Marina Ginover, da Base Urbana, e Jorge Pessoa, da

Pessoa Arquitetos (2 ${ }^{\mathrm{a}}$ fase)

\section{Equipe}

Base Urbana: Livia Marquez, Matheus Tonelli, Patricia Mieko, Paula Saad, Julie Trickett, Thais Marcussi, Juliana Barsi, Tânia Helou, Tiago Testa, Florencia Testa, Luisa Fecchio, Marinho Velloso, Rebeca Grinspum, Cadu Marino, Daniel Guimarães

Paisagismo (2a. fase)

Base Urbana + Pessoa Arq e Oscar Bressane

\section{Área}

1a. fase (2005-2009): $26.240 \mathrm{~m}^{2}$ ao longo de $500 \mathrm{~m}$ de extensão

2a. fase (2014): extensão de 1,2km

\section{Atividades}

contemplação

esportes

recreação infantil

\section{Elementos}

caminhos

escadas

pontes

quadras esportivas (4.97) campo de futebol

pista de skate

bancos

playground

equipamentos de ginástica

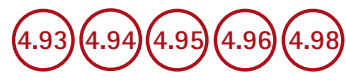



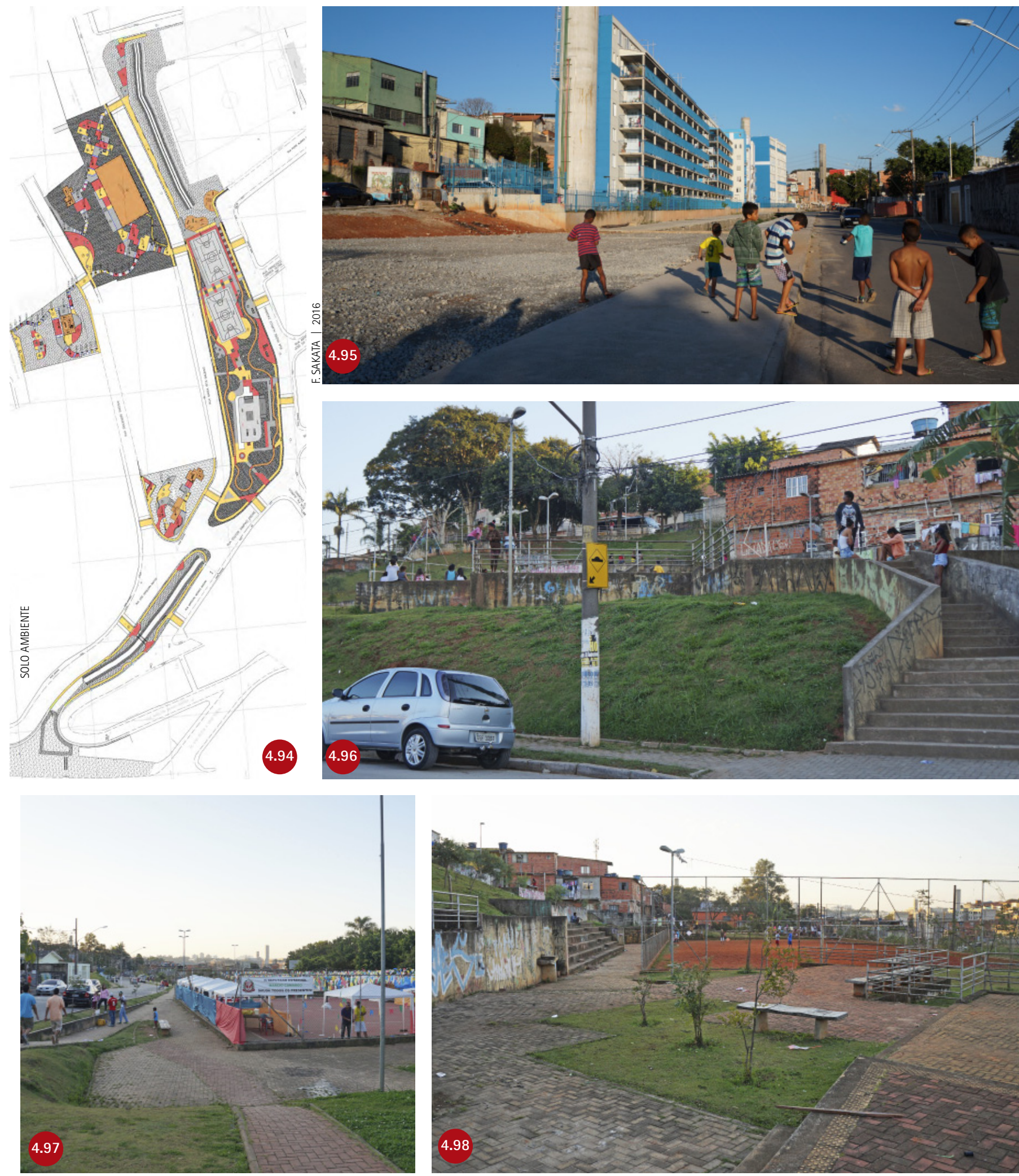
CAPITULO 4. DESENHOS

\section{Parque da Juventude}

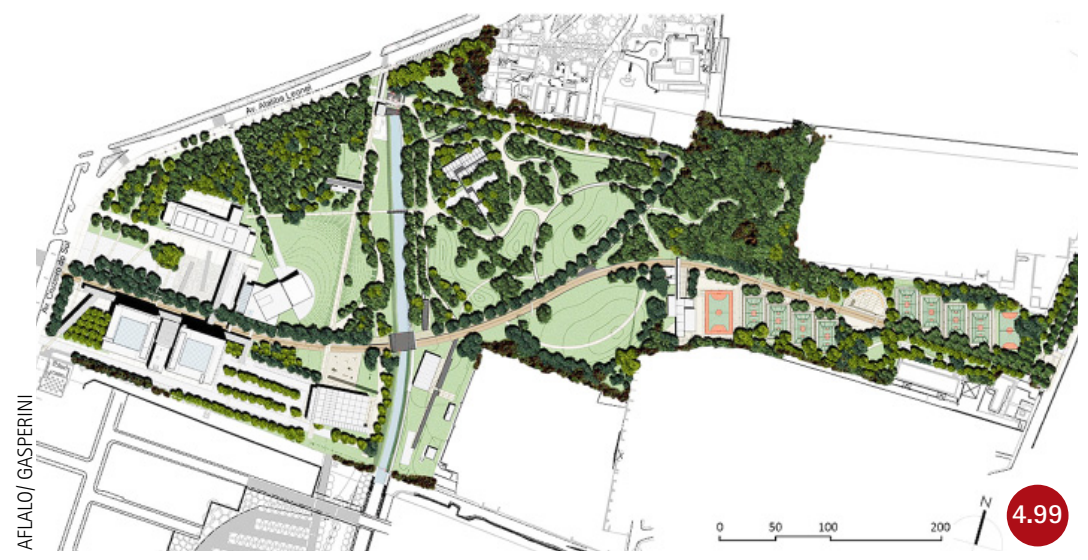

Complexo cultural, recreativo e esportivo, construído no local do antigo Complexo Prisional do Carandiru pelo governo do Estado para livrar o local do estigma do massacre ocorrido em 1992. Ao longo dos anos de sua implantação entre 2002 (demolição de parte do presídio) e 2007, o projeto foi alterado e a área destinada ao parque reduzida.

A implantação foi dividida em três fases: 1) Área Esportiva, com quadras poliesportivas, espaços para prática de skate e patins, pistas de cooper, entre outros equipamentos; 2) Área Central, com gramados ondulantes e bosques com trilhas, caminhos, passarelas, entre outros elementos que remetem à ideia tradicional de parque; 3) Área Institucional, onde ficam as Escolas Técnicas e a Biblioteca de São Paulo - sem gradis ou fechamentos. No local há um piso onde são montados palcos para eventos que atraem até 30 mil pessoas. Estes e a permissão da exploração comercial do estacionamento permitem ao Estado arrecadar pequena parcela de recursos necessária à manutenção. $\mathrm{A}$ área esportiva, que funcionava até às $22 \mathrm{~h}$, a partir de 2015, passou a fechar também às 18 h, também para reduzir custos.

0 conjunto tem fácil acesso pelo metrô e se localiza em ponto estratégico para as conexões da Zona Norte com o resto da cidade, valorizando toda a região além do parque. 0 projeto foi impecavelmente desenhado e construído. Os caminhos de saibro são ladeados por morrinhos gramados côncavos, levemente elevados, para o conforto tanto de quem senta nos gramados como de quem os percorre. 0 trecho dos gramados contemplativos foi desenhado com curvas; 0 das quadras e biblioteca, com planos retangulares e linhas retas. Calcula-se que receba 150 mil visitantes/mês mas tem sido percebido como inseguro o que tem restringido o uso durante a semana.

Trata-se do grande parque público do período entre 2000 e 2015, com projeto único, sem outros de igual qualidade e importância urbanística e simbólica no pais.
SÃO PAULO

Endereço:

Avenida Cruzeiro do Sul, 2630

Bairro: Santana

Data | 2007

Autor

Rosa Kliass

José Luiz Brenna (coautor)

Equipe:

Alessandra da Silva, Gláucia Pinheiro, Mauren Oliveira

Arquitetura e coordenação:

Aflalo/ Gasperini arquitetos

Área | $240.000 \mathrm{~m}^{2}$

\section{Atividades}

contemplação

esportes

recreação infantil

atividades culturais

\section{Elementos}

caminhos 4.105 4.106 quadras esportivas (4.103) 4.107) pista de skate mesas e bancos 4.101 playground 4.104 trilhas

sanitários

lanchonete

academia ao ar livre passarela sobre a muralha ruínas de edificação não concluída

$$
\text { do presídio } 4.102
$$

espaço para cão

(criado posteriormente)

biblioteca

escola técnica

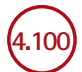



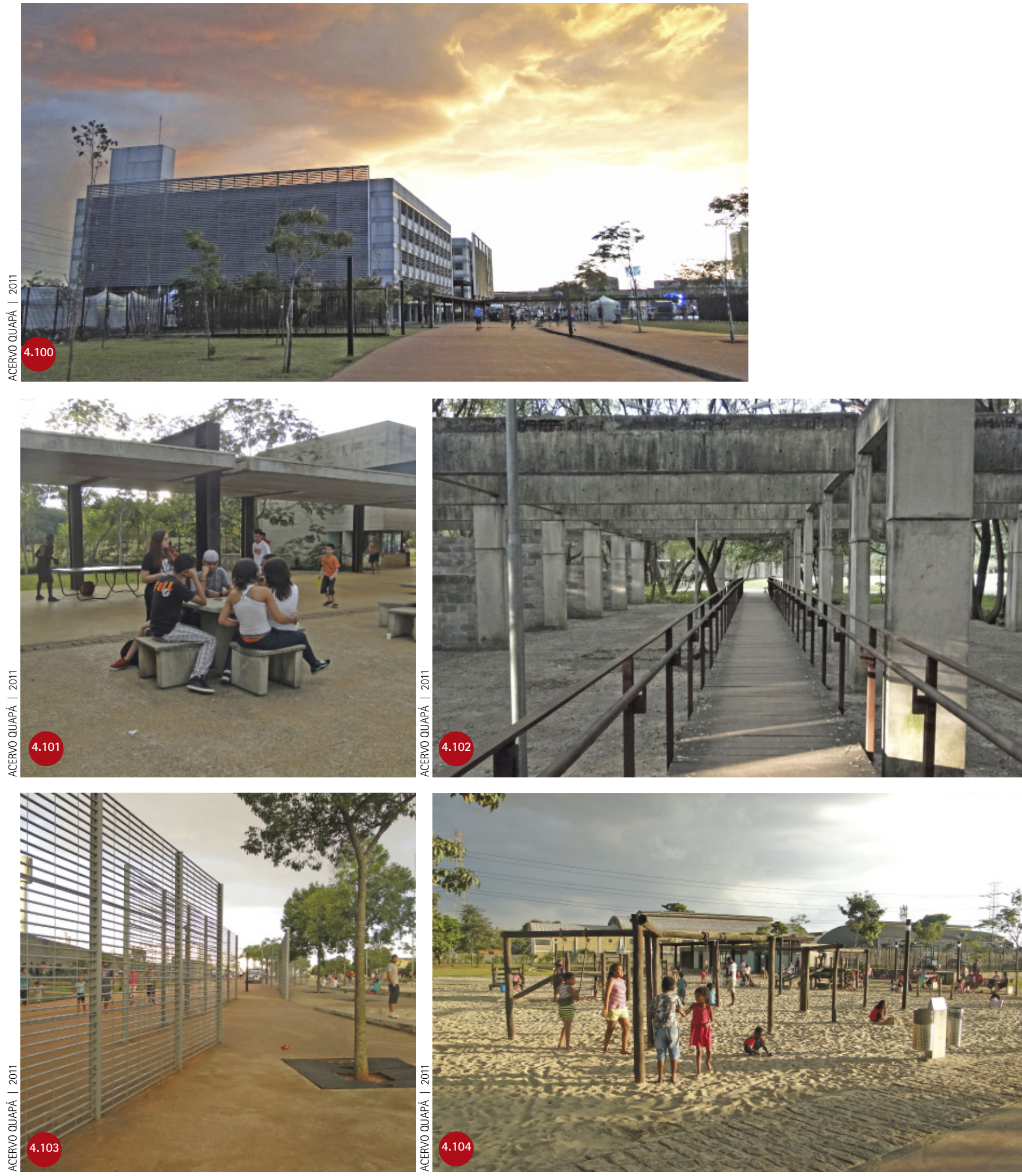


\section{DESAFIOS PARA GESTÃO E MANUTENÇÃO}

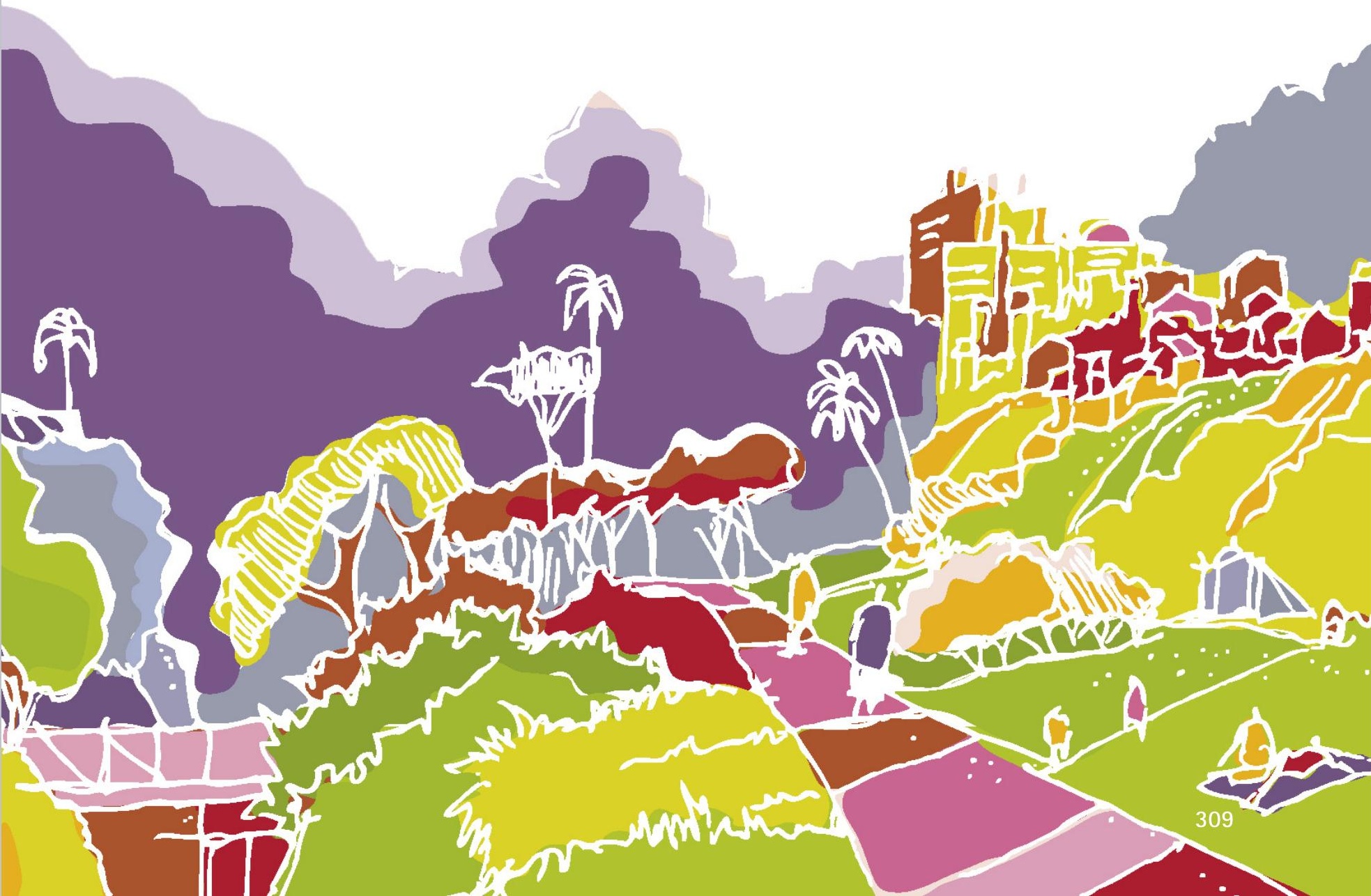




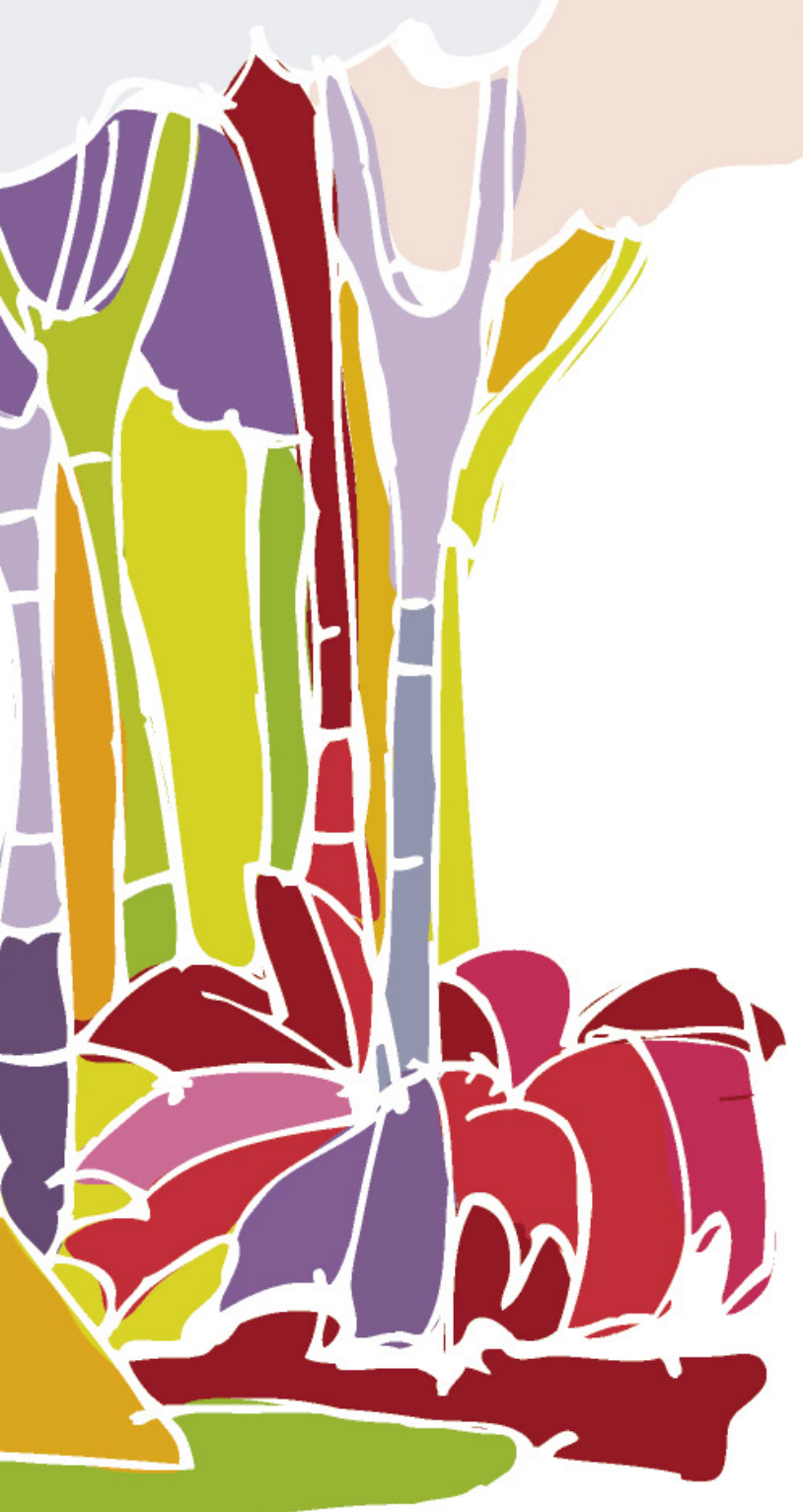


1 JACOBS, Jane. Morte e vida das grandes cidades americanas. São Paulo: Martins Fontes, 2011.
Jane Jacobs, que escreveu Morte e vida das grandes cidades americanas $^{1}$ em 1961, não gostava de parques. Achava-os propícios para usos marginais, pela falta de pessoas transitando, pela falta dos vizinhos que vigiam - os "olhos da rua". Parques, para serem úteis, teriam que ser multifuncionais e muito atraentes. Achava que as calçadas largas - com mais de sete metros - é que eram bons espaços urbanos, úteis para circulação, convivência e lazer.

A realidade das cidades brasileiras é bem diferente: as calçadas são estreitas, mal pavimentadas, desniveladas, obstruídas ou descontínuas, às vezes perigosas. A numerosa população urbana aproveita os grandes parques, em especial aqueles com áreas abertas gramadas e arborizadas e com bons equipamentos de lazer, localizados nos bairros mais valorizados da cidade. Nos domingos ensolarados, não haveria calçadas que comportassem as multidões que afluem aos parques em busca da sociabilização urbana e festiva em espaços públicos bem tratados.

Os parques mais simples, como os parques lineares junto aos conjuntos habitacionais, quando são apropriados pela população, se aproximam da calçada multiuso descrita por Jacobs.

Quando eram poucos, a manutenção dos parques estava relativamente mais bem equacionada nas cidades do que a manutenção de praças e outros logradouros públicos. Mas, conforme cresceu o número de parques e surgiram parques em bairros mais pobres e parques de conservação ambiental, aumentaram os problemas. Para este trabalho, além das observações realizadas em levantamentos de campo, foram obtidos relatos de gestores de parques municipais e estaduais da cidade de São Paulo (onde a manutenção é sempre difícil) e realizadas entrevistas não sistematizadas sobre questões 
relativas à gestão em outras cidades. Sugere-se que o tema abordado nesta tese seja objeto de trabalhos que aprofundem as questões aqui levantadas.

Verifica-se que nos espaços livres urbanos existe clara relação entre apropriação e manutenção. Parques de uso frequente e intenso tendem a ter melhor manutenção. Contudo, nos bairros de renda mais baixa, mesmo quando a apropriação existe e é intensa - a única opção de lazer das pessoas - a manutenção não está garantida. 0 Parque do Sapé, em São Paulo, ainda que tenha muito uso, não tem regularidade na manutenção. Em todas as cidades, as condições dos espaços livres nos bairros mais pobres são nitidamente piores. Nos bairros das classes mais altas, a qualidade e a manutenção dos equipamentos mostra-se superior.

\section{Práticas cotidianas}

Um conjunto de parques em excelente estado de manutenção em 2017, na região norte de Belo Horizonte, contava com uma mesma equipe de funcionários, que programava atividades de forma rotativa. As equipes eram compostas por dois funcionários fixos de cada parque, mas o encarregado observou ser mais eficiente emprestar os funcionários fixos para compor uma equipe maior, que centrava esforços em um parque de cada vez. É um pequeno exemplo de gestão integrada de parques de igual categoria em uma mesma região, que, de modo informal, permitiu racionalizar e incrementar o processo de manutenção.

Em Curitiba, na década de 1990, a existência de um corpo técnico planejando o processo de expansão dos espaços livres para o lazer levou à maior racionalização da manutenção em relação à observada em outras cidades. Para os mobiliários urbanos e brinquedos, os projetistas optaram pela simplicidade, pela repetição e pelo aperfeiçoamento do desenho em função da resistência, da segurança para o usuário e da facilidade de manutenção. Assim, nos playgrounds mantidos pela prefeitura, os brinquedos se repetiam nas diferentes 

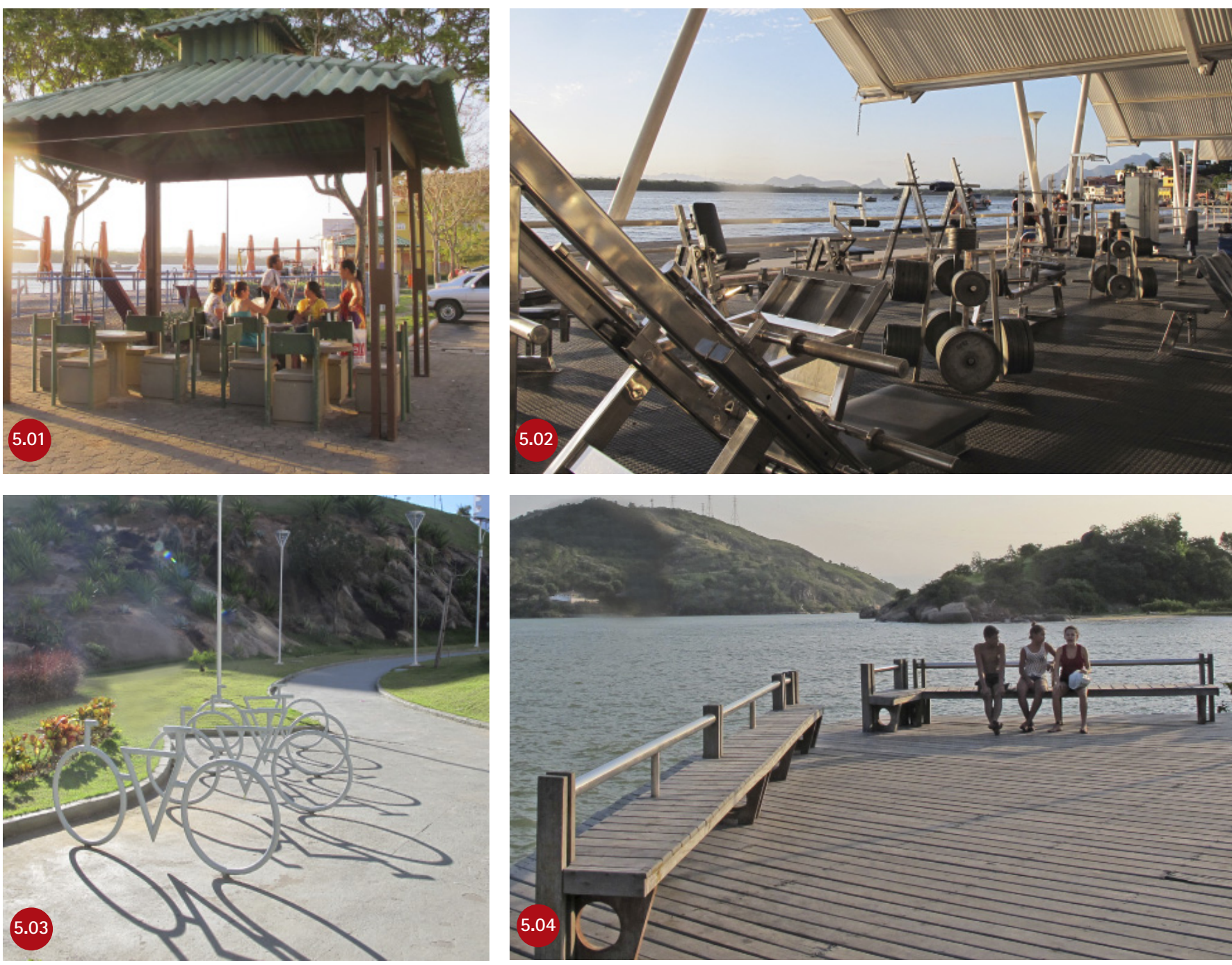

Mobiliários urbanos em Vitória: os bancos com encosto e a academia de ginástica no calçadão da Ilha das Caieiras; o paraciclo do Parque Chácara Paraíso (2013); os bancos e o deck na Praça do Papa (2008); e a tirolesa na Praça da Ciência (2008), localizada junto à orla, na Enseada do Suá.

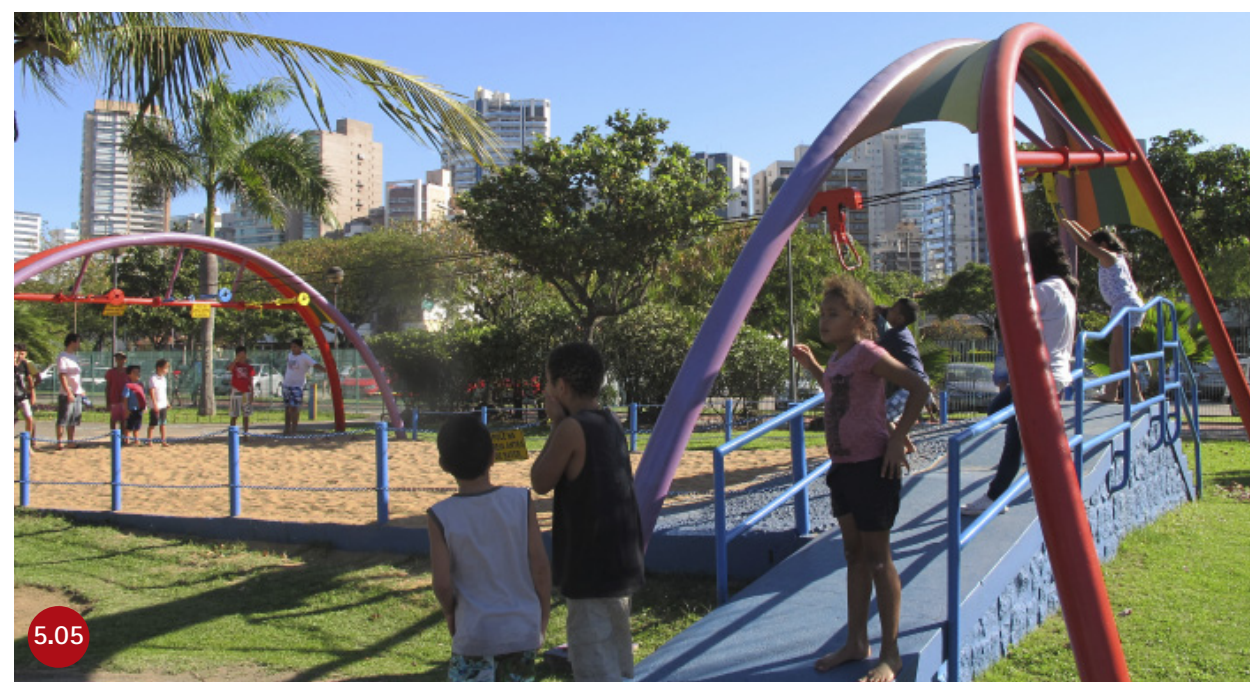


2 Um estudo sobre a manutenção de praças em São Paulo (SP), que buscou aplicar a sistematização para espaços livres, constatou que os estudos de manutenção focam edifícios e instalações industriais. Foi proposto um sistema de manutenção levando em conta ações preventivas e corretivas, estas programadas a partir de check-lists simples. 0 trabalho também constatou que a manutenção preventiva do brinquedo do estudo de caso - que custou originalmente $R \$ 18.324,00$ teria o custo de anual de $R \$ 784,00$. Como não houve nenhum tipo de manutenção, ao final de dois anos os brinquedos estavam enferrujados e sem condição de uso, o que levou à perda total do equipamento. Por menos de um décimo do custo do equipamento, o contribuinte não teria tido o prejuízo de $\mathrm{R} \$ 18.324,00$.

NAMIKI, Fábio. Manutenção de praças públicas. 2005. 151f. Dissertação (Mestrado Profissional em Habitação) - Instituto de Pesquisas Tecnológicas do Estado de São Paulo, São Paulo, 2005. praças. Ao ser informada sobre uma gangorra quebrada, a equipe de manutenção tinha ferramentas, peças e conhecimento técnico para o reparo. Isto não significa que os mobiliários devam ser homogeneizados mas que devem haver estratégias para manutenção.

O grau de sofisticação dos espaços públicos e dos mobiliários urbanos em países desenvolvidos é muito superior ao existente no Brasil. Sistemas de manutenção em funcionamento permitem reduzir e planejar custos de manutenção, informar os projetistas sobre os desenhos, materiais e técnicas mais eficientes e de maior durabilidade. A existência de um sistema pode melhorar a qualidade global dos espaços livres a serem construídos e reduzir custos. Dados sobre o projeto e o patrimônio permitem realizar planejamentos de curto prazo que envolvem previsão de custos e definição da forma e prazos de contratação das diversas atividades². Em todas as grandes cidades, a manutenção dos mobiliários urbanos é difícil. É comum serem implantadas peças de boa qualidade e elas serem perdidas por falta de estrutura para consertá-las quando necessário.

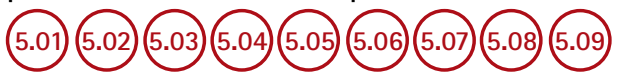

Além disso, a regularidade da manutenção diminui o vandalismo, conforme mostram as experiências do Metrô de São Paulo. Para isto é fundamental ter dados sobre o que será mantido, as partes que compõem os equipamentos e as demandas de funcionamento. Categorizar os espaços livres e ter dados de campo consistentes sobre eles são partes importantes para manutenção e projeto.

\section{Problemas tradicionais}

Em Maringá (PR), somente um de seus dois parques originais, o Ingá, está consolidado e em uso. 0 segundo parque previsto, o dos Pioneiros, está cercado como reserva florestal em meio ao tecido urbano. E o Horto Florestal, um parque em potencial, encontrava-se fechado em 2018, desde 2003. Outros parques foram posteriormente criados, bem como o sistema de corredores verdes ou parques 
lineares, ainda com ocupação precária, não passando de simples reservas florestais. ${ }^{3}$ (5.10)

No Brasil as administrações municipais tradicionalmente apresentam problemas de descontinuidade entre gestões de governo, falta de coordenação entre as secretarias municipais, desarticulação entre secretarias e concessionárias de infraestrutura e instâncias estaduais do governo. lsto é lugar-comum no relato dos servidores a respeito de seu trabalho cotidiano. A situação muda quando uma obra ou um programa político se tornam a marca da gestão de determinado prefeito ou governador. Nestes casos, secretarias, concessionárias e contratados trabalham coordenadamente, as obras alcançam qualidade superior e os prazos são apertados ${ }^{4}$. Em Manaus, o grande parque linear proposto pelo Prosamim foi desenvolvido sob os olhos do governador, assim como o Parque Madureira, no Rio de Janeiro, pelo prefeito - que o declarou, ao final de uma gestão de oito anos, como sua obra mais importante.

Mesmo nos parques criados em conjunto com a iniciativa privada observamos descontinuidades e problemas de manutenção, ainda que, no conjunto, tendam a ter manutenção mais regular. (5.11) (5.12) Em 2017 alunos da Escola Politécnica da USP, que desenvolviam estudos para a gestão de parques municipais em São Paulo, não conseguiram obter quaisquer dados sobre os gastos de manutenção dos parques existentes, pois a prefeitura não disponibilizou informações. 0 grupo listou, então, os serviços e a mão de obra necessários para a gestão do Parque Chácara do Jockey e estimaram valores de mercado. ${ }^{5}$ Sem dados para o planejamento e sem a institucionalização da manutenção, as decisões que envolvem a manutenção dos parques sobrecarregam seus administradores.

\section{Um ator muito importante}

Os administradores dos parques são peça fundamental da gestão. Braço operacional e porta de entrada e saída para políticas públicas simultaneamente, detêm a tarefa de perceber as demandas e
3 MENEGUETTI, Karin S.; REGO, Renato Leão; BELOTO, Gislaine Elizete. Maringá:a paisagem urbana e o Sistema de Espaços Livres. Maringá: UEM, 2009.

4 SAKATA, Francine. Paisagismo urbano: requalificação ou criação de imagens. São Paulo: Edusp, 2011.

5 CUNHA, Claudio E.; OJIMA, Felipe B.; ALCARAZ, Felipe E.; SILVA, João Gustavo P. da. Desestatização de Parques Urbanos Municipais da cidade de São Paulo: 0 caso do Parque Chácara do Jockey. 2017. 120p. Trabalho de Conclusão de Curso (Graduação em Engenharia Civil) - Escola Politécnica da Universidade de São Paulo, São Paulo, 2017. 
Em Maringá (PR), o Parque do Ingá (1971) está consolidado e em uso. Prefeito em 2007, Silvio Barros, relatou no evento Arq. Futuro (2014), investimentos em atividades atrativas de público e tentativas de realizar a concessão do parque e de sua manutenção do parque mas, na abertura da licitação, nenhuma empresa se inscreveu.

Parque Colina de São Francisco (2007), São Paulo. Feito em parceria com a construtora Gafisa, tem manutenção a cargo do município.

Pequeno parque público em terreno próximo ao Parque Colina de São Francisco. Possuía dois playgrounds quando estruturado em 2004. Um dos playgrounds, instalado com vista para a entrada e a rua, sempre teve uso; o outro, em área rebaixada, do fundo, praticamente não teve. Em 2018 o playground mais utilizado não existe mais; o que nunca teve uso ainda existe.
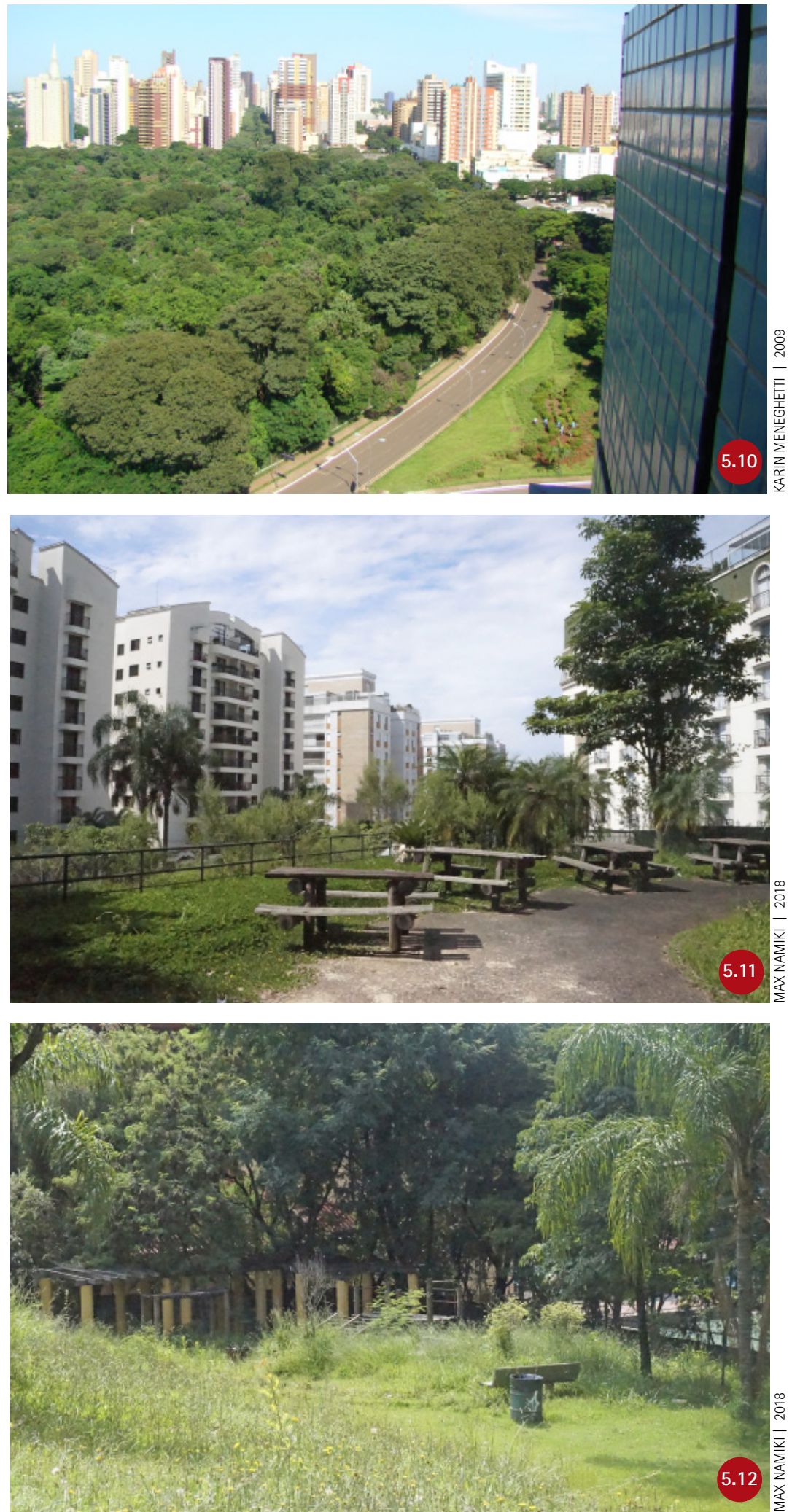
traduzi-las para a Secretaria responsável, mas nem sempre existem canais de comunicação direta entre eles. Seu escopo de atividades envolve a contratação de serviços de segurança e manutenção; relacionamento com subordinados, superiores e subprefeitura; disciplinamento de usos e intermediação em conflitos a eles relacionados, sejam cotidianos ou inusitados. Os administradores devem conciliar pessoas que desejam silêncio e as que fazem barulho. Devem resolver casos de animais abandonados, incêndios, furtos, funcionários com problemas disciplinares, falta de recursos para atividades promovidas etc.

Em 2008 o Instituto Sócio Ambiental (ISA) e a Secretaria do Verde e Meio Ambiente (SVMA) do Município de São Paulo conduziram estudos para a elaboração de subsídios para a gestão dos parques urbanos municipais. Realizado com administradores de parques, o estudo revelou que alguns têm mais talento para questões administrativas, outros para relações comunitárias, que há troca informal de experiências - sendo esta recomendável de forma sistematizada e organizada. Em um dos casos, a gestão do Parque Chácara das Flores, realizou-se uma pesquisa com os usuários, revelando que os moradores próximos consideravam o parque um espaço para a violência. A partir desta pesquisa, o administrador e sua equipe realizaram um trabalho de reforço da segurança e de aproximação com os moradores. A percepção dos frequentadores em relação ao parque melhorou. ${ }^{6}$

\section{Demandas do público}

Para a elaboração dos subsídios de gestão, o estudo da prefeitura encomendou uma pesquisa com usuários de 38 parques municipais paulistanos em 2008, revelando que a maioria dos entrevistados $(80 \%)$ mora perto do parque que frequenta; a maioria (81\%) vai ao parque pelo menos uma vez por semana; 63\% vão à pé; $68 \%$ vão para atividades físicas. A manutenção dos parques da amostra foi bem avaliada pelos frequentadores. Os itens espaço, vegetação/ jar-
6 Este trabalho (recomendado para leitura) envolveu questionários, reuniões e oficinas realizados em cada parque, com a administração, o conselho gestor e a comunidade de frequentadores. Também foram feitas pesquisas com os usuários e levantamentos de campo. Finalmente, elaborou-se um roteiro para a elaboração dos planos de gestão. Como instrumentos de gestão para parques municipais foram sugeridos: programas gerais (para todos os parques), Plano de Manejo (para os grandes parques naturais), zoneamento (para os médios e pequenos parques naturais ou históricos) e programas especificos (para os médios e pequenos parques naturais e para os médios históricos).

WHATELY, Marussia et al. Parques urbanos municipais de São Paulo: subsidios para a gestão. São Paulo: Instituto Socioambiental, 2008. 
dinagem e limpeza foram avaliados como ótimos ou bons por 90\% dos usuários. Os entrevistados com renda familiar de até dois salários mínimos foram responsáveis pela aprovação das atividades de lazer e cultura - acima da média. Este resultado reforça a importância do papel dos parques em áreas carentes de espaços de lazer, pois, para muitas pessoas, são a única opção para recreação e esporte.

As respostas indicaram que as pessoas se preocupam com a recuperação e os cuidados em relação aos recursos naturais. Utilizam os parques para caminhar, correr, andar de bicicleta, descansar, participar de atividades por eles oferecidas em benefício da própria saúde física/mental. Existe o entendimento de que a saúde ambiental do espaço é importante.

A presença de equipamentos e eventos de outras secretarias e entidades (cursos, centros de convivência e cooperativas) também foi avaliada como importante para aumentar a frequência de usuários. lsto apontou a necessidade de as secretarias de governo buscarem trabalhar de forma integrada, oferecendo serviços em parques, pois há vantagens para todos os envolvidos.

\section{Conselhos gestores}

7 A atuação dos Conselhos Gestores nos Parque Municipais está prevista na Lei № 15.910 de 27 de novembro de 2013. Seu Decreto regulamentador está em elaboração. Prefeitura Municipal de São Paulo, 6 dez. 2017.

Disponivel em: <http://www.prefeitura. sp.gov.br/cidade/secretarias/meio_ambiente/parques/conselhos_gestores/index. php?p=40498>.
A mesma pesquisa revelou o desconhecimento generalizado dos frequentadores de parques sobre a existência e o papel dos conselhos gestores. Em São Paulo, os Conselhos Gestores dos Parques Municipais foram criados em 2003 para garantir a participação popular no planejamento, gerenciamento e fiscalização das atividades que ocorrem nos parques. 0 objetivo é envolver a comunidade na discussão das políticas públicas de forma consultiva. ${ }^{7}$

Os conselhos paulistanos são constituídos por, no mínimo, quatro representantes da sociedade civil - três representantes dos frequentadores do parque e um de movimentos sociais, instituições ou entidades locais, ou seja: um representante dos trabalhadores do parque, órgãos públicos ou empresas privadas, o administrador 
do parque, um indicado pela subprefeitura e um indicado por outra Secretaria Municipal - na área de educação, cultura, esportes, lazer e recreação, saúde ou segurança urbana.

Os moradores do entorno que costumam participar dos conselhos nem sempre são representativos dos frequentadores dos parques e muitas vezes apresentam demandas conservadoras, como restringir eventos que impliquem maior público, devido a barulho ou movimento.

Contudo, é da natureza do parque ter seus usos pactuados entre a sociedade e o poder público. As regras de participação e representatividade é mais um acordo, entre muitos, a amadurecer.

\section{Novos parques, novas demandas de manutenção}

À medida que surgem novas categorias de parques, torna-se necessário desenvolver novos processos de gestão e manutenção. Nos conjuntos analisados, é considerável a grande diversidade dos parques no que se refere às dimensões, funções, serviços prestados (ambientais e de lazer) e preservação de patrimônio.

A partir deste conjunto, foram sistematizados os principais desafios para gestão:

- construir o programa de atividades de cada um em função de sua vocação e promover a articulação entre eles;

- trabalhar a percepção de segurança em parques que fazem divisa com comunidades carentes e que são considerados inseguros;

- atender as novas demandas de manutenção dos "parques lineares" que se conectam diretamente com calçadas e ruas e requerem gestão e manutenção mais parecida com a das calçadas e praças;

- atrair visitantes e proteger de invasões e usos marginais os parques naturais inseridos na mancha urbana ou muito próximos dela;

- conservar as áreas demarcadas para parques, mas sem usos;

- lidar com os custos do aumento do número de parques num contexto de crise. 


\section{Da articulação}

$\mathrm{Na}$ pesquisa, os administradores dos parques municipais de São Paulo responderam de modo divergente sobre qual seria o papel do parque. Deduziu-se que, no entendimento dos administradores, o papel de cada parque variava por estar relacionado com o histórico da sua criação. Assim, praças transformadas em parques tinham um papel; áreas públicas abandonadas convertidas em parque, tinham outro e assim por diante.

Dessa forma, no desenvolvimento do plano de gestão, foi recomendado que os administradores tivessem ciência da história do parque como uma das maneiras de entender o seu papel, as relações existentes no local e seus frequentadores. Também se orientou que cada administrador localizasse o parque em um mapa para identificar as possibilidades de influência mútuas entre o "seu" parque e os outros - do entorno imediato e da região.

0 que foi recomendado para ser feito por conta própria pelos administradores é papel de todas as instâncias de administração e da sociedade. Cada parque deve ser entendido como uma peça do sistema. Cada parque pode ter seu programa de atividades definido em função da sua localização e dos frequentadores - efetivos e potenciais. As relações do parque com as demais áreas verdes da sua região e do município não são mais responsabilidades apenas de seus administradores.

A manutenção dos parques tradicionais das cidades, ainda que haja dificuldades, é relativamente estável, e sempre há condições para os usos recreativos e esportivos. Nos novos parques associados ao mercado imobiliário, a manutenção tende também a ser boa. Em São Paulo, o problema do Parque do Jardim das Perdizes 8 é o pouco uso. Jornalistas noticiam na imprensa, intrigados: como um parque tão bem equipado e conservado recebe tão poucos frequentadores? Provavelmente, a população para a qual foi divulgado seja a dos

8 Disponivel em: <http://www1.folha. uol.com.br/cotidiano/2016/10/1822065-novo-e-vazio-parque-na-zona-oeste-de-sp-tem-duas-areas-para-criancas. shtml>. 


\section{Da insegurança}

Em 2016 a prefeitura paulistana, com mais de 117 parques sob sua gestão, contava com apenas três bases de manutenção, nas quais faltavam equipes e material. Parte dos 24 parques lineares implantados entre 2006 e 2012 foi locada em vizinhanças de baixa renda - em áreas públicas sem vocação para a apropriação por não serem visiveis a partir da rua -, sendo depredada. 0 Parque Linear Guaratiba, na Zona Leste, ficou sem vigilantes devido a problemas contratuais e características do local: movimentado durante o dia, foi depredado e passou a ser evitado pela população ${ }^{9}$, que relata a presença de usuários de drogas. ${ }^{10}$ Em 2009 o Parque Consciência Negra, em Cidade Tiradentes, Zona Leste de São Paulo, foi inaugurado sem os brinquedos previstos, teve a fiação elétrica roubada e não reposta.

Esse mesmo destino havia tido boa parte das praças do Programa Centros de Bairro, que as equipou para o lazer na periferia entre 2001 e 2004. Pouco frequentadas e sem vigilância, mesmo os mobiliários mais resistentes não restaram. Parques em vizinhanças de menor renda, quando possuem espaços fechados e pouco visíveis, tendem a ser percebidos como inseguros.

Em Belo Horizonte, em 2017, o Parque Alexander Brandt estava fechado. Trata-se de uma área de conservação convertida em parque por meio do Programa Parque Preservado em 1996. Praticamente todo coberto por bosque, possuía apenas uma pista, brinquedos e estação de ginástica. Devido ao pouco uso e envolvimento pela comunidade, foi fechado. Moradores relatam que, por não ter policiamento ao redor, muitos assaltos acontecem: "passou a representar perigo para os cidadãos"." 5.13

Em Taguatinga, no Distrito Federal, uma reportagem de 2017 relata problemas com furtos, tentativas de assalto e presença de usuários de drogas em parques. Os frequentadores entrevistados relataram problemas de manutenção e o medo sentido ao frequentá-los. Na portaria, a catraca era inoperante; havia postes de luz defeituosos, pistas para caminhada inacabadas e um dos seis campos de futebol
9 NAGANO, Wellington T. Parque Linear Itaim como Espaço Livre Público. 2017. 93 f. Memorial de Qualificação (Mestrado em Arquitetura e Urbanismo) - Faculdade de Arquitetura e Urbanismo, Universidade de São Paulo, São Paulo, 2017.

10 Disponivel em: <http://sao-paulo. estadao.com.br/noticias/geral,na-periferia-area-de-lazer-fica-abandonada-imp-,679143>.

11 Disponivel em: <http://www.peticaopublica.com.br/pview.aspx?pi=BR101950>.

12 Disponivel em: <http://www. correiobraziliense.com.br/app/noticia/ cidades/2017/09/29/interna_cidadesdf,629918/frequentadores-de-parques-de-taguatinga-convivem-com-a-inseguranca.shtml>.

13 Disponivel em: <http://www1.folha. uol.com.br/cotidiano/2016/08/1798310-falta-de-seguranca-faz-parque-da-juventude-fechar-mais-cedo.shtml>. 
Em 2017, o Parque Alexander Brandt, em Belo Horizonte, estava fechado, com aspecto de abandono, as cercas parcialmente destruídas, sem previsão para voltar a abrir.
14 Disponivel em: <http://www.correio24horas.com.br/noticia/nid/mulher-e-estuprada-quando-fazia-caminhada-no-parque-sao-bartolomeu/>. Abril de 2016.

15 Disponivel em: <http://www. paraiba.com.br/2017/02/14/92118-parques-publicos-de-campina-grande-viram-pontos-de-crimes-tumultos-e-assaltos>.

16 Disponivel em: <http://www.ondefuiroubado.com.br/sao-paulo/SP>. Acesso em: 22 jan. 2018.

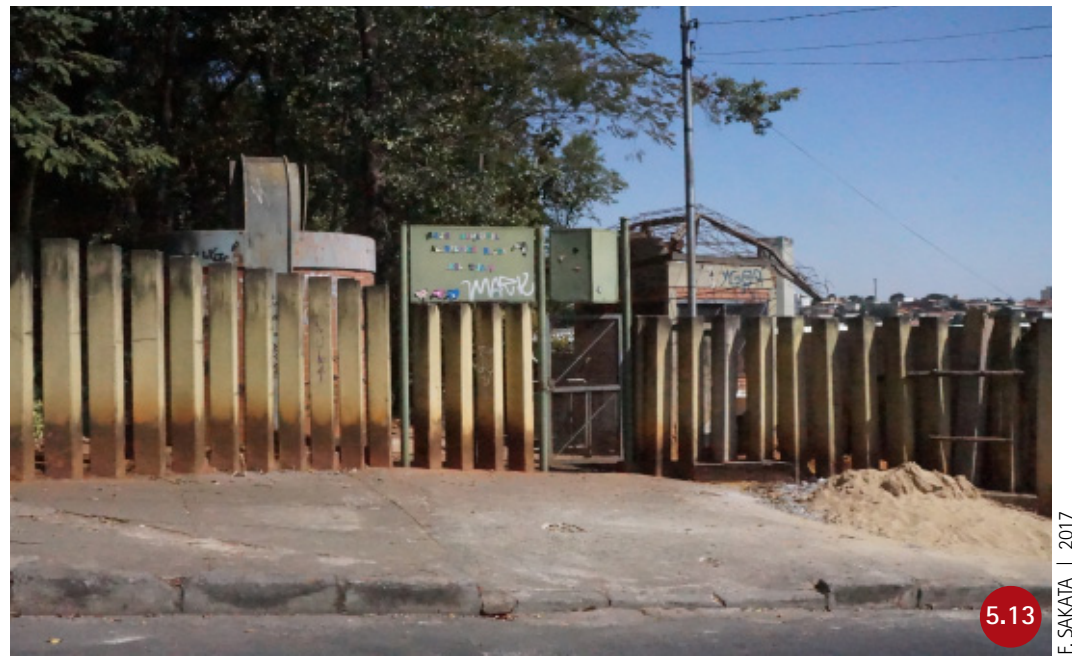

tem a trave do gol caída no chão. Sobre o Taguaparque, a Polícia Militar relatou que há anos mantinha dois policiais por turno em ronda, sendo o patrulhamento reforçado nos fins de semana. Entre janeiro e agosto de 2017, 17 ocorrências foram registradas - a maioria, tentativas de roubo. Segundo a polícia, era um parque seguro. ${ }^{12}$ Fica clara a percepção de insegurança gerada pela falta de manutenção e apropriação.

No mesmo período, o Parque da Juventude, em São Paulo, registrou 87 ocorrências, sendo 48 roubos. ${ }^{13}$ Foram relatados arrastões perto das quadras, e a polícia atribui o fato ao intenso fluxo existente, uma vez que o parque fica próximo da saída do metrô, do Shopping Center Norte, de conjuntos habitacionais e dois albergues públicos.

Em Salvador, um caso de estupro no Parque São Bartolomeu, em 2016, foi noticiado por todos os jornais soteropolitanos. ${ }^{14}$ Em Campina Grande, foram noticiados roubos de celulares por menores armados. ${ }^{15}$ Entretanto, o site "onde fui roubado" - que convida pessoas que sofreram assaltos a informar a localização e o tipo de violência sofrida em mapas de muitas cidades brasileiras - mostrava ocorrências nas ruas de São Paulo, Rio de Janeiro, Belo Horizonte e Salvador, e praticamente nenhuma ocorrência em parques. Isto sugere que o problema que precisa ser equacionado neles é o da percepção de segurança, para que as pessoas se sintam acolhidas e os parques cumpram o seu papel de espaço de lazer e contemplação. ${ }^{16}$ 


\section{Grandes parques}

Parques urbanos concebidos como UCs, mesmo não tendo ainda planos de manejo para funcionarem como tal, são criados para desempenhar a função ambiental, e não mais o lazer e a recreação. Mas, sem apropriações sociais, como garantir a integridade destas áreas?

Nos municípios do Vetor Oeste da Grande São Paulo, observamos ${ }^{17}$ que a existência da administração no parque e do corpo de funcionários é decisiva na preservação relacionada a áreas não demarcadas e sem gestão. Mas, dependendo das pressões, não é medida suficiente.

Em Salvador, o Parque Metropolitano de Pituaçu perdeu 275 dos seus 665 hectares desde que foi criado em 1973. Seus novos limites foram estabelecidos em decretos sucessivos, negociados entre o Estado e o Município. As áreas já ocupadas por invasões - de baixo e de alto padrão - foram mantidas para regularização posterior. Nos jornais, as perdas são atribuídas à omissão do poder público, que ao longo dos anos não se posicionou em relação às ocupações e não solucionou a situação fundiária com os antigos proprietários..$^{18}$ É preciso compreender que os agentes construtores da cidade exercem pressões nos vetores de expansão e que os parques não são a única possibilidade para as terras urbanas. Existe uma disputa pela terra e a legislação que cria grandes parques não diminui a demanda por moradias, pelo contrário. (5.14)

\section{Parcerias e gestão privada de parques públicos}

Em São Paulo, o Parque Lina e o Paulo Raia, ao lado do Centro Empresarial Itaú Conceição, têm gestão compartilhada com o banco, que arca com a manutenção de equipamentos existentes, segurança e jardinagem. 0 contrato, vitalício, foi firmado em 1985, quando da construção das torres e da estação do Metrô, entrando em vigor em 2004. A parceria permite a desburocratização de ações simples
Na página oposta:

Parque Metropolitano de Pituaçu (1973), Salvador. As fotos aéreas mostram as invasões em meio às árvores.

Parque Lina e Paulo Raia (1981), São Paulo, de gestão compartilhada com a instituição financeira que é sua vizinha.

17 COELHO, Leonardo L; SAKATA, Francine. Parques e proteção ambiental no vetor oeste da região metropolitana de São Paulo. COLÓQUIO QUAPÁ SEL, 10, Brasilia, 2015.

18 A legislação que criou o parque previa a existência de áreas residenciais, esportivas e educacionais no entorno, o que teria justificado o surgimento do bairro do Imbuí, a instalação do Estádio de Pituaçu e da Universidade Católica do Salvador (UCSal) - que recebeu, por doação, a área onde está instalado o campus de Pituaçu. Disponivel em: <http://atarde.uol.com.br/ bahia/salvador/noticias/1274006-parque-de-pituacu-perdeu-58-da-sua-area-original>. De 17 fev. 2008. 

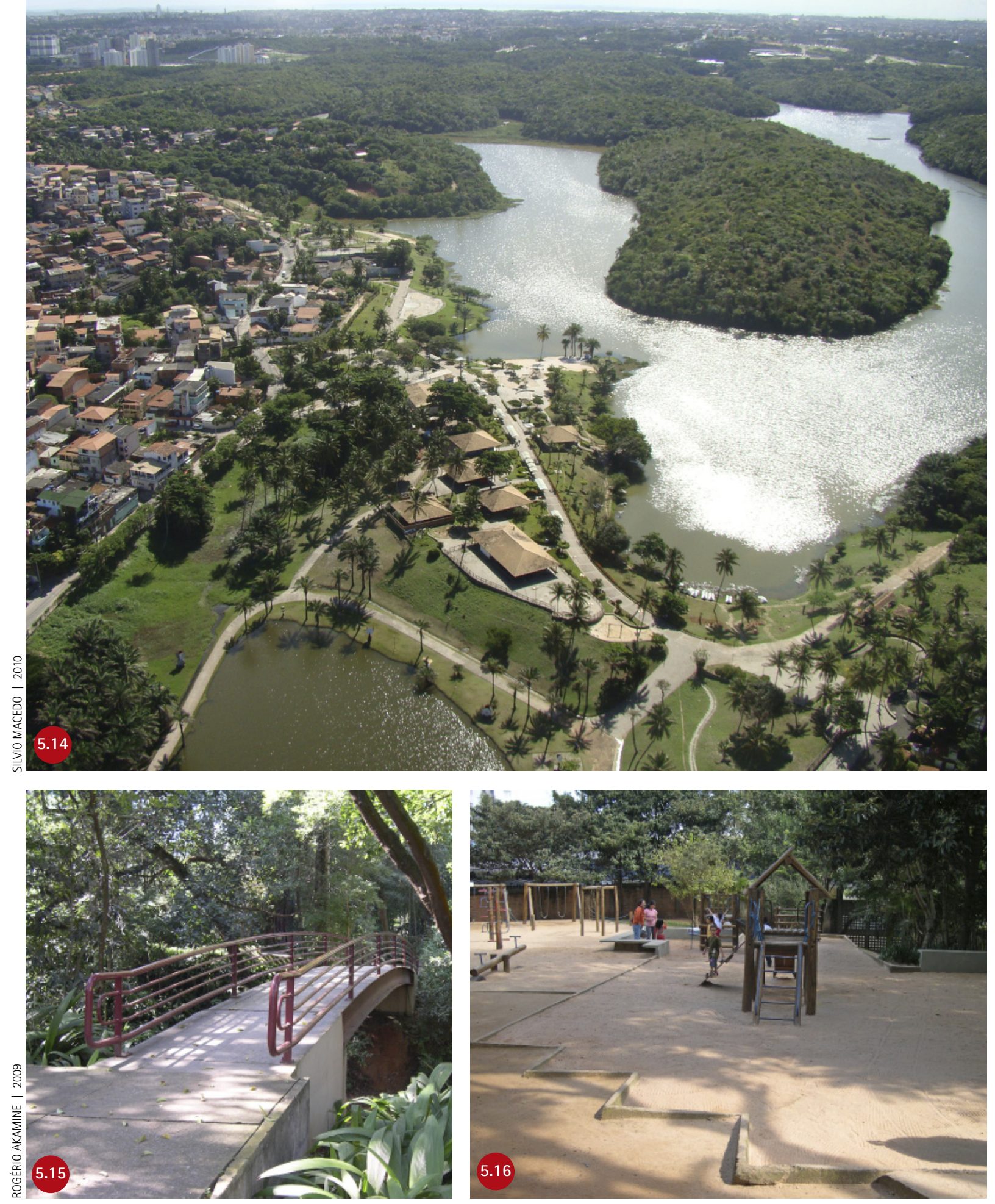

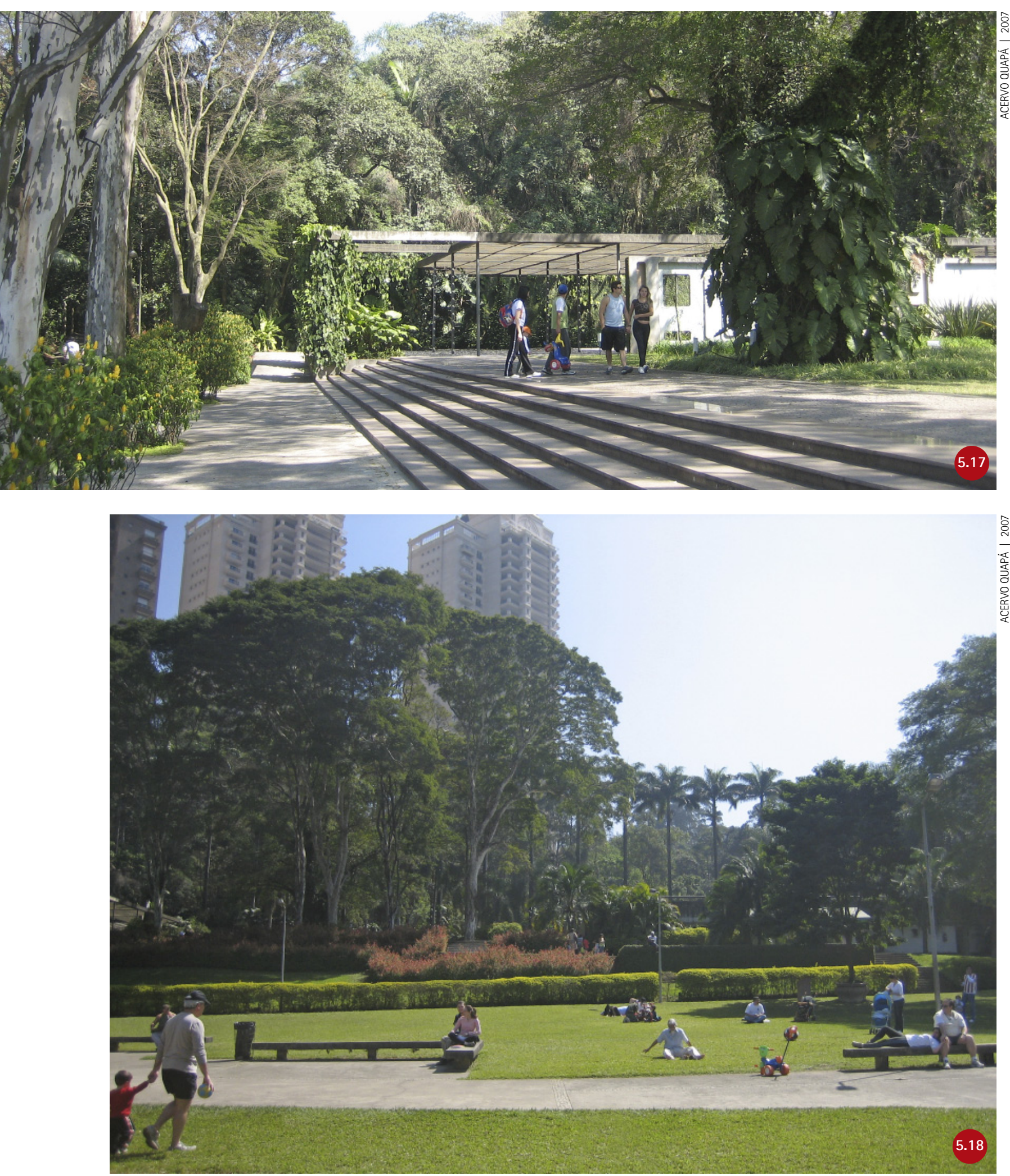
Parque Burle Marx, em São Paulo, é um dos mais restritivos: bolas, bicicletas, patinetes e animais de estimação não são bem-vindos. Piqueniques são permitidos apenas em uma área fora do parque, ao lado do estacionamento e podem durar até 2 horas.
19 WHATELY, Marussia et al. Parques urbanos municipais de São Paulo: subsídios para a gestão. São Paulo: Instituto Socioambiental, 2008, p. 98.

20 Em 2017, Rafael Birmann, presidente do conselho da Fundação Aron Birmann, apresenta dados mostrando que o parque custa, anualmente, um montante da ordem de 1,5 milhões de reais, e que consegue arrecadar em receitas próprias um valor da ordem de 0,8 milhão de reais (aproximadamente 50\% do custo total) ao ano. CUNHA et al., 2017. de manutenção. Na estrutura atual da administração pública, pequenas decisões às vezes precisam percorrer longos caminhos e a demora na resolução é desproporcional à questão. ${ }^{19} 5.15$

No caso do Parque Burle Marx, em São Paulo, o convênio de 1995 prevê gestão privada, feita pela Fundação Aron Birmann ${ }^{20}$. Sua área foi doada por exigência da Lei de Parcelamento do Solo (Lei 6766/79), na época da construção dos condomínios de luxo do entorno. Os jardins existentes no terreno - de autoria de Burle Marx, para uma residência que não havia sido construída - foram restaurados e incorporados ao parque. Trata-se de um equipamento público que não onera a prefeitura e mas que também não é democrático: o acesso é difícil, é proibido o uso de bolas, bicicletas e a realização de piqueniques, restringindo a apropriação pela população mais carente, que mora nas imediações. 0 caso do Parque Jardim das Perdizes é similar, gerido por uma associação criada para este fim e custeada pelos condomínios. É público, mas, por ser gradeado e estar contido entre os edifícios, não se mostra tão convidativo para a população dos bairros próximos. (5.17) 5.18

Há outros exemplos de entidades privadas colaborando na gestão de parques públicos paulistanos por meio de convênios, aluguéis ou patrocínios para projetos pontuais. 0 impulso privatizante e a crise econômica instaurada a partir de 2014 sobrecarregaram ainda mais os administradores de parques. Somou-se às suas muitas atribuições a de atrair recursos, gerenciar contratos de propagada e de realização de eventos. Um convênio entre o governo do Estado e a Companhia de Gás de São Paulo (Comgás) permitiu que a empresa arcasse com metade dos custos da ampliação do Parque Villa-Lobos entre 2004 e 2006. Em 2013 um novo convênio possibilitou o mesmo acordo para a implementação do Parque Candido Portinari na área que estava cedida para um canteiro de obras do Metrô. Os eventos que ocorrem nestes dois parques, inclusive o aluguel de uma área para o Cirque du Soleil, rendem recursos para um fundo de manutenção de parques. 0 Parque do lbirapuera realizou parceria com o Banco Real para reforma de lixeiras e placas de sinalização; com a Nike para reforma e manutenção do campo de futebol; com uma construtora para reforma de banheiros. Contudo, ambos são exceções no conjunto dos parques públicos, pois têm alta visibilidade e são cobiçados para propaganda e ações de marketing. 
0 Instituto Semeia tem promovido, desde 2004, estudos e palestras com foco no estabelecimento de parcerias público-privadas para a gestão de parques naturais e urbanos - especialmente para os parques nacionais. Busca trabalhar com as administrações para a implementação de projetos que sejam bons para a população e, simultaneamente, atrativos para os investidores. Entre as questões que precisam ser desbravadas estão os modelos de parcerias e as barreiras técnicas e jurídicas que podem impedir que as parcerias alcancem os resultados esperados ou que sejam colocadas em prática. Junto com os governos estaduais do Paraná, Rio de Janeiro e da Prefeitura de São Paulo, o Instituto trabalhou no apoio estratégico à equipe de governo para o lançamento de Procedimentos de Manifestação de Interesse (PMI). ${ }^{21}$ Através de palestras, tem promovido a ideia de que só se luta pela preservação daquilo que se conhece e, portanto, é preciso apresentar os parques às pessoas para que elas se tornem aliadas.

\section{Sobre a desestatização}

A SVMA teve seu orçamento reduzido a partir de 2014, enquanto a demanda por recursos e pessoal para sua manutenção vem acompanhando o aumento do número de parques municipais. A gestão da prefeitura iniciada em 2017 defendeu a desestatização de vários equipamentos públicos. Em relação aos parques, selecionou 14 para que a iniciativa privada proponha estudos e modelagens que servirão de base para um edital de licitação.

A gestão pública demonstra deficiências inerentes à atividade estatal, como o engessamento de verbas. Estas, se comprometidas para a compra de determinado material, não podem ser utilizadas para outro, mesmo que mais necessário. Verifica-se lentidão para renovar contratos e licitações, centralização de decisões importantes, pouca participação popular e pouca transparência. 0 processo de desestatização gera polêmica. 0 próprio prefeito tem sido pouco assertivo em definir o que planeja para os parques da cidade e quais os limites que serão colocados para agentes privados que eventualmente venham a gerir estes espaços públicos.
21 Disponivel em: <http://www.semeia. org.br/como-trabalhamos>. 
Parque Chácara do Jockey

(2016), São Paulo, no mês de sua inauguração. Foi escolhido como estudo de caso de uma simulação de desestatização pelo fato de ser relativamente grande $\left(143.000 \mathrm{~m}^{2}\right)$, pouco conhecido e apresentar várias possibilidades de uso $\mathrm{e}$ fontes de receita.
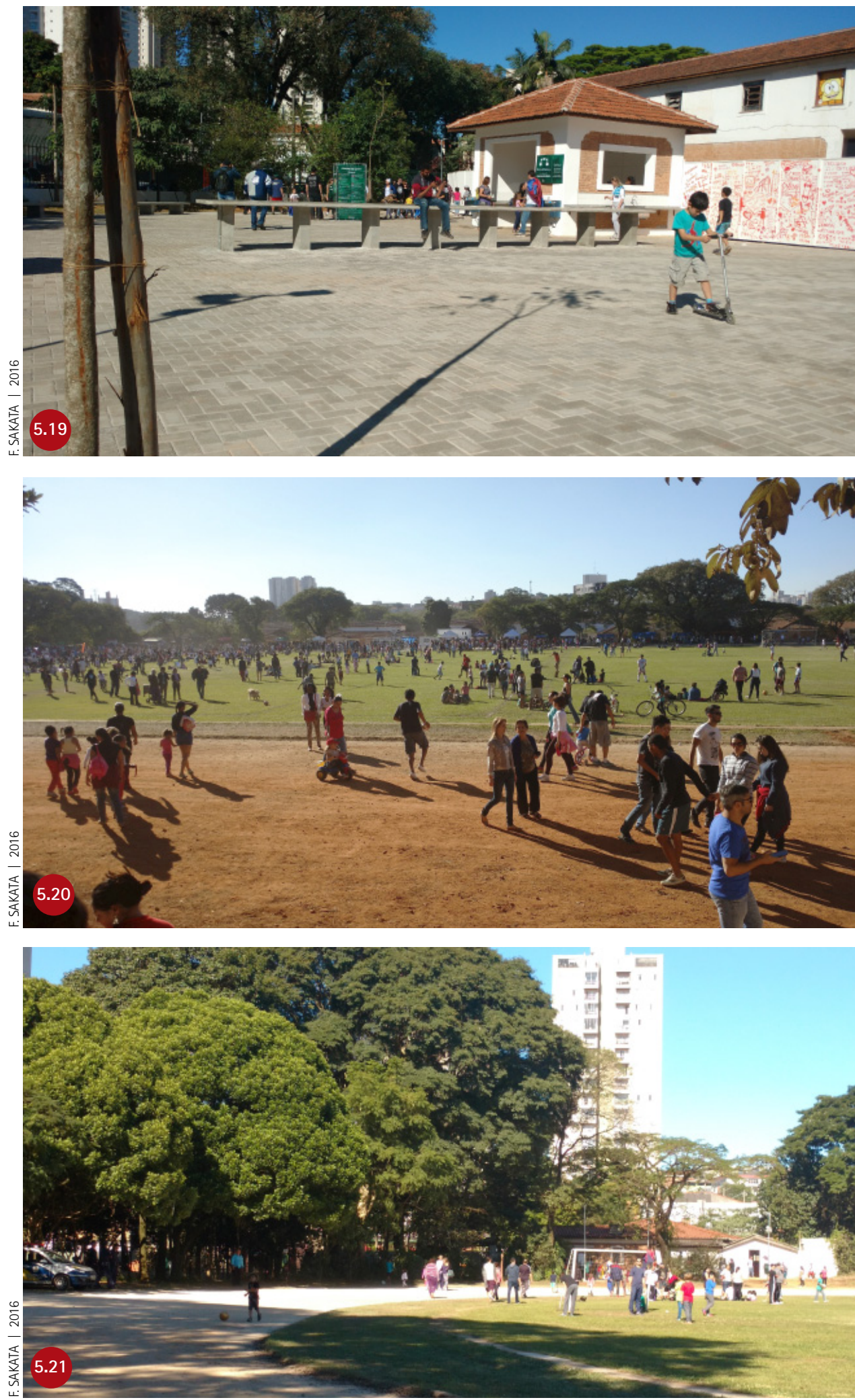


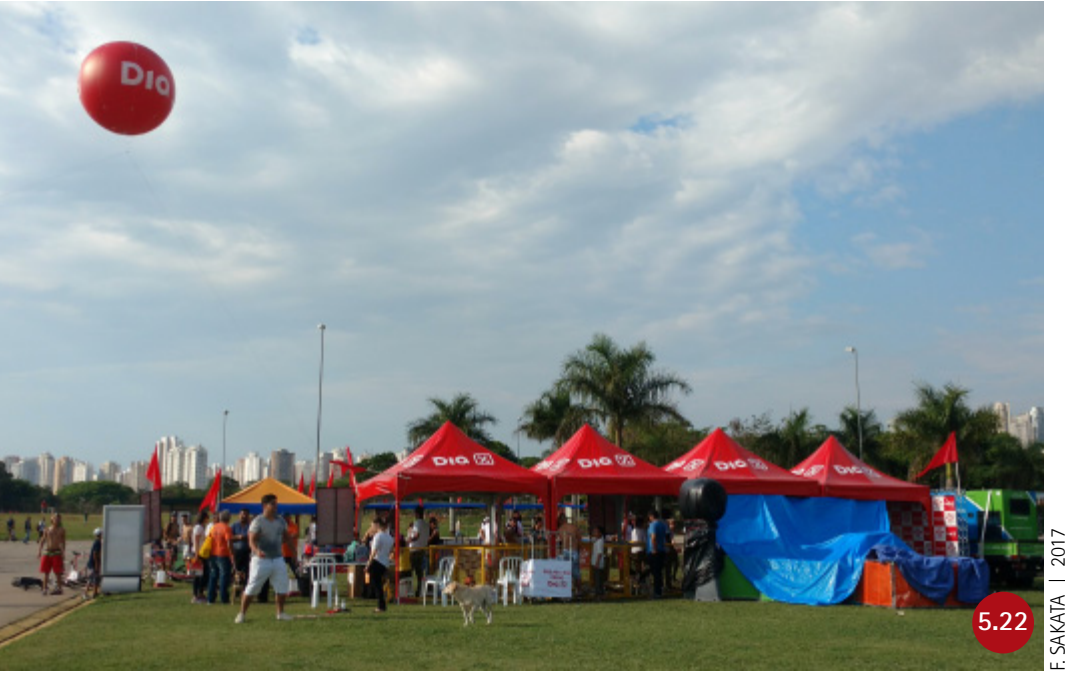

Uma pesquisa realizada na Escola Politécnica da Universidade de São Paulo (EPUSP)22 investigou a questão projetando custos, receitas potenciais e investimentos gerais para o Parque Chácara do Jockey (2016). Para os autores, a concessão do parque seria vantajosa para o governo municipal, trazendo redução de gastos, melhorias das condições de uso e aumento do número de visitantes. Entretanto, o parque precisa de muitos investimentos e só chegaria perto da autossuficiência no fim de um período de dez anos (prazo da concessão). Para a iniciativa privada, a desoneração total da máquina pública não seria, neste caso, um bom negócio.

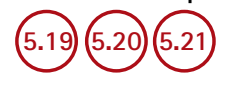

A opinião pública tem levantado questões importantes: o que acontecerá com a gestão dos parques não rentáveis na periferia? Programas sociais e ambientais não vinculados ao retorno financeiro teriam espaço em parques sob a gestão privada? Haveria mais participação popular e transparência? Reservar espaços para eventos privados nos parques é uma forma de privatizá-lo?

Para parques tradicionais, especialmente os localizados em bairros de elite, é interessante estudar a desoneração parcial, tendo em mente que não são o lugar da propaganda sem limites. (5.22)

Para parques nas periferias, o poder público terá que contar com outras fontes de renda para a manutenção do sistema de espaços livres públicos que, como infraestrutura urbana, são investimentos de sua responsabilidade.
O Parque Villa-Lobos, em São Paulo, recebeu o evento "Patrulha Canina", em dezembro de 2017, com o patrocínio de marcas de produtos para pets. $\mathrm{Na}$ ocasião, havia no parque mais de 30 empresas com ações de propaganda. Conceitualmente parques eram espaços sem propaganda; hoje, não mais.
22 CUNHA, Claudio E.; OJIMA, Felipe B.; ALCARAZ, Felipe E.; SILVA, João Gustavo P. da. Desestatização de Parques Urbanos Municipais da cidade de São Paulo: 0 caso do Parque Chácara do Jockey. 2017. 120p. Trabalho de Conclusão de Curso (Graduação em Engenharia Civil) - Escola Politécnica da Universidade de São Paulo, São Paulo, 2017. 


\section{CONSIDERAÇÕES FINAIS}

O desejo por espaços para caminhadas e corridas, passeios com cachorros, footing e encontros - durante o dia e também à noite não é exclusivo a esta ou àquela classe social. No Dique do Tororó, em Salvador, ou em volta do Parque Taquaral, em Campinas, ou no calçadão da Avenida Ricardo Paranhos, de Goiânia, pessoas buscam os espaços livres cotidianamente.

Grandes parques - como o lbirapuera, o Farroupilha e o Aterro do Flamengo - foram especialmente responsáveis por difundir o desejo por parques em todas as cidades brasileiras. Nestes espaços, a experiência que a pessoa vive consigo, com o outro e com a paisagem é positiva e transformadora. 0 público adquire a esperança de poder reproduzir estas experiências em outros lugares, mas as condições não são as mesmas nas diferentes partes da cidade.

O sistema de espaços livres urbanos funciona de forma articulada - calçadas de ruas mais comerciais ou mais residenciais, vielas e escadas, praças, centros esportivos, parques ou ciclovias. Além da mobilidade e do lazer, estes espaços cumprem funções de drenagem, abastecimento de energia, circulação de mercadorias etc., articulando-se com outras infraestruturas urbanas. Por serem espaços livres públicos quase sempre vegetados, usados nos momentos de lazer e, em geral, contarem com estrutura de manutenção melhor que a de outros espaços livres, os parques foram alçados à categoria de espaços urbanos de sucesso em termos de visibilidade e retorno político para muitas administrações municipais. Entre 2000 e 2017, foram criados 234 parques nas 16 capitais apresentadas neste tra- 
balho, sem considerar as intervenções qualificadoras nas orlas marítimas. Deste total de parques, 83 \% foram criados para preservação ambiental e provisão de lazer, incluindo os casos com remoção de moradias que envolvem a questão habitacional. Há uma parcela de parques nas cidades que foi destinada apenas à preservação, como forma de conter a ocupação, especialmente no Rio de Janeiro e no Distrito Federal e que tem visitação restrita, das quais identificamos 17 mas é possivel que sejam mais e que representam 7\% em quantidade, mas têm as áreas mais signiticativas. Identificamos 10 parques (4\%) associados diretamente à promoção de empreendimentos imobiliários em áreas de expansão deste mercado - ainda que parte maior tenha sido feita em parceria com construtoras e se preste à valorização da terra. Seis parques (cerca de 2,5\%) tiveram ênfase na provisão de lazer sem fins ambientais; quatro estiveram fortemente ligados à promoção da cidade com fins turísticos; e quatro como propaganda de empresas. Das ações relacionadas a parques, 97,5\% se apropriaram do discurso ambiental, que serviu para garantir a reserva da terra, ou a obtenção de recursos, ou simplesmente o aumento da aceitação, da visibilidade nas propagandas imobiliárias ou políticas. 6.61

Devido ao conjunto de parques encontrado, este trabalho revisa a definição de parque urbano desenvolvida em Parques urbanos no Brasil (2001) para os parques do século XX, que os caracterizava como espaços para a recreação de massa. Neste início de século $X X 1$, observa-se o termo e a figura do parque sendo utilizados, em alguns casos, exclusivamente como instrumentos de preservação ambiental nas cidades. 6.01

Na prática, o fato de a área ser, por determinação legal, área de proteção ambiental, seja particular ou pública, não garante sua proteção. Verificou-se tal situação nos municípios da Grande São Paulo, nos quais metade da área é protegida pela legislação ${ }^{1}$, mas não tem, de fato, nenhuma garantia de que não serão ocupadas. Apenas as áreas demarcadas como parques urbanos estão mais bem protegidas. A criação dos parques com cercamentos, gestão e uso público passou a ser a solução padrão para tentar garantir a preservação. Entretanto, o uso público depende de haver demanda da população, de haver alguma estrutura e, principalmente, manuten-
Gráfico: parques implantados entre 2000-2017 por motivação

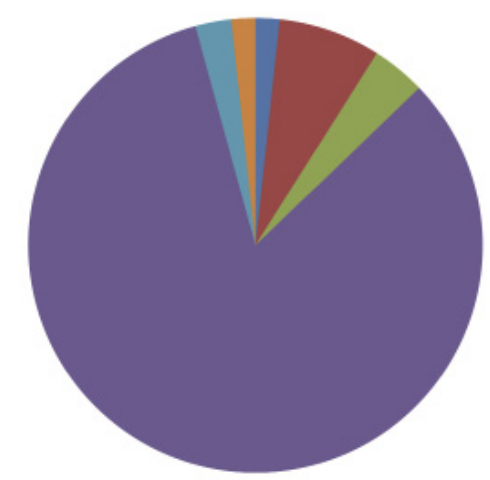

PRESERVAÇÃO AMBIENTAL E - PROVISÃO DE LAZER

UNICAMENTE CONSERVAÇÃO

PROMOÇÃO IMOBILIÁRIA

PROMOÇÃO URBANA E TURISTICA

LIGADOS A EMPREENDIMENTO IMOBILIÁRIO AÇÃO INSTITUCIONAL/ PROPAGANDA DE EMPRESA
1 LOYOLLA, Leonardo Coelho; SAKATA, Francine. Parques e proteção ambiental no vetor oeste da região metropolitana de São Paulo. Colóquio QUAPÁ-SEL, 10, Brasilia, 2015. 


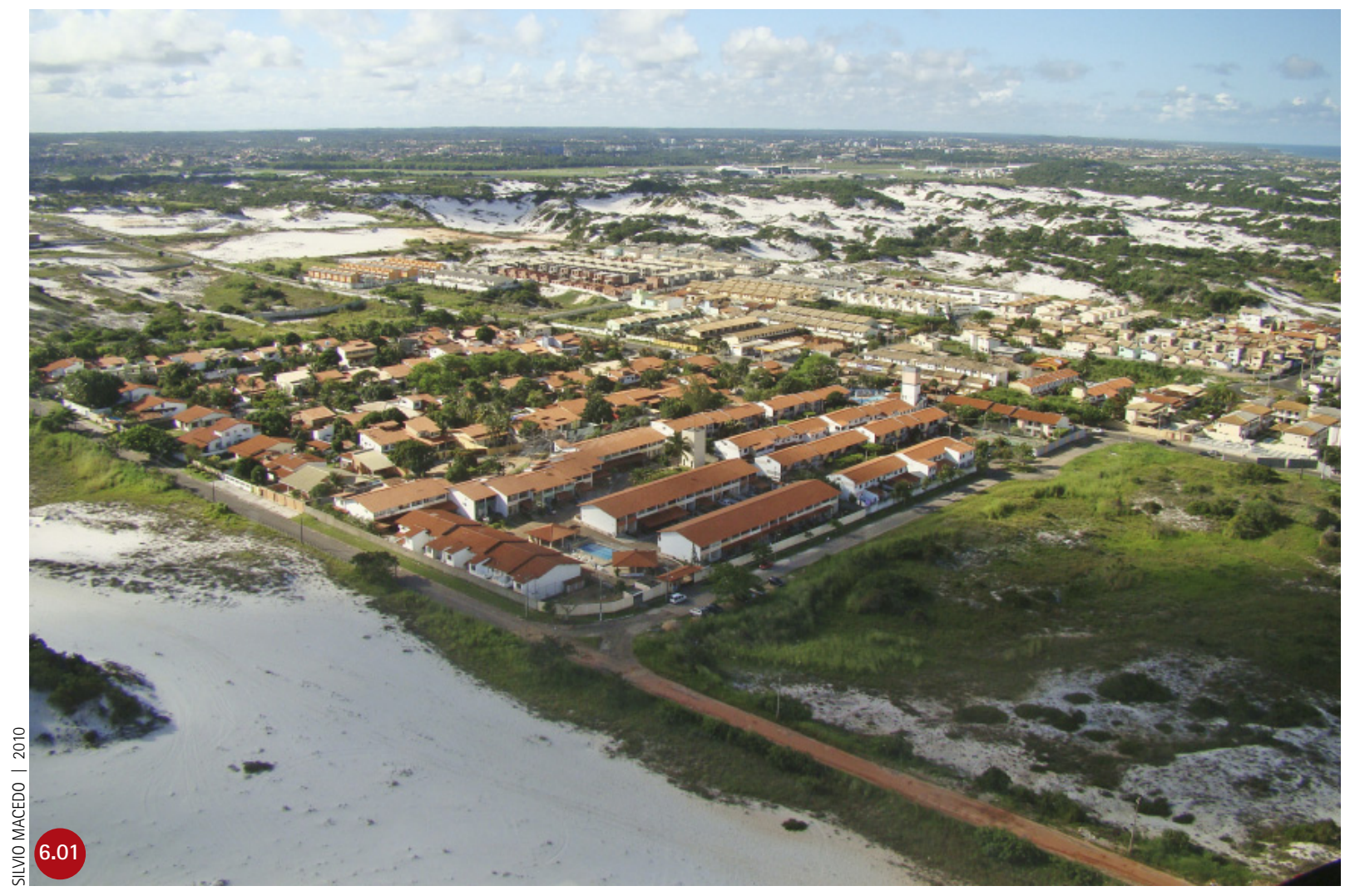

Parque das Dunas (2008), em Salvador: uma forma de tentar resguardar parte das dunas da ocupação por camadas de rendas médias e altas. Os donos dos terrenos foram indenizados com créditos tributários municipais, porém não ficaram satisfeitos, já que, ainda que a legislação ambiental não Ihes permitisse construir, isto vinha sendo feito. ${ }^{2}$

2 "Eles [os donos dos terrenos] argumentam que estes 'papéis' já são de difícil comercialização e agora querem saber como fica o investimento anterior deles. Porque tem-se dito que naquela região não há direito de construir, mas há, sim, a possibilidade de construir."

ESTEVES, Lucas. Ambientalista defende concessão de créditos tributários no Abaeté. BNews. 15 mar. 2013. Disponivel em: <https://goo.gl/CFVMsj>. ção. Sem manutenção, as áreas são percebidas como inseguras, e a população tem medo de frequentá-las.

Assim, nesta tese, conclui-se que o parque urbano brasileiro do século XXI é um espaço livre público destinado ao lazer ou à conservação ambiental. 1dealmente, ambos papéis devem estar presentes, pois esta é a resposta mais eficiente para estas duas importantes questões - ambas com graves e urgentes carências em nossas cidades. Contudo, neste início do século XXI, a gestão e as formas de apropriação social das reservas urbanas ainda não estão equacionadas. 0 Parque da Cratera de Colônia, em São Paulo, criado em 2007 junto da represa de Guarapiranga, e as ocupações de baixa renda na Zona Sul da cidade, ainda não possuem programas de usos que possam ser assumidos pela prefeitura. Dez anos depois de criado, o parque ainda não está aberto ao uso. 0 Parque Jequitibá, criado em 2006 (São Paulo, Zona Oeste) após forte mobilização popular, segue em implantação, lentamente, havendo a promessa de que seja aberto ao público em 2018. 
Observou-se que umas das principais formas de viabilizar a criação de parques em São Paulo, Brasília, Vitória e Goiânia foram os TCA ou os TAC que são, basicamente, multas aplicadas a quem cometeu ou cometerá dano ao meio ambiente. Trata-se de instrumentos recentes, fruto da evolução da legislação ambiental, que não ocorreu igualmente em todos os Estados. Em São Paulo, as compensações ambientais foram inicialmente feitas com a doação de mudas de árvores, entretanto, com o tempo, compreendeu-se ser mais interessante que o poder público as aproveitasse para terceirizar não só a coordenação dos projetos, mas também seu desenvolvimento e a execução das obras. Com isto, pôde implantar, em curto período de tempo, 82 parques por toda a cidade.

As taxas que empreendedores privados ou grandes obras de infraestrutura públicas precisam pagar pela compensação de danos ambientais, como multas, são flutuantes. Por serem recursos apenas disponibilizados quando se realizam grandes obras, com remoção de expressivo número de árvores, é difícil fazer planejamentos com estes recursos - capturados de obras: por não estarem destinados inicialmente aos parques não se pode contar com eles para o planejamento da manutenção. Contudo, foi possível aplicá-los em obras previamente planejadas. Em Goiânia, as áreas para parques foram delimitadas, e as obras executadas conforme as verbas eram disponibilizadas. Buscar formas de financiar a estruturação da gestão e a manutenção de parques é um desafio que segue posto para as administrações públicas.

Os parques de Goiânia integraram programas de criação de parques da Secretaria de Meio Ambiente, mas foram, ao mesmo tempo, parte de operação consorciada do mercado imobiliário. 0 resultado, no que se refere a projeto, obra e uso foi de alta qualidade. Isto deu muita visibilidade aos parques, que passaram a ser planejados, nos anos seguintes, para áreas menos dinâmicas para o mercado imobiliário, em um projeto de grande abrangência - o Parque Macambira Anicuns, com 23 quilômetros de extensão.

No Rio de Janeiro, foram demarcados parques naturais, mas apenas três parques para provisão de lazer foram implantados nos últimos dez anos, nenhum na Zona Sul. Um deles, o Recanto do Trovador, 
na Vila lsabel, foi remodelação e outros dois, os parques Madureira e Radical de Deodoro, foram feitos com projetos completos e padrão de construção alto para a média nacional quando se trata de espaços públicos, e tiveram grande visibilidade. Esta postura se contrapôs à experiência paulistana, pela qual foram feitos vários parques mais simples, com custos mais baixos para que estender a área da obra, em bairros menos centrais. 0 Parque Madureira (255.000m²), o Deodoro (500.000m²), o Recanto do Trovador $\left(41.260 \mathrm{~m}^{2}\right)$ e o Piscinão de Ramos (26.414m²), de 2001, somam cerca de $822 \mathrm{mil} \mathrm{m}^{2}$, contra 8,9 milhões de $\mathrm{m}^{2}$ do Programa 100 parques de São Paulo. 0 programa paulistano atuou de modo mais discreto em área maior, mas, no curto prazo, do ponto de vista do número de frequentadores e da gestão dos espaços criados, a intervenção com maior qualidade em uma área menor foi mais vantajosa para o poder público e para os frequentadores.

Em relação à distribuição dos parques pelos bairros da cidade, neste início do século XX1 foram criados parques na periferia, não apenas nos bairros consolidados e valorizados, como era praxe no século $X X$. Isto ocorreu nas cidades em que foram criados muitos parques - Goiânia, São Paulo, Brasília, Belo Horizonte e Curitiba. Mas não significa que tenham sido criados parques em toda a periferia: foram feitos onde houve oportunidades de fazê-los - normalmente quando da existência de algum terreno público com recurso a preservar. Estas oportunidades não surgiram igualmente por todo o território. Assim, a distribuição deste tipo de espaço livre, quando houve, não foi equitativa.

As oportunidades de criação de parques surgem com ainda mais força quando são interessantes ao mercado imobiliário, o que ocorre apenas nos vetores de expansão dos investimentos imobiliários, e não por toda a cidade. Muitos pequenos parques surgiram em áreas destinadas por lei para uso público, em loteamentos, por meio de acordos com as prefeituras. Também houve casos em que as construtoras simplesmente equiparam áreas públicas em bairros valorizados.

A implantação de parques articulados com interesses imobiliários não é novidade, mas neste século, com o boom imobiliário atin- 
gindo praticamente todas as cidades brasileiras, com produtos para várias classes sociais, não surpreende que muitos dos parques construídos no período sejam consequências desta aliança de interesses. É importante destacar que, se por um lado o discurso do mercado imobiliário ao vender a proximidade do parque valoriza seus empreendimentos, por outro valoriza os próprios parques. É interesse do mercado que os parques sejam cada vez mais vistos como espaços desejáveis e interessantes para toda a sociedade - o que também acontece com a indústria da saúde e do esporte, interessada na mesma valorização. Não é possível, nem inteligente, negar a associação dos parques com os vários interesses econômicos envolvidos. A melhor saída é assumir esses interesses e se articular com eles na implementação e gestão destes espaços.

Em Fortaleza, ainda que não tenham sido feitos parques nos últimos vinte anos, foi incansavelmente discutido o caso da demarcação do Parque do Cocó, ao longo das margens relativamente bem conservadas do Rio Cocó. A área se localiza no vetor de expansão do mercado residencial de alto padrão, com os preços dos imóveis equiparados aos da orla marítima. A criação do parque cumpriria três objetivos:, maior valorização dos imóveis para o mercado imobiliário; disciplinar a ocupação, evitando que a área seja ocupada por palafitas ou casas; a população ganha o equipamento de lazer público, que tende a ser bem mantido.

Quando o Estado arca integralmente com o investimento que corresponde à implantação do parque em área do interesse dos incorporadores, mesmo em prol da qualidade urbana e da população em geral, ele favorece a reprodução do capital privado com recursos públicos. Assim, os casos em que o poder público compartilha a criação dos parques, como em Goiânia, ou em que repassa integralmente a obra para a iniciativa privada, como o Parque do Povo, podem ser considerados avanços. (6.02)

A discussão do Parque Augusta, em São Paulo, serve para ilustrar o debate que surge nestas situações. 0 terreno, situado na Rua Augusta, com cerca de $24.000 \mathrm{~m}^{2}$, é avaliado em cerca de R\$ 120 milhões. Como boa parte da área conta com vegetação protegida
3 "O já bastante cobiçado quadrilátero formado pelas avenidas Cidade Jardim, Brigadeiro Faria Lima, Juscelino Kubitschek e Nações Unidas ficou ainda mais desejado após ganhar seu próprio jardim. Nos últimos três anos, o preço do metro quadrado por lá mais que dobrou, chegando à cifra atual de 23.000 reais. É bem mais alto do que a média do bairro (15.000 reais) e fica hoje apenas atrás do da Vila Nova Conceição, em termos de valores da capital." https://vejasp.abril.com. br/cidades/apartamentos-proximos-ao- parque-do-povo-batem-recorde-de-valorizacao/ "Imóveis próximos ao Parque do Povo batem recorde de valorização». Veja SP. 22 de dezembro de 2012. Consultado em 30 de novembro de 2017 
Parque do Povo (2008), São Paulo. 0 Itaim era ocupado por torres residenciais e comerciais de alto padrão, mas não contava com espaço público para recreação e lazer. Uma construtora arcou com a sua criação em um terreno da Caixa Econômica assumido pela prefeitura. Análises imobiliárias mostram que, com o "jardim do bairro", os imóveis ao redor alcançaram recorde de valorização. ${ }^{3}$

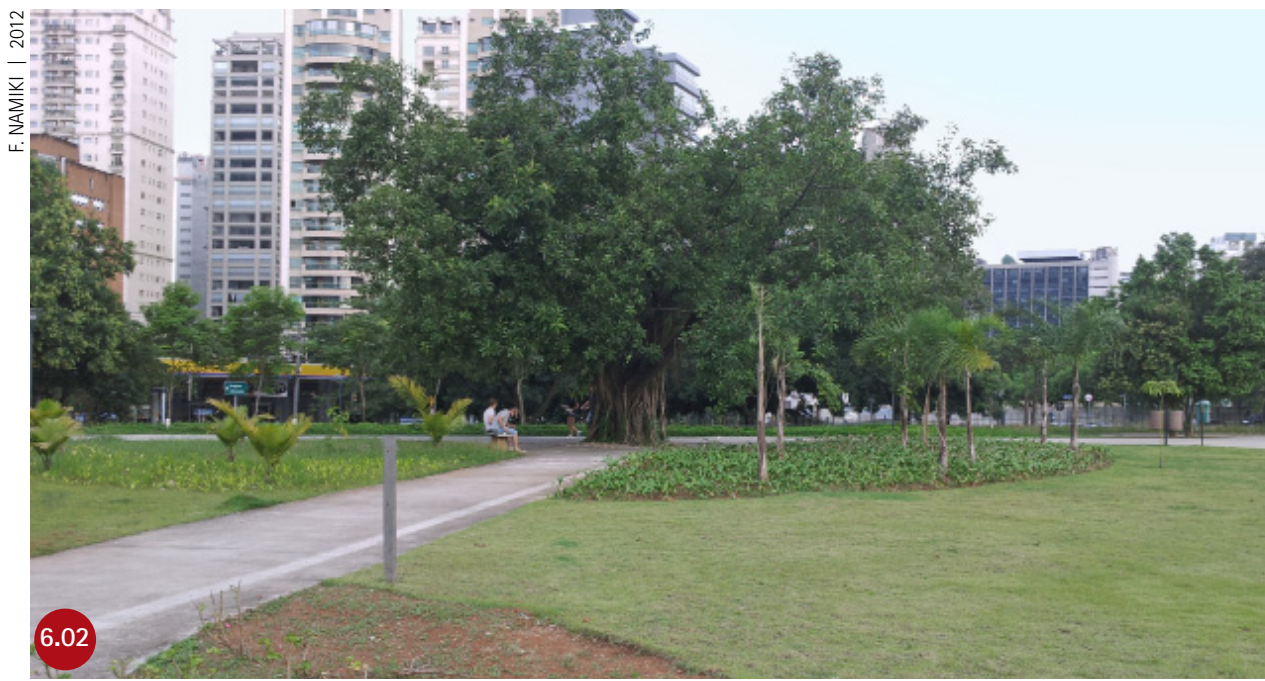

Terreno do Parque Augusta, São Paulo.

Antiga ponte férrea sobre o Rio Tietê junto ao Parque Leopoldina Villas-Boas e antigas edificações no terreno destinado a este parque, em São Paulo. A prefeitura ivenstiu em um projeto paisagístico e arquitetônico para o parque mas as articulações necessárias para impulsionar esta obra não se constituíram e não há previsão de implantação.
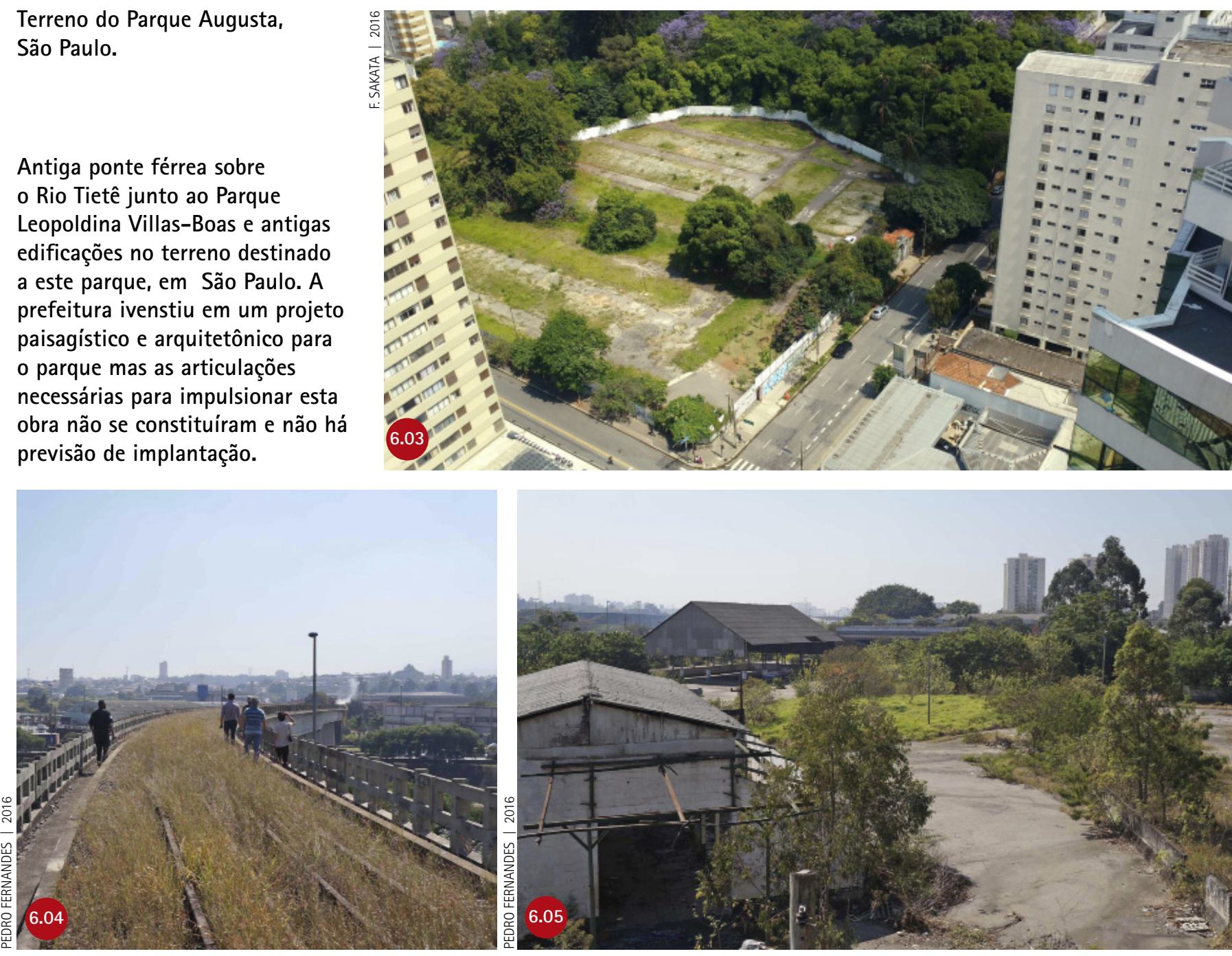
por lei, os investidores tentam desenvolver projetos que abram parte do térreo com acesso livre à população. Os moradores do entorno pedem que a prefeitura desaproprie a área inteira e crie o parque "100\% público". A prefeitura adotou duas posições: durante a gestão 2013-2016, tentou mediar um acordo entre os investidores - as construtoras Cyrela e Setin - e os movimentos sociais, propondo que o empreendimento imobiliário concilie a construção das torres com a abertura do térreo para a população e a preservação da vegetação. Argumentava-se que a desapropriação geraria enorme investimento público em área já servida por infraestrutura e, portanto, não prioritária, e que a gestão privada permitiria a existência de áreas de uso público com horários de funcionamento mais flexíveis e manutenção compatível com os tipos e níveis de uso previstos. (6.03) 0 acordo não avançou por não conseguir encontrar um projeto que conciliasse as expectativas dos investidores e dos movimentos. A gestão 2017-2020, admitindo não ter recursos para a desapropriação, propôs trocar a área da Augusta por outro terreno público, com $18.000 \mathrm{~m}^{2}$, junto da Marginal Pinheiros. A troca foi questionada pelo Ministério Público e por parte da imprensa e, até o momento, o impasse não foi resolvido. Este debate confirma a dificuldade de negociação e os interesses antagônicos que movem os três agentes - a população, o poder público e os investidores imobiliários. Confirma igualmente o peso e a importância dos parques urbanos na pauta destes agentes.

Programas de uso acertados e bons projetos paisagísticos são absolutamente necessários. Eles viabilizam os arranjos que tornam possíveis os parques, tornam possiveis a execução e a manutenção de melhor qualidade e estão na base da apropriação dos espaços pelas pessoas. Projetos de parques que valorizam a cidade em seu entorno tornam duradouro o investimento feito no espaço público. 6.046 .056 .066 .07

Algumas cidades, como Rio Branco, Campo Grande e Curitiba, definiram a locação dos parques em seus planos diretores. Em Goiânia, Brasília e Belo Horizonte, foram reservadas várias áreas para parques e a implantação ocorre conforme a demanda da população, os recursos e a conveniência política. Nas demais cidades, parece 338
Na página oposta, parques com intensa apropriação social em São Paulo: Parque do Trote, Centro de Esportes Radicais e Parque Linear do Sapé, São Paulo. 

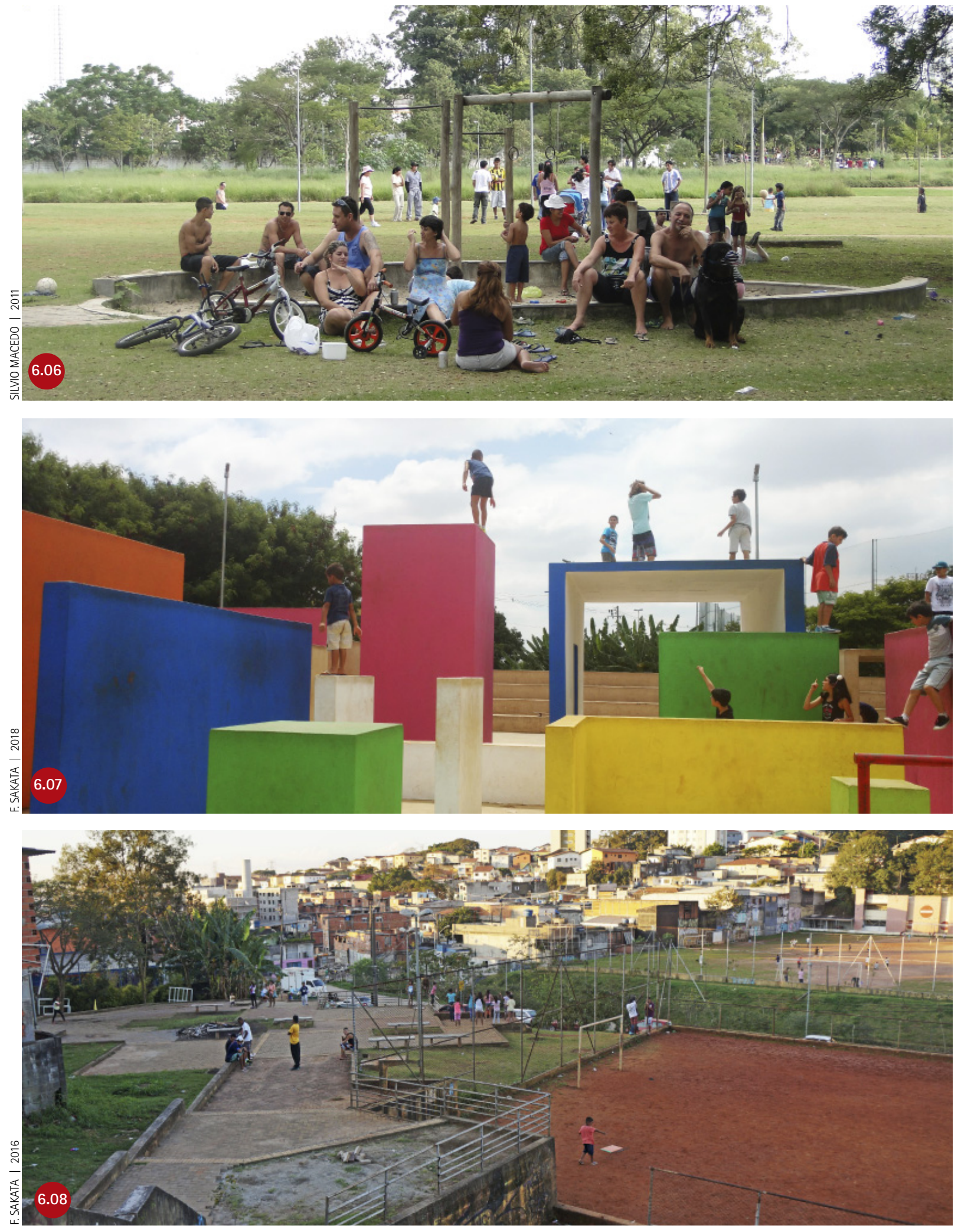
não haver critérios para a implantação de parques, que surgem por oportunidades, e faltam programas de uso articulados com as demandas da população e o planejamento da manutenção. 0 poder público precisa criar estruturas e desenvolver modelos para lidar com esta categoria de espaços livres.

Com a reserva de faixas ao longo dos cursos d'água, o Código Florestal impôs a criação de um estoque de áreas para parques. Reservar este estoque é importante, é um recurso para que as cidades possam fazer parques em médio e longo prazo. A localização pode não ser conveniente do ponto de vista da demanda e pode não haver muitas condições de gerir as áreas no presente e de vir a conectá-las no futuro, mas, no contexto de cidades não desenhadas, foi um modo de abrir possibilidades.

Mesmo sendo reservadas e nomeadas como parques, é difícil garantir a integridade de muitas destas áreas - porém, se não fossem reservadas, as dificuldades de convertê-las no futuro seriam ainda maiores. 0 investimento em parques foi válido e não teve custo alto. Comparados a outros equipamentos públicos, a implementação e a manutenção dos parques não é cara. Mesmo quando o sucesso não veio, por problemas de gestão, pouco se perdeu em termos de recursos investidos.

A fauna é importante, assim como a permeabilidade do solo e a regulação da temperatura. Contudo, a preservação ambiental deve estar articulada com as necessidades cotidianas das pessoas e o funcionamento da cidade. Os parques urbanos de maior qualidade são aqueles apropriados pelas pessoas, com público variado em dias e horários diferentes, mesmo que a estrutura se resuma a caminhos e bancos. Parte da população brasileira experimentou neste início de século, pela primeira vez, a possibilidade de usufruir cotidianamente de parques. É preciso persistir nesta direção. 6.08

São necessários estudos sobre criação, projetos, apropriação, gestão e articulação de parques e de outros espaços públicos. As escolas de Arquitetura costumam dar ênfase ao projeto, mas seria salutar que houvesse profissionais com formação em Arquitetura e Urbanismo distribuídos por toda a cadeia da construção civil e da administração pública. 


\section{REFERÊNCIAS BIBLIOGRÁFICAS}

ABRAHÃO, Sérgio L. Espaço público: do urbano ao político. São Paulo: Annablume; Fapesp, 2008.

ALEX, Sun. Projeto da praça: convívio e exclusão no espaço público. São Paulo: Senac, 2008.

BARTALINI, Vladimir. Parques públicos municipais de São Paulo: a ação da municipalidade no provimento de áreas verdes de recreação. 1999. $354 \mathrm{f}$. Tese (Doutorado em Arquitetura e Urbanismo) - Faculdade de Arquitetura e Urbanismo, Universidade de São Paulo, São Paulo, 1999.

BENFATTI, D.; QUEIROGA, E.; SILVA, J. Megalópole, urbanização fragmentada e esfera de vida pública contemporânea. Encontro Nacional de Ensino de Paisagismo em Escolas de Arquitetura e Urbanismo no Brasil - ENEPEA, 10, Porto Alegre. Anais.: PUC-RS, 2010. CD-ROM.

BRASIL, Lei № 9.985, De 18 de julho de 2000. Regulamenta o art. 225, incisos I, II, III e VII da Constituição Federal, institui o Sistema Nacional de Unidades de Conservação da Natureza e dá outras providências. Presidência da República. Casa Civil. Subchefia para Assuntos Jurídicos.

CAMPOS, A. C. A (Org.) et al. Quadro dos sistemas de espaços livres nas cidades brasileiras. São Paulo: FAUUSP, 2012.

et al. Sistemas de espaços livres: conceitos, conflitos e paisagens. São Paulo: FAUUSP, 2011.

CARVALHO, Sidney. Análise comparativa das paisagens urbanas de São Paulo, Rio de Janeiro e Distrito Federal no início do século XXI: forma urbana e sistema de espaços livres no Brasil contemporâneo. 2018. 344 p. Tese (Doutorado em Arquitetura e Urbanismo) - Faculdade de Arquitetura e Urbanismo, Universidade de São Paulo, São Paulo, 2018.

CASIMIRO, Matheus de Vasconcelos. A invenção e reinvenção do parque público paulistano: um olhar sobre a produção municipal. 2018. Dissertação (Mestrado em Arquitetura e Urbanismo) - Faculdade de Arquitetura e Urbanismo, Universidade Presbiteriana Mackenzie, São Paulo, 2018. 
COELHO, Leonardo L. Dispersão, fragmentação e paisagem: relações entre dinâmicas naturais e urbanas no vetor oeste da Região Metropolitana de São Paulo. 2015. Tese (Doutorado em Arquitetura e Urbanismo) - Faculdade de Arquitetura e Urbanismo, Universidade de São Paulo, São Paulo, 2015.

Compensação ambiental: uma alternativa para viabilização de espaços livres públicos para lazer e convívio na cidade de São Paulo. 2008. 211 p. Dissertação (Mestrado em Arquitetura e Urbanismo) - Faculdade de Arquitetura e Urbanismo, Universidade de São Paulo, São Paulo, 2008.

; SAKATA, Francine. Parques e proteção ambiental no vetor oeste da Região Metropolitana de São Paulo. Colóquio Quapá-SEL, 10, Brasília, 2015.

COSTA, Stäel Alvarenga Pereira et al. Os espaços livres na paisagem de Belo Horizonte. Paisagem e Ambiente. São Paulo: FAUUSP, n. 26, 2009, p. 51-72.

; GIMMLER NETO, Maria Manoela. Fundamentos de morfologia urbana. Belo Horizonte: C/Arte, 2015.

CUNHA, Claudio E.; OJIMA, Felipe B.; ALCARAZ, Felipe E.; SILVA, João Gustavo P. da. Desestatização de Parques Urbanos Municipais da cidade de São Paulo: o caso do Parque Chácara do Jockey. 2017. 120p. Trabalho de Conclusão de Curso (Graduação em Engenharia Civil) - Escola Politécnica da Universidade de São Paulo, São Paulo, 2017.

CUSTÓDIO, Vanderli. Relatório Oficina Quapá-SEL II Salvador, 1 a 4 de junho de 2014.

CRANZ, Galen; BOLAND, Michael. Defining the sustainable park: a fifth model for urban parks. Landscape Journal, 23:2-04. 2004.

FARAH, Ivete; SCHLEE, Mônica Bahia; TARDIN, Raquel (Orgs.). Arquitetura paisagística contemporânea no Brasil. São Paulo: Senac, 2010.

FERREIRA, Luciana Schwandner. Manejo da vegetação na cidade de São Paulo: supressão e compensação. 0 caso do distrito da Vila Andrade. 2012. 202p. Dissertação (Mestrado em Arquitetura e Urbanismo) - Faculdade de Arquitetura e Urbanismo, Universidade de São Paulo, São Paulo, 2012.

GALENDER, Fany. Uma contribuição ao estudo do Sistema de Espaços Livres do município de São Paulo. São Paulo: FAUUSP, 2012.

; CAMPOS, Ana Cecilia M. de Arruda. Ações públicas em São Paulo voltadas para recuperação dos corpos d'água: percepção e apropriação. APPs Urbana 2014. Seminário Nacional sobre o tratamento de Áreas de Preservação Permanente em meio urbano e restrições ambientais ao parcelamento do solo, 3, Belém (PA), 2014.

HOLDEN, Robert. Diseño del espacio publico internacional. Barcelona: Gustavo Gilli, 1996.

JACOBS, Jane. Morte e vida das grandes cidades americanas. São Paulo: Martins Fontes, 2011.

JELLICOE, Geoffrey; JELLICOE, Susan. El paisaje del hombre. Barcelona: Gustavo Gili, 1995. 
KLIASS, Rosa G. Os Parques urbanos de São Paulo. São Paulo: Pini, 1993. 2006.

Desenhando paisagens, moldando uma profissão. São Paulo: Senac,

LEMOS, Isabela et al. Relatório Oficina Quapá-SEL Campo Grande, 10 a 14 de abril de 2018.

MACEDO, Silvio Soares. Quadro do paisagismo no Brasil. São Paulo: FAUUSP/ Quapá, 1999.

Paisagismo brasileiro na virada do século: 1990-2010. São Paulo:

Edusp; Campinas: Unicamp, 2012.

; SAKATA, Francine. Parques urbanos no Brasil. São Paulo: Edusp, 2001.

MACIEL, Marieta Cardoso. Programa Parque Preservado. Paisagem e Ambiente. São Paulo: FAUUSP, n. 15, dez/2001, p. 103-126.

MEDEIROS, Mirelli B. Parques urbanos em Belo Horizonte: a evolução de uma paisagem cultural. Colóquio Íbero-americano Paisagem Cultural, Patrimônio e Projeto, 3, Belo Horizonte, 15 a 17 de setembro de 2014.

MENEGUETTI, Karin S.; REGO, Renato Leão; BELOTO, Gislaine Elizete. Maringá:a paisagem urbana e o Sistema de Espaços Livres. Maringá: UEM, 2009.

NAGANO, Wellington T. Parque Linear Itaim como Espaço Livre Público. 2017. 93f. Memorial de Qualificação (Mestrado em Arquitetura e Urbanismo) Faculdade de Arquitetura e Urbanismo, Universidade de São Paulo, São Paulo, 2017.

NAMIKI, Fabio. Manutenção de brinquedo em praças públicas. Paisagem e Ambiente. São Paulo: FAUUSP, n.24, 2007, p. 9-18.

Manutenção de praças públicas. 2005. 151f. Dissertação (Mestrado Profissional em Habitação) - Instituto de Pesquisas Tecnológicas do Estado de São Paulo, São Paulo, 2005.

PANZINI, Franco. Projetar a natureza: arquitetura da paisagem e dos jardins desde as origens até a época contemporânea. São Paulo: Senac, 2013.

PEDROSO, Carlos Auguro Mulatinho de Queiroz; SILVA, Felipe Francisco Pereira da. Equipamentos de esporte e lazer na cidade: planejamento dos parques urbanos do Recife, PE, Brasil. Revista Digital EFDeportes. Buenos Aires, Ano 16, n. 158, julho de 2011.

PEGORARO, Rafael Lopez. Transformação urbana no Brasil: estudo de cinco centros urbanos. Relatório Científico Final. São Paulo: FAPESP, 2017. Processo FAPESP: 2015/04226-9

QUEIROGA, Eugenio. A megalópole e a praça: o espaço entre a razão de dominação e a ação comunicativa. 2001. 351f. Tese (Doutorado em Arquitetura e Urbanismo) - Faculdade de Arquitetura e Urbanismo, Universidade de São Paulo, São Paulo, 2001.

Dimensões públicas do espaço contemporâneo: resistências e transformações de territórios, paisagens e lugares urbanos brasileiros. 2012. 
284p. Tese (Livre-Docência) - Faculdade de Arquitetura e Urbanismo da Universidade de São Paulo, São Paulo, 2012.

QUEIROGA, Eugenio; BENFATTI, Denio M. Sistemas de espaços livres urbanos: construindo um referencial teórico. Paisagem e Ambiente. São Paulo: FAUUSP, n. 24, 2007, p. 81-87.

REIS FILHO, Nestor Goulart. Notas sobre urbanização dispersa e novas formas de tecido urbano. São Paulo: Via das Artes; Fapesp, 2006.

RIBEIRO, Victória Mendes. Uso e ocupação recente de áreas pouco adensadas e suas áreas livres no espaço urbano brasileiro: o caso das cidades de Anápolis, Uberlândia, Palmas, Brasilia, Cuiabá e Goiânia. Relatório Científico Final - FAPESP 2016/21205-8. São Paulo: FAUUSP, 2018.

ROBBA, Fabio. A praça contemporânea nas grandes capitais brasileiras: do programa à forma projetual. 2004. Tese (Doutorado em Arquitetura e Urbanismo) - Faculdade de Arquitetura e Urbanismo, Universidade de São Paulo, São Paulo, 2004.

; MACEDO, Silvio Soares. Praças brasileiras. São Paulo: Edusp, 2001.

ROLNIK, Raquel. A cidade e a lei: legislação, política urbana e territórios na cidade de São Paulo. São Paulo: Studio Nobel/FAPESP, 1997.

ROMANUS, Luciana Evans. Sistemas de Espaços Livres na Região Metropolitana de Curitiba. 2016. Relatório Científico. São Paulo: CNPq, 2016.

ROYER, Luciana de Oliveira. Financeirização da política habitacional: limites e perspectivas. 2009. 193f. Tese (Doutorado em Arquitetura e Urbanismo) - Faculdade de Arquitetura e Urbanismo, Universidade de São Paulo, São Paulo, 2009.

SANDRE, Adriana F. O planejamento ambiental à luz da ecologia da paisagem: estudo aplicado da zona de amortecimento do Parque Estadual da Cantareira. 2017. 235f. Dissertação (Mestrado em Ciências) - Faculdade de Arquitetura e Urbanismo, Universidade de São Paulo, São Paulo, 2017.

SOUZA, Conrado Blanco de. APPs fluviais urbanas e sistemas de espaços livres: uma análise da influência do Código Florestal na forma das cidades brasileiras. 2015. 166f. Dissertação (Mestrado em Arquitetura e Urbanismo) - Faculdade de Arquitetura e Urbanismo, Universidade de São Paulo, São Paulo, 2015.

SOUZA, Roberto Sakamoto Rezende de. O papel das leis e das instituições para a conservação da diversidade ambiental e cultural na Baixada Santista. 2018. Tese (Doutorado em Arquitetura e Urbanismo) - Faculdade de Arquitetura e Urbanismo, Universidade de São Paulo, São Paulo, 2018.

SAKATA, Francine. Paisagismo urbano: requalificação e criação de imagens. São Paulo: Edusp, 2011.

; DONOSO, Veronica; REIS, Juliana. Relatório Oficina Quapá-SEL

Porto Alegre - 4 a 6 de abril de 2018, Universidade Federal do Rio Grande do Sul. FAUUSP, 2018. 
TAKAESU, Luciana Satiko. Potencial para o lazer dos parques municipais de São Paulo. 2014. Monografia - Faculdade de Arquitetura e Urbanismo, Universidade de São Paulo, São Paulo, 2014.

TAYLOR, Lisa. Urban open spaces. New York: Rizzoli International Publications, 1981.

TURNER, Tom. City as landscape: a post-postmodern view of design and planning. Londres: Capman Hall, 1996.

WEINGARTNER, Gutemberg. A construção de um sistema: os espaços livres públicos de recreação e de conservação em Campo Grande, MS. 2008. 192 p. Tese (Doutorado em Arquitetura e Urbanismo) - Faculdade de Arquitetura e Urbanismo, Universidade de São Paulo, São Paulo, 2008.

WHATELY, Marussia et al. Parques urbanos municipais de São Paulo: subsídios para a gestão. São Paulo: Instituto Socioambiental, 2008.

Reportagens, sites de instituições e leis citados foram registrados nas notas de rodapé. A ABNT estabelece que seja anotada, nas citações de sites, a data do acesso mas esta informação é menos relevante para o leitor que a data da postagem do texto ou artigo, que costuma estar disponivel. Assim, preferimos anotar a data da publicação do referido texto na internet e não a data do acesso. 


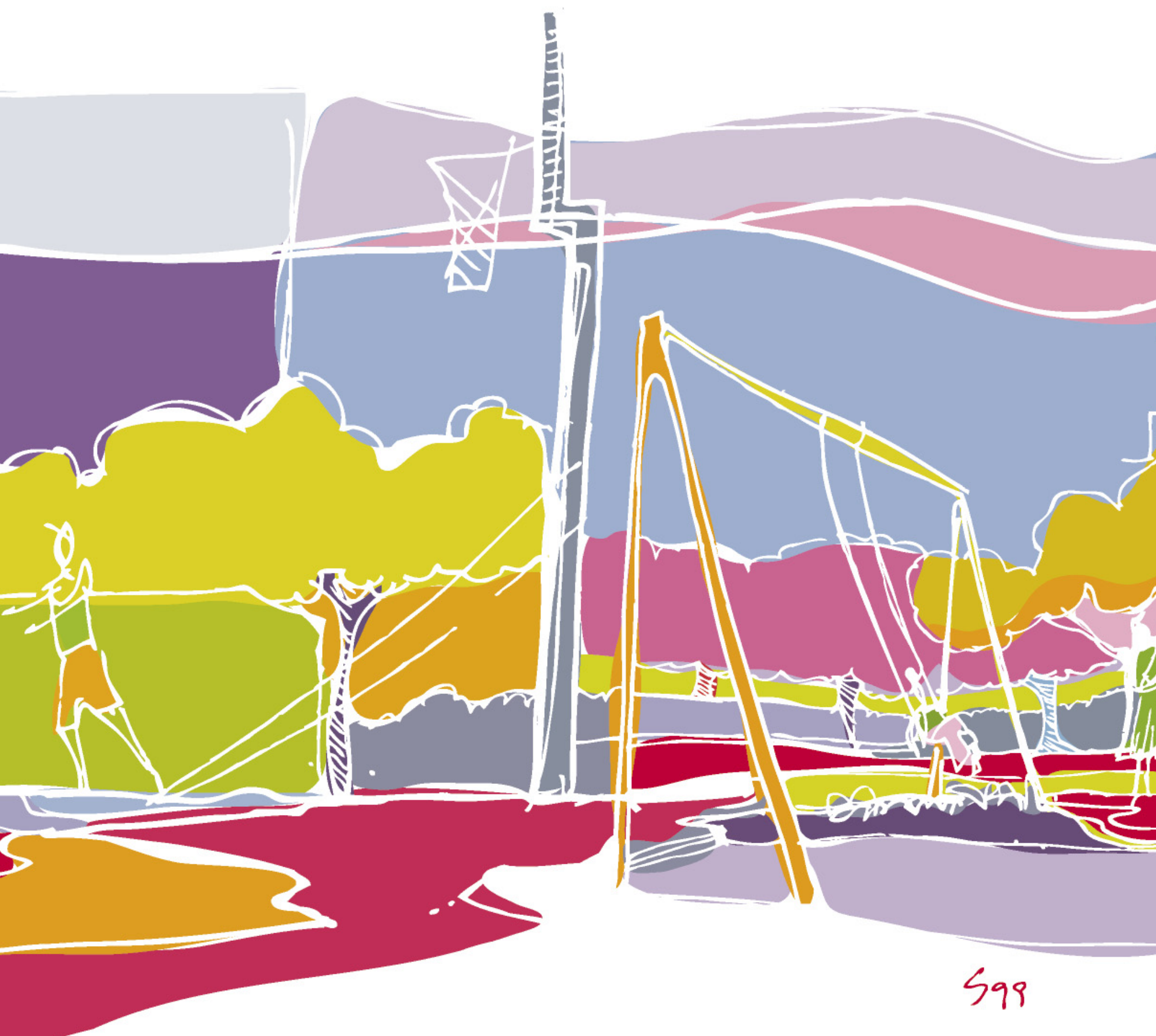


